\author{
UNIVERSIDADE DE SÃo PAULO \\ FaCUldade DE Filosofia, Letras E CiÊNCIAS Humanas \\ DePartamento de Letras ClásSicas E Vernáculas \\ Programa de Pós-GraduaÇão EM Letras ClásSiCAS
}

\title{
A ADIVINHAÇÃO NA TRAGÉDIA DE ÉSQUILO
}

BeAtriz Cristina de PAOli CoRReiA

Tese apresentada ao Departamento de Letras Clássicas e Vernáculas da Faculdade de Filosofia, Letras e Ciências Humanas da Universidade de São Paulo, para obtenção do título de Doutor em Letras Clássicas.

Orientador: Prof. Dr. José Antonio Alves Torrano

SÃo PAULO

2015 


\section{Folha de Aprovação}

CORREIA, Beatriz Cristina de Paoli. A adivinhação na tragédia de Ésquilo. Tese de

Doutorado em Letras Clássicas. São Paulo: Universidade de São Paulo, 2015. $407 \mathrm{pp}$.

Tese examinada por:

Prof. Dr. José Antonio Alves Torrano (USP)

Profa. Dra. Adriane da Silva Duarte (USP)

Prof. Dr. Flávio Ribeiro de Oliveira (UNICAMP)

Prof. Dr. Joaquim Brasil Fontes Jr. (UNICAMP)

Profa. Dra. Lucia Rocha Ferreira (UNIFESP)

Prof. Dr. Wilson Alves Ribeiro Jr. - suplente

Prof. Dr. Fernando Brandão dos Santos (UNESP) - suplente

Profa. Dra. Maria Celeste Consolin Dezotti (UNESP) - suplente

Profa. Dra. Giuliana Ragusa de Faria (USP) - suplente

Profa. Dra. Tatiana Oliveira Ribeiro (UFRJ) - suplente

São Paulo, de julho de 2015 . 


\section{RESUMO}

A adivinhação na tragédia de Ésquilo

Esta tese estuda a adivinhação nas sete tragédias supérstites de Ésquilo - entendendo-se a adivinhação não no sentido estrito de revelação de fatos futuros, mas no sentido mais amplo de um diálogo que se estabelece entre as instâncias divina e humana valendo-se de formas e recursos variados. Assim, a análise e interpretação destas tragédias priorizam os diversos aspectos deste diálogo divinatório para mostrar a adivinhação como fundamento da construção de estratégias dramáticas na tragédia esquiliana, por informar e definir tanto a peculiaridade desta poética quanto sua visão do mundo.

Palavras-chave: tragédia grega; adivinhação; Ésquilo; Agamêmnon; Coéforas; Eumênides; As Suplicantes; Os Persas; Sete contra Tebas; Prometeu Cadeeiro. 


\section{Abstract \\ Divination in the tragedy of Aeschylus}

This thesis studies divination in the seven surviving tragedies of Aeschylus. Divination is taken here not in the strict sense of revelation of future events, but in the broader sense of a dialogue that is established between divine and human levels through a variety of forms and resources. Thus, the analysis and interpretation of these tragedies prioritises the different aspects of this divinatory dialogue, in order to show that divination is the basis for constructing the dramatic strategies in the tragedies of Aeschylus, since it informs and defines both the particular features of this poetics and its view of the world.

Keywords: greek tragedy; divination; Aeschylus; Agamemnon; The Choephori; The Eumenides; The Suppliants; The Persians; Seven agaisnt Thebes; Prometheus Bound. 


\section{DEDICATÓRIA}

À memória de meu pai, João Batista Correia.

À minha mãe, Joana de Paoli.

Ao meu padrasto, Fausto Faria.

Ao meu companheiro, Marcelo Barbosa.

Aos meus mestres, Jaa Torrano e Gilson Sobral. 


\section{Agradecimentos}

Ao Professor Titular Doutor Jaa Torrano, por ter me recebido na USP, pelos ensinamentos tantos e tão valiosos, por ter pacientemente me acompanhado nessa longa e acidentada jornada, pela confiança e pela amizade, pelas oportunidades, por Ésquilo e por Eurípides, por tudo e por mais um pouco.

À Capes e ao PPGLC-USP, pela bolsa de doutorado.

Aos Professores e colegas do Grupo de Pesquisa "Estudos sobre o Teatro Antigo" do Departamento de Letras Clássicas e Vernáculas da FFLCH-USP, pela grata oportunidade de ouvi-los e de ser ouvida.

Aos Professores Doutor Henrique Cairus e Doutora Tatiana Ribeiro, pela generosa acolhida na UFRJ, pelo apoio inconteste, pelos sábios conselhos e pela inestimável amizade.

À amiga Ana Paula Miranda e a seu marido, o Professor Doutor Peter Forshaw, do Departamento de Artes, Religião e Ciências Sociais da Universidade, de Amsterdã, Holanda; ao Professor Titular de Filologia Grega, Ángel Ruiz Pérez, do Departamento de Latim e Grego da Faculdade de Filologia da Universidade de Compostela, Espanha; à Professora Doutora Laurel Bowman, Professora de Estudos Greco-Romanos da Universidade de Victoria, British Columbia, Canadá; a Monika Murdoch Asztalos, Professora de Estudos Clássicos do Departamento de Filologia, Estudos Clássicos, História da Arte e das Ideias, da Universidade de Oslo, Noruega, e editora do periódico norueguês Symbolae Osloenses; à Ana Iriarte, Professora Titular do Departamento de Estudos Clássicos da Universidade do País Basco, pela valiosa contribuição com aporte bibliográfico.

À Professora Doutora Marcia Dobson, do Departamento de Estudos Clássicos do Colorado College, em Colorado Springs, no Colorado, Estados Unidos, pela imensa confiança e generosidade que demonstrou ao me enviar sua tese de doutorado ainda inédita.

À Milena de Oliveira Faria, pelos versos de Aristófanes, e a Wilson Alves Ribeiro Jr., pelos versos de Sófocles.

À Marina Albuquerque de Almeida, pela eficiente e paciente revisão.

À Milena Ambrosio Telles, pela fraterna amizade.

A meu companheiro e à minha família, pelo amor incondicional. 


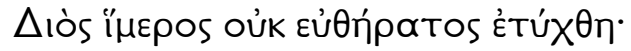

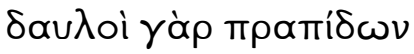

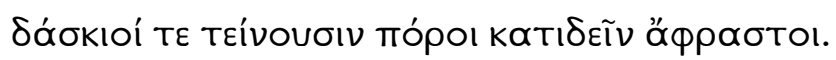

Ésquilo, As Suplicantes, vv. 87-90 


\section{SUMÁRIO}

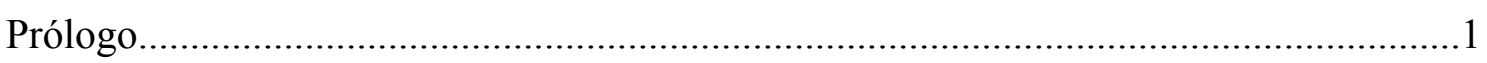

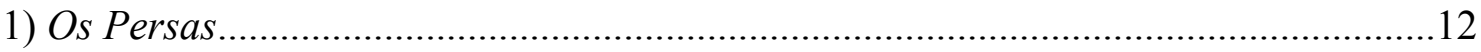

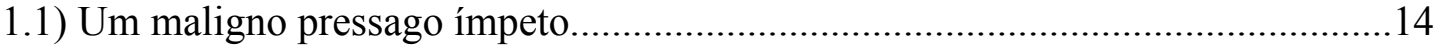

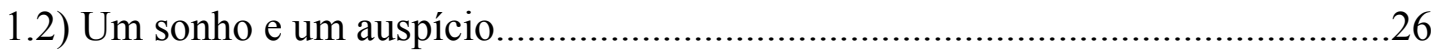

1.3) Necromancia e o espectro de Dario..................................................................43

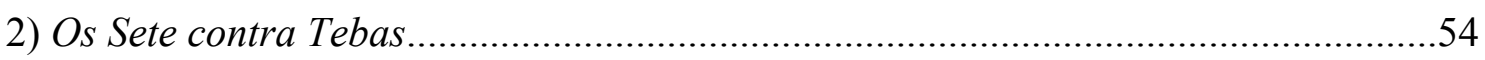

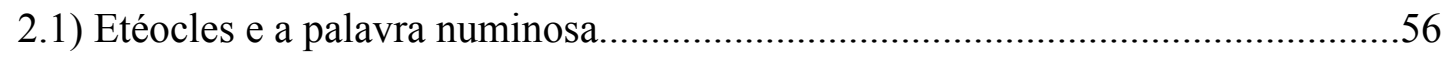

2.2) A maldição profética de Édipo........................................................................64

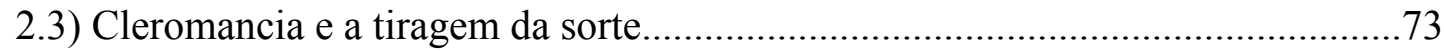

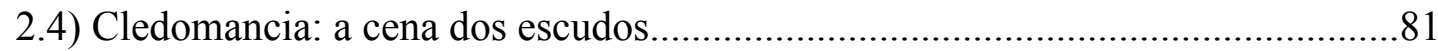

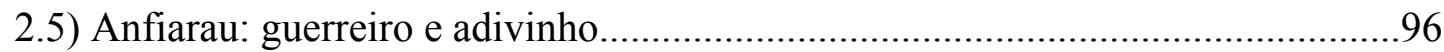

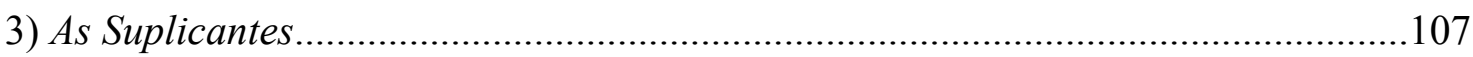

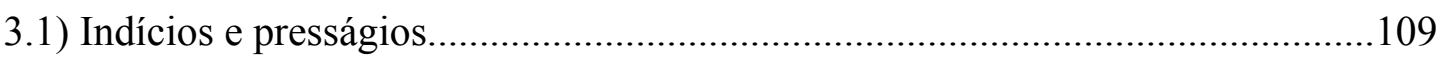

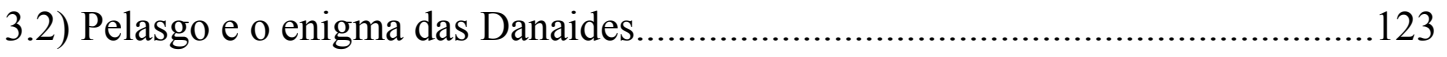

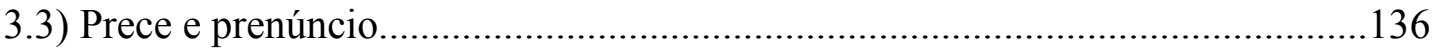

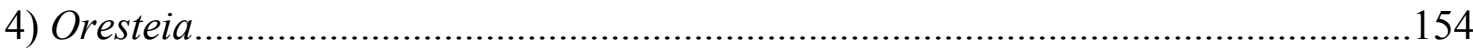

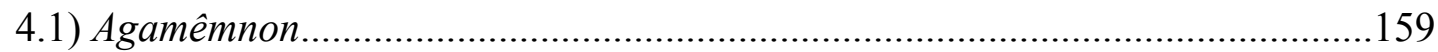

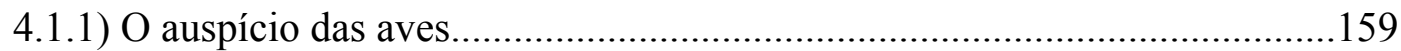

4.1.2) Palavras, imagens e sentimentos proféticos..........................................183

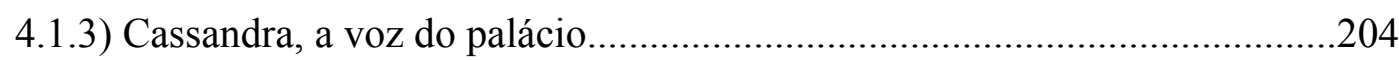

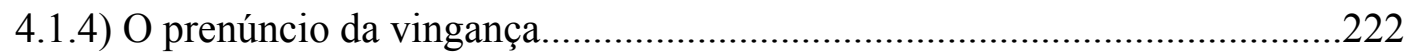

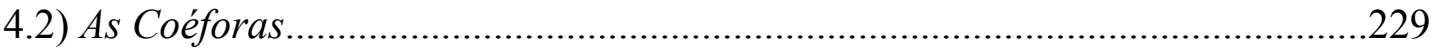

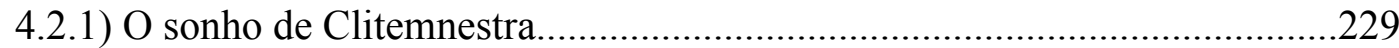

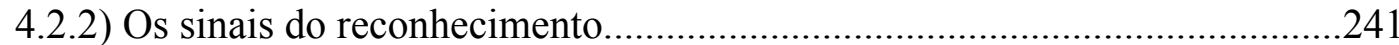

4.2.3) Orestes e o oráculo de Apolo................................................................259

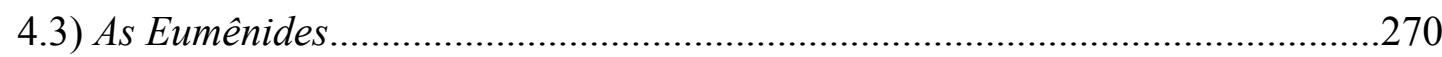

4.3.1) O oráculo de Apolo em Delfos..............................................................270

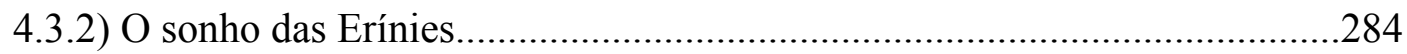

4.3.3) A palavra auspiciosa e a palavra imprecatória..........................................28

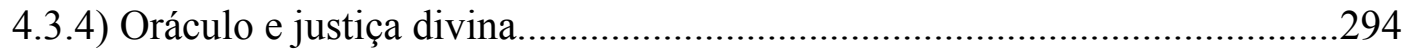




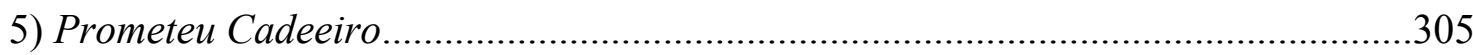

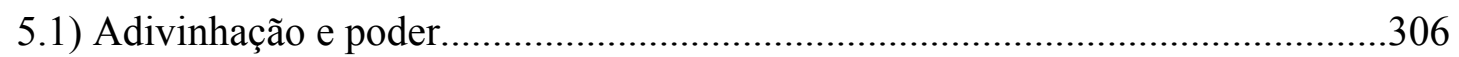

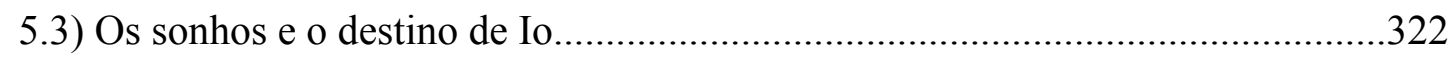

5.2) Adivinhação e os dons de Prometeu...............................................................330

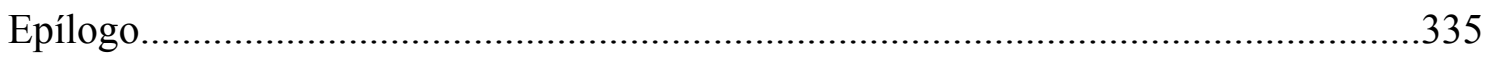

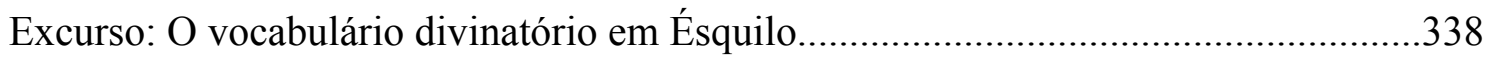

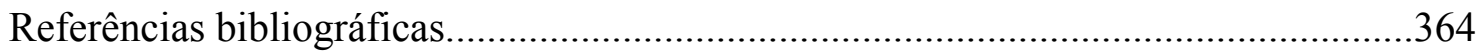




\section{Prólogo}

A adivinhação encontra-se privilegiadamente presente na obra de Ésquilo. Nas sete tragédias supérstites do poeta, figuram direta ou indiretamente adivinhos, profetisas, santuários oraculares, sonhos proféticos, prodígios, pressentimentos, além de uma variegada gama de formas de adivinhação, tais como a cledomancia, a cleromancia, o haruspicismo, a necromancia, entre outras.

Todas essas formas de adivinhação, no entanto, nem sempre se encontram tão claramente distintas na obra de Ésquilo: nem tão claramente distintas entre si e nem tão claramente distintas da própria tessitura do texto esquiliano.

Primeiramente, as definições do que se constitui um ou outro modo de adivinhação não necessariamente se aplicam de forma unívoca, de modo que a fronteira entre uma e outra modalidade de adivinhação não é tão explícita quanto se poderia imaginar a princípio. Essas categorizações das distintas práticas divinatórias criam frequentemente limites artificiais para esse diálogo com o divino que é a arte divinatória. Assim, quando a Rainha dos Persas narra como uma águia, refugiando-se junto ao altar de Apolo, foi perseguida e atacada por um falcão (Pe. 205-10), os limites entre auspício e prodígio se embaraçam. E esse auspício/prodígio é por sua vez uma parte integrante do sonho que a Rainha narra ao Coro, fazendo parte de um mesmo diálogo divinatório: um vem reforçar o sentido e a inevitabilidade do outro.

Em segundo lugar, as fronteiras entre as palavras, as imagens poéticas - isto é, as metáforas, os símiles, as alegorias - e os sinais divinatórios constantemente se diluem na trama do texto dramático de Ésquilo. As imagens utilizadas na construção de sua poética surgem muitas vezes como uma simples metáfora, construída sobre um determinado aspecto da realidade, tais como o cultivo, o sacrifício ritual, a vida pastoril, mas que, por seu contexto ou sua recorrência, adquirem de pronto um aspecto sinistro e insidioso, tornando-se, sem que necessariamente se perceba de imediato, um prenúncio de males inevitáveis. O símile das águias no párodo anapéstico do Agamêmnon (Ag. 4959), por exemplo, à medida que vai sendo construído ao longo do canto do Coro, adquire a força de um auspício, tão significativo e profético quanto o auspício das aves interpretado no párodo lírico por Calcas. Do mesmo modo, no párodo lírico dos Persas, a metáfora do jugo que Xerxes lança ao redor do pescoço do mar (Pe. 71-2) revela-se significativamente profética e um elemento importante para a interpretação do sonho da 
Rainha, narrado ao Coro no primeiro episódio. E, nos Sete contra Tebas, a palavra em seu sentido ordinário e a palavra cledomântica são indissociáveis em grande parte da cena dos escudos no segundo episódio dessa tragédia.

Tendo isso em vista, é necessário ainda considerar que praticamente não há, na sociedade grega antiga, algo mediante o que, dependendo da ocasião e das circunstâncias, não possa ser considerado um sinal divinatório, um suporte por meio do qual se expressa um sinal divino. Assim, na tragédia esquiliana, as palavras, as imagens poéticas, os nomes próprios, a presença ou a ausência de alguém ou de algo, a fala ou o silêncio, podem ser interpretados como sinais numinosos. Como observa Peradotto (1969, p. 10), em seu artigo a respeito da recorrência de kledónes na Oresteia, muito do que tem sido visto como ironia dramática em Ésquilo deveria ser reinterpretado como um uso literário da cledomancia ${ }^{1}$. Essa sua afirmação é interessante, porque acusa um desconhecimento das possibilidades do uso que Ésquilo faz da adivinhação em sua tragédia e, consequentemente, aponta para o fato de que conhecer de forma mais aprofundada essas possibilidades e esses usos permitiria mais bem compreender a obra do autor à medida que se dispõe de mais ferramentas para interpretá-la.

Como então distinguir, se possível, e, mais importante, como interpretar, na tragédia de Ésquilo, esses sinais divinatórios? É necessário, primeiramente, procurar compreender o que se entende, no âmbito desta pesquisa, por adivinhação ou arte divinatória.

Mais do que um modo de prever o futuro, a adivinhação é antes um diálogo entre as esferas humana e divina. Os sinais divinatórios têm como sujeito de sua elocução os deuses, cujo ponto de vista expressa um conhecimento numinoso. $\mathrm{O}$ homem tem de interpretar esse conteúdo de forma a adaptá-lo à sua capacidade de compreensão, limitada como está pela finitude de sua condição de homem mortal. Esse diálogo, porém, não é uma via de mão única: ou seja, o homem pode ser surpreendido por uma interpelação numinosa, mas também pode solicitá-la, tal como quando se dirige a um santuário oracular ou sacrifica um animal para obter a anuência divina ao sinal de ataque na linha de combate, por exemplo.

Como observa Crahay (in VERNANT et al., 1974, p. 215), ao fazer uma breve análise dos verbos utilizados na ação oracular e ressaltar a importância desses verbos na

\footnotetext{
${ }^{1}$ De fato, para Peradotto (1969, p. 10), "literary cledonomancy, so far as Aeschylean dramaturgy is concerned, may be a better critical term for the verbal part of what has traditionally (and often vaguely) been called tragic irony".
} 
voz média, o que se pode constatar, segundo o autor, é o estabelecimento de um diálogo, que ele denomina de "diálogo oracular", termo retomado e utilizado também por Vernant (1974).

A expressão "diálogo oracular" é bastante pertinente, mas tem o demérito de reproduzir a supremacia do que se convencionou chamar de adivinhação intuitiva - isto é, a adivinhação inspirada, de que a profetisa de Delfos é a mais exemplar representante - sobre a adivinhação dita técnica - ou seja, a adivinhação que se vale de um repertório de sinais preestabelecidos ${ }^{2}$. O que se propõe aqui é reformular essa expressão empregando o termo "divinatório" no lugar de "oracular", de forma a incluir devidamente nesse diálogo com o divino todas as formas de adivinhação e evitar essa distinção artificial que se faz entre adivinhação intuitiva, inspirada, extática, que se baseia na linguagem humana, por um lado, e, por outro, adivinhação mecânica, dedutiva, que se fundamenta em objetos, animais, fenômenos da natureza. Ainda mais artificial se torna essa distinção quando se procura estudar a adivinhação dentro do contexto de uma representação dramática, em que tudo que restou são as palavras do poeta.

Se a adivinhação é, pois, entendida como um diálogo com o divino, é importante procurar conhecer o funcionamento dos métodos divinatórios, pois estes estabelecem os meios e as regras desse diálogo. Não se trata, porém, de elaborar uma sistematização ou uma categorização descritiva, mas sim de procurar compreender a lógica interna do pensamento que subjaz à possibilidade mesma desse diálogo divinatório.

A adivinhação é um elemento estrutural e estruturante da tragédia de Ésquilo, definindo, ao mesmo tempo, muitas de suas estratégias dramáticas, a peculiaridade de sua poética e sua visão de mundo.

Uma das características mais peculiares à estrutura dramática de Ésquilo é a de um movimento ascendente e prolongado de tensão dramática que culmina com um acontecimento trágico a ser lamentado. Estudos como os de Jacqueline de Romilly ( $\mathrm{La}$ crainte et l'angoisse dans le théâtre d'Eschyle, de 1971) e de Martin L. West (Studies in Aeschylus, de 1990) notabilizaram essa estrutura da tragédia esquiliana. Assim, por

\footnotetext{
${ }^{2}$ Bouché-Leclercq, em Histoire de la Divination dans l'Antiquité, cujo primeiro volume foi publicado em 1879, distingue entre adivinhação indutiva e dedutiva; Halliday, em Greek Divination: A Study of its Methods and Principles, obra de 1913, distingue entre adivinhação intuitiva e indutiva. Ambas as obras foram reeditadas em 2003. Outros autores mais recentes como Flacelière (Devins et oracles grecs, de 1965) e Bloch (La adivinación en la antigüedad, de 1991) também seguem o mesmo tipo de distinção entre as formas de adivinhação.
} 
exemplo, no capítulo denominado "The Formal Structure of Aeschylean Tragedy", West distingue duas fases nas tragédias de Ésquilo - uma de tensão e uma de distensão -, recorrendo para tanto à metáfora de uma bateria: há um primeiro momento de “carregamento" (charging phase), ao longo da qual a tensão e o suspense aumentam, e um momento posterior de "descarregamento" (discharging phase), em que o tão aguardado acontecimento se realiza e se dá lugar às lamentações, às recriminações, às partidas etc.

O que se observa é que essa tensão dramática cresce à medida que surgem no texto indícios cada vez mais inequívocos da certeza e da inevitabilidade do acontecimento trágico, de forma que se poderia dizer que, quanto mais certo e inevitável um acontecimento se torna ao longo da tragédia, mais ele surpreende e comove quando por fim se realiza ${ }^{4}$. Ora, esses indícios, em sua maioria, apresentam-se sob a forma de sinais divinatórios, de modo que o aumento do suspense e da tensão dramática são diretamente proporcionais à aparição, no texto, desses sinais, sejam sob a forma de sonhos, auspícios, pressentimentos, oráculos ou simples imagens poéticas e palavras de sentido ominoso. Observe-se, por exemplo, como, nos Persas, a trágica destruição do exército comandado por Xerxes é prenunciada desde o primeiro verso, com a utilização de um kledón, o ominoso particípio do verbo oíkhomai. A partir de então, como observa Goward (2004, p. 26), "any event in the play becomes heightened because it may be the moment at which the predicted fulfilment is beginning". Também Aélion (1984, pp. 140-1) observa algo importante a esse respeito:

[...] les spectateurs d'Eschyle n'ignoraient rien de la fin avant de venir assister à la représentation au théâtre de Dionysos. Eschyle n'avait pas à chercher comment voiler la clarté trop grande de son anticipation aux yeux des spectateurs. Ce qui import davantage, c'est de savoir si elle demeure voilée aux yeux des personnages du drame. [...] L'opposition entre le savoir des spectateurs, sûrs que rien n'empêchera la réalisation de ce qui est annoncé, et l'attitude ou l'aveuglement des personnages crée une forme de tension qui n'est pas moins forte que la tension créée par l'attente d'un dénouement inconnu.

Porém, além de criar suspense, expectativa, temor, angústia, os sinais divinatórios, ao emoldurarem os acontecimentos, informam e conformam o

\footnotetext{
${ }^{3}$ Observe-se que West não considera que Prometeu Cadeeiro seja da autoria de Ésquilo e, portanto, essa análise estrutural que ele empreende diz respeito apenas às demais seis tragédias supérstites.

${ }^{4}$ Segundo George Steiner (2001, p. 163), esse seria o paradoxo da tragédia. Como observa o autor, "la visión trágica de la literatura griega descansa en esta paradoja insondable: el acontecimiento más previsible, más obediente a la lógica interna de la acción, es también el que más sorprende”.
} 
entendimento desses acontecimentos dos quais são parte integrante. A miríade de sinais divinatórios nos Persas que prenuncia o destino do exército de Xerxes e encontra realização em sua arrasadora derrota são a expressão da justiça de Zeus, que se realizou no curso dos acontecimentos, a despeito da esperança do espectro de Dario de que os oráculos que o predisseram demorassem a se cumprir (Pe. 739-41).

Quanto à poética esquiliana, esta se caracteriza por uma abundante utilização de imagens poéticas, que se sobrepõem umas às outras, formando muitas vezes verdadeiros conglomerados metafóricos, cujo sentido torna-se difícil de deslindar e que rendeu a seu autor a fama que o personagem Eurípides nas Rãs lhe atribui de possuir uma linguagem ininteligível ( $R a$. 923-6), de ser difícil de compreender (oủ pớ $\delta \iota^{\prime} \tilde{T} v, R a$. 928-30) e que deixa estupefato e pensativo até mesmo o próprio deus do teatro ( $R a$. 930-2)! ${ }^{5}$

A complexidade, a obscuridade, a polissemia, a ambiguidade, características que distinguem a poética esquiliana, são justamente características comumente atribuídas aos oráculos e a todas as formas de adivinhação que requerem uma hermenêutica dos sinais divinos.

É comum a asserção de que a ambiguidade oracular é uma criação literária ou uma idealização teórica e que a maioria dos oráculos da vida "real", os oráculos "históricos", seriam os baseados em um modelo binário, isto é, que poderiam ser respondidos com um sim ou com um não, ou em modelos do âmbito do que é preferível,

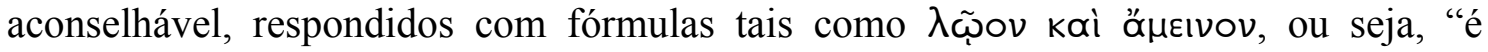
melhor e preferível que se faça tal coisa...". No entanto, ainda que assim o seja, não é em vão que as representações dramático-literárias dos oráculos os caracterizem como sendo fundamentalmente ambíguos, de difícil compreensão, de difícil interpretação. Essa caracterização é um modo de formular e de explicitar o descompasso existente entre a sabedoria divina e o limitado conhecimento humano, entre o ponto de vista divino - mediante o qual se revela um grau de verdade, de conhecimento e de ser próprios aos deuses imortais - e o ponto de vista humano - limitado por um grau de conhecimento, de verdade e de ser próprios aos homens mortais.

\footnotetext{
5 Veja-se também a crítica do personagem de Eurípides, nas Rãs, sobre os prólogos esquilianos. Eurípides, dirigindo-se a Ésquilo, diz o seguinte: "Então me voltarei para os seus prólogos, / de modo que a primeira parte da tragédia / deste homem destro eu ponha à prova primeiro: / pois ele não era claro na

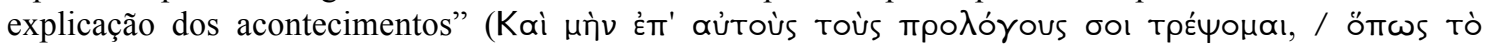

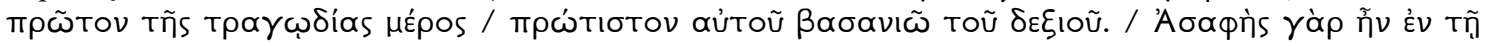

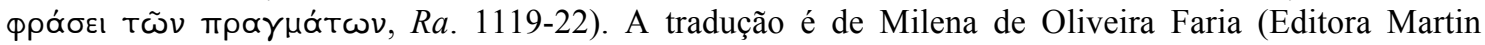
Claret, no prelo).
} 
Sendo assim, a ambiguidade, a dificuldade de percepção e de interpretação desses sinais ou mesmo o erro trágico a que podem conduzir um personagem falam justamente de uma característica essencial do diálogo divinatório: o descompasso entre o conhecimento divino e o humano. Retratar essa ambiguidade dos sinais divinos é um modo de formular e de refletir sobre a relação entre as esferas divina e humana, sobre os limites inerentes à condição humana, sobre a verdade e a justiças divinas, temas cardinais na tragédia esquiliana.

O sentido do trágico em Ésquilo está estritamente ligado ao diálogo divinatório; a hamartia, de acordo com a definição de Crahay (in VERNANT et al., 1974, p. 217), é "une aberration de la connaissance en face du problème que posait l'oracle".

Como o texto esquiliano é repleto de sinais divinatórios - e tais sinais são entendidos, pensados e representados como sendo complexos, polissêmicos, ambíguos, enigmáticos -, a própria urdidura poética de Ésquilo se confunde com esses sinais divinatórios, de modo que as imagens, as metáforas, revestem-se muitas vezes de um valor profético; carregam em si sinais prolépticos. Seu sentido proléptico, porém, se é claro para os espectadores, nem sempre é assim percebido pelos personagens em cena.

Ao analisar o relato sobre Cambises nas Histórias de Heródoto, Crahay (in VERNANT et al., 1974, p. 216) observa que as intervenções de caráter divinatório se espalham ao longo da narrativa. Aparece um primeiro sinal divinatório, que a princípio é deixado de lado, mas que ao final, quando de sua realização, une-se aos demais sinais que igualmente surgiram no curso dos acontecimentos e foram negligenciados pelo rei, mostrando enfim sua força destrutiva. "On songe", diz o autor, "au terme allemand qui sert à rendre une bombe à retardement: Blindgänger".

Algo muito semelhante parece ocorrer nas tragédias de Ésquilo. Há um acúmulo de sinais divinatórios ao longo do drama, os quais muitas vezes passam despercebidos, são negligenciados ou mal interpretados pelos personagens cujo destino eles revelam, de forma que, como um blindgänger, "explodem" inadvertidamente, revelando o seu poder de realização e a sua veracidade.

Nos Persas, por exemplo, a Rainha, ao tomar conhecimento do destino do exército persa, exclama: "Ó visão noturna, manifesta em sonho, / com que clareza me mostraste os males!” (Pe. 518-9) ${ }^{6}$. Do mesmo modo o faz seu companheiro, o rei Dario: "Pheû! Veio veloz o ato de oráculos, a meu filho / Zeus incumbiu cumprir ditas divinas;

\footnotetext{
${ }^{6}$ A numeração dos versos e todas as citações das sete tragédias de Ésquilo correspondem às traduções de Jaa Torrano (2004 e 2009).
} 
eu, porém, / cria que os Deuses as cobrariam em longo tempo" (Pe. 739-41). E, finalmente, Xerxes, ao entrar em cena com suas vestes esfarrapadas: "Ió! / Infeliz sou por esta hedionda / sorte, a mais imprevisível! / Com que crueldade o Nume atacou / o povo persa!” (Pe. 909-12). Já nas Coéforas, diante de seu filho, chega a Clitemnestra o momento do reconhecimento do destino que lhe fora prenunciado em sonhos: "Ai de mim, esta serpente pari e nutri: / era muito adivinho o pavor dos sonhos" (Co. 928-9). E, nos Sete contra Tebas, Etéocles, ao saber que irá confrontar seu próprio irmão, reconhece a inexorabilidade da maldição de seu pai e a veracidade de seus sonhos: "Ferveram as imprecações de Édipo, / assaz verdadeiras visões de espectros / de sonhos, divisoras de haveres pátrios" (Se. 709-11).

Mas a tragédia de Ésquilo não mostra somente as consequências desastrosas para os personagens ao negligenciarem ou mal interpretarem um sinal divino; ela também retrata o esforço interpretativo do ser humano ante a interpelação divina, a atitude hermenêutica do homem frente ao signo, o movimento da ignorância ao conhecimento e o dilema que muitas vezes este se lhe impõe. O texto esquiliano convida seu espectador (ou seu leitor) a espelhar esse mesmo esforço interpretativo dos personagens, essa mesma hermenêutica dos sinais, a adquirir o entendimento do que está acontecendo e a refletir sobre as questões que surgem daí.

Sendo assim, ainda que seja unânime entre os estudiosos a ideia de que a adivinhação em Ésquilo é um elemento importante e recorrente em sua obra, esta tese pretende demonstrar que a real relevância desse elemento em suas tragédias, assim como sua significação para a compreensão das mesmas, ainda não foi valorizada em sua justa medida.

A maioria dos estudos existentes que contemplam o tema da adivinhação pode ser dividida, de forma resumida, em algumas categorias; a saber:

1) Estudos da religião na Grécia antiga, em que se focaliza o seu aspecto religioso e se analisam as relações entre a adivinhação e conceitos tais como acaso, predestinação, destino, livre-arbítrio, onisciência divina.

2) Estudos de história político-social na Grécia antiga, em que se focaliza a sua função social e a relação da adivinhação com a política, dando-se ênfase aos casos de intervenção política através do oráculo de Delfos ou seu papel orientador na fundação das colônias atenienses etc.

3) Estudos dedicados exclusivamente a um tipo de adivinhação ou à adivinhação de modo geral, em que se menciona a sua importância político-religiosa, mas se 
privilegia a descrição, elencando-se as diversas formas de adivinhação, seus usos práticos e métodos, evidenciando-se o seu exotismo, o que há de inusitado, curioso e pitoresco, e exemplificando com oráculos em que fazem parte os jogos de palavras, entre outros.

4) Estudos históricos e arqueológicos, em que se analisam as evidências materiais dos santuários oraculares e as inscrições em que se encontram documentadas perguntas e respostas oraculares. Esses estudos pretendem compreender como realmente funcionavam essas instituições, a história de seu desenvolvimento e de que realmente se compunham as questões que aí se apresentavam.

5) Estudos que privilegiam a relação entre um determinado autor ou gênero literário e a adivinhação, categoria na qual este trabalho pretende se encaixar. Tais estudos de fato são relativamente pouco numerosos e ainda mais escassos são os que se concentram na análise da arte divinatória na obra de Ésquilo.

Vale ressaltar que, em todas as categorias supracitadas, há um predomínio do estudo sobre o oráculo de Delfos. Esse oráculo, pelo que nele há de inexplicável, de intangível, por sua profunda complexidade e por sua enorme importância, ofuscou não somente os demais santuários oraculares como também as demais formas de adivinhação. Sendo assim, Delfos, a Pítia e o que ficou conhecido como adivinhação extática dominam a cena dos estudos sobre a adivinhação. De certa forma, e não sem razão, esse oráculo apolíneo eclipsou todo o resto, e esse processo iniciou-se já na Antiguidade. Veja-se, por exemplo, a defesa que Heródoto faz de Delfos, no episódio do "teste dos oráculos" feito por Creso, no livro II (46-9) das suas Histórias. E os tratados de Plutarco sobre Delfos consagraram essa soberania da forma de adivinhação ali praticada.

No que se refere à adivinhação em Ésquilo, o artigo de Vicaire ("Pressentiments, préssages, prophéties dans le théâtre d'Eschyle", de 1963) é uma referência de abordagem geral da adivinhação na tragédia esquiliana; o livro de Roberts (Apollo and his Oracle in the Oresteia, de 1984) é indispensável para a análise de Apolo e de seu oráculo na Oresteia; o artigo de Cameron sobre a cledomancia nos Sete contra Tebas ("The Power of the Words in the Seven against Thebes", de 1970) é um marco na 
história da interpretação dessa tragédia e o artigo de Peradotto sobre a cledomancia na Oresteia ("Cledonomancy in the Oresteia", de 1969) também se tornou uma referência".

Há ainda artigos pontuais sobre determinadas passagens em Ésquilo, como o estudo de Moreau sobre o sonho de Atossa ("Le songe d'Atossa. Perses, 176-214. Éléments pour une explication de textes", de 1992/1993) e o recente artigo de Catenaccio sobre o sonho de Clitemnestra ("Dream as Image and Action in Aeschylus' Oresteia", de 2011).

E há, obviamente, muitos outros estudos sobre a adivinhação que não necessariamente se encaixam nas categorias supracitadas, como, por exemplo, o estudo de Kugel (1990), intitulado Poetry and Prophecy: The Beginnings of a Literary Tradition, em que se discute a origem comum do poeta e do profeta.

Todos esses estudos fazem diferentes aproximações ao tema e se utilizam de diversos métodos de análise da questão. Igualmente, esta tese se baseia em uma variedade de abordagens críticas e consiste amplamente na leitura atenta do texto trágico. Todavia, algumas diretrizes teóricas e alguns conceitos fundamentais se impõem:

1) $\mathrm{O}$ conceito de pensamento mítico como um pensamento que se caracteriza pelos seguintes traços: a) a oralidade; b) a concretude; c) a importância dos nomes divinos e da palavra em geral; d) o repertório de sinais divinos; e) o nexo necessário entre verdade, conhecimento e existência ${ }^{8}$. Esse é o tipo de pensamento, ou atitude mental, que subjaz à prática divinatória, considerando-se que o pensamento mítico grego tem uma atitude de alerta quanto às aparências do mundo. $\mathrm{O}$ homem está atento aos sinais divinos que o interpelam através das aparências do mundo, ou, dito de outra maneira, está atento às aparências do mundo, porque, nas aparências do mundo, os deuses o interpelam. ${ }^{9}$

2) A noção mítica de deuses como regiões do ser, como aspectos fundamentais do mundo, como formas-fundamento. Esse conceito norteia esta pesquisa em sua abordagem da prática divinatória, da tragédia grega e da cultura grega antiga em geral ${ }^{10}$.

\footnotetext{
${ }^{7}$ Outro trabalho bastante significativo é a tese de doutorado de Marcia Dobson, defendida em Harvard em 1976 e intitulada "Oracular language: its style and intent in the Delphic oracles and in Aeschylus' Oresteia", mas, ainda que esporadicamente citada, permanece anda inédita.

${ }^{8}$ Conferir Torrano (1996), O Sentido de Zeus: O mito do mundo e o modo mítico de ser no mundo.

${ }^{9}$ Vernant, em Mito e Sociedade na Grécia Antiga (1992, p. 91), observa que o homem grego antigo "tem a impressão de [...] que a própria realidade é, no fundo, linguagem. O universo lhe aparece como a expressão das potencias sagradas que, revestidas de formas diversas, constituem a trama verdadeira do real, o ser atrás das aparências, a significação além dos sinais que a manifestam".

${ }^{10}$ Conferir igualmente Torrano (1996).
} 
3) A existência, na tragédia esquiliana, de uma dialética trágica, em que se distinguem e se confundem quatro pontos de vista - o divino, o numinoso, o heroico e o humano $^{11}$. Por meio das diversas formas de adivinhação, os personagens são interpelados pelo nume e nessa interpelação, em que se confrontam diferentes pontos de vista, múltiplas questões se apresentam ao ser humano.

4) $\mathrm{O}$ entendimento de que a adivinhação é fundamentalmente um diálogo com o divino. $\mathrm{O}$ fato de que ela tenha desempenhado na sociedade grega antiga uma função social muito prática e concreta, seja nas decisões políticas, seja no processo de colonização de territórios, seja no dia-a-dia das pessoas comuns, é inegável, mas igualmente inegável é o fato de que, mesmo no seu aspecto mais concreto e mais banal, o diálogo com o divino continua sendo o fundamento de toda prática divinatória.

Esta tese dedica um capítulo a cada uma das sete tragédias supérstites de Ésquilo. Ao final, encontra-se um excurso, escrito concomitantemente com os capítulos, em que se faz um levantamento e um breve estudo do vocabulário essencial da prática divinatória na tragédia esquiliana.

${ }^{11}$ Conferir o estudo introdutório da tradução da Oresteia por Torrano (2004). 
1. OS PERSAS 


\section{OS PERSAS}

Os Persas foi representada em 472 a.C., em Atenas, e é considerada a mais antiga das tragédias supérstites de Ésquilo. De acordo com a didascália, a tetralogia apresentada por Ésquilo era composta ainda de Fineu (Fr. 258-60), Glauco Potnieu (Fr. 36-42) e, possivelmente, do drama satírico Prometeu, o Acendedor do Fogo (Fr. 204-9), sem que houvesse, a princípio, uma conexão temática entre as peças. Os Persas têm como argumento a derrota infligida pelos gregos em Salamina, em 29 de setembro de 480 a.C., ao exército persa, então comandado por Xerxes, fillho do já falecido rei Dario.

A história dessa expedição dos persas contra os gregos é relatada com riqueza de detalhes também por Heródoto nos livros VII e VIII de suas Histórias. No livro VIII, Heródoto diz que "Xerxes envia aos Persas um mensageiro que lhes anunciasse o

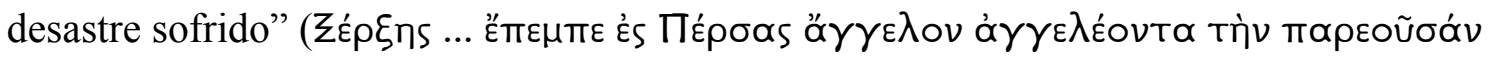
бфı бuнфори́v, Hdt. VIII, 98) ${ }^{1}$, e é a chegada desse mensageiro a Susa e o relato da derrota do exército persa que constituem a ação central dos Persas.

A ação dramática transcorre em Susa, capital do império persa. No párodo, subdividido em párodo anapéstico (Pe. 1-64) e lírico (Pe. 65-154) $)^{2}$, o Coro, composto por anciãos conselheiros do Rei, aguardam com temor e apreensão notícias do poderoso exército que Xerxes levou para conquistar a Grécia. No primeiro episódio (Pe. 155531), a Rainha ${ }^{3}$ entra em cena e relata ao Coro o sonho perturbador que teve naquela noite e o auspício que avistou ao se levantar, sendo aconselhada pelo Coro a invocar a proteção de seu falecido marido, o rei Dario. Em seguida, surge um Mensageiro com as notícias da completa derrota do exército persa e da sobrevivência de Xerxes. O Coro e a Rainha lamentam o infortúnio, enquanto o Mensageiro narra em detalhes o confronto entre gregos e persas. O Coro, no primeiro estásimo ( $P$ e. 532-97), lamenta a atitude imprudente de Xerxes e as perdas sofridas. No segundo episódio (Pe. 598-622), a Rainha entra novamente em cena portando oferendas aos deuses ínferos e, no segundo estásimo (Pe. 623-80), o Coro profere os cantos rituais necessários à invocação do espectro de Dario. No terceiro episódio (Pe. 681-851), o espectro de Dario aparece e,

\footnotetext{
${ }^{1}$ Tradução de José Ribeiro Ferreira e Carmen Leal Soares (2002).

${ }^{2}$ A numeração dos versos e todas as citações das sete tragédias de Ésquilo correspondem à tradução de Jaa Torrano (Oresteia: 2004 e Os Persas, Os Sete contra Tebas, As Suplicantes, Prometeu Cadeeiro: 2009).

${ }^{3}$ Ésquilo não menciona o nome da viúva de Dario, mas Heródoto a denomina "Atossa, filha de Ciro" (Hdt. VII, 2).
} 
informado da terrível derrota sofrida pelo exército, diz que um oráculo se cumpriu e seu cumprimento foi precipitado pela hýbris de Xerxes, ao ter construído uma ponte sobre o Helesponto para a passagem de seu exército à Europa e ao ter desrespeitado os templos das cidades conquistadas. Aconselha, então, os persas a não mais atacarem a Grécia e prenuncia, ainda, a derrota em Plateia do exército remanescente. O Coro recorda, no terceiro estásimo ( $P$ e. 852-908), o exitoso governo de seu antigo rei e daqueles que o precederam. No êxodo (Pe. 909-1076), Xerxes finalmente entra em cena e, juntamente com o Coro, entoa um longo e pungente lamento.

Como se verá, um diálogo divinatório permeia a tragédia e os sinais divinos concentram-se particularmente no párodo e na primeira cena do primeiro episódio, antes da chegada do Mensageiro, bem como no terceiro episódio, quando da aparição do espectro de Dario. Tais sinais - cuja presença e assertividade crescem à mesma proporção que a tensão dramática - prenunciam, desde o primeiro verso, a derrota do exército persa em Salamina e, uma vez anunciada, esses sinais, ao mesmo tempo em que aportam uma interpretação para essa derrota, passam a prenunciar os revezes que os persas hão de sofrer na vindoura batalha de Plateia, pois o destino funesto do exército persa não se esgota no presente, mas invade e atemoriza o porvir.

O diálogo divinatório nesta tragédia dá-se, como se poderá observar, mediante palavras e imagens proféticas, o sentimento pressago dos membros do Coro, o sonho e o auspício vistos pela Rainha, a referência a antigos oráculos, as profecias do espectro de Dario e demais elementos portadores de sentido numinoso. Por meio desse diálogo divinatório, atinge-se não somente uma bem elaborada estrutura dramática, mas também se realiza uma interpretação de um dos acontecimentos mais significativos para os gregos do século V a.C., além de uma profunda reflexão sobre os limites do exercício de poder e sobre a inexorabilidade da justiça de Zeus. 


\section{1) Um maligno pressago ímpeto}

Ésquilo inicia o párodo dos Persas citando quase literalmente o verso inicial de uma tragédia de Frínico intitulada Fenícias, representada quatro anos antes e que também versava sobre a derrota do império persa em Salamina. Exclamado por um eunuco, que preparava os assentos para os conselheiros do império persa, o primeiro

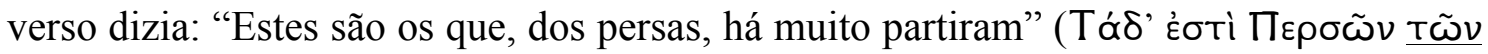
$\pi \alpha \dot{\alpha} \alpha \iota$ $\beta \varepsilon \beta \eta \kappa o ́ t \omega \nu)^{4}$. Ésquilo, no entanto, utiliza-se de outro verbo para indicar a ausência dos persas e retira o advérbio $\pi \alpha \dot{\alpha} \lambda \propto$ I: "Estes, dos persas que se foram” (Tá $\delta \varepsilon$

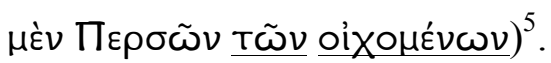

Trata-se de uma modificação bastante significativa, que ultrapassa a mera adequação do verso à métrica do párodo anapéstico. Os verbos ßáivw, adotado por Frínico, e ol'xou๙ı, utilizado por Ésquilo, têm ambos o sentido tanto de "partir" quanto

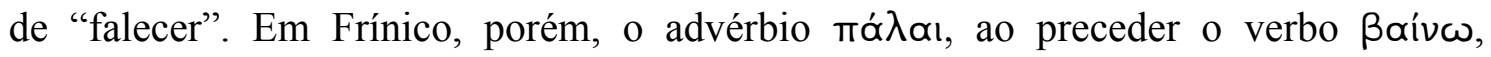
evitaria, a princípio, um possível sentido ominoso para o verbo. Como só restou o verso inicial dessa tragédia perdida, não há como saber ao certo. Já no verso inicial de Ésquilo, há claramente um sentido ambíguo no uso do verbo oỉxouđı. Por sua vez, essa ambiguidade estende-se para além da ambiguidade própria à função poética do texto, visto que era familiar aos espectadores de Ésquilo uma forma de adivinhação denominada "cledomancia" $\mathrm{K} \lambda \eta \delta \delta$ é $v$ é uma palavra cuja duplicidade de sentido é entendida por quem a ouve como um sinal divino, um presságio.

Na palavra cledomântica, convergem um sentido ordinário, que exprime o ponto de vista humano de quem a pronuncia, e um sentido numinoso, que exprime um ponto de vista divino e que, por isso, constitui-se, para quem a ouve, em um presságio. Assim,

\footnotetext{
${ }^{4}$ A edição do fragmento é de Snell (1971) e a tradução é nossa.

${ }^{5}$ Conferir o anexo "A Word in the Persae" no livro de Winnington-Ingram (1983, pp. 198-9).

${ }^{6} \mathrm{O}$ termo "cledomancia" (formado pela junção de $\left.\kappa \lambda \eta \delta \omega \dot{\nu}+\mu \alpha \nu \tau \varepsilon i ́ \alpha\right)$ não se encontra dicionarizado em língua portuguesa. Segue-se, aqui, a tendência das demais línguas que compõem a bibliografia deste trabalho: os autores de língua espanhola utilizam igualmente o termo "cledomancia" ou ainda "cledonomancia"; os de língua inglesa, "cledomancy" ou "cledonomancy"; os de língua francesa, "clédonomancie" ou "clédonisme"; os de língua italiana, "cledomanzia", "cledonomanzia" ou "cledonismo". Entre os autores antigos, não há uma denominação específica para a cledomancia;

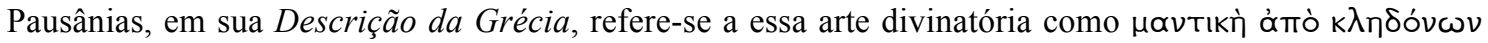
(IX, 11, 7). A palavra $k \lambda \eta \delta o v o \mu \alpha v \tau \varepsilon i ́ \alpha$ não é empregada por nenhum autor grego antigo e é usada esparsamente por autores gregos modernos, sendo que também, atualmente, não se encontra dicionarizada.
} 
quando, por exemplo, na Odisseia de Homero, os pretendentes, ignorando que se dirigiam a Odisseu, disseram-lhe "Hóspede, Zeus te conceda e as demais sempiternas deidades, / o que no espírito almejas e o peito anelar de mais grato"7 (Zeús toı Soín,

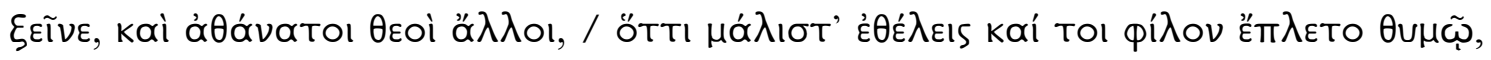
Od. XVIII, 112-3), Odisseu percebeu nessas palavras um sentido numinoso, o qual the prenunciava a realização de seu maior desejo, a morte dos pretendentes, razão pela qual

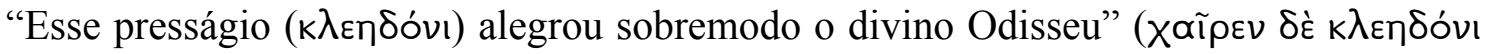

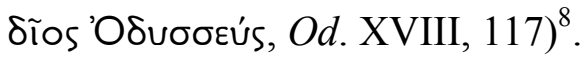

Da mesma forma, do ponto de vista humano do Coro, o sentido do verbo ol’Xouaı é o de que os persas partiram, ausentaram-se, mas, do ponto de vista divino, esse verbo tem um sentido numinoso e prenuncia a perda do exército. Esse prenúncio encontra cumprimento quando o Mensageiro, no primeiro episódio, ao relatar a notícia da derrota persa, retoma o mesmo verbo ao exclamar: "A flor dos persas se foi na

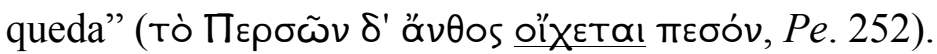

A ambiguidade cledomântica presente nesse primeiro verso da tragédia é, contudo, momentaneamente desfeita no segundo com a presença do adjunto adverbial

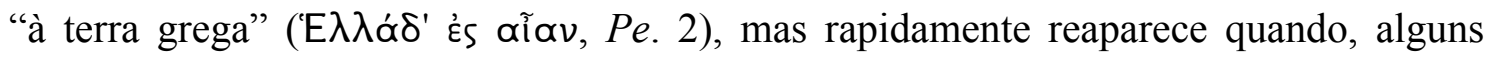
versos depois, o Coro retoma o mesmo verbo ao dizer "já / um maligno pressago ímpeto

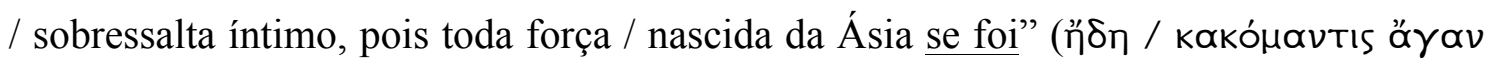

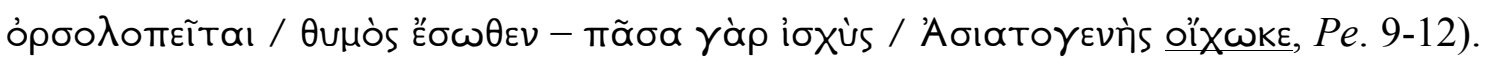
Aqui, o aspecto ominoso do verbo é reforçado, visto que aparece antecedido de um outro sinal divinatório, que é o mau pressentimento de que fala o Coro.

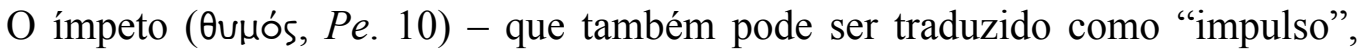
"pensamento", "sentimento" - é descrito pelo Coro como um "adivinho maligno"

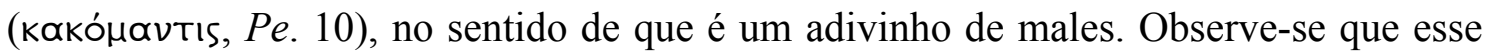

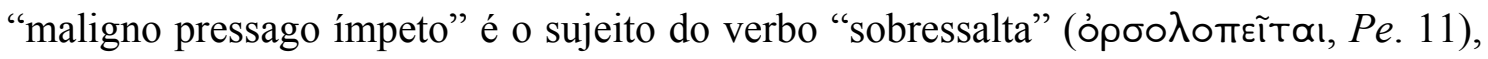
que se encontra na voz médio-passiva. Trata-se, assim, da descrição de uma forma de adivinhação em que os sinais divinatórios manifestam-se mediante um sentimento

\footnotetext{
${ }^{7}$ As citações da Ilíada e da Odisseia correspondem às traduções de Carlos Alberto Nunes (2004 e 2001, respectivamente), exceto quando indicado.

8 A cledomancia, como se vê, encontra-se presente já na epopeia homérica. Homero utiliza indistintamente os termos $\kappa \lambda \eta \delta \omega \dot{v}$ e $\phi \eta ́ \mu \eta$ para designar as palavras das quais seus heróis depreendem

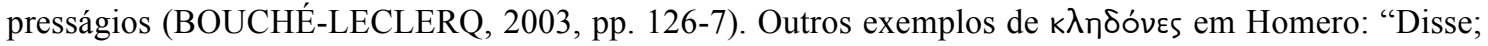

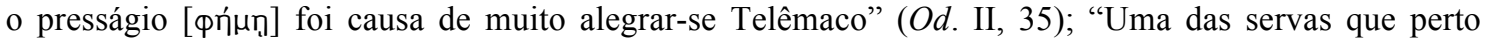
moíam, lhe disse o presságio [фń́n v]" (Od. XX, 104); e "Isso disse ela; o divino Odisseu muito com o

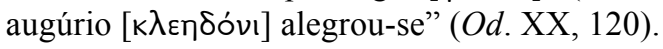


vaticinante que possui e domina a quem o tem e de que o homem não é o sujeito agente, mas o sujeito paciente. Assim, a dimensão do sentimento também constitui um suporte para a revelação de sinais divinos e, consequentemente, para a expressão de um ponto de vista divino.

Esse mau pressentimento acomete o Coro ao pensar no regresso do rei e de seu exército, de que não se tem notícia, pois, como afirma: "nenhum mensageiro, / nenhum

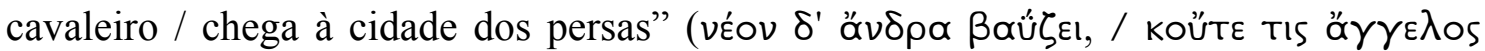

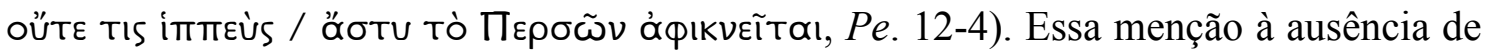
mensagens tanto justifica o mau pressentimento do Coro quanto cria (ou reforça) a expectativa da chegada de um mensageiro. Barrett (2004, pp. 242-3) observa que, nesta passagem, Ésquilo se utiliza do recurso da "apresentação através da negação" (presentation-through-negation device); isto é: mencionar que nenhum mensageiro chegou seria uma forma de reconhecer a expectativa da audiência de que um mensageiro já deveria ter chegado trazendo notícias da guerra.

Nesse sentido, é interessante observar que, em sua narrativa, Heródoto diz que, para comunicar aos seus a vitória que representou a tomada de Atenas, "Xerxes enviou

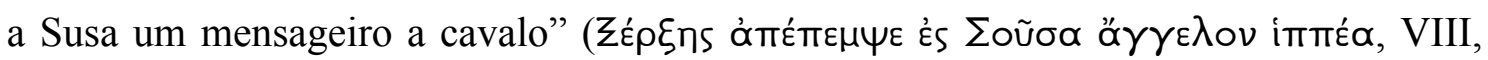
54), e, ao relatar o envio de um segundo mensageiro persa com a notícia da derrota naval em Salamina, descreve o sistema persa de envio de mensagens, nomeia-o e

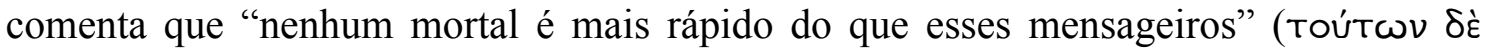

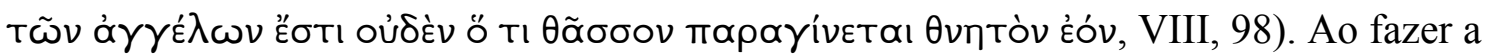
comparação entre o primeiro e segundo mensageiro, o historiógrafo ainda fornece uma descrição da reação dos persas diante da mensagem de cada um: a notícia da tomada de Atenas "encheu de tanto contentamento os Persas deixados na pátria que cobriram todas as ruas com ramos de mirtos, queimaram aromas e as pessoas entregaram-se a festejos e

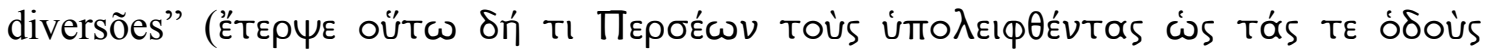

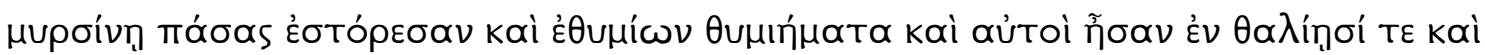

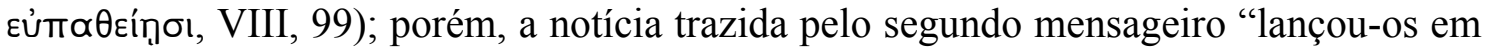
tal consternação que todos rasgaram as vestes e soltaram gritos e lamentos sem fim"

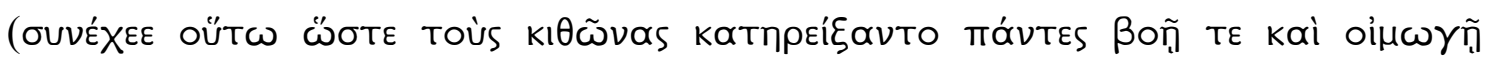

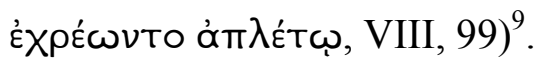

\footnotetext{
${ }^{9}$ Tradução de José Ribeiro Ferreira e Maria de Fátima Silva (2002).
} 
Dentre as diferenças que se encontram nos relatos de Ésquilo e de Heródoto sobre esse episódio de grande importância para a história da Atenas do século $\mathrm{V}$, uma é justamente a ausência de um primeiro mensageiro anunciando a tomada de Atenas, já que em Ésquilo só aparece o mensageiro que anuncia a derrota em Salamina. Essa diferença é bastante eloquente no que diz respeito à poética esquiliana. O motivo dessa ausência nos Persas deve-se à própria poética esquiliana, cuja estrutura dramática é a de um movimento crescente do temor e da angústia, sentimentos estes que se expressam sob a forma de um mau pressentimento e se intensificam com toda sorte de sinais divinatórios ${ }^{10}$. Sendo assim, a própria ausência do mensageiro se converte em mais um sinal numinoso a prenunciar a derrota do exército persa.

Para apaziguar o sobressalto de um coração vaticinante e a angústia que lhe inspira a ausência de mensagens, o Coro evoca a partida do grandioso exército, listando os nomes de seus comandantes e os povos que compõem o magnífico império e descrevendo o grande líder dessa multidão incontável de homens. Trata-se de uma longa lista, em que figuram 17 nomes próprios e cinco povos: os próprios persas ( $P$ e. 21-32), os egípcios (Pe. 33-9), os lídios (Pe. 41-8), os mísios (Pe. 49-52) e os babilônios (Pe.

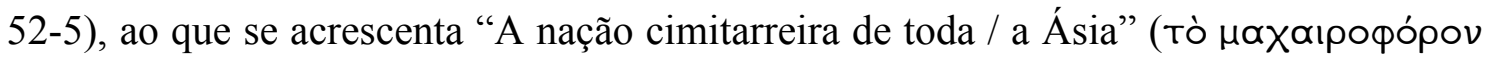

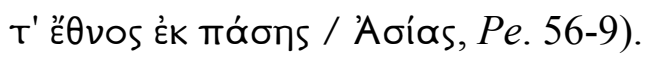

O efeito dramático obtido, por uma ironia trágica, é, no entanto, exatamente o oposto. Primeiramente, note-se que o Coro finaliza a enumeração dos guerreiros e de

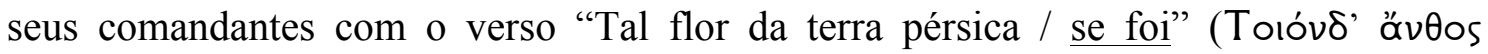

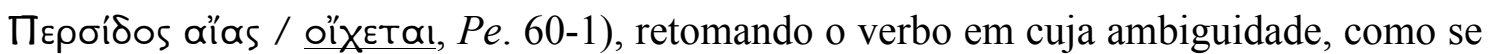
viu, reside um $k \lambda \eta \delta \omega$, um sinal divino, de modo que os nomes recém-arrolados pelo Coro adquirem de pronto uma conotação fúnebre, como se os Fiéis tivessem acabado de declamar uma lista de nomes de pessoas finadas, sobrepondo-se, desse modo, um tom ominoso a um tom ufanista ${ }^{11}$. Além disso, o Coro finaliza dizendo que todos esses homens que "se foram" é a razão pela qual "toda a terra asiática nutriz chora" (тépı

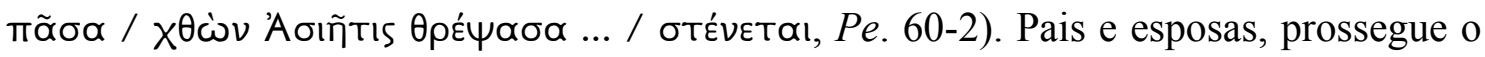
Coro, estão saudosos e temerosos pelo tempo que se alonga e por isso o lamento, mas é notável a justaposição que há entre "A nação cimitarreira de toda / a Ásia” (тò

\footnotetext{
${ }^{10}$ Já em uma poética como a de Sófocles, poder-se-ia imaginar a chegada do primeiro mensageiro, a que se seguiria um canto de júbilo - constituindo, assim, um anticlímax -, seguida da chegada do segundo mensageiro, a que se sucederia, por sua vez, o lamento da catástrofe.

${ }^{11}$ Para Anderson (1972, p. 169), o primeiro catálogo de chefes persas possui um tom ufanista, mas ominoso; o segundo, um tom lutuoso; e o terceiro, um tom de reprovação.
} 


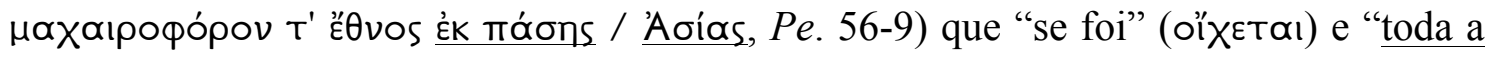

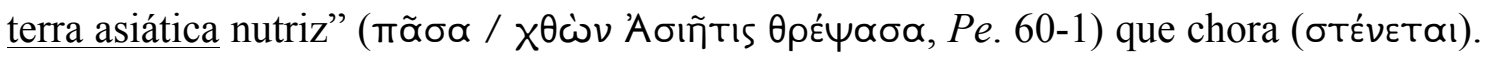
Essa imagem de total ausência justaposta a um total lamento é um prenúncio do que irá dentro em breve acontecer quando da chegada do Mensageiro ${ }^{12}$.

Esses nobres homens e seu grande guia, canta o Coro na primeira estrofe do párodo lírico, perpetraram um feito audacioso: a construção de uma ponte sobre o Helesponto, pela qual pudessem chegar à Europa ${ }^{13}$. O Coro a descreve, no entanto,

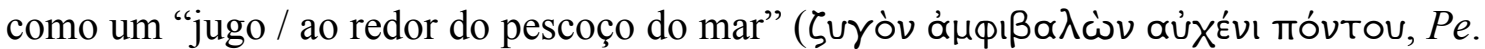

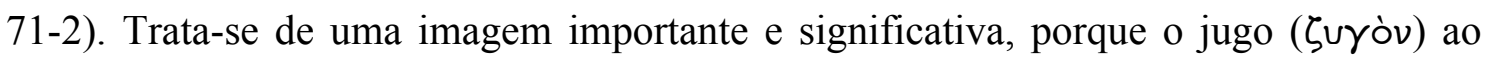
redor do pescoço evoca a ideia de uma submissão que se impõe à força, de um aprisionamento, de uma domação de algo que não pode ser nem submetido, nem aprisionado, nem domado, visto que se trata de uma instância divina.

O jugo era a principal peça nos arreios dos animais para a cavalgadura ou para o trabalho de carga (DUMORTIER, 1975, p. 12). Seu sentido metafórico é o de servidão, escravidão, dominação (ITALIE, 1964, p. 124), o que fica evidente quando, vinte versos antes, o Coro diz: "Dizem os vizinhos do sagrado Tmolo / que lançarão jugo servil

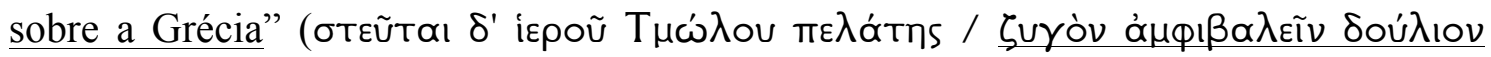
'E $\left.\lambda \lambda \alpha_{\alpha} \delta \mathrm{I}, P e .49-50\right)$. Hogan (1984, pp. 222-3) observa que, embora a imagem do jugo seja uma imagem comum em Ésquilo e tenha outros sentidos ${ }^{14}$, o poeta a utiliza nesta tragédia como um símbolo do despotismo persa, de modo que, nesta passagem sobre a construção da ponte sobre o Helesponto, "submeter ao jugo" significa sujeição política. É certo que esse aspecto político da imagem do jugo está presente e se faz mais evidente no sonho da Rainha e também quando, no primeiro estásimo, o Coro diz que, destruído

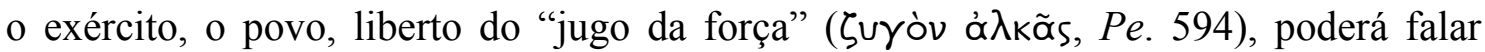
livremente. Porém, tão ou mais importante do que o aspecto político da imagem do jugo é seu aspecto sacrílego, principalmente nesta passagem. Há de se lembrar que, para o

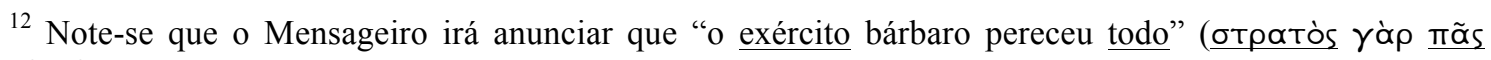
ö $\lambda \omega \lambda \varepsilon \beta \alpha \rho \beta \alpha ́ \alpha \omega \nu, P e .255)$; alguns versos adiante, ele diz novamente que "todo o exército / pereceu" (

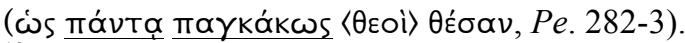

${ }^{13}$ De acordo com Heródoto (VII, 33-4), a ponte foi construída entre Ábidos - uma antiga cidade da Mísia, na Ásia Menor, situada no atual cabo Nagara, na costa asiática - e uma ponta de terra, que, do outro lado, na costa europeia, à frente de Ábidos, se situava entre a antiga cidade de Sestus e a cidade de Máditos (atual Maydos).

${ }^{14}$ Cf. Dumortier (1975a, pp. 12-26). Para o helenista, a imagem do jugo é a principal metáfora utilizada por Ésquilo nos Persas e, embora figure na obra de outros autores com o mesmo sentido, é o poeta de Elêusis quem irá desenvolvê-la e utilizá-la de forma mais pungente e original.
} 
pensamento mítico, o exercício da política, em todas as suas formas, dá-se pela participação em Zeus, que é o fundamento de todo exercício do poder.

Há, dessa forma, um sentido ominoso nessa imagem, numa clara alusão a uma atitude transgressiva, a uma hýbris, por parte de Xerxes, como o espectro de Dario, no terceiro episódio, irá confirmar ao qualificar o ato de seu filho de audácia ( $\theta$ páoøı, Pe. 744), de uma doença da mente (vóoos $\rho \rho \varepsilon v \tilde{\omega} v, P e .750$ ), de uma afronta a Posídon e aos demais deuses (Pe. 750).

Essa mesma ideia de que a construção da ponte sobre o Helesponto comporta uma atitude impiedosa por parte de Xerxes está presente em Heródoto e encontra expressão no episódio narrado pelo historiógrafo por ocasião da travessia do Rei à Europa. Segundo Heródoto, quando Xerxes ordenou a construção de pontes sobre o Helesponto para unir a Ásia à Europa, encarregou de tal missão os fenícios, que utilizaram na construção cabos de linho branco, e os egípcios, que utilizaram cabos de papiro. Finalizada a obra, sobreveio uma tempestade que a destruiu. Foi então que Xerxes mandou açoitar o mar, como se narra a seguir:

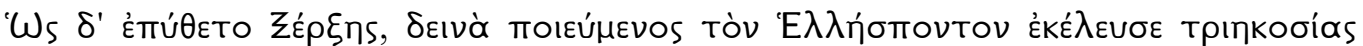

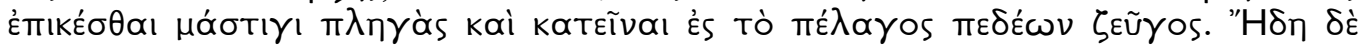

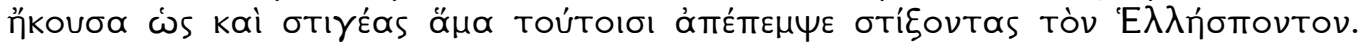

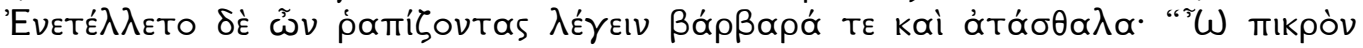

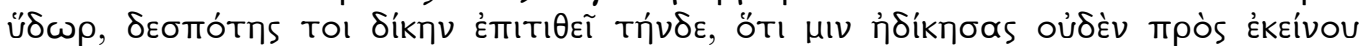

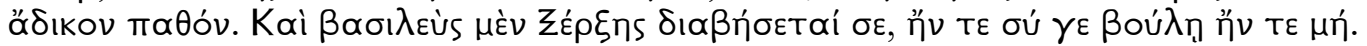

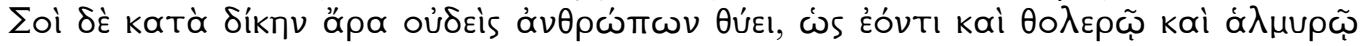

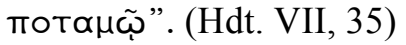

Informado desse fato, Xerxes, furioso, mandou castigar o Helesponto com trezentas chicotadas e lançar ao mar um par de travões. Ouvi dizer até que ele tinha mandado juntamente com os executores dessas ordens pessoas incumbidas de marcar o Helesponto com um ferro em brasa. É certo, porém, que ele ordenou aos encarregados de açoitá-lo que cumprissem as suas ordens pronunciando as seguintes palavras bárbaras e arrogantes: "Água amarga! Nosso senhor te inflige este castigo porque o ofendeste sem ter sofrido da parte dele ofensa alguma. O rei Xerxes te atravessará, queiras ou não. É muito justo que nenhum homem te ofereça qualquer sacrifício, pois és apenas um rio turvo e salobro" ${ }^{15}$.

Essa imagem da imposição do jugo e da domação, que no texto esquiliano aponta para uma atitude impiedosa por parte de Xerxes e por isso tem um sentido ominoso, irá ressurgir no sonho descrito pela Rainha, revelando, assim, a sua verdadeira dimensão profética.

${ }^{15}$ Tradução de Mário da Gama Kury (1988, 2a . ed.). 
A seguir, o Coro descreve Xerxes e, ao retratá-lo como o grande guia da expedição, observa-se uma sobreposição da figura do Rei à figura do deus Ares. Xerxes na primeira antístrofe é descrito como o "guia impetuoso da Ásia multiviril" ( um epíteto tradicional de Ares em Homero ${ }^{16}$ - e, na segunda estrofe, diz-se dele que, "instigando o carro sírio, / conduz o hábil arqueiro Ares / contra ínclitos lanceiros"

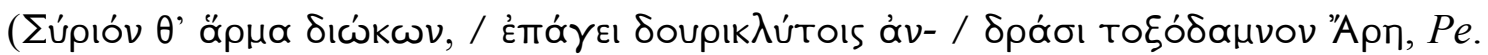
84-6). Tanto essa imagem de Xerxes como uma epifania do deus Ares quanto o verso

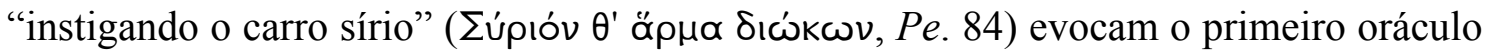
entregue por Delfos à delegação ateniense por ocasião da invasão persa.

Heródoto, no livro VII, reproduz integralmente as palavras da Pítia, as quais desvelavam aos atenienses um futuro catastrófico, em que tudo seria destruído pelo fogo

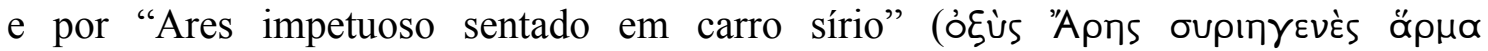
$\delta เ \omega \dot{\kappa} \omega \nu)^{17}$.

Há muito ceticismo sobre a autenticidade dos oráculos délficos reproduzidos por Heródoto e discute-se a influência que o texto de Ésquilo pode ter exercido sobre essa passagem do historiógrafo, mas o fato é que dificilmente o oráculo de Delfos não teria sido consultado em ocasião tão premente e de tamanha importância e dificilmente sua resposta não teria sido conhecida pelos cidadãos atenienses. Para Bowden (2005, p. 102), "this is probably the most well-known consultation of Delphi in Greek history". Standford (1942, p. 42) acredita que os oráculos da época da invasão persa eram provavelmente familiares a qualquer cidadão ateniense e que encontrar alusão a estes

\footnotetext{
${ }^{16} \mathrm{Na}$ Ilíada, o epíteto seguido do nome do deus - Đoũpos "Apns - é recorrente: V, 30, 35, 355, 454, 507 , 830, 904; XV, 127, 142; XXI, 406; XXIV, 498.

${ }^{17} \mathrm{O}$ oráculo completo diz o seguinte: "Por que estais aí assim, homens sem sorte? / Fugi, e já, de vossa terra e das alturas / dessa vossa cidade circular; fugi / para os confins da terra; nem vossa cabeça / nem vosso corpo tem firmeza; nem as pontas / de vossas pernas nem de vossas mãos nem nada / entre elas há de ser poupado; tudo está / em lamentáveis condições e destruído / por um incêndio e por Ares impetuoso / sentado em carro sírio; ele vai arruinar / além de tua fortaleza muitas outras / e logo entregará ao fogo violento / muitos templos dos deuses, e suas imagens, / de pé, estão banhadas de suor e trêmulas / de espanto, e do alto teto corre sangue negro, / sinal de males certos. Ide do lugar / santo e enfrentai vossos

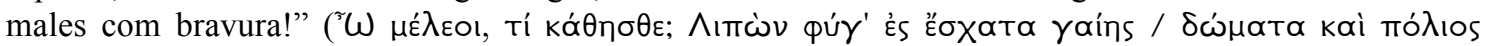

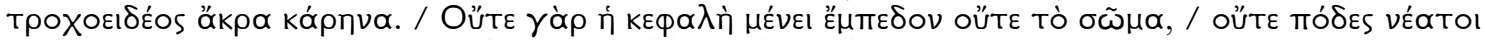

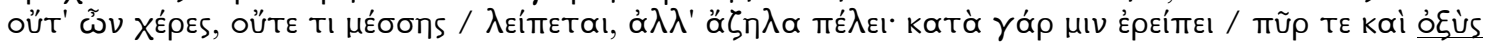

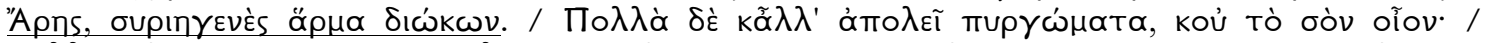

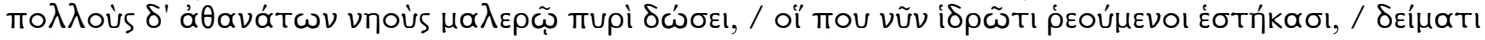

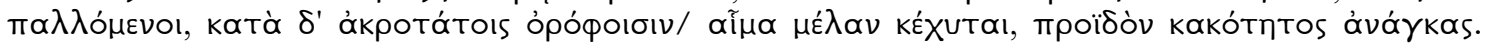

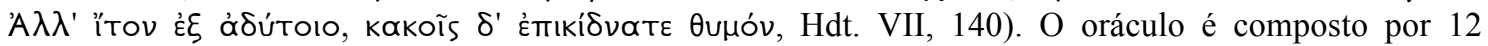
hexâmetros. A tradução é de Mário da Gama Kury (1988, 2a . ed.). Crahay (1956, p. 296) chama a atenção para o tom épico, de influência homérica na composição dos hexâmetros. Quanto à influência homérica na linguagem oracular, conferir o artigo de Ibáñez (1988).
} 
em Ésquilo é algo esperado. Para Couch (1931, p. 273), Ésquilo claramente usa essa expressão "instigando o carro sírio" com a certeza de que os espectadores irão ter em mente o alarmante oráculo délfico. Rosenbloom (2006, p. 43) também não tem dúvidas de que Ésquilo faz uma alusão proposital ao oráculo délfico e acredita que essa alusão sugere a data de circulação do oráculo: entre 481/80 e 473/72 a. $\mathrm{C}^{18}$.

Ora, se o conteúdo desse primeiro oráculo entregue aos teoros era, muito provavelmente, familiar aos cidadãos atenienses, da mesma forma o era o do segundo oráculo que lhes foi entregue.

Ainda de acordo com Heródoto (VII, 141), os teoros atenienses, tomados de grande aflição pelas palavras que lhes foram transmitidas pela Pítia, seguiram o conselho de um notável cidadão de Delfos e consultaram novamente o oráculo na qualidade de suplicantes, rogando a Apolo um vaticínio mais favorável e ameaçando o deus de permanecerem no templo até a morte, o que traria uma terrível poluência ao santuário. Foi-lhes entregue, então, um segundo oráculo, mais propício, cuja interpretação astuta de Temístocles garantiu a vitória naval em Salamina - o famoso oráculo do "muro de madeira"19.

Crahay (1956, p. 298) faz uma observação interessante, a de que os dois oráculos são complementares: "Quant au contenu de ces vaticinations, il me paraît clair que les deux oracles forment un tout: leur portée sembable, leur habile gradation, leur similitude d'images et de style indiquent une conception unique". Bowden (2005, p. 106), seguindo a sugestão de Crahay, afirma que "it is reasonable to suggest that the two respondes quoted by Herodotus are actually halves os a single verse-oracle of twentyfour lines".

\footnotetext{
${ }^{18}$ Quanto à dificuldade de datação das respostas da Pítia, conferir o artigo de Evans (1982).

${ }^{19}$ O oráculo diz o seguinte: "Palas não pode aplacar totalmente Zeus / Olímpio, embora se disponha a lançar mão / para movê-lo de palavras numerosas / e convincentes; ela será tão inflexível quanto o aço: / quando o inimigo tiver conquistado tudo / que fica entre a colina de Cêcrops e o antro / de Citairon divino, Zeus onividente / dará à Tritogênia um último reduto / inexpugnável de madeira; ele será / a tua salvação e de teus filhos todos. / Não esperes quieta os homens a cavalo / nem as levas de infantaria que virão / do interior. Vamos! Recua! Dá as costas! / Inda virá o dia em que terás poder / para enfrentá-los todos e para vencê-los! / Por ti, divina Salamina, morrerão / os filhos das mulheres! Que isto aconteça /

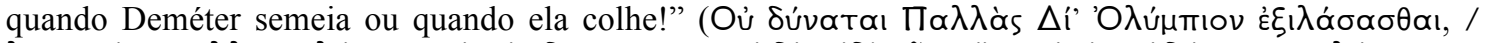

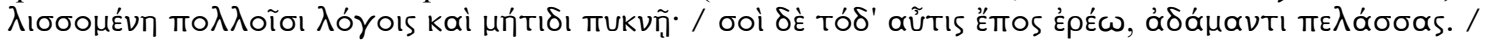

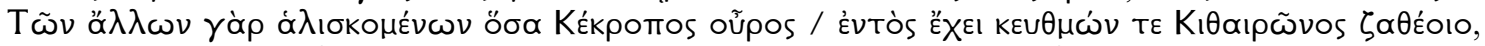

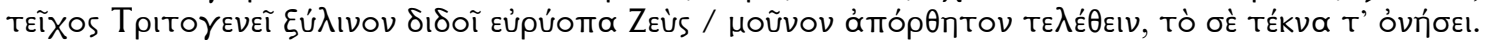

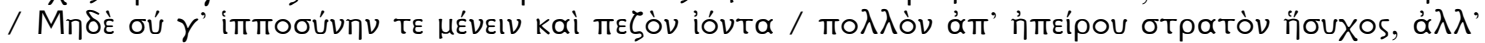

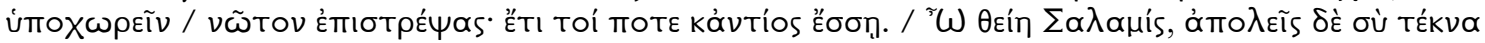

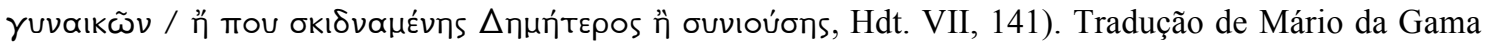
Kury (1988, 2a . ed.). Também esse oráculo é composto por 12 hexâmetros.
} 
De qualquer forma, é inegável que esses dois oráculos fazem parte de um mesmo diálogo oracular, de modo que, se a descrição de Xerxes nos Persas como uma epifania do deus Ares e o verso supramencionado aludem ao primeiro oráculo recebido pelos atenienses, este, por sua vez, alude à sua contraparte, isto é, ao segundo oráculo, em que a possibilidade da derrota persa é contemplada. Há assim uma ligação indissolúvel entre o oráculo de Apolo em Delfos e o desfecho da guerra.

Essa imagem quase monstruosa de Xerxes - como uma epifania de Ares que

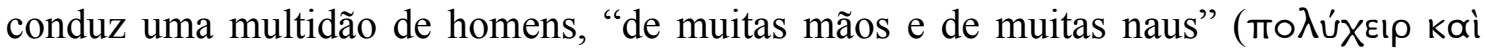
по入uvaútns, $P e .83$ ), e que caminha em direção à Europa para destruí-la - colocada como está entre a menção à construção da ponte como um jugo ao redor do pescoço do mar e entre a alusão ao diálogo oracular que se deu em Delfos na ocasião, remetendo-se assim ao seu desfecho, ironicamente denota que essa destruição causada por Ares irá se abater não sobre os gregos mas sobre quem o conduz, isto é, sobre os próprios persas.

Essa alusão ao oráculo pítio é, portanto, um elemento relevante, ainda que sutil, e que se soma a outros no párodo para prenunciar a catástrofe sofrida pelos persas. Menos sutil e mais evidente, no entanto, é o uso recorrente, no párodo, de palavras que

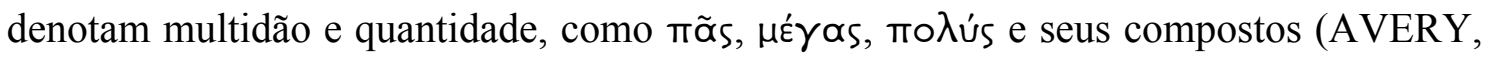
1964, p. 176), de modo a enfatizar principalmente a grandeza, mas também a riqueza do exército persa. Tanto Ésquilo quanto Heródoto ressaltam essas duas características peculiares ao exército e ao povo persa. Para Saïd (1998a, p. 321), na obra dos dois autores, "o poderio persa baseia-se antes de mais nada e sobretudo em número".

Os números e a riqueza persas em Heródoto são realmente dignos de nota. $\mathrm{O}$ historiógrafo relata que o contingente do exército persa totalizava cinco milhões e duzentos e oitenta e três mil e duzentos e vinte homens e levou sete dias e sete noites para atravessar, ininterruptamente, as pontes construídas sobre o Helesponto (VII, 56); vários rios secaram por terem saciado a sede dos soldados (VII, 187) e muitas cidades se viram totalmente desprovidas de víveres por terem tido de alimentar o Rei e suas tropas (VII, 118-9). Além disso, entre os despojos de guerra, foram encontrados inúmeros objetos de ouro e prata pertencentes aos persas, tais como tendas, leitos, crateras, taças, vasos, caldeirões, braceletes, colares e espadas (IX, 80).

Ésquilo também salienta esses dois mesmos aspectos do poderio persa. Assim, no párodo, chama-se atenção à riqueza quando o Coro se refere às "multiáureas sedes"

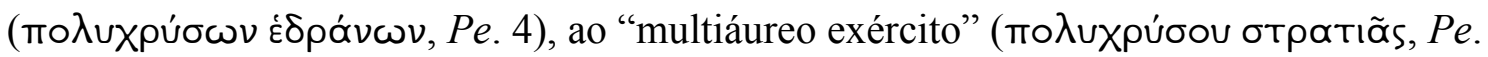

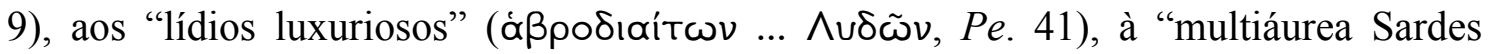




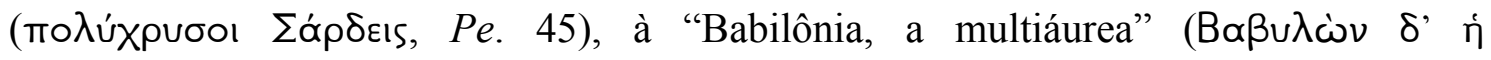

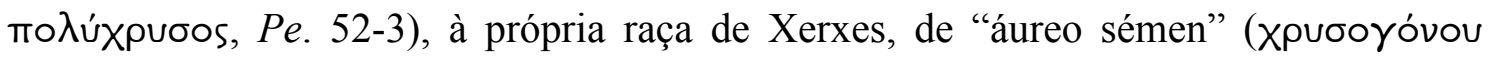
$\gamma \varepsilon v \varepsilon \tilde{\alpha} s, P e .80)$. E o Coro destaca também a multidão e a quantidade, referindo-se ao

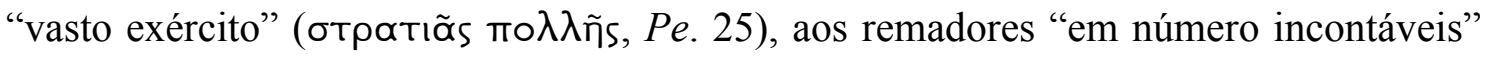

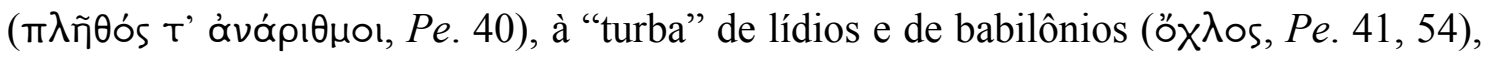
aos "muitos carros" (

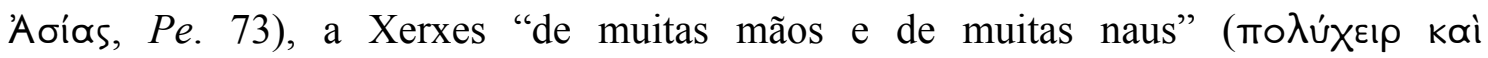

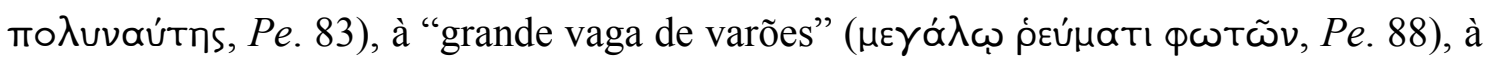

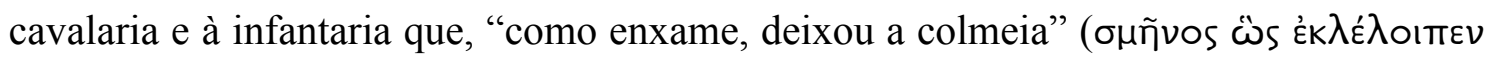
$\mu \varepsilon \lambda ı \sigma \sigma \tilde{\alpha} \nu, P e .127-8)$.

Para Avery (1964, p. 176), essa recorrência é um expediente utilizado por Ésquilo para, por um lado, magnificar o poder e a riqueza do império persa e, por outro, após a notícia da derrota, enfatizar a magnitude do desastre sofrido. Mas Kelley (1979, p. 213-4) vai além e percebe nessa insistência na quantidade e na opulência persas um elemento ominoso, uma vez que todas as referências ao grande número do exército culminam, na fala de Dario, no composto úmepró $\lambda \lambda$ ous, "os numerosos demais" (Pe.

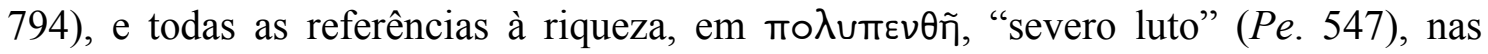
palavras do Coro.

Para se compreender como essas palavras que denotam excesso numérico e riqueza excessiva podem pressagiar um desastre, é necessário ter em mente uma doutrina comum à piedade grega - e particularmente presente nos cantos corais de Ésquilo - de que a grande riqueza é intrinsecamente iníqua e prejudicial a quem a possui, pois abre caminho para a transgressão (ü $\beta$ pis), despertando assim a recusa dos

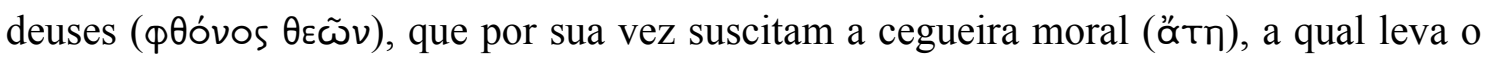
homem a agir contra seus verdadeiros interesses, por não ser capaz de percebê-los, e cujo resultado é a ruína, a destruição (ő $\lambda \varepsilon \theta \rho \circ \varsigma)$.

É interessante observar que essa mesma reflexão sobre os limites da condição humana encontra-se explicitamente presente em Heródoto, ao reproduzir o sensato discurso que Artábanos, tio paterno de Xerxes, dirigiu a este na assembleia de notáveis que o próprio Xerxes convocara para comunicar sua decisão de, construindo uma ponte sobre o Helesponto, invadir a Hélade. A intenção de Artábanos é dissuadir o sobrinho dessa ideia e, para tanto, em sua longa fala, ele se utiliza do seguinte argumento: 


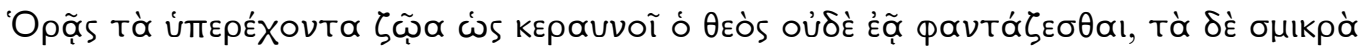

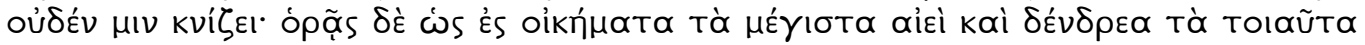

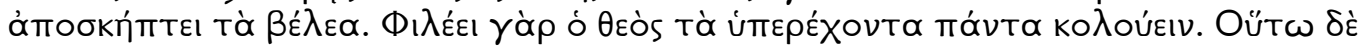

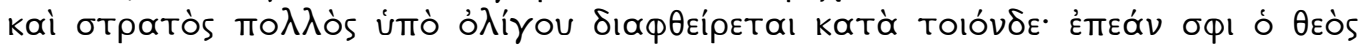

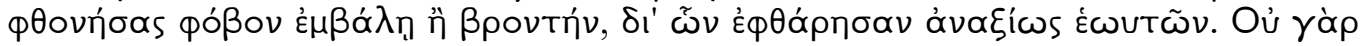

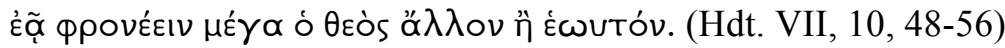

Vê como a divindade fulmina com o seu raio os animais de grande porte, sem permitir que eles o ostentem, enquanto ela não faz qualquer mal aos pequenos. Vê como ela atinge sempre com seus dardos as casas e as árvores mais altas; de fato, a divindade se compraz em rebaixar tudo que se eleva. Pela mesma razão um exército numeroso às vezes é aniquilado por um pequeno, quando, por exemplo, a divindade despeitada inspira-lhe um terror pânico ou o apavora com o ribombar de trovões, a tal ponto que ele é humilhantemente dizimado. Em verdade, a divindade não admite pensamentos altaneiros a não ser em si mesma ${ }^{20}$.

Em vista disso, a descrição que o Coro faz do exército em sua extraordinária magnitude e riqueza e a caracterização de seu líder como uma epifania divina, não produz, como se esperaria, o efeito desejado; em vez de tranquilizar o Coro, suscita neste justamente essa reflexão sobre os limites da condição humana, como se lê nas terceiras estrofe e antístrofe:

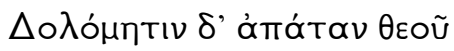

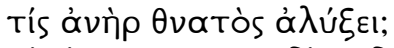

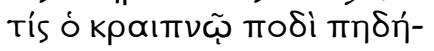

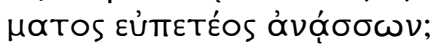

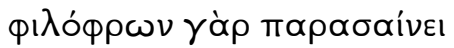
ßрото̀v घis äpkuas "Aта,

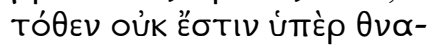

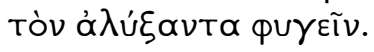

\author{
Do fraudulento logro de Deus \\ que homem mortal há de escapar? \\ Quem com rápido pé salta \\ um salto bem dado? \\ Erronia acolhe benévola \\ o mortal nas redes, \\ quando não há para ele \\ como evitar nem fugir.
}

(Pe. 93-101)

Além disso, prossegue o Coro, contrariando o antigo costume de guerrear em solo, o exército se lançou em um novo domínio, o marítimo, confiante "nas sutis tramas

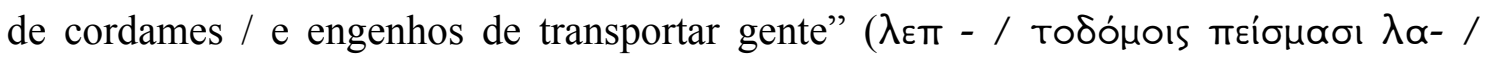

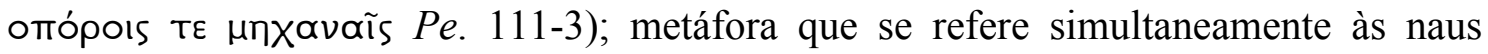
utilizadas por Xerxes em combate e à própria construção da ponte unindo Ásia e Europa, haja vista que a ponte fora construída, tal como informa Heródoto (VII, 36) com naus amarradas por cordames. Sendo assim, os persas saíram de seu domínio terrestre, que até então lhes assegurara a expansão e a manutenção do império, e se arriscaram em novos domínios e estratégias de guerra. Vale lembrar que, por ocasião da

${ }^{20}$ Tradução de Mário da Gama Kury (1988, 2ª . ed.). 
encenação dos Persas, Atenas era uma potência marítima, de modo que, se por um lado as "sutis tramas de cordames" e os "engenhos de transportar gente" aludem à perdição de Xerxes e de seu exército, por outro aludem à salvação e a consagração dos atenienses.

O fato é que todas essas reflexões suscitam o temor do Coro, que subitamente exclama: "Assim vestido de negro o meu / coração dilacera-se de pavor / oâ!, pelo

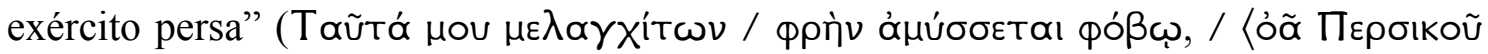

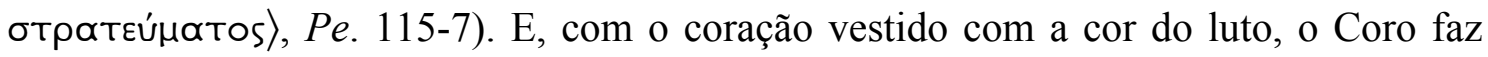
votos de que a cidade não se saiba vazia de seus homens por tê-los perdido.

Note-se que o Coro inicia seus votos, na quinta estrofe, utilizando a construção

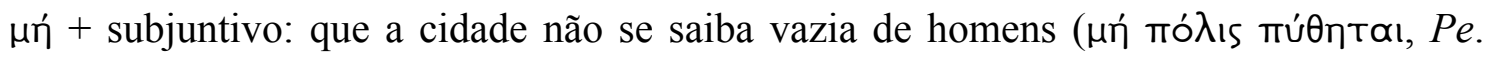
117-8), mas, em seguida, ao dar continuidade ao relato do que ele teme e do que faz votos de que não aconteça, acaba por descrever uma cena profundamente desoladora, que adquire proximidade e imediatismo pelo uso do futuro e do presente do indicativo.

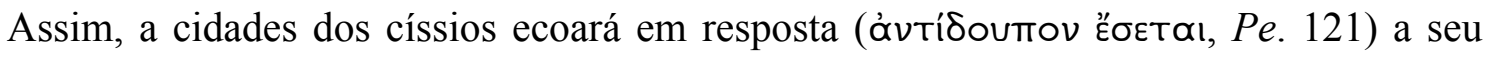
grito de dor; por dor, o bando de mulheres clama (ámúw 124) dilacerando seus véus; os leitos vazios dos homens estão cheios de lágrimas

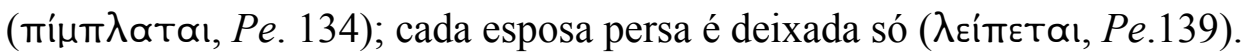

Dessa forma, o Coro, sem o saber, prefigura e antevê o sofrimento, a dor, o sentimento de perda que os seus irão sofrer. E se, ao final do párodo, o Coro ainda se pergunta: "Será vencedor / o fluxo do arco, ou prevalecente / a pontiaguda força da

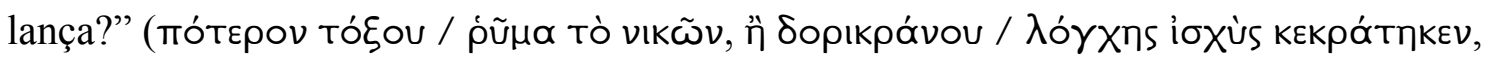
Pe. $146-8)^{21}$, é porque, de seu ponto de vista mortal e humano, a despeito do mau pressentimento de seu coração pressago, ainda é impossível conhecer o desfecho da guerra, mas, do ponto de vista divino, que se expressa mediante os sinais numinosos que se imiscuíram na fala e no próprio coração do Coro, a resposta já está dada.

\footnotetext{
${ }^{21}$ As referências ao arco e à lança nesta tragédia dizem respeito à forma de combate persa e grega, respectivamente, como se esclarece na esticomitia entre a Rainha e o Coro, em que a Rainha pergunta "O

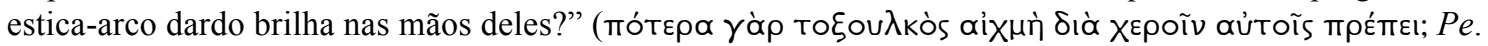

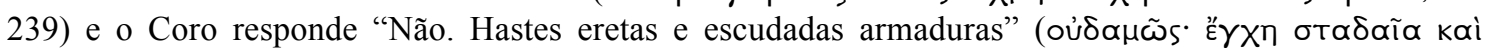

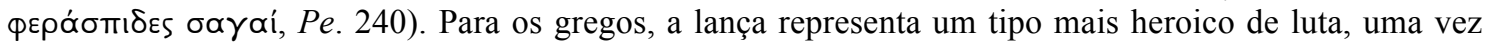
que pressupõe um embate corpo a corpo, o que requer maior bravura, enquanto os persas, com seus arcos, lutam de longe (PULQUÉRIO, 1998, p. 22, nota 11). Dessa forma, tal referência, além de estabelecer uma contraposição entre as duas etnias, marca também a superioridade grega.
} 


\section{2) Um sonho e um auspício}

Sentados diante do palácio, onde se reuniram para ponderar sobre a sorte de Xerxes e de seus homens ${ }^{22}$, os membros do Coro, nos anapestos finais do párodo, anunciam a entrada da Rainha, ante a quem ajoelham-se em sinal de reverência ${ }^{23}$.

Ao ver a Rainha, o Coro a exalta como luz "igual a olhos de Deuses" ( $\theta \varepsilon \tilde{\omega} \nu$ ǐ $\sigma o v$ ó $\phi \theta \alpha \lambda \mu$ оĩs, $P e .150)$, como suprema soberana, esposa de um deus e também mãe de um deus. Nesse louvor claramente excessivo, em que a figura humana do soberano se confunde com a do deus - note-se o vocabulário: $\theta \varepsilon \tilde{\omega} \nu$ íoov ó $\phi \theta \alpha \lambda \mu$ oĩs (Pe. 150), $\theta \varepsilon \circ \tilde{u}$

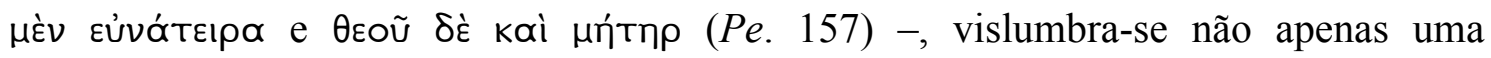
característica do despotismo persa, mas uma atitude hybristés, blasfema, e, portanto, passível de punição divina, tal como se prenuncia na oração condicional, de sentido claramente ominoso, "se o Nume antigo hoje não abandonou o exército" (El Tı $\mu$ ก̀

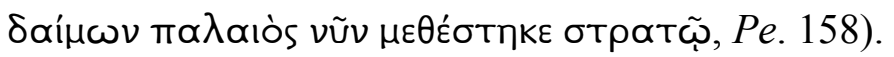

A Rainha, então, fala de suas aflições, pois teme tanto a perda da riqueza do império como a perda de seu guardião. Em sua fala, novamente se observam palavras relativas à riqueza persa, cuja recorrência, como se viu no párodo, recobre-as de um

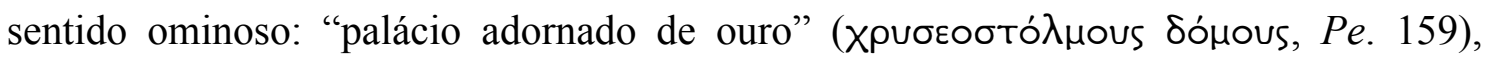

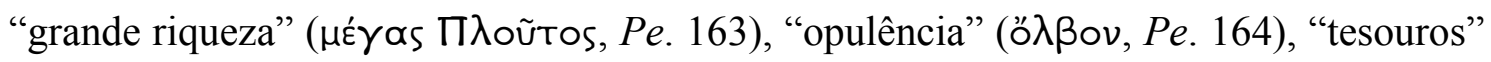

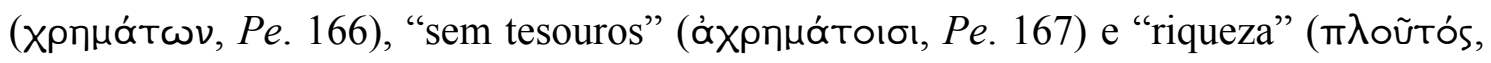
Pe. 168). Toda essa opulência se faz visível ao espectador, pois a Rainha entra em cena em uma carruagem e seus trajes eram representativos do luxo da realeza oriental ${ }^{24}$.

A Rainha, em seguida, diz-se à procura de conselhos por causa de um sonho que lhe pareceu o mais claro, dentre todos os sonhos com os quais convive desde que seu

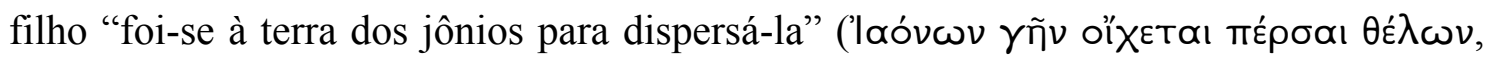

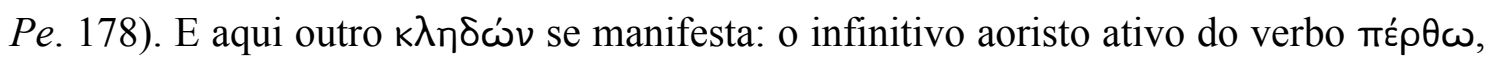

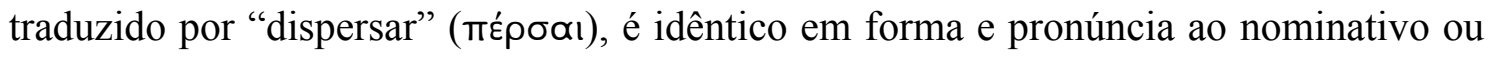

\footnotetext{
${ }^{22}$ Para uma aprofundada discussão sobre a motivação cênica para a entrada do Coro de Fiéis no párodo, conferir o estudo de Taplin (2001, pp. 61-70).

${ }^{23}$ A genuflexão era um costume próprio ao despotismo oriental e particularmente estranho à mentalidade grega, com seu ideal democrático e de isonomia entre os cidadãos. Para o significado desse gesto cênico nos Persas, conferir o artigo de Sider (1983, pp. 188-191).

${ }^{24}$ Sobre a importância da entrada da Rainha, conferir o artigo de Thalmann (1980, pp. 268-9); sobre suas possibilidades cênicas, ver Taplin (2001, pp. 75-9).
} 
ao vocativo plural do nome próprio "Persas" (Пદ́pбaı), tal como se pode constatar sete

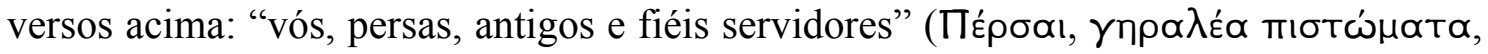
Pe. 171) (MOREAU, 1992/1993, p. 39). Assim, nesse jogo de palavras de caráter etimológico, se expressa um ponto de vista numinoso, o de que o próprio nome da etnia - persas - prenunciaria seu destino nessa guerra: a dispersão, a devastação, a destruição, não dos inimigos, como diz a Rainha, mas de si mesmos.

É nesse contexto repleto de frases e palavras de uma ambiguidade ominosa e, por isso mesmo, de tensão dramática, que a Rainha narra enfim seu sonho:

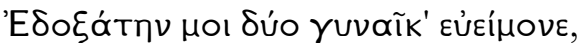

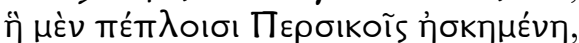

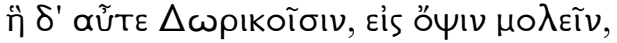

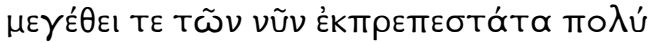

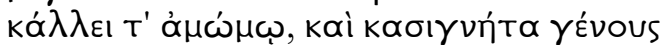

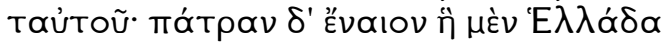

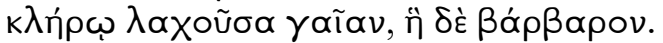

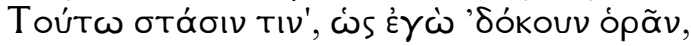

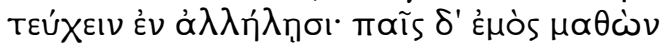

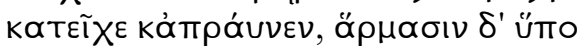

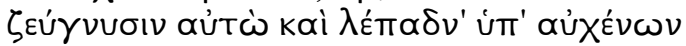

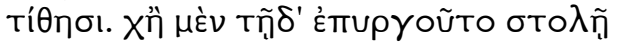

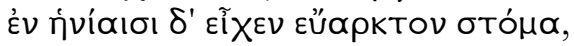

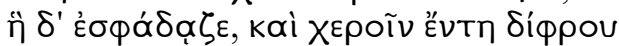

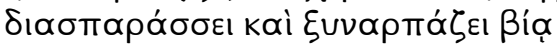

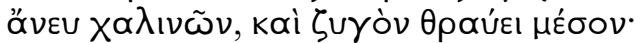

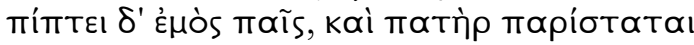

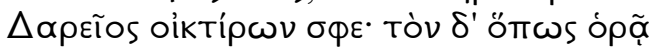

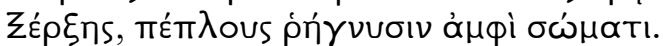

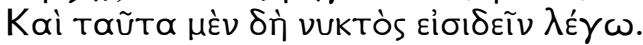

\author{
Pareceu-me que duas mulheres bem vestidas, \\ uma paramentada com véus pérsicos, \\ outra, com dóricos, viessem-me à vista, \\ mais notáveis que a de hoje no porte \\ e na beleza perfeita, irmãs do mesmo tronco, \\ uma habitava a Grécia, a outra, a terra \\ bárbara, no sorteio recebidas por pátria. \\ Ao que me parecia ver, houve, entre ambas, \\ uma querela, e meu filho, quando soube, \\ tentava conter e acalmar, e sob o carro \\ atrelas as duas, e põe-lhes o jugo \\ no pescoço. Uma se orgulhava dos jaezes \\ e nas rédeas tinha a boca dócil ao mando, \\ a outra esperneia e despedaça os arreios \\ com as mãos, arrebata com violência, \\ desenfreada, e quebra o jugo ao meio. \\ Cai o meu filho e aproxima-se o pai \\ Dario a lastimá-lo. E quando o vê, \\ Xerxes rasga as vestes sobre si mesmo. \\ Isso é o que vos digo ter visto à noite.
}

(Pe. 181-200)

Em primeiro lugar, é interessante observar que, de acordo com a Rainha, o que distingue esse seu sonho dos demais com os quais ela diz conviver desde a partida de seu filho é a claridade ('̇vapyès, $P e .179$ ) do que ela viu. Note-se ainda que a Rainha descreve o ato de sonhar como uma visão noturna: ela diz que ainda não "tinha visto"

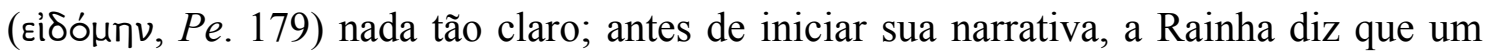

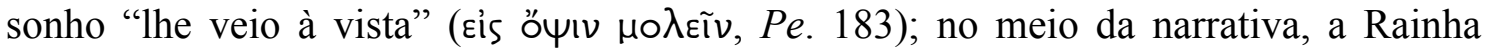
novamente enfatiza o caráter visual de sua experiência onírica, dizendo "ao que me

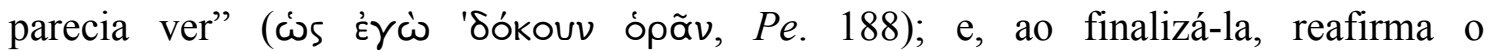
entendimento do sonho como visão - "Isso é o que vos digo ter visto à noite" (kaì

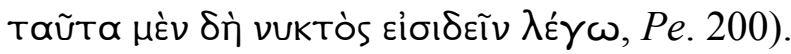


Trata-se de uma observação bastante conhecida a de que o ato de sonhar, sobretudo em Homero, é descrito não como uma experiência interior, subjetiva, de que o sujeito é agente, mas como uma experiência exterior, que, desde fora, vem até aquele que dorme, sendo este não mais que um "receptor passivo de uma visão objetiva" (DODDS, 1951, p. 105).

Dessa exteriorização do sonho dá testemunho, de forma mais expressiva, a descrição dos sonhos nas epopeias homéricas: o sonho de Agamêmnon (Il. II, 5-75), o de Aquiles (Il. XXIII, 62-107), o de Príamo (Il. XXIV, 677-89), o de Penélope com sua irmã (Od. IV, 794-841), o de Nausícaa (Od. VI, 15-50) e o de Penélope com os gansos (Od. XIX, 535-58). Garrido \& Lobo (2003, p. 79) observam, nas descrições homéricas de sonhos, as seguintes características: 1) a recorrência de verbos de movimento -

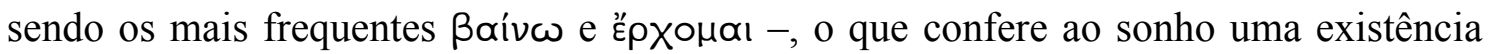
espacial independente daquela do sonhador, que se encontra passivamente deitado; 2) o

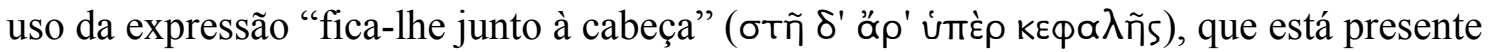

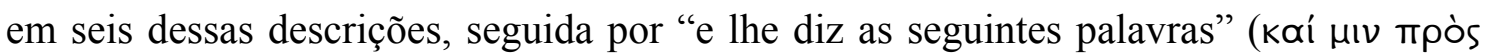

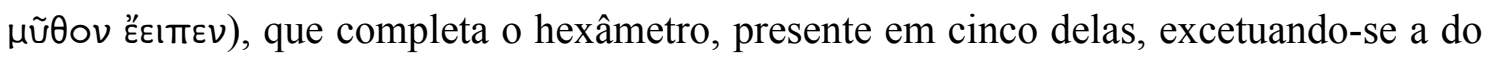
sonho de Agamêmnon; 3) afora o sonho de Penélope com a águia e os gansos, em todos os demais, há a aparição de uma figura onírica, ${ }^{25}$ que se dirige até o sonhador, coloca-se junto à sua cabeça, chama a atenção ao estado de sono em que se encontra quem sonha ${ }^{26}$ e lhe profere algumas palavras.

Observe-se que o conteúdo das palavras proferidas pelas figuras oníricas - seja uma ordem, um pedido ou palavras de consolo - é transmitido clara e diretamente em forma de discurso direto, em que se interpela o sonhador em $2^{\mathrm{a}}$ pessoa do singular, não havendo assim necessidade de o destinatário do sonho, ao acordar, recorrer a alguém para lhe ajudar a interpretar o sonho. As mensagens oníricas são transmitidas por palavras - as palavras são a verdadeira substância desses sonhos. Harris (2009, p. 23) denomina esse tipo de sonho de "epifânico" ou "sonho mensageiro", diferentemente do sonho por ele denominado "episódico", que constitui uma sequência de eventos.

\footnotetext{
${ }^{25}$ O Sonho sob a figura de Nestor para Agamêmnon (Il. II, 20-2), o espectro de Pátroclo para Aquiles (Il.

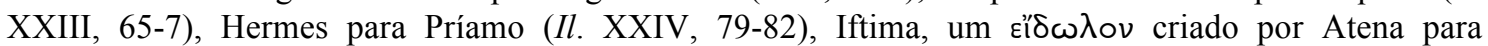
Penélope (Od. IV, 795-8) e Atena sob a figura da filha de Dimante para Nausícaa (Od. VI, 22-4).

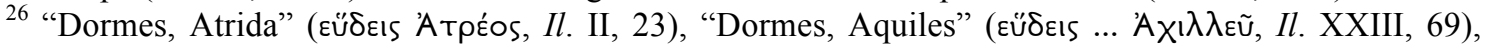

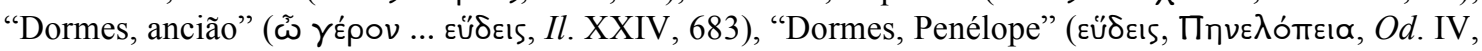
804).
} 
Quanto ao sonho de Penélope com os gansos, este apresenta uma estrutura mais complexa, constituindo uma narrativa onírica. Harris (2009, p. 50) observa que:

What may be the most famous dream in the Homeric poems, Penelope's dream about the eagle and the geese in Odyssey XIX, is something of a hybrid: it describes an episode - Penelope's twenty geese were eating and she was enjoying the sight, when an eagle swept down and killed them all, to her dismay. Then there follows a kind of epiphany: the eagle returned, and in a human voice explained that he was Odysseus come to inflict vengeance on the suitors.

Além de ser um tipo diferente de sonho, em que palavras e imagens se entremeiam, o sonho de Penélope se distingue por haver uma necessidade expressa de interpretação. Ela mesma o assinala, antes de narrá-lo a Odisseu, então disfarçado de

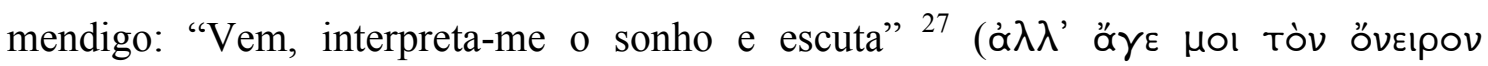
úmókpıvaı kaì ăkovoov, $\mathrm{Od}$. XIX, 535). Observe-se o uso do mesmo verbo que Ésquilo utiliza para a ação de interpretar um sonho, kpívw, que, ao fim na narrativa onírica, ressurge nas palavras de Odisseu à esposa, como se verá a seguir.

Curiosamente, a interpretação do sonho é um dos elementos que constituem a própria narrativa onírica: após o massacre dos gansos pela águia, esta se dirige a Penélope e, falando-lhe diretamente, explica que ela na verdade é Odisseu, que retorna, e os gansos, os pretendentes, que serão por ele massacrados. Então, Odisseu, após ouvilo, tomando a palavra, não faz mais que confirmar a interpretação oferecida pelo próprio sonho, dizendo: "Mulher, não é possível interpretar o sonho de outra forma"

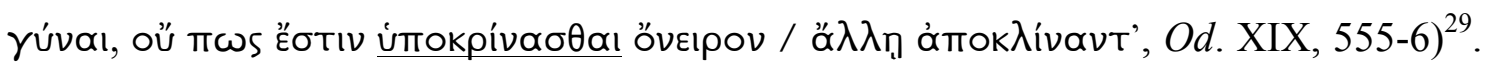
Esse seria, portanto, o único sonho em que, em Homero, o sonhador depara-se com uma narrativa onírica que necessita de interpretação ${ }^{30}$, ainda que, na poesia homérica, haja

\footnotetext{
${ }^{27}$ Tradução nossa.

${ }^{28}$ Tradução nossa.

29 Pode-se entender o ataque da águia aos gansos, tal como sugere Pratt (1994), como um auspício avistado por Penélope em seu sonho, auspício este que, de acordo com a autora, poderia ter um sentido ominoso, o que explicaria dois aspectos desse sonho que costumam intrigar os helenistas: a ênfase que Penélope dá à descrição de seu luto pelos gansos e o fato de ela pedir que o mendigo o interprete, a despeito de a águia, em sonho, ter-lhe claramente oferecido uma interpretação.

${ }^{30}$ Para Dodds (1951, p. 106), esses dois tipos de sonhos que aparecem em Homero - o de Penélope com os gansos e os demais - não implicam necessariamente a coocorrência de duas atitudes do homem grego antigo frente ao sonho - uma mais primitiva, em que não haveria elaboração simbólica, e uma posterior, em que há um conteúdo a ser interpretado simbolicamente -, mas sim uma distinção entre diferentes tipos de experiência onírica. Dessa forma, não seria necessário recorrer à hipótese de uma interpolação tardia ao poema homérico para explicar por que o sonho de Penélope requer uma interpretação simbólica, enquanto os demais são sonhos ditos "objetivos".
} 
menção à atividade do intérprete de sonhos (óveıpómoגos), a que se faz referência duas vezes (Il. I, 63 e V, 149).

Ressalve-se que, no processo de exegese da narrativa onírica, é necessário levar em consideração um aspecto fundamental dos sonhos para os gregos - a de que eles trazem em sua maioria informações sobre o futuro, de forma que sua interpretação leva à revelação de uma realidade externa e não interna, como creem as interpretações psicológicas ou psicanalíticas deste e de outros sonhos na literatura grega antiga (PRATT, 1994, pp. 148-9) ${ }^{31}$.

Dodds (1951, p. 107) observa que, para os gregos, a única diferença fundamental entre os sonhos era de fato entre os significativos e os não-significativos, distinção esta já formulada na famosa passagem sobre os portões de chifre e de marfim, através dos quais, como narra Penélope, passam os sonhos enviados aos mortais (Od. IXX, 560 ff. $)^{32}$. Note-se que, na diferenciação elaborada por Penélope entre os sonhos que chegam passando por uma ou outra porta, o que os distingue é o fato de estes se realizarem ou não; assim, os que atravessam os portões de marfim enganam

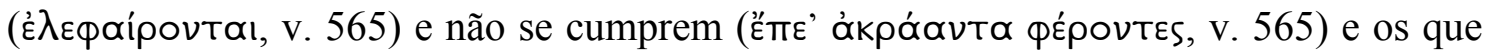

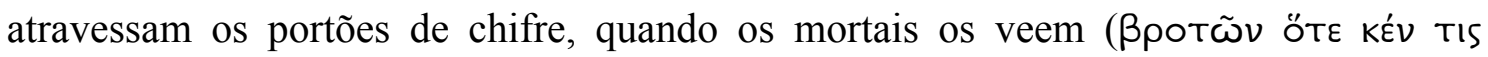

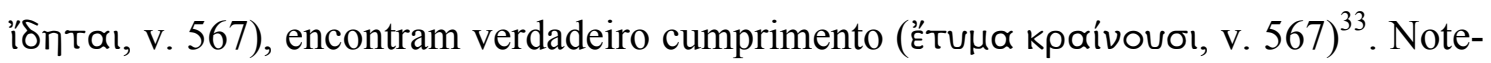
se ainda que, nessa distinção feita por Penélope, estão presentes as características mais comuns aos sonhos homéricos: sua descrição através de verbos de movimento ( $\varepsilon^{\prime} \lambda \theta \omega \sigma$,

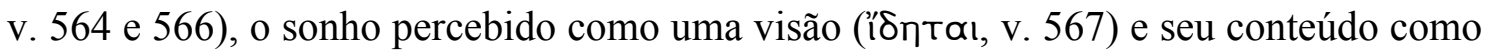
palavra falada ('̈́тв', v. 565).

\footnotetext{
${ }^{31}$ Para interpretações que consideram o aspecto psicanalítico dos sonhos, utilizando conceitos tais como "conteúdo latente", "conteúdo manifesto", "condensação", "deslocamento", "elaboração secundária", entre outros, conferir os estudos de Devereux (1975) e de Meneses (2002), quem dá especial atenção ao sonho de Penélope com os gansos (conferir pp. 65-113), sobre o qual observa: "o sonho de Penélope é um sonho premonitório [...], de uma perspectiva clássica. De uma perspectiva psicanalítica, seria um sonho típico de realização de desejo" (p. 89).

${ }^{32}$ Observe-se que Virgílio, na Eneida (VI, 893-6), reproduz essa mesma distinção homérica: "Duas do Sono são as portas: destas / Uma córnea se diz, por onde às sombras / Verdadeiras se dá fácil saída; / De cândido marfim é a outra: os manes / Mandam por esta ao mundo os falsos sonhos." (Sunt geminae Somni portae, quarum altera fertur / cornea, qua veris facilis datur exitus umbris; / altera candenti perfecta nitens elephanto, / sed falsa ad caelum mittunt insomnia Manes). Tradução de José Victorino Barreto Feio e José Maria da Costa e Silva (2004). Para um estudo detalhado e abrangente dos antigos sistemas de classificação dos sonhos, tais como os propostos por Artemidoro e Macróbio, conferir o artigo de Kessels (1969). Conferir também o artigo de Del Corno (1982).

${ }^{33}$ Observe-se que o próprio jogo de palavras em grego se baseia na realização ou não dos sonhos: pelas

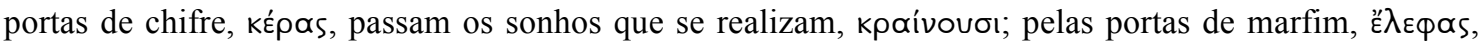

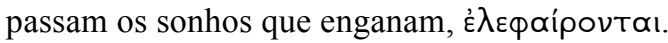


O exemplo mais eloquente de um sonho enganoso, que não se cumpre, encontrase justamente em Homero, no início do canto II da Ilíada, quando Zeus, por ter atendido à súplica de Tétis, decide enviar a Agamêmnon um sonho ruinoso (oũ $\lambda \circ v$ öveıpov, $v$. 6). Mantendo-se todas as características dos sonhos nesse poeta, Zeus ordena que o Sonho, aqui personalizado, vá (ßáok', v. 8 - verbo de movimento) até o acampamento e, dirigindo-se ( $\dot{\lambda} \lambda \theta \omega ่ \nu$, v. 9 - verbo de movimento) à tenda de Agamêmnon, diga-lhe

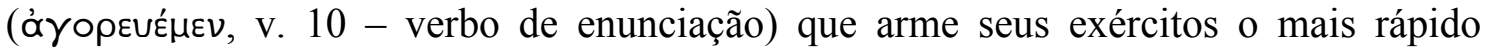
possível e ataque, pois, não havendo mais dissenso entre os deuses, Troia está fadada à ruína. Então o Sonho, obedecendo, partiu ( $\beta \tilde{n}$, v. 16 - verbo de movimento), foi (ík $\propto v \varepsilon$, v. 17 - verbo de movimento) até o acampamento dos aqueus, dirigiu-se ( $\beta \tilde{\eta}$, v. 18 verbo de movimento) à tenda de Agamêmnon, colocou-se (otñ, v. 20 - verbo de

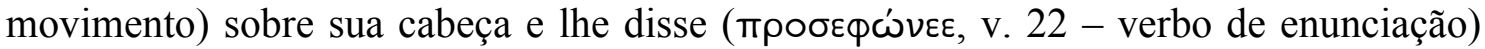
que, sendo estimado por Zeus, era enfim chegada a hora de tomar Troia. Esse sonho

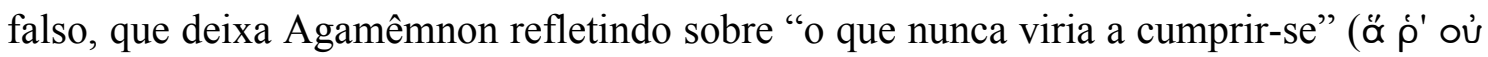

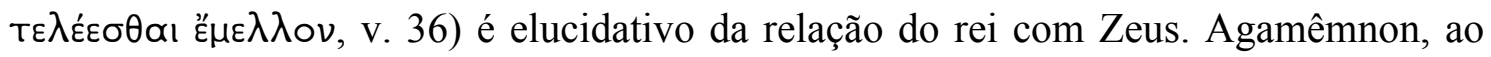
desonrar Aquiles, comporta-se como um mau rei, porque faz um mau uso do poder que exerce enquanto o "rei dos reis", visto que ultraja aquele de cuja bravura depende o sucesso de sua expedição. O sonho engana Agamêmnon porque ele é soberbo, é hybristés, e aponta assim para uma atitude inadequada do rei com relação ao exercício do poder, o que, por sua vez, aponta para uma atitude inadequada de Agamêmnon com relação a Zeus. Note-se que, ao narrá-lo ao conselho, Agamêmnon não pede uma interpretação de seu sonho; ele o expõe como uma ordem.

Quanto aos sonhos na tragédia esquiliana, algumas características próprias à descrição dos sonhos homéricos permanecem, havendo, no entanto, como se verá, uma predominância dos sonhos episódicos, em que há uma narrativa onírica a ser interpretada. Essa predominância não é, todavia, uma característica particular de Ésquilo, mas sim do próprio século V, em que, como observa Lobo (1992, p. 65), há uma multiplicação desses sonhos na literatura ${ }^{34}$, sem que necessariamente tenha havido uma substituição de um tipo de sonho por outro ${ }^{35}$.

Quanto às peculiaridades dos sonhos esquilianos, Lévy (1981, p. 142) afirma que é possível resumi-las da seguinte forma: os sonhos em Ésquilo são em geral visuais,

\footnotetext{
${ }^{34}$ Vejam-se, entre outros, Heródoto I, 107-8; Sófocles, El. 417-30; Eurípides, I.T. 44-60; Aristófanes, Eq. 1090-5 e $V$. 13-53. Sobre a literatura onirocrítica grega, conferir o artigo de Lobo (1992).

${ }^{35}$ Isso poderá ser observado na análise do sonho de Io em Prometeu Cadeeiro (Capítulo 5).
} 
premonitórios e perturbadores, e o poeta se detém naquilo que o sonhador parece ter visto, no que o sonho revela sobre o futuro e no efeito que a experiência onírica causa em quem sonha.

No que diz respeito ao sonho relatado pela Rainha ao Coro de Fiéis, observamse algumas características dos sonhos homéricos. Como se viu, o sonho "vem à vista", havendo assim a percepção do sonho como visão (Eis ö $\psi(v)$ e a ideia de movimento ( $\mu \circ \lambda \varepsilon \tilde{v} v)$. Note-se, no entanto, que a Rainha inicia o relato de seu sonho com o verbo

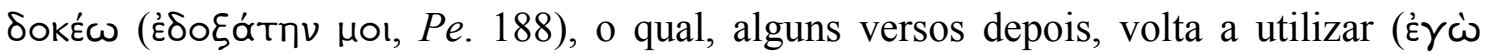
'Sókouv, Pe. 188). O uso, para descrever o conteúdo de um sonho, como ocorre aqui,

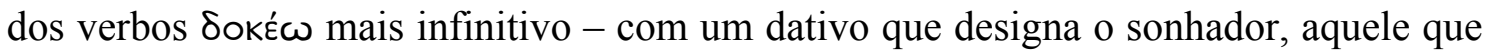
vivencia o sonho - ou ópóc mais infinitivo - com o sujeito do verbo designando o sonhador mais oração completiva de particípio - é característico não somente de Ésquilo como de outros autores do período clássico. Para Garrido \& Lobo (2003, p. 83), essa construção sintática, inexistente em Homero, seria um sinal de um processo de interiorização da experiência onírica, visto que coloca em evidência o sujeito percipiente.

O uso dessa construção sintática não implica, necessariamente, a descrição de um sonho episódico. Assim, em Heródoto, por exemplo, narra-se como Xerxes, decidido pelos conselhos de seu tio Artábanos a não marchar contra a Hélade, teve, durante a noite, a seguinte visão: "pareceu-lhe que um homem de elevada estatura e de

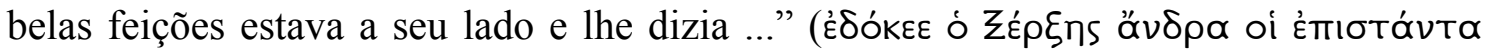

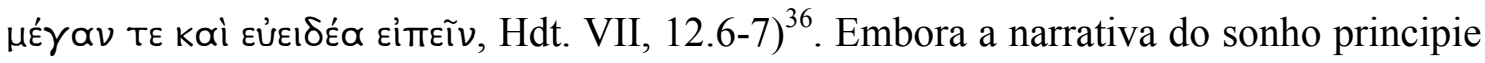

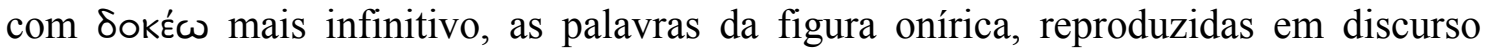
direto, interpelam Xerxes, dirigindo-se diretamente a ele em $2^{\mathrm{a}}$ pessoa do singular, e lhe ordenam a não desistir da expedição contra a Grécia; isto é, o que se segue é um típico sonho “epifânico" ou "mensageiro", conforme a classificação de Harris (2009, p. 23).

Quanto ao sonho da Rainha, à diferença dos sonhos homéricos, nenhuma figura onírica dirige suas palavras diretamente ao sonhador; ao contrário, todas as personagens permanecem em silêncio: o aspecto delas e suas ações é que compõem o conteúdo narrativo do sonho e, portanto, estão sujeitos à interpretação.

A Rainha descreve a visão de duas mulheres. Estas, nota a Rainha, são diferentes das mulheres hodiernas por seu porte e por sua beleza. Quanto a seu aspecto, a beleza e

\footnotetext{
${ }^{36}$ Tradução de Mário da Gama Kury (1988, 2ª . ed.).
} 
a estatura incomuns das duas mulheres - características próprias dos deuses em Homero (OTTO, 2005, p. 117) - são um sinal do aspecto divino do que elas representam. E mais se pode dizer da sua aparência: uma está vestida à moda persa - "paramentada com véus

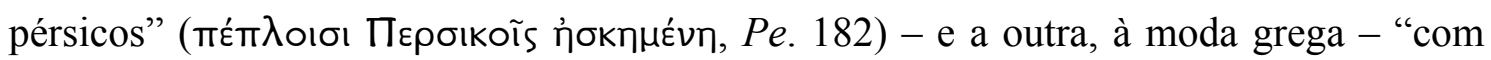
dóricos" ( $\triangle \omega$ pıког̃oıv, $P e .183)$.

Moreau (1992/1993, pp. 40-1) apresenta três possíveis interpretações para essas mulheres. Numa primeira interpretação, elas representariam a Europa e a Ásia, filhas de Oceano, tal como figura em Hesíodo, pois, na Teogonia (337 ff.), entre as filhas de Tétis e de Oceano, encontram-se Europa e Ásia. Sendo, no entanto, muito geral, essa interpretação não parece satisfatória, porque não é a Ásia e a Europa inteiras que estão em questão nos Persas. Em uma segunda interpretação, a mulher que aceita orgulhosamente o jugo representaria os gregos da Ásia e a que o recusa, os gregos da Europa. Também essa possibilidade interpretativa não é satisfatória, porque, além do fato de a aceitação dócil do jugo persa não representar exatamente o comportamento dos gregos da Ásia, a oposição entre gregos e persas, tão importante nesta tragédia, encontrar-se-ia desfeita. A terceira e mais simples interpretação seria a mais satisfatória: a mulher vestida à moda persa representaria o povo persa e a vestida à moda grega, $\mathrm{o}$ povo grego. Elas são irmãs, como observa a Rainha - "irmãs do mesmo tronco"

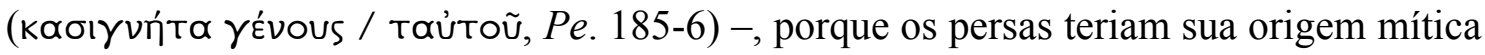
em Perseu, filho de Dânae, fecundada por Zeus mediante uma chuva de ouro (Pe. 7980); o filho de Perseu com Andrômeda, Perses, seria então o ancestral epônimo dos persas $(P e .145-6)$.

Quanto à ação onírica, a Rainha relata primeiramente o seguinte: havendo uma querela entre ambas, Xerxes, ao tomar conhecimento desta, procura dirimi-la e atrela as duas mulheres a seu carro, colocando-lhes o jugo sobre o pescoço.

De acordo com Moreau (1992/1993, p. 42), a interpretação da simbologia da ação de Xerxes seria fácil e clara não somente para os que hoje leem a tragédia, mas sobretudo para os gregos de então, visto que, no livro III da Onirocrítica de Artemidoro, o significado da imagem de um carro puxado por seres humanos coincide com o significado do sonho da Rainha, como se pode observar nas seguintes passagens:

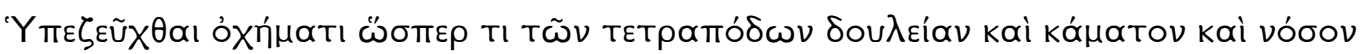

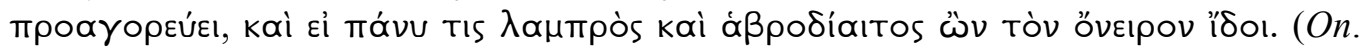
III, 18) 
Ser atrelado a um carro como um quadrúpede prenuncia escravidão, cansaço e doença, mesmo se quem veja o sonho seja um homem brilhante e faustoso.

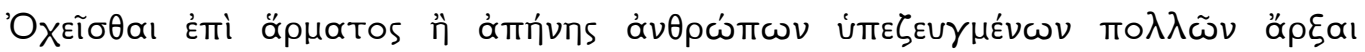

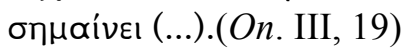

Viajar em uma carruagem ou em um carro puxado por homens indica que se terá poder sobre muita gente $(\ldots)^{37}$.

Não parece ser necessário, no entanto, recorrer ao célebre tratado do século II d.C. para se explicar por que a simbologia da ação de Xerxes parece tão clara. A chave para a sua interpretação encontra-se no próprio relato do sonho, uma vez que os elementos necessários para tanto já foram previamente fornecidos pelo Coro no párodo e o sentido dessa interpretação já foi involuntariamente apontado pelo Coro em função do contexto em que esses elementos figuraram.

No início do párodo lírico, na primeira menção feita à ponte sobre o Helesponto, viu-se que esta é descrita pelo Coro como um "jugo / ao redor do pescoço do mar"

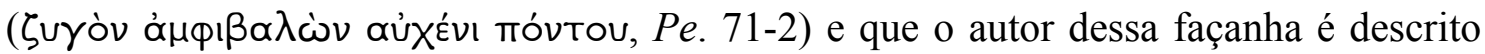

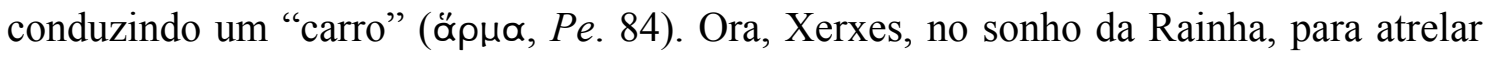

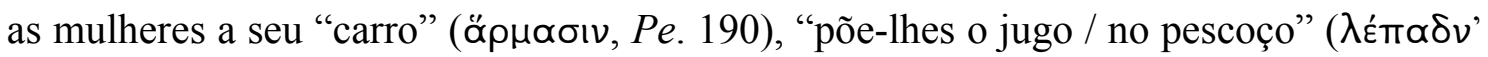

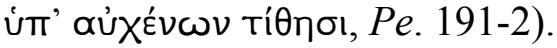

Viu-se também que o ato de construir uma ponte sobre o mar, ao ser descrito como um jugo ao redor do pescoço, caracteriza-o como uma atitude de dominação, de domação de uma divindade por parte de Xerxes. Essa mesma ideia está presente no sonho quando Xerxes, para conter a querela entre as duas mulheres, essas mulheres qualificadas como divinas por seus atributos, impõe-lhes o jugo, isto é, doma-as. A imagem do jugo, com seu sentido sacrílego de subjugar os deuses, já figura, portanto, no canto do Coro, de modo que, quando recorre no sonho da Rainha, é facilmente interpretável.

Dando sequência à narrativa, a Rainha relata que, enquanto uma das mulheres cede docilmente ao jugo imposto por Xerxes, a outra o rejeita veementemente. Aqui aparece de forma mais clara o aspecto político da imagem da imposição do jugo: a mulher vestida à moda persa não somente aceita docilmente ser submetida à dominação imposta pelo Rei como se orgulha dos jaezes, isto é, dos instrumentos que a colocam nessa condição e a simbolizam. Sendo assim, essa mulher de aspecto divino e

\footnotetext{
${ }^{37}$ Tradução nossa.
} 
comportamento animal representa tanto o povo persa como a sua forma de governo, uma vez que os persas se submetem de bom grado a seu déspota (a genuflexão do Coro no fim do párodo é um indício disso), entregando-se a seu comando e indo aonde quer que sejam conduzidos. Note-se que, na primeira antístrofe do párodo lírico, na imagem de Xerxes conduzindo seu exército, diz-se que ele "tange [...] a tropa / divina"

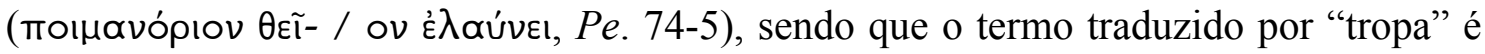
moı ${ }^{2}$ vópıov, que literalmente significa "rebanho". E, na esticomitia que se segue à narrativa do sonho, a Rainha indaga ao Coro "Que pastor preside e domina o exército?"

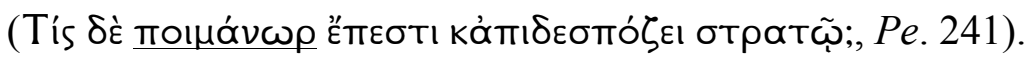

Por outro lado, o comportamento da mulher vestida à moda grega é exatamente o oposto. Xerxes trata-a do mesmo modo, atrelando-a a seu carro, mas ela esperneia

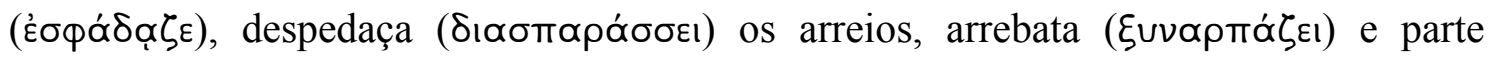

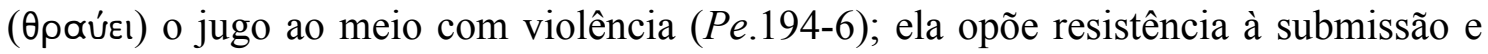
reage de todas as formas - notem-se os quatro versos de ação - para se desprender do domínio de Xerxes. Essa mulher não-domesticável representa assim o povo grego e sua forma de governo, baseada na isonomia, na ideia de justiça e na participação de todos os cidadãos no poder, e para o qual a liberdade é um valor tão apreciado, quão temido é o poder concentrado nas mãos de um único homem. Isso fica claro na resposta que o Coro dá à Rainha na esticomitia: os gregos "Não se dizem servos nem submissos a ninguém"

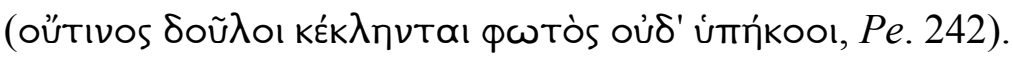

A atitude indomável da mulher vestida à moda grega faz com que Xerxes caia de seu carro. Para Moreau (1992/1993, p. 42), a queda de Xerxes seria simbolicamente ambígua, uma vez que poderia significar a derrota, a perda do poder ou a morte. Essa ambiguidade, segundo o autor, somente seria desfeita quando da chegada de Xerxes diante do Coro, no êxodo. No entanto, considerando-se o espectador ateniense, parece pouco verossímil que tal ambiguidade tenha existido, uma vez que se sabia que Xerxes não havia morrido no decurso da guerra e nem que, devido ao sistema de governo persa, poderia perder o poder, como esclarece a própria Rainha ao dizer que, mesmo derrotado, por não ter de prestar contas ao país, Xerxes "será o mesmo senhor desta

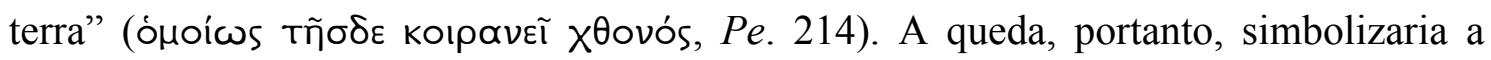
derrota do exército liderado por Xerxes.

Por fim, a Rainha relata que, quando Xerxes cai, seu pai, Dario, aparece para lastimá-lo. Note-se que, até aqui, as quatro referências feitas ao falecido rei 
evidenciaram: 1) sua ascendência divina - quando o Coro alude ao fato de Dario ser descendente de Perseu, filho de Zeus (Pe. 145-6); 2) sua riqueza - quando a Rainha

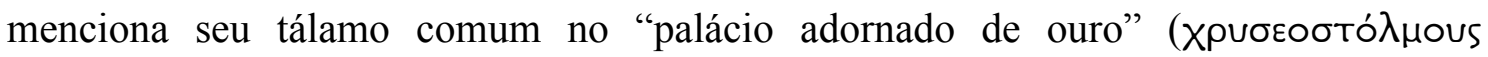
Sónous, Pe. 159); 3) seu favorecimento divino - explicitado pela Rainha ao dizer que tal riqueza foi conquistada "não sem um deus" (oủk ơvvev $\theta \varepsilon \tilde{\omega} v$ тıvós, Pe. 164); 4) e, por fim, o próprio aspecto divino de Dario - quando o Coro o chama "Deus de persas"

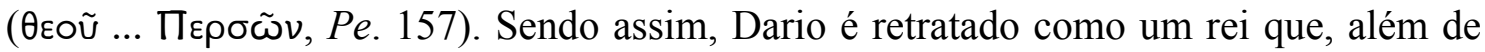
ter sido próspero, possuía ascendência, favor e aspecto divinos. É, portanto, a figura desse divino Dario que se aproxima de Xerxes caído.

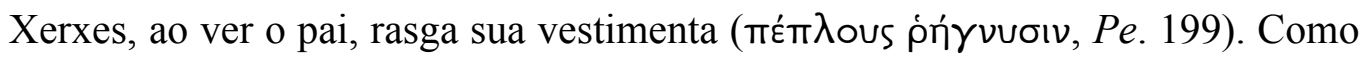
se pode observar no início do relato que a Rainha faz de seu sonho, ela menciona em primeiro lugar a vestimenta das mulheres que ela diz ter visto. Seus trajes as distinguem e, consequentemente, também distinguem gregos e persas: a sobriedade, a simplicidade, a moderação por um lado e o adornamento, o luxo, a riqueza excessiva por outro ${ }^{38}$. A aparição de Dario no sonho prefigura a aparição de seu espectro em cena no terceiro episódio, em cuja evocação se mencionam suas sandálias açafroadas e sua tiara real $(P e$, 660-2); isto é, peças de vestimenta que simbolizam seu próspero e pretérito reinado. Portanto, essa atitude do Rei é eloquente e, ao mesmo tempo em que expressa o desespero, a lástima e a vergonha causados pela sua queda e dão a dimensão da totalidade e da irredutibilidade de sua derrota, também simboliza a perda da riqueza e do poder do império, como tem sido observado pelos helenistas ${ }^{39}$.

Se há uma contraposição entre as figuras das duas mulheres - uma se veste à moda persa e a outra, à moda grega; uma habita a Ásia e a outra, a Europa; uma aceita docilmente o jugo e a outra, rejeita-o - há também uma contraposição entre as figuras de Xerxes e Dario - os andrajos de um e o esplendor real das vestes do outro; o presente ruinoso de um e o passado glorioso do outro; a hýbris e a cegueira moral de um e a prudência e a sabedoria do outro; a punição divina sofrida por um e o pretérito favorecimento divino desfrutado por outro. Essa contraposição entre Xerxes e Dario, no

\footnotetext{
38 Todas as menções à riqueza e ao ouro pérsico se contrapõem à resposta que o Coro dá à Rainha, quando esta pergunta pela riqueza grega e o Coro menciona as minas de Láurion, fonte de prata (Pe. 2378).

${ }^{39}$ Veja-se, por exemplo, o artigo de Thalmann (1980), no qual o autor se debruça especificamente sobre a relação nesta tragédia entre o vestuário e o poderio do império persa. Veja-se também o estudo de Saïd (1988, p. 341), em que a autora observa que, "si les vêtements déchirés du Roi peuvent ainsi avec tant de force symboliser l'anéantissement de la richesse et de la force de l'empire perse, c'est que dans une monarchie absolue l'État coïncide avec la personne du roi. Et la même logique [...] peut imposer à la fin l'image d'une destruction totale par le seul spectacle d'un roi en haillons".
} 
entanto, se fará mais nítida e se acentuará no decorrer da tragédia e é construída por Ésquilo a despeito da exatidão histórica ${ }^{40}$.

Em vista disso, a imagem de um rei com tão vastos domínios, com tantos súditos e de tão grande riqueza - como se veio salientando até aqui - despedaçando as vestes sobre o corpo é tão poderosa e significativa nesta tragédia que é ainda mencionada quatro vezes. Assim, o Mensageiro, em seu relato do combate, narra como Xerxes, lastimando, despedaçou suas vestes, tal qual a Rainha vê em seu sonho:

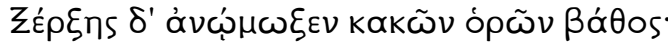

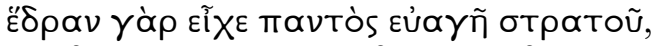

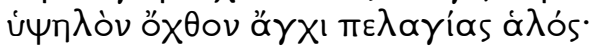

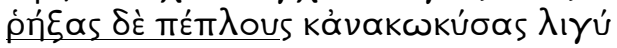

Xerxes lastima ao ver o fundo dos males, pois de seu posto via bem todo o exército, num alto monte perto da planície do mar. Rasgou as vestes e lastimou em voz alta.

(Pe. 465-8)

Também o espectro de Dario, prevendo as condições do retorno de seu filho, aconselha a Atossa o seguinte:

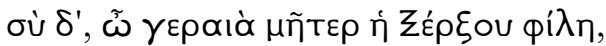

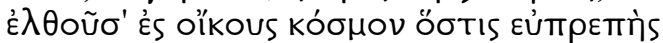

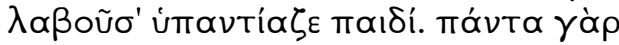

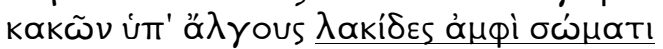

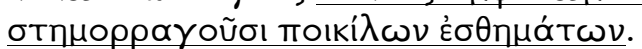

Tu, ó anciã, querida mãe de Xerxes, vá ao palácio, escolhe vestes convenientes e vá ao encontro do filho; pois sob a dor dos males, as lascas de vestes coloridas em volta do corpo estão todas laceradas.

(Pe. 832-6)

A Rainha, sai de cena no terceiro episódio, aflita, dizendo:

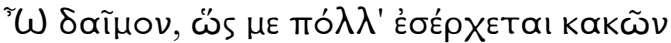

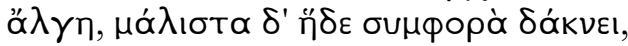

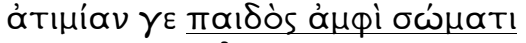

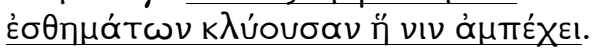

Ó Nume, como me varam as muitas dores de males, e este infortúnio mais aflige, ao ouvir que ignominiosas vestes envolvem o corpo de meu filho.

E, por fim, é o próprio Xerxes que descreve sua atitude no momento da derrota:

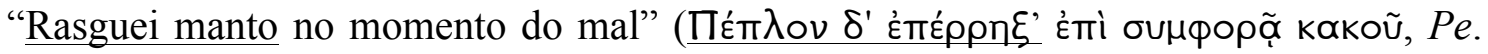
1030).

Vê-se, portanto, como uma das principais imagens do sonho, a de Xerxes em andrajos, é retomada ao longo da tragédia, reforçando dessa forma a dimensão

\footnotetext{
${ }^{40} \mathrm{O}$ desastre sofrido por Dario em Maratona é minimizado (Pe. 779-81) e, de acordo com Heródoto, Dario morreu em meio aos preparativos para uma nova invasão à Hélade (VII, 1).
} 
numinosa do sonho, em que primeiramente se prenunciam e depois se veem cumpridos os desígnios divinos e a realização da justiça de Zeus.

Esse aspecto indubitavelmente vaticinante do sonho é ainda reforçado pelo auspício das aves avistado pela Rainha. Ela narra ao Coro que, ao se levantar e prepararse para fazer oferendas aos Numes protetores, avistou o seguinte:

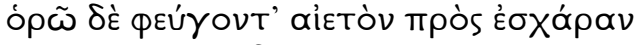

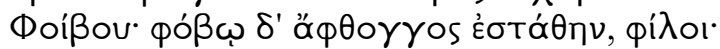

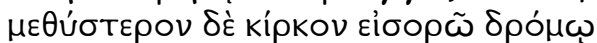

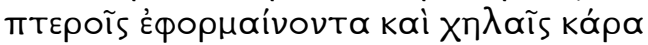

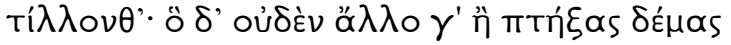

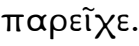

Vejo uma águia refugiar-se junto ao altar de Febo, de pavor fiquei sem voz, amigos. Depois avisto um falcão a vibrar velozes asas e a depenar com as garras a cabeça da águia, que nada senão encolher o corpo contrapunha.

A narrativa da visão diurna do auspício é contígua à narrativa da visão noturna do sonho. Em ambas, Atossa vê - ópãv (Pe. 188) e ópw̃ (Pe. 205) - imagens cujo grau de realidade se distingue em função dos diferentes estados em que ela se encontra - isto é, no estado de vigília ou adormecida -, mas que se caracterizam igualmente por serem sinais divinatórios, exprimindo, dessa forma, um ponto de vista numinoso e, por isso mesmo, necessitando de interpretação.

Primeiramente, a Rainha vê uma águia (aỉ̇òv) refugiando-se junto ao altar de Apolo, o que lhe causou um pavor ( $\left.\phi \beta_{\beta} \omega\right)$ tal que a deixou emudecida (ö $\phi \theta \circ \gamma \gamma \circ \varsigma$ ). A sua reação se explica pelo tipo de ave que ela avistou, pelo local de sua aparição e pelo seu comportamento.

É necessário ter em mente que os pássaros, com sua diversidade de espécies, de gritos, de plumagens e de comportamento, foram uma fonte inesgotável de presságios para os gregos. Já em Homero, a arte de interpretar o voo dos pássaros, ou ornitomancia $^{41}$, ocupa um lugar importante no diálogo entre homens e deuses. Calcas, o adivinho que guiou e acompanhou o exército grego por ocasião da guerra de Troia, é

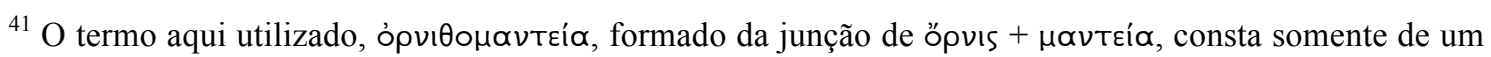
escólio aos últimos versos de Os Trabalhos e os Dias de Hesíodo, em que Proclo observa: “Alguns fazem

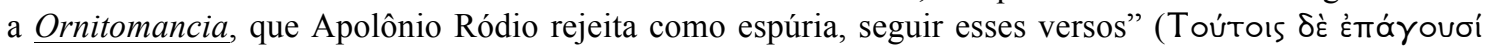

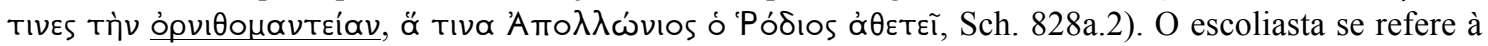
obra que Hesíodo teria escrito sobre a ornitomancia e que teria justamente esse título, mas da qual não restou nenhum fragmento. Platão, no Fedro, fazendo um jogo etimológico entre os termos oỉnoıs, vóos e

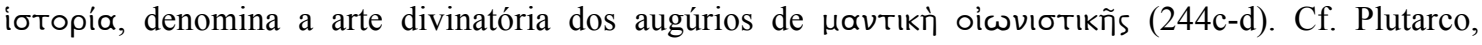
Sollert. animal, 975.A.1-B.3.
} 


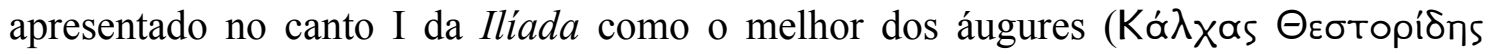

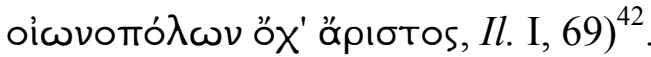

A ornitomancia é uma arte divinatória complexa e da qual, entre os gregos, não se pode dizer que tenha se tornado tão precisa quanto a arte augural entre os romanos. Pode-se inferir, no entanto, alguns princípios básicos em que ela se baseia: a observação do voo dos pássaros, do grito, da localização espacial de sua aparição, de seu comportamento, de a que espécie pertencem etc.

É importante considerar que nem todos os pássaros são aptos a fornecer presságios $^{43}$. Na Odisseia, por exemplo, o pretendente Eurímaco, indignado com a interpretação de Haliterses - que se sobressaía em seu conhecimento a respeito dos pássaros - sobre a aparição de duas águias na assembleia convocada por Telêmaco, diz: "Aves sem-número voam debaixo do Sol luminoso, / mas não são todas fatídicas"

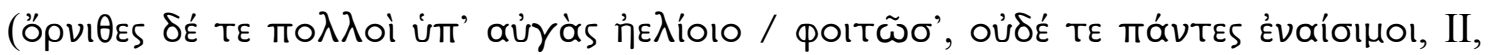
181-2).

É necessário, portanto, observar primeiramente a espécie das aves. No Prometeu Cadeeiro, Prometeu explica que há aquelas espécies que são favoráveis por natureza (Pr. 489-90). Além disso, é preciso atentar-se, como observa o Titã, à relação que essas espécies mantêm entre si: "quais seus hábitos, / ódios, amores e assentos comuns" (kờ

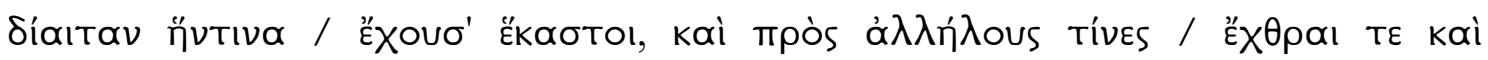

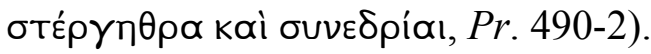

A primeira ave avistada pela Rainha, a águia, está entre as mais nobres no imaginário grego, pois é uma ave sagrada, associada a Zeus. Homero a chama de "a

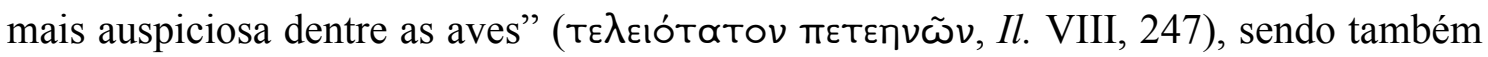
a mais forte e a preferida de Zeus (Il. XXIV, 290-5). Avistá-la, portanto, pode ser em si mesmo um sinal numinoso, tal como acontece na Ilíada; após desafiar Heitor com duras palavras, uma águia passou à direita de Ajax Telamônio, o que fez com que os aqueus emitissem imediatamente um grito de júbilo e se sentissem encorajados (Il. XIII, 821-3).

\footnotetext{
${ }^{42}$ Esse título de melhor dos áugures também o recebe Heleno entre os troianos: "o nobre filho de Príamo,

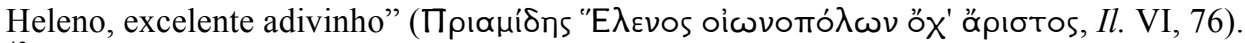

${ }^{43}$ Como esclarece Bouché-Leclercq (pp. 107-119), os pássaros-presságios, por excelência, são as aves de rapina, dentre as quais águias, abutres, corvos e gralhas formam o grupo principal. Outras aves, porém, foram registradas pelos antigos como pássaros-presságios, tais como o milhafre, o falcão, a garça, o abetouro, a carriça, a coruja, a gaivota e o pica-pau, mas não se trata, evidentemente, de uma lista exaustiva. De fato, dada a complexidade da ornitomancia, não se pode afirmar que tal ou qual espécie de pássaros não tenha servido a seus propósitos.
} 
Assim, nos Persas, além de avistar uma águia, um pássaro-presságio por

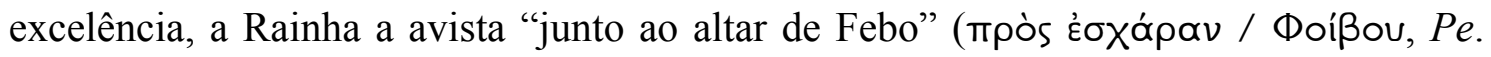
205-6), isto é, em um espaço consagrado a Apolo, o patrono da adivinhação, o que é bastante significativo. Igualmente significativo é o fato de essa águia estar se refugiando

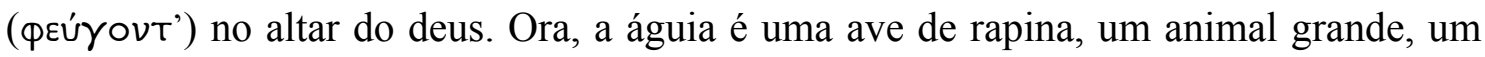
predador por natureza e seu comportamento fugidio chama a atenção. Em função disso, a Rainha se assusta e emudece: uma reação que poderia indicar a sua ciência de que está em presença de um sinal divino.

Prosseguindo em sua narrativa, a Rainha diz que em seguida avistou um falcão, que, vindo ao encalço da águia, com suas garras lhe depenou a cabeça. Ora, o falcão também é uma ave nobre, associada geralmente a Apolo. Na Odisseia (XV, 525-8), quando Telêmaco está retornando a Ítaca na companhia do adivinho Teoclímeno, um falcão surge à direita, o que o adivinho interpreta como um sinal auspicioso. Destaca-se sua velocidade e sua ligação com o deus Apolo, pois é qualificado de "o mensageiro de

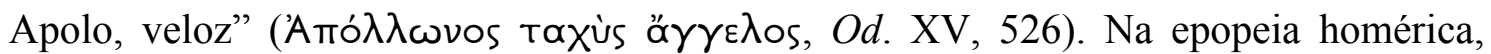
esse é o único auspício descrito em que o pássaro-presságio é nomeadamente um falcão

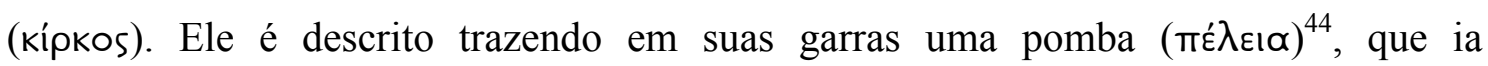
depenando. A pomba é certamente a mais comum de suas presas (ARNOTT, 2007, p. $148)^{45}$. Em Homero, além da passagem supracitada, encontra-se ainda referência a esse fato em um símile - "Como no monte o gavião, a mais lestes de todas as aves, / mui

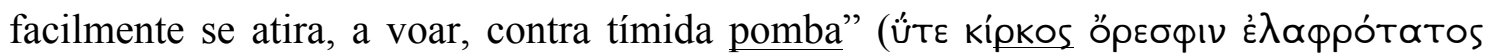

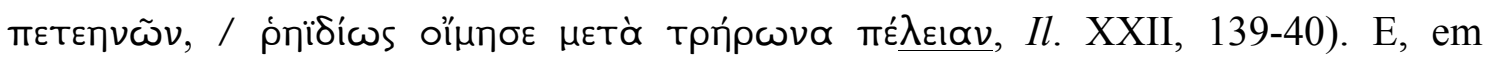
Ésquilo, uma metáfora que percorre toda As Suplicantes é a de pombas perseguidas por gaviões, como na seguinte passagem: “[...] no santuário, qual bando de pombas, /

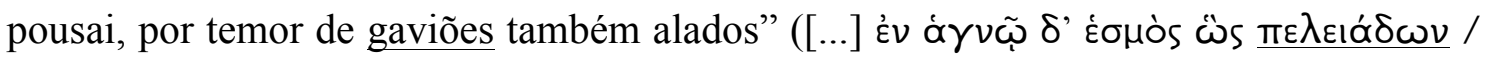

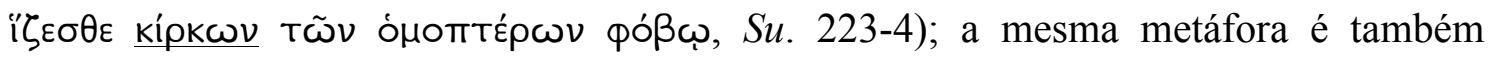
referida no Prometeu Cadeeiro - "falcões deixados não longe de pombas" (kípkol

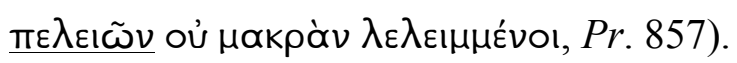

\footnotetext{
${ }^{44}$ Note-se que, nas aparições homéricas da águia em que esta traz uma presa em suas garras, ela também

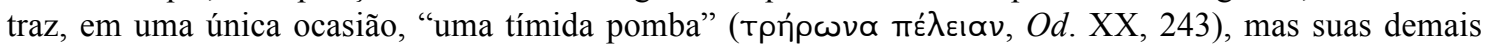

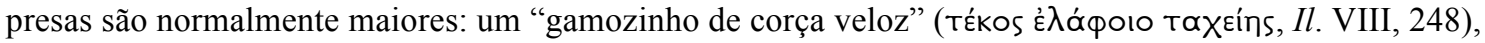

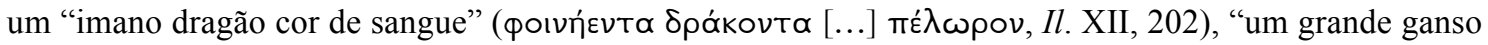

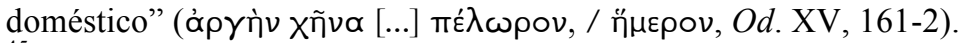

${ }^{45}$ Conferir Aristóteles, H.A. 620a 22-33.
} 
Embora o falcão seja predador de outros animais, a águia, muito provavelmente, não se encontra entre estes. Note-se que, no auspício homérico em que o falcão aparece, ele depenava ( $\left(\mathrm{T}^{\prime} \lambda{ }\right)$ ) com suas garras uma pomba; já no auspício avistado pela Rainha, o falcão depena ( $\left(i^{\prime} \lambda \lambda \circ v \theta^{\prime}\right)$ uma águia.

Dito isto, o que a Rainha descreve é, evidentemente, um auspício, mas, em realidade, trata-se de um auspício que é, ao mesmo tempo, um prodígio. Ainda que ambas as aves, a águia e o falcão, estejam entre as mais nobres para os gregos antigos, não pertencem ao mesmo nível hierárquico; na hierarquia dos pássaros, a águia é claramente uma ave superior. Não seria de se esperar, portanto, que a águia fosse acuada e tivesse sua cabeça depenada por um falcão, uma ave que lhe é inferior ${ }^{46}$.

A interpretação desse auspício prodigioso é, assim, bastante clara: o mais forte é inesperadamente vencido pelo mais fraco. O auspício prenuncia, portanto, não apenas uma vitória, mas uma vitória inesperada e por isso mesmo prodigiosa, tal como foi a vitória grega em Salamina. É curioso observar que esse sentido está presente de forma semelhante na interpretação que Heródoto fornece do prodígio que marcou o fim da travessia do Helesponto pelo exército persa. Segundo o historiógrafo, depois de terem todos atravessado a ponte, uma jumenta pariu uma lebre. Esse prodígio, ignorado por Xerxes, era, para Heródoto, de fácil interpretação: "Isso significava evidentemente que Xerxes estava levando contra a Hélade uma expedição pomposíssima e magnífica, mas

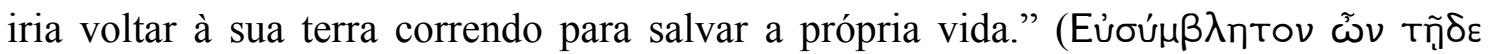

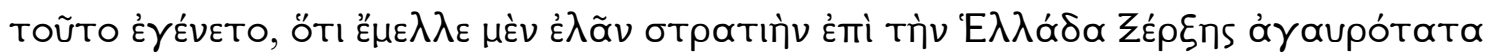

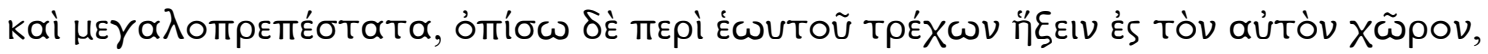
VII, 57.3-6).

Após finalizar a narrativa do auspício, a Rainha exclama: "Isto, para mim, é

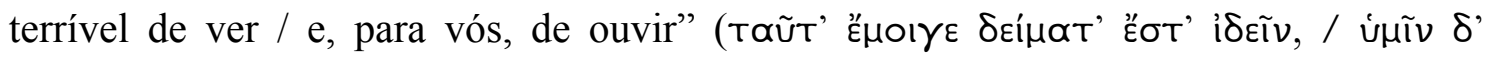
ớkoúદıv, Pe. 210-11). Ela parece expressar desse modo uma consciência não somente do aspecto numinoso de suas visões como também do seu caráter temível e angustiante,

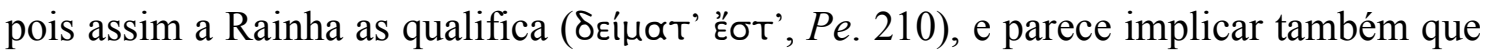
essa consciência é compartilhada com o Coro: se para ela é algo terrível de ver, para ele é algo terrível de ouvir. O que é terrível de ver e de ouvir se referiria aqui tanto ao seu sonho quanto ao auspício - tudo o que foi narrado até então parece estar contido no

${ }^{46}$ Conferir Arnott (2007, p. 148). Segundo o autor, kípkos é o nome dado à menor ave de rapina da

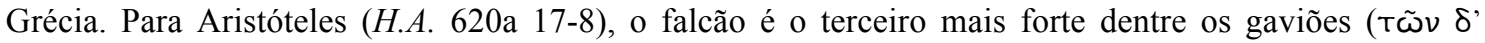

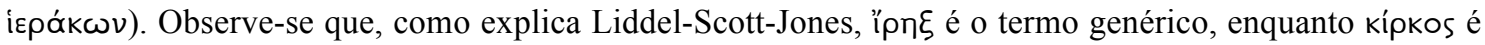
o específico. 
pronome demonstrativo (тđũT', Pe. 210). Trata-se afinal de um mesmo diálogo divinatório, em que se enuncia, mediante sinais diferentes, um mesmo destino ruinoso para os persas.

A Rainha, porém, finaliza sua fala expressando incerteza sobre o sucesso de seu filho, o que revela a limitação, imposta por sua condição mortal, de entender o que os sinais dos quais foi destinatária prenunciam; esse foi, aliás, o motivo de a Rainha ter vindo em busca do conselho do Coro de Fiéis. E, ante essa situação angustiante provocada por sinais que ela sabe serem divinatórios, mas que ultrapassam seu entendimento, a Rainha se conforta antecipadamente ao dizer que, mesmo sendo derrotado, seu filho não terá de prestar contas ao país e seguirá sendo seu soberano.

Essa mesma caracterização do despotismo persa presente na fala da Rainha encontra-se também no cauteloso conselho que o Coro de Fiéis dá à sua soberana, sugerindo-lhe apenas que peça proteção aos deuses e faça libações aos mortos e à alma

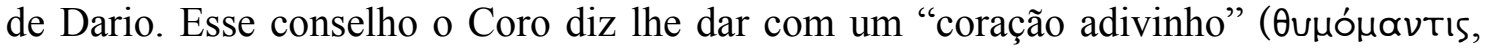
Pe. 224). Mas o coração do Coro, como se viu, não é somente um "coração adivinho"; é

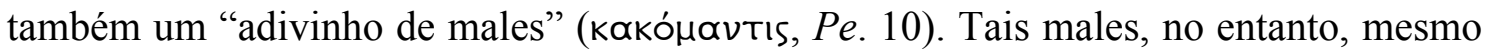
que o Coro os admitisse, não poderia comunicá-los à sua soberana, pois o jugo do despotismo persa, esse jugo que Xerxes, no sonho da Rainha, tenta impor à Grécia, pesa também sobre sua própria língua. Sendo assim, não lhe resta alternativa senão ser considerado no momento um "benévolo (...) intérprete deste sonho" (عüvous ...

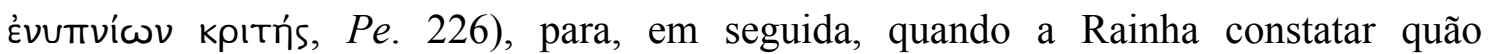
claramente seu sonho the prenunciou os males, passar a ser considerado um mau

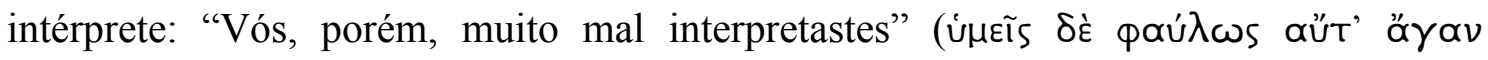
Éкрі́vate, Pe. 520).

Mas eis que vem chegando o Mensageiro a anunciar a derrota persa e, com ela, o cumprimento da justiça de Zeus, de modo que todos os sinais divinatórios que se manifestaram até então encontram sua realização, assim como todas as ambiguidades se desfazem, nos seguintes versos:

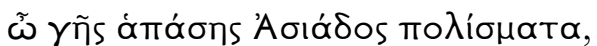

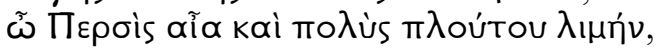

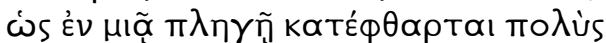

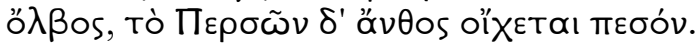

Ó cidadelas de toda a terra asiática!

Ó terra persa e vasto porto de riqueza! Como de um só golpe se perdeu vasta opulência! A flor dos persas se foi na queda.

(Pe. 249-52) 


\section{3) Necromancia e o espectro de Dario}

O relato do Mensageiro traz a realização dos desígnios divinos em toda a sua força de realidade, em toda sua violência e em toda a sua extensão. Ludibriados pelos gregos, a magnífica e por demais numerosa frota persa foi duramente derrotada; seus melhores e mais nobres homens sofreram uma emboscada e foram mortos na ilha de Psitália; os que escaparam da morte em combate encontraram-na em seu caminho de volta à pátria, vitimados por sede e fome ou pelas águas geladas do Estrímon. Se Xerxes sobreviveu, poucos de seus homens sobreviveram com ele. Para o Mensageiro, não resta dúvida de que "um Nume assim destruiu o exército, / pesando pratos de não equivalente

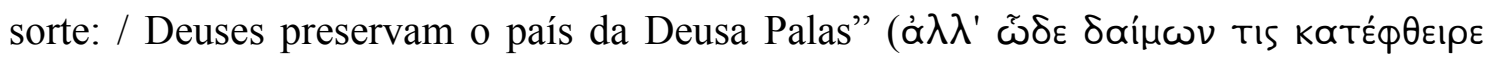

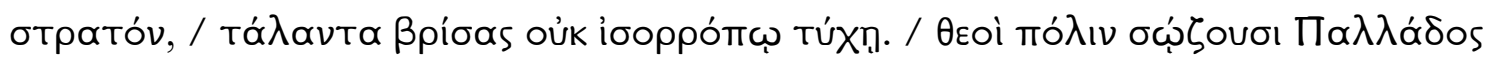
$\theta \varepsilon \tilde{\alpha} \varsigma, P e .345-7)$.

Os desígnios divinos se realizaram tal qual foram prenunciados. Para Aélion (1984, p. 136), pode-se dizer que o relato do mensageiro "correspond point par point au contenu symbolique du songe de la reine", de forma que tanto a narrativa onírica quanto o auspício que a segue constituem uma mise en abyme, em que se refletem os aspectos mais significativos de toda a tragédia.

De fato, à claridade dos sinais divinatórios corresponde a claridade do relato feito pelo Mensageiro ${ }^{47}$, que se pode dividir em cinco momentos. Primeiramente, o Mensageiro nomeia os líderes mortos em combate naval (Pe. 302-30); trata-se do segundo catálogo de nomes ${ }^{48}$. Depois, ele relata o tamanho de ambas as frotas $(\mathrm{Pe}$. 337347) e os acontecimentos que ocorreram antes e durante o confronto ( $P e$. 353-432). Por fim, ele relata o combate na ilha de Psitália $(P e .447-471)$ e a fuga por terra dos persas sobreviventes (Pe. 480-514).

O segundo catálogo de nomes dos chefes persas evoca o primeiro catálogo, de forma que, desfeitas as ambiguidades e tendo se revelado verdadeiros os kledónes, agora se sabe definitivamente que tais homens partiram para a morte. Àqueles nomes juntam-se agora outros, a respeito dos quais, no entanto, não apenas não paira qualquer

\footnotetext{
${ }^{47}$ Para um estudo detalhado do discurso do Mensageiro nos Persas, bem como das angelíai na tragédia grega, conferir a obra de Barrett (2002).

${ }_{48}$ Para uma relação entre este segundo catálogo de nomes e as listas atenienses de mortos em combate, conferir o artigo de Ebbott (2000).
} 
dúvida sobre sua morte, como ainda se descreve cruamente como seus corpos jazem insepultos, ao sabor do balanço das marés, ensanguentados, caídos por terra.

A descrição do tamanho da frota, por sua vez, confirma o que havia de ominoso na descrição do Coro a respeito do tamanho e da riqueza do exército persa, em que resplandecia, materialmente, na quantidade e na opulência do exército, a hýbris de seu líder, Xerxes. Não só a imensidão do tamanho do exército é proporcional à imensidão dos mortos, mas também, por uma ironia trágica, foi a própria imensidão desse exército que foi responsável pela derrota naval em Salamina: "muitos navios atulhavam / o

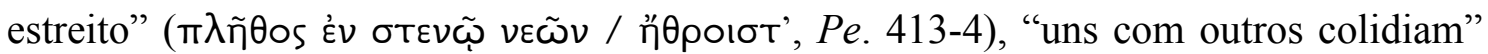

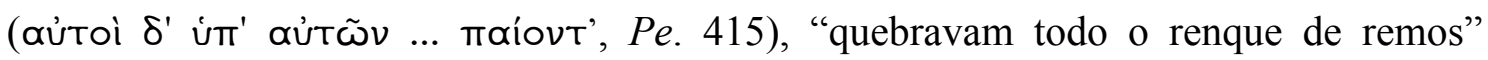

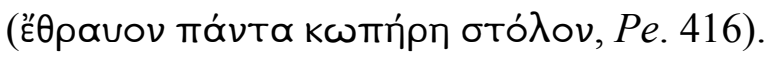

À indagação da Rainha sobre quem teria iniciado o combate, o Mensageiro

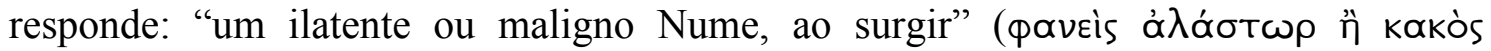
$\delta \alpha i ́ \mu \omega \nu, P e .354)$ e narra em seguida como um grego do exército ateniense os enganou, trazendo a falsa informação de que eles fugiriam naquela noite ${ }^{49}$. Heródoto nos informa que Temístocles enviou um de seus serviçais, um homem chamado Sicino, para dizer aos comandantes persas que os helenos iriam pôr-se em fuga. Note-se que, enquanto em Heródoto todas as personagens envolvidas nesse acontecimento são nomeadas, em Ésquilo só o nome de Atenas é citado. Isso se deve a uma injunção do gênero trágico, dado o vínculo entre a tragédia e a democracia ateniense. Sendo a tragédia uma expressão da democracia ateniense e sendo a democracia ateniense muito suspeitosa dos que são demasiado grandes e, por isso, eventuais candidatos a tiranos, exalta-se unicamente a cidade de Atenas. Aqui, no entanto, essa ausência de nomes não apenas serve à exaltação da cidade de Atenas, mas também contribui para que a descrição de como os gregos surpreenderam os persas com seu ataque inesperado adquira um caráter epifânico. Ouve-se, ao nascer do dia, o clamor dos gregos e o som do clarim, o que provoca pavor nos guerreiros persas, e, de repente, como uma aparição, surge à vista a

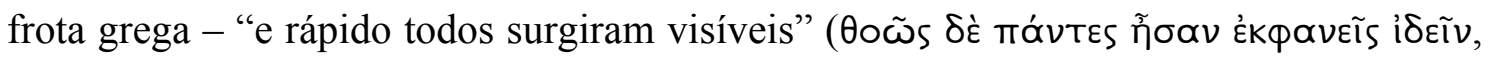
Pe. 398) -, cujo avanço é acompanhado da exortação ao combate, reportada em discurso direto pelo Mensageiro:

\footnotetext{
${ }^{49}$ Conferir parágrafo 75 do livro VIII das Histórias de Heródoto.
} 


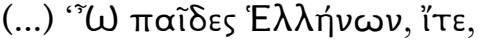

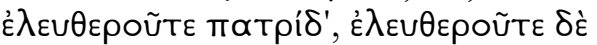

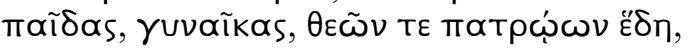

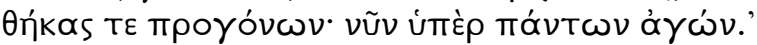

(...) "Ó, filhos de gregos, ide, libertai vossa pátria, libertai vossos filhos, mulheres, templos de Deuses pátrios e túmulos dos pais, por todos é o combate."

O massacre dos nobres persas em Psitália - ilha mencionada não pelo nome, mas por ser onde passeia o deus Pã - é consequência da estratégia de Xerxes de posicionar ali seus homens mais vigorosos, corajosos, nobre e leais, para que pudessem, a partir desse ponto estratégico, matar os inimigos e salvar os amigos. Para o Mensageiro, no

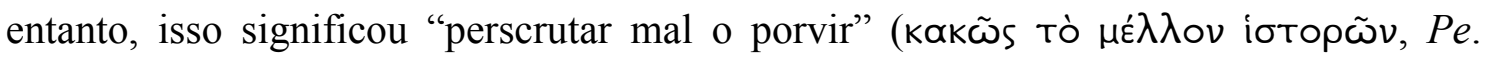

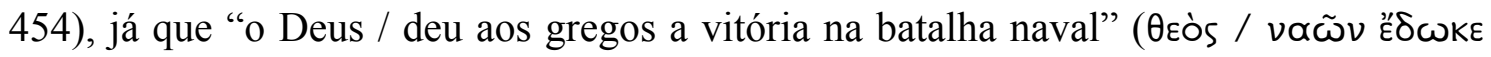

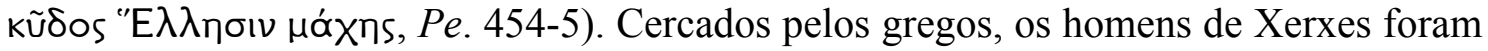
dizimados.

Dos capitães sobreviventes do combate marítimo, poucos conseguiram retornar à pátria. Fugindo por terra, a terra mesma os acolheu com escassez de água e de alimentos em territórios acaio e tessálico, fazendo-os sucumbir à fome e à sede. Na Trácia, à noite, o rio Estrímon foi congelado, pois um "Deus / suscitou um inverno precoce" ( $\theta$ eòs /

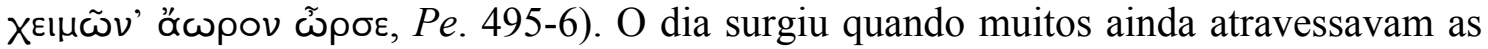
águas congeladas do Estrímon, que derreteram com calor do sol, levando-os à morte.

Tal como é, o relato do Mensageiro dá, portanto, testemunho do que há de numinoso nos acontecimentos que ele narra, visto que são o cumprimento de um desígnio divino prenunciado mediante uma constelação de sinais divinatórios. Isso fica evidente quando a Rainha, findo o relato do Mensageiro, exclama: "Ai de mim! Mísera, destruído o exército! / Ó visão noturna, manifesta em sonho, / com que clareza me

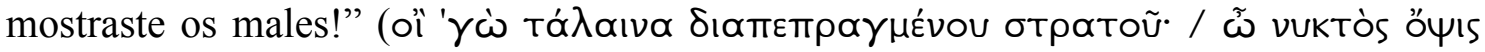

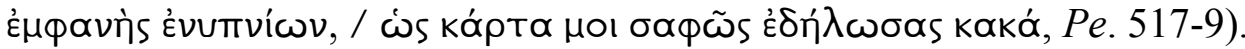

Apesar de a Rainha acusar o Coro de ter "interpretado mal" (qaú $\lambda \omega s$... Ékpívate, $P e .520)$ seu sonho, ela declara que seguirá o conselho do Coro: fará súplicas e trará oferendas aos deuses, à Terra e aos finados, na expectativa de que no "porvir

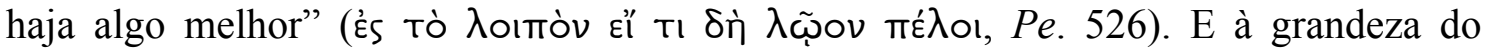
desastre ocorrido corresponde o grande lamento do Coro no primeiro estásimo e a grandeza do ritual com que a Rainha e o Coro evocarão o espectro de Dario no segundo estásimo. 
Como observa Jouan (1981) - no artigo em que analisa as cenas de evocação dos mortos na tragédia grega ${ }^{50}$-, muito se especulou sobre o tipo e a origem deste ritual levado em cena por Ésquilo nesta tragédia, procurando-se ressaltar ora seu aspecto exótico, oriental, ora seu aspecto puramente grego, ora seu aspecto exclusivamente estético-literário.

Mais vale, no entanto, procurar observar os elementos constitutivos do ritual, qual o estatuto daqueles que o praticam e a quem se destina, com que finalidade o fazem e que divindades a ele se associam, para mais bem compreender seu sentido na tragédia em que se insere.

Primeiramente, a Rainha entra em cena, no segundo episódio, portando oferendas propiciatórias aos mortos para verter sobre o túmulo do marido, as quais se constituem de:

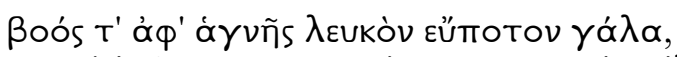

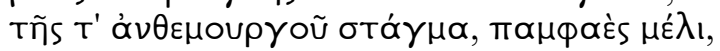

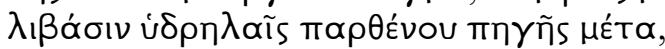

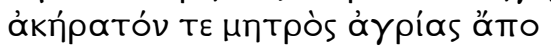

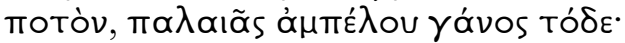

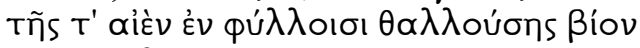

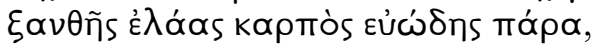

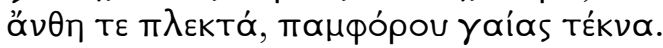

alvo potável leite, de consagrada novilha, e destilado por flórea operária, fúlgido mel, com gotas de água de virgínea fonte, e sem mescla, vindo de mãe silvestre, este potável licor de vetusta videira, e proveniente da sempre frondosa loira oliveira o oloroso azeite, e flores trançadas, filhas de terra fértil.

(Pe.611-18)

Dentre esses elementos, o leite, o mel, a água e o vinho são comuns às libações fúnebres e já figuram como parte do ritual prescrito por Circe a Odisseu para invocar o espectro do adivinho Tirésias, no livro XI da Odisseia $^{51}$. Nas Coéforas, a invocação que os irmãos Orestes e Electra fazem a Agamêmnon é precedida do derramamento de libações sobre o túmulo do falecido rei; todavia, não se faz menção ao conteúdo de tais

\footnotetext{
${ }^{50}$ Jouan (1981, pp. 403-4) distingue quatro tipos possíveis de interpretação, que, desde o estudo de Headlam do início do século XX ("Ghost-Raising, Magic, and the Underworld". $C R, 16,1902$, pp. $52-$ 61), vêm sendo propostas pelos helenistas; a saber: 1) cena de magia necromântica oriental, 2) cena de magia necromântica grega, que reflete práticas contemporâneas a Ésquilo, 3) cena de caráter puramente religioso, fundamentada na prática das honras heroicas; 4) cena de caráter estético-literário, em que se transpõe à cena a Nékya homérica.

${ }^{51}$ Seguindo as instruções de Circe, Odisseu cruza o Oceano até a morada de Hades em busca das revelações do espectro do adivinho Tirésias. Ao chegar ao local prescrito por Circe, Odisseu cava um buraco e ao seu redor derrama libações de leite e mel, de vinho suave e de água; em seguida, esparge cevada branca e evoca os mortos, prometendo-lhes sacrifícios, em especial para o adivinho tebano. A seguir, o herói imola um carneiro e uma ovelha negros, cujo sangue derrama-se sobre o buraco, enquanto seus companheiros pelam e queimam as reses, orando a Hades e a Perséfone. Surgem, então, as almas dos mortos, as quais Odisseu com sua espada tem de manter afastadas do sangue, reservado primeiramente a Tirésias.
} 
libações, descritas apenas pelo termo xoai ${ }^{52}$. Porém, as libações oferecidas a Agamêmnon por Ifigênia em Ifigênia em Táurida, de Eurípides, são justamente leite, mel água e vinho (E. IT. 159-166) ${ }^{53}$.

O destaque que se dá à pureza das oferendas de Atossa deve-se, de acordo com Jouan (1981, p. 412), à dignidade excepcional de seu destinatário; poder-se-ia também acrescentar o estatuto de quem as oferece, uma rainha, e a gravidade da situação em que são ofertadas.

Acompanham o derramamento das libações os hinos entoados pelo Coro. A Rainha pede aos anciãos do Coro que "invoquem" (óvaka $\lambda \varepsilon \tilde{\sigma} \sigma \varepsilon \varepsilon, P e$. 621) Dario

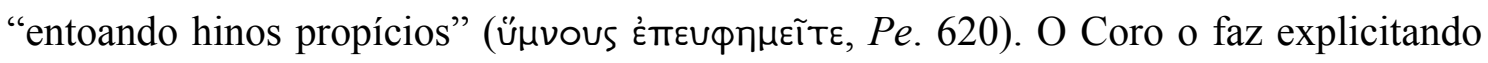
inicialmente o papel que cabe a cada uma das partes - à Rainha, verter as libações; a ele, o Coro, entoar hinos propícios - e também a finalidade do ritual fúnebre: pedir a benevolência dos guias dos finados - numes ctônios, Terra, Hermes e Hades -, para que enviem a alma de Dario à luz, já que o rei seria o único entre os mortais que lhes saberia indicar o fim de seus males. Seguem-se assim três pares de estrofe e antístrofe, seguidos de um epodo, em que o Coro invoca o rei, exaltando-o como a um deus, e as divindades ctônias. Tal canto, assim da aparição do espectro de Dario, é qualificado por este como

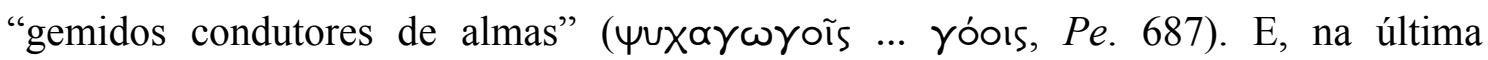
antístrofe, o Coro postula mais um motivo para que a alma do Rei venha à luz: para que possa ouvir notícias e novas dores (Pe. 665-6).

As libações e os hinos pretendem assim estabelecer uma comunicação entre os vivos e o morto, a fim de que este, inteirando-se da situação, possa descobrir se no porvir há algo melhor, como asseverou a Rainha ( $P e .526)$, e indicar o termo de tais males, como postulou o Coro (Pe. 631-2).

Ora, invocar a alma de um morto para dela obter conselhos e prenúncios é a finalidade de um tipo de adivinhação denominado necromancia. De acordo com Ogden (2001), saber a causa da ira de um morto e como aplacá-la parece ter sido o principal motivo para a prática necromântica. Consultavam-se os mortos, no entanto, por diversos outros motivos, em busca de resposta para questões tais como a localização de um

\footnotetext{
${ }^{52}$ Conferir versos 15, 23, 87, 149, 156 e 164 .

${ }^{53}$ Dizem os versos pronunciados por Ifigênia: "Verter-lhe-ei / estas libações e a taça de mortos / no dorso da terra, / e as fontes de vacas montesas, / e as libações víneas de Baco, / e o fulvo lavor de abelhas, /

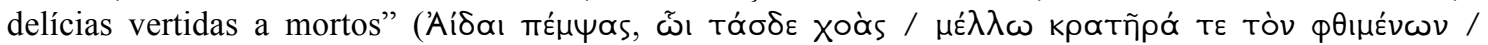

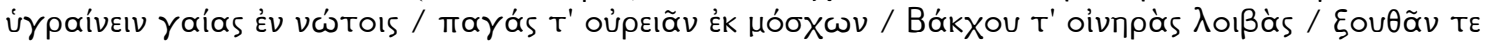

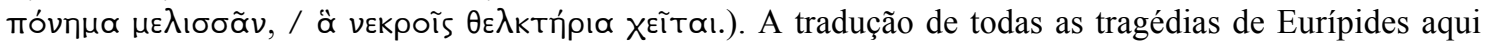
citadas são de Jaa Torrano (Editora Iluminuras, no prelo).
} 
tesouro, a data da morte do consulente ou de terceiros, o desfecho de uma guerra, entre outras. Porém, por ser um ritual solene e complexo, não era uma prática ordinária.

Ainda segundo o autor, muito mais popular parece ter sido a incubação praticada sobre o túmulo de heróis: após cumprir determinados ritos, o consulente dormia sobre o túmulo do herói de cuja alma desejava obter revelações e as recebia em seus sonhos. A necromancia podia ser realizada tanto em um nekyomanteîon, isto é, um oráculo dos mortos, quanto, simplesmente, junto às sepulturas. Os oráculos dos mortos - dentre os quais os mais conhecidos eram o do rio Aqueronte na Tesprotia, o do rio Averno na Campanha, o de Heracleia Pôntica e o de Tênaro - eram considerados um ponto de convergência entre o mundo dos vivos e o dos mortos, mas esse entrecruzamento de mundos parece ter sido considerado estando presente também nos túmulos, o principal local para se consultarem os mortos.

O ritual de invocação do espectro de Dario, tal como apresentado por Ésquilo, remete a um ritual necromântico, o que por sua vez remete à questão a respeito do poder divinatório da alma do morto. Ogden (2001, pp. 231-50), com base nos relatos da antiguidade greco-romana, encontrou diferentes e fragmentárias explicações, diretamente expostas ou subjacentes aos textos, quanto à presciência dos mortos e concluiu que não há unanimidade entre os antigos quanto ao dom divinatório dos mortos. A natureza diversificada e, por vezes, contraditória da atitude do homem grego em relação à morte, aos mortos e à vida post-mortem, refletir-se-ia na atitude dos gregos quanto à necromancia, sendo, portanto, como conclui o autor, impossível caracterizar uma atitude única dos antigos frente a essa prática divinatória. Veja-se então, no caso específico desta tragédia esquiliana, qual a relação que se estabelece entre o espectro de Dario e a adivinhação.

No terceiro episódio, respondendo à invocação, o antigo soberano finalmente surge sobre seu túmulo. Saudando o Coro de anciãos e percebendo a presença de sua esposa, o que lhe causa certo temor, o espectro de Dario questiona seus interlocutores sobre o motivo pelo qual fora chamado: "por que dor o país padece, / geme, golpeia, e

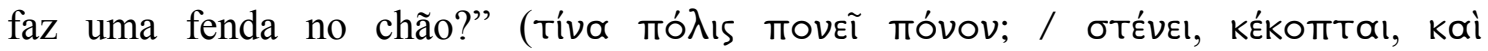

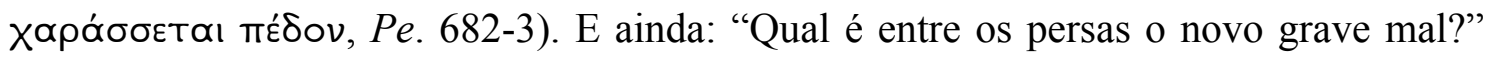

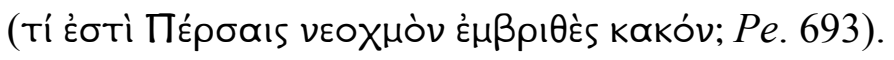

Visto que o reverente pudor impede o Coro de lhe dirigir a palavra, é a Rainha quem lhe esclarece que "o novo grave mal" é a destruição do poderio persa. Demonstrando desconhecimento dos fatos atuais, Dario pergunta, então, à sua antiga 
companheira se acaso foi a peste ou a sedição a causa dessa desgraça (Pe. 715). Igualmente, pergunta-lhe qual de seus filhos foi responsável pela condução do exército, se a invasão se deu por mar ou por terra, qual a extensão da derrota, se seu filho ainda vive e se houve sedição contra este.

Ao fim da esticomitia entre Dario e a Rainha, após ter sido posto a par de todas as informações relativas à catástrofe, o antigo Rei exclama "Pheû! Veio veloz o ato de oráculos, a meu filho / Zeus incumbiu cumprir ditas divinas" (

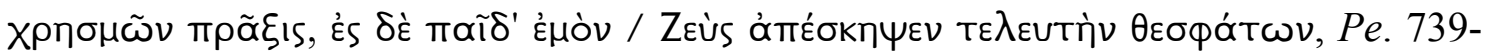
40) e, a partir desse momento, demonstra ter conhecimento do passado recente, quando fala, por exemplo, que, chegados à Grécia, os guerreiros persas tiveram uma atitude sacrílega perante estátuas, altares e templos de deuses (Pe. 809-12); do presente, ao mencionar que o exército sofre por seus mal feitos (Pe. 813); do futuro próximo, quando anuncia o iminente retorno de Xerxes (Pe. 832-6); e do futuro distante, quando prenuncia a batalha em Plateia (Pe. 816-7), que teve lugar um ano depois, em 479 a.C.

A questão da extensão e da origem do conhecimento divinatório de Dario é comumente abordada entre os estudiosos de Ésquilo. Dario possuiria poderes divinatórios advindos de sua condição de morto ou o que ele profetiza seria o conteúdo de oráculos por ele recebidos em vida e dos quais, ao tomar conhecimento dos últimos acontecimentos, ele se recordaria?

Para Rosenbloom (2006, p. 91), é a notícia da salvação de Xerxes que desencadeia a lembrança das predições de um oráculo, mas o conhecimento de Dario quanto ao futuro se restringiria ao seu conhecimento desse oráculo. Para Rose (1950, p. 265), Dario é como os espectros homéricos, incapazes de saber o que acontece no mundo contemporâneo, embora possa prever, em certa medida, acontecimentos futuros com grande sabedoria. Michelini (1982, p. 144-5) argumenta que, aparentemente, o que desengatilha a lembrança de um oráculo em Dario é a notícia da sobrevivência de Xerxes, a partir do que seria justificado supor que o oráculo mencionasse uma grande derrota militar por terra e por mar da qual o rei saísse vivo. No entanto, para a autora, a súbita recordação de um oráculo obedece mais a propósitos estilísticos e dramáticos, uma vez que, mencionado o oráculo ao fim da esticomitia, Dario passa do papel de questionador para o de profeta.

No entanto, mais importante do que o conhecimento que ele possui dos fatos e o motivo pelo qual ele o possui é a interpretação que o espectro de Dario faz de tais fatos. Ora, a tragédia grega fornece numerosos exemplos de que não é suficiente apenas 
possuir o conhecimento dos desígnios divinos; é necessário saber interpretá-los e respeitá-los. Para tanto, os requisitos imprescindíveis são a sabedoria e a moderação, qualidades que o personagem de Dario claramente detém e que Ésquilo continuamente enfatiza.

Dario é evocado, no segundo estásimo, como "o venturoso / Rei igual a Nume"

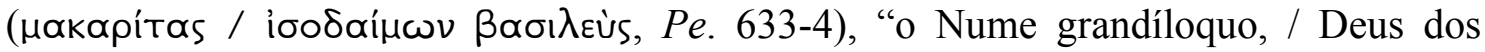

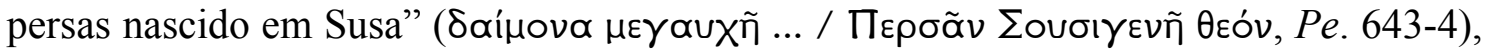

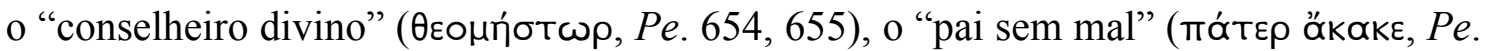
663,671 ). É a alma de um rei "igual a Deus" (iøó $\theta \varepsilon o s, P e .856$ ) que surge sobre o

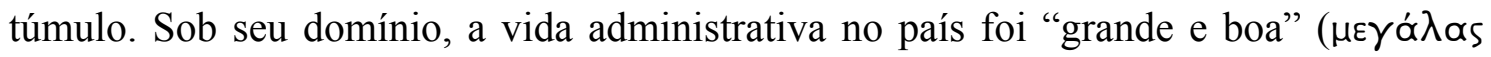

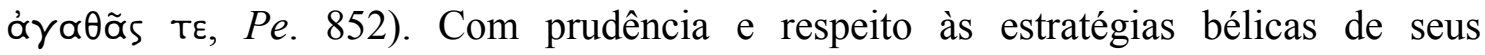
antecessores, conduziu seu exército à conquista de muitas cidades, sem, no entanto, trazer dor ou luto ao país. Assim o Coro celebra, no terceiro estásimo, Dario e seu reinado.

Portanto, esse homem sábio e prudente, ao possuir um conhecimento divinatório e as qualidades necessárias para bem interpretá-lo, expressa uma interpretação dos acontecimentos que explica os motivos pelos quais o presente se revela tão sinistro e o futuro permanece ainda tão ameaçador: a destruição do poderio persa é descrita por Dario como a realização de um oráculo, ou seja, como o cumprimento de um desígnio divino. Tal realização foi antecipada pela atitude de Xerxes e corroborada pelos deuses,

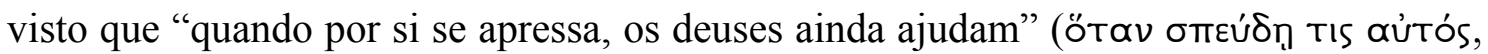

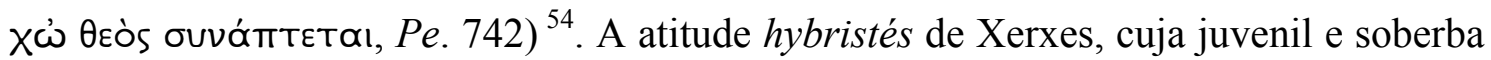
audácia o levou a construir uma ponte sobre o Helesponto e a queimar templos e estátuas divinos, supondo-se capaz de superar Posídon e todos os demais deuses, mostrou-se enfim sujeita à prestação de contas: Zeus, como esclarece Dario, é um

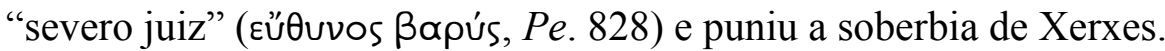

É interessante observar como em Heródoto encontra-se presente uma interpretação da vitória grega muito semelhante à interpretação da derrota persa fornecida pelo espectro de Dario, tal como se pode perceber na seguinte passagem do discurso de Temístocles aos atenienses:

\footnotetext{
${ }^{54}$ Jouanna (1992/1993, p. 86-7), analisando o emprego desse provérbio na tragédia grega, conclui que seu uso dá-se regularmente com um sentido positivo, isto é, de encorajamento de uma determinada ação pela certeza do auxílio divino; Ésquilo, no entanto, sem alterar o provérbio, utiliza-o em um contexto oposto, impregnando-o assim de uma amarga ironia e revelando que a ajuda divina também se dá quando se trata de ações iníquas.
} 


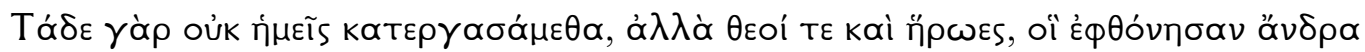

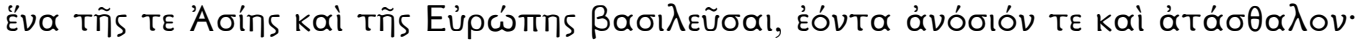

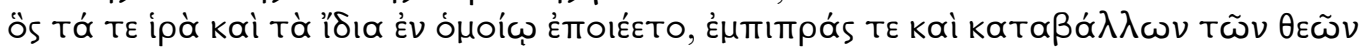

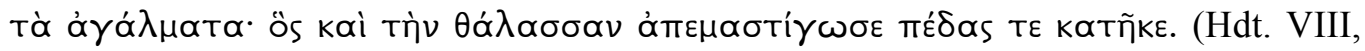
109)

É que não fomos nós que realizamos este feito, mas os deuses e os heróis que não aceitaram de bom grado que um só homem governasse a Ásia e a Europa, para mais uma pessoa ímpia e iníqua que tratou do mesmo modo templos e casas particulares, queimando e derrubando as imagens dos deuses, e que até fez açoitar o mar e lhe lançou cadeias. ${ }^{55}$

O cumprimento do destino desvelado pelo oráculo não se esgota, no entanto, na batalha de Salamina, em cuja derrota reside apenas uma parte da "fonte de males"

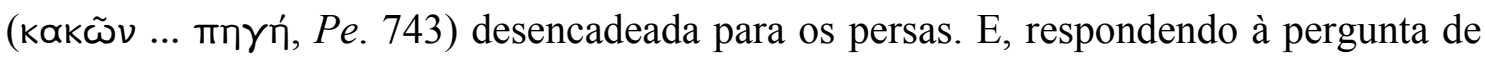
sua antiga companheira - "Como depois ainda / estaríamos o mais bem, o povo persa?"

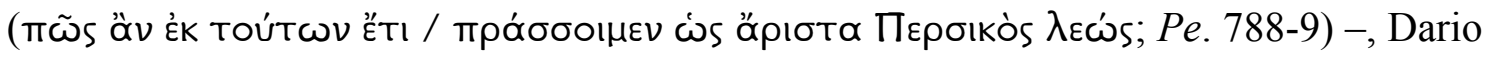
aconselha seus interlocutores a não enviarem mais uma expedição ao território grego, pois o exército persa é muito grande e a própria terra se torna uma aliada dos gregos ao

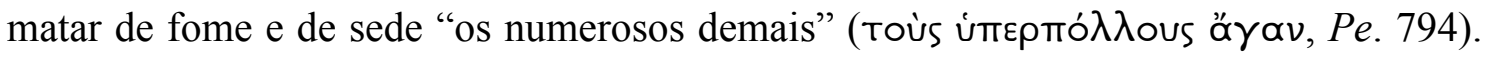
Assim, o vasto exército mobilizado por Xerxes revela-se, afinal, como tão bem prenunciaram todos os indícios, perniciosamente excessivo.

De tão vasto contingente, revela Dario, apenas poucos homens regressarão, "se convém confiar / em oráculos de Deuses, ao ver a situação / presente, pois vêm não ora

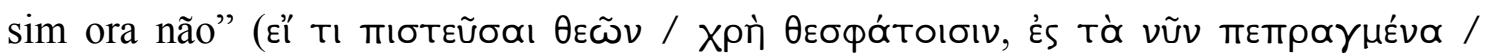

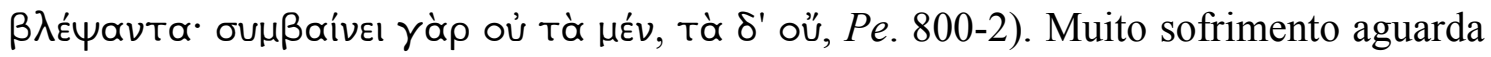
o restante do exército na Hélade e muito sangue será derramado "no chão de Plateia,

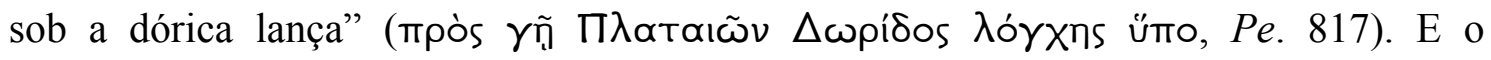
sofrimento pelo qual passam e ainda hão de passar é fruto de sua "soberbia e de planos

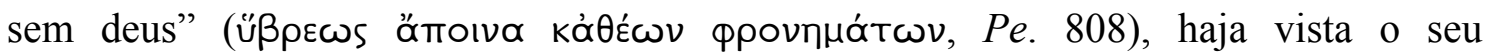
comportamento sacrílego com estátuas, altares e templos de deuses, pilhados, revirados e queimados por eles. Com isso, deve-se entender que "mortal não deve ter soberbo pensar. / A soberbia, ao florescer, produz a espiga / de erronia, cuja safra toda será de

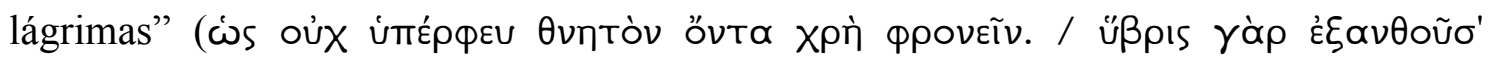

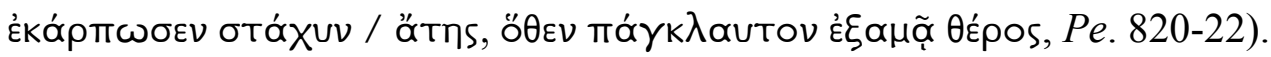

${ }^{55}$ Tradução de José Ribeiro Ferreira e Carmen Leal Soares (2002). 
Lágrimas, afinal, foi o que restou de tão vasto e opulento exército. Dario condena essa opulência, admoestando:

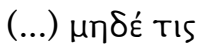

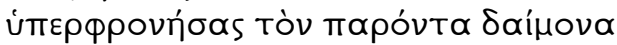

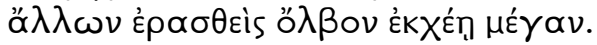

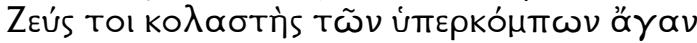

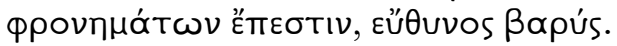

(...) ninguém, por desprezo ao seu presente Nume por querer outros, verta grande opulência. Zeus punitivo vigia os demasiados soberbos pensamentos, severo juiz.

(Pe. 824-8).

E é a esse severo juiz que também Xerxes presta contas. A afirmação da Rainha, no primeiro episódio, de que, mesmo derrotado, seu filho não estaria sujeito à prestação de contas revela-se, afinal, equivocada. Primeiramente porque Xerxes está claramente tendo de prestar contas aos deuses por sua hýbris e depois porque o Coro, quando da chegada do Rei em cena, exige-lhe também uma prestação de contas ao lhe perguntar insistentemente sobre o destino dos companheiros que levou consigo em tão malfadada expedição.

Mas antes dos pungentes lamentos finais de Xerxes e do Coro, o espectro de Dario, tendo cumprido o papel para o qual fora invocado, retira-se ao mundo dos mortos, afastado do qual, como previamente avisara, não poderia permanecer por muito tempo. E, despedindo-se com o seguinte conselho: "alegrai-vos, entre males, / concedendo à vida o prazer de cada dia, que aos mortos a riqueza não serve" (X⿳ípєt',

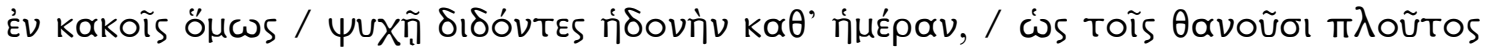

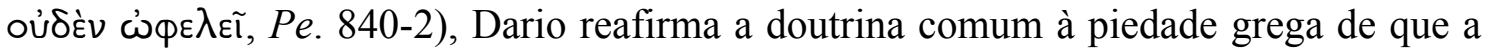
grande riqueza é intrinsecamente iníqua, por abrir caminho para a hýbris, a qual, incitando a recusa dos deuses, conduz à ruína, tal como conduziu Xerxes e o império persa. 
2. OS SETE CONTRA TEBAS 


\section{OS SETE CONTRA TEBAS}

A tragédia Os Sete contra Tebas, de acordo com a didascália, era a terceira da tetralogia com que Ésquilo obteve a vitória em 467 a.C e que compreendia ainda as tragédias Laio e Édipo e o drama satírico A Esfinge. A unidade temática dessa tetralogia, como sugerem os títulos das peças, reside nos acontecimentos funestos que atingiram a casa real de Tebas ao longo de três gerações: a de Laio, a de Édipo e a dos filhos deste, Etéocles e Polinices.

Pelo fato de Os Sete ser a última tragédia a compor a trilogia e a única supérstite, pode-se apenas inferir, dos fragmentos que restaram das duas outras tragédias e do próprio texto dos Sete, os acontecimentos representados em Laio e em Édipo. Conjectura-se que a primeira tragédia narraria as consequências funestas da desobediência de Laio a um oráculo de Apolo que o impedia de ter filhos. A segunda tragédia narraria a descoberta por parte de Édipo do parricídio e do incesto por ele cometidos, sua consequente reação, arrancar seus próprios olhos, e a maldição que ele lança sobre seus filhos ${ }^{1}$.

A terceira e última parte da trilogia sobre a casa real de Tebas narra, fundamentalmente, o cumprimento da maldição de Édipo sobre seus filhos: a morte que, inevitavelmente, um trará ao outro. Os Sete inicia-se, pois, na iminência de mais um acontecimento ruinoso: os filhos de Édipo, sobre os quais pesa a maldição do pai, encontram-se em lados opostos na guerra que está prestes a se travar pelo poder real de Tebas. Etéocles, detentor do poder, prepara-se para enfrentar o exército argivo que Polinices e Adrasto reuniram e que está prestes a atacar a cidade.

A ação dramática transcorre em Tebas. No prólogo (Se. 1-77), Etéocles apresenta a situação: a cidade encontra-se sitiada e o adivinho Tirésias prediz a iminência de um forte ataque. O Mensageiro chega trazendo notícias que confirmam as predições do adivinho, descrevendo a fúria sangrenta dos generais. No párodo ( $\mathrm{Se}$. 78180), o Coro, temendo pelo destino da cidade e agarrando-se às estátuas dos deuses, invoca proteção divina. Etéocles, no primeiro episódio (Se. 182-286), repreende-o duramente. No primeiro estásimo (Se. 287-368), o Coro, ainda temeroso e suplicando aos deuses, descreve o retrato triste e desolador de uma cidade tomada por inimigos. $\mathrm{O}$

\footnotetext{
${ }^{1}$ Para uma análise conscienciosa dos fragmentos de Laio e Édipo e hipóteses sobre o conteúdo dessas tragédias, conferir a introdução à edição de Hutchinson dos Sete contra Tebas (1985) e a obra de De Dios, Esquilo: Fragmentos, Testimonios (2008).
} 
segundo episódio (Se. 369-719) é a parte central da tragédia, tanto por seu conteúdo como por sua extensão. Nele, o Mensageiro conta a Etéocles e ao Coro a qual general do exército inimigo coube cada uma das sete portas da cidade. Tendo designado os respectivos opositores, Etéocles declara que irá defender a porta que coube a seu irmão Polinices. No segundo estásimo (Se. 720-791), o Coro rememora o triste destino de Édipo e de Laio, pressentindo que a terrível maldição que Édipo lançou sobre os filhos começa a se realizar. É o que acontece quando, no terceiro episódio ( $S e$. 792-821), o mensageiro traz a notícia da morte dos irmãos, para desespero do Coro, que, no terceiro estásimo ( $\mathrm{Se}$. 822-847), lamenta-se pela desdita dos filhos de Édipo. No êxodo (Se. 8481004), entram em cena Antígona e Ismene, lamentando a sorte de seus irmãos e de sua estirpe. Finalmente, na cena final (Se. 1005-1078), o arauto anuncia a interdição ao sepultamento de Polinices, considerado traidor pela cidade, o que provoca a rebelião de Antígona, que afirma haver de sepultá-lo a qualquer custo ${ }^{2}$.

O diálogo divinatório, nos Sete, dá-se mediante uma miríade de sinais numinosos, que compreendem os vaticínios de dois ilustres adivinhos, Tirésias e Anfiarau, o oráculo apolíneo entregue a Laio, um sonho profético mencionado por Etéocles, a maldição de Édipo sobre seus filhos, a tiragem da sorte e uma profusão de palavras e imagens cledomânticas. A cledomancia é, aliás, nesta tragédia, um dos mais importantes suportes para o diálogo divinatório que se trava ao longo da ação dramática.

A importância da palavra falada perpassa toda a tragédia: contra Tebas, essa

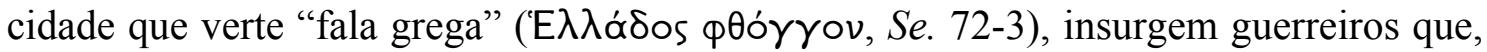
tendo pronunciado um juramento (Se. 45-60), agridem a cidade e os deuses com suas palavras insultantes, ameaçadoras, agourentas e com seus escudos igualmente

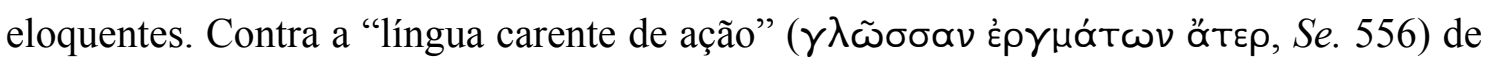
tais inimigos, Etéocles contrapõe os braços (Se. 473, 554, 623-4) de homens hostis a discursos presunçosos (Se. 410), que se definem pela ação. Salvando assim a cidade, Etéocles, no entanto, perece, pois pesa sobre ele e seu irmão "a palavra votiva do pai"

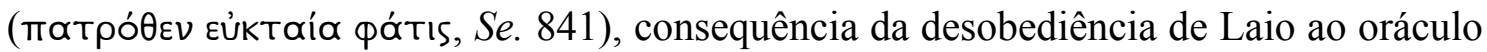
"três vezes pronunciado" em Delfos (тріs Eimóvтos, Se. 746) e cujo cumprimento

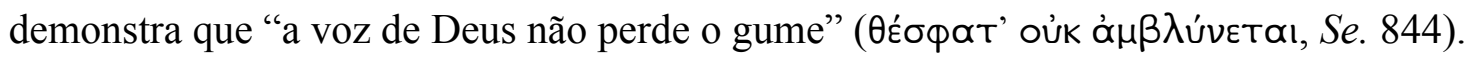

\footnotetext{
${ }^{2}$ Para uma discussão sobre a autenticidade da parte final da tragédia, vejam-se, entre outros: R. D. Dawe, "The End of Seven against Thebes", CQ, 17 (1), 1967, p. 16-28; H. Lloyd-Jones, "The End of the Seven against Thebes", CQ, 9 (1), 1959, p. 80-115; A. L. Brown, "The End of Seven against Thebes", CQ, 26 (2), 1976, p. 206-19; E. Flintoff, "The Ending of the Seven Against Thebes", Mnemosyne, 33 (3/4), 1980, p. 244-71.
} 


\section{1) Etéocles e a palavra numinosa}

A tragédia inicia-se com o discurso de Etéocles convocando todos os cidadãos tanto os mais jovens quanto os mais velhos - para defender seu solo pátrio. O motivo da exigência do empenho de todos na defesa da cidade é a interpretação que o adivinho faz do auspício das aves, que revela a iminência de um severo ataque à cidade de Cadmo. Pondera Etéocles que, se até então a divindade os tem favorecido, agora o momento decisivo chegou e é assim enunciado por Etéocles:

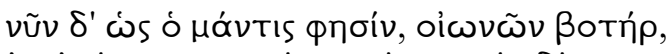

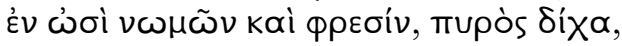

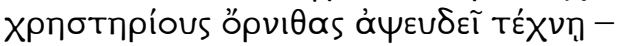

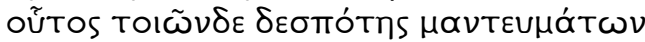

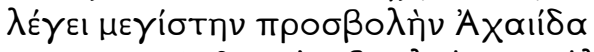

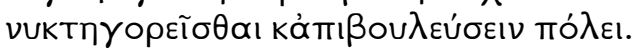

mas, agora, diz o adivinho pastor de pássaros, longe da pira, à escuta e em busca, atento às aves augurais, com arte sem mentira, esse déspota de tais modos de adivinhar diz que à noite se reúne para decidir-se o maior assalto aqueu contra a cidade.

(Se. 24-9)

O conteúdo do vaticínio - a reunião das tropas para decidir o assalto aqueu contra a cidade - é precedido de quatro versos em que se descrevem 1) o modo de adivinhação empregado pelo adivinho: a ornitomancia, visto que ele é dito um "pastor

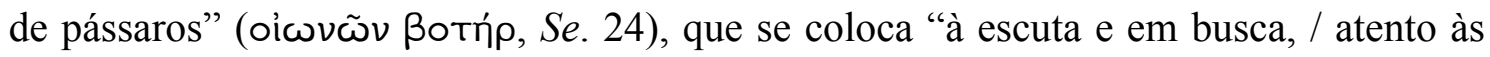

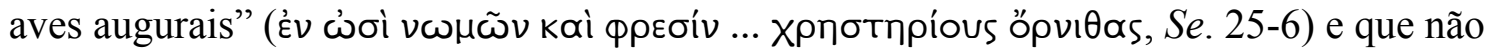
recorre a outra forma de adivinhação, a piromancia; logo, "longe da pira" (mupòs síx $\propto$, Se. 25); 2) a excelência do adivinho em tal arte divinatória: ele é qualificado como um

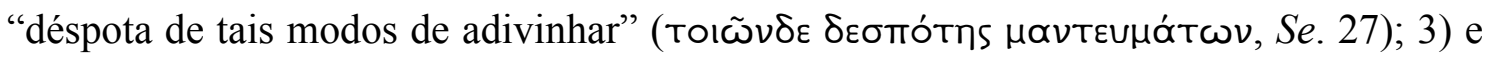

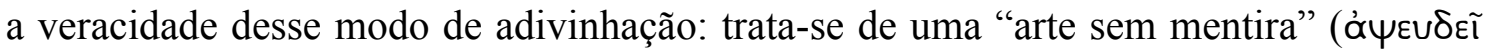
TÉXvท̣, Se. 26).

Ainda que o adivinho não apareça em cena e se faça presente apenas através da proclamação que Etéocles faz de seu vaticínio e ainda que Ésquilo não o nomeie, sabese que se trata de Tirésias, famoso por estar presente nos mais importantes acontecimentos da casa real de Tebas e que é um dos mais ilustres adivinhos da Antiguidade. Ele desfruta de tal renome que Circe, na Odisseia, envia Odisseu a uma viagem ao Hades para consultá-lo, descrevendo-o da seguinte forma: 


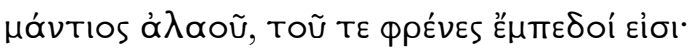

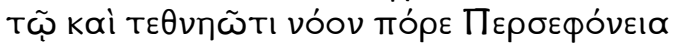

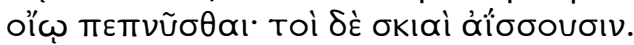

cego adivinho, cuja alma os sentidos mantém ainda intactos.

A ele, somente, Perséfone deu conservar o intelecto

mesmo depois de ser morto; as mais almas esvoaçam quais sombras. (Od. X, 493-5)

Circe atribui-lhe ainda o epíteto de "pastor de guerreiros" (ő $\rho \chi \propto \mu \varepsilon \lambda \propto \tilde{\omega} \nu, O d$. $\mathrm{X}, 538)$ e, quando da chegada de sua alma junto a Odisseu, ele é descrito tendo um

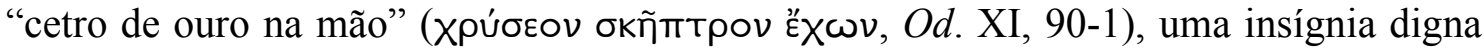
de sua autoridade; na Ilíada, o sacerdote de Apolo, Crises, é descrito também portanto

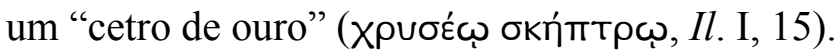

No que concerne à natureza do dom divinatório de Tirésias e à sua cegueira, a poesia homérica não oferece nenhuma informação, mas, em narrativas pós-homéricas, há diferentes versões a esse respeito. Uma delas, transmitida por Calímaco, conta que, como sua mãe, a ninfa Cariclo, costumava acompanhar Atena, deu-se o caso de Tirésias ver a deusa completamente nua em um de seus banhos. Como castigo, Atena tocou-lhe os olhos, cegando-os. Sua mãe, porém, rogou à deusa que restituísse a visão a seu filho. Como era impossível para Atena desfazer o mal que lhe havia causado, a deusa o compensou, outorgando-lhe o dom da adivinhação, grande renome, uma vida longa e o privilégio de manter a consciência mesmo após a morte (Call. Hino $V, 121-30)^{3}$.

Apolodoro, em sua Biblioteca, narra, além desta versão, que ele atribui a Ferécides, outras duas. Em uma delas, o dom da adivinhação é-lhe inato, mas ao revelar segredos que os deuses não desejavam compartilhar com os mortais, Tirésias foi por eles castigado com a cegueira. Em outra versão, conta Apolodoro que o dom da adivinhação the foi outorgado por Zeus (Píndaro o chama "profeta de Zeus": N., I, 60). Tirésias, tendo encontrado num bosque um casal de serpentes copulando, feriu-as, transformando-se em seguida em mulher, mas, tendo reencontrado as mesmas serpentes

\footnotetext{
${ }^{3}$ Diz Atena nos versos de Calímaco: "farei dele um adivinho digno de ser cantado pelas gerações futuras, / de certo, muito mais notável do que os outros. / Conhecerá os pássaros, os de bom augúrio, os que voam / em vão e os que fazem presságios não favoráveis. / Muitos oráculos aos Beócios, muitos a Cadmo / irá proferir e, mais tarde, aos grandes Labdácidas. / Dar-lhe-ei um grande bastão, que conduzirá seus pés aonde lhe convir; / dar-lhe-ei também um termo da vida que por muito tempo se adia. / E será o único

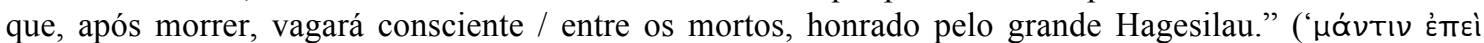

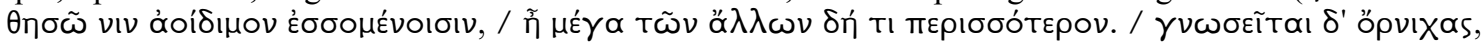

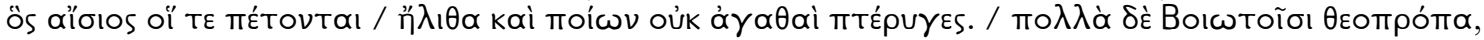

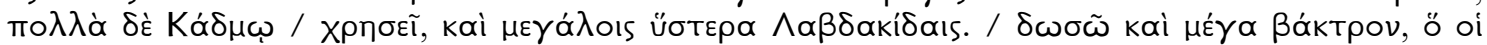

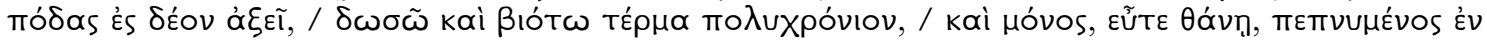

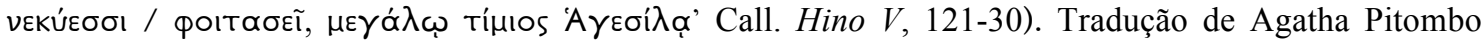
Bacelar (2007).
} 
unindo-se novamente, voltou a ser homem. Tal experiência o tornou apto a responder à questão, postulada por Zeus e Hera, de quem sente maior prazer no amor: o homem ou a mulher. Por ter respondido que era a mulher, Hera vingou-se de Tirésias cegando-o, mas Zeus lhe concedeu o dom divinatório e uma vida longa (III, 6, 7). Esse mito foi retomado posteriormente por Ovídio nas Metamorfoses ${ }^{4}$.

Quanto à morte do adivinho, Apolodoro (III, 7, 3), Pausânias (IX, 33) e Diodoro $(I V, 67,1)$ narram o mesmo: após a tomada de Tebas pelos epígonos, Tirésias partiu em fuga e, tendo bebido das águas da fonte Telfusa, ali morreu. Não foi, entretanto, no local de sua morte que se instalou o oráculo de Tirésias e sim em Orcômeno, cidade rival de Tebas. De acordo com Bouché-Lecquercq (2003, pp. 764-5), este é um dos menos conhecidos oráculos heroicos. É provavelmente um oráculo tardio e, no século I d.C., Plutarco (De Def., 434 C) diz que o oráculo de Tirésias emudeceu, desaparecendo completamente ${ }^{5}$.

O que é notável nessas narrativas acerca de Tirésias é o fato de a sua cegueira aparecer relacionada a um castigo divino e o dom divinatório, juntamente com a longevidade, a um ato de compensação pela punição sofrida. Essa intervenção divina direta sofrida por Tirésias por parte dos deuses garante-lhe uma autoridade inigualável.

$\mathrm{Na}$ tragédia grega, algumas características básicas se mantiveram na representação de Tirésias; a saber, a sua cegueira e a sua idade avançada, símbolo tanto

\footnotetext{
${ }^{4}$ Dizem os versos: "conta-se Jove, ébrio de néctar, ter deixado / seus graves afazeres e travado alegre / prosa com Juno: 'Sentes mais prazer que os homens / no sexo, certamente', ele teria dito. / Ela negou. Aprouve-lhes levar o assunto / a Tirésias, nos dois modos de Vênus, douto. / Pois com dois toques de bastão em verde relva / violara a cópula de duas grandes víboras; / e de homem fez-se fêmea, por encantamento, / durante sete outonos. No oitavo as reviu / e diz: 'Se vossas chagas têm tanto poder / de mudar em contrário a sorte do agressor, / ora vos ferirei'. Batendo em ditas cobras, / retorna à forma antiga e ao modo de nascença. / Feito arbitro, então, desta rixa jocosa, / põe-se ao lado de Jove. A Satúrnia ficou, / dizem, bem mais zangada que o caso pedia, / e os olhos do juiz danou à noite eterna. / O pai onipotente, posto não ser lícito / divo feito anular, em troca de olhos deu-lhe / a visão do futuro e a pena mitigou-lhe." (forte Iovem memorant diffusum nectare curas / seposuisse graves vacuaque agitasse remissos / cum Iunone iocos et 'maior vestra profecto est, / quam quae contingit maribus' dixisse 'voluptas.' / illa negat. placuit quae sit sententia docti / quaerere Tiresiae: Venus huic erat utraque nota. / nam duo magnorum viridi coeuntia silva / corpora serpentum baculi violaverat ictu / deque viro / factus (mirabile) femina septem / egerat autumnos; octavo rursus eosdem / vidit, et 'est vestrae si tanta potentia plagae' / dixit, 'ut auctoris sortem in contraria mutet, / nunc quoque vos feriam.' percussis anguibus isdem / forma prior rediit, genetivaque venit imago. / arbiter hic igitur sumptus de lite iocosa / dicta Iovis firmat: gravius Saturnia iusto / nec pro materia fertur doluisse suique /iudicis aeterna damnavit lumina nocte; / at pater omnipotens (neque enim licet inrita cuiquam / facta dei fecisse deo) pro lumine adempto / scire futura dedit poenamque levavit honore, Metam. III, 318-38). Tradução de Raimundo Nonato Barbosa de Carvalho (2010).

${ }^{5}$ Para um apanhado mais completo a respeito de Tirésias, as narrativas a ele associadas e suas profecias, conferir Bouché-Leclercq (2003, pp. 298-301; 764-5); sobre o papel de Tirésias como mediador, conferir o artigo de Carlos García Gual (1975); a respeito do papel de Tirésias como adivinho e mago, conferir o artigo de Marcello Carastro (2007); sobre a experiência de mudança de sexo de Tirésias, conferir Loraux (1989).
} 
de sua sabedoria quanto de sua incomum longevidade. Ele é associado principalmente à arte augural. No Édipo Rei, de Sófocles, após as revelações de Tirésias, o Coro o chama

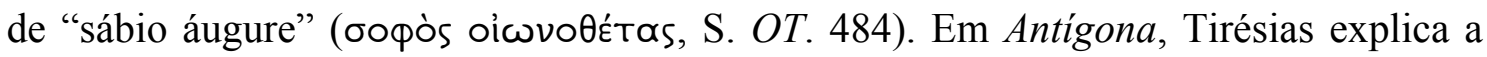
Creonte o que observou dirigindo-se a seu "antigo assento augural, porto de todos os

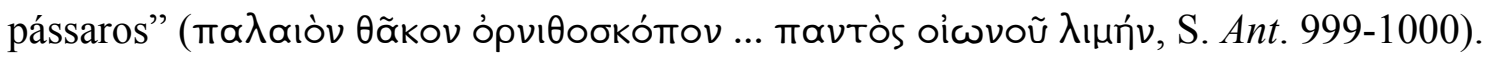
Nas Fenícias, de Eurípides, Tirésias entra em cena para comunicar os vaticínios que

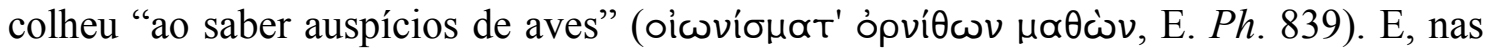
Bacantes, Penteu, irado com Tirésias, ordena a um de seus homens que destrua o lugar

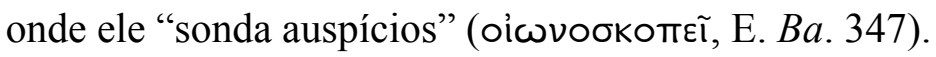

A tragédia retratou-o fazendo predições ou dando conselhos referentes aos funestos acontecimentos que compõem a história dos Labdácidas, como acontece nos Sete. Sua dignidade e sabedoria são sempre ressaltadas e os insultos que a ele lhe dirigem Édipo ou Creonte nas tragédias de Sófocles, ou Creonte e Penteu nas tragédias de Eurípides, somente acentuam o poder da áte que perturba o espírito e obnubila o discernimento dos reis tebanos.

Diferentemente das tragédias supracitadas, nos Sete, os vaticínios de Tirésias são amplamente considerados por Etéocles; como se viu, o líder tebano apresenta Tirésias como um pastor das aves augurais, que exerce de forma soberana a sua arte, uma arte que não mente. É a interpretação que o adivinho faz dos auspícios que leva Etéocles, no prólogo, a conclamar todos os cidadãos para que se preparem para o combate.

Diante da certeza do ataque iminente dos argivos, Etéocles, no verso inicial da

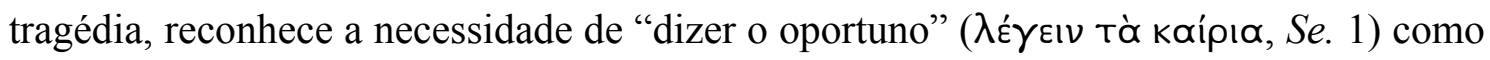
seu dever enquanto dirigente e defensor da cidade de Tebas. Dizer o oportuno, em situação tão premente, é convocar todos os cidadãos à guerra, não importando se muito jovens ou muito velhos; é incitar-lhes o ardor bélico, relembrando-lhes a dívida que têm com a terra mãe que os criou; é dar instruções para que se posicionem para a batalha, ocupando as ameias, os portais, os parapeitos e os bancos das torres, as portas de saída; é também reportar os vaticínios do adivinho, conferindo dessa forma à mobilização e à participação de todos um caráter divinamente inelutável. Porém, dizer o oportuno, do ponto de vista da piedade grega, é também proferir palavras de bom augúrio e evitar a todo custo as de sentido ominoso.

Como se viu no capítulo precedente, a prática da cledomancia se fundamenta na percepção da linguagem como um aspecto fundamental do mundo: a palavra possui um nume que nela reside e que faz com que ela se cumpra, sendo, desse modo, profética. 
Essa mesma relação do homem grego com a linguagem está na base do poder da maldição, da solenidade do juramento e da gravidade do perjúrio, do temor à imprecação pública, do uso de eufemismos e de antífrases, da prática da eufemia. São tanto formas de empenhar corretamente a palavra falada quanto de cuidado com seu uso em virtude de um reconhecimento de que a palavra falada, dependendo da ocasião e do contexto, é numinosa.

Veja-se, por exemplo, no Agamêmnon, o cuidado que os algozes de Ifigênia têm de amordaçá-la no momento de seu sacrifício, de modo que ela não lançasse uma maldição sobre o palácio (Ag. 235-7). E, na Teogonia de Hesíodo, a divindade que perjurasse sofreria o mais brutal dos castigos (Th. 794-804). Observe-se a preocupação do Coro, no Agamêmnon, em relação à imprecação pública (Ag. 456-7). Tome-se o exemplo da palavra "noite", que frequentemente é chamada eủpoóvns (benévola), pois, além de designar uma parte do dia, a palavra "noite" também é o nome de uma divindade, cujo domínio é o da privação do ser e, assim, para evitar a invocação desse aspecto do mundo, utiliza-se o eufemismo. Veja-se como na Ifigênia em Áulida, de Eurípides, quando a jovem parte voluntariamente para o sacrifício, ela pede aos dânaos que silenciem, isto é, que observem a eufemia (I.A. 1.469).

Por essa razão, quando Etéocles, no prólogo, fala sobre a possibilidade de serem malsucedidos na batalha, rapidamente ele procura neutralizar essas palavras de mau agouro pronunciando de antemão uma fórmula verbal apotropaica. Ele diz: "se, aliás,

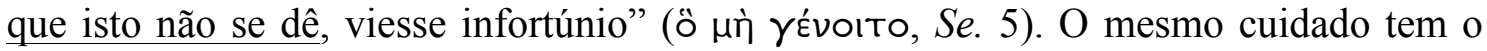
Mensageiro, no segundo episódio, ao descrever as ameaças proferidas pelos atacantes. Em meio ao relato das ameaças de Capaneu à cidade, ele insere uma fórmula verbal

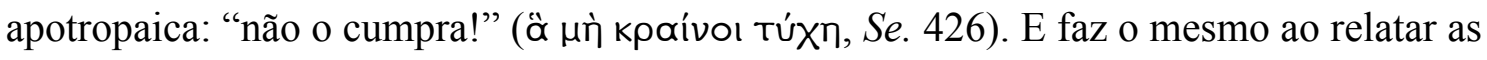

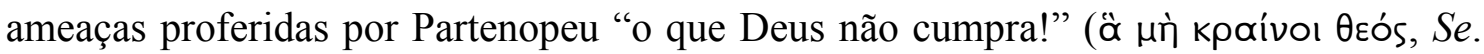
549).

Apesar de todo o cuidado de Etéocles, no prólogo, em "dizer o oportuno"

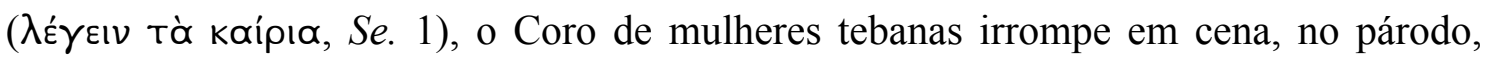
aterrorizado, descrevendo, em seu canto, a alarmante proximidade do exército argivo, cujo estrépito chega a seus ouvidos, e as piores desgraças que podem advir dessa iminente guerra: a morte, o saque, a escravidão.

Por tal atitude do Coro, Etéocles, no primeiro episódio, repreende-o severamente. Viu-se nessa dura repreensão de Etéocles um traço de misoginia (BACON, 1964, p. 30), ou de comportamento excessivo, hybristés (PODLECKI, 1964, 
pp. 284-5), ou ainda de impiedade por Etéocles impedir o Coro de mulheres a fazer suas preces (GOLDEN, 1964, pp. 80-82). Porém, como observa Cameron (1970, p. 99), a atitude repreensiva de Etéocles é duplamente motivada: tais demonstrações de terror por parte do Coro representam um perigo para a cidade à medida que podem provocar desordem e espalhar o pânico, enfraquecendo, assim, o ânimo dos guerreiros; mas também representam outro tipo de perigo, o de as mulheres, em sua algazarra, pronunciarem palavras ominosas, augurando, assim, um destino adverso à cidade.

O mesmo pode ser dito a respeito da insistência de Etéocles para que o Coro fique em silêncio. Durante o primeiro episódio, Etéocles ordena às mulheres tebanas que se calem quatro vezes seguidas:

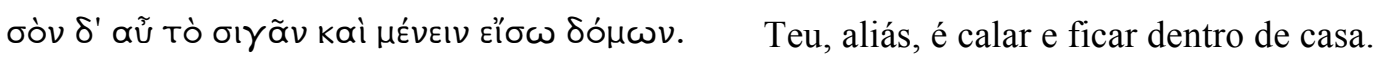

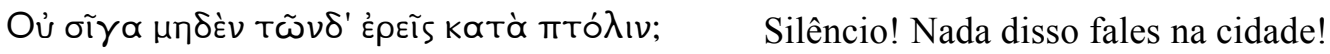

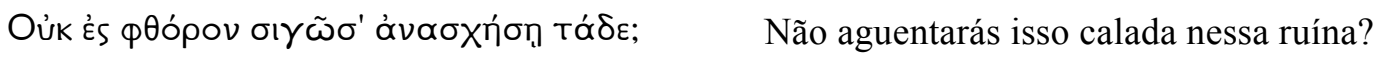

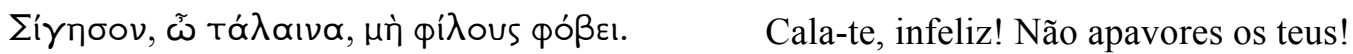

Essa insistência de Etéocles no silêncio do Coro tem a mesma dupla finalidade: não espalhar terror e desordem e, principalmente, não engendrar uma sorte funesta ao proferir, descuidadamente, palavras de mau agouro.

A mesma preocupação com o poder funesto das palavras de mau agouro está presente quando Etéocles repreende as mulheres tebanas por suas súplicas aos deuses. Note-se que o próprio Etéocles declara não se opor à honra aos numes (Se. 236); ou seja, não se trata de coibir uma prática piedosa por parte do Coro. $\mathrm{O}$ verdadeiro motivo da repreensão do filho de Édipo às súplicas aos deuses das mulheres tebanas diz respeito à linguagem em que elas formulam suas preces. Por esse motivo, Etéocles diz:

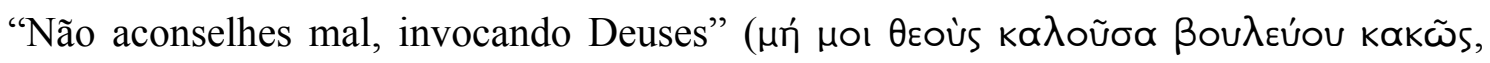
Se. 223). Ora, o momento da súplica ao pé das estátuas, assim como o do sacrifício e o 
da consulta a oráculos, é um momento solene, que requer a prática da eufemia, de forma que palavras ominosas devem ser cuidadosamente evitadas. Mas o que o Coro de mulheres tebanas faz é exatamente o oposto. Vejam-se alguns exemplos das súplicas feitas pelo Coro no párodo:

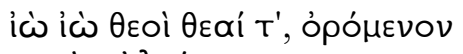

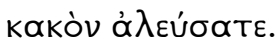

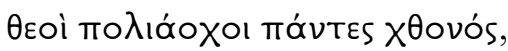
¿̌ $\delta \varepsilon \tau \varepsilon \pi \alpha \rho \theta \varepsilon ́ v \omega \nu$

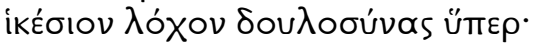

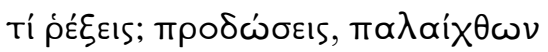
"Apпs, тờv Tعóv;

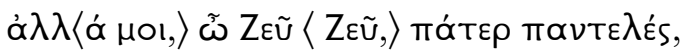

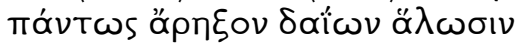

Iò iò! Deuses e Deusas

Repeli o mal emergente.

(Se. 86-7)

Deuses que tendes a cidade todos, vinde do chão. Contemplai a tropa de virgens súplice contra a escravidão.

(Se. 109-11)

Que farás? Ó Ares, antigo terrícola trairás a tua terra?

(Se. 104-5)

Eia, ó Zeus, Zeus, pai perfectivo, afasta toda captura por inimigos

(Se. 113-4)

O que Etéocles procura fazer o Coro entender no primeiro episódio é que tal linguagem não é conveniente à invocação aos deuses, pois pode trazer a ruína para a cidade. Assim, quando o Coro exclama: "Deuses cidadãos, não me façais servas!" ( $\theta \varepsilon o i$

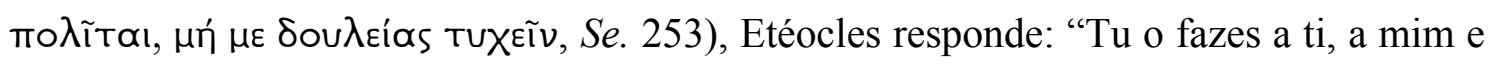

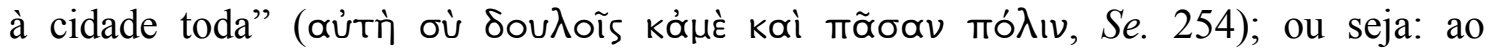
pronunciar essa frase ominosa, o Coro está augurando, mesmo sem o querer, um destino de escravidão para a cidade. Do mesmo modo, quando o Coro diz: "Míseras, como

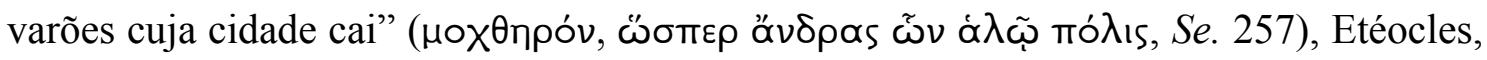
temendo o agouro de que a cidade será tomada, repreende-o novamente: "Retratar-te-ás,

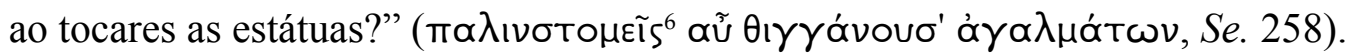

Não conseguindo convencê-las a manterem-se caladas, Etéocles lhes aconselha, então, a reformular suas súplicas: "e pede o melhor: a aliança dos deuses" (عủxou tò

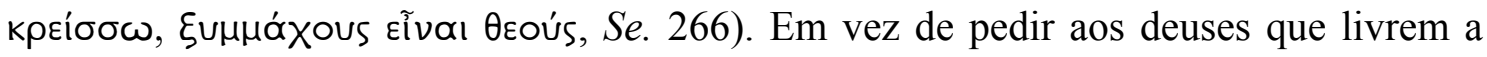
cidade da destruição, uma súplica que sugere de forma explícita essa destruição, Etéocles lhes aconselha a pedir aos deuses que sejam seus aliados, uma súplica isenta de

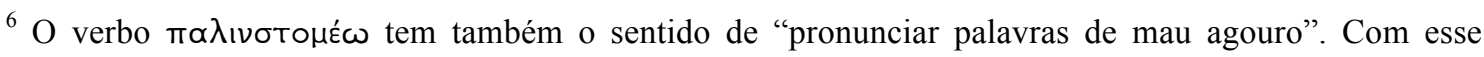
sentido o traduzem Smyth (1922), Mazon (1995), Sommerstein (2008), Tonelli (2013).
} 
palavras ominosas, de forma a não precipitar, assim, o cumprimento de um destino funesto à cidade. E assim conclui:

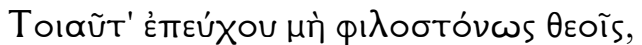

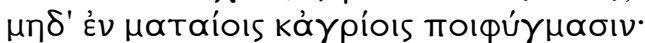

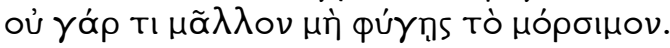

Assim suplica aos Deuses, sem pranteios, sem esses inúteis e selvagens suspiros, pois por nada mais não escaparás à sorte.

(Se. 279-81).

Apesar de Etéocles mostrar respeito às palavras vaticinantes de Tirésias, apesar de ele mesmo ter o cuidado de evitar palavras de mau agouro ao se dirigir aos seus concidadãos e apesar de todo o esforço que ele faz para que o Coro de mulheres tebanas não pronuncie palavras ominosas em sua súplica aos deuses, por uma ironia trágica, imiscuem-se em seu discurso sinais divinos que, mediante uma ambiguidade cledomântica, prenunciam sua própria ruína. $\mathrm{O}$ destino funesto que pende sobre Etéocles e que se prenuncia desde o prólogo é consequência da maldição - outra expressão da palavra numinosa - que Édipo lançou sobre seus filhos.

No prólogo, Etéocles dirige-se a seus concidadãos, incitando-os a acudir à sua cidade, aos altares dos deuses, "aos filhos e à Terra mãe, primeira nutriz" (TÉkvoıs TE,

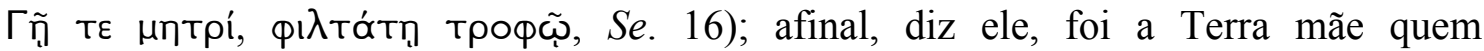
benevolamente os criou e os educou e agora devem pagar a dívida dessa criação protegendo-a do inimigo. Essa exortação para que se proteja a Terra mãe e seus filhos é especialmente significativa no caso dos tebanos, chamados por Etéocles de “concidadãos de Cadmo" (Se. 1), visto que estes são descendentes "dos homens

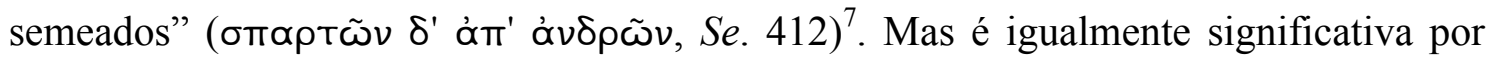
chamar a atenção para a própria origem de Etéocles. Ele e seu irmão são fruto, como dirá o Coro no segundo estásimo, da ousadia de Édipo de "semear / o sacro sulco

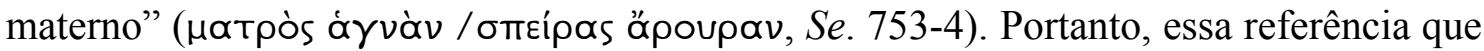
Etéocles faz aos filhos, à Terra mãe que cria e nutre e à dívida que se tem para com ela adquire um sentido ominoso, visto que alude à sua origem incestuosa e à dívida que ele há de pagar por isso, isto é, seu fim trágico de morrer em combate com seu irmão.

Da mesma forma, no primeiro episódio, o Coro dirige-se a ele chamando-o não pelo seu nome, mas por "filho de Édipo" (Oíઠírtou tékos, Se. 203). Aqui, a referência

\footnotetext{
${ }^{7}$ De acordo com Apolodoro (Bibl. III, 4, 1), quando Cadmo chegou à região de Tebas, ele matou uma serpente que ali habitava e, aconselhado por Atena, semeou os seus dentes. Da terra surgiram homens inteiramente armados que começaram a lutar entre si. Dos sobreviventes descendem as mais nobres famílias tebanas.
} 
às origens de Etéocles faz-se tanto mais ominosa quanto mais explícita. O próprio nome de Édipo evoca a maldição que está para se cumprir. O mesmo acontece no início do segundo episódio, quando, à vista da chegada do Mensageiro com notícias do exército inimigo, e da chegada do próprio Etéocles, o Coro refere-se a ele novamente como "o

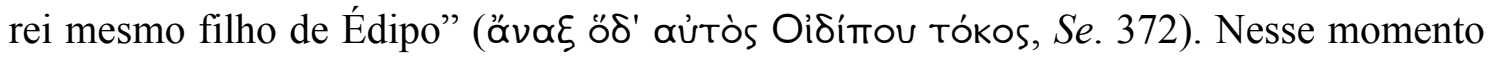
crucial, em que o Mensageiro vem relatar como o inimigo dispôs os seus líderes e espera saber como Etéocles disporá os seus, novamente há uma referência às origens do rei, que, tanto por sua natureza como pela maldição que aguarda cumprimento, torna-se ominosa, prenunciando sua ruína.

O Coro só irá se dirigir a Etéocles dessa forma novamente ao fim do segundo episódio, quando Etéocles, sabendo que seu irmão foi designado para a sétima porta, decide confrontá-lo, tendo compreendido que chegou o momento da realização da maldição de seu pai. O Coro, em sua primeira tentativa de dissuadi-lo de combater o irmão, chama-o novamente de "filho de Édipo" (Oííitrou tékos, Se. 677). Nesse momento, o sentido ominoso dessa denominação aponta não apenas para a inevitável ruína dos irmãos, mas também para o fracasso de qualquer tentativa das mulheres tebanas de dissuadirem Etéocles, pois elas apenas ecoam o inelutável: Etéocles é filho de Édipo e, como tal, pende sobre ele uma fatal imprecação.

\section{2) A maldição profética de Édipo}

Como se viu, a maldição é uma das formas que adquire a relação do homem grego antigo com a linguagem. Como observa Giordano (1999, p. 13), a maldição, "una volta articolata diviene una potenza, una forza, un'azione". A palavra imprecatória é, por natureza, uma palavra profética. Veja-se, por exemplo, como, em Édipo em Colono,

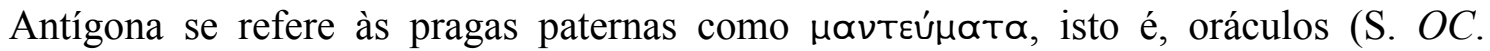
1425). As divindades que na tragédia grega presidem o cumprimento das maldições são as Erínies e há uma relação tão intrínseca entre ambas que muitas vezes confundem-se entre si. Nas Eumênides, o Coro de Erínies apresenta-se diante de Atena dizendo serem “as filhas da Noite eterna / Imprecações” (Nuktòs ai̊uñs tékva / ’Apaí ..., Eu. 416-7). E, nos Sete, o Coro diz que as pragas de Édipo foram uma "Erínis imprecada pelo pai" (татрòs عủktaíav 'Epıvúv, Se. 723). 
A maldição paterna parece ter um caráter ainda mais inelutável. É interessante observar essa constatação por parte de Platão. Diz o filósofo em As Leis:

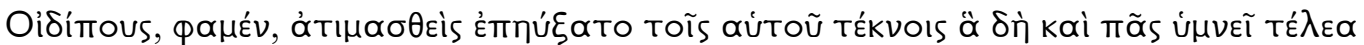

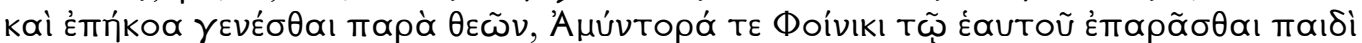

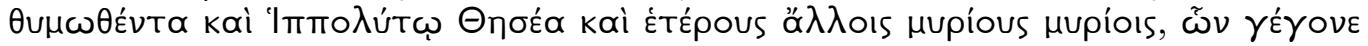

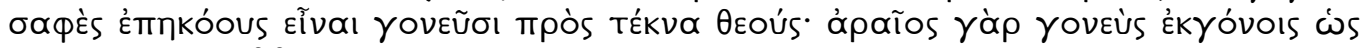

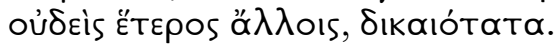

Segundo a narrativa, quando Édipo foi desonrado, invocou maldições sobre seus filhos, que, conforme atestam todos os homens, foram concedidas pelos deuses e cumpridas; e se conta como Amíntor em sua ira amaldiçoou seu filho Fênix e Teseu amaldiçoou Hipólito, e inúmeros outros pais amaldiçoaram inúmeros outros fillhos, maldições concedidas pelos deuses que provaram claramente como estes atendem os pedidos dos pais contra seus filhos, pois a maldição de um pai enunciada contra seus filhos e filhas é mais poderosa do que qualquer maldição de uma pessoa contra qualquer outra, e com muito maior justiça. (Pl. Leg. XI, 931.b.5-c.3) ${ }^{8}$

No que se refere à maldição de Édipo, não há, nos Sete, referência explícita ao motivo pelo qual Édipo amaldiçoou seus filhos e as pistas encontradas no texto desta tragédia de qual tenha sido o conteúdo da imprecação evocam, como se verá, a forma enigmática dos oráculos. No entanto, ao se examinarem os textos anteriores e posteriores à tragédia esquiliana, constata-se que, embora os motivos para a maldição variem, o conteúdo é invariavelmente a morte dos irmãos às mãos um do outro.

No que diz respeito ao motivo que levaram Édipo a amaldiçoar Etéocles e Polinices, dois fragmentos da Tebaida são elucidativos. Em um fragmento (PEG 2),

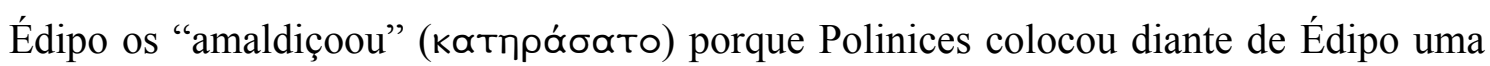
mesa de prata e uma taça de ouro pertencentes a Cadmo e proibidas por Édipo de ser

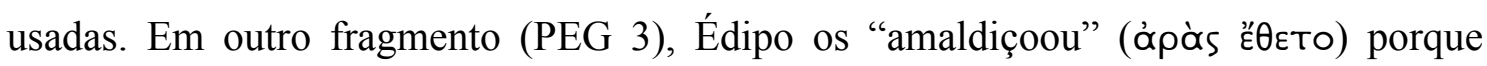
Etéocles e Polinices serviram-lhe, num banquete sacrificial, uma coxa em vez da espalda do animal, como costumavam fazer. Em ambos os fragmentos, as razões para a maldição são explícitas: derivam de atitudes inadequadas da parte de um ou de ambos os filhos para com Édipo, atitudes que mostrariam uma negligência à autoridade e à honra devida ao pai.

Em Édipo em Colono, de Sófocles, o motivo para a maldição de Édipo é também bastante explícito e mais de uma vez enunciado: o fato de ter sido expulso da cidade de Tebas e nenhum de seus filhos terem vindo ao seu socorro ou tentado impedir o seu exílio, o que para ele significa ter sido expulso por seus próprios filhos (S. OC. 427-30;

\footnotetext{
${ }^{8}$ Tradução de Edson Bini (2010).
} 
599-601; 1354-9), e que por sua vez também implica uma negligência e uma desonra sofrida por Édipo da parte de Etéocles e Polinices.

Nas Fenícias, de Eurípides, no prólogo dito por Jocasta, há informações explícitas sobre o motivo de Édipo ter amaldiçoado seus filhos. Nessa tragédia euripidiana, Édipo ainda vive, mas oculto, mantido em reclusão por seus filhos, motivo pelo qual, diz Jocasta, ele os amaldiçoa (ápàs à pã tå, E. Ph. 63-68). O mesmo motivo é repetido por Tirésias no terceiro episódio (E. Ph. 872-7). Assim, novamente, o que desencadeia a maldição é uma desonra e uma negligência por parte dos filhos para com o pai.

$\mathrm{Na}$ Biblioteca de Apolodoro, também aparece o motivo pelo qual Édipo amaldiçoou Etéocles e Polinices: "lançou maldições sobre os filhos, que, presenciandoo ser expulso da cidade, não o socorreram" (åà̀s Toĩs maı

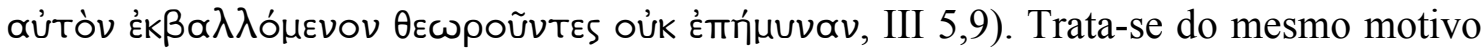
que figura em Édipo em Colono.

Nos Sete, há apenas um par de versos a respeito dos quais se pode perscrutar a razão da maldição de Édipo. No segundo estásimo, o Coro de mulheres tebanas, temendo o pior após a decisão de Etéocles de combater seu irmão, fala do momento em que Édipo, tendo descoberto que desposara sua mãe, perpetrou dois males: furou seus próprios olhos e amaldiçoou seus filhos. Diz o Coro:

TÉKVOIs $\delta^{\prime}$ ápaı̃̃s

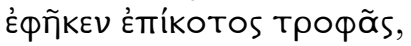

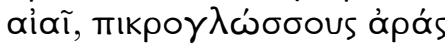

e ressentido por alimento lançou sobre os filhos aiâ̂! - acerbas pragas

Há uma controvérsia a respeito do termo трофãs. Como se viu, há mais de uma versão para a causa da maldição de Édipo e as traduções variam de acordo com a interpretação de cada tradutor a respeito de qual dessas versões Ésquilo estaria seguindo. Há os que traduzem трофń como alimento, refeição, nutrição, fazendo uma referência bastante explícita à versão de um dos fragmentos da Tebaida, em que Etéocles e Polinices servem ao pai uma parte do animal sacrificado indigna de sua honra e autoridade. Para citar alguns exemplos, vejam-se as seguintes traduções:

Luego, resentido con sus hijos por aquella comida de antaño - ¡ay, ay! - profirió con amarga lengua las maldiciones. (Tradução de Bernardo Perea Morales, 1986.) 
et, indigne d'être si maigrement servi, il lança, hélas! contre ses fils des imprécations amères. (Tradução de Émile Chambry, 1946)

e contro i figli, furente per il rancore

in cui era stato nutrito, aiái

lanciò maledizioni amare (Tradução de Angelo Tonelli, 2013)

Há ainda os que traduzem tрoфń num sentido mais generalizado de cuidado, desvelo, suporte, sustento. $\mathrm{O}$ episódio do banquete sacrificial pode estar implícito, mas mais evidente é a negligência dos filhos com o pai, em descumprimento da gerotrophia. Vejam-se alguns exemplos:

And against his sons, because of their cruel tendance, he launched malisons of wrath (ah me! malisons of bitter tongue). (Tradução de Herbert Weir Smyth, 1922)

Et contre ses fils mêmes, indigné de leurs piètres soins, hélas! il lança des imprécations amères. (Tradução de Paul Mazon, 1995)

against his sons, in vengeful anger

they had not sustained him,

he launched, alas, embittered curses (Tradução de Christopher Collard, 2008)

and angered with his sons

for their wretched maintenance of him he left fly at

them

(ah, ah!) the curses of a bitter tongue (Tradução de Alan H. Sommerstein, 2008)

E ai figli scagliò dall'amara

lingua le maledizioni

per le avare cure (Tradução de Leone Traverso, 2010)

Por fim, há ainda traduções em que o termo трофri é entendido como progênie, de modo que a maldição de Édipo teria sido lançada sobre os seus filhos mediante o horror da descoberta de que estes eram frutos do incesto, como defende Hutchinson (1985, p. xxv):

And then, against these sons, in wrath at twisted lineage, he launched these bitter-tongued

Curses (Tradução de Anthony Hecht e Helen H. Bacon, 1991)

O que é notável nessa passagem é o fato de que Ésquilo, ao apenas aludir à razão pela qual Édipo lançou uma maldição sobre os filhos - condensando-a na expressão 
غ̇тí́котоs трофа̃ s, o que permite explorar toda a polissemia do termo трофń, dando margem a múltiplas interpretações sem que se possa se decidir categoricamente por nenhum -, faz com que a ênfase recaia sobre a maldição em si mesma, distanciando-a de qualquer causalidade, o que lhe confere uma autonomia e um poder dignos das divindades que presidem o cumprimento das maldições familiares e com as quais se confundem: as Erínies.

A primeira menção que se faz nos Sete a respeito da maldição de Édipo é ao final do prólogo, quando, após o relato do Mensageiro de que o exército inimigo está próximo e pronto para o ataque, Etéocles exclama:

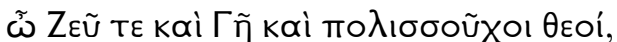

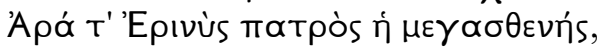

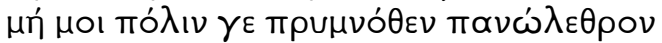

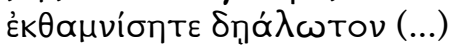

Ó Zeus e Terra, e Deuses tutelares da cidade, e Imprecação, Erínis do pai, a de grande força, não extirpeis minha cidade, toda em ruína, desde a raiz, pilhada (...)

Nessa prece, há uma identificação direta entre a Imprecação (’Apó) e a Erínis do

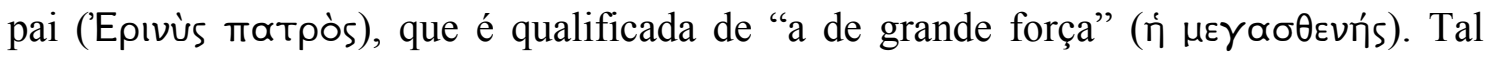
identificação se manterá em todo o decorrer da tragédia. Etéocles evoca a maldição de seu pai juntamente com Zeus e Terra, uma imagem da totalidade do universo, e os deuses protetores da cidade, para que esta não seja destruída. O seu temor não é, portanto, o de matar e morrer às mãos de seu irmão, mas o de ver Tebas em ruínas, tomada pelo exército inimigo. Aqui, Etéocles correlaciona a maldição de Édipo com o destino de toda a cidade de Tebas frente à iminente guerra e não com sua própria destruição.

A próxima menção à maldição paterna só figura ao final do segundo episódio, após Etéocles ser informado pelo Mensageiro de que Polinices foi sorteado para a sétima porta, quando então exclama:

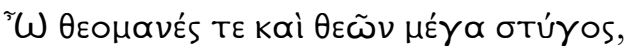

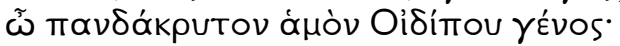

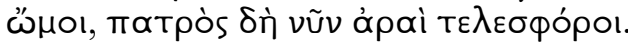

Ó furor de Deus, grande horror de Deus!

Ó toda pranteada nossa raça de Édipo!

Ómoi! Cumpridoras são as pragas paternas.

É apenas neste momento que Etéocles parece perceber que as pragas rogadas por seu pai começam a se cumprir e que significam lutar diretamente contra o seu irmão. Após esse reconhecimento de Etéocles de que se cumpre a maldição de Édipo, vem o 
reconhecimento de sua proximidade - "A negra Praga odiosa de meu caro pai / sem

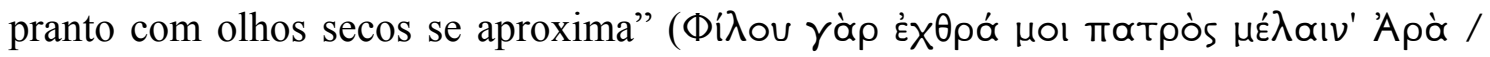

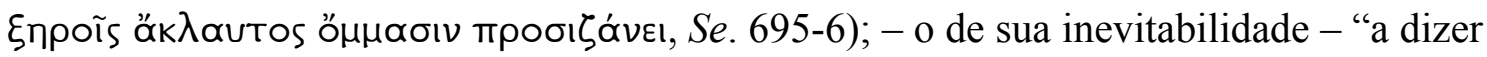

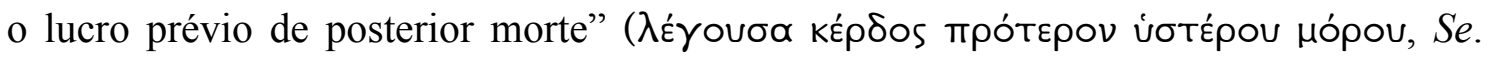
697), isto é, se ele inelutavelmente irá morrer, que pelo menos ele tenha o "lucro"

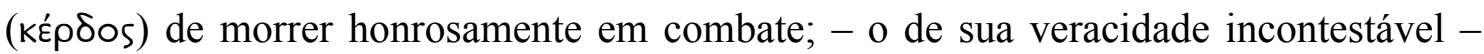
"Ferveram as imprecações de Édipo, / assaz verdadeiras visões de espectros / de sonhos,

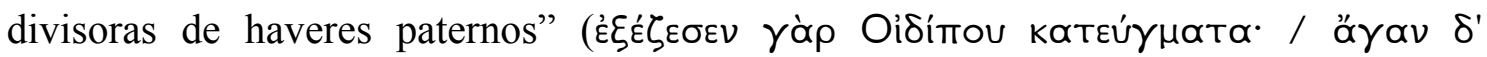

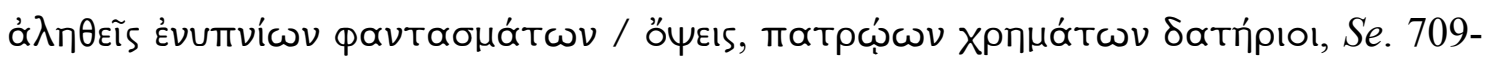
11), ou seja, foi prenunciada por um sonho que agora ele reconhece como profético, como um sinal divino.

É a partir de então que a maldição de Édipo começa a se desvelar, mas de uma forma bastante diferente daquela das outras fontes que explicitam qual tenha sido o conteúdo da maldição. Veja-se, assim, como, nos fragmentos da Tebaida, relatam-se as maldições. No primeiro fragmento, irado com Polinices, Édipo a seus filhos disse "que eles não dividiriam os bens paternos em benevolente amizade, mas para ambos haveria

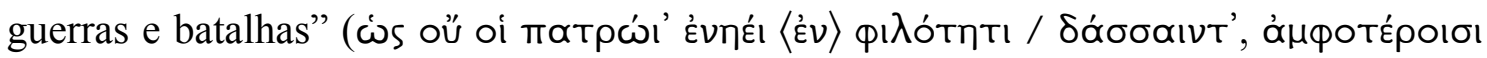

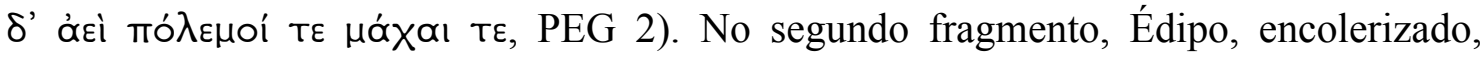
"Rogou ao soberano Zeus e aos outros imortais que pelas mãos um do outro desceriam à

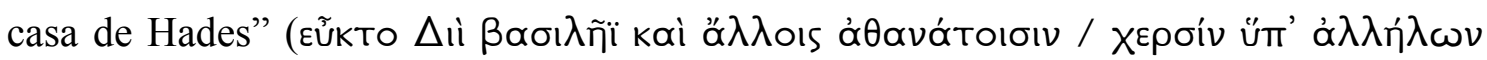

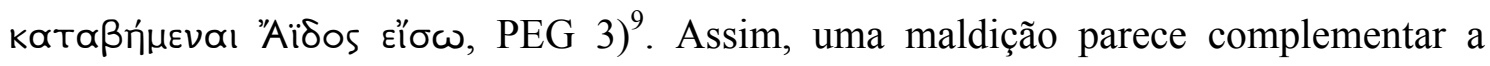
outra: Etéocles e Polinices dividiriam os bens paternos conflituosamente, o que os levaria à morte às mãos um do outro. Trata-se de um enunciado claro, unívoco, que não dá margem a equívocos e má interpretações.

O mesmo se pode perceber em Édipo em Colono. Édipo, no quinto episódio, diz a Polinices, quando este lhe vem demandar que siga com ele até Tebas, pois disso depende a vitória na batalha que está para travar com o irmão:

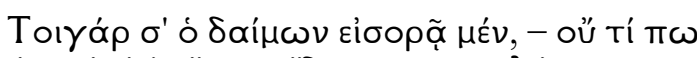

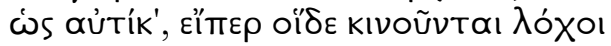

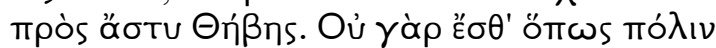

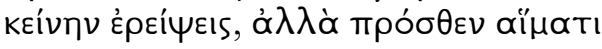

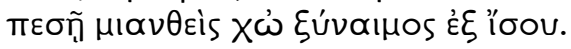

Um olho imortal te vigia. Se não detiveres teus homens, marcharão para a ruína às portas de Tebas. Não tomarás jamais aquela cidade. Antes de entrares, teu sangue manchará a terra, misturado com o sangue do teu irmão.

(S. OC. 1370-4)

\footnotetext{
${ }^{9}$ A edição dos fragmentos é de West (2003) e a tradução é nossa.

${ }^{10}$ As traduções do Édipo em Colono são de Donaldo Schüler (2002), exceto quando indicado.
} 
E finaliza dizendo, na sequência: "Tais são as Imprecações que lancei antes

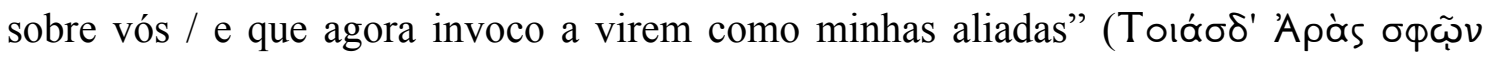

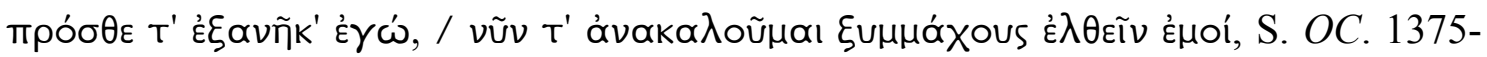

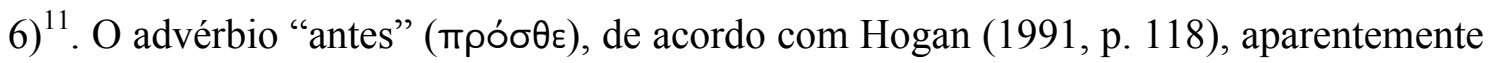
se referiria a uma passagem do primeiro episódio, quando Ismene chega trazendo notícias de Tebas, em que Édipo faz a seguinte prece aos deuses:

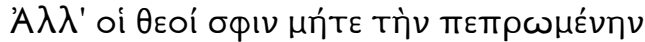

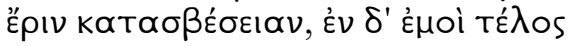

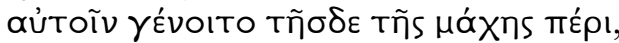

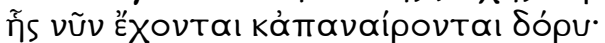

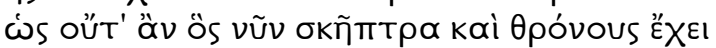

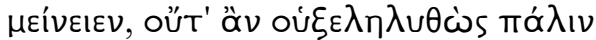

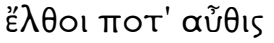

Que os deuses não extingam essa rixa providencial, caiba a mim pronunciar a última palavra sobre este conflito de lanças erguidas contra lanças. Não prospere o que agora coroado ocupa o trono nem o arrebate o filho que agora vive no exílio.

Além disso, no terceiro episódio, quando Creonte vem convencer Édipo a acompanhá-lo até Tebas, este lhe diz: "A sorte de meus filhos é esta: a terra que /

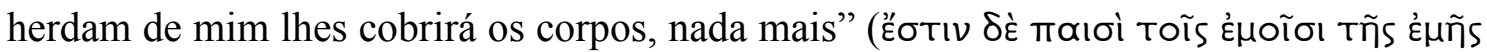

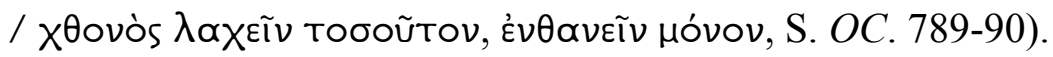

A maldição de Édipo, portanto, em Édipo em Colono, é, por assim dizer, formulada em três partes, sendo que a cada vez se desvela um novo aspecto de seu conteúdo funesto. Assim, primeiramente, Édipo impreca que nenhum de seus filhos permanecerá no trono de Tebas; num segundo momento, que a herança que lhes caberá será somente a terra a cobrir seus corpos e nada mais; por fim, que a expedição à cidade de Cadmo está fadada à ruína e que o sangue de ambos, misturados, mancharia a terra; ou seja, morreriam às mãos um do outro. Dessa forma, a cada vez que Édipo se refere à maldição, ela se torna cada vez mais explícita e inequívoca.

Em Eurípides, nas Suplicantes, há apenas uma breve menção à maldição paterna. Teseu pergunta a Adrasto por que Polinices deixou a cidade de Tebas e Adrasto

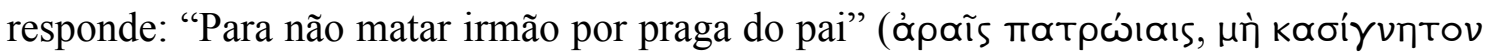
kтớvol, E. Supp. 149-50). Nas Fenícias, o conteúdo da imprecação é explicitado por

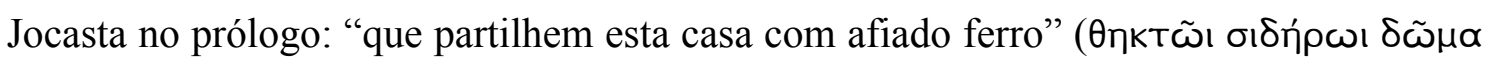

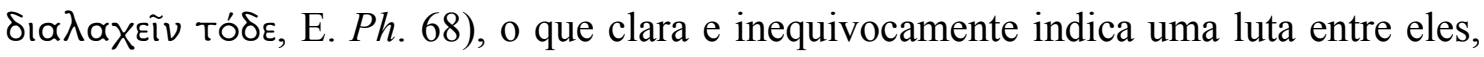

\footnotetext{
${ }^{11}$ Tradução nossa.
} 
de forma que, quando, no quinto episódio, Creonte recebe a notícia da morte dos irmãos, ele pergunta ao Mensageiro: "Como aconteceu a morte dos dois filhos / e a luta

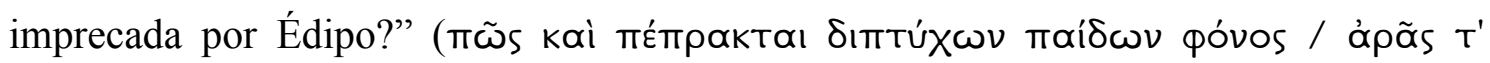

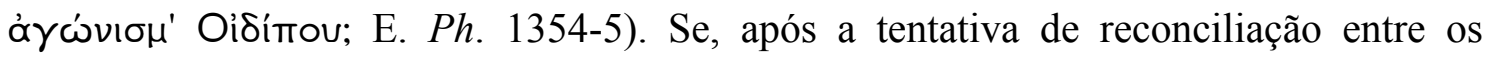
irmãos proposta por Jocasta, nenhum deles fez qualquer concessão e se manteve firme em seu propósito de guerrear, a única alternativa possível é dirimir a querela mediante uma luta até a morte.

Bastante diferente é o tratamento dado à maldição de Édipo nos Sete. No segundo estásimo, tendo Etéocles saído para combater seu irmão, o Coro de mulheres tebanas diz, na primeira estrofe:

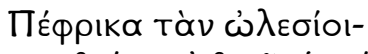
кov $\theta \varepsilon o ́ v$, oủ $\theta \varepsilon \circ \mathrm{I}_{s}$ ómoíav,

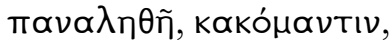

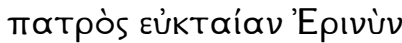

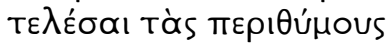

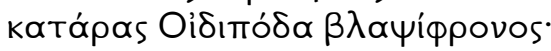

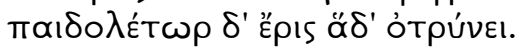

\author{
Dá-me horror que a lesa-lares \\ Deusa dissímil dos Deuses \\ verdadeira maligna adivinha \\ Erínis imprecada pelo pai \\ cumpra as iracundas \\ pragas de Édipo demente, \\ filicida Rixa aqui ativa.
}

(Se. 720-6)

Retoma-se, nesta estrofe, a mesma identificação entre imprecação e Erínis. Aqui, a Erínis é triplamente qualificada: é lesa-lares, é dissímil dos deuses e é "verdadeira

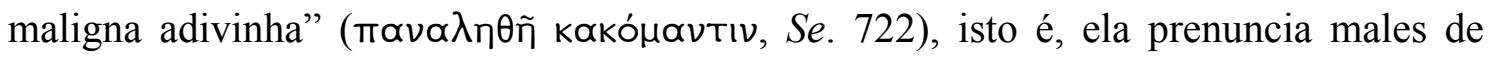
forma totalmente verdadeira. O mal que ela prenuncia é o cumprimento das pragas de Édipo: a filicida rixa. E como ela o prenuncia? É necessário, para responder a essa questão, observar antes a primeira antístrofe:

Zદ́vos $\delta \dot{~ k \lambda ก ́ p o u s ~ \varepsilon ́ T ा \nu \omega-~}$ $\mu \tilde{\alpha}, X \alpha \dot{\alpha} \lambda \cup \beta O S \Sigma k v \theta \tilde{\omega} v$ ơmoıkos,

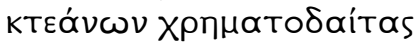

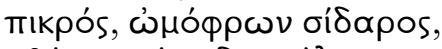

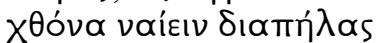

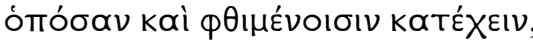

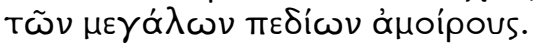

Hóspede, forasteiro da Cítia, o aço distribui as herdades: divisor de bens e de posses, o amargo cruel ferro sorteou residirem na terra que os contenha defuntos sem parte nas grandes planícies.

Tanto a estrofe como a antístrofe supracitadas evocam alguns versos anteriores, em que Etéocles faz referências às imprecações de Édipo em correlação com visões oníricas: "Ferveram as imprecações de Édipo, / assaz verdadeiras visões de espectros /

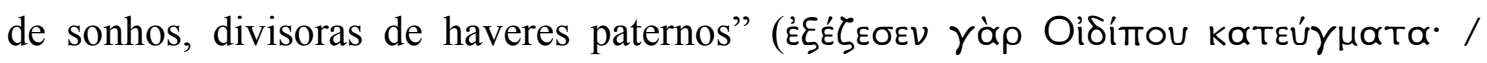




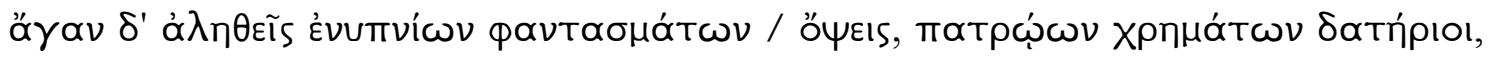

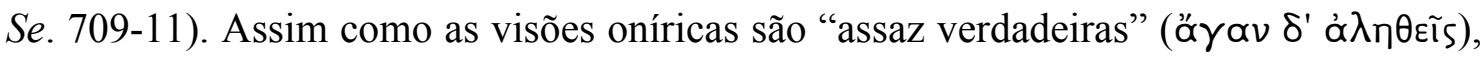
a Erínis é uma maligna adivinha "totalmente verdadeira" ( $\pi \propto v \alpha \lambda \eta \theta \tilde{\eta})$. E, assim como

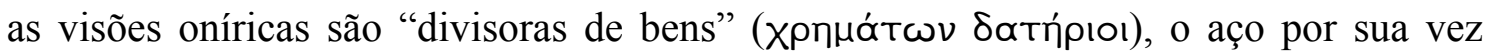

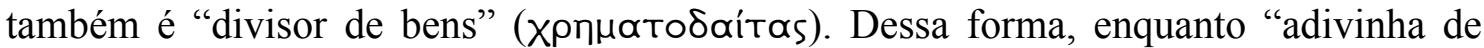

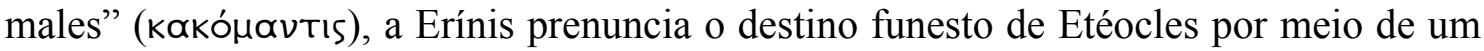

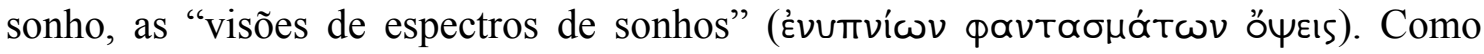
observa Manton (1961, p. 78):

The utterance of the curse which called the Erinys into action and with which the Erinys is elsewhere identified (70), is itself a form of prophecy. But the Erinys may also be said to have acted as prophet in sending or appearing in the dream mentioned by Eteocles (710-1).

A imagem do estrangeiro da Cítia como o árbitro da querela entre os irmãos sobre a divisão dos bens paternos - que se revela ser na verdade o aço, que, mediante um mútuo massacre, acaba determinando que o único bem que eles herdarão será a terra a lhe cobrir os corpos mortos - é uma imagem própria de sonhos proféticos e de oráculos. $\mathrm{O}$ fato de Etéocles, no momento em que percebe que está indo de encontro à realização da maldição de Édipo, isto é, indo de encontro ao mútuo fratricídio, exclamar como eram verdadeiras as suas visões oníricas é um indício, nas tragédias supérstites de Ésquilo, da compreensão da inelutabilidade e da veracidade do destino prenunciado por um sinal divino. Como se viu, a Rainha, nos Persas, ao saber da derrota do exército persa, exclama: "Ó visão noturna, manifesta em sonho, / com que clareza me mostraste

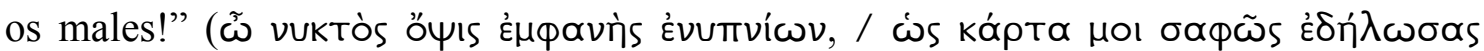
kakớ, Pe. 518-9). E Clitemnestra, como se verá no Agamêmnon, ao perceber que terá morte pelas mãos de seu filho, exclama: "Ai de mim, esta serpente pari e nutri: / era

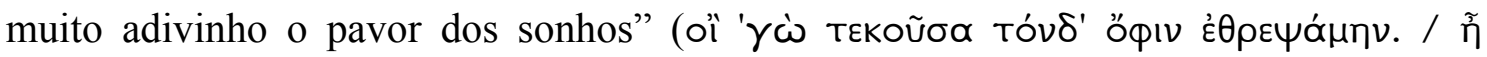

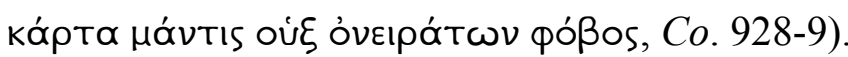

Há, assim, um duplo reconhecimento da parte da Etéocles: o reconhecimento do verdadeiro sentido da maldição de seu pai e o do verdadeiro sentido das visões oníricas que o prenunciaram. Quando, portanto, o Coro fala do estrangeiro da Cítia como o divisor dos bens paternos, ele parece estar explicitando o sentido há pouco compreendido por Etéocles. Mas tal sentido seria o do sonho a que ele se refere, como

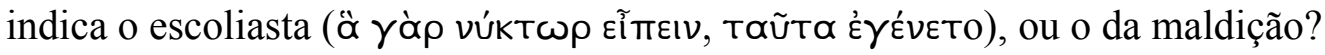


O Coro, relembrando a imprecação de Édipo, diz que este lançou a seguinte praga:

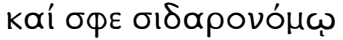

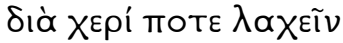

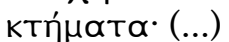

de obterem no sorteio

com a mão munida de ferro

os haveres $(\ldots)$

O Coro parece não estar citando verbatim a maldição paterna. Burnett (1973, p. 359) acredita que a maldição no Édipo esquiliano fosse algo como: "May a bitter Ares guide you, as you portion out my property with iron-bearing hand!”. Por outro lado, Manton (1961, p. 78) observa que "there is no need to suppose that such imagery was part of the curse of Oedipus". E, para Hutchinson (1985, p. xxix), "there are no grounds for believing the curse to have been not a curse but a riddling oracle. Attempts to find a double meaning, misapprehended by Eteocles, hold no attraction a priori, and have not in fact been made at all probable".

Não se trata, no entanto, de determinar se a maldição que foi pronunciada na tragédia precedente tinha um aspecto enigmático, ambíguo, tal como um oráculo, mas é inegável que, nos Sete, da forma como ela é aludida, a maldição tem inegavelmente um caráter oracular, como prova a reação de Etéocles e o subsequente canto do Coro após saberem que Polinices está na sétima porta e será confrontado por seu irmão.

Qual seria, então, a chave para a interpretação dessas duas formas de manifestações divinas: a maldição e o sonho? De que forma esses elementos se combinam para formar parte de um único e mesmo diálogo divinatório?

\section{3) Cleromancia e a tiragem da sorte}

No prólogo, após a fala de Etéocles, o Mensageiro entra em cena trazendo notícias da movimentação da tropa argiva. O que ele vem relatar é o cumprimento do vaticínio de Tirésias: dissera o adivinho que o inimigo "se reúne para decidir-se / o maior

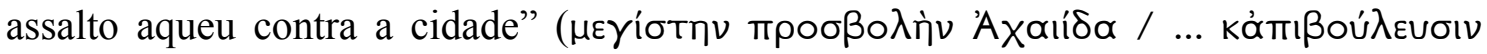

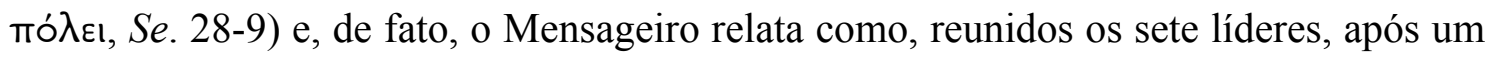
juramento, sorteavam em quais das sete portas cada um deles se posicionaria.

A descrição que deles faz o Mensageiro é significativa; ele os observa enquanto prestam um juramento: 


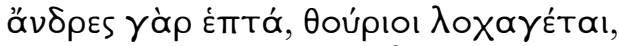

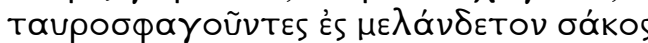

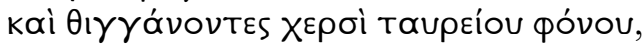

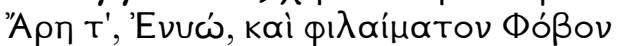

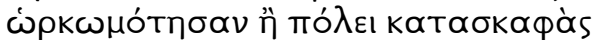

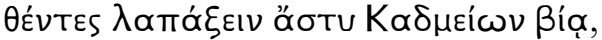

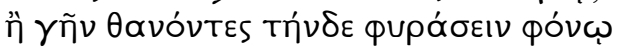

Sete homens, impetuosos guias de tropas, degolando touro em escudo de alças negras e tingindo a mão com o sangue taurino, por Ares, por Enio e por sanguinário Pavor juraram: ou destruir a fortaleza e devastar a cidade dos cadmeus com Violência, ou mortos molhar esta terra com sangue.

$\left(\right.$ Se. 42-8) ${ }^{12}$

Trata-se de um juramento solene, pronunciado enquanto se toca a vítima sacrificial. Como todo juramento ritual, contém a jura - "destruir a fortaleza e devastar

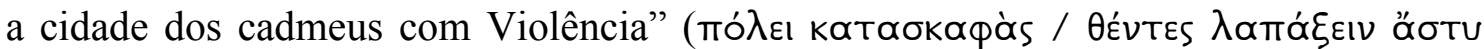

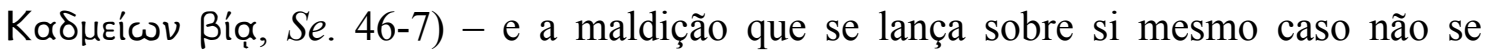

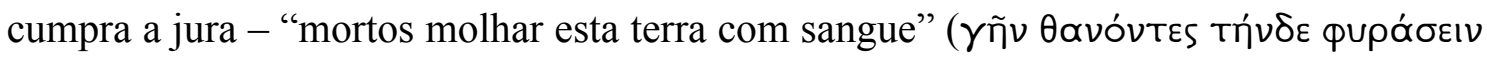
фóvफ, Se. 48) $)^{13}$. O que se sobressai, no entanto, é a violência explícita dessa cena de juramento, em que se ressalta o caráter sanguinário e destrutivo dos chefes argivos. Os sete homens são designados "impetuosos" (Өoúpıoı, Se. 42), um epíteto de Ares. Eles degolam a vítima sacrificial, um touro e, com as mãos ensanguentadas, juram por três divindades bélicas, sendo que a última recebe o epíteto de "sanguinário" ( Se. 45); e, se mortos, dizem que hão de ensanguentar a terra. A destruição da cidade é

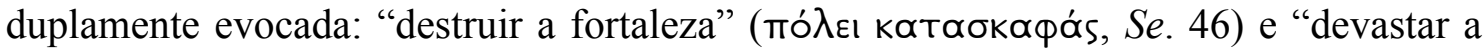

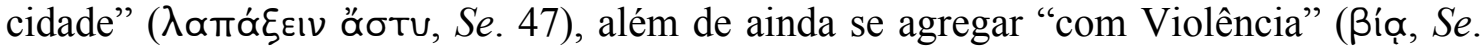
47). Nesta cena testemunhada pelo Mensageiro, começa a se delinear o caráter hybristés dos sete atacantes.

Ironicamente, apesar de todo esse furor bélico, sabe-se que os chefes argivos, à exceção de Adrasto, perecem em combate. Dá-se portanto que, embora eles não o saibam, é um juramento de morte: eles estão fadados a molhar a terra dos cadmeus com seu sangue. Essa ironia dramática segue à continuação do relato do Mensageiro: "Com

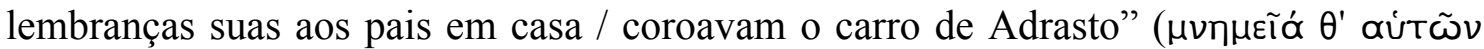

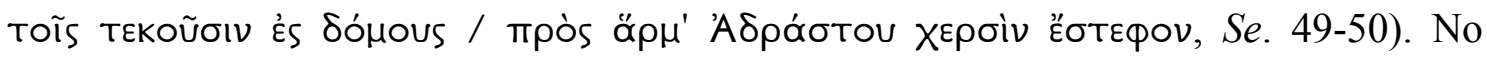

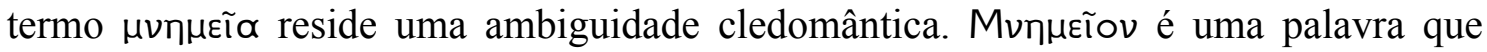

\footnotetext{
${ }^{12}$ Aristófanes, em Lisístrata, menciona essa cena dos Sete; quando Lindavitória pergunta a Dissolvetropa que juramento deveriam prestar, esta responde: "Degolar uma vítima no escudo, / como dizem Ésquilo ter

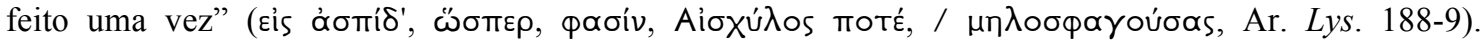
Tradução de Adriane da Silva Duarte (2005).

${ }^{13}$ Sobre o juramento na tragédia grega, conferir Performing Oaths in Classical Greek Drama, de Judith Fletcher (2012), e sobre o juramento da na Grécia Antiga, conferir Oaths and Swearing in Ancient Greece, de A. H. Sommerstein e Isabelle Torrance (2014).
} 
tanto significa lembrança, recordação, como também monumento fúnebre, túmulo. Trata-se, portanto, de recordações fúnebres que eles enviam aos seus através de Adrasto, o único sobrevivente entre eles.

O Mensageiro prossegue seu relato dizendo que partiu enquanto os chefes argivos faziam o sorteio que designaria a posição de cada um em cada uma das sete portas da cidade: "deixava-os no sorteio de como cada um, / tirada a sorte, levaria a

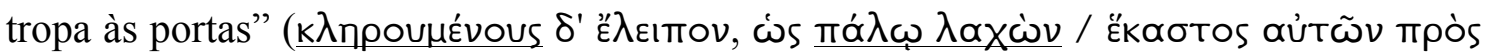

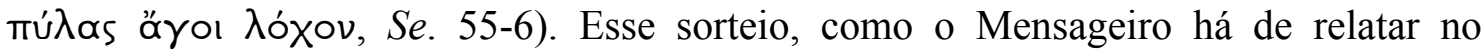
decorrer do segundo episódio, foi feito no bojo de um capacete ( $\mathrm{Se}$. 458-9).

Note-se a ênfase do uso de vocábulos relacionados à tiragem da sorte.

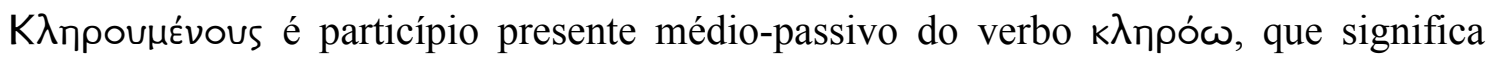

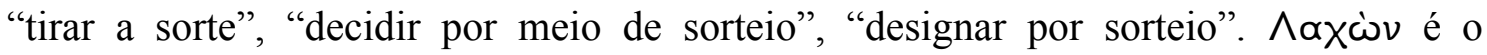
particípio aoristo ativo do verbo $\lambda \alpha \gamma \times \alpha \dot{v} \nu \omega$, que significa "obter por sorte", "ser designado por sorteio", “caber por sorte”. E má $\lambda \omega$ é o dativo de má $\lambda$ os, que significa "sorte; sorteio", "parte que cabe por sorteio; lote". Fazem ainda parte do universo

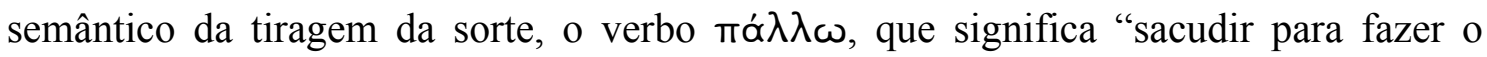
sorteio; sortear", "sacudir, chacoalhar as sortes" e o substantivo $k \lambda \tilde{n} \rho \circ$, que significa tanto "seixos, peças de madeiras para realizar sorteio", "sorteio", quanto "o que se obtém por sorteio; parte; porção", "oráculo" e "parte de herança; herança".

O termo $k \lambda \tilde{n} \rho o s$ aparece também utilizado em uma forma de adivinhação denominada cleromancia. Em Píndaro, o adivinho Mopso aparece "vaticinando por

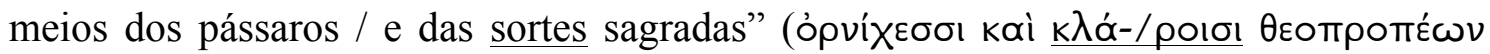
iєpoĩs, Pi. P. 338-9). Em Eurípides, nas Fenícias, Tirésias pede à sua fillha que segure em suas mãos "as peças / que colhi ao saber auspícios de aves" (kińpous ... / oüs

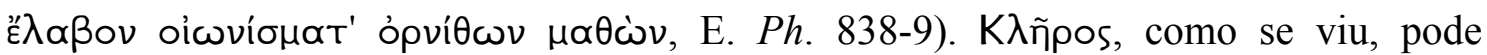
também ter o sentido de "oráculo", "vaticínio". Assim, no Íon, diz-se de Apolo que ele distribui "vaticínio" ( knрогіs, E. Ion 908) em Delfos.

A tiragem da sorte, mesmo quando não utilizada por adivinhos, mas por pessoas comuns, é ainda assim uma forma de diálogo com o divino. Vejam-se, por exemplo, estes dois exemplos da Ilíada. No canto III, por ocasião do duelo entre Páris e Menelau, ante a necessidade de decidir qual dos dois lançaria primeiro a lança, dá-se um sorteio mediado por Heitor e Odisseu: 


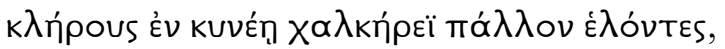

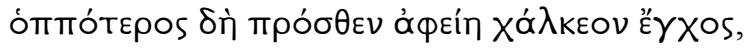

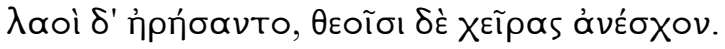

agitaram o elmo de bronze, no qual duas marcas haviam deposto, para que a sorte apontasse o primeiro a atirar a aênea lança.

Súplices, todos imploraram, aos deuses as mãos elevando. (Il. III, 315-7)

No canto IX, trata-se de escolher, entre noves voluntários, aquele que irá enfrentar Heitor; Nestor, como mediador, é quem os instrui a tirar a sorte:

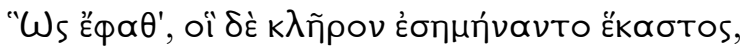

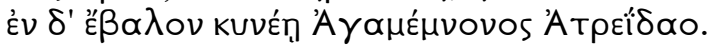

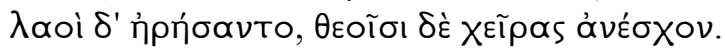

Obedeceram-lhe prestes, marcando cada um uma pedra, que, depois, no elmo vistoso lançaram do Atrida Agamémnone.

Súplices, todos imploraram, aos deuses as mãos elevando. (Il. VII 175-6)

Note-se o uso da fórmula "Súplices, todos imploraram, aos deuses as mãos elevando", que aparece ao final de ambas as descrições da tiragem da sorte. Trata-se de uma forma de tomar decisão que repousa na expectativa de uma mediação divina. Assim, quiseram os deuses que fosse Páris o sorteado a atirar sua lança em primeiro lugar no duelo com Menelau e que fosse Ájax a confrontar-se com Heitor, vendo-se assim atendidas as preces que muitos fizeram: “Que seja Ájax Telamônio, Zeus pai, o sorteado, ou Diomedes, / ou faze a escolha cair no monarca da rica Micenas!” (Zeũ па́์ Il. 179-80).

Esse caráter divinatório da tiragem da sorte está presente também em seu uso, para diversos propósitos, na democracia ateniense. Como é sabido, tirava-se a sorte até mesmo para a eleição de cargos públicos (DERMONT, 2000, pp. 300-2). A respeito do uso do sorteio como instrumento da democracia ateniense, Bordes (1987, p. 149) diz o seguinte: “Certaines ressemblances, toutes proportions gardées, entre le tirage au sort et les oracles me paraissent dénoter une même forme de mentalité, d'utilisation du divin"14.

\footnotetext{
${ }^{14}$ Platão, n'As Leis, faz o seguinte comentário a esse respeito: "O $\mathrm{O}$ favor dos deuses e da fortuna caracteriza a sétima forma de governo, na qual um homem se adianta para um lance da sorte e declara que se ganhar será com justiça o governante, e se não o conseguir assumirá seu lugar entre os governados".

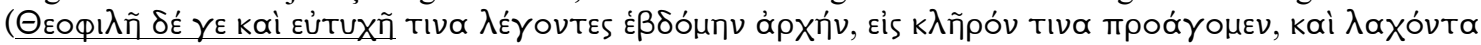


A imagem da tiragem da sorte é recorrente nos Sete e por isso mesmo bastante significativa. Viu-se como o Mensageiro, no prólogo, narrou em detalhes o sorteio entre os líderes do exército argivo - para saberem diante de quais portas cada um deles se posicionaria -, dando ênfase no uso de vocábulos relacionados à tiragem da sorte.

No párodo, o Coro de mulheres tebanas, em meio às suas preces, faz nova referência ao sorteio entre os chefes argivos anteriormente descrito pelo Mensageiro:

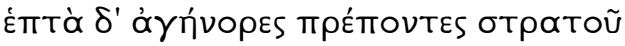

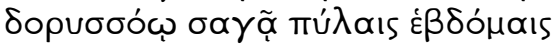

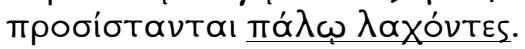

Sete guerreiros seletos do exército, com missivas armas, tiradas as sortes, aproximam-se das sete portas.

No segundo episódio, o relato do Mensageiro consiste primeiramente em dizer a Etéocles qual chefe foi destinado a qual porta da cidade. Assim, ele inicia seu relato: "Eu diria bem ciente dos adversários / que diante das portas cada um está sorteado"

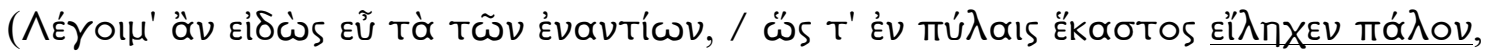
Se. 375-6). Ao falar do segundo atacante, o Mensageiro diz: "Capaneu teve no sorteio as

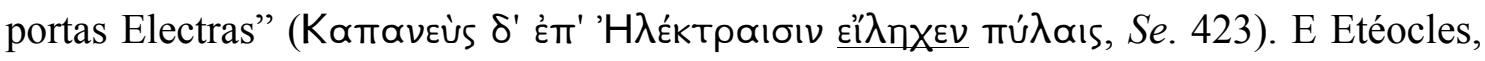
quando termina de assignar o oponente de Capaneu, diz ao Mensageiro: "Diz outro

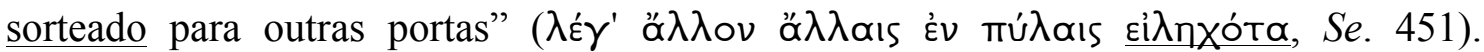
Prosseguindo seu relato, o Mensageiro anuncia o terceiro oponente:

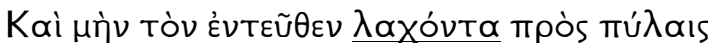

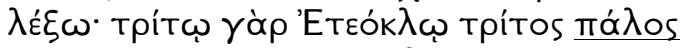

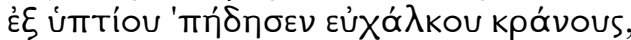

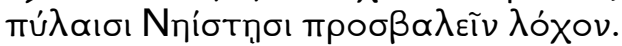

Quem depois foi sorteado para as portas, direi: a Etéoclo, terceiro, o terceiro lance saltou do revirado brônzeo elmo, investir a tropa nas Portas Novas.

(Se. 457-60)

Do mesmo modo, ao designar Hipérbio para combater Hipomedonte na quarta porta, Etéocles diz que Hipérbio "quer perscrutar a sua porção no uso da sorte"

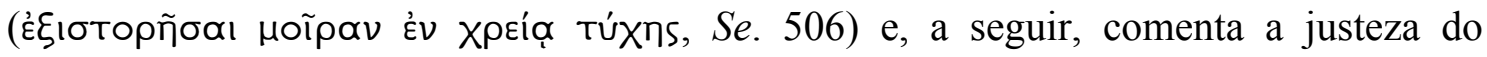
confronto entre ambos dizendo que, a Hipérbio, "Hermes bem o conduziu" (Se. 508). A referência a Hermes é significativa, visto que pertence ao domínio desse deus os encontros fortuitos, sejam estes benéficos ou maléficos, os ganhos e as perdas inesperadas, a sorte, o que acontece de súbito. Por essa razão, é um deus associado à 
cleromancia $^{15}$. Reforça-se assim, nesta passagem, não apenas a ideia do sorteio, mas também a sua relação direta com a vontade divina.

A tiragem da sorte como forma de revelação de desígnios divinos aparece de forma explícita nas palavras de Etéocles quando este percebe a realização da maldição paterna ao saber que seu irmão está na sétima porta e que deve combatê-lo. À tentativa do Coro de dissuadi-lo, Etéocles responde:

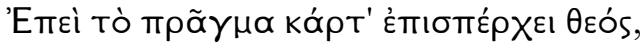

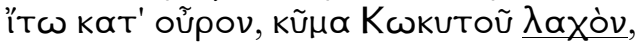

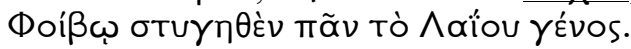

Quando Deus mesmo impele à ação, vá com o vento à onda do Cocito sorteada toda a estirpe de Laio odiada por Febo.

(Se. 689-91)

Ao saber que, por sorteio, coube a Polinices a sétima porta - o que significa que, tendo designado os demais guerreiros tebanos para as portas precedentes, resta-lhe ocupar a defesa da última porta -, Etéocles percebe que coube por sorteio à estirpe de Laio ser levada à morte.

Essa associação entre a tiragem da sorte e o destino funesto proveniente da rixa entre os irmãos pela divisão dos bens paternos é retomada pelo Coro, no segundo estásimo, justamente quando este se refere à maldição de Édipo: “o amargo cruel ferro /

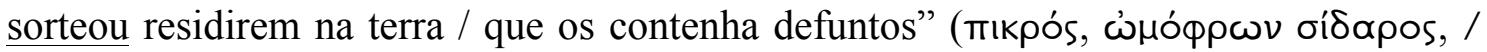

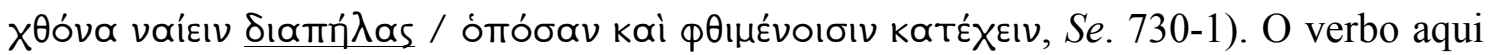

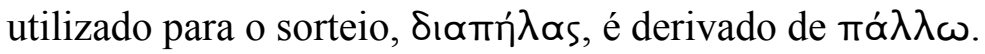

O recurso à tiragem de sorte para a divisão de bens paternos entre irmãos não era uma prática estranha à sociedade grega antiga, embora, como ressalta Thalmann (1978, pp. 63-9), não se saiba nada a respeito das leis da hereditariedade no século $\mathrm{V}$ a.C. Contudo, como argumenta o autor, isso não significa que os espectadores do drama clássico não estivessem familiarizados com essa prática.

Em Homero, no canto XV da Ilíada, Posídon, indignado com a ordem que recebera de Zeus através de Íris para que se afastasse da guerra e retornasse à assembleia dos deuses, explica por que não quer obedecer a Zeus:

\footnotetext{
${ }^{15}$ Em A Paz, de Aristófanes, quando Hermes diz a Trigeu que ele está perdido, Trigeu responde: "Se for o meu destino, assim seja. Mas afinal de contas você é Hermes e vai ter de fazer o sorteio para ver quando

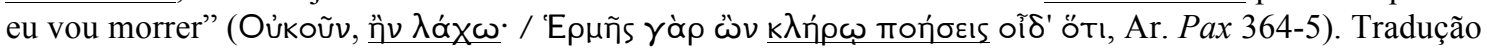
de Mário da Gama Kury (1968). Bouché-Leclercq (2003, p. 540), comentando sobre o Hino Homérico a Hermes (v. 550 et seq.), conclui: "Hermès reste donc, d'après la version adoptée par l'auteur de l'hymne homérique, le détenteur de la méthode cléromantique".
} 


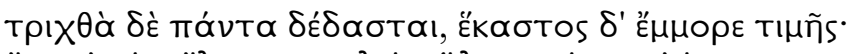

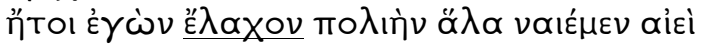

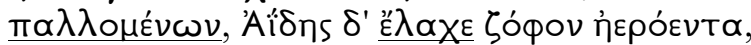

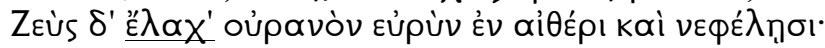

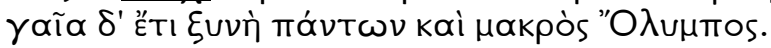

Foi divido em três partes o mundo; cada um teve a sua.

Postas em sorte, me coube morar para sempre no reino

do mar espúmeo; a Hades forte foram as trevas sombrias entregues;

o vasto Céu, pelas nuvens cercado e pelo éter, a Zeus.

A terra imensa e o alto Olimpo, em comum para todos ficaram. (Il. XV, 189-93)

O mesmo uso da tiragem de sorte na divisão da herança entre irmãos aparece no canto XIV, da Odisseia, em que Odisseu, disfarçado, narra ao porqueiro Eumeu a história da morte de seu falso pai e de como os filhos legítimos tiraram à sorte a divisão dos bens paternos:

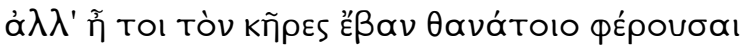

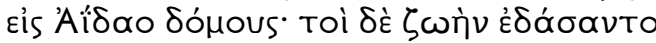

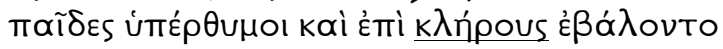

Mas as deidades da Morte o levaram, por fim, para a casa de Hades, e a herança deixada foi posta, a seguir, em partilha pelos seus filhos altivos, que tudo por sorte dividem. (Od. XIV, 207-9)

No que se refere à transmissão do poder real não há, nos Sete e em nenhum outro texto supérstite anterior a Ésquilo, qualquer referência à primogenitura, seja de Etéocles ou de Polinices. Em Édipo em Colono, de Sófocles, Polinices é o primogênito e, por assim sê-lo, reclama o direito ao trono de Tebas ${ }^{16}$, embora Édipo ignore esse argumento. Já nas Fenícias, de Eurípides, Etéocles é o primogênito ${ }^{17}$, embora ele não utilize a primogenitura como argumento para se manter no poder e não cedê-lo a seu irmão, conforme havia sido combinado. A versão do mito em que os filhos de Édipo concordam em revezar o poder real a cada ano, acordo este que Etéocles desfaz ao se

\footnotetext{
${ }^{16}$ Diz Ismene a Édipo e a Antígona: "No conflito entre os dois irmãos, o mais / jovem, contrariando a lei

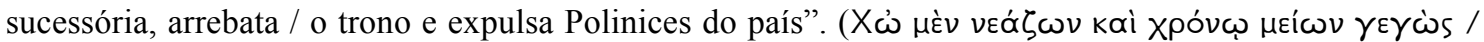

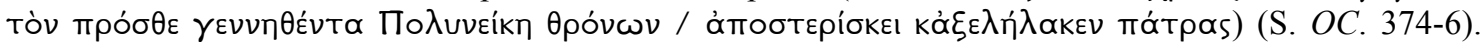
Mais adiante, é o próprio Polinices que proclama sua progenitura: "Fui expulso do meu solo pátrio por pretender / ocupar teu assento soberano, direito que / me cabia por ser o filho mais velho. / Violando o

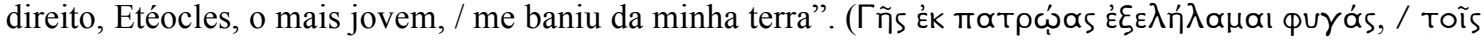

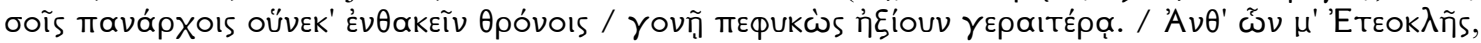

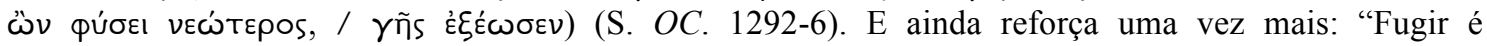

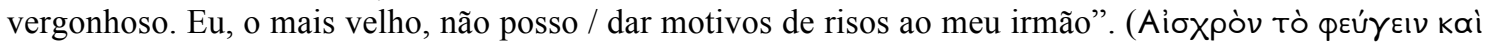

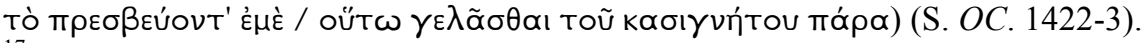

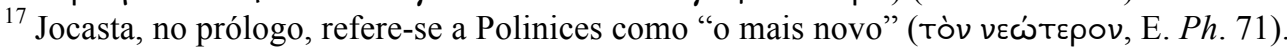


recusar, ao término de seu prazo como rei, a entregar o trono a Polinices, figura, entre os tragediógrafos, somente em Eurípides ${ }^{18}$.

Da querela entre os irmãos nos Sete, tudo o que se sabe é a acusação que faz

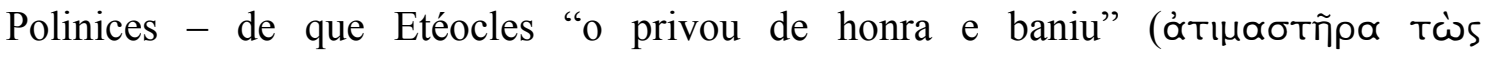

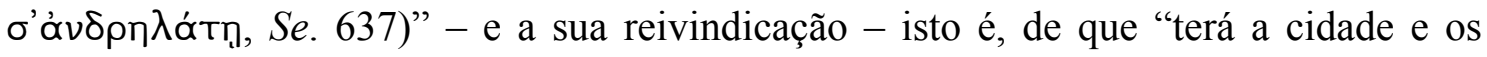

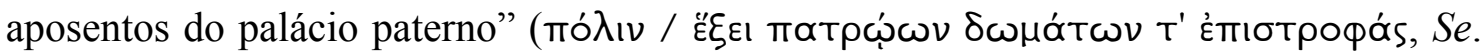
647-8).

Sabe-se, como aponta Thalmann (1978, pp. 66-7), que, havendo discórdia entre

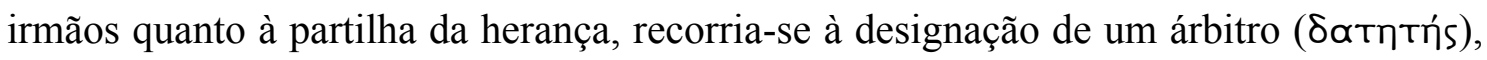
sob cuja supervisão tirava-se a sorte.

Em um fragmento do Papiro de Lille (P. Lille 76abc e 73) atribuído a Estesícoro, Jocasta $^{19}$ propõe a divisão da herança paterna entre Etéocles e Polinices por meio da tiragem da sorte; assim, um ficaria com a herança imobiliária - as terras e provavelmente a realeza - e o outro com a mobiliária - os tesouros, o gado etc. -, imigrando para outro lugar:

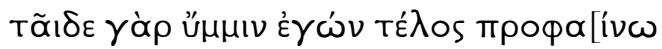

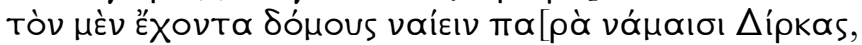

Tòv $\delta$ ' ámíl

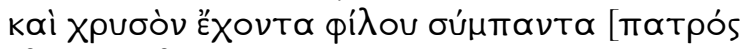

$k \lambda \propto \rho \circ \pi \alpha \lambda \eta \delta$ òv ös å̀

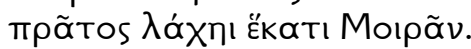

TOŨTo $\gamma \alpha \rho$ äv $\delta$ Кह́ $\omega$

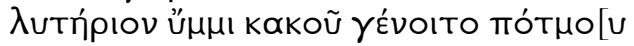

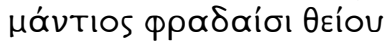

Esta é a decisão que eu vos anuncio:

que um, tendo as moradas junto às águas de Dirce, ali habite;

e que o outro, tendo todas as possessões

e o ouro do caro pai, parta,

\footnotetext{
${ }^{18}$ Diz Jocasta no prólogo das Fenícias: "concordes fixaram Polinices o mais novo / exilar-se antes de bom grado deste solo, / e Etéocles ficar e manter o cetro da terra, / alternando cada ano. Ao instalar-se ao

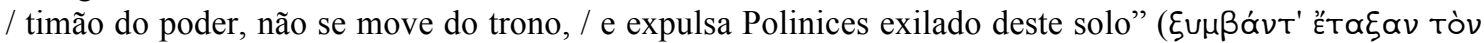

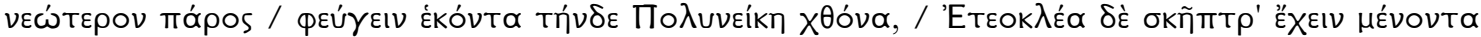

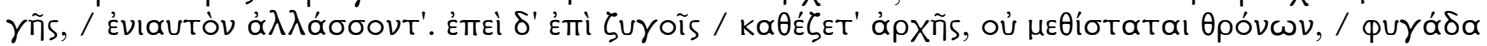

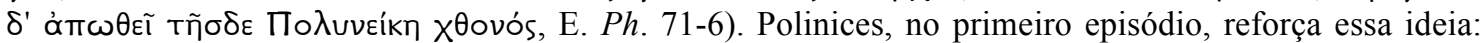
"Saí de bom grado eu mesmo do país, / dei-lhe poder na pátria o ciclo do ano / para deter por turno de novo o poder, / e não vir por ódio e por recusa dele / fazer e sofrer um mal, que acontece. / Ele, que aprovou e jurou por Deuses, / nada fez do prometido, mas retém / ele a realeza e minha parte da casa"

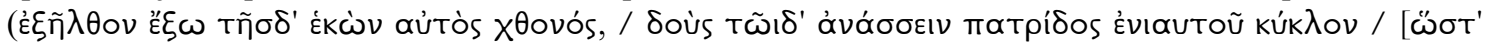

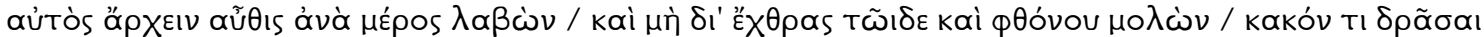

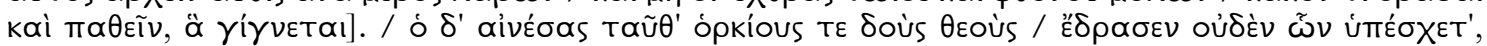

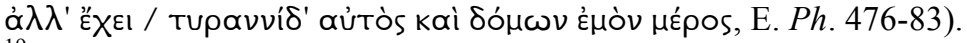

19 Há dúvidas quanto à sua identidade. Conferir, para uma discussão a esse respeito, o artigo de Antonietta Gostoli (1978) intitulado "Some Aspects of the Theban Myth in the Lille Stesichorus".
} 
aquele que, primeiro, tirando a sorte, obtiver esse lote, com a ajuda da Moira.

Pois creio que isso seria para vós uma libertação do destino funesto que prediz o divino adivinho. (v. 219-228) ${ }^{20}$

Nesse caso, é Jocasta quem assume o papel de árbitro para o sorteio das partes da herança, mas, nos Sete, o árbitro que vai presidir a tiragem da sorte é o forasteiro da Cítia. Descobrir a real identidade desse forasteiro é perceber quão verdadeiras eram as

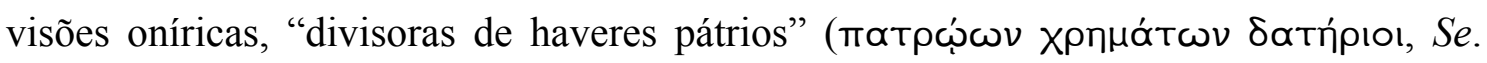
711); é encontrar a chave interpretativa para resolver o enigma da maldição de Édipo,

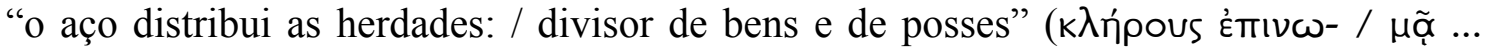

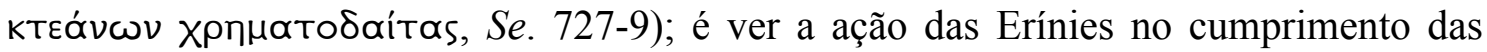
pragas, "de obterem no sorteio / com a mão munida de ferro / os haveres" ( $\sigma \phi \varepsilon$

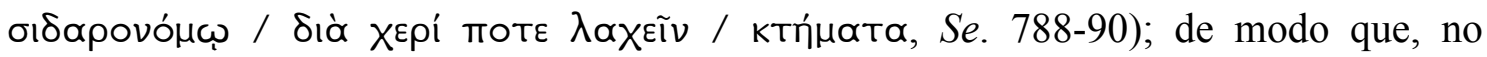
terceiro episódio, o Mensageiro possa assim declarar a morte dos irmãos:

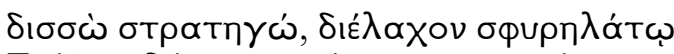

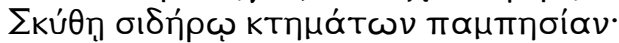

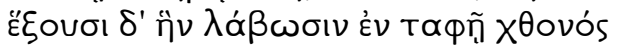

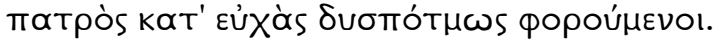

os dois guias repartiram com lavrado ferro cita a plena posse dos haveres. Terão a terra que pegarem na tumba, levados por infelizes preces do pai.

(Se. 816-19)

\section{4) Cledomancia: a cena dos escudos}

Como se viu, kledón é uma palavra pronunciada cuja duplicidade de sentido constitui um sinal divino para quem a ouve. Há casos em que o presságio contido no kledón realiza-se por si mesmo. Existem casos, no entanto, em que o presságio se realiza ao ser aceito, mas aceito de modo a, mediante uma interpretação em que se recontextualiza a palavra, ser favorável para quem o aceita.

Heródoto, por exemplo, relata que os lacedemônios receberam um oráculo de Delfos dizendo-lhes que pedissem a Xerxes uma reparação pela morte de Leônidas e que aceitassem o que ele lhes desse. Enviaram então um arauto ao Grande Rei com a demanda de reparação. Ao ouvi-la, o Grande Rei começou a rir e, depois de um tempo em silêncio, apontou para Mardônio, que estava em sua companhia, e disse: "Pois bem, será Mardônio, aqui presente, que lhes dará a satisfação adequada" ("Toıłáp oథı

\footnotetext{
${ }^{20}$ A edição do fragmento é de Hutchinson (1985) e a tradução é nossa.
} 


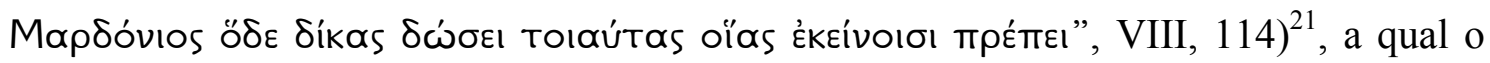
arauto aceitou, partindo em seguida. Inadvertidamente, Xerxes selou o destino de Mardônio, augurando sua morte como uma reparação pela morte de Leônidas. Tendo sido morto em combate pelos lacedemônios, Heródoto diz que "nesse dia Mardônio pagou o justo preço pela morte de Leônidas, de acordo com o oráculo dito aos

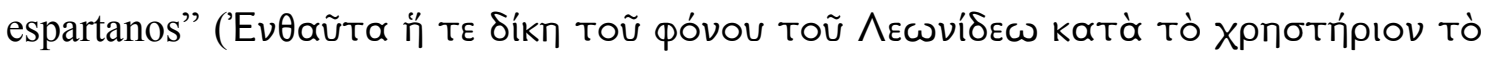

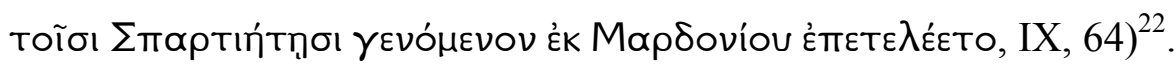

Do mesmo modo, Perdicas obteve a realeza macedônica. Como pagamento pelo trabalho que lhe foi dedicado por Perdicas e seus irmãos, o rei, apontando para um raio de sol que entrava no local por um buraco de chaminé, disse: "Eis o salário digno de vós

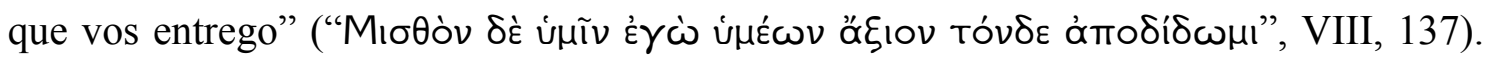
Enquanto seus irmãos ficaram atônitos, Perdicas disse: “Aceitamos, ó rei, o que nos

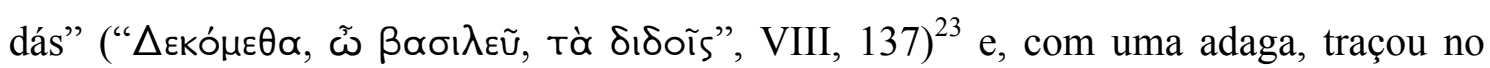
chão um círculo em volta da luz do sol e fez o gesto de guardá-lo no bolso, repetindo-o três vezes. Alertado por um conselheiro sobre a gravidade do que havia dito, o rei mandou matá-los, mas em vão. O augúrio se cumpriu e Perdicas tornou-se rei: o sol que estrava pela fresta e iluminava um pedaço do chão era afinal o mesmo sol que iluminava toda a terra do país ${ }^{24}$.

$\mathrm{Na}$ discussão entre Egisto e o Coro de anciãos, em Agamêmnon, Egisto empunha-lhes a espada e o Coro responde: "Empunho também, não recuso morrer"

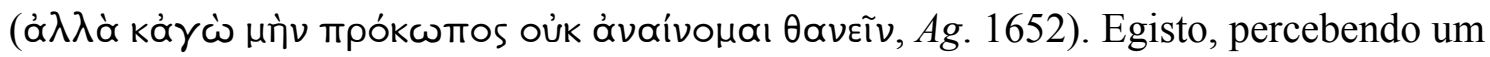

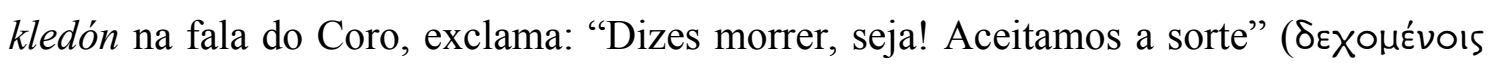

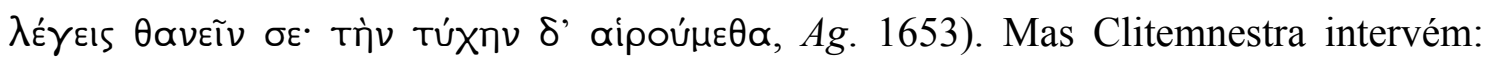

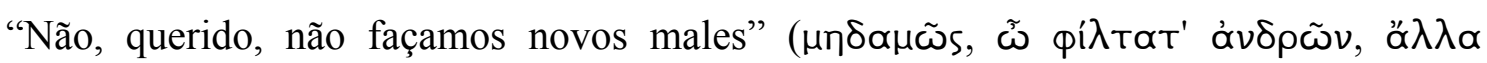

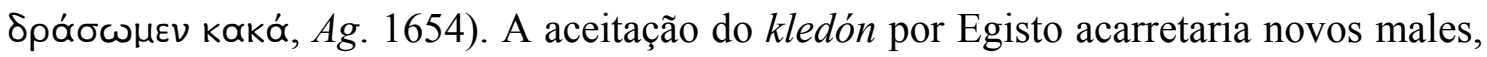
isto é, novas mortes; nesse caso, a morte dos anciãos.

Nomes próprios também podem ser entendidos como kledónes, revelando um destino individual. O kledón contido nos nomes também pode ser aceito. Assim, segundo Heródoto, Leutiquides, antes as súplicas de um sâmio, perguntou qual era o seu nome e tendo este respondido que era Hegesístratos, isto é, condutor do exército, disse:

\footnotetext{
${ }^{21}$ Tradução de José Ribeiro Ferreira e Carmen Leal Soares (2002).

22 Tradução de Mário da Gama Kury (1988, 2ª . ed.).

23 Tradução de José Ribeiro Ferreira e Carmen Leal Soares (2002).

${ }^{24}$ Outros exemplos de aceitação de kledónes em Heródoto: I, 63; IX, 91.
} 


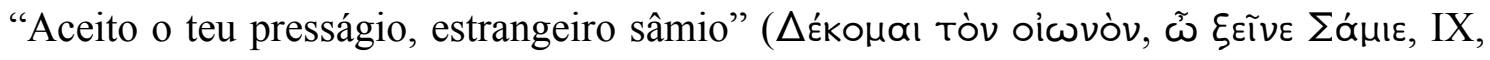

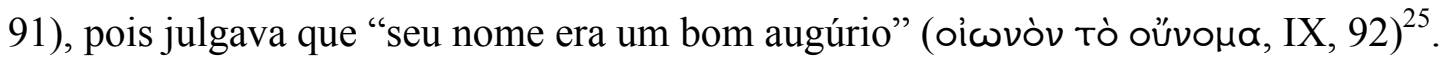

Em Agamêmnon, o Coro comenta quão verdadeira é a previsão do destino

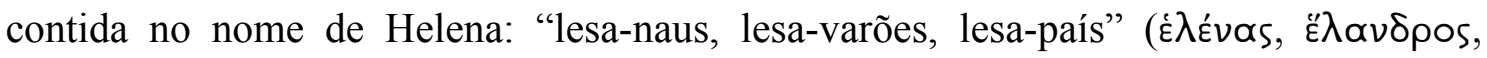
غ̇ $\varepsilon_{\pi} \pi т \mathrm{o}$ is, $A g$. 689-90), e, para Cassandra, o trocadilho com o nome de Apolo é

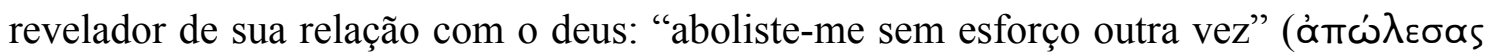

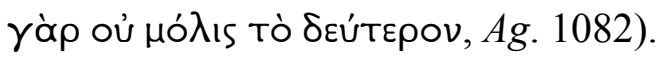

Nos Sete, na prece de Etéocles, no prólogo, de que "Zeus defensor / epônimo

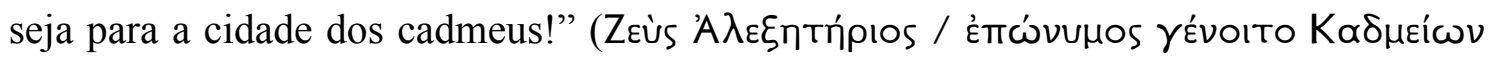

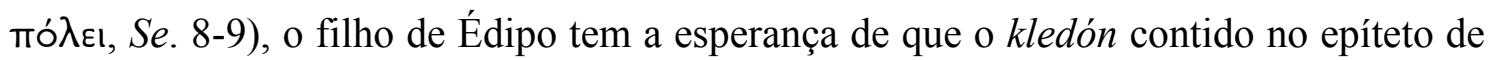
Zeus se cumpra; isto é, Etéocles espera que Zeus defensor seja "fiel a seu nome"

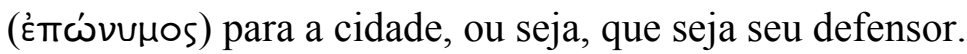

Tanto Etéocles quanto o adivinho Anfiarau mostram-se cientes do kledón contido no nome de Polinices. No segundo episódio, ao reportar as invectivas que Anfiarau faz a Polinices, o Mensageiro diz que o adivinho o fez "revirando o nome /

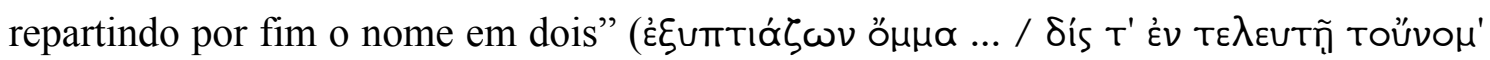

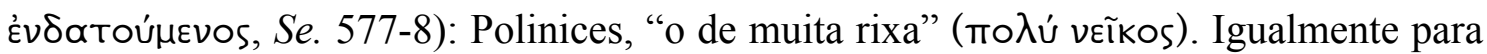
Etéocles, o nome de Polinices, diante da iminência do embate entre os irmãos, revela-se

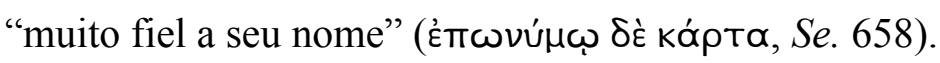

Também o Coro, no terceiro estásimo, lamentando a morte dos irmãos, diz que

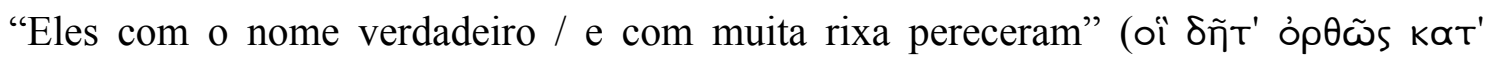

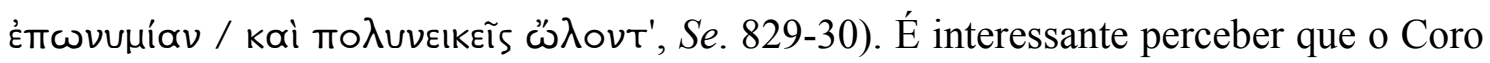
reconhece o cumprimento do kledón contido no nome de Polinices como revelador do destino de ambos os irmãos, visto que ambos, unidos pela maldição paterna, uniram-se na morte por causa de muita rixa. Mas qual seria o kledón contido no nome de Etéocles que seria igualmente um prenúncio do destino também de Polinices? Bacon (1991, p. 14) sugere que, embora a etimologia correta do nome de Etéocles seja "o de verdadeira

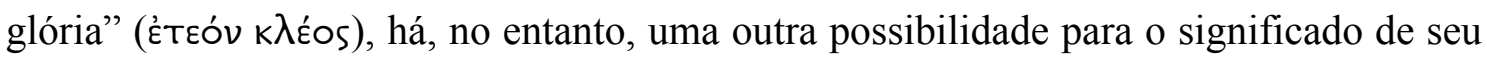

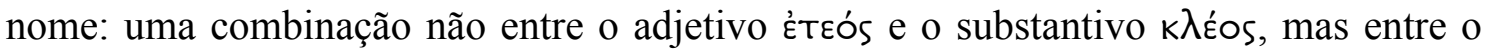

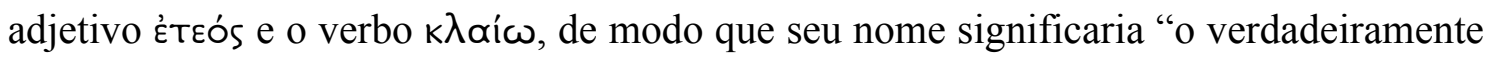
chorado" ou "o verdadeiro alvo de lamentos". Essa possibilidade outra, ominosa, do kledón contido no nome de Etéocles seria, segunda a autora, imediatamente apresentada

\footnotetext{
${ }^{25}$ Tradução de Mário da Gama Kury (1988, 2ª . ed.).
} 
no prólogo, quando o filho de Édipo diz que, se a cidade obtém sucesso, este será creditado aos deuses - como de fato o será (Se. 822-4) -, mas, se fracassa,

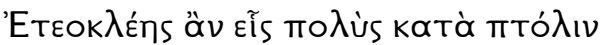

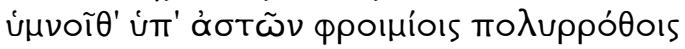

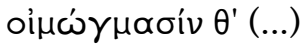

Etéocles só seria muito hineado na cidade pelos cidadãos, com proêmios multíssonos e com prantos (...)

As suas palavras se revelariam afinal proféticas: seu nome será lamentado, mas não por causa da destruição da cidade e sim por causa de sua própria destruição, cumprindo-se, dessa forma, o kledón outro, ominoso, contido em seu nome ${ }^{26}$. Ao final, como observou o Coro, não apenas os kledónes contidos em seus nomes se cumpriram individualmente, mas ambos os kledónes revelaram-se verdadeiros para ambos os irmãos, pois por muitas rixas são agora os dois verdadeiramente chorados. Assim, no êxodo, o Coro fala de seus trágicos destinos como "aflitos lutos do mesmo nome"

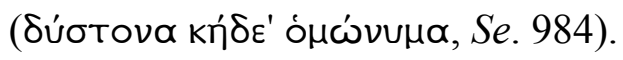

A percepção do kledón e sua aceitação constituem um fator de grande importância para uma mais abrangente compreensão da cena dos escudos no segundo episódio. Em primeiro lugar, deve-se considerar que, como observa Peradotto (1969, pp. 8-9), a cledomancia se aplica a momentos de crise ou de grande preocupação quanto ao futuro. São esses os momentos retratados pela tragédia. Portanto, prossegue o autor, os espectadores de Ésquilo estavam atentos às palavras que pudessem prenunciar ou precipitar o destino de um personagem, já que, em sua maioria, já tinham conhecimento desse destino. Assim, aquilo que, para o leitor moderno, pode parecer um sutil jogo de palavras, não apresentava maiores dificuldades de entendimento e de interpretação para os espectadores da tragédia.

$\mathrm{Na}$ cena dos escudos, a cledomancia corrobora enormemente para o efeito dramático da cena. Trata-se de uma tragédia de cunho guerreiro, mas seria impossível representar efetivamente uma cena de batalha, tanto pelo número reduzido de atores como pela prerrogativa de que cenas de morte e de violência explícita não devem ser representadas. A batalha, portanto, dá-se verbalmente. A cada descrição do inimigo feita pelo Mensageiro, a batalha é perdida e, a cada resposta de Etéocles, a batalha volta a ser ganha. A tensão dramática, portanto, está sempre elevada, pois, nesse jogo

\footnotetext{
${ }^{26}$ Zeitlin (2009, p. 22) endossa a interpretação de Bacon a respeito do sentido ominoso oculto no nome de Etéocles. Conferir também o artigo de Hubbard, "Tragic Preludes: Aeschylus 'Seven against Thebes' 4$8 "(1992)$.
} 
cledomântico de percepção, ressignificação e aceitação de presságios, a guerra está sendo verbalmente travada diante da plateia, principalmente se considerarmos que, para o homem grego à época de Ésquilo, eventos acontecem não apenas por aquilo que se faz, mas também por aquilo que se $\operatorname{diz}^{27}$.

Os escudos são, na expressão de Vidal-Naquet (2005, p. 253), “objetos falantes”; isto é, interpelam Etéocles e o convidam a desvendar-lhes o sentido numinoso. São, nesse sentido, verdadeiros kledónes, mediante os quais se expressam os desígnios divinos.

A cena dos escudos é estruturada em pares de discursos intercalados por um breve comentário do Coro. O Mensageiro indica a Etéocles qual atacante argivo foi sorteado para cada uma das sete portas da cidade, descrevendo sua atitude, suas bravatas e os emblemas em seus escudos ${ }^{28}$, e Etéocles responde comentando essa descrição e designando por sua vez um oponente tebano.

O termo mais utilizado por Ésquilo para se referir ao emblema dos escudos é

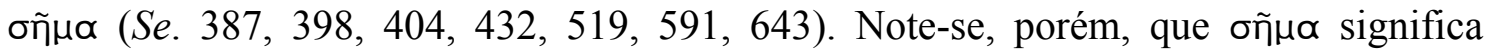
igualmente "sinal dos deuses", "augúrio", "presságio". O que se pretende observar, portanto, é que, nessa cena, as bravatas dos argivos, assim como os emblemas e as inscrições sobre os escudos, são percebidas por Etéocles como kledónes, os quais ele aceita, ressignificando-os, de modo a profetizarem a vitória de Tebas e a derrota dos inimigos. Para Bacon (1991, p. 9), os escudos dos sete guerreiros argivos são na verdade enigmas que Etéocles tem de decifrar, assim como ele tem de decifrar o enigma da maldição de Édipo e assim como Édipo teve de decifrar o enigma da Esfinge. Portanto, para Zeitlin (2009, p. 23), "Eteokles' best defense against the curse of his father and on behalf of his own name is attention to language and control of the discourse".

O Mensageiro entra em cena no início do segundo episódio e anuncia quem do exército argivo foi sorteado para a primeira porta, as Portas Prétides. Trata-se de Tideu,

\footnotetext{
${ }^{27}$ Nas Coéforas, o Coro, ao evocar Agamêmnon, pergunta-lhe: "Ó pai, mísero pai, com que / palavra ou com que feito / lograria trazer-te de lá / onde te retém o repouso?" (Co. 315-18). No Prometeu Cadeeiro, Io conta que seu pai "enviava a Delfos e a Dodona frequentes mensageiros, que consultassem o oráculo, para saberem o que ele devia dizer ou fazer para agradar os deuses" (Pr. 658-60).

${ }_{28}$ Para um meticuloso estudo sobre o assunto, conferir o artigo de George Henry Chase, "The Shield Devices of the Greeks", de 1902. Como observa o autor, encontram-se já nos poemas homéricos três passagens em que se descrevem emblemas de escudos - na Ilíada, descrevem-se o pavoroso emblema do escudo de Atena (V, 739-43), o de Agamêmnon (XI, 36-40) e, extensamente, o de Aquiles (XVIII, 478608) - e, segundo Heródoto, foram os cários quem ensinaram os helenos "a pôr emblemas nos escudos"

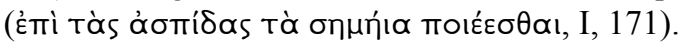


que, enfurecido, vitupera o adivinho Anfiarau, em razão de sua desaprovação à travessia do Ismeno. Sua avidez pela batalha é comparada pelo Mensageiro à do cavalo que, bufando, dispara ao soar a trombeta. O seu escudo é assim descrito pelo Mensageiro:

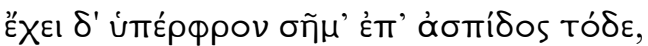

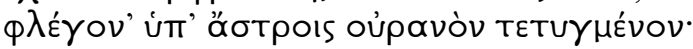

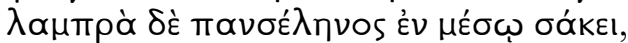

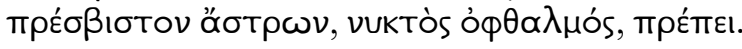

Tem sobre o escudo este soberbo signo: o firmamento feito fúlgido de astros e lúcida a lua cheia no meio do escudo esplende, venerável astro, olho da noite.

(Se. 384-90)

Note-se que o emblema do escudo de Tideu é qualificado como "soberbo signo"

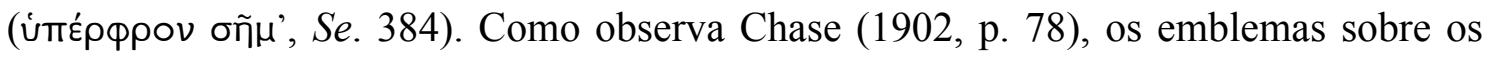
escudos muitas vezes tinham por objetivo inspirar medo nos inimigos. Ora, a noite, como se viu, é não apenas um período do dia, mas também uma divindade que evoca um aspecto do mundo que é o da privação de ser. Mas Etéocles inicia sua resposta dizendo não temer adornos de homens e que "nem se tornam vulnerantes os signos" (T⿳亠㐅

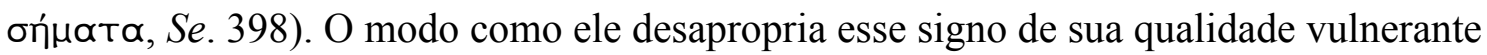

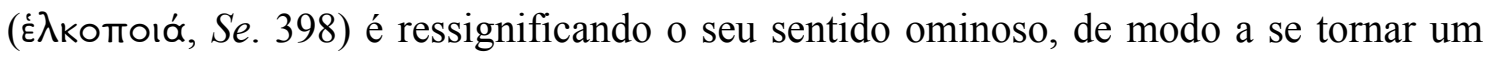
bom augúrio para o desfecho do embate. Etéocles percebe nesse emblema um kledón e o aceita; ele o faz, porém, de modo a prenunciar não a morte, a destruição, a ruína de Tebas, mas sim a de Tideu. Dessa maneira, por um jogo de palavras, ele inverte o mau augúrio: o "olho da noite" (vuktòs ó $\theta \alpha \lambda \mu o ́ s, ~ S e . ~ 390)$, epíteto da lua, passa a pressagiar a morte de Tideu, em quem há de cair "a noite sobre olhos" ( $v$ ù $\xi$ Ė

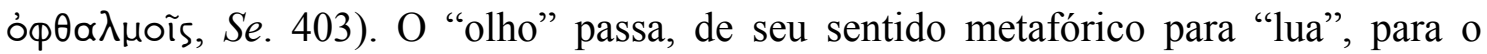
sentido literal dos "olhos" de Tideu, e a "noite" passa de seu sentido literal para o sentido metafórico de "morte".

Ao ressignificar o kledón, a "demência" de Tideu revela-se "divinatória" ( $\mu$ ớvTıs

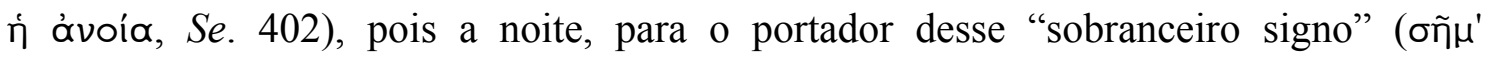
úméрконтоv, Se. 404), corretamente e com justiça, mostrar-se-á fiel a seu nome

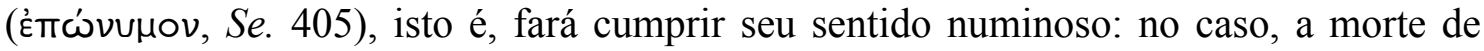

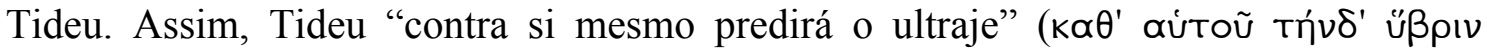

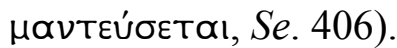

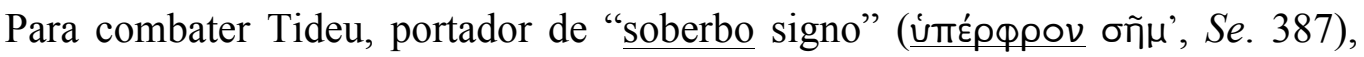

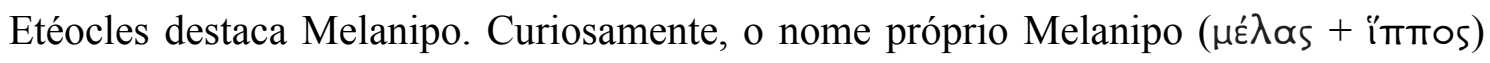
significa "cavalo negro" e, como adjetivo, é encontrado somente em um fragmento (69) 
de Ésquilo, em que figura como epíteto da noite: "escapando da escuridão / da sagrada

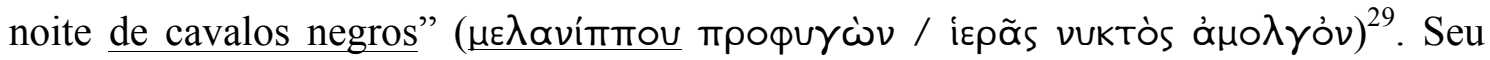
nome pode também ser um bom augúrio no sentido de que Melanipo, o de negro cavalo, irá contrapor-se àquele que foi comparado pelo Mensageiro a um cavalo bufante ( $\mathrm{Se}$. 393-4). Melanipo é um homem nobre, venerável, que tem horror às "palavras

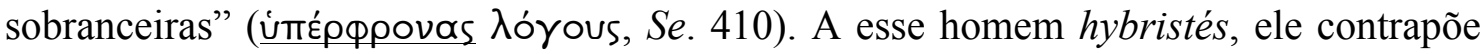

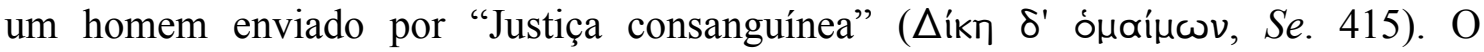
comentário do Coro reforça essa ideia: para as mulheres tebanas, Melanipo "ergue-se

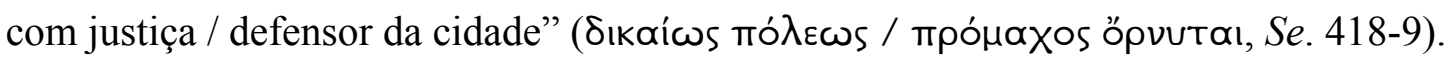

Capaneu é o líder argivo sorteado para a segunda porta, as Portas Electras. Sua hýbris fala por si mesma: sua vanglória é tão blasfema que, antes mesmo de o Mensageiro reproduzi-la, conclui que "ele não pensa em termos humanos" (oủ kat'

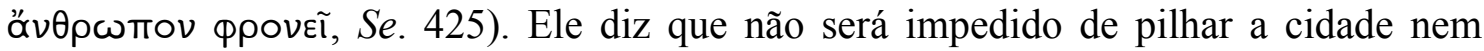
mesmo por Zeus, cujo poder fulminante de seus raios ele compara desdenhosamente ao calor do meio-dia. Seu escudo é assim descrito pelo Mensageiro:

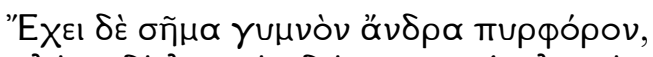

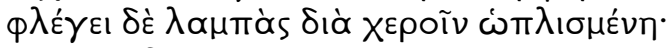

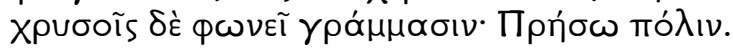

Tem por signo um homem nu ignífero, o archote como arma nas mãos arde, em letras de ouro diz: "Queimarei a cidade".

(Se. 432-4)

Quando o Mensageiro pergunta quem Etéocles enviará contra esse "soberbo"

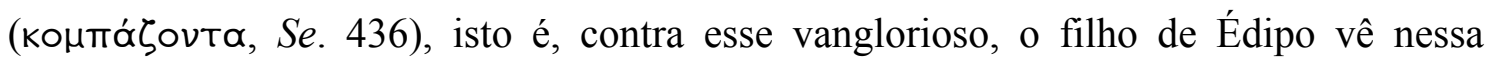
vanglória uma vantagem, visto que, de tais pensamentos levianos, "a língua se torna o

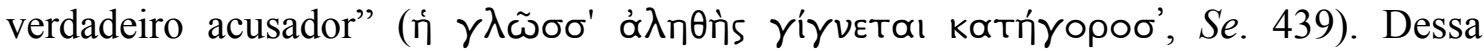
forma, assim como a demência de Tideu era divinatória, prenunciando a sua própria ruína, a língua de Capaneu será para ele seu verdadeiro traidor, pois, sendo mortal, desonra os deuses e eleva sua voz a Zeus, revelando, assim, toda a extensão de sua hýbris, o que atrairá inevitavelmente o descontentamento divino.

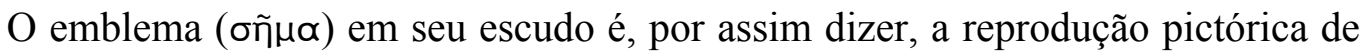
sua vanglória: um homem nu, isto é, que não precisa de armadura, portador de fogo (тupфópos), carregando nas mãos um archote ardente e que tem por máxima a frase

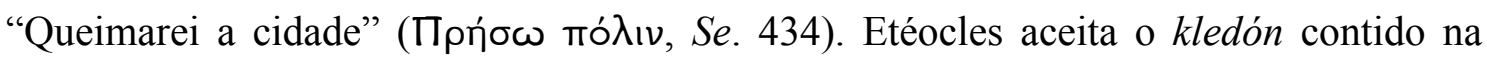
palavra "ignífero" (mupфópos, Se. 432) e o ressignifica, de modo que "ignífero"

\footnotetext{
${ }^{29}$ A edição do fragmento é de Sommerstein (2008) e a tradução é nossa.
} 
(тupфópov, Se. 444) passe a qualificar não o homem nu, mas o raio que, "com justiça"

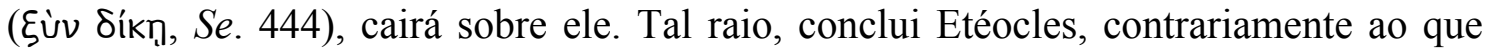
dissera Capaneu, não será em nada comparável ao calor do meio-dia. Novamente, então, o sentido ominoso do escudo de um atacante é revertido em um bom presságio para a salvação de Tebas: a morte de Capaneu pelo raio de Zeus ${ }^{30}$. Também o Coro sublinha a ressignificação do kledón feita por Etéocles em sua prece: "Pereça quem roga pragas à cidade / e fulminante raio o refreie" ("O

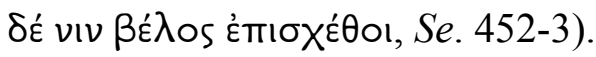

Contra Capaneu, Etéocles envia Polifontes, um homem que ele descreve ser possuidor de um "árdego ânimo" ( ă$^{\prime} \theta \omega \nu$... $\left.\lambda \tilde{n} \mu \alpha S e .448\right)$; assim, contra aquele que traz em seu escudo, literalmente, um "portador de fogo", opõe-se um homem cujo ânimo é descrito metaforicamente como "ardente". Contra o hybristés Capaneu, Etéocles envia um homem que terá, ao guardar a segunda porta da cidade, a benevolência de Ártemis e dos demais deuses tutelares.

Etéoclo é o atacante sorteado, no terceiro lance, para se posicionar ante a terceira porta, as Portas Novas. O Mensageiro descreve Etéoclo volteando cavalos que fremem sob os freios e de cujas focinheiras sai o bárbaro som dos sopros de suas narinas. Seu escudo é assim descrito:

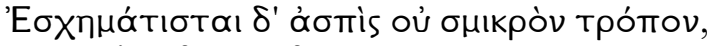

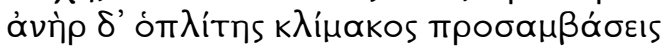

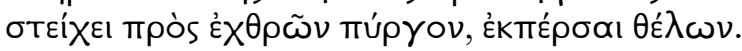

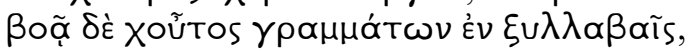

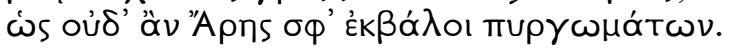

O escudo tem efígie não humilde: um hoplita galga por degraus de escada a torre de inimigos querendo queimá-la e no feixe de letras ainda este grita que nem Ares o expulsaria do forte.

(Se. 465-9)

O kledón que aqui Etéocles aceita e ressignifica está contido tanto na imagem de um hoplita galgando a torre de uma cidade para queimá-la quanto no desafio a Ares inscrito no escudo de Etéoclo.

Megareu, o defensor tebano designado por Etéocles para fazer frente a Etéoclo é

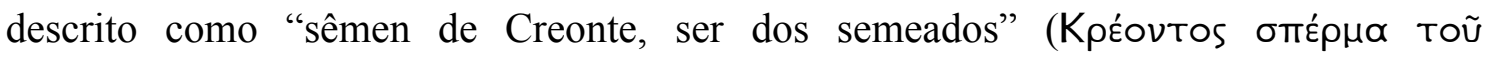

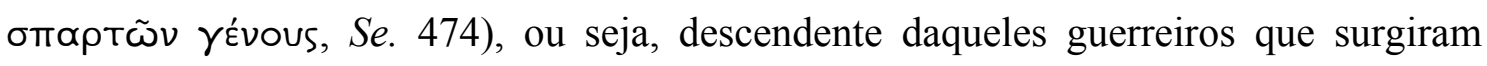
armados da terra quando Cadmo semeou os dentes da serpente. Não há evidência no texto dos Sete de que Ésquilo esteja utilizando a versão do mito em que a serpente

\footnotetext{
${ }^{30}$ Tanto em Sófocles quanto em Eurípides, diz-se que Capaneu, ao tentar escalar as torres de Tebas, foi fulminado pelo raio de Zeus. Conferir, de Sófocles, Antígona (131-3), e, de Eurípides, As Suplicantes (496-9; 639-40; 934; 985) e As Fenícias (1180-1).
} 
morta por Cadmo é considerada filho de Ares, o que faria de Megareu um descendente

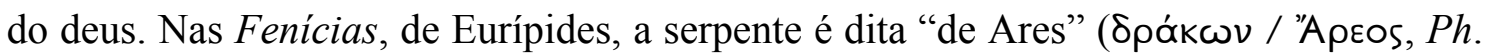
657-8) e, segundo Tirésias, o motivo para que se sacrifique o filho de Creonte é que, "por antigo rancor de Ares a Cadmo, / ele pune a morte da terrígena cobra" (Kó $\delta \mu \omega ı$

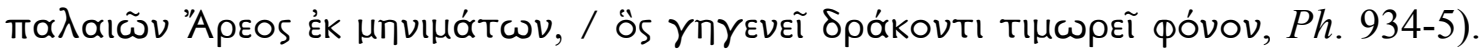
Independentemente disso, trata-se de uma divindade intrinsicamente ligada à cidade de Tebas. O Coro, no primeiro estásimo, refere-se a Ares como "antigo terrícola"

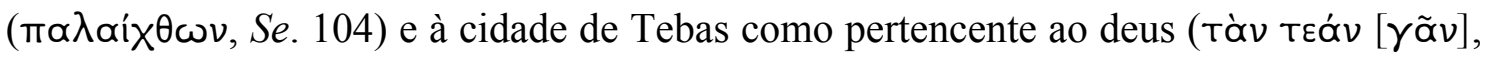
$\mathrm{Se}$. 105). Ares é visto, assim, como protetor da raça de Cadmo (Se. 412).

Logo, esse guerreiro protegido pelo deus que Etéoclo insulta, que não recua ante os relinchos dos furiosos cavalos de seu opositor, irá, diz Etéocles, ou morrer em defesa da cidade, pagando assim a sua dívida de criação com a terra mãe, ou pegar "os dois

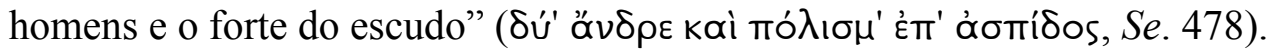

O sentido ominoso do emblema de um hoplita galgando a torre de uma cidade para, queimando-a, tomá-la, ainda que contra a vontade de Ares, um dos seus deuses tutelares, é ressignificado por Etéocles de forma a prenunciar que Megareu, protegido (e talvez descendente) de Ares, tomará tanto o homem que porta o escudo, Etéoclo, quanto o homem e o forte representados em seu escudo. Etéocles cria assim uma equivalência entre a realidade em si mesma - um guerreiro portanto um escudo para atacar da cidade - e a realidade para qual o símbolo aponta - um homem tomando uma cidade. Dessa forma, não será Etéoclo que, como em seu emblema, escalará as torres da cidade para tomá-la, mas sim Megareu, que, tomando a ambos os homens e a cidade, com o espólio adornará o palácio paterno $(S e .479)^{31}$. Esse é o sentido numinoso que Etéocles aceita como um presságio favorável aos tebanos.

O atacante sorteado para a quarta porta, dita de Atena Onca, é Hipomedonte. O Mensageiro assim descreve o seu terrível escudo:

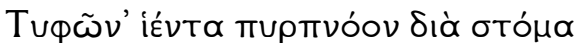

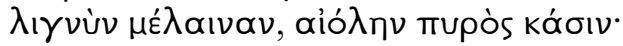

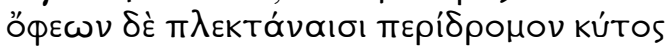

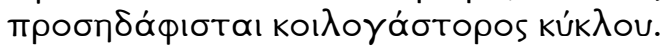

Tífon a lançar pela boca ignívoma, fumo negro, volúvel irmão do fogo: por laços de víboras o redondo invólucro do côncavo ventre do círculo se fixa.

(Se. 493-6)

\footnotetext{
${ }^{31}$ Segundo Cameron (1970, p. 103), quando Etéocles diz que Megareu há de enfeitar o "palácio de seu

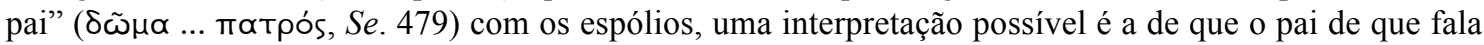
seja Ares e a casa, seu templo. Mas, mesmo considerando que o pai a que Etéocles se refere não seja Ares, o palácio ainda pode ser interpretado como o templo do deus, enquanto protetor de Tebas.
} 
O sentido ominoso da imagem de Tífon é bastante evidente. Inimigo de Zeus, foi uma terrível ameaça, segundo a Teogonia, à soberania do pai dos deuses e dos homens (Th. 820-80). A sua representação no escudo de Hipomedonte assemelha-se à do poema hesiódico, com as imagens do fogo e das serpentes ${ }^{32}$.

Etéocles primeiramente diz que a própria deusa Atena Onca, vizinha das portas ante as quais Hipomedonte se posiciona, repelirá, por ódio a ultraje de homem, essa

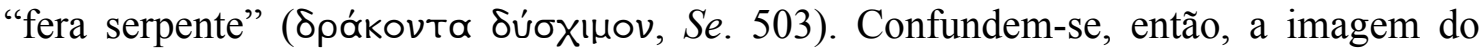
escudo, feita por um não reles "fabricante de emblemas" (onuatoupyòs, Se. 491) - isto é, a imagem de Tífon com suas serpentes - com "a figura e grande vulto de

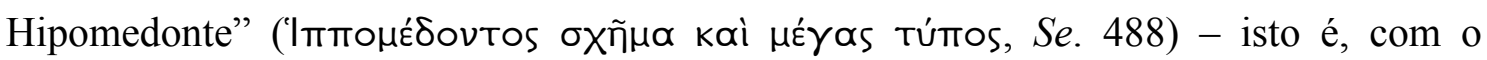
próprio portador do escudo.

É mediante essa associação entre o signo e o seu portador que Etéocles, aceitando o kledón, ressignifica-o de modo a prenunciar a vitória de Tebas. Assim, contra Hipomedonte, Etéocles envia Hipérbio, cujo escudo tem por emblema a imagem de Zeus com seu raio nas mãos, de forma que não são apenas Hipomedonte e Hipérbio que lutarão um contra o outro, mas também "Deuses inimigos nos escudos colidirão"

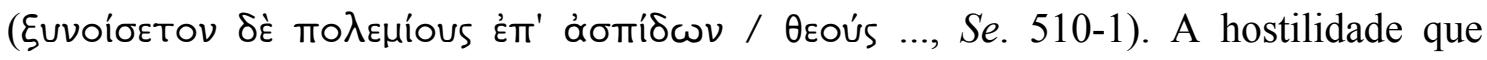
Etéocles diz existir de Hipérbio contra Hipomedonte - "homem hostil a este homem

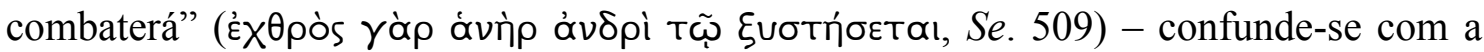
hostilidade existente entre Zeus e Tífon.

Se, como afirma Etéocles, Zeus pode mais do que Tífon na batalha e ninguém jamais viu Zeus vencido, o combate entre o argivo e o tebano está selado: assim como Zeus saiu vitorioso da luta contra Tífon, também Hipérbio, "em razão do signo" (трòs

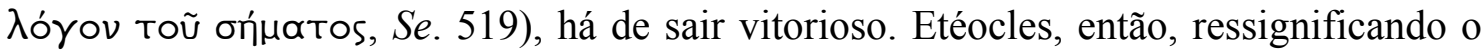
kledón, prenuncia que Hipérbio obterá em seu confronto com Hipomedonte o mesmo resultado obtido por Zeus em seu embate com Tífon.

O Coro, expressando a sua confiança na vitória de Hipérbio, faz um jogo de palavras também cledomântico. Visto que o emblema do inimigo traz uma imagem "adversária de Zeus" (Tòv $\Delta$ iòs ávtítutrov, Se. 521), Hipomedonte, a quem o Mensageiro descreveu como uma "grande figura" ( $\mu \varepsilon ́ \gamma$ as túmos, Se. 488), cairá de

\footnotetext{
${ }^{32}$ Dizem os versos de Hesíodo: “(...) Dos ombros / cem cabeças de serpente, de víbora terrível, / expeliam línguas trevosas. Dos olhos / sob cílios nas cabeças divinas faiscava fogo / e das cabeças todas fogo

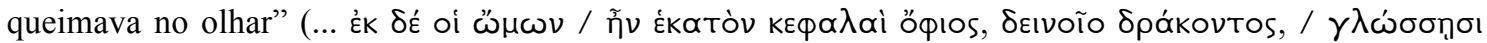

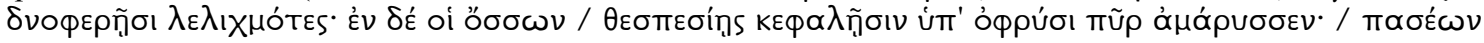

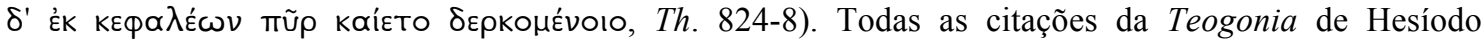
correspondem à tradução de Jaa Torrano (2001).
} 
cabeça ante as portas. Ou seja: essa grande "figura" (тútros) é, na verdade, "adversária" (ávтítutrov) de Zeus e, conforme todos os adversários de Zeus, sucumbirá, pois, como dissera Etéocles, ninguém viu jamais Zeus vencido (Se. 514).

O atacante sorteado para a quinta porta, as Portas de Bóreas, é Partenopeu, mas seu nome só é anunciado pelo Mensageiro após uma longa descrição. Segundo observações de Cameron (1970, p. 105) e Zeitlin (2009, p. 68), o nome de Partenopeu é apresentado pelo Mensageiro a Etéocles como um enigma a ser decifrado. Ele é descrito

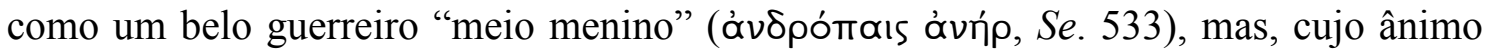

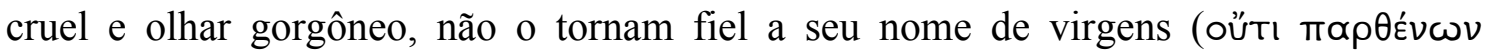

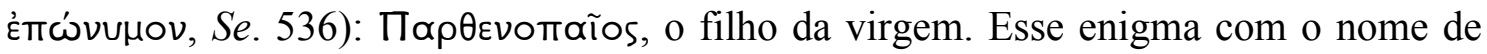
Partenopeu é condizendo com a imagem que ele traz em seu escudo:

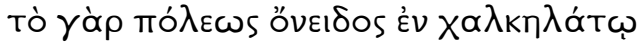

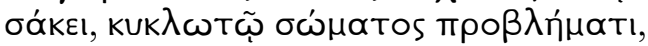

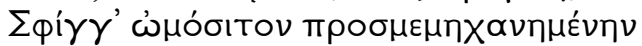

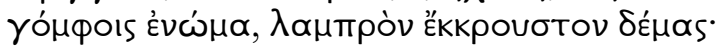

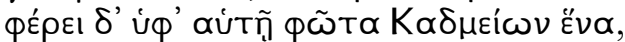

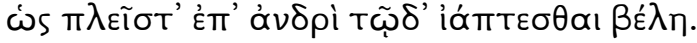

o opróbrio da cidade está no brônzeo escudo, circular proteção do corpo. Esfinge crudívora, cavilhada com arte, ele manejava, figura lavrada a rutilar, que traz sob si um homem dos cadmeus de modo a caírem nele muitos dardos.

(Se. 539-44)

A Esfinge no escudo de Partenopeu é um emblema particularmente ominoso para a cidade de Tebas. Esse jovem guerreiro pretende introduzir na cidade a imagem

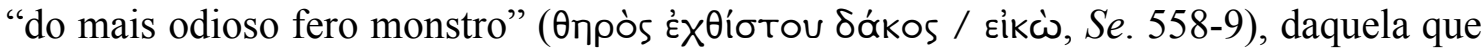
é descrita pelo Coro no segundo estásimo como "a morte raptora de homens" (тòv $v$

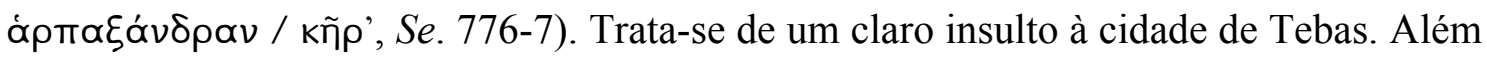
de evocar o antigo drama vivido pelos tebanos, a figura do cadmeu que a Esfinge traz sob si está posicionada de modo a receber a maior parte dos dardos. Assim, no combate, os tebanos se verão obrigados a atingir um concidadão, aquele representado no escudo.

Etéocles para combater Partenopeu designa Actor, que não permitirá nem que suas bravatas entrem na cidade, nem que atravesse as portas aquele que carrega tão odioso signo. Diz Etéocles que é a Esfinge que receberá muitos dardos e, como paga por tal tratamento, voltar-se-á contra o próprio Partenopeu.

Também aqui, signo e realidade se confundem, e é dessa forma que Etéocles aceita o kledón e o ressignifica, de modo a pressagiar a ruína de Partenopeu e a salvação de Tebas. 
O sorteado para a sexta porta, as portas Homoloides, é o adivinho Anfiarau. O Mensageiro o descreve lançando acusações contra Tideu e Polinices. Trata-se de uma personagem singular, como se verá a seguir. Ele não profere ameaças contra os deuses e contra a cidade nem ostenta símbolo algum em seu escudo, conforme relata o Mensageiro: "Disse tranquilo o adivinho com o escudo / brônzeo; signo não havia no

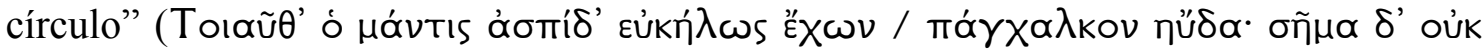

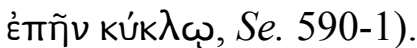

Não há, portanto, para Etéocles, nenhum kledón a ser interpretado, nenhum presságio a ser aceito. Enquanto no caso dos demais atacantes, ao ressignificar os seus kledónes, Etéocles prenunciou a morte de cada um, Anfiarau, enquanto adivinho, prediz a sua própria morte: "Eu mesmo tornarei pingue esta terra, / adivinho oculto sob terra

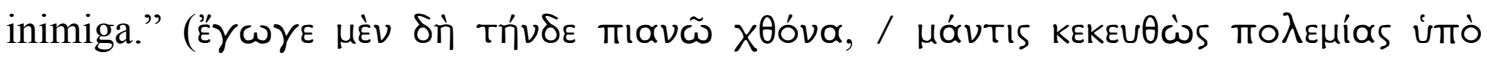
xӨovós, Se. 587-8).

O último atacante, posicionado ante a sétima porta, é Polinices. O Mensageiro relata as ameaças de Polinices, de que, tendo conquistado a cidade, irá enfrentar Etéocles, para matar e morrer junto, ou puni-lo com o mesmo desonroso exílio a que ele foi submetido pelo irmão. Seu escudo é assim descrito pelo Mensageiro:

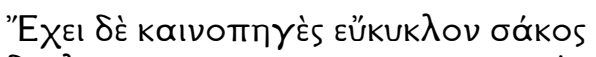

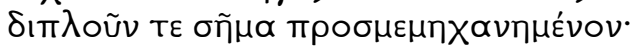

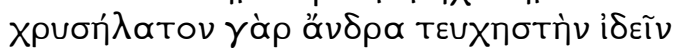

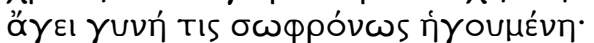

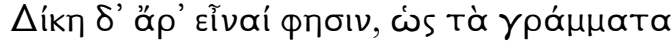

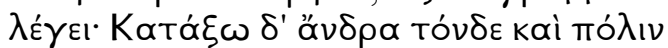

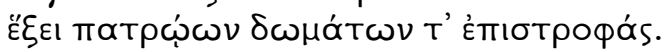

Tem recém-fabricado redondo escudo e duplo signo acrescentado com arte: feito de ouro se vê um varão guerreiro, uma mulher o guia com prudente passo, e diz ser Justiça como falam as letras: "Conduzirei este varão e terá a cidade "e os aposentos do palácio paterno."

(Se. 642-8)

Diferentemente do que vinha fazendo até então, Etéocles recusa o o kledón no emblema do escudo de seu irmão. Etéocles poderia, como conjectura Cameron (1970, p. 108), ressignificar o verbo kaтó $\gamma \omega$ (conduzir), em cuja ambiguidade reside um kledón.

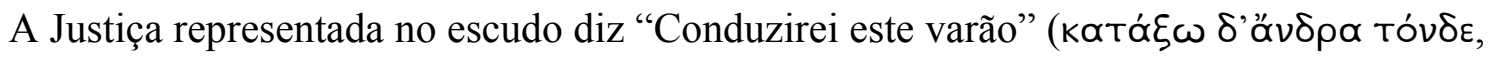

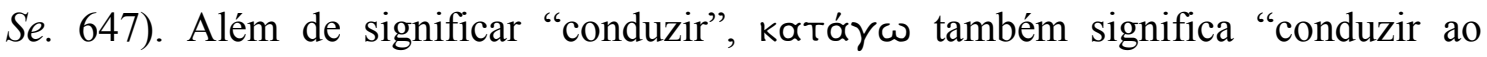

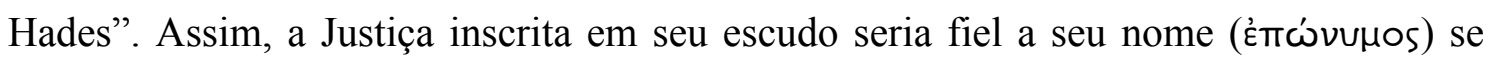
conduzisse Polinices ao Hades. No entanto, ao invés de aceitar o presságio, ressignificando-o, de modo a ser desfavorável a Polinices, ele o renega: "Seria sim com toda justiça falso nome / Justiça, se convivesse com quem tudo ousa." (ก̃ $\delta \tilde{\eta} \tau^{\prime}$ ơv Eïn

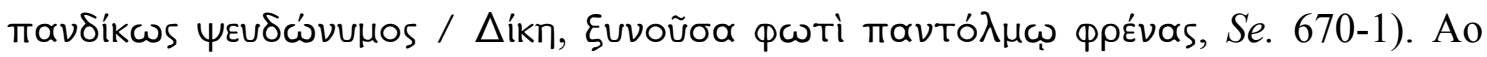




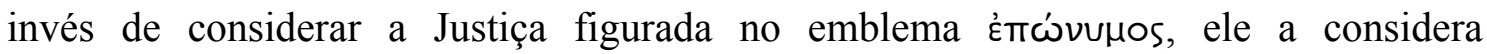

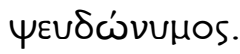

O enigma que Etéocles desvenda ao saber que seu irmão seria o atacante posicionado à sétima porta não é mais o enigma do kledón do escudo de Polinices e sim o enigma da maldição de Édipo. Nesse momento, como observa Vidal-Naquet (2005, p. 252), Etéocles compreende que "essa rede de emblemas que pretendem anunciar a queda de Tebas não apenas pressagia sua salvação, mas também o desastre da casa dos Labdácidas, a morte de Etéocles e de Polinices". Etéocles se percebe preso na mesma teia em que se encontram seus inimigos: assim como eles não poderão escapar ao destino funesto que sua hýbris e suas palavras ominosas determinaram para si, também Etéocles não poderá escapar ao destino fatal engendrado pela maldição de Édipo.

A relação cuidadosa de Etéocles com as palavras, sua crença no nume que nelas reside, em seu caráter profético, que o leva a reconhecer como seu dever "dizer o oportuno" (Se. 1), a fim de não engendrar a ruína da cidade, é a mesma relação que, por uma ironia trágica, leva-o à compreensão da inevitabilidade do confronto com seu irmão e de sua impotência para reverter o destino fatal que o aguarda. Tudo o que ele pode fazer, então, é insultar Polinices e constatar quão verdadeiro é o presságio contido no nome do irmão; a partir de agora, não lhe é mais possível ressignificar o presságio nem do nome de Polinices nem do emblema de seu escudo.

Ao interpretar e ressignificar os presságios percebidos nas palavras, nas inscrições e nos emblemas dos escudos dos argivos, Etéocles procurou assegurar a salvação da cidade, mas, por uma ironia trágica, a salvação da cidade depende de sua própria morte e da morte de seu irmão, de "toda a estirpe de Laio odiada por Febo" (Se. 691). Pesa, assim, sobre Etéocles e Polinices não apenas a maldição de seu pai, mas também o antigo oráculo entregue a Laio em Delfos.

A primeira alusão a esse oráculo entregue a Laio encontra-se em Píndaro. $\mathrm{Na}$ Olímpica II, ao dar exemplos sobre os reveses da fortuna, Píndaro narra como o infortunado encontro entre Laio e Édipo:

(...) ËKTEıve $\wedge \tilde{\alpha}-$ ov hópluos viós

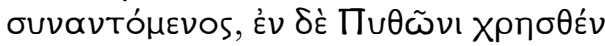

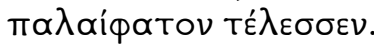

(...) reencontrando-se, o predestinado filho matou Laio, e cumpriu-se o antigo oráculo proclamado em Pito.

(Pi. Olymp. II, 42-4) $)^{33}$

\footnotetext{
${ }^{33}$ A edição é de Puech (1999) e a tradução é nossa.
} 
Píndaro narra a morte de Laio às mãos de seu filho como o cumprimento de um antigo oráculo; ou seja, Édipo era um filho predestinado ( $\mu$ ópıнos) a matar o pai.

A versão mais conhecida de tal oráculo é a que figura no Édipo Rei de Sófocles. Jocasta diz:

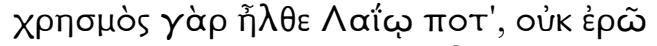

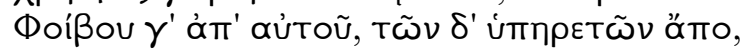

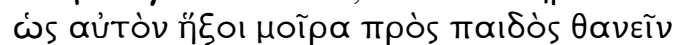

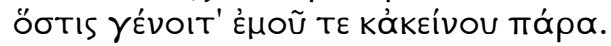

Um oráculo foi dado a Laio certa vez,

Por Febo, não direi, mas por seus servidores:

Seria sua sorte morrer às mãos de um filho

Que lhe era de nascer de mim e dele.

(S. OT. 711-4) $)^{34}$

O oráculo pode ser assim expressado: se um filho fosse gerado de Jocasta e Laio

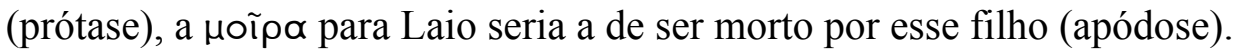

No argumento de Édipo Rei, encontram-se os seguintes versos oraculares:

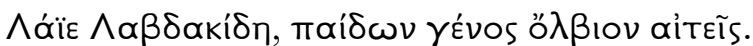

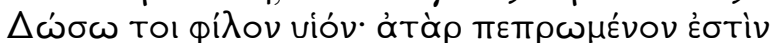

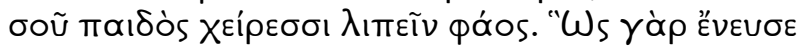

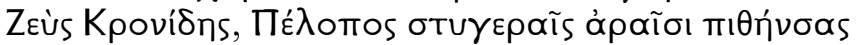

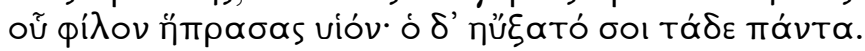

Ó Laio Labdácida, pedes próspera prole de filhos, terás sim o teu filho, mas isso para ti será a morte, perder a vida nas mãos do próprio filho, anuiu Zeus Crônida ao atender hórrida prece de Pélops cujo filho raptaste e ele te lançou essa praga toda. ${ }^{35}$

Aqui, o oráculo apresenta um caráter bem mais inelutável: o que está destinado

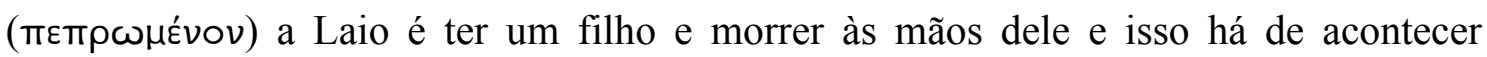
porque Zeus anuiu dar cumprimento à maldição imprecada por Pélops quando Laio raptou-lhe o filho ${ }^{36}$.

Em Édipo em Colono, Édipo, defendendo-se das acusações de Creonte, diz: “oráculos disseram a meu pai / que ele seria morto por um filho" (

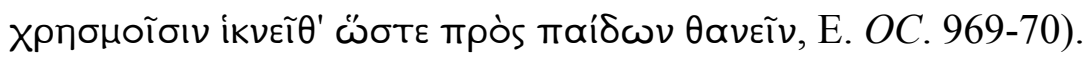

\footnotetext{
34 Tradução de Ordep Serra (2007).

${ }^{35}$ Laurentianus XXXII-9, fol. 49. Os mesmos versos aparecem sem modificação no manuscrito das Fenícias e os três primeiros versos, na Antologia Palatina, XIV, 67, 1-3, conforme indica a edição da Belles Lettres do Édipo Rei (1994). A tradução é de Jaa Torrano (Editora Iluminuras, no prelo).

${ }^{36}$ Trata-se de Crisipo. Sobre a relação entre Laio e Crisipo, conferir De Dios (2008).
} 
Nas Fenícias, Jocasta, no prólogo, reproduz as palavras do oráculo entregue a Laio:

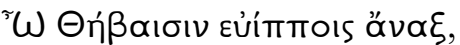

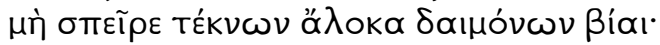

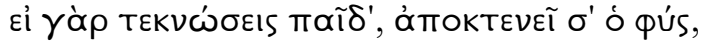

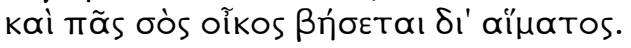

"Ó rei de cavaleiros tebanos,

"não semeies filial sêmen contra Numes!

"Se fizeres filho, a ti, pai, te matará

"e toda tua casa se irá pela matança."

Há primeiramente uma admoestação: não gerar filho contra a vontade dos numes, de modo que, se Laio gerar filhos (prótase), será não apenas morto por esse filho como também terá toda a sua linhagem destruída (apódose). Enquanto, nos demais oráculos, o destino enunciado é apenas o de Laio ser morto pelo filho, em Eurípides há uma maior abrangência, visto que não se trata apenas da morte de Laio, mas sim de toda sua linhagem.

Ésquilo, nos Sete, inclui ainda mais um elemento: o destino da cidade de Tebas. Quando Etéocles sai de cena no final do segundo episódio, o Coro, no segundo estásimo, canta o temor de ver cumprida a imprecação de Édipo. Diante desse temor, o Coro rememora a origem do funesto destino dos Labdácidas, referindo-se a "antigos

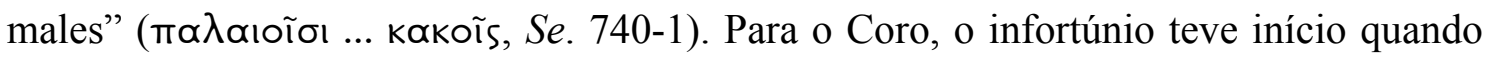
Laio, tendo recebido um oráculo, descumpriu-o:

\author{
$\Pi \alpha \lambda \alpha \iota \gamma \varepsilon v \tilde{n} \gamma \grave{\alpha} \rho \lambda \lambda^{\prime} \gamma \omega$

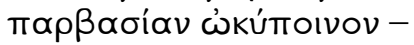

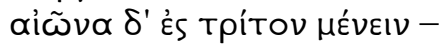

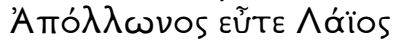 \\ Bíạ, tpis kiтtóvtos Év

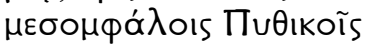

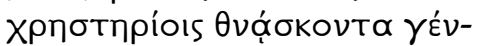 \\ vas äт
}

\author{
Digo a antiga originária \\ transgressão logo punida \\ mas perdura por três vidas \\ quando Laio, à força de Apolo \\ no umbilical oráculo pítio \\ três vezes lhe dizer \\ se morrer sem filhos \\ salvar a cidadela
}

Note-se a ênfase dada à elocução do oráculo: tpis eimóvtos (três vezes pronunciado). Halliday (1913, p. 162-3), à parte o óbvio efeito dramático da repetição do oráculo, não duvida da possibilidade de este ter sido realmente dado três vezes a Laio. Torrance (2007, p. 60) chama atenção para o fato de que não era incomum pedir um novo oráculo quando o primeiro recebido era insatisfatório e conclui que "no blame can be attributed to Laius for returning to the oracle three times in a attempt to receive a different one". Laio, porém, não recebeu uma resposta mais favorável e o fato de, 
apesar de o mesmo oráculo ter sido três vezes pronunciado e ainda assim ele ter gerado

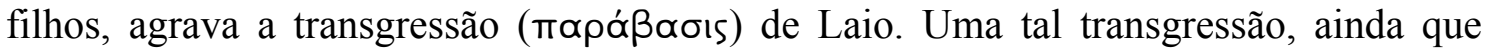
rapidamente punida, perdura por três gerações, o que implica a mesma ideia encontrada em Sófocles, de que gerar filhos afetaria não somente o seu destino, mas também o de seus descendentes. No entanto, o oráculo dizia que, se ele quisesse salvar a cidade (prótase), deveria morrer sem filhos (apódose). A sua morte às mãos de Édipo é apenas uma parte da punição sofrida por Laio; a outra parte é o fato de colocar a sua cidade em risco, o que realmente acontece quando da chegada de Polinices e do exército argivo. Assim, nesse oráculo, enuncia-se não somente o destino do génos de Laio, mas também de sua pólis.

Etéocles contribui para a salvação da pólis ao ressignificar os kledónes dos atacantes argivos na cena dos escudos e, ao mesmo tempo, sela o destino de seu génos: a cidade será salva, mas a estirpe de Laio perecerá ${ }^{37}$.

\section{5) Anfiarau: guerreiro e adivinho}

Anfiarau é uma personagem singular, que se destaca exercendo tanto o papel de adivinho quanto o de guerreiro. Em Homero, Anfiarau é denominado "condutor de guerreiros, / o predileto de Zeus poderoso e de Apolo, que afeto / muito extremado lhe

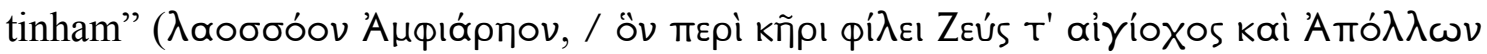
/ таvтоínv фıภótпт', Od. XV, 244-5).

Essa menção que no texto homérico se faz a Anfiarau se insere na apresentação do adivinho Teoclimeno, com quem Telêmaco se encontra em Pilos e a quem acolhe em seu barco de partida de Pilos para Ítaca. Teoclimeno é primeiramente caracterizado por ser alguém de algum país distante, que fugira de Argos por causa de um assassinato, mas, a seguir, é apresentado como adivinho pertencente à linhagem de $\operatorname{Melampo}^{38}$ (Od.

\footnotetext{
${ }^{37}$ A esse respeito, Marlène Ryzman, em seu artigo "The Curse, the Oracle and the Sisters in Aeschylus' Septem", de 1989, diz o seguinte: "As to the destruction of the race, the explanation is quite simple: the 'race' has become extinct, but the sister do exist. There is no contradiction or inconsistency: the family line has ended bacause the sons are dead. [...] It is natural for the choral members to regard the house as being extinguished because there are no male inheritors" (p. 26).

${ }^{38}$ Segundo Bouché-Leclercq (2003, pp. 288), Melampo pode ser considerado o mais antigo dos adivinhos

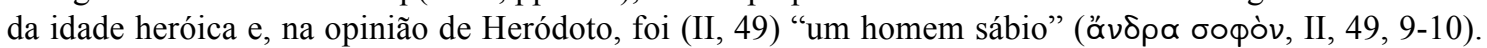
Narra Apolodoro (I, 9, 11) que Melampo adquiriu o dom divinatório quando, num campo em Pilos, sua terra-natal, encontrou no tronco de um carvalho um ninho de serpentes cujos pais haviam sido mortos por seus servidores. Apiedando-se dos filhotes, Melampo os tomou a seu cuidado. Quando cresceram, porém, enquanto Melampo dormia, as serpentes lamberam-lhe as orelhas e, ao despertar, percebeu que
} 
XV, 223-5). De acordo com a genealogia estabelecida por Homero (XV, 242-56), Melampo teve dois filhos: Mântio e Antífates. De Antífates nasceu Ecleu, pai do adivinho Anfiarau. De Mântio, nasceu Clito e o adivinho Polifides. De Polifides, nasceu Teoclimeno, também adivinho, que é acolhido por Telêmaco em seu barco. Dessa forma, tanto Anfiarau quanto Teoclimeno são melampodidas, isto é, adivinhos descendentes de Melampo. O fato de pertencerem a essa linhagem lhes confere uma autoridade mântica particular.

A qualidade de médico-adivinho, embora fizesse parte de sua herança mântica, parece ter sido praticada por Anfiarau somente depois de sua morte ${ }^{39}$. Em Ésquilo,

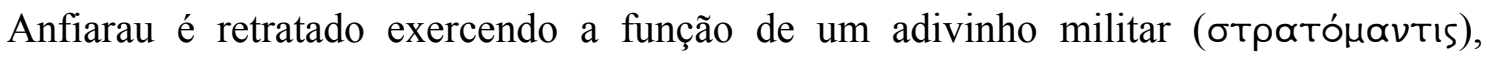
adivinho que acompanha o exército e tem como uma de suas atribuições oferecer sacrifícios e averiguar se a disposição dos deuses é ou não favorável à transposição de fronteiras, rios e mar e à ordem de ataque.

O poder divinatório de Anfiarau, desde as primeiras alusões literárias, como em Homero (Od. XV, 245), aparece ligado a Apolo ${ }^{40}$. Em Ésquilo, Anfiarau é capaz de conhecer o futuro graças a Apolo (Se. 618).

Assim como Calcas está intimamente ligado à história da expedição dos gregos contra Troia, Anfiarau está intimamente ligado à história da expedição liderada por Adrasto e Polinices contra Tebas. Há, portanto, uma diferença fundamental entre ambos: enquanto Calcas, apesar das adversidades, prenuncia a vitória da expedição guerreira de que faz parte, Anfiarau prenuncia a sua derrota. Por que então, Anfiarau,

compreendia a linguagem dos pássaros, passando, assim, a exercer a ornitomancia. É, no entanto, na qualidade de médico-adivinho que Melampo aparece em uma das narrativas mais conhecidas a seu respeito. Heródoto (IX, 34) narra como Melampo curou a loucura que se abateu sobre as mulheres argivas, obtendo para si e para seu irmão parte das prerrogativas reais de Argos. O episódio em que fica prisioneiro de Fílaco por haver tentado roubar seus bois é já mencionado na Odisseia (XV, 231-6), mas é Apolodoro (I, 9, 12) quem dá detalhes de como conseguiu se libertar através de sua arte divinatória e também, por meio dela, conseguiu curar a infertilidade de Íficlos, filho de Fílace, de quem por fim levou os bois como recompensa. Para um estudo detalhado da biografia de Melampo, conferir o artigo "Melampo. Breve biografia di un indovino guaritore", de Francesca Marzari (2012). Conferir também o artigo "Les pouvoirs des devins et les récits mythiques: l'exemple de Mélampous", de Emilio Suárez de la Torre (1992), em que o autor analisa a construção de uma complexa narrativa acerca da história de Melampo.

${ }^{39}$ No oráculo de Anfiarau, praticava-se, como acredita Bouché-Leclercq (2003, pp. 765-8), a incubação, isto é, a oniromancia com fins medicinais. Era essa, aliás, a forma de adivinhação comum à maioria dos oráculos heroicos. Após certos rituais de purificação, que poderiam compreender a abstinência de certos alimentos, o jejum e o sacrifício expiatório, o consulente dormia no templo sobre a pele de um animal. Em sonhos, o médico-adivinho, semelhantemente ao que ocorria nos famosos templos de Asclépio, indicava o tratamento necessário.

${ }^{40}$ Há, em Pausânias (II, 13, 7), um relato curioso sobre a primeira vez em que se manifestou em Anfiarau o poder divinatório. Em Filionte, Anfiarau, tendo passado uma noite numa casa, desde então chamada "oracular", começou a profetizar. Para os habitantes da cidade, no entanto, antes de tal acontecimento Anfiarau não era mais do que um homem comum e desprovido de quaisquer conhecimentos divinatórios. 
prevendo o malfadado destino da expedição contra Tebas, ainda assim encontra-se como um dos sete líderes do exército argivo? Exclama Etéocles ao saber que ele era o homem sorteado para a sexta porta: "Phêิ! Que auspício associa o homem / justo aos outros ímpios mortais! (

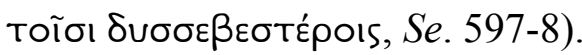

Em Homero, as duas referências encontradas sobre Anfiarau não dizem respeito nem às suas qualidades como guerreiro nem à sua atuação como adivinho; o que se destaca é a sua morte prematura por causa de sua esposa, fato duplamente mencionado na Odisseia. Ao descer ao Hades, Odisseu vê, dentre tantas almas de esposas e filhas de nobres guerreiros, "a odiosa Erifila, / que o ouro aceitou cobiçado, por troca do esposo

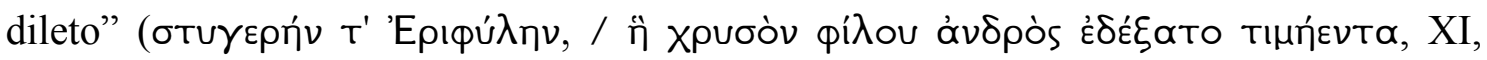
326-7). E, no canto XV, diz-se que Anfiarau "não viu a velhice; / em Tebas veio a

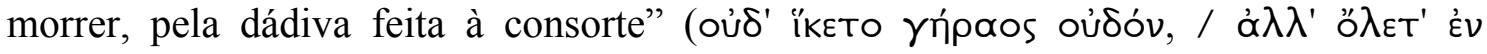

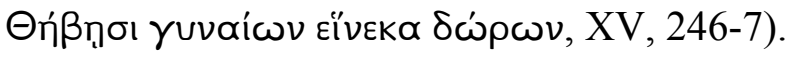

Também em Píndaro, Erífile aparece como a causadora da morte de Anfiarau

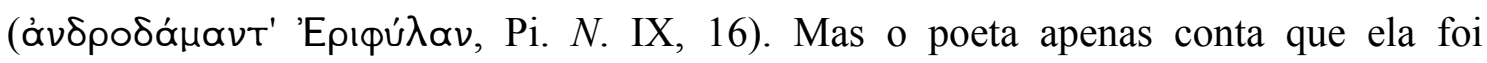
entregue como esposa ao adivinho para selar o juramento que pôs fim à discórdia entre Anfiarau e Adrasto (Pi. N. 13-17).

No entanto, em um escólio ao verso 326 do canto XI da Odisseia, o escoliasta explica que Anfiarau, tendo se casado com Erífile e se reconciliado com Adrasto, jurou que, em desentendimentos futuros, ela seria a juíza. À época da expedição contra Tebas, Anfiarau procurou dissuadir os argivos profetizando a sua derrota, mas Polinices subornou Erífile com o colar de Harmonia, de modo que Erífile decidisse a favor de Adrasto, o que obrigou Anfiarau a participar da expedição, mesmo contra sua vontade. Compelido, assim, pelas circunstâncias, Anfiarau juntou-se ao exército de Adrasto, tendo, no entanto, incumbido seu filho Alcmeon de, antes de marchar contra Tebas com os epígonos, matar a mãe $\mathrm{e}^{41}$.

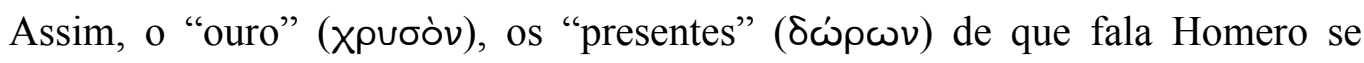
refeririam ao colar de Harmonia e o fato de Erífile ser considerada, tanto em Homero quanto em Píndaro, responsável pela morte do adivinho seria em razão de ela tê-lo coagido a participar de uma expedição cujo resultado seria funesto, tal como o próprio Anfiarau previra.

\footnotetext{
${ }^{41}$ Essa mesma versão figura em Apolodoro (III, 6, 2).
} 
O Mensageiro, ao anunciar a Etéocles que Anfiarau encontra-se na sexta porta, exalta-lhe as qualidades, chamando-o "o mais sábio / exímio na luta, adivinho, o forte

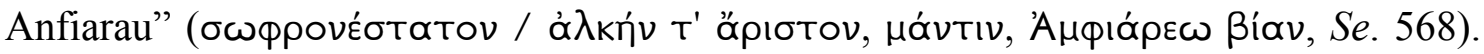
Também Etéocles a ele se refere utilizando-se dos adjetivos mais honoríficos: "homem

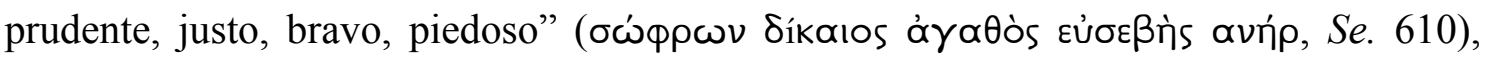

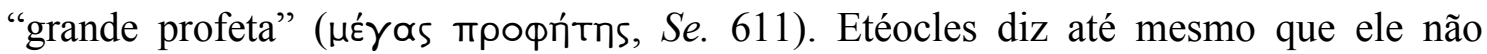
atacará as portas; não por falta de bravura, mas por saber que deve morrer na batalha. No entanto, embora ele seja justo - qualidade que o filho de Édipo menciona duas vezes

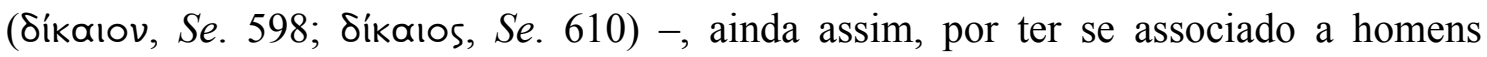

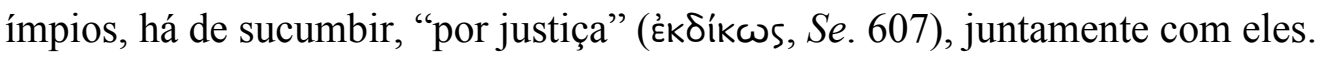

A primeira menção a Anfiarau no texto é bastante significativa. Ao reportar a Etéocles qual foi o guerreiro argivo sorteado para a primeira porta, o Mensageiro diz que o furor guerreiro de Tideu encontra a desaprovação do adivinho, pois Anfiarau desaconselha a travessia do Ismeno, visto que "as vítimas não se revelam propícias" (oủ

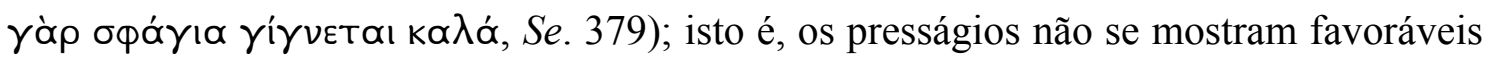
ao iminente ataque argivo.

O fato de os presságios não se mostrarem favoráveis evidencia o caráter funesto da expedição, uma expedição que, de acordo com Homero e Píndaro, estava fadada ao fracasso desde o início. Agamêmnon, na Ilíada, conta ao filho de Tideu, Diomedes, que seu pai certa vez esteve em Micenas com Polinices a fim de recrutar guerreiros para o ataque à cidade de Tebas, mas, embora os micênios estivessem dispostos a lhes

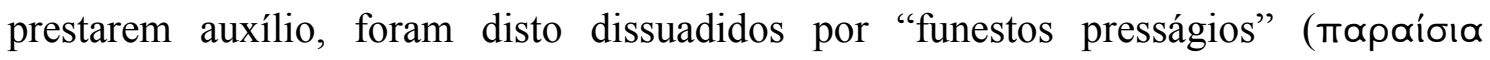

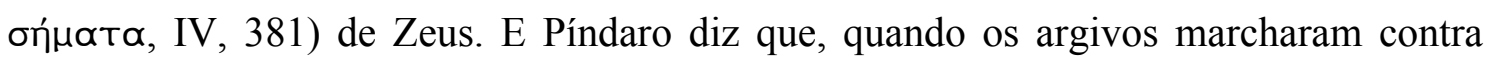

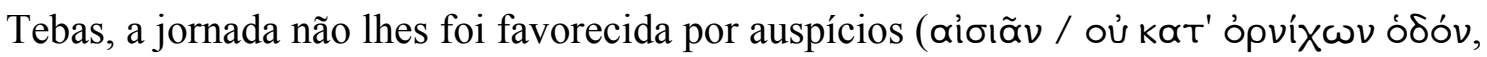
Pi. N. 18-9) e Zeus não os encorajou, fazendo brilhar seu raio, a deixarem suas casas, mas sim a renunciar à expedição (Pi. N. 19-20).

Nos fragmentos da tragédia Hipsípile, de Eurípides, narra-se um incidente acontecido durante a passagem do exército argivo pelo vale de Nemeia. Hipsípile, ama do filho ainda bebê do rei Licurgo e da rainha Eurídice, levou Anfiarau a uma fonte de água pura para que este fizesse sacrifícios, conforme lhe solicitara. Tendo deixado o bebê no chão, enquanto ela colhia flores, a criança foi morta por uma serpente guardiã da fonte. Anfiarau, então, tomando a defesa da ama, diz à lamentosa mãe do bebê que a morte deste era um "auspício" (ópvıӨ $\propto$, Fr. 60.80) não destinado a ela, a rainha, mas ao 
exército argivo, cujo único, dentre os sete líderes, a retornar vivo da expedição contra Tebas seria Adrasto (Fr. 60.85-7). A morte da criança seria assim um prenúncio do desastre da expedição, pois seu nome, ’Apxénopos (Fr. 60.78), pressagiava "o início do destino", ou "o primeiro morto" 42 .

Ainda que todos esses sinais desfavoráveis que precederam a chegada do exército às portas de Tebas não estejam presentes nos Sete, o desfavor divino que acompanhou a expedição argiva desde o seu início se revela nos desafios que os chefes argivos lançam aos deuses, como se cientes de seu desfavor. Assim, Tideu, acusa Anfiarau de covardia quando este tenta dissuadi-lo de atravessar o Ismeno em função de presságios não-propícios: "vitupera o hábil adivinho Eclida: / 'Adula morte e batalha, sem coragem"” (Se. 382-3). Ora, insultar dessa forma Anfiarau, um adivinho sob a proteção de Apolo, é insultar o próprio deus. É o que acontece quando, na Ilíada, Agamêmnon ultraja Crises, sacerdote de Apolo. O deus responde imediatamente ao ultraje a seu protegido enviando ao acampamento aqueu uma peste destruidora (Il. I, 912).

Capaneu declara que há de arrasar a cidade, quer a divindade queira ou não, e que nem mesmo Zeus, de cujos raios ele desdenha, o impedirá: "nem a rixa de Zeus / ao golpear o chão trava os seus passos” (Se. 428-9). Etéoclo desafia a Ares mediante a inscrição em seu escudo, que diz que "nem Ares o expulsaria do forte" (Se. 469). Hipomedonte desafia a Zeus ao trazer em seu escudo a imagem de um de seus mais terríveis desafiantes, Tífon (Se. 492-3). Partenopeu jura por sua lança, venerada por ele mais do que os próprios deuses, que há de devastar Tebas "à força de Zeus" (Se. 531-2). Polinices, imprecando um destino funesto para a cidade e para seu próprio irmão, "invoca / Deuses pátrios da terra paterna vigias / de que suas preces aconteçam todas" (Se. 639-41); ora, invocar os deuses pátrios de uma cidade para que eles o ajudem a tomá-la é, no mínimo, um insulto a esses deuses.

Portanto, quando o Mensageiro diz a Etéocles, logo no início do segundo episódio, que "o adivinho não o [Tideu] deixa passar o Ismeno: / as vítimas não se

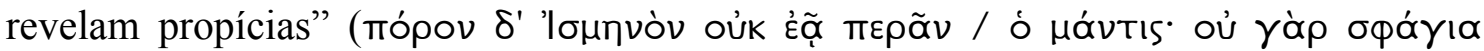

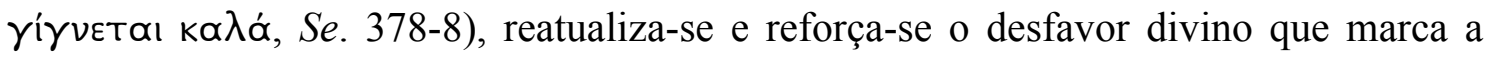
campanha militar dos argivos, de modo que, por mais que estes insultem, provoquem e

\footnotetext{
${ }^{42}$ Apolodoro diz que a criança se chamava Olfetes e que Anfiarau viu na morte do menino um prenúncio do futuro da expedição e por isso o denominaram Arquemoro. Em sua honra, foram fundados os jogos nemeus (III, 6, 4).
} 
ameacem, a partir do momento em que é dito que as vítimas não se revelam propícias, significa que eles estão agindo contra a vontade divina proclamada pelo adivinho, e agir contra os desígnios divinos é um ato de hýbris que não há de restar impune. O filho de Capaneu, na Ilíada, diz a Agamêmnon que Tebas foi facilmente tomada pelos epígonos,

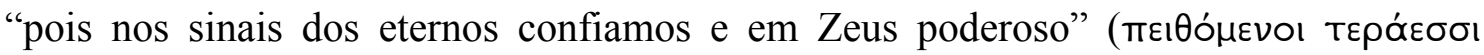

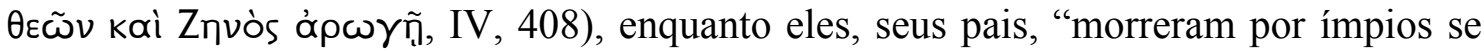

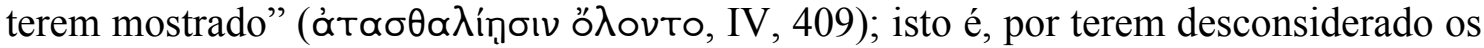
sinais divinos.

Igualmente, nas Suplicantes, de Eurípides, Teseu pergunta a Adrasto se ele, antes de levar a cabo a expedição, consultou adivinhos e as chamas de pira e, quando Adrasto responde que não, Teseu diz: "Não foste, parece, com o favor dos deuses" (oủk

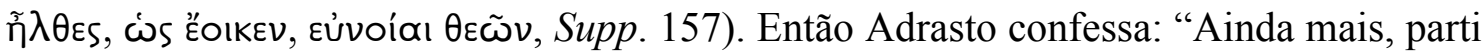

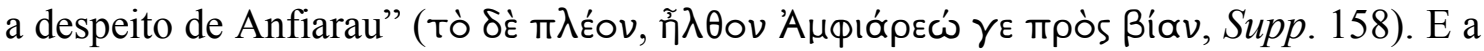
conclusão a que chega Teseu é a seguinte: "Agiste com bravura em vez da prudência"

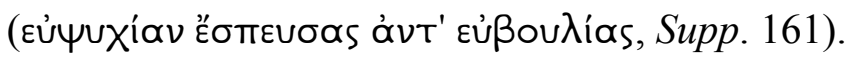

Prudência é, aliás, uma das características distintivas de Anfiarau nos Sete. O Mensageiro, após reproduzir as palavras do adivinho, diz que ele falou "tranquilo"

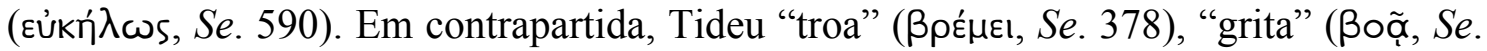

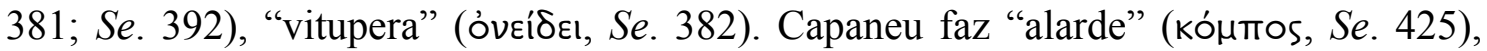

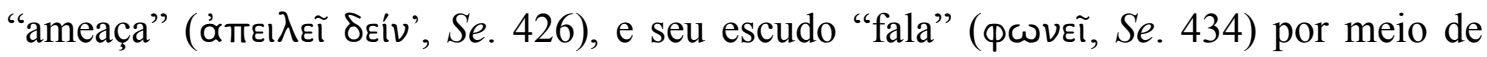
suas letras de ouro. Da mesma forma, a inscrição no escudo de Etéoclo "grita" (ßoạ̃, Se.

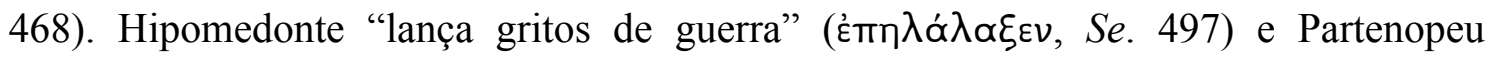

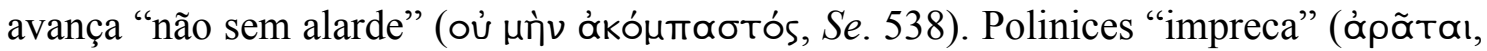
Se. 633), "brada” (áuтعĩ, Se. 439) e as letras em seu escudo "falam” ( $\lambda \varepsilon ́ \gamma \varepsilon l, ~ S e .647$.

Sendo assim, os chefes argivos bradam, gritam, vituperam, alardeiam, proferem ameaças, lançam clamores de guerra; suas armas tilintam, seus cavalos resfolegam; seus escudos, com seus emblemas e inscrições, falam, ameaçam, provocam. A essa eloquência dos chefes argivos Anfiarau contrapõe a sua fala tranquila e o silêncio de seu escudo sem emblema, pois "ama calar ou falar o oportuno" ( kaípı̊, Se. 619). Enquanto os demais são ruidosos e mostram descuido quanto às palavras, Anfiarau mostra-se tão ciente quanto Etéocles de que é preciso “dizer o

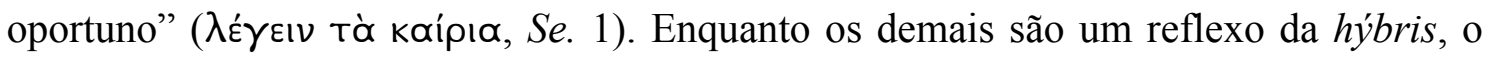
adivinho é um reflexo da sofrosýne, pois, diz o Mensageiro, ele colhe "com espírito 


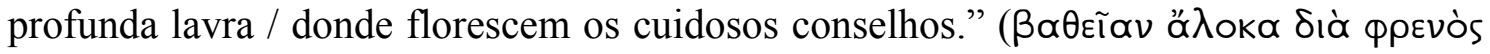

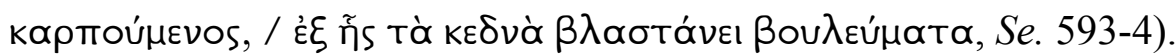

Uma vez que Anfiarau "ama calar ou falar o oportuno", as palavras atribuídas a ele pelo Mensageiro têm um valor especial. Enquanto adivinho, Anfiarau mantém um diálogo com os deuses e, portanto, é conhecedor dos desígnios divinos. Note-se que o discurso de Anfiarau é o único a ser reproduzido pelo Mensageiro em discurso direto. E o que fala o adivinho?

A Tideu:

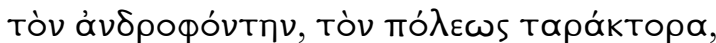

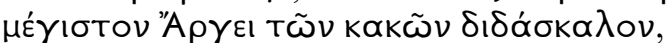

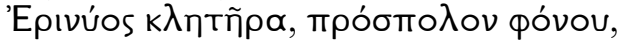

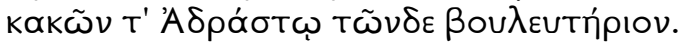

"o homicida, o perturbador de cidade, "o mestre exímio dos males de Argos, "provocador de Erínis, servo da morte, "conselheiro destes males de Adrasto."

$(\mathrm{Se} .572-5)$

E a Polinices:

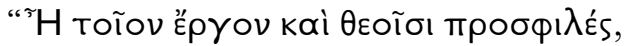

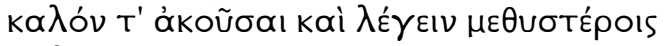

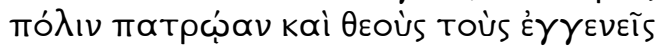

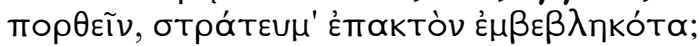

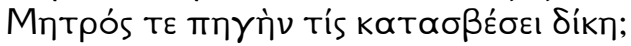

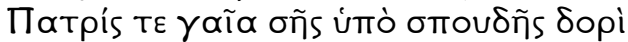

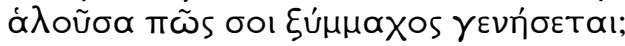

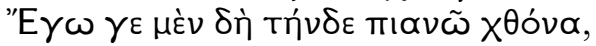

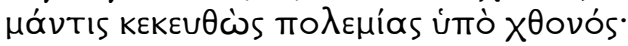

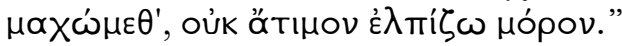

"Tal é a proeza, grata aos Deuses, "bela de ouvir e de dizer aos pósteros, "pilhar cidade paterna e Deuses pátrios "com a invasão de exército forasteiro? "Que Justiça extinguirá a fonte materna?

"A terra pátria, por teu zelo capturada “à lança, como se tornará tua aliada?

"Eu mesmo tornarei pingue esta terra, "adivinho oculto sob terra inimiga.

"Lutemos! Não espero morte sem honra."

(Se. 580-9)

Primeiramente, Anfiarau acusa Tideu de ser o instigador da guerra, o que faz referência ao combate travado entre Tideu e Polinices, ambos banidos de suas pátrias, à porta de Adrasto. Nas Suplicantes de Eurípides, Adrasto conta a Teseu que recebera um oráculo délfico de que deveria dar suas filhas em casamento ao javali e ao leão e, quando viu Tideu e Polinices brigando em sua porta, comparou-os na batalha a feras. Adrasto então fez deles seus genros e prometeu a ambos restituir-lhes a pátria. (Supp. 131-146). Nas Fenícias, Polinices conta a Jocasta essa mesma versão da história ( $P h$. 408-29).

A outra acusação que faz o adivinho é a Polinices. Suas reprimendas deixam claro que não há justiça possível ao se conduzir um exército estrangeiro para dizimar a terra pátria. Para Moreau (1976, pp. 163-3), uma das funções da personagem de 
Anfiarau nos Sete é designar os culpados e, portanto, "l'injustice est du côté de Polynice. [...] C'est Amphiaraos le sage qui le déclare. C'est donc la vérité". Cameron (1968, p. 252) pensa o mesmo: “Justice is without question solely on Eteocles' side. [...] The strongest evidence in Eteocles' behalf comes from the enemy: the respected seer Amphiaraus specifically lays all blame on Polyneices"43. Thalmann (1978, p. 21), no entanto, discorda de que a justiça esteja do lado de Etéocles. Para o autor, a ênfase que Ésquilo dá ao fato de que os irmãos padecem de um destino comum resultante de um ato mútuo implica que eles dividem igualmente a responsabilidade pela guerra. Hutchinson (1985, pp. 142-3) acredita que, na primeira seção da tragédia, Polinices é apresentado como culpado e Etéocles como moralmente superior, mas, depois que Etéocles decide combater seu irmão, ambos adquirem uma igualdade moral. Sommerstein (2010, pp. 82-8) encontra no texto indícios de que Polinices é o primogênito, de forma que haveria justiça em sua reivindicação pelo trono, mas não em seu ataque à cidade; do mesmo modo, Etéocles age de forma justa ao defender sua cidade, mas de forma injusta ao exilar seu irmão. Para Torrance (2007, pp. 35-6), ambos são igualmente culpados e ao mesmo tempo não culpados, porque suas escolhas - a de Polinices de atacar Tebas e a de Etéocles de ir ao confronto com seu irmão - são o resultado tanto de seu livre-arbítrio quanto da vontade divina.

De fato, a acusação de Anfiarau não diz respeito à reivindicação de Polinices em si, mas ao modo como ele leva a cabo essa reivindicação, conduzindo um exército para destruir a sua própria pátria. “Que Justiça extinguirá a fonte materna?” (Se. 584), pergunta o adivinho. De seu ponto de vista, essa guerra não é justa. Polinices, através de seu escudo, afirma que a justiça está ao seu lado. É ela que irá lhe restituir a cidade e o palácio paterno. Do seu ponto de vista, a guerra que ele move é justa. Etéocles rejeita isso dizendo que a justiça não preside nem as ações nem o espírito de seu irmão, que jamais esteve ao lado dele e certamente não estará agora que ele invade sua pátria com um exército inimigo. Portanto, do seu ponto de vista, tanto Polinices quanto suas ações não são justas.

Não é portanto uma tarefa simples apontar nos Sete de que lado a justiça está, porque a justiça não se apresenta como algo único e imutável; ela sofre refrações, à medida que é percebida sob o ponto de vista de cada personagem. A justiça é ambígua, porque ao mesmo tempo em que ela é um traço do comportamento humano, ela é

\footnotetext{
${ }^{43} \mathrm{O}$ autor repete o mesmo argumento em seu livro Studies on the Seven against Thebes of Aeschylus, 1971 pp. 26-8.
} 
também uma figuração do divino. Etéocles chama Justiça de "a filha virgem de Zeus"

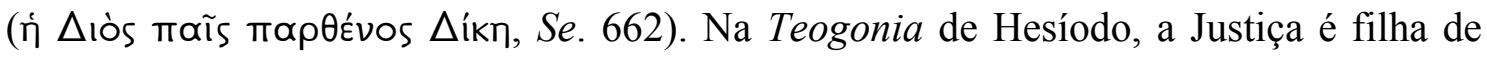
Zeus e de Têmis, é uma das Hórai, as horas, as estações. De Zeus e de Têmis nasceram

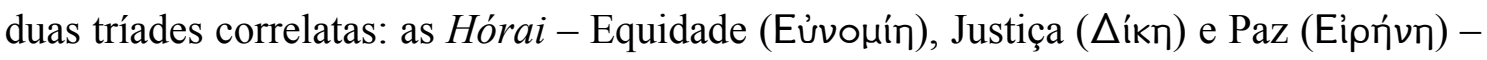

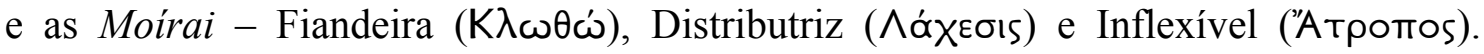
Então, a Justiça, enquanto uma das estações, manifesta-se no horizonte temporal, no curso dos acontecimentos. Para Etéocles e Polinices, no curso dos acontecimentos está a morte de ambos às mãos um do outro, cumprindo assim a maldição de seu pai e o antigo oráculo de Apolo entregue a Laio; isto é, cumprindo-se assim os desígnios divinos e, neles, a justiça de Zeus.

Para Anfiarau, no curso dos acontecimentos também está a morte. Ele mesmo a prenuncia: "Eu mesmo tornarei pingue esta terra, / adivinho oculto sob terra inimiga" (Se. 587-8). Não se trata, no entanto, de uma morte qualquer e sim de uma morte prodigiosa. Conta Píndaro que, derrotados os argivos, Anfiarau fugiu em seu carro, sendo perseguido por Periclimeno. Estando prestes a ser morto pelas costas por seu perseguidor, Zeus, não permitindo que assim sucumbisse, com um golpe de seu raio entreabriu a terra sob os passos do herói, que o engoliu com seu carro e seus cavalos (Pi. $N$. IX, 24-6) ${ }^{44}$. O local em que tal intervenção divina ocorreu e que acolheu o corpo de tão nobre personagem tornou-se a sede de um oráculo heroico: o oráculo de Anfiarau ${ }^{45}$. Quando o adivinho diz que, adivinho oculto sob a terra de Tebas, ele enriquecerá a região, alude-se tanto à sua morte prodigiosa quanto ao seu oráculo.

Foi esse oráculo que, de acordo com Píndaro, predisse a Adrasto a morte de seu filho na guerra que os epígonos moveram contra Tebas (Pi. P. VIII, 39-56). Também foi esse oráculo que, segundo Heródoto, recebeu os enviados de Creso no episódio em que o rei da Lídia resolveu pôr à prova os oráculos de helenos e líbios. Embora o oráculo de Delfos tenha sido reconhecido como o mais fidedigno, Heródoto relata que, mesmo não tendo conhecimento da resposta dada aos mensageiros de Creso, o rei "reconheceu haver recebido também desse oráculo uma resposta não mentirosa" (I, 49) ${ }^{46}$. Heródoto

\footnotetext{
${ }^{44}$ Conferir também Píndaro N. X, 8-9; O. VI, 13-4; Sófocles El. 837-40; Eurípides Suppl. 500-1; 925-8; Apolodoro Bibl. III, 6, 8.

${ }^{45}$ Há, no entanto, notícia de dois oráculos de Anfiarau: um situado no caminho entre Tebas e Potniai, onde se encontra um pequeno santuário, próximo ao local da desaparição do guerreiro-adivinho, e outro na cidade de Oropos, na Eubéia. As duas sedes oraculares podem ter coexistido durante algum tempo, até que o oráculo de Oropos tenha sobrepujado o de Tebas em notoriedade e em número de visitantes, como supõe Bouché-Leclercq (2003, p. 766), ou o oráculo de Anfiarau pode ter sido transferido, por volta do último quarto do século V, a Oropos, como conjectura Vicaire (1979, p. 5).

${ }^{46}$ Tradução de Mário da Gama Kury (1988, 2ª . ed.).
} 
(VIII, 133-134) reporta ainda uma outra consulta ao oráculo tebano de Anfiarau: o persa Mardônio $^{47}$, numa atitude semelhante à de Creso, mandou um enviado, Mis, testar o maior número de oráculos possível; dentre eles, o oráculo tebano de Anfiarau. Para tanto, Mis pediu que um não-tebano fizesse a consulta, pois aos tebanos lhes era proibido consultar o adivinho. O motivo de tal proibição se explicava pelo fato de Anfiarau, por meio de seu oráculo, ter ordenado que os tebanos escolhessem entre tê-lo como adivinho ou como aliado; tendo eles escolhido o herói como aliado, deveriam, pois, renunciar ao privilégio de seus dons proféticos.

Adivinho, guerreiro, herói oracular: uma personagem de tal envergadura - a quem Ésquilo atribui os epítetos mais honoríficos - não poderia senão morrer gloriosamente e caminhar de forma tranquila e honrada para a sua morte. Para o Mensageiro, a ausência de emblema no escudo do adivinho significa que ele "não quer

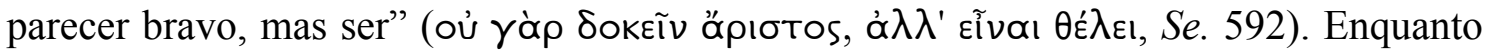
os demais guerreiros argivos não podem perceber que os emblemas de seus escudos pressagiam e precipitam sua própria ruína, Anfiarau, ciente de seu destino, não necessita de nenhum emblema. Ele mesmo é o profeta de sua própria morte.

\footnotetext{
${ }^{47}$ Também Plutarco (De Def. 412 A-B) faz menção à consulta de Mardônio.
} 
3. AS SUPLICANTES 


\section{AS SUPLICANTES}

Em 1952, foi publicado um relevante fragmento do papiro de Oxirrinco (Oxyrhynchus Papyri XX, 2256, fr. 3), que faria parte da didascália, em que se diz que Ésquilo ganhou o primeiro prêmio com a tetralogia relativa ao mito das Danaides, ficando Sófocles com o segundo lugar. Daí conclui-se que a representação das Suplicantes não se realizou, como até então se supunha, em torno de 490 a.C., mas sim por volta de 463 a.C., o que lhe destituiu do posto da mais antiga tragédia supérstite de Ésquilo. As Suplicantes, de acordo com a didascália, formaria parte de uma tetralogia composta ainda pelas tragédias Os Egípcios e As Danaides e pelo drama satírico Amimone.

Muito se especula entre os helenistas sobre a ordem das tragédias na composição da trilogia e, também, em que consistiria seu conteúdo. Como teria Ésquilo encenado o mito das Danaides? Quais elementos fariam parte dessa trilogia? Que aspectos fundamentais teria Ésquilo querido ressaltar? $\mathrm{Na}$ tentativa de responder a essas questões, costuma-se recorrer a outros autores que narraram ou mencionaram a história das Danaides e aos parcos fragmentos que restaram das outras duas tragédias perdidas.

Quanto aos elementos constitutivos da história das cinquentas filhas de Dânao, são aludidos por diversos autores de diferentes épocas. Segundo Garvie (1969, p. 164), tais autores apresentam uma versão diferente para quase todos os detalhes da história, mas se podem encontrar quatro elementos que são praticamente comuns a todas essas versões: 1) a existência de dois irmãos, Dânao e Egito, descendentes de Io, que possuem respectivamente cinquenta filhas e cinquenta filhos; 2) a ocorrência de uma querela entre esses dois irmãos; 3) o casamento entre os cinquenta filhos e as cinquenta filhas, as quais, sob as ordens de Dânao, assassinam seus esposos na noite de núpcias; 4) a desobediência de Hipermnestra, que poupa a vida de seu marido Linceu. Sendo assim, é muitíssimo improvável, pondera Garvie, que Ésquilo, uma vez que os elementos um e dois figuram em suas Suplicantes, não tivesse, no transcorrer de sua trilogia, incluído os elementos três e quatro.

A ação trágica nas Suplicantes transcorre nas proximidades de Argos. No párodo (Su. 1-39), entra em cena o Coro de Danaides formulando uma prece a Zeus Suplicante, sob a proteção do qual se colocam essas recém-chegadas à terra argiva, aonde vêm fugindo de indesejadas núpcias com os Egipcíades. No primeiro episódio (Su. 176-523), após as Danaides se refugiarem junto ao altar dos deuses, sob as instruções de Dânao, 
entra em cena o rei Pelasgo, indagando a origem dos forasteiros e os motivos que os trouxeram aos seus domínios. O Coro revela sua ligação com a terra argiva através da figura de Io, de quem se declara descendente, e pede que Pelasgo the dê asilo. Encontrando-se no dilema de dar asilo às Danaides e entrar em guerra com os Egipcíades ou não conceder asilo e incorrer na ira de Zeus Suplicante, o rei Pelasgo declara a necessidade de consultar o povo de Argos, saindo de cena juntamente com Dânao, que recomenda às Danaides formular preces aos deuses locais, o que elas fazem no primeiro estásimo ( $S u$. 524-99). No segundo episódio ( $S u$. 600-29), o rei Pelasgo anuncia a decisão unânime tomada pelos argivos de conceder asilo às jovens e, no segundo estásimo ( $\mathrm{Su}$. 630-709), elas formulam preces ao povo argivo. No terceiro episódio (Su. 710-75), Dânao anuncia ao Coro a aproximação do navio dos Egipcíades. No terceiro estásimo (Su. 776-824), o Coro, ante a iminente chegada de seus inimigos, expressa seu repúdio às núpcias indesejadas e clama pela justiça de Zeus. No quarto episódio (Su. 825-1017), entra em cena o Coro dos Egipcíades e seu arauto, confrontando o rei Pelasgo e ameaçando as Danaides de levá-las à força, atitude que encontra reprovação por parte do rei. No êxodo (Su. 1018-73), contrapõem-se um canto de repúdio ao matrimônio com os Egipcíades e um canto de louvor ao poder de Afrodite.

Diferentemente das demais tragédias esquilianas supérstites, não há, nas Suplicantes, nenhuma menção a um oráculo, nenhuma maldição, nenhum sonho profético, nenhum auspício avistado, nenhum personagem que ostente o título de adivinho. Goward (2004, p. 56) observa que a ausência de uma narrativa proléptica nesta tragédia, além de chamar atenção por ser algo inusitado na tragédia esquiliana, torna o entendimento da trilogia muito difícil.

No entanto, é necessário observar que a ausência de uma narrativa proléptica entendida como um sonho, um vaticínio, um oráculo, um auspício - não significa contudo a ausência de sinais prolépticos, isto é, a ausências de sinais numinosos, como se irá observar. A ambiguidade esquiliana, a construção de suas imagens poéticas e os kledónes são, nesta tragédia, o instrumento de um diálogo divinatório que, a despeito do que se poderia pensar a princípio, não se encontra ausente nas Suplicantes. Por sua sutileza, no entanto, ao espectador e ao leitor é dada a possibilidade de contemplar de forma privilegiada, juntamente com os heróis desta tragédia, a impenetrabilidade do grande espírito de Zeus (Su. 1048-9) e a imperscrutabilidade de seu pensamento (Su. 87- 
90), e de procurar desvendar, tal qual esses heróis, os caminhos que conduzem à certa, ainda que imprevisível, justiça divina.

\section{1) Indícios e presságios}

No párodo, o Coro das Danaides entra em cena invocando Zeus Suplicante, para que seja propício às que ali chegam vindas do estuário do Nilo. Dizem elas que chegam a Argos na condição de fugitivas (

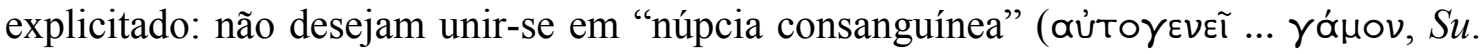
8-9) ${ }^{1}$ com os filhos de Egito, cujo intento de desposá-las elas descrevem como "ímpio"

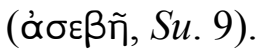

Há um extenso debate a respeito do motivo pelo qual as Danaides rejeitam a união com os seus primos. Onde repousaria o caráter ímpio (ảoєßńs) que elas atribuem a esse casamento? No fato de seus pretendentes serem seus primos de primeiro grau? No fato de elas rejeitarem o casamento em si mesmo? Ou no fato de seus pretendentes insistirem numa união à revelia do consentimento das Danaides e, principalmente, à revelia do consentimento do pai delas?

Como observa Bonner (1902, p. 131) em seu estudo sobre o mito das Danaides, o casamento entre primos de primeiro grau não era considerado ilícito nem no Egito nem na Grécia. Além disso, se o casamento entre primos fosse um problema, como explicar a união entre Hipermnestra e Linceu, que aparece em várias versões do mito e que, de acordo com o Prometeu Cadeeiro, deu origem a toda "prole real de Argos" (Pr. $869) ?$

Restariam, portanto, duas alternativas: as Danaides rejeitam somente seus primos como pretendentes ou todos os homens de uma forma geral. Garvie (2006, p. 221) observa que muitas passagens nas Suplicantes apontam para uma hostilidade voltada especificamente para os Egipcíades $(S u .30 ; 80 ; 104 ; 223-31 ; 335 ; 741 ; 750$; 817 ; 1063), mas que um igual número de passagens aponta para uma atitude misândrica do Coro das Danaides (Su. 144-50; 392; 426, 528-30; 643; 790; 798-9; 804-7; 818; 1017). Winnington-Ingram (1961, p. 144) acredita que a diferença entre o ódio a um casamento forçado e o ódio ao casamento enquanto tal não pode ser superestimada e

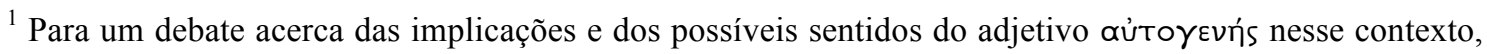
conferir, entre outros, Garvie (2006, p. 218-25), Johansen \& Whittle (1980, pp. 12-5, vol. II) e Verdenius (1985, pp. 283-4).
} 
que "the violent approach of the sons of Aegyptus has warped the feminine instincts of the Danaids and turned them against marriage as such". De acordo com esses autores, haveria assim um movimento de uma inicial recusa a pretendentes indesejados para uma recusa do casamento em si mesmo. Essa visão encontra apoio no fato de que a misandria implicaria uma ofensa à deusa Afrodite, tal como a misoginia de Hipólito, em Eurípides, provocou a vingança da deusa ${ }^{2}$. A admoestação que o segundo Coro faz no êxodo às Danaides, para que não descuidem de Cípris (Su. 1034-40), endossa essa visão, bem como o belo fragmento 44 da tragédia perdida As Danaides. Nesse fragmento, a deusa Afrodite fala da força universal da união amorosa ${ }^{3}$ e, portanto, tal fragmento é visto como parte da resolução dos conflitos através de uma reconciliação das Danaides com o casamento e a procriação, o que aconteceria ao final da trilogia. Porém, se elas são assim avessas ao gênero masculino, qual seria o sentido dos versos em que Dânao recomenda longamente uma atitude de pudor às suas filhas quando estas, uma vez acolhidas pela cidade, estão sendo levadas para as suas acomodações (Su. 9911009)?

Dânao, aliás, é um elemento que precisa ser considerado nessa discussão. Notese que, no prólogo, ele é caracterizado pelas Danaides como "guia do conselho"

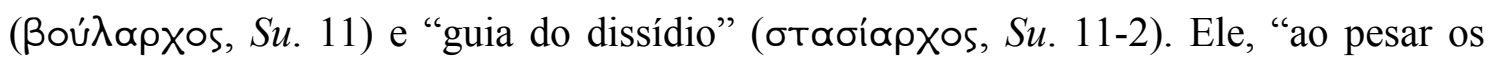

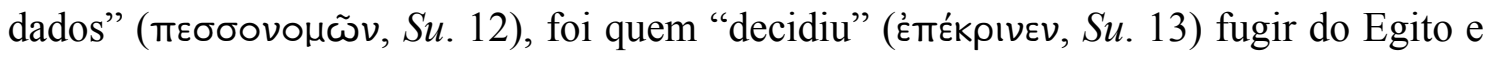
ir até Argos a fim de evitar a indesejada união entre suas filhas e os filhos de seu irmão. A recusa de Dânao em conceder as mãos de suas filhas apontaria, assim, para uma injunção política, ainda que nas Suplicantes não se mencione em nenhum momento a origem da discórdia entre os irmãos. Qual seria, porém, a natureza do desentendimento entre Dânao e seu irmão Egito e quais as implicações políticas trazidas pelo possível casamento entre seus filhos, não se pode determinar ${ }^{4}$. É mais plausível, portanto,

\footnotetext{
${ }^{2}$ A respeito da misandria das Danaides, conferir ainda os artigos de Zeitlin (1996), Lévy (1985), Spier (1962), Alaux (2001).

${ }^{3}$ Diz o fragmento: "O Céu sagrado gosta de penetrar a Terra, / e o amor pela união apodera-se da Terra: / a chuva caindo do Céu úmido sobre ela / fá-la inchar, e produz para os mortais / alimentos para os rebanhos e o grão de Deméter, / e desse casamento úmido o fruto das árvores / cresce até à perfeição, e eu

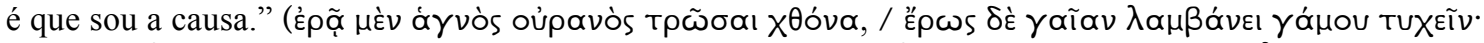

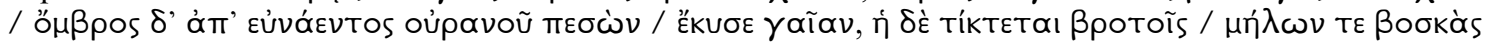

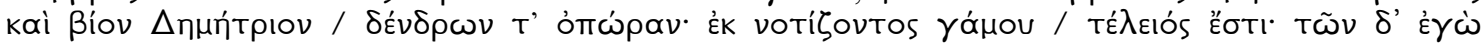
mapaítios.). A edição do fragmento é de Sommerstein (2008) e a tradução é nossa.

${ }^{4}$ A referência mais clara a esse respeito provém de uma fonte tardia. Higino, em suas Fábulas, diz o seguinte: "Dânao, filho de Belo, teve de muitas esposas cinquenta filhas, o mesmo número de filhos que teve seu irmão Egito, o qual queria assassinar o irmão Dânao e suas filhas para obter sozinho o reino paterno; demandou então ao pai as filhas como esposas para seus filhos." (Danaus Beli filius ex pluribus coniugibus quinquaginta filias habuit, totidemque filios frater Aegyptus, qui Danaum fratrem et filias eius
} 
considerar que o caráter ímpio (ơoєßńs) que as Danaides atribuem a esse casamento repouse no fato de que se trata de uma união que se pretende alcançar pela força, sem o consentimento das jovens e de seu pai.

Sommerstein (1996, p. 144) chama a atenção para a existência, em algumas versões tardias do mito das Danaides, de um oráculo entregue a Dânao que dizia que ele haveria de ser morto por seu genro ou, mais especificamente, por um dos filhos de Egito. Para o autor, isso seria uma forma bastante coerente de explicar a recusa de Dânao e de suas filhas ao casamento com os Egipcíades e sua fuga do Egito. Em sua tentativa de reconstrução da trilogia, Sommerstein conjectura que esse oráculo fora realmente entregue a Dânao nos Egípcios, tragédia que ele considera ter sido a primeira da trilogia. Um escólio ao próprio texto das Suplicantes parece apontar para o que poderia ser a existência de um oráculo. No párodo, as Danaides rogam que os Egipcíades pereçam no mar antes de usurparem o poder de Dânao e pisarem em leitos

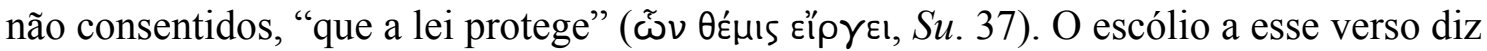
o seguinte: "dos quais é justo proteger-nos para que o pai não seja morto" (డ̃v tò

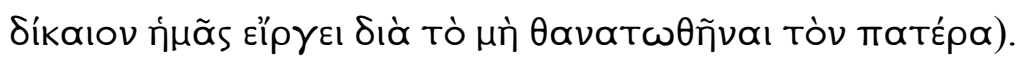

Referências a esse oráculo podem ser encontradas em outras fontes. Em um escólio à Ilíada I, 42, diz-se o seguinte:

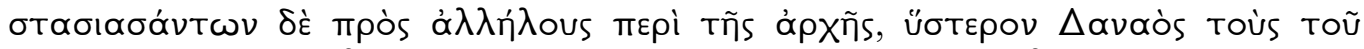

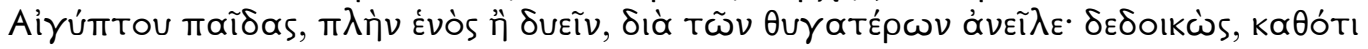

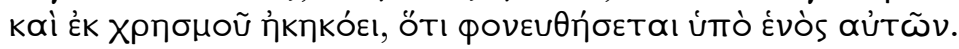

Tendo havido uma disputa entre eles pelo poder, depois Dânao matou os filhos de Egito por intermédio de suas filhas, exceto um, que escapou da ruína; temia o que havia ouvido de um oráculo: que seria morto por um deles.

Em um comentário de Eustácio ao mesmo verso da Ilíada, diz-se que: “Quando Dânao recebeu um oráculo dizendo que desconfiasse dos filhos de Egito, fugiu de lá [do

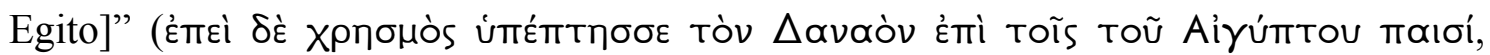

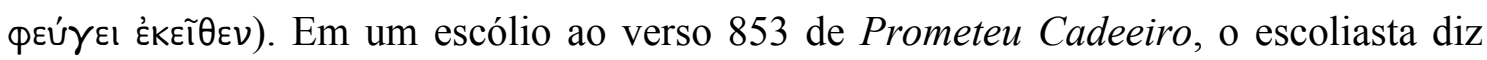
que "Dânao temia por fim ser morto por um dos filhos de Egito (pois certa vez lhe havia sido entregue um oráculo a esse respeito)" (

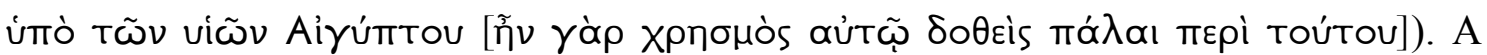

interficere uoluit ut regnum paternum solus obtineret; filiis uxores a fratre poposcit.) A edição é de Rose (1933) e a tradução é nossa. 
esse mesmo oráculo encontra-se referência também em escólios à Tebaida de Estácio, tanto ao verso 222 do livro II - "Dânao tomou conhecimento de um oráculo, que dizia que ele pereceria às mãos de seu genro" (Danaus responso comperit, quod generi sui manibus interiret) - quanto ao verso 269 do livro VI - "Dânao soube por um oráculo que seria morto por um filho de seu irmão Egisto" (Danaus deprehendit oraculo se ab uno Aegypti fratris filio occidendum).

Em um escólio ao verso 872 de Orestes, de Eurípides, o oráculo também é mencionado, mas aqui se diz que este fora entregue após o casamento entre as Danaides e os Egipcíades:

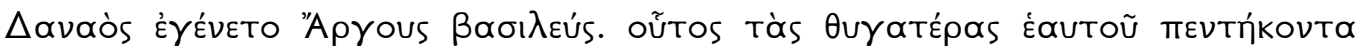

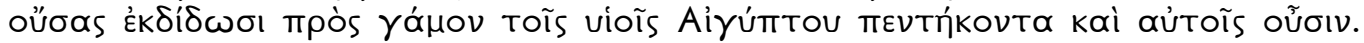

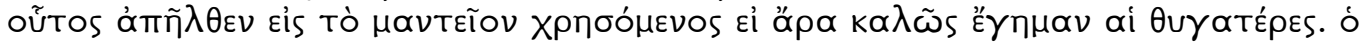

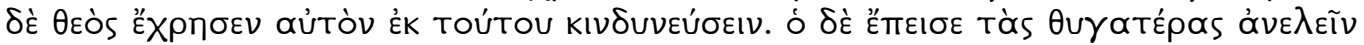

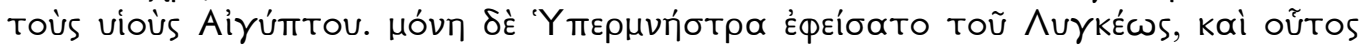
غ̇ßớ̉ $\varepsilon \cup \sigma \varepsilon v$ "Apyous.

Dânao tornou-se rei de Argos. Ele deu em casamento as suas filhas, que eram cinquenta, aos filhos de Egito, que também eram cinquenta. Ele foi ao oráculo perguntar se as filhas tinham feito um bom casamento. $\mathrm{O}$ deus respondeu-lhe que ele estava em perigo por causa disso. Ele então convenceu as filhas a matarem os filhos de Egito. Somente Hipermnestra poupou Linceu, e ele tornou-se rei de Argos. ${ }^{5}$

Evidentemente, trata-se apenas de uma conjectura apoiada em comentários tardios e, por essa mesma razão, não encontra o apoio de muitos helenistas, ainda que estes porventura mencionem en passant a possibilidade da existência de um oráculo. No entanto, trata-se de uma conjectura que, embora não encontre apoio textual, baseia-se na acertada ideia de que há sempre uma tradição oracular associada a um acontecimento relevante. A ausência, particularmente em uma obra de Ésquilo, de um oráculo - ou um sinal divino outro tão contundente quanto um oráculo - é, por assim dizer, tão embaraçosa que dá margem a tais especulações. Rösler (in LLOYD, 2007, p. 180) acredita que o conhecimento de um oráculo na trilogia a que pertence As Suplicantes é um fato tão necessário para o entendimento dessa tragédia que, para o autor, "if one does not possess this knowledge, then the effect is not of a built-up tension but of misunderstanding and confusion".

Havendo ou, mais provavelmente, não havendo um oráculo que impedisse Dânao de entregar suas filhas em casamento aos Egipcíades e, a despeito de todas as

\footnotetext{
${ }^{5}$ A tradução dos escólios citados é nossa.
} 
diferentes versões do mito das Danaides, bem como a despeito de todas as tentativas de reconstrução das demais peças perdidas da trilogia, há ao menos uma certeza: as Danaides acabam por desposar os Egipcíades e, aconselhadas pelo pai, matam-nos em sua noite de núpcias (exceto Hipermnestra). Para Murray (1958, p. 10), esse é o único acontecimento no mito que se pode assegurar com certeza ter formado parte da trilogia esquiliana, pois é encontrado na única fonte que o autor considera realmente confiável: o próprio Ésquilo. Murray refere-se a uma passagem do Prometeu Cadeeiro em que o Titã diz o seguinte à jovem Io:

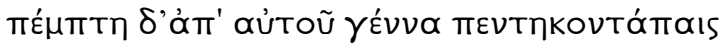

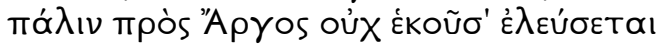

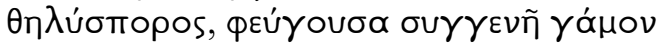

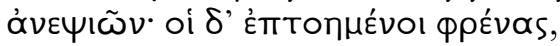

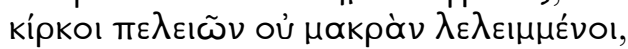

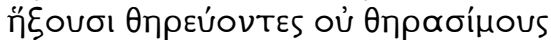

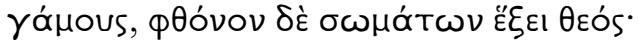

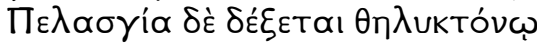

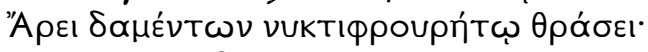

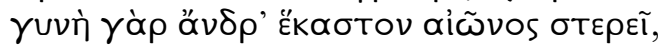

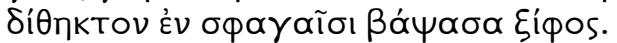

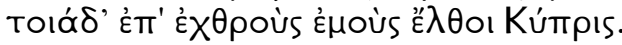

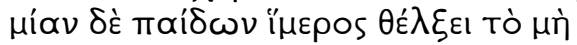

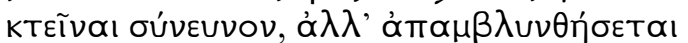

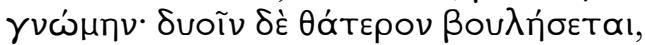

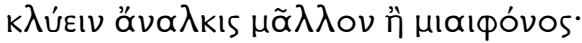

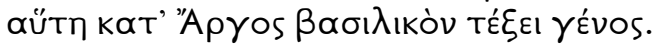

Cinco gerações depois, cinquenta filhas virão outra vez a Argos, a contragosto, fêmeas sementes a fugir de congêneres núpcias com primos; mas eles, aturdidos, falcões deixados não longe de pombas, chegarão, caçadores de não caçáveis núpcias. Deus terá ciúmes dos corpos. Fêmeo Ares letal molhará terra pelásgia com os mortos por noctivígil audácia, pois cada mulher massacrará o marido, tingindo na garganta a bigúmea espada. Assim seja Cípris para meus inimigos. O desejo de filhas seduzirá só uma a não matar o marido, mas abrandará a sua mente, e ela preferirá a fama de inerme à de poluída por sangue. Ela dará à luz a prole real de Argos.

(Pr. 853-69)

Portanto, quer elas recusem o casamento motivadas por uma repulsa ao casamento em si ou ao gênero masculino, quer por uma injunção política, quer pela postura violenta de seus pretendentes de quererem forçar uma união contrária à sua vontade e à de seu pai; ao final, elas irão recusar de forma violenta esse casamento por meio de um assassinato doloso. Sendo assim, como observa Gantz (1978, p. 279), "the murders to come are not, of course, any part of the initial plot, yet the play's language through pun, double meaning, and innuendo - reminds us again and again of the brutal denouement to their suit".

Observe-se que, no prólogo, a explicação da finalidade de sua chegada a Argos, fugir de núpcias indesejadas, é precedida de uma causal de condição negativa: "não para

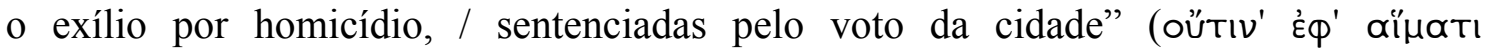

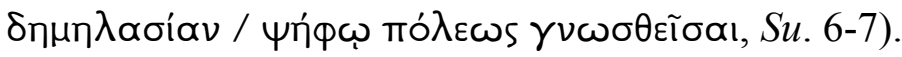


Esses dois versos apresentam múltiplas implicações. Ao dizerem que fogem não

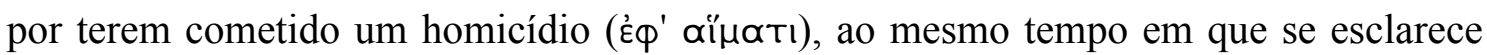
que chegam livres de qualquer poluência advinda de um tal crime, prenuncia-se o homicídio que de fato as Danaides irão cometer: um crime igualmente "consanguíneo"

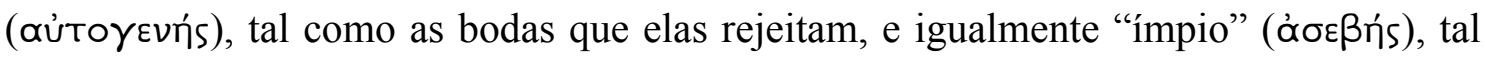
como elas agora descrevem o intento dos filhos do Egito.

Além disso, na alusão que se faz ao exílio "pelo voto da cidade" ( $\psi$ ńфफ

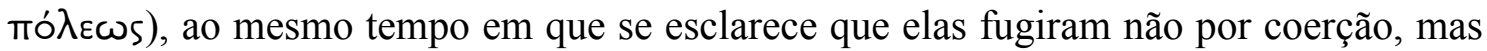
por sua própria vontade, prenuncia-se a votação que o rei Pelasgo conduzirá na assembleia de Argos, por força da coerção de sua condição de suplicantes, para decidir o dilema que a chegada de Dânao e suas filhas lhe impõe: incorrer na ira de Zeus

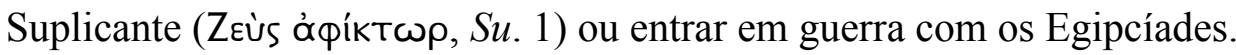

O termo $\Psi \tilde{n} \phi о$ S, "voto", "decreto", e derivados são recorrentes a partir do

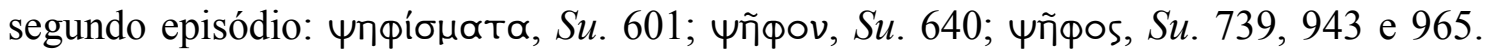
Em seu contexto imediato, tais termos aludem à votação e à decisão tomada em assembleia a respeito do destino das Danaides. Em um contexto mais amplo, especulase que poderiam também aludir, prenunciando-a, a uma cena de julgamento que poderia ter ocorrido na última tragédia da trilogia ${ }^{6}$. A questão que se coloca é quem seria a personagem a ser julgada: Dânao, por ter orquestrado a morte dos filhos de Egito; Hipermnestra, por ter desobedecido seu pai e poupado Linceu; ou ainda as 49 Danaides, por terem assassinado seus maridos ${ }^{7}$ ?

O julgamento a que Dânao é submetido em algumas versões do mito encontra respaldo em Eurípides, quando, em Orestes, o Mensageiro vem comunicar ao filho de Agamêmnon o que foi decidido em assembleia a respeito de seu destino e descreve o local em que o povo se reuniu, fazendo alusão a um primeiro julgamento, o de Dânao por seu irmão Egito:

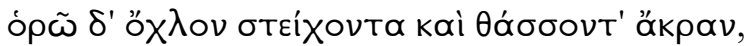

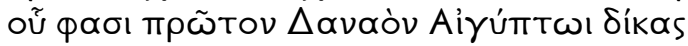

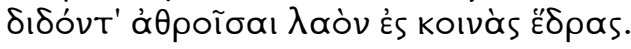

Vejo o povo andar e sentar-se no alto, onde se diz Dânao primeiro unir povo em sede comum e ser punido por Egito.

(Or. 871-3)

\footnotetext{
${ }^{6}$ Há um consenso entre os helenistas de que a última tragédia da trilogia é As Danaides.

${ }^{7}$ A conhecida punição das Danaides no Hades, a de encherem de água um vaso furado, é amplamente reconhecida como uma adição tardia ao mito. A esse respeito, conferir Bonner (1902).
} 
Um escólio ao verso 872 procura esclarecer as circunstâncias em que ocorreram esse julgamento:

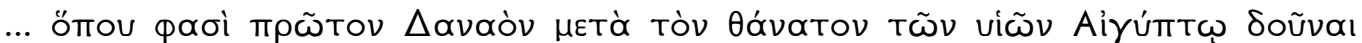

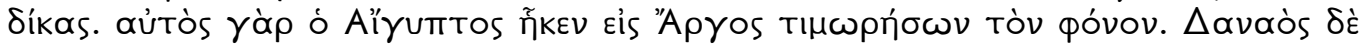

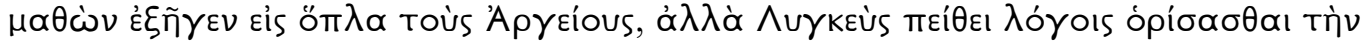

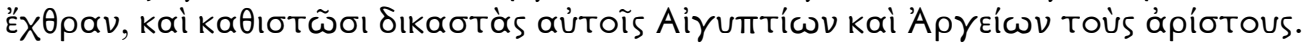

... [o local] onde se diz primeiro Dânao ter sido julgado pelo assassinato dos filhos de Egito. O próprio Egito foi a Argos para vingar o assassinato. Dânao, tomando conhecimento, incitou os argivos às armas, mas Linceu persuadiu-o com palavras a pôr de lado a inimizade e foram instituídos juízes para eles, os melhores dentre os egípcios e os argivos. ${ }^{8}$

Também em Pausânias (II, 19, 6) há um relato a respeito de um julgamento, mas o réu não é mais Dânao e sim Hipermnestra:

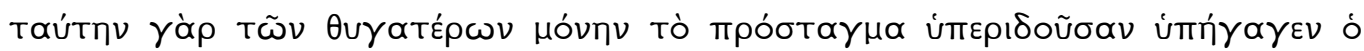

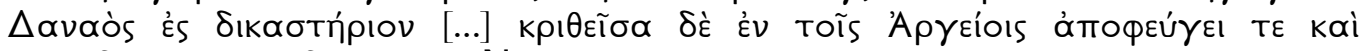
A

Pois, por ela ser a única das suas filhas a desobedecer o seu comando, Dânao levou-a a julgamento. [...] Ela foi absolvida em seu julgamento pelos argivos e, por causa disso, dedicou uma imagem à Afrodite Portadora da Vitória. ${ }^{9}$

No que se refere a um possível julgamento, especula-se que o fragmento 44, acima mencionado, faria parte de um discurso de defesa feito pela deusa Afrodite, seja de Hipermnestra ou de Dânao. Essa possibilidade é sugerida tomando-se por comparação a Oresteia, cujo desfecho dá-se pelo julgamento de Orestes, nos quais os deuses tomam parte ativa ${ }^{10}$.

Trata-se novamente de especulações, mas é interessante observar o princípio básico que as movimenta: a de que, nas tragédias de Ésquilo, principalmente quando se trata da primeira de uma trilogia ${ }^{11}$, os acontecimentos mais significativos são

\footnotetext{
${ }^{8}$ Tradução nossa.

${ }^{9}$ Tradução nossa.

${ }^{10}$ Para a possibilidade da existência de um julgamento nas Danaides e um debate sobre seu conteúdo, conferir as obras de Murray (1958, pp. 77-87), Garvie (2006, pp. 204-33), De Dios (2008, pp. 252-73), Papadopoulou (2011, pp. 15-24).

11 As Suplicantes são geralmente aceitas como a primeira peça da trilogia, mas, como observa De Dios (2008, p. 177), a partir dos anos 1990, ganhou força a hipótese de que As Suplicantes seriam precedidas pelos Egípcios, hipótese esta que se sustenta basicamente na aceitação da possibilidade de um oráculo ter sido entregue a Dânao, como se observou anteriormente.
} 
prenunciados, se não por sonhos, oráculos e auspícios, por imagens e palavras. Gantz, (1978, pp. 279-80), por exemplo, observa o seguinte a respeito das Suplicantes:

The technique is not dissimilar to that at work in the Agamemnon; here as there language in its poetic role often tells us more about the characters than does the same language considered dramatically. Suggestions of the Danaids' true nature and their ultimate choice of action pervade the play from its inception. ${ }^{12}$

À continuação, guiadas pelos conselhos de seu pai, as Danaides dizem ter vindo à terra argiva por ser a pátria de Io, que, pelo toque e pelo sopro de Zeus, deu origem à linhagem a qual elas pertencem. É nesta região, pela qual estão ligadas por sua

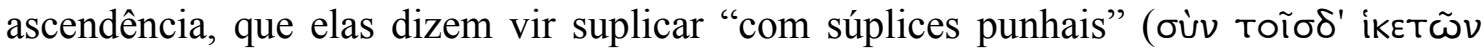

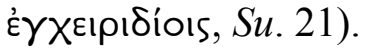

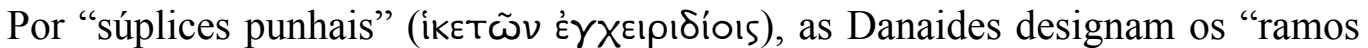

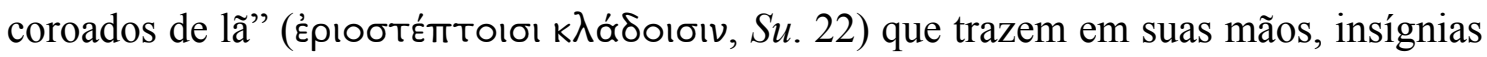
de sua condição de suplicantes. Há, no entanto, uma ambiguidade cledomântica no

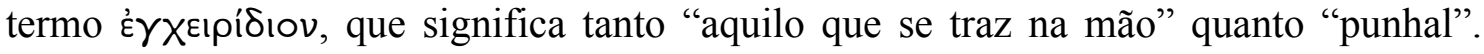
Como observam Johansen \& Whittle (1980, p. 21, vol. II), "in Herodotus and Attic prose the word means exclusively 'hand-knife', 'short sword', and it is reasonable to assume that this was the current sense when the play was written"13.

Há, portanto, aqui, um prenúncio da transfiguração de sua condição de suplicantes, trazendo às mãos um ramo envolto em lã, para a condição de assassinas, trazendo às mãos um punhal coberto de sangue. Gantz (1978, p. 280) chama atenção

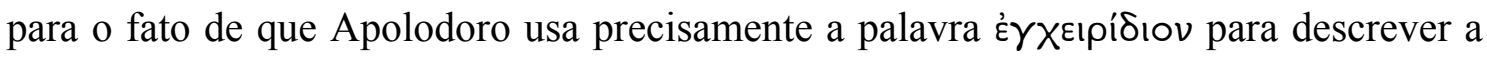

\footnotetext{
${ }^{12}$ Winnington-Ingram $(1961$, p. 141) tem um posicionamento similar: "In the Oresteia we can see how themes introduced in the Agamemnon are carried over into the Choephorai and, in many cases, find their culmination in the closing scene of the Eumenides. It is a reasonable assumption that Aeschylus used similar methods in the Danaid trilogy and that themes which are developed in the Supplices were taken up and developed further in the succeeding plays". Murray (1958, pp. 9-10) observa o seguinte: "There is little overt foreshadowing in the extant play (although much inheres in the imagery [...])". Para Bednarowski (2009, p. 229), "Those who knew the Danaids' story would have been more likely to view this play as the first installment in the treatment of the myth of the Danaids, who will marry and then murder these pursuers on their wedding night. These spectators would likely see the play as preparation for the impending murder and would, for obvious reasons, have been suspicious of everything the Danaids do. They might nevertheless be curious as to how and why Aeschylus' Danaids will kill the Aegyptids and thus alert to any sign that the Danaids will end up marrying them despite indications to the contrary".

${ }^{13}$ Curiosamente, em Heródoto (V, 20), narra-se que Alexandre, filho de Amintas, rei da Macedônia, decide preparar uma armadilha para os enviados persas que lhes vieram demandar submissão ao rei Dario e, durante um banquete, abusaram de suas mulheres. Ele então concebe o seguinte dolo: pede que as mulheres se retirem e envia em seu lugar jovens macedônios disfarçados de mulheres, jovens a quem ele

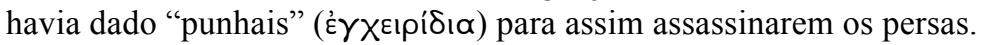


arma empregada pelas Danaides em sua sangrenta noite de núpcias: “Quando sorteou os casamentos, [Dânao], tendo organizado uma baquete, deu punhais às suas filhas" (ف́s $\delta \dot{\varepsilon}$

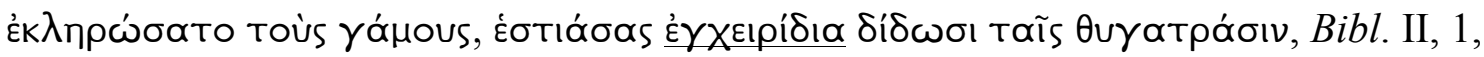
5). Winnington-Ingram (1961, p. 148) e Sommerstein (1996, p. 149), em suas tentativas de reconstrução das duas outras tragédias perdidas, especulam que, no párodo das Danaides, após as bodas de consequências funestas, elas entrariam em cena carregando dessa vez, em vez de ramos de suplicantes, os punhais manchados de sangue utilizados no assassínio de seus maridos.

Todavia, mesmo se atendo exclusivamente ao horizonte dos acontecimentos nas Suplicantes, os "súplices punhais" mantêm a força de sua ambiguidade cledomântica, pois prenunciam o caráter ameaçador para o rei de Argos e seu povo que a condição de suplicantes das Danaides irá adquirir no decorrer da tragédia. São um símbolo da sua condição ambígua: os súplices ramos coroados de lã às mãos de indefesas donzelas revelar-se-ão afinal um poderoso instrumento de coerção para o rei e seus súditos, que, ao lhes dar abrigo, entrarão em guerra com os Egipcíades.

A seguir, o Coro das Danaides invoca os pátrios numes de Argos, os deuses supremos, os heróis locais e Zeus Salvador, para que o acolha súplice. Nessa mesma prece, elas pedem que seus perseguidores - que elas qualificam de "bando transgressor

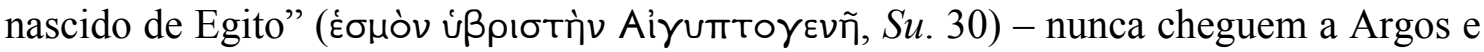
pereçam em uma violenta tempestade marítima, antes de que possam usurpar o poder de seu tio, Dânao, e compartilhar de leitos conjugais não consentidos. No entanto, tais preces, como se verá, não serão atendidas, já que, no quarto episódio, os fillhos de Egito, incólumes, desembarcam em Argos. O desejo pela morte dos Egipcíades, no entanto, permanecerá igualmente incólume e, se os deuses não cuidaram da destruição de seus inimigos, elas mesmas o farão, assassinando-os.

A prece das Danaides se volta então à invocação de Épafo, nascido do toque de Zeus, e à lembrança dos sofrimentos padecidos por Io, que elas dizem que irão oferecer como indícios fiéis de sua consanguinidade com os cidadãos argivos. Tais indícios

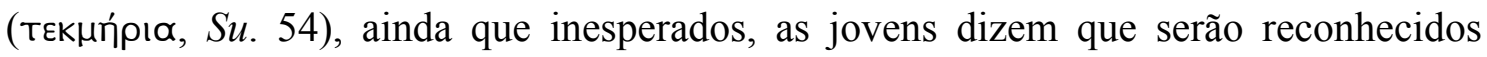

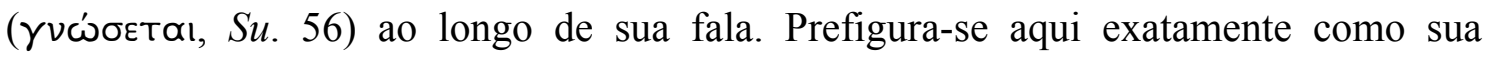
declaração de serem argivas vai ser recebida pelo rei: a princípio, será algo inesperado, mas ao longo da fala será reconhecido por Pelasgo. 
As Danaides então se voltam para as suas próprias aflições, dizendo:

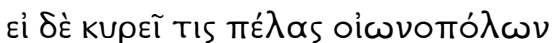

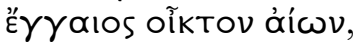

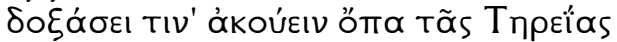

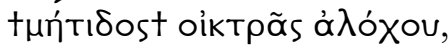

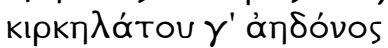

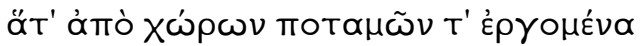

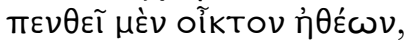

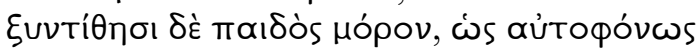

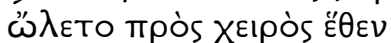

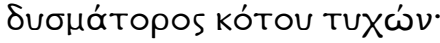

Se há por perto algum áugure nativo a ouvir o lamento, há de crer ouvir a voz da esposa de Tereu, lamentosa de sua astúcia, rouxinol perseguido por falcão.

Expulsa de campos e de rios, pranteia o lamento da moradia e assim compõe a sorte do filho: morto por ela pereceu por sua mão sob a cólera de áspera mãe.

De que fala a voz da esposa de Tereu? A história de Tereu parece ter sido o argumento de uma tragédia homônima perdida de Sófocles. A versão mais célebre é a que narra Ovídio nas Metamorfoses (VI, 421-674): Tereu era um rei trácio que desposou Procne, a filha do rei de Atenas, Pandíon. Juntos, eles tiveram um filho chamado Ítis. Saudosa de sua irmã, Filomela, Procne pede a Tereu que vá até Atenas buscá-la, porém, em sua viagem de regresso, Tereu violenta Filomela e, para que esta não pudesse denunciá-lo, corta sua língua. Isso não impede, todavia, que Procne descubra o crime do marido: através de bordados, Filomela denuncia o crime à irmã. Em cólera, Procne mata Ítis e serve ao marido as carnes do filho morto. Ciente do banquete funesto, Tereu persegue as duas irmãs, mas, antes de alcançá-las, os deuses transformam Tereu em falcão (ou poupa), Procne em rouxinol e Filomela em andorinha. E, assim, transformada em pássaro, Procne continua a ser perseguida pelo marido, agora na forma de falcão, e a lamentar a morte do filho através de seus gorjeios: "Ítis! Ítis!"14.

A identificação do lamento das Danaides com o canto choroso do rouxinol é, no entanto, muito mais do que um tópos literário e tem mais profundas ressonâncias. Ela aponta para a comunidade de destinos entre as Danaides e a esposa de Tereu: tal como as Danaides, Procne também é perseguida; tal como elas, também é exilada de sua pátria; e, tal como elas, também lamenta sua sorte. Dessa figura lamentosa e digna de piedade que é a esposa de Tereu, emerge a autora de um terrível crime. Da figura súplice e lamentosa que são as Danaides, emergirão também as autoras de um crime igualmente terrível. Como observa Sommerstein (1977, p. 68), "both [...] have a violent

\footnotetext{
${ }^{14}$ Para um estudo compreensivo sobre o mito de Procne e Tereu e suas variantes, conferir o artigo de Fontenrose (1948).
} 
as well as a piteous side to their nature". Assim, o destino de uma prenuncia o destino coletivo das Danaides: assim como Procne/rouxinol respondeu à violência masculina de que foi vítima com o assassínio de seu filho, também as Danaides irão responder à

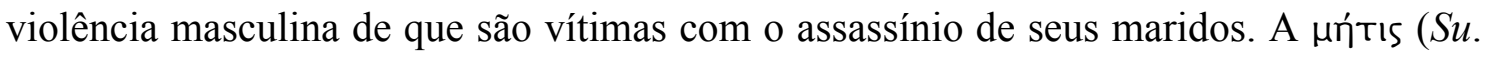
61) de Procne, ao enganar seu marido com um banquete em que serviu as carnes de seu filho, prenuncia a $\mu$ ńtıs das Danaides, que irão assassinar seus maridos na noite de núpcias, exatamente quando eles estarão mais vulneráveis aos punhais que elas trazem escondidos. Como observa González (2008, p. 27), “el infanticidio materno, del lado de Procne, se hace equivalente a un crimen que destruye toda posibilidad de descendencia, el de Danaides".

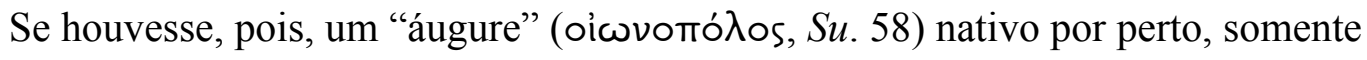
ele poderia, ao ouvir o lamento das Danaides, que se confunde com o lamento de Procne/rouxinol, interpretar corretamente o sentido ominoso do auspício, a prenunciar sangrentos males.

Invocando os deuses pátrios como vigilantes da justiça, as Danaides pedem que frustrem a tentativa dos filhos de Egito de contrair núpcias contra a sua vontade, pois isso seria uma transgressão e os deuses têm "real horror à transgressão" (üßpıv $\delta^{\prime}$

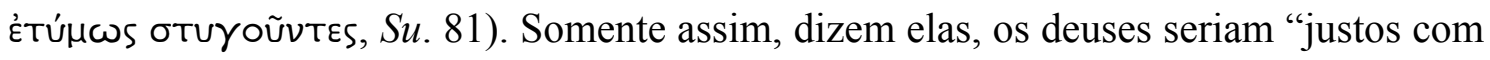

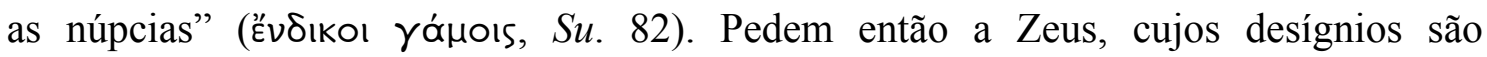
imperscrutáveis, que não permita que essa nova transgressão se realize.

O canto lastimoso por suas dores é descrito pelas Danaides como lamentações fúnebres que elas, ainda em vida, prestam a si mesmas, acompanhadas da dilaceração de suas vestes. Reconhecendo que a travessia segura por mar até Argos é um sinal divino propício, elas pedem que Zeus seja também propício à realização do motivo dessa travessia: escapar às núpcias indesejadas. Invocam também a proteção da deusa Ártemis, para que, irada com a perseguição de virgens, ela, também virgem, torne-se sua defensora.

Por fim, as Danaides, contemplando a possibilidade de suas súplicas não serem atendidas pelos deuses olímpios, e principalmente por Zeus, ameaçam tornarem-se suplicantes de Zeus dos defuntos, enforcando-se com laços:

घỉ $\delta \dot{\varepsilon} \mu \eta ́, \mu \varepsilon \lambda \alpha \nu \theta \dot{\varepsilon} s$

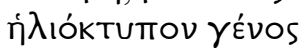

Tòv Yáıov,

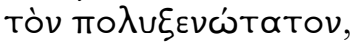

Se não, - gente de negra tez

brunida de sol,

junto ao térreo

hospitaleiro de muitos, 


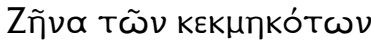

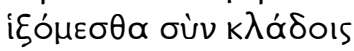

áptóvåıs $\theta \alpha$ voũoaı,

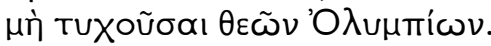

Zeus dos defuntos,

suplicaremos com ramos,

mortas nos laços, -

se não tocarmos Deuses Olímpios.

(Su. 154-61)

Explicita-se aqui mais inequivocamente a ambiguidade ominosa da condição de suplicantes das Danaides, anteriormente simbolizadas por seus "súplices punhais", pois seu caráter ameaçador para a cidade começa a tomar forma: essa ameaça de suicídio por

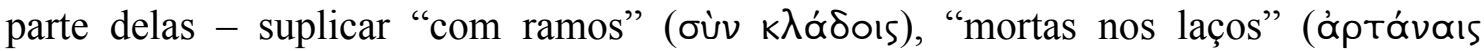
$\theta \propto \nu \circ \tilde{\sigma} \sigma \mathrm{l})$-, caso suas preces não sejam atendidas, prefigura a mesma ameaça que, no primeiro episódio, elas farão ao rei Pelasgo caso ele não as acolha, a de enforcarem-se

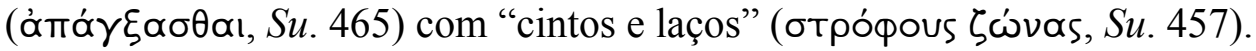

No primeiro episódio, Dânao recomenda que suas filhas sejam "prudentes" (фроvєĩv, Su. 176), tal como ele foi um pai "prudente" (фроvоũvтı, Su. 176) ao guiá-las à terra firme em que se encontram. Na poeira e no chiado dos eixos dos carros, Dânao percebe a iminente chegada de líderes locais a demandar quem sejam os recémchegados e, assim, aconselha suas filhas a buscarem asilo junto ao altar dos deuses sobre a colina:

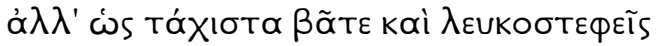

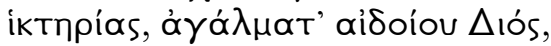

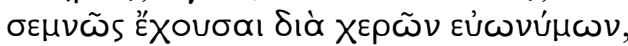

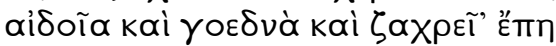

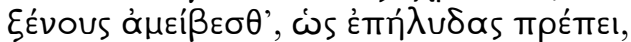

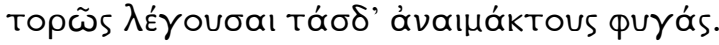

Eia, vinde o mais, tendo solenes súplices ornamentos de Zeus Reverente coroados de alva lã na mão de bom nome, respondei falas reverentes, ternas, úteis, aos hóspedes, como convém a forasteiros, a falar claro deste exílio limpo de sangue.

(Su. 191-6)

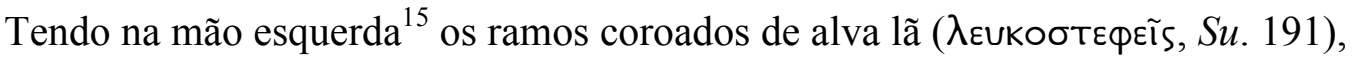
Dânao aconselha-as, assim, a responder o que lhes for demandado e falar claramente de seu exílio "limpo de sangue" (ávåıáktous, Su. 196). Como seu viu, as Danaides, no párodo, esclarecem que seu exílio não foi motivado por nenhum homicídio ( $S u$. 6). Viu-se também que nessa alusão ao homicídio residiria um prenúncio do crime que de fato elas irão cometer ao assassinarem seus próprios maridos. Aqui, esse mesmo prenúncio é reforçado através da fala de Dânao e ganha ainda implicações mais imediatas. "Limpo de sangue" (ávaııákTous) caracteriza verdadeiramente o exílio das

${ }^{15}$ De acordo com o ritual da súplica, Dânao as instrui a segurar os ramos "na mão de bom nome"

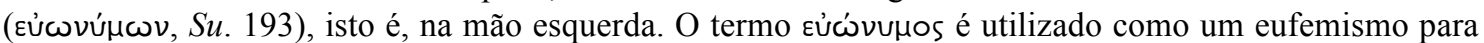
o lado esquerdo, pois o lado esquerdo é o lado de onde provêm os maus auspícios. Sobre os aspectos rituais da súplica nas Suplicantes, conferir Belfiore (2000, pp. 41-5). 
Danaides desde o ponto de vista do momento presente: elas não carregam a mácula de nenhum derramamento de sangue e sua chegada, a salvo, à terra firme, após uma longa viagem marítima desde o Egito, elas mesmas reconhecem como um favor dos deuses, ao falarem de uma viagem "sem procela" (áxદípatov, $S u$. 136), em que seu navio era conduzido "com brisas" (бùv mvođĩs, Su. 136). No entanto, se considerado desde o ponto de vista de um futuro próximo, seu exílio não será de forma alguma ớvaínakTos e sim aínরктós. Como o rei Pelasgo em breve irá descobrir, ambas as alternativas que elas lhe apresentarão serão sangrentas: ele terá as mãos sujas de sangue se, não atendendo às suas súplicas, for assim responsável pelo suicídio delas e se, atendendo às suas súplicas, der início a uma guerra com os Egipcíades, em que sangue será

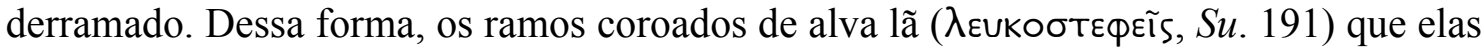
carregam em suas mãos figuram uma vez mais como uma expressão da ambiguidade ominosa da sua condição de suplicantes.

Acolhendo os conselhos paternos, as Danaides pedem a vigilância e a piedade de Zeus e, enquanto se dirigem ao altar sobre a colina, Dânao indica os demais deuses que também devem ser invocados de modo a lhes serem propícios: Apolo, porque, como elas, também já experimentou o exílio e assim poderia apiedar-se delas; Posídon, para que, assim como bem lhes conduziu em sua travessia marítima, bem as receba em terra firme; e Hermes, para que, como deus mensageiro, possa lhes anunciar a boa notícia de sua libertação. Por fim, Dânao aconselha suas filhas a venerar o altar comum dos deuses, dizendo:

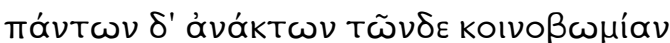

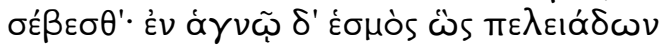

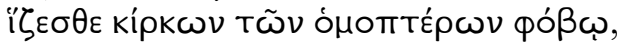

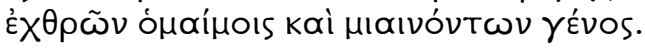

O altar comum destes deuses soberanos todos, venerais; no santuário, qual bando de pombas, pousai, por temor de gaviões também alados, hostis a consanguíneos e poluentes da casa.

(Su. 222-25)

Para descrever a atitude que, ante o altar comum dos deuses, as Danaides devem ter, Dânao recorre a um símile: o de um bando de pombas que, temendo a perseguição de gaviões, buscam refúgio pousando nos altares dos deuses. Para Dumortier (1975, p. 1), a metáfora principal nas Suplicantes é a de um voo de pombas fugindo de um gavião. Note-se que, no párodo, as Danaides se referem aos Egipcíades como o "bando" 


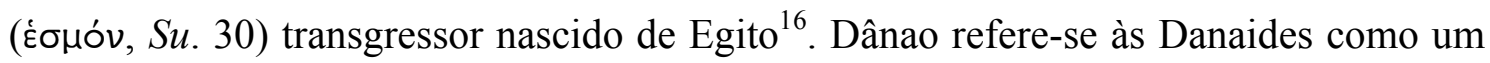

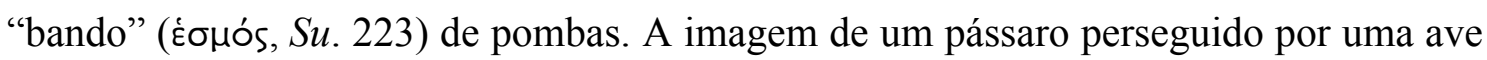
de rapina evoca a história de Procne/rouxinol perseguida por Tereu/falcão, com a qual elas próprias descreveram anteriormente a sua situação e na qual, como se viu, reside o prenúncio do assassinato dos Egipcíades por suas mãos.

Porém, como se viu no primeiro capítulo, a perseguição da pomba por um gavião é uma imagem estritamente relacionada ao universo da ornitomancia. $\mathrm{Na}$ Odisseia (XV, 525-8), um gavião avistado à direita trazendo em suas garras uma pomba é considerado um bom auspício pelo adivinho Teoclimeno. Já nos Persas, um gavião perseguindo uma águia, uma ave hierarquicamente superior, é claramente um mau auspício para o povo persa (Pe. 205-10). O gavião, que, na mesma passagem supramencionada da Odisseia, é descrito como "o mensageiro de Apolo, veloz"

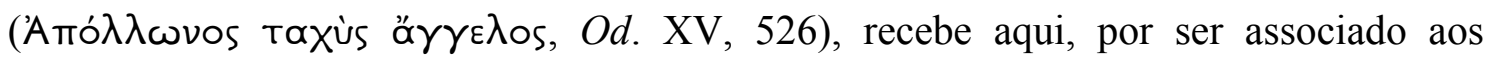

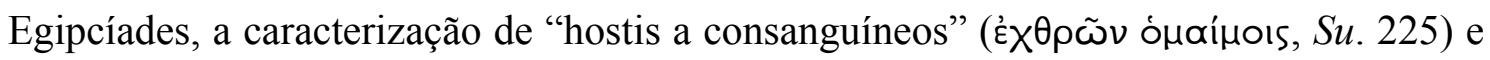

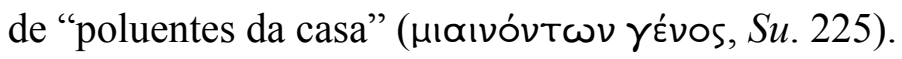

Se esse símile das pombas perseguidas por gaviões - por sua estreita relação com o universo da ornitomancia e por sua grande significância dentro desse mesmo universo -, fosse interpretado como um auspício, o que ele prenunciaria? Se houvesse

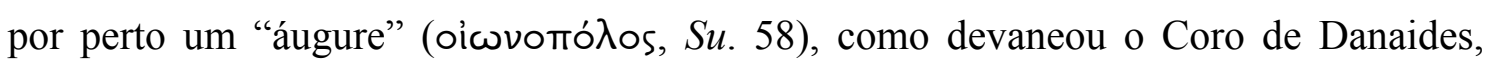
qual seria a sua interpretação?

Dânao estabelece primeiramente uma correlação entre o bando de pombas que se refugia por temor no santuário com as Danaides e entre os gaviões alados com os seus perseguidores, os Egipcíades ${ }^{17}$. Então ele se pergunta:

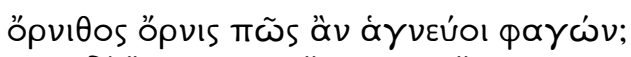

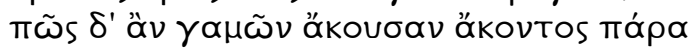

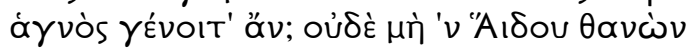

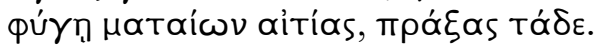

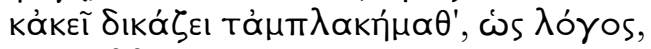

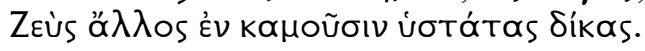

Como seria puro o pássaro voraz de pássaro? Como, se desposa à força contra forçado pai, seria puro? Nem morto, junto de Hades, escape à acusação de lascívia, se assim age. Também lá, outro Zeus, ao que se conta, entre mortos, juiz póstumo, julga crimes.

(Su. 226-31)

\footnotetext{
${ }^{16}$ De acordo com Johansen \& Whittle (1980, pp. 30-1, vol. II), a palavra Éouós neste contexto "properly means a (settling) swarm of birds". Para os autores, a caracterização dos Egipcíades como um bando "foreshadows the many more or less detailed images of predatory or preyed-on creatures which are employed throughout the paly to describe the relations between the Danaids and their cousins".

${ }^{17}$ Note-se que a imagem da pomba perseguida pelo gavião está presente também no Prometeu Cadeeiro com a mesma relação entre ave e personagem: "mas eles, aturdidos, / falcões deixados não longe de

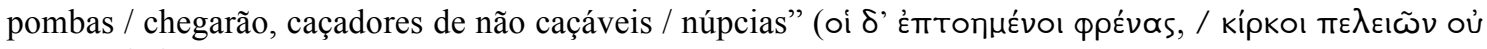

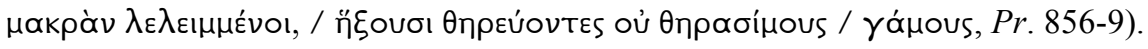


Os Egipcíades/gaviões são descritos, como se viu, como "hostis a consanguíneos e poluentes da casa" (Su. 225). Como então seria "puro" (đ́yveúol, Su. 226) o pássaro que devora o pássaro? Como poderia uma união enfaticamente descrita como pretendida

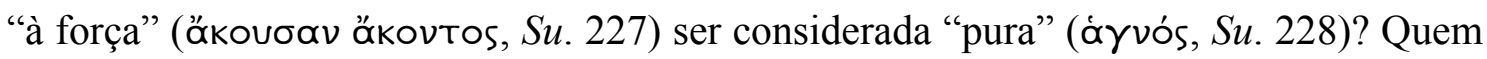
assim age, nem morto, junto ao outro Zeus, aquele que como juiz julga crimes no

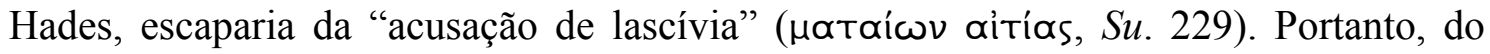
ponto de vista de Dânao, esse símile exprime uma impiedade, uma hýbris por parte dos Egipcíades, e, enquanto auspício, prenunciaria um castigo para os perseguidores de suas filhas. De fato, trata-se de um auspício que se revelará verdadeiro: por justiça divina, a hýbris dos Egipcíades será punida com a perda da própria vida às mãos daquelas a quem agora eles perseguem tal qual gaviões atrás de pombas.

Trata-se, no entanto, de apenas um aspecto desse símile/auspício. Sem que Dânao o saiba, a descrição dos gaviões como "hostis a consanguíneos" e "poluentes da casa" aplicar-se-á também às suas filhas, quando, como um "pássaro voraz de pássaro"

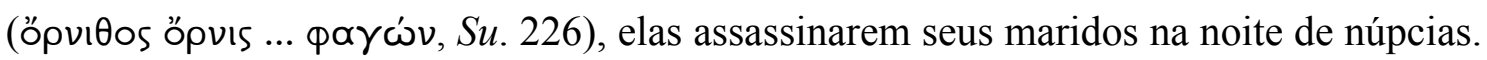
Invertendo-se as relações entre as aves e as personagens, o símile torna-se um auspício a prenunciar, com igual veracidade, o crime das Danaides.

\section{2) Pelasgo e o enigma das Danaides}

Surge, então, o rei Pelasgo, no primeiro episódio. O início da interlocução entre o rei e o Coro das Danaides constitui-se da tentativa de Pelasgo em saber a identidade

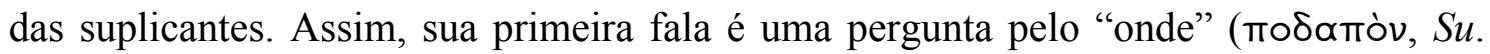
234), isto é, pela origem das Danaides:

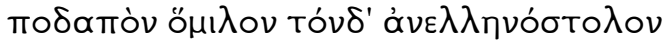

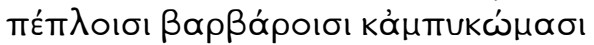

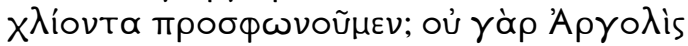

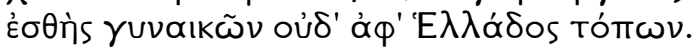

Donde é este bando de trajes não gregos, com vestimentas e diademas bárbaros, faustoso, com quem falamos? Não de Argos são as vestes das mulheres, nem da Grécia.

(Su. 234-7)

À primeira vista, chama a atenção do rei Pelasgo os trajes e os adornos utilizados pelas Danaides, em cujo aspecto faustoso ele reconhece uma origem bárbara; mulheres assim vestidas, afirma o rei, não são nem de Argos nem da Grécia. 
A pergunta pelo "onde" é sucedida por uma consideração a respeito de "como"

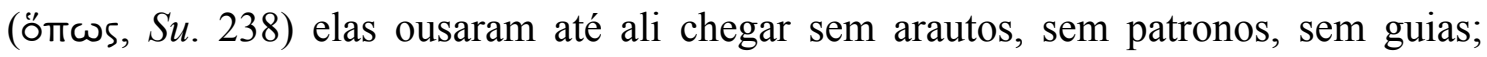

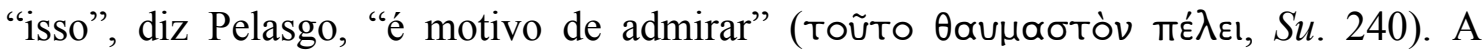
chegada inadvertida, e por isso mesmo ousada, desse grupo de mulheres vestido à moda

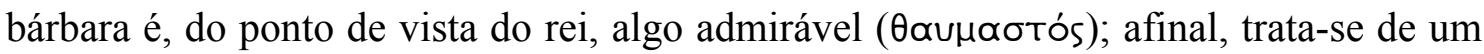
acontecimento extraordinário.

Pelasgo reconhece, porém, nessas mulheres a condição de suplicantes pelos ramos que trazem consigo. Os seus ramos de suplicante são, portanto, para o rei, o único indício que lhes conferiria, por conjectura, uma identidade grega. Muito mais, diz

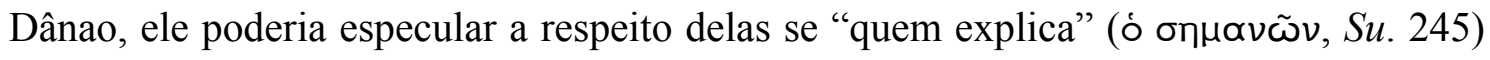
fosse desprovido de voz. Assim, ele demanda às Danaides que lhe expliquem quem são afinal. Porém, elas adiam o desvelamento de sua identidade devolvendo a pergunta que lhes foi feita com outra pergunta, a indagar Pelasgo a respeito da sua posição social.

Pelasgo então concede-lhes o beneplácito de ser ele o primeiro a identificar-se. Ele se identifica como filho do terrígeno Palécton e senhor soberano dessa terra, cujo nome advém de sua realeza e cujos vastos domínios se estendem pela Grécia continental. E explica por que a região foi denominada Ápia:

`A

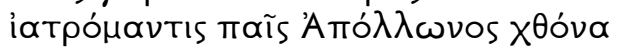
тท́

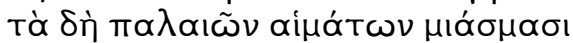

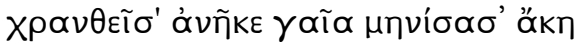

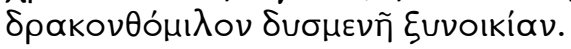

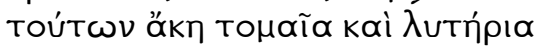

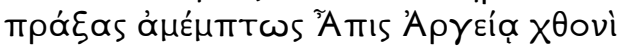

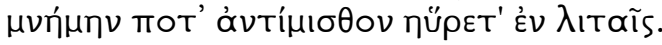
Ápis veio do lado de lá de Naupacto, médico-adivinho filho de Apolo limpou esta terra de feras homicidas, que, pela poluências de antigos cruores conspurcada, a terra produziu furiosa, moradia de hostil multidão de serpentes. Remédios cortantes e libertadores disso Ápis sem vitupério deu à terra argiva e em paga foi lembrado em preces.

(Su. 262-70)

Como observam Johansen \& Whittle (1980, p. 211, vol. II), a história de Ápis, médico-adivinho filho de Apolo, que libertou a região de uma multidão de serpentes, não é referida por nenhum outro autor antigo em nenhum outro texto supérstite, exceto por Eustácio (D.P. 414), que diz que “Ápis, o filho de Foroneu, vindo do Epiro libertou

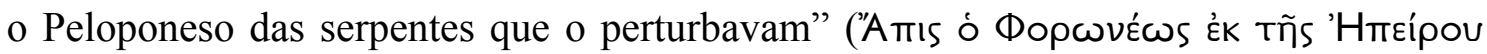

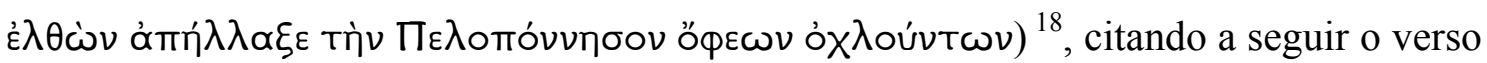
262 das Suplicantes de Ésquilo.

\footnotetext{
${ }^{18}$ A edição é de Müller (1861) e a tradução é nossa.
} 
Note-se que, assim como as Danaides cruzaram o mar para chegar a Argos, também outrora o médico-adivinho Ápis cruzou o mar - ele veio “do lado de lá” (દ̇k тépas, Su. 262) de Naupacto, isto é, de além-mar. Ele veio, no entanto, na condição de médico-adivinho (iárpómavтıs, Su. 263) e, enquanto tal, sua chegada foi benéfica para a região. Ápis, ali encontrando uma terra conspurcada - cuja "poluência" ( $\mu$ íað $\mu \alpha$ ) advinda de antigo "sangue derramado" ( $\alpha i ̃ \mu \alpha)$ fez com que a terra produzisse uma

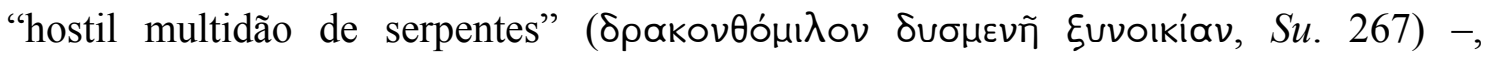
purificou-a com remédios (äkn, $S u$. 266, 268).

Como em breve Pelasgo irá descobrir, as Danaides chegam perseguidas pelos

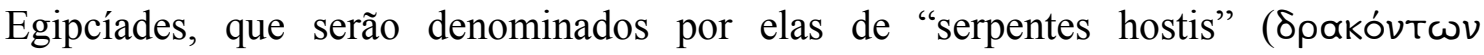

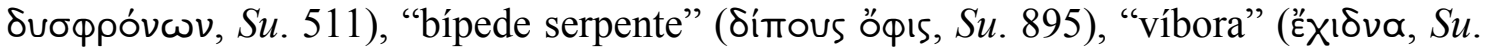
896), "monstro" ( $\delta$ ákos, Su. 898); ou seja, elas trazem novamente um mal para essa terra. Não há mais, no entanto, um médico-adivinho que, como outrora, possa purificá-

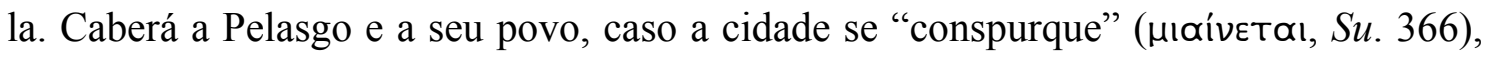
encontrar "remédios" (ớkn, Su. 367) para purificá-la.

Assim, a história do médico-adivinho Ápis, por seu paralelismo com a história das Danaides, adquire um sentido ominoso, pois é um prenúncio do que irá acontecer:

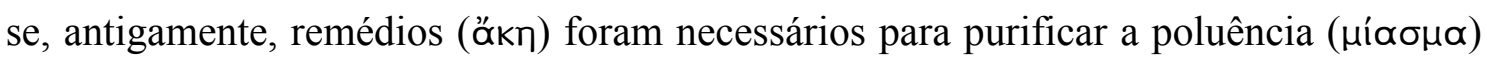
causada pelo derramamento de sangue ( $\propto$ İ $\mu \alpha$ ), em breve serão necessários novamente

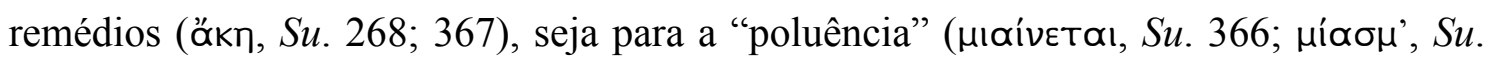
473), caso as Danaides cumpram a ameaça de se enforcarem; seja para o

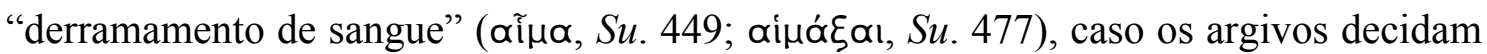
entrar em guerra com os Egipcíades; seja para a poluência advinda do derramamento de sangue, quando as Danaides assassinarem seus maridos.

Finda sua apresentação, Pelasgo demanda que as Danaides, com breves palavras,

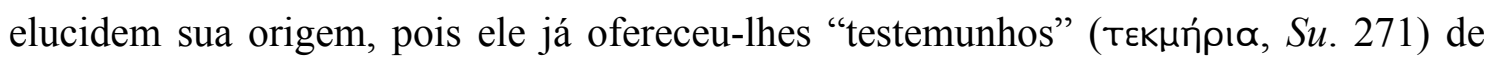
sua realeza. Obedecendo ao conselho do pai, que, anteriormente à chegada de Pelasgo,

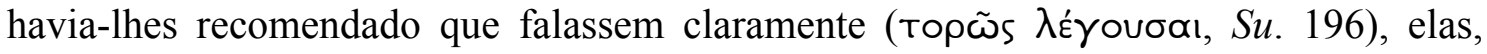

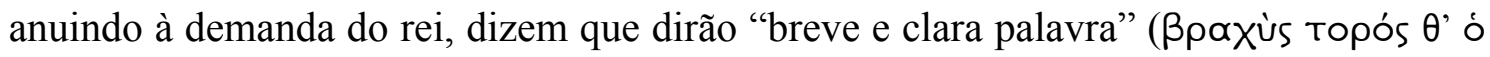
$\mu \tilde{\theta} 0$ os, Su. 274). Assim o fazem, declarando-se de origem argiva, por serem prole de Io, a nobre novilha, e nessa declaração dizem dar a conhecer "toda a verdade" (å $\lambda \eta \theta \tilde{\eta}$ по́́vта, Su. 276). Para Pelasgo, suas palavras são "incríveis" (åmiota, Su. 277). O que há de incrível em as Danaides se dizerem argivas é a sua aparência, que ele diz ser 
muito mais condizente com a das mulheres líbias, das nômades indianas e, se portassem

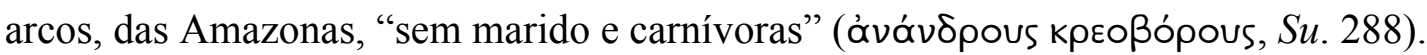

Essa comparação das Danaides com as Amazonas é tão significativa quanto controversa. Alguns autores argumentam que tal comparação sugere não apenas o aspecto bárbaro das Danaides, mas também a natureza de seu posicionamento contra o casamento $^{19}$. Como observa Vernant (1992, p. 30):

O casamento é para a moça o que a guerra é para o rapaz: para ambos, esses acontecimentos marcam a realização de suas respectivas naturezas [...]. Além disso, uma moça que se recusa a casar, renunciando ao mesmo tempo à sua "feminilidade", vê-se de alguma forma rejeitada para o lado da guerra, tornando-se paradoxalmente equivalente a um guerreiro. É o que se constata, o plano do mito, com os personagens femininos do tipo das Amazonas [...].

As Danaides teriam assim uma natureza semelhante àquela das Amazonas e, por se recusarem ao casamento, viveriam num universo masculino. Um fragmento de um poema de Melanípides, em que ele descreve as Danaides, sugere esse seu aspecto masculino:

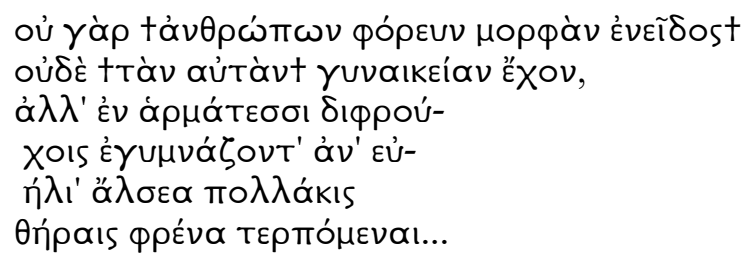

Pois não apresentavam o aspecto de homens nem o aspecto próprio feminino, mas corriam com carros de duplos cavalos por bosques ensolarados, regozijando-se muitas vezes com a caça às feras... (Fr. 1$)^{20}$

Em Hécuba, de Eurípides, ante o desprezo de Agamêmnon à força feminina, a rainha responde: "Por quê? Elas não mataram Egipcíadas? / Não despovoaram Lemnos de varões?" (Hec. 886-7). Traça-se, dessa forma, um paralelo entre as Danaides e as mulheres de Lemnos, mulheres estas que repeliram violentamente seus maridos.

\footnotetext{
${ }^{19}$ Conferir os artigos de Lévy (1985, p. 42); Zeitlin (1988, p. 238); Turner (2001, p. 32); Papadopoulou (2011, pp. 53-4).

${ }^{20}$ A edição é de Page, em Poetae melici Graeci (1962), e a tradução é nossa. A respeito da caracterização das Danaides nesse fragmento poético de Melanípides, conferir o artigo de Moreau (1994/1995), "Las Danaïdes de Mélanippidès: La femme virile".
} 
Para Garvie (2006, pp. 215-6), no entanto, diferentemente das Amazonas, as Danaides não possuem uma natureza belicosa; além disso, as Amazonas, embora recusem a dominação masculina, não rejeitam a união amorosa.

É necessário considerar, porém, que, embora essa menção às Amazonas não signifique uma explicitação da natureza das Danaides nesta tragédia de Ésquilo, a

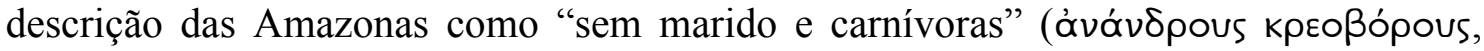
Su. 288) é significativa. De acordo com Heródoto (IV, 110), os citas chamam as Amazonas de "Oiorpatas" (Oiópтrata), o que, diz ele, na língua grega significa

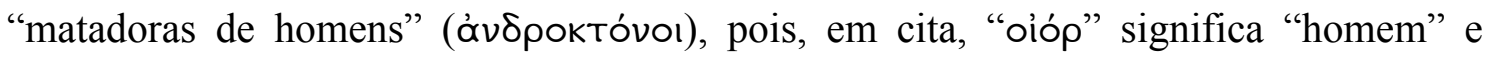
"Taтó" significa "matar",21. Portanto, para Johansen \& Whittle (1980, p. 230, vol. II),

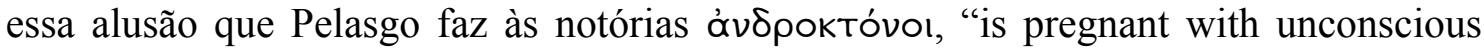
prophecy". A comparação que Pelasgo faz entre elas parece ser, assim, mais acertada do que o rei pode perceber, uma vez que não apenas elas se recusam a aceitar os Egipcíades como maridos, como também irão assassiná-los para permanecerem na

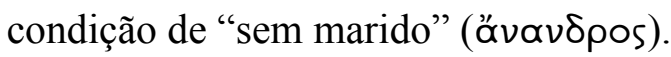

Pelasgo, então, aceitando a premissa de que as Danaides sejam argivas, tal como se declaram, pergunta como poderia ser argiva sua origem e família. Ora, a presença imprevista dessas jovens virgens exóticas, de tez morena e com vestes e adornos incomuns, que se apresentam sob a proteção de Zeus Suplicante e se dizem argivas de origem, é uma presença numinosa a anunciar desígnios divinos que escapam à compreensão do rei. As Danaides são, dessa forma, para Pelasgo um enigma que ele tem de decifrar, mas que, uma vez decifrado, não se mostrará propício e benéfico nem para ele nem para seu país. Para tentar solucionar esse enigma, porém, Pelasgo deve tomar conhecimento de duas questões fundamentais: primeiramente, como é possível que as Danaides se declarem argivas e, em um segundo momento, pelo que suplicam junto ao altar dos deuses.

Note-se que, no párodo, o Coro de Danaides diz que falará aos argivos dos males de Io, mostrando assim indícios fiéis de sua consanguinidade. Tais "indícios fiéis"

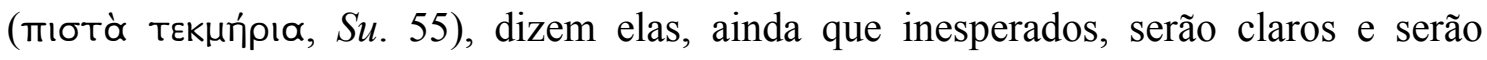
"reconhecidos" ( $\gamma v \omega \dot{\sigma \varepsilon t a l, S u . ~ 56) ~ p o r ~ s e u s ~ i n t e r l o c u t o r e s . ~ P e l a s g o, ~ q u a n d o ~ e l a s ~}$ primeiramente se declaram argivas, diz que suas palavras são "incríveis" (å̆mı

\footnotetext{
${ }^{21}$ Narra o historiógrafo a respeito das Amazonas que, após serem vencidas pelos helenos, estes levaram as sobreviventes consigo em suas naus, mas que, em alto-mar, elas os atacaram e os massacraram (Hdt. IV, 110).
} 
277). Chegou então o momento de mostrar seu conhecimento sobre Io, isto é, oferecer a

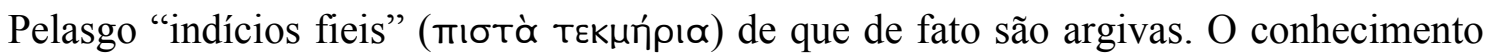

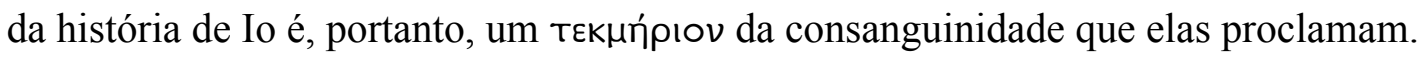

Assim, como prova de sua ascendência argiva, as Danaides oferecem o conhecimento de que, outrora, em Argos, Io foi uma sacerdotisa guardiã do templo de Hera. Pelasgo reconhece essa informação como verdadeira e a partir de então passa a fazer diversas perguntas - nove no total, excluindo-se os versos corrompidos concernentes à história de Io, como se pusesse à prova o conhecimento que dela dizem ter as Danaides e, assim, a assertividade de sua declarada origem argiva.

No decurso da esticomitia entre as Danaides e o rei, tece-se a história de Io: a mortal sacerdotisa de Hera atraiu os amores de Zeus, provocando a cólera da deusa, que transforma a jovem em novilha. Zeus, no entanto, une-se a ela em forma de touro. Hera designa o onividente Argo para vigiar a novilha, mas é morto por Hermes, e então envia um aguilhão para persegui-la em longa corrida, que termina ao chegar a Canopo e a Mênfis, onde Zeus com sua mão liberta-a dos sofrimentos pelo nascimento de seu filho Épafo, epônimo do toque de seu pai ${ }^{22}$. Filha de Épafo, Líbia gerou Belo, pai dos contendentes irmãos Dânao e Egito.

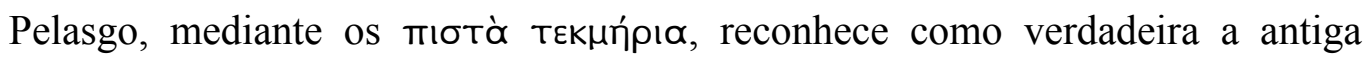
ligação entre as Danaides e a terra argiva: "Parece-me que participais desta terra / em

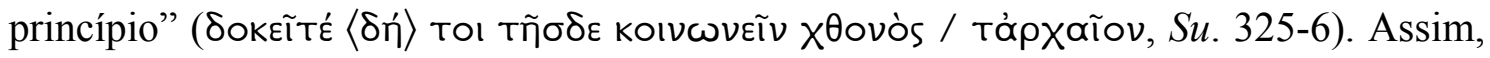
esclarecida a primeira parte do enigma - como é possível que as Danaides se declarem argivas -, resta saber pelo que suplicam junto ao altar dos deuses.

Pelasgo, primeiramente, pergunta por que golpe de sorte deixaram o palácio paterno. As Danaides respondem que fugiram de seu país por "ódio à união conjugal"

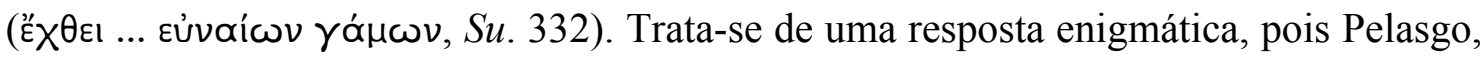
que não está a par dos acontecimentos, ainda não pode entender toda a implicação de tal ódio à união conjugal. Por essa razão, o rei reformula de forma mais específica a sua pergunta: “Que suplicas a estes Deuses juntos, / coroados de lã recém-colhidos ramos?”. O caráter ambíguo de seus recém-colhidos ramos coroados de lã (入

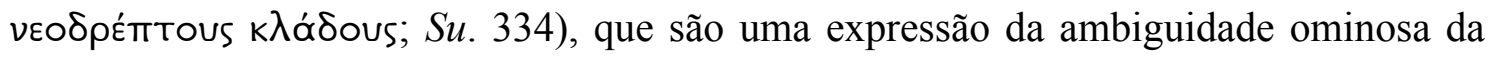
condição de suplicantes das Danaides, está prestes a se desvelar para o rei.

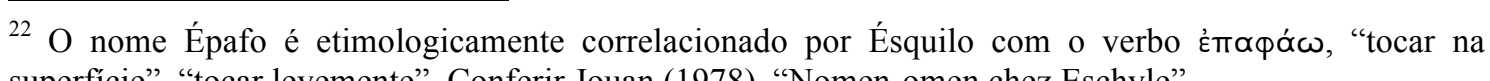
superfície", "tocar levemente". Conferir Jouan (1978), "Nomen-omen chez Eschyle". 
À pergunta "que suplicas?" as Danaides respondem que suplicam para que não sejam servas na família de Egito, mas se evadem de responder à próxima questão

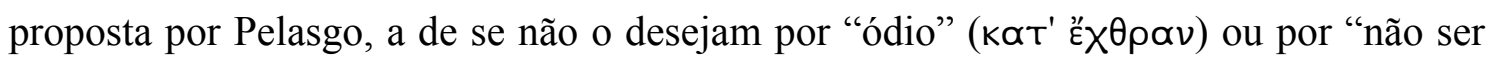

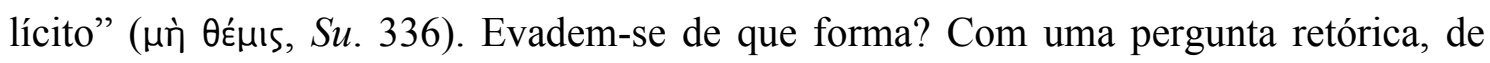

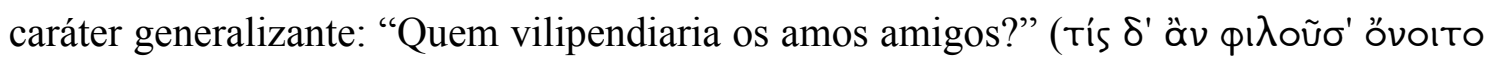

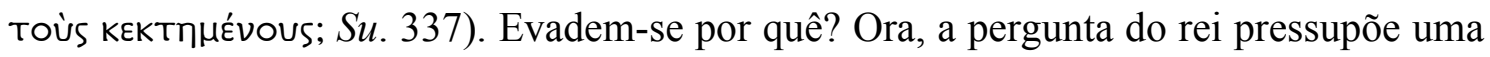
alternativa inexistente para elas: não desejam unir-se aos filhos de Egito por ódio "ou" (ที) por não ser lícito. Observe-se que, no párodo, as Danaides pedem aos deuses que seus perseguidores pereçam no mar antes de usurparem o poder de seu pai e pisarem em

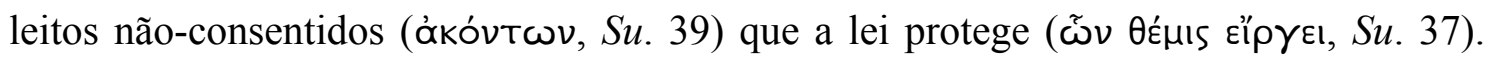

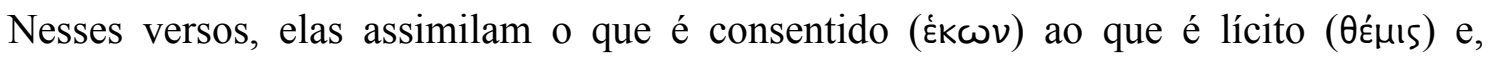

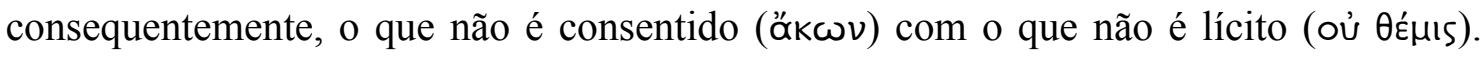
Dessa forma, o seu ódio ( $E^{\prime} \chi \rho \alpha$ ) advém de uma união que se pretende alcançar sem consentimento e, por isso mesmo, de seu ponto de vista, ilícita. Elas assim apagam as fronteiras entre o que é particular - o não-consentimento seu e de seu pai a esse casamento - e o que é geral - os costumes, as vigências, as leis.

Pelasgo então aborda a questão do ponto de vista da piedade, perguntando:

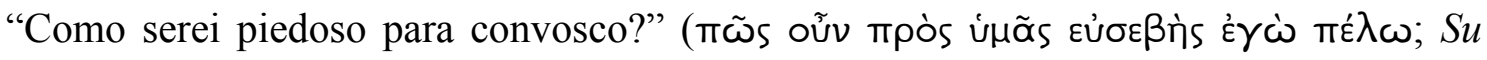

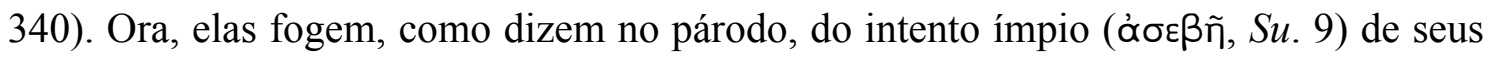

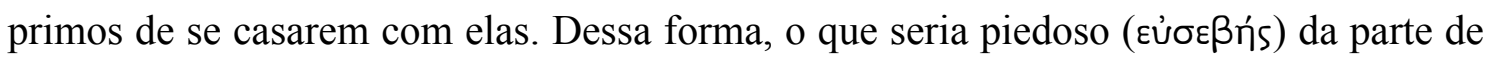
Pelasgo para com elas seria não entregá-las a seus perseguidores, como elas respondem:

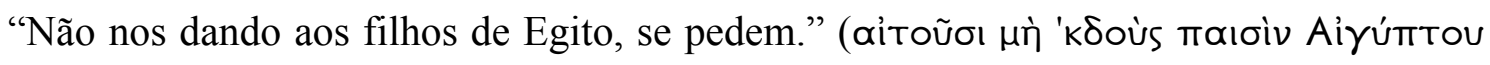
то́ $\lambda ı$ เ Su. 341).

Não entregá-las aos Egipcíades implica, no entanto, começar uma nova guerra e

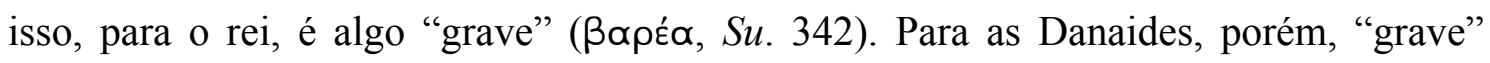

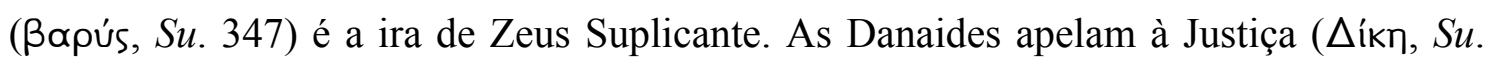
343), dizendo que esta defende os seus aliados, o que pressupõe que a Justiça está a seu

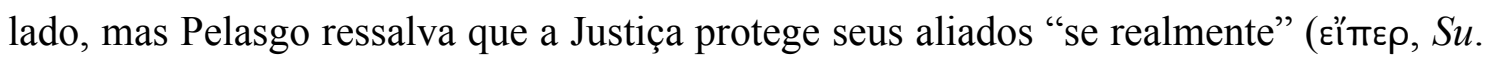
344) participa do princípio em causa, isto é, se houver realmente justiça na rejeição das Danaides ao casamento com seus primos.

Respondidas as duas questões fundamentais - como é possível que as Danaides se declarem argivas e pelo que suplicam junto ao altar dos deuses - o rei Pelasgo vê-se confrontado com um terrível dilema e reconhece nos ramos de suplicantes, que cobrem 
os altares dos deuses, a sua ambiguidade ominosa: "Estremeço ao ver estes altares

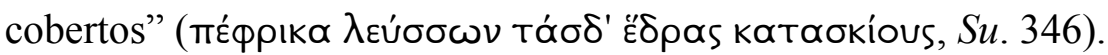

Diante das reiteradas súplicas das Danaides, Pelasgo adverte-as de que não estão a suplicar junto à sua lareira, mas sim junto a um altar público, de modo que não se trata de algo que ele possa decidir sozinho, uma vez que as consequências de sua decisão dizem respeito a todo seu povo. As Danaides respondem de forma a apagar as fronteiras entre o indivíduo Pelasgo, detentor do poder real, e o povo e cidade que ele representa na condição de rei. Elas dizem a Pelasgo: "Tu és a cidade, tu és a população" (бú Tol

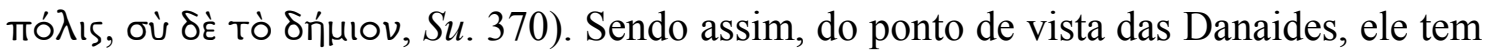
todo o poder necessário para decidir sozinho como lhe aprouver, já que não está sujeito à prestação de contas, de forma que cabe a ele somente evitar a poluência. À menção da palavra poluência (åyos, Su. 375), que agora se configura como uma possibilidade real para ele e sua cidade, o rei procura afastar o mau agouro com uma frase de caráter

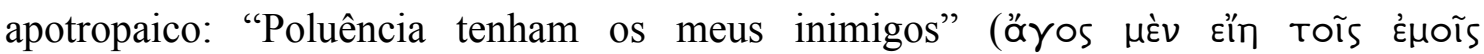

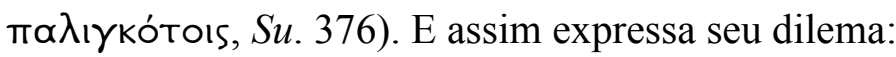

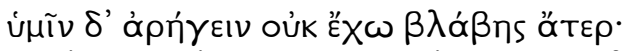

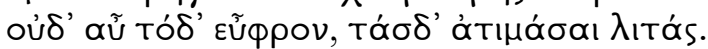

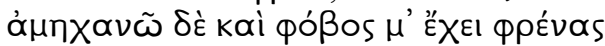

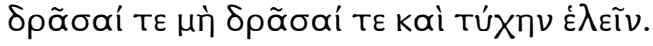

Não posso defender-vos sem dano, nem é prudente desprezar as preces. Perplexo, e pavor me toma o espírito, por agir e por não agir e pela sorte.

(Su. 377-80)

A resposta das Danaides à aporia do rei é novamente um apelo à ira de Zeus Suplicante, que, dizem elas, abate-se sobre os mortais que não alcançam a "legítima

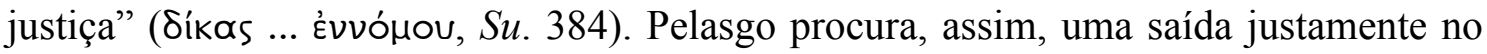

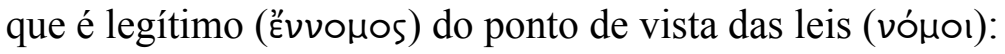

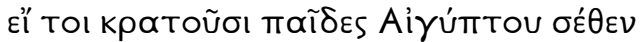

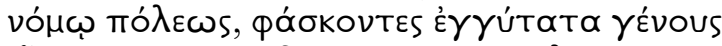

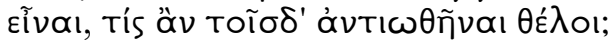

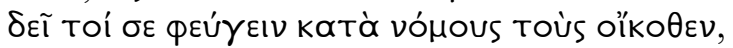

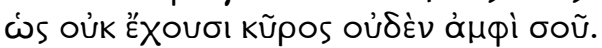

Se os filhos de Egito têm poder sobre ti, por lei civil, como parentes próximos, quem poderia contrapor-se a eles? Deves alegar, conforme leis pátrias, que eles não têm autoridade sobre ti.

(Su. 387-91)

As Danaides, no entanto, evadem-se uma vez mais de responder uma pergunta concernente à licitude e à legalidade de sua oposição à união com os Egipcíades. A sua resposta consiste em expressar o desejo de nunca ser submetida ao poder dos varões e demandar ao rei que, tomando a Justiça como aliada, decida em favor da veneração 


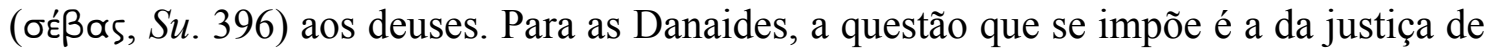
Zeus; não se trata de interpretar as leis civis. Pelasgo, porém, insiste que ele não pode ser tomado como juiz nessa causa sem que seu povo participe da decisão; assim, ainda

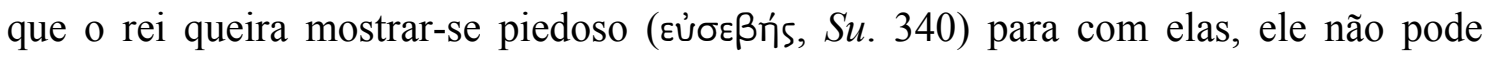
subtrair-se ao seu dever cívico de consultar os argivos quanto ao curso da ação. Mas as Danaides voltam a expressar o ponto de vista de que a justiça está do seu lado, dizendo

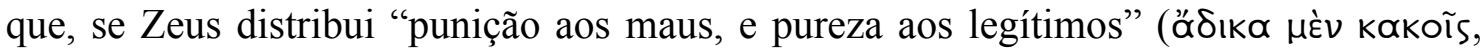

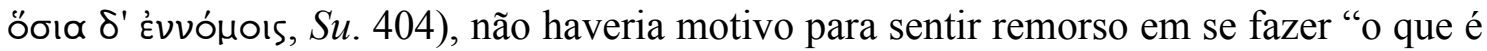

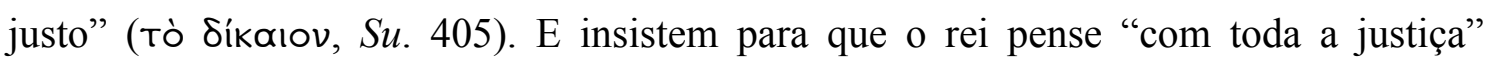

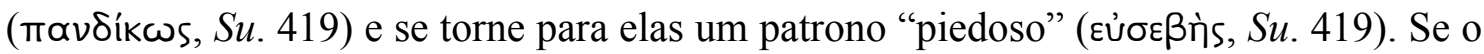
rei pretende guardar-se da cólera divina, é necessário que ele reconheça $(\gamma \nu \tilde{\omega} \theta$ ı, $S u$. 426) a transgressão viril (ưßpıv ơvépwv, Su. 426), não permitindo que elas sejam arrastadas de junto das imagens dos deuses "contra justiça" (ßíạ Síkas, Su. 430), pois

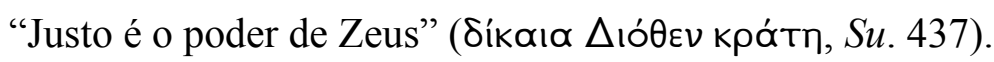

O dilema de Pelasgo é um dilema que está intimamente relacionado com a questão da justiça, como torna evidente tanto a insistência das Danaides de que sua causa é justa quanto a sua insistência na hýbris de seus perseguidores, a que elas se referem oito vezes ao longo do drama ${ }^{23}$.

Desvendar, pois, o enigma das Danaides implica saber o que é mais justo, mas,

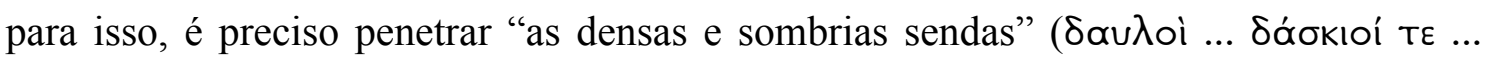
Tópoı, Su. 89-90) do pensamento de Zeus, que "se prolongam imperscrutáveis" (твívovoiv ... ä́paotol, $S u$. 90). Por isso, Pelasgo permanece imobilizado ante o

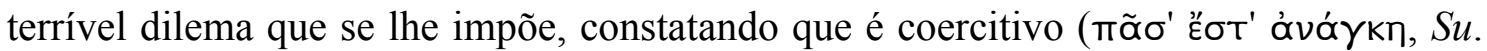
440) travar uma guerra seja com uns, os deuses, seja com outros, os Egipcíades. Pondera o rei que, para a perda de propriedades ou para palavras inoportunas, há

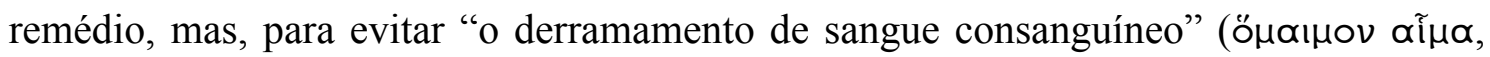
Su. 449), deve-se fazer muitos sacrifícios a muitos deuses.

Do ponto de vista de Pelasgo, derramar sangue consanguíneo significa derramar sangue de seus concidadãos argivos em uma guerra contra os Egipcíades ${ }^{24}$, mas há um sentido outro, numinoso, para esse derramamento de consanguíneo sangue: a morte dos

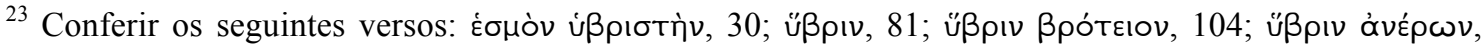

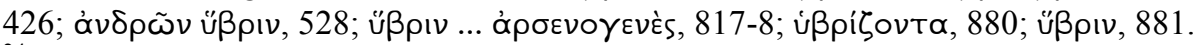

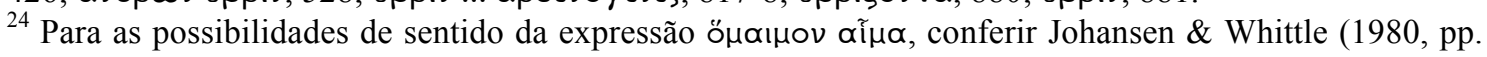
354-6, vol. II); Belfiore (2000, p. 42); Bednarowski (2009, p. 289).
} 
Egipcíades às mãos de suas primas. Esse sentido numinoso, que se imiscui na fala de Pelasgo, recobre seu dilema de uma tragicidade ainda mais excruciante, pois, ainda que, ao final, ele evite a poluência suscitada pelo desprezo à sacralidade das súplicas, não será capaz de evitar, no futuro, a poluência suscitada pelo crime que será cometido por essas mesmas suplicantes.

Para tentar mobilizar o rei e tirá-lo de seu impasse, as Danaides decidem dar um passo a mais. Lançam então ao rei um enigma para ele desvendar, dizendo "Tenho cintos e laços, atavios de mantos" ( $S u$. 457). O rei não percebe mais do que o sentido imediato dessas palavras e responde comentando apenas que devem ser convenientes às mulheres. Elas então entregam uma primeira pista para a solução do enigma, ao

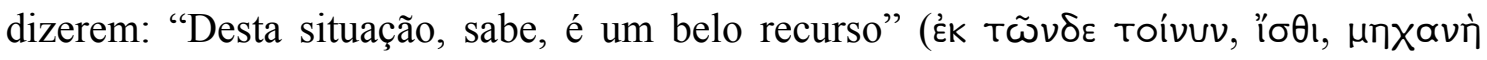
к $\alpha \lambda$,,$S u$. 459). Os cintos e os laços, que em seu uso ordinário são convenientes para o vestuário feminino, como observou o rei, tornam-se assim um "belo recurso" ( $\mu \eta \chi \propto$ ๆ̀ k $\alpha \lambda$ ń) para que saiam da difícil situação em que se encontram, através do uso extraordinário que deles as Danaides ameaçarão fazer. Tal recurso, porém, será "belo" ( $\propto \alpha \lambda$ ) para elas, que assim conseguirão coagir o rei, mas não será nada belo para Pelasgo.

O rei, no entanto, ainda não desvendou o enigma, mas agora já percebe que está diante de algo enigmático e de que precisa de mais informação: "Diz, que palavra aqui

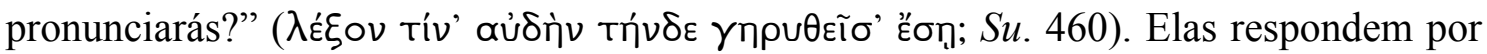
meio de uma oração condicional, mas exprimem apenas a prótase - "Se não prometeres

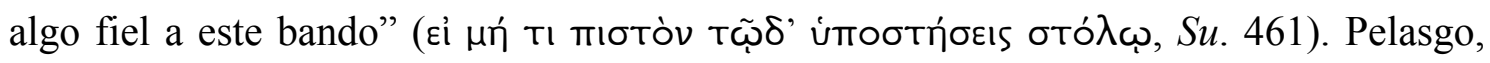
então, aproxima-se do cerne do enigma: "De que te serve o recurso dos cintos?" ( тí бo।

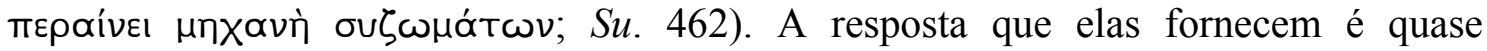

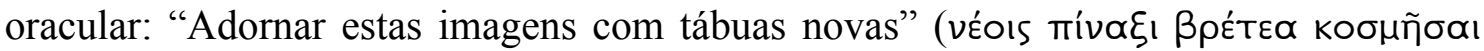

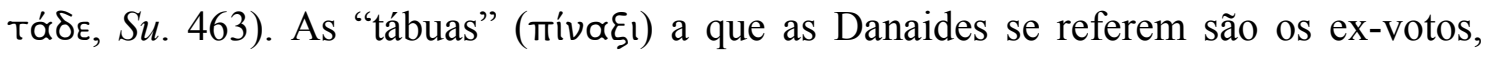
costumeiramente colocados juntos às estátuas dos deuses. Seus corpos, no entanto, é que, pendurados das estátuas como ornamentos, serão ex-votos "novos" (véols), isto é, inesperados. Pelasgo então reconhece a qualidade oracular de suas palavras -

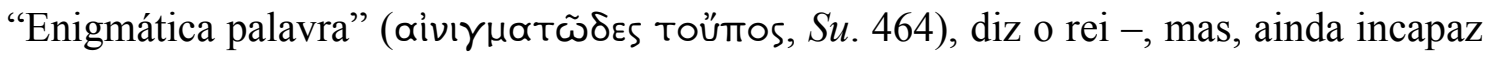

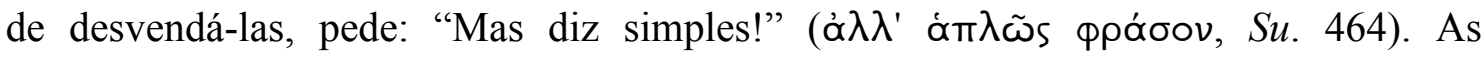
Danaides, então, desvelam para o rei o enigma: "Destes Deuses, rápido, enforcar-nos"

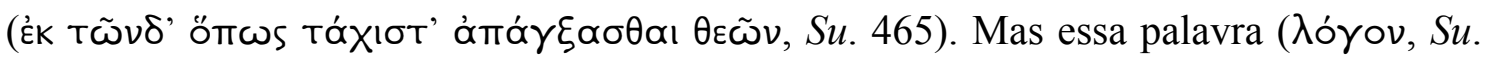


466), dita simplesmente, é perturbadora e fustiga o coração do rei. E é pela reação de

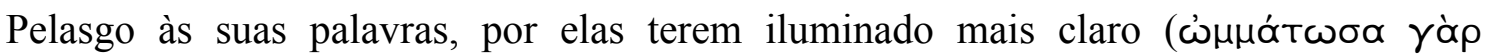

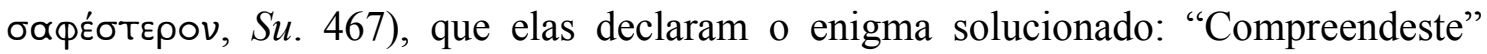

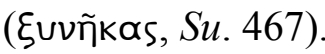

A ameaça de suicídio, anteriormente feita a Zeus mesmo, no párodo (Su. 15462), configura-se como um recurso coercitivo extremo. A esse mesmo expediente recorreram, segundo Heródoto (VII, 140), os teoros atenienses quando, ante a iminência da invasão persa, receberam do oráculo de Delfos uma resposta não propícia. Fizeram então uma nova consulta ao oráculo, dessa vez na qualidade de suplicantes, dirigindo as seguintes palavras ao deus:

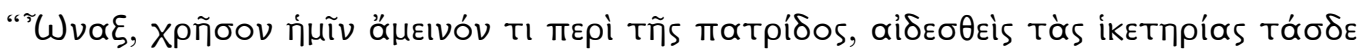

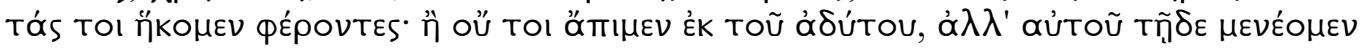

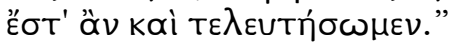

"Dá-nos, Senhor, uma resposta mais favorável a respeito de nossa pátria em atenção aos ramos de suplicantes com os quais aqui viemos a ti, ou então não sairemos do lugar santo e ficaremos aqui até morrer!"25

Foi-lhes, então, entregue um segundo oráculo, mais propício, evidenciando-se, assim, que os teoros atenienses, mediante a ameaça de causar uma terrível poluência no templo de Apolo, lograram persuadir o deus. Parece tratar-se assim de um recurso legítimo do ponto de vista da piedade grega. Porém, enquanto os teoros atenienses recorreram a esse expediente para salvar a sua cidade da ameaça de destruição pelos persas, as Danaides, ao recorrerem a um expediente semelhante, estão na verdade colocando em risco a cidade de Argos e seu povo, seja mediante a poluência de seu suicídio coletivo, seja mediante uma guerra contra os Egipcíades. E trata-se de uma cidade e de um povo com os quais elas invocam um vínculo ancestral. Nesse sentido, como observa Murray $(1958$, p. 80$)$, "the Danaids are as great a danger to the state as are the Egyptians".

As Danaides logram persuadir o rei, mas não por tê-lo convencido da justiça de sua causa e sim porque elas ameaçam sua cidade com uma poluência que, ao ser

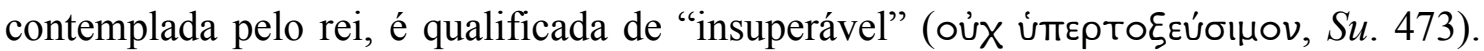
Desequilibram-se, portanto, os pratos da balança e a relação entre suplicante e suplicado se desconfigura, uma vez que elas passam a ter poder sobre o rei. Há, dessa forma, algo

\footnotetext{
${ }^{25}$ Tradução de Mário da Gama Kury (1988, 2ª . ed.).
} 
de hybristés na ameaça das Danaides e, como elas mesmas dizem, os deuses têm horror à hýbris (Su. 79-71).

Ante essa ameaça das Danaides, Pelasgo é forçado a reconsiderar os termos de seu dilema. O suicídio das cinquenta jovens junto às estátuas dos deuses traria uma

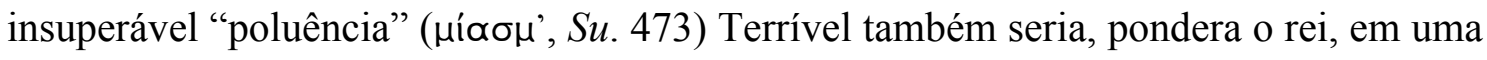

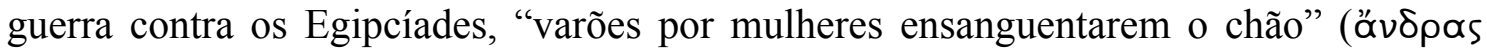

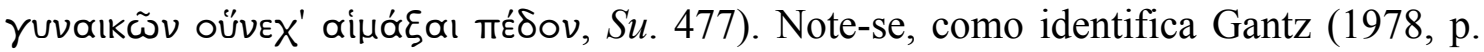
282-3), a ambiguidade ominosa desse verso: o rei pensa nas Danaides como a causa indireta do derramamento de sangue de varões; porém, seu papel há de se mostrar muito mais efetivo, uma vez que varões irão morrer não somente por sua causa, em uma guerra inevitável contra os seus perseguidores, mas também por suas próprias mãos, quando elas assassinarem os Egipcíades em sua noite de núpcias. A ameaça das Danaides é, assim, tão ambígua quanto a sua condição de suplicantes, pois, assim como elas agora se mostram dispostas até mesmo a morrer para evitar as núpcias com seus primos, elas se mostrarão, no porvir, dispostas até mesmo a matar para evitar essas mesmas núpcias. Como observa Belfiore (2002, p. 42), “This threat of suicide [...] has a function in the characterization of the Danaïds, revealing the intensity of their fears and showing them to be capable of violent acts". Igualmente, para Johansen \& Whittle (1980, p. 37, vol. I), as repetidas ameaças de suicídio são, além de um sinal de seu desespero, "an inverted presage of their future crime".

Reconsiderados os termos de seu dilema, sob o jugo da coerção, o rei constata

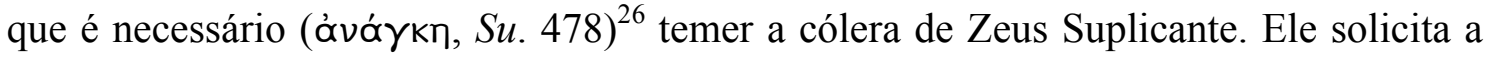
Dânao que deposite os ramos de suplicantes em outros altares públicos, de modo a dar a conhecer a súplica a todos os cidadãos. Ao ver os ramos, estes se apiedariam e poderiam

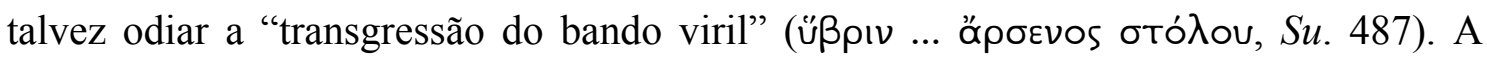
hýbris dos Egipcíades, reiteradamente apontada pelas Danaides, surge pela primeira e única vez reconhecida pelo rei, tal como as Danaides lhe haviam demandado:

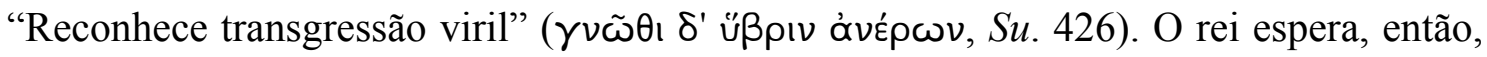
que também o seu povo a reconheça e, reconhecendo-a, odeie-a.

Dânao, dizendo ter encontrado no rei Pelasgo um patrono "reverente" ( $\alpha i$ Soĩov, $S u .491)$, solicita ao rei uma escolta para dirigir-se aos altares públicos, de modo que ele possa andar pela cidade com segurança, já que sua aparência, tão diversa da dos argivos,

\footnotetext{
${ }^{26}$ Conferir "Remarques sur le 'nécessaire' et la 'nécessité' chez Eschyle", artigo de A. Rivier (1968, pp.
} 17-8). 
poderia fazer com que, por temor, alguém o matasse, ignorando tratar-se um amigo. A sua aparência, diz Dânao, condiz com a estirpe que o Nilo produz. A sua ousadia (Өpóoos, Su. 498) - que, em seu caso, significaria adentrar sozinho a cidade e aproximar-se dos altares públicos - poderia produzir "pavor" (фóßov, Su. 498) e, assim, alguém (TIS, Su. 499), por ignorância (ởyvoías üno, Su. 499), poderia matar um "amigo" ( mesma aparência têm os Egipcíades, também eles cria da terra do Nilo. A sua ousadia a de pretenderem unir-se com suas primas contra a sua vontade - causa pavor na Danaides, que, não por ignorância, irão elas mesmas matar não apenas um amigo, mas seus parentes próximos, seus maridos.

Pelasgo então instrui as Danaides a se voltarem para o bosque, deixando junto

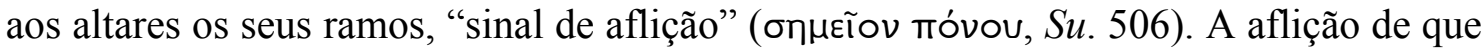
os ramos se fazem sinal não diz respeito apenas à condição das Danaides como

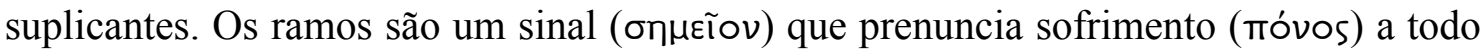
o povo argivo. A guerra se impõe no horizonte dos acontecimentos e, a cada nova alusão, torna-se cada vez mais inelutável (Su. 341-3; 410-3; 439-40; 474-7; 740; 934-7; 950).

Temendo abandonar seu local de súplica, Pelasgo assegura-lhes que estarão

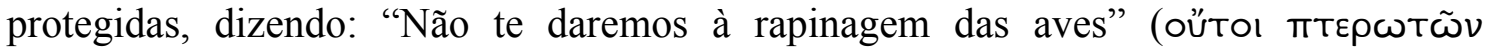

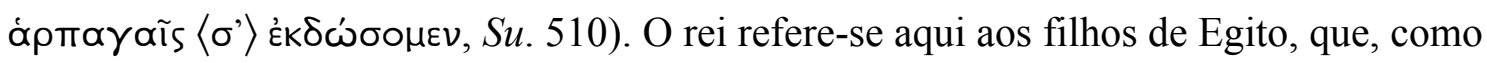

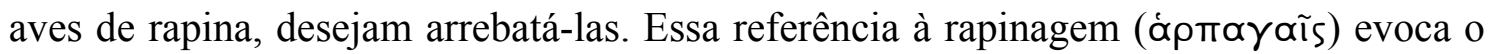

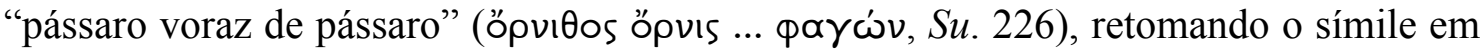
que as Danaides são comparadas a um bando de pombas perseguidas por gaviões, os Egipcíades. Lá, elas, frágeis pombas, buscavam refúgio nos altares dos deuses; aqui, Pelasgo lhes assegura que elas não mais precisam do altar como proteção, pois ele e seu povo são agora o seu refúgio. E, na pergunta subsequente das Danaides - "Mas, se a

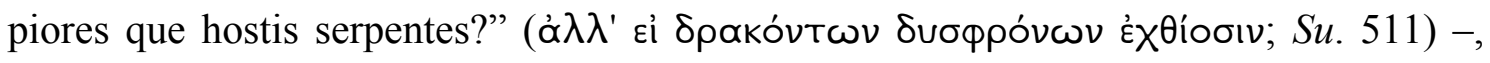
evoca-se a história do médico-adivinho Ápis, que no passado eliminou a "hostil

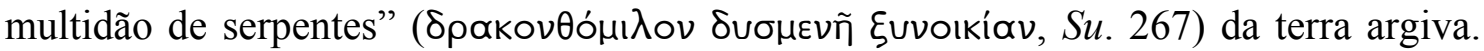
Outrora, foi preciso a intervenção desse filho de Apolo para combater as serpentes com seus remédios (đåkn, Su. 268; 367); agora, é a Pelasgo e a seu povo que cabe essa difícil tarefa de, em conjunto, encontrar remédios (ăkn, Su. 367) para essas novas serpentes que a qualquer momento trarão os cruores da guerra. Pelasgo, no entanto, precisa 


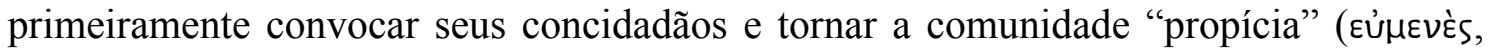
$S u$. 518). Propícia também deve ser a fala das Danaides, de forma que ele recomenda às

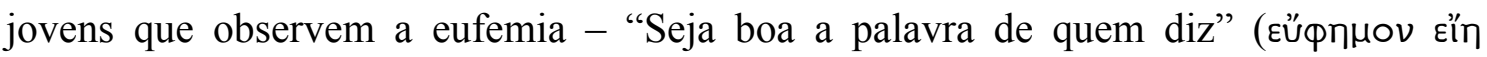

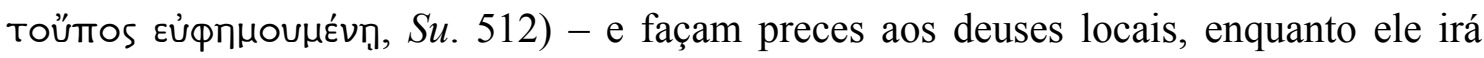
instruir Dânao a falar de forma conveniente aos argivos.

\section{3) Prece e prenúncio}

O rei, ao final do primeiro episódio, instrui as Danaides a fazer preces aos

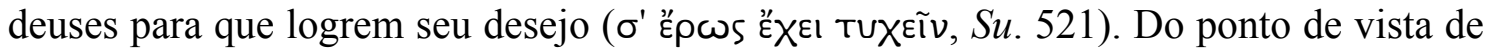
Pelasgo, o desejo das Danaides é o de que lhes seja concedido o asilo e, como isso depende do que for decido na assembleia argiva para onde ele e Dânao se dirigem, parece-lhe acertado que as jovens dediquem suas preces aos deuses locais. No entanto, em vez de fazer preces aos deuses locais, as Danaides dirigem suas preces a Zeus. Isso parece apontar para o fato de as Danaides desejarem mais veementemente outra coisa. Lembre-se do caso de Odisseu, disfarçado, em seu próprio palácio: após expulsar o impertinente mendigo Iro, os pretendentes lhe desejaram que Zeus e os demais deuses lhe concedessem o que fosse mais caro ao seu coração. Odisseu alegrou-se com esse kledón, que prenunciava a morte dos pretendentes, pois isso era o mais caro ao seu coração $^{27}$. Do mesmo modo, o mais caro ao coração das Danaides é a morte dos seus perseguidores. Isso é o que elas pedem a Zeus em suas preces.

Assim, no primeiro estásimo, as jovens invocam o deus para que se deixe persuadir e repila com horror a transgressão (ưß lançando a sua nau no mar purpúreo. As Danaides reiteram, dessa forma, o pedido feito no párodo de que os Egipcíades pereçam durante sua travessia marítima:

\section{(...) $\alpha^{\alpha} \rho \varepsilon v o \pi \lambda \eta \theta \tilde{\eta} \delta$

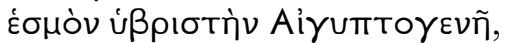

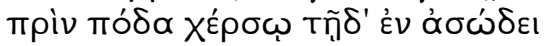

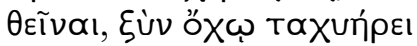

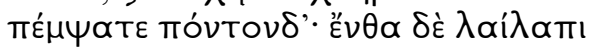

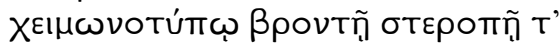

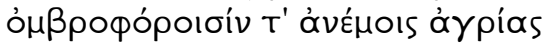

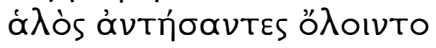

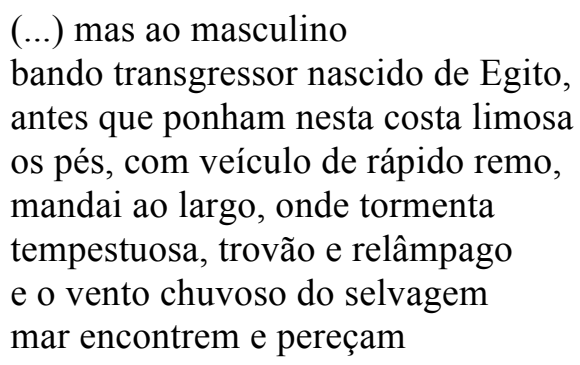
mandai ao largo, onde tormenta tempestuosa, trovão e relâmpago e o vento chuvoso do selvagem mar encontrem e pereçam

(Su. 29-36).

\footnotetext{
${ }^{27}$ Conferir Homero, Od. XVIII, 112-7.
} 
Aqui, também a hýbris dos Egipcíades aparece como argumento das Danaides para pedirem ao deus que naufraguem. A nau dos Egipcíades é descrita como "a erronia

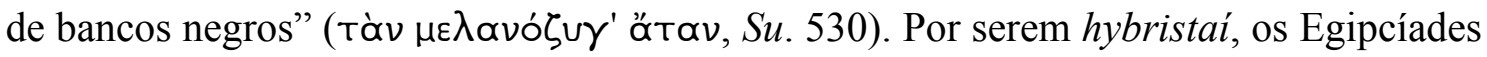
encontram-se sob o domínio da áte. É a áte que conduz os navios de bancos negros, que vem em perseguição sobre os bancos negros. Ora, o resultado da áte, essa cegueira moral que leva o homem a agir contra seus próprios interesses por não ser capaz de percebê-los, é a ruína. Dessa forma, ao virem ao encalço das Danaides, os Egipcíades caminham para sua própria morte. Essa ruína aqui se prenunciaria por um kledón. De

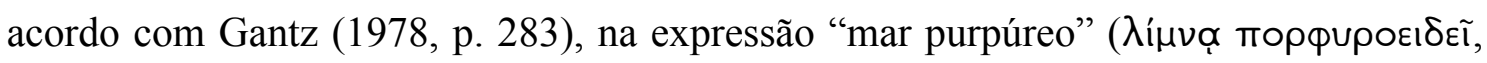
$S u$. 529), o termo $\lambda i ́ n v \eta$, traduzido por "mar", significa igualmente "água parada", "lago", "poça"28. Assim, para o autor, nessa ambiguidade reside um prenúncio: os Egipcíades não irão se afogar no mar e chegarão ilesos a Argos, como se vê no quarto episódio, mas no porvir cairão na poça purpúrea de seu próprio sangue.

Esse pedido reiterado de que os Egipcíades morram em sua travessia pelo mar pode ser visto, como aponta Berdnarowsky (2009, p. 257-8), não como um último esforço para escapar de seus perseguidores, "but as an indication of the Danaids' deepseated desire to see them dead", o que revelaria um aspecto violento do caráter das Danaides. O autor faz, no entanto, uma ressalva, lembrando que o Coro de mulheres nos Sete contra Tebas também pede aos deuses que os atacantes argivos morram ( $S e .312-7)$ e nem por isso se considera que as mulheres tebanas tenham algum potencial para atos violentos. Deve-se considerar, no entanto, que o Coro nos Sete deseja a morte dos inimigos para que toda a cidade seja salva, isto é, para o bem de um destino coletivo, e esses inimigos são estrangeiros com os quais elas não têm nenhum grau de parentesco. Em contrapartida, as Danaides desejam a morte de pessoas próximas, conterrâneas e consanguíneas, para o bem de um destino particular, o seu próprio.

Que destino as Danaides contemplam? O assassínio de seus maridos está, no momento, completamente fora de seu horizonte. Antes de saber se o exílio lhes foi concedido pelo povo argivo, as jovens vislumbram apenas duas possibilidades para escapar do casamento com seus primos: morrerem eles no mar ou morrerem elas enforcadas. Que eventos, que palavras, que golpes do destino fazem-nas desposar os

\footnotetext{
${ }^{28} \mathrm{Na}$ obra supérstite de Ésquilo, o termo tem, na maioria das ocorrências, o sentido de "lago". Conferir Italie (1964, p. 168).
} 
Egipcíades e assassiná-los depois, é impossível saber; tais respostas perderam-se juntamente com as duas outras tragédias que compunham a trilogia esquiliana.

Há, no entanto, um destino que elas procuram emular: o de sua ancestral Io. A emulação chega ao ponto da identificação. As Danaides chegam aos "relvosos prados"

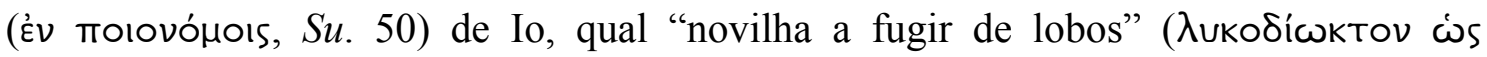

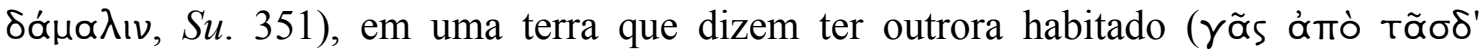
Ëvoıkol, Su. 537); elas se denominam um miserável "rebanho" (тоíuvav, Su. 642) ${ }^{29}$. Essa identificação se explica tanto por uma necessidade piedosa de obter a benevolência

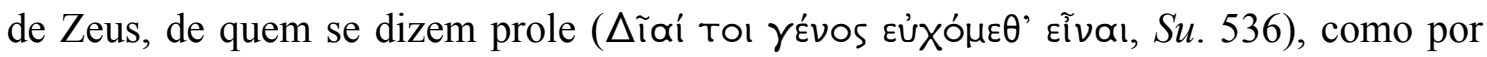
uma necessidade política de obtenção de asilo junto ao povo argivo, terra mãe de Io, para, desse modo, conseguirem escapar da indesejada união com os Egipcíades.

Para Murray (1958, p. 73), o mito de Io é utilizado por Ésquilo como uma alegoria através da qual se prenunciaria o destino das Danaides:

The prophetic Io imagery performs the function of foreshadowing events to occur in the Egyptians and Danaids; more important, it provides one of the keys to correct interpretation of the trilogy, since in some cases it foreshadows not only events but the development of motives and character.

Embora os paralelos entre Io e as Danaides sejam reconhecidos - a existência de pretendentes desejosos dessas virgens, a travessia por longas distâncias, a relação entre Argos e o Egito, o sofrimento das jovens -, a proposta de Murray encontrou a objeção de vários autores pelo fato de ele identificar a relação permeada de violência entre os Egipcíades e as Danaides com a relação entre Zeus e Io, que, nas Suplicantes, não se caracteriza pela violência e sim pela benevolência ${ }^{30}$.

É para esse aspecto benevolente de Zeus que as Danaides se voltam em suas preces. Assim, evocando a ancestral amizade entre Zeus e Io, as Danaides, já que são suas descendentes, pedem que o deus lhes seja igualmente benéfico, renovando, através delas, sua benevolência para com Io. Elas então descrevem o itinerário das errâncias de Io, desde Argos até à terra banhada pelo Nilo, como se elas o tivessem percorrido ao

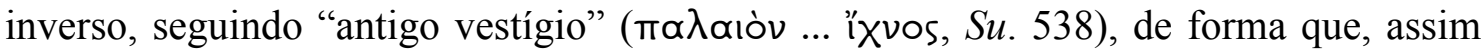
como Zeus, com seu toque libertador, pôs fim ao sofrimento de Io, o deus possa

\footnotetext{
${ }^{29}$ Para um meticuloso estudo sobre as imagens associadas ao mito de Io nas Suplicantes, conferir a obra de Murray (1958).

${ }^{30}$ A esse respeito, conferir Belfiore (2000, pp. 47-9); Bednarowsky (2009, pp. 266-8).
} 


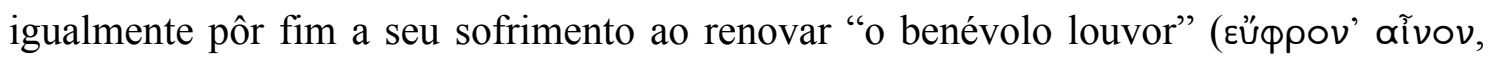
Su. 534).

O benévolo louvor de Zeus para com Io deu-se através da união sexual e da procriação. Io, em Argos, era uma virgem sacerdotisa de Hera. Ao ser pretendida por Zeus e ao, unindo-se com o deus, despertar o ciúme de Hera, foi forçada a abandonar sua terra natal e, em suas andanças, chegou ao Egito. Lá, os habitantes da região foram

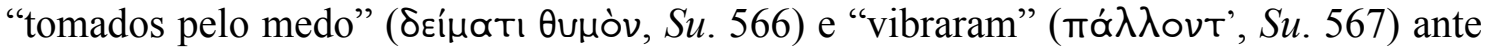

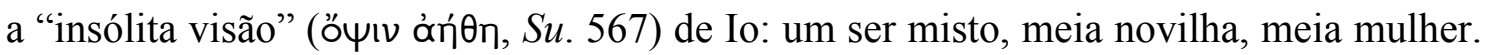
Ficaram "admirados do prodígio" (тépas $\delta$ ' żดáußouv, Su. 570), essa rês "difícil de

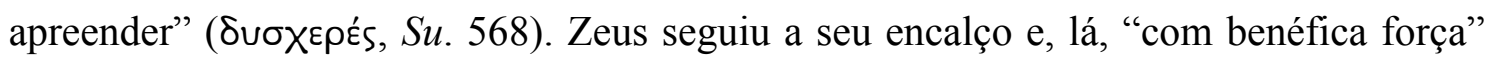

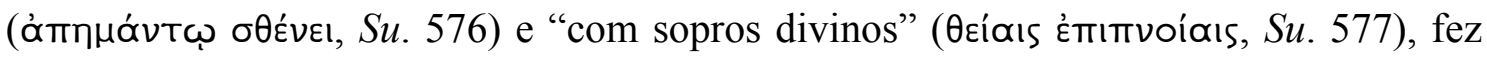
cessar seu pranto, unindo-se a ela. Dessa união frutífera, nasceu Épafo.

O renovado benévolo louvor por que as Danaides pedem é o de, acolhidas as súplicas pelos argivos, não serem forçadas a desposar os Egipcíades, isto é, não serem forçadas à união sexual e à consequente procriação. Elas, como dizem, percorrem o caminho inverso de Io. No Egito, são pretendidas por seus primos; para fugir deles, foram forçadas a abandonar sua terra natal e, atravessando o mar, chegam a Argos. A

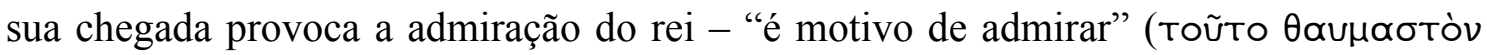

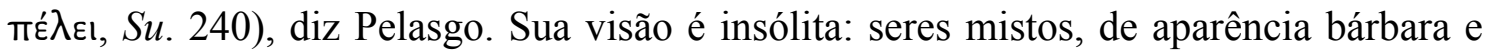
declarada origem argiva. Suas palavras são "incríveis" (ơmıota, Su. 277); elas são um

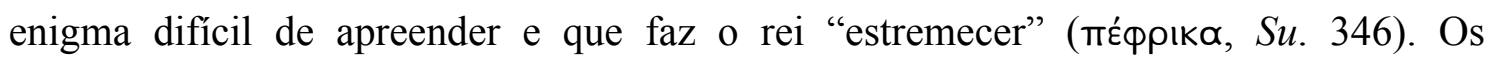
Egipcíades seguem a seu encalço e, não se podendo determinar se pela força ou se pela persuasão, unem-se a elas. Mas se trata de uma união infrutífera: ao invés de uma nova vida, a morte.

Se, portanto, de alguma forma, há algum prenúncio na história de Io, esse diz respeito ao destino que, se não esta tragédia, o mito reserva a Hipermnestra. Ela não se negará à união sexual e à procriação; sua união com Linceu será frutífera: dela nascerá a prole real de Argos. Quanto às demais Danaides, a história de Io seria, para utilizar a expressão de Johansen \& Whittle, “an inverted presage”, como inverso é o caminho que elas percorrem.

No segundo episódio, Dânao entra em cena anunciando a resolução do povo argivo. Reunidos em assembleia e persuadidos pelo argumento do rei Pelasgo de que, por temor à ira de Zeus Súplice, fossem evitados os males suscitados por uma poluência 


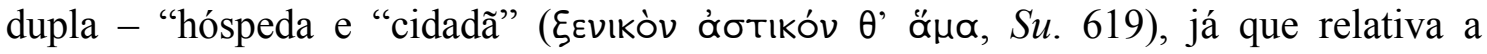
hóspedes descendentes de ancestrais comuns -, os cidadãos argivos, em unanimidade, ergueram sua mão direita, decretando, assim, que se conceda asilo às Danaides. Ante a boa nova, as Danaides propõem-se pronunciar preces benéficas aos argivos, que elas

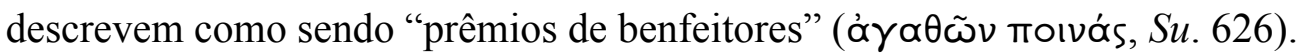

Nessa descrição que se faz das preces como prêmios, manifesta-se um kledón: o termo traduzido por "prêmios" (moıvás), como observa Torrano (2009, pp. 236-7), tem também o sentido de "pena", "punição", além de dar nome a uma figuração do divino, a deusa Punição ${ }^{31}$. Essas preces, ditas benéficas e a benfeitores, são, do ponto de vista das Danaides, uma recompensa ao povo argivo pelo benefício que lhes foi concedido. No entanto, do ponto de vista divino, a recompensa que elas trarão a seus benfeitores será a guerra e a poluência suscitada pelo crime contra seus primos - uma dupla poluência, hóspeda e cidadã -, e são essas "penas" que aqui se prenunciam.

Essa descrição das preces com o ambíguo termo moıvaí é significativa. $\mathrm{O}$ segundo estásimo é composto por essas preces ditas "penas"; assim, as preces das Danaides aos argivos revestem-se da mesma ambiguidade ominosa que o termo que as descreve: constituem-se, do ponto de vista das Danaides, do pedido de prêmios a seus benfeitores, mas, do ponto de vista divino, constituem-se de prenúncios das penas que esses benfeitores sofrerão. As preces por bens, sob esse aspecto, tornam-se prenúncio de males $^{32}$.

Assim, invocando os deuses filhos de Zeus, as Danaides pedem que Ares não destrua a terra pelásgia:

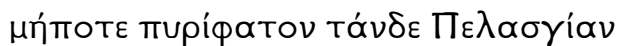

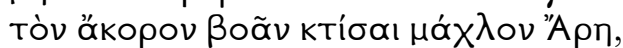

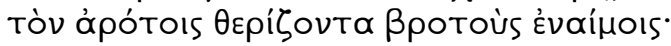

nunca incendeie a terra pelásgia lúbrico Ares insaciável de gritos, ceifeiro de mortais nas lavras de sangue

(Su. 634-6)

Nessa imagem, o deus que se manifesta na carnificina é descrito como "lúbrico

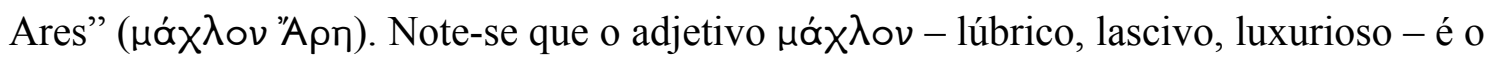
mesmo que, em Hesíodo, descreve a excitação sexual que acomete as mulheres no

\footnotetext{
${ }^{31}$ Para moıvń com o sentido de "pena", "punição", conferir, em Ésquilo, os seguintes versos: Ag. 1223, 1340; Co. 936; Eu. 203, 464, 543, 981; Pr. 112, 176, 223, 268, 620, 564. Para Пoเvท́ como nome de uma

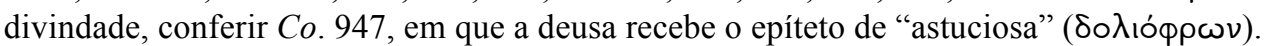

32 Turner (2001, p. 36) observa que muitos comentadores percebem, nesse canto das Danaides pelos argivos, "an ironic foreshadowing". Conacher (1996, pp. 94-5) fala de "sinister ironies" e de "hidden ironies" imiscuindo-se nessa ode. Conferir Murray (1958, pp. 79-80).
} 
verão, quando, diz o poeta, "as mulheres são mais ardentes e os homens, mais

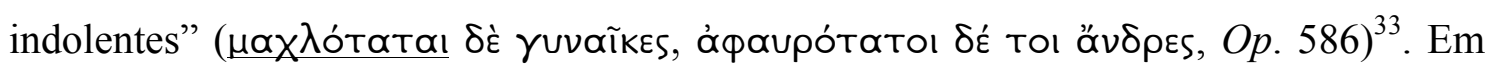

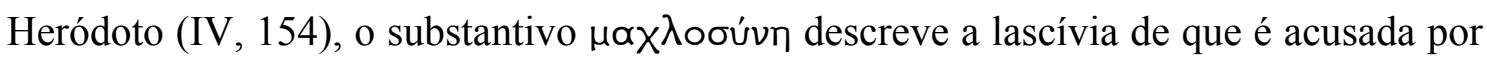
sua madrasta a jovem Fronime, que viria a ser mãe de Bato, rei da Líbia. Além disso, o termo traduzido por "lavras" (ápótoıs) tem o sentido metafórico de união sexual e procriação. É esse sentido que, no Crátilo (406b), ao falar sobre o nome da deusa Ártemis, Platão emprega para dizer que a deusa "odeia a geração de filhos do homem na

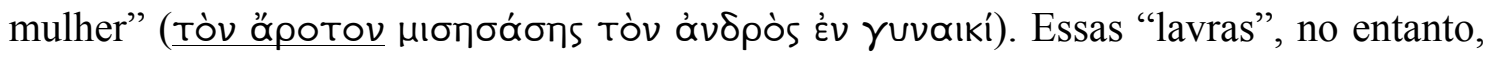
são aqui ditas "de sangue" (Évaínoıs), o que remete ao deus cujo epíteto, desde Homero,

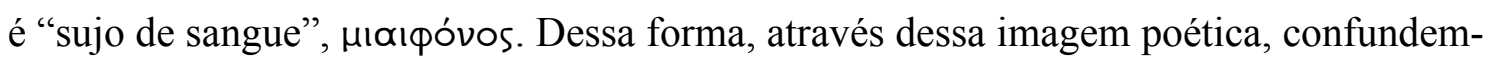
se os domínios de Ares e Afrodite.

Trata-se assim de uma imagem poética que prenuncia a guerra que se travará por desejo de núpcias e, ao mesmo tempo, as sangrentas núpcias das Danaides, visto que na noite de núpcias, os noivos participam de Afrodite através da excitação e da união sexual, mas, na noite de núpcias das Danaides, as jovens, recusando os dons de Afrodite, participarão de Ares através do sangrento massacre de seus maridos ${ }^{34}$. Note-se que, no Prometeu Cadeeiro, o morticínio dos Egipcíades é descrito como uma epifania

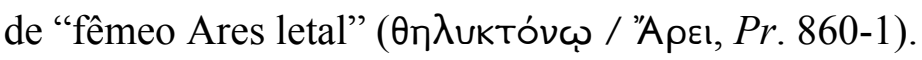

Isso - que Ares não destrua a terra pelásgia - as Danaides dizem pedir "porque" (oüVEk', Su. 639) os argivos honraram Zeus ao acatarem suas súplicas e votarem favoravelmente à sua causa. Assim, à causa - honra a Zeus Suplicante - segue-se o efeito - a ausência de Ares ${ }^{35}$. Mas, sob o ponto de vista do sinal divino que se manifesta através da imagem poética com que se descreve o deus da carnificina, o efeito será exatamente o oposto: a presença de Ares em terra pelásgia, seja sob a forma da guerra entre argivos e Egipcíades, seja sob a forma do assassínio cometido pelas Danaides.

As Danaides prosseguem, dizendo que, ao terem acatado as suplicantes de Zeus

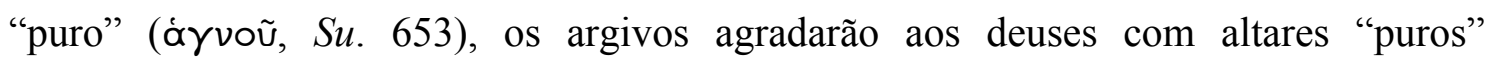
(k $\propto \theta \propto \rho o \tilde{\sigma}, S u$. 654). Esse reforço no caráter imaculado tanto de Zeus quanto dos altares dos deuses, precede o pedido das jovens de que a cidade não seja maculada pela peste, nem pelo derramamento de sangue, nem pela ação de Ares.

\footnotetext{
${ }^{33}$ Tradução de Luiz Otávio Mantovaneli (2011).

${ }^{34}$ Conferir Gantz (1978, p. 285); Conacher (1996, p. 94); Bednarowsky (2009, p. 318).

${ }^{35}$ Belfiore (2000, p. 46) observa que "The blessings of all the gods, and of Zeus in particular, will not be given merely as answers to the Danaïds' prayers but will follow as effect from cause".
} 
Pedem as Danaides que "nunca a pestilência esvazie / de varões esta cidade"

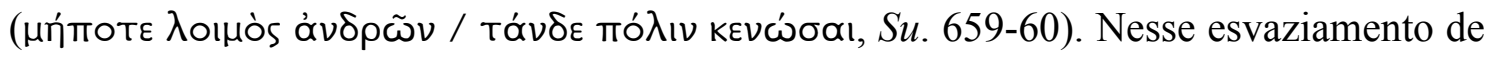
homens da cidade, Gantz (1978, pp. 284-5) identifica uma ambiguidade a prenunciar o assassínio praticado pelas Danaides no porvir: não será a peste que esvaziará a cidade de homens, mas as Danaides esvaziarão a cidade de certos homens. Murray (1958, pp. $31 ; 80)$ divisa uma outra ambiguidade nessa oração: o substantivo ơ $v \delta \rho \tilde{\omega} v$, genitivo de

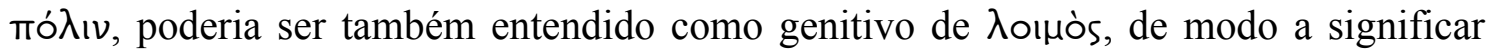

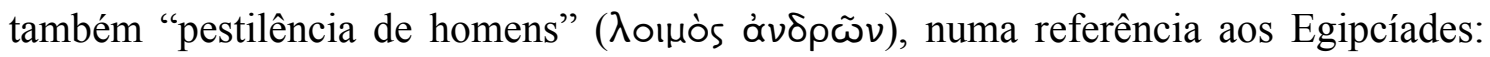
eles seriam uma pestilência de homens que, trazendo a guerra, esvaziariam a cidade de

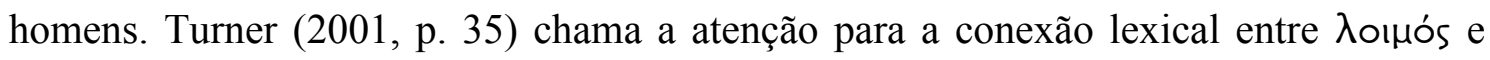
$\lambda$ ũ $\alpha$, um sinônimo de $\mu$ ía $\sigma \mu \alpha$, e para o fato de que, como instrumento de punição divina, a peste e a poluência são afins. Para o autor, essa conexão se explicita no papel de Apolo tanto como o deus da peste como o deus da purificação.

A seguir, as jovens pedem que "nem a rixa de nativos / com mortes sangre o

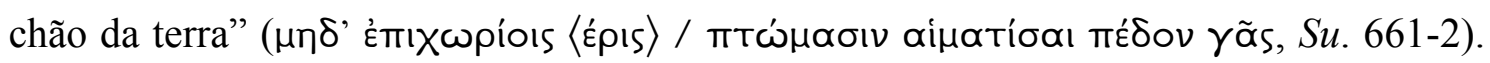
Do ponto de vista das Danaides, as jovens, ao pedirem que não haja "rixa de nativos"

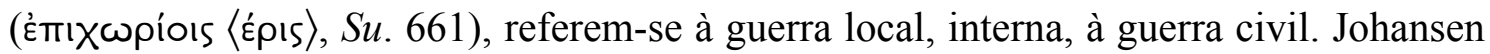
\& Whittle (1980, pp. 29-30, vol. III), no entanto, percebem uma ironia nesses versos, já que foi justamente pelo fato de os argivos, ao votarem a favor causa das Danaides,

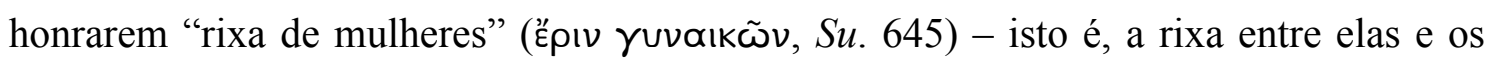
Egipcíades - que agora elas pedem que não haja "rixa" (غ́pıs, Su, 661), o que, para os autores, parece improvável, já que tudo leva a crer que a rixa entre os argivos e os

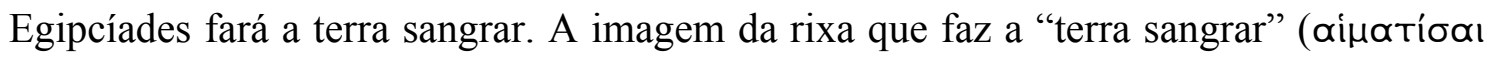

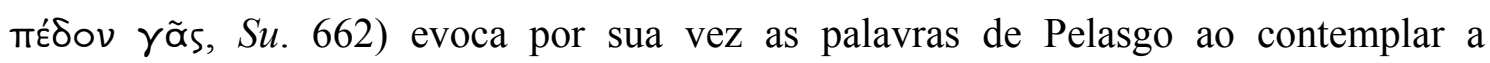
possibilidade da guerra contra os Egipcíades, varões por mulheres “ensanguentarem o

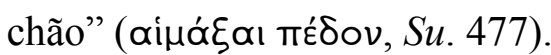

Na sequência, as Danaides voltam a pedir pela benevolência de Ares: "nem o amante de Afrodite / Ares funesto aos mortais / devaste o velo" ( $\mu \eta \delta$ ' Aqpoठítas /

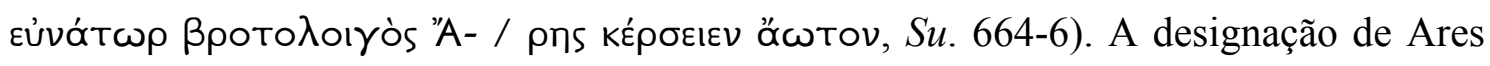
como "o amante de Afrodite" faz ressurgir a ominosa associação entre os domínios de Ares e Afrodite, o que, como se viu, constitui um prenúncio tanto da guerra contra os Egipcíades quanto das núpcias sangrentas das Danaides. 
A menção a Ares é retomada na terceira estrofe:

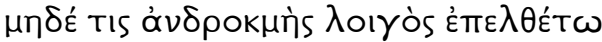
Tóv $\delta \varepsilon$ mó $\lambda ı v \delta \alpha i ́ \zeta \omega v$,

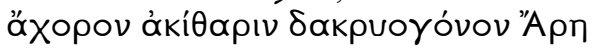

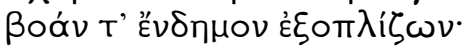

Nenhum massacre homicida sobrevenha a dilacerar esta cidade, a armar lacrimoso Ares sem dança nem lira e a violência na região.

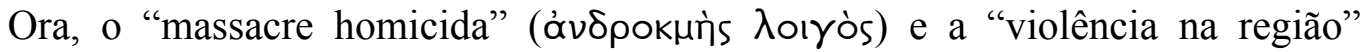

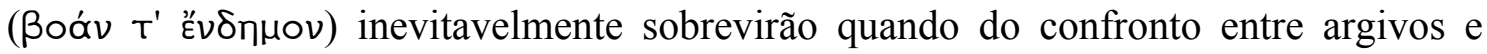
Egipcíades e quando da morte destes por suas primas ${ }^{36}$.

$\mathrm{Na}$ quarta estrofe, Ares é ainda uma vez mais mencionado. Desejando aos argivos um governo prudente, as Danaides pedem que sejam conciliadores com os

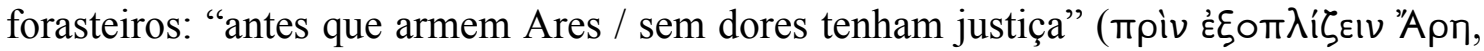

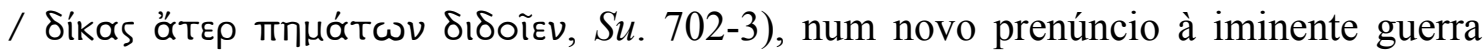
com os Egipcíades.

Observe-se que Ares é a segunda divindade mais evocada nas preces das Danaides para os argivos (Su. 635, 665, 681 e 702), ficando atrás somente de Zeus, sete vezes nomeado. Este segundo estásimo se compõe de quatro estrofes e de quatro antístrofes e Ares é citado em todas as estrofes. O nome do deus, com a violência e a privação de ser que ele evoca, pontua, como um refrão, o canto das Danaides, carregando suas preces de um sentido ominoso. Ironicamente, elas pedem que os

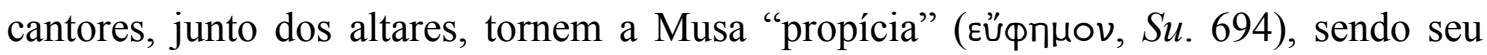
próprio canto não-propício ( $\delta \dot{\sigma} \varnothing \eta \mu \circ \varsigma)$.

A Apolo, as Danaides pedem que seja benévolo, de modo que o "enxame"

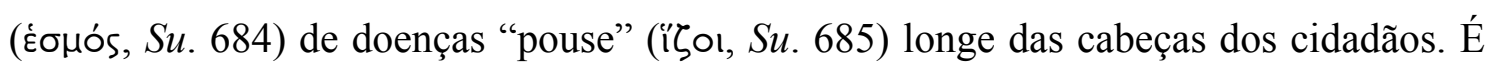
digna de nota essa imagem das doenças como um enxame, pois evoca simultaneamente

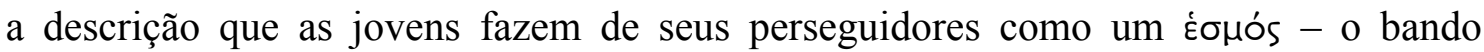

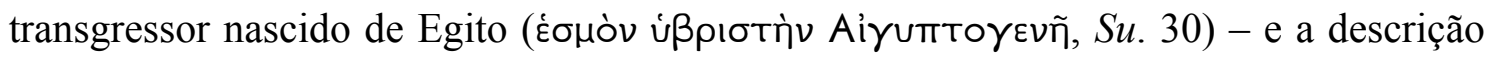
que Dânao faz das Danaides como um Éouós - um bando de pombas (غ̇ouòs

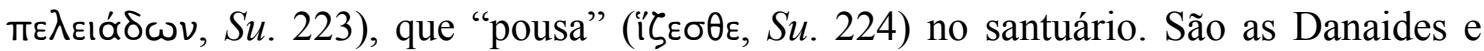
seus perseguidores, com sua rixa, que serão, afinal, para os cidadãos de Argos como um

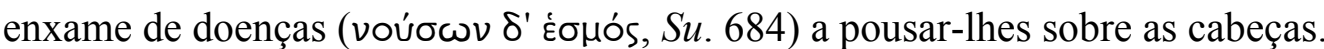

\footnotetext{
${ }^{36}$ Conferir Murray (1958, p. 80), Gantz (1978, pp. 284-5); Turner (2001, p. 36); Bednarowsky (2009, p. $318)$.
} 
A Zeus, as jovens pedem pela fertilidade da terra e dos rebanhos e, à Ártemis Hécate, pelo bom parto das mulheres. Essa referência das Danaides à fertilidade e à procriação é vista por Conacher (1996, p. 101) como um paradoxo, já que as jovens se recusam à união conjugal. Belfiore (2000, p. 61) vê nessas passagens um indício da reconciliação das Danaides com Afrodite, que se daria o final da trilogia ${ }^{37}$. Note-se, no entanto, que a fertilidade do solo, dos rebanhos e das mulheres é justamente aquilo que, sob a perspectiva dos acontecimentos vindouros, elas irão comprometer com a poluência de seu crime, de modo que também essa sua prece pela fertilidade de Argos reveste-se de um sentido ominoso.

As Danaides incluem ainda em suas preces um pedido pelo bom governo da cidade. Na segunda estrofe, dizem elas: "Assim bem se governe a cidade / dos que

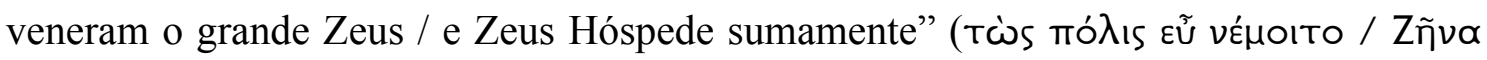

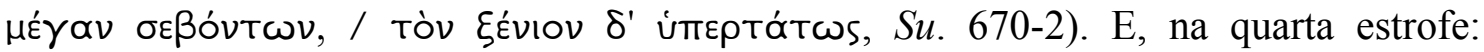
"Intrépido conserve os cargos / o povo que governa a cidade, prudente império de

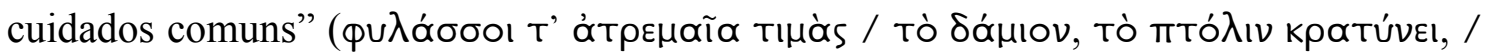

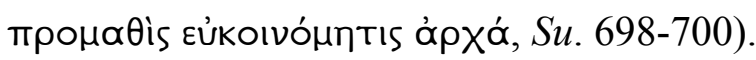

A menção a Zeus Hóspede é significativa. Tendo a sua súplica sido acolhida, as

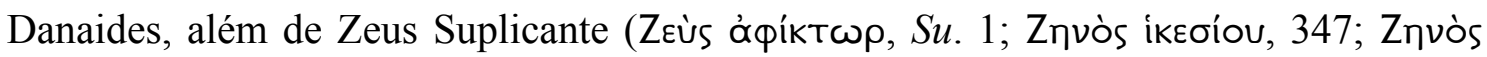

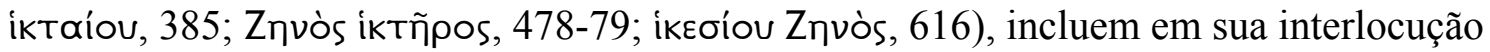
Zeus Hóspede (Zeùs Ģ́vios, Su. 627; Zñva tòv Ģ́viov, 671-2). A partir do momento em

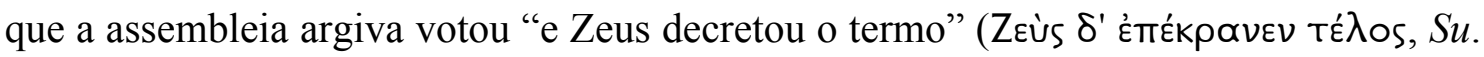

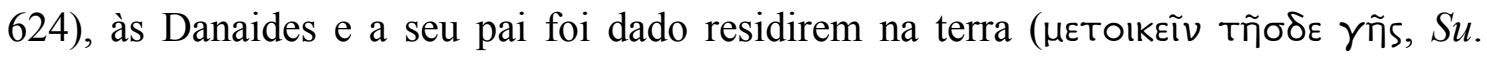

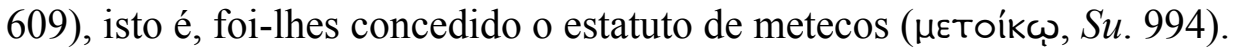

Essa condição de hóspedes é ressaltada quando, no quarto episódio, Pelasgo oferece às Danaides a escolha de residirem em habitações reais ou em casas públicas (Su. 957-61), escolha esta reforçada por Dânao (Su. 1009-11). Bakewell (1997, p. 214) observa que "one of the primary conditions of $\mu \varepsilon$ токі́a at Athens was that metics were normally barred of É $\gamma$ KTnбıs, ownership of a house or land. They were accordingly forced to stay with friends or rent dwellings". Dânao, no entanto, ressalta que, onde

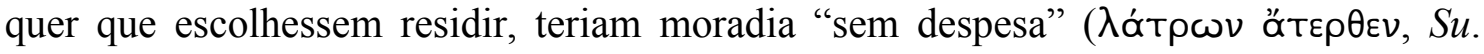
1011); isto é, em um ou em outro caso, seriam hóspedes.

\footnotetext{
${ }^{37}$ Belfiore (2000, p. 61-2) observa similaridades de tema e vocabulário entre tais passagens e o discurso de Afrodite no fragmento 44.
} 
No entanto, tradicionalmente, Dânao é tido como o sucessor de Pelasgo no trono. Para alguns autores, como Winnington-Ingram (1961, p. 146) e Johansen \& Whittle (1980, pp. 48, 50, vol. I), Pelasgo morre no combate entre argivos e Egipcíades e Dânao se torna rei. Para outros autores, como Zeitlin (1988, p. 235, n. 5), Sommerstein (1996, p. 148) e Turner (2001, p. 36), Dânao ascende ao poder como týrannos. Como exatamente ele sai de sua condição de estrangeiro, de meteco, de hóspede para a condição de rei ou týrannos, é impossível determinar, dada a perda das demais tragédias da trilogia. Uma pista, porém, parece residir no fato de lhe ser dada uma escolta de lanceiros (Su. 985). Foi com uma guarda individual que, de acordo com Heródoto (I, 59), Pisístrato tornou-se tirano de Atenas e, de acordo com Aristóteles $(R h$. 1357b.30-6), o mesmo sucedeu também com Teágenes em Mégara.

Mesmo adquirindo a realeza, a relação de Dânao e de suas filhas com Zeus Hóspede não se esgota. Winnington-Ingram (1961, p. 146) sugere que, assim como Zeus Suplicante preside As Suplicantes, Zeus Hóspede presidiria a segunda tragédia, Os Egípcios, hipótese esta apoiada por Garvie (2006, p. 182), de forma que, para ambos os autores, o crime orquestrado por Dânao e perpetrado pelas Danaides seria um crime contra Zeus Hóspede, o que resultaria numa poluência para Dânao, suas filhas e também para a cidade de $\operatorname{Argos}^{38}$.

Para Turner (2001, pp. 37-8), as preces das Danaides referentes ao governo da cidade de Argos prenunciam a tirania de Dânao. Assim, na segunda estrofe, as jovens associam o bom governo da cidade com a veneração a Zeus Hóspede. Enquanto Pelasgo bem governa, pois venera Zeus Hóspede, acolhendo a elas e a seu pai em sua cidade, Dânao, enquanto týrannos, irá, ao contrário, ofender o deus. Não se podem determinar quais tenham sido as negociações entre as duas partes que conduziram ao casamento entre as Danaides e os Egipcíades, mas considera-se que, como os acontecimentos se dão em Argos, os Egipcíades ali estão nesse período na condição de hóspedes, de forma que seu assassinato é uma violação das leis da hospitalidade.

Na quarta estrofe, o bom governo é associado à conservação das honras pela cidade, que é descrita como um prudente império de cuidados comuns. É exatamente assim que Pelasgo governa Argos, com prudência e sempre deliberando em conjunto com seus concidadãos, de forma que as suas decisões são um reflexo da vontade de seu

\footnotetext{
${ }^{38}$ Garvie (2006, p. 182): "If Danaus becomes king and the murder is committed in the royal apartments, then it is an offence against Zeus Xenios"; Winnington-Ingram (1961, p. 146): "If they choose - or rather Danaus chooses for them - the royal apartments, and if Danaus becomes king and inherits the royal palace, then the murder of the sons of Aegyptus is the murder of guests under his own roof".
} 
povo (Su. 365-9; 397-401; 517-8; 963-5). A prudência de Pelasgo está associada à sua

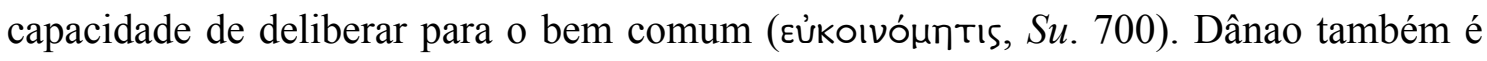

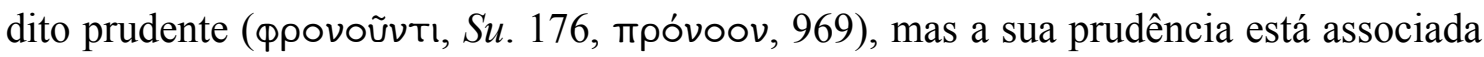

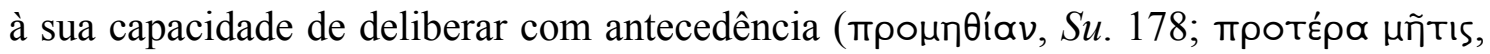

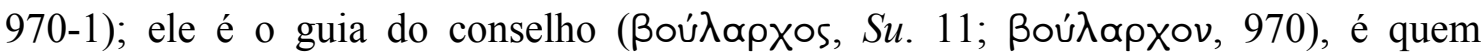
planeja e faz executar. Sommerstein (1977, p. 67) detecta uma ambiguidade no termo

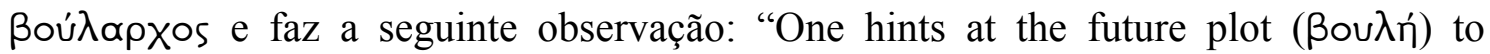
murder the sons of Aigyptos, which by all accounts was contrived by Danaos". Sendo assim, enquanto týrannos, o que ele delibera é uma forma de assassinar seus sobrinhos, protegendo seus interesses e os de suas filhas, a despeito da ofensa a Zeus Hóspede e a despeito das consequências que os argivos irão sofrer em razão da poluência advinda desse crime.

No terceiro episódio, após louvar as preces feitas por suas filhas, Dânao anuncia a aproximação das naus dos Egipcíades, mas, antes de fazê-lo, pede que suas filhas não temam o que irá em seguida dizer: "não temais, porém, ao ouvirdes do pai / estas

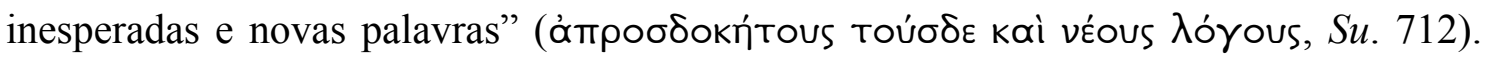
Ora, Dânao e suas filhas sabiam que os Egipcíades viriam atrás deles. A súplica que as Danaides dirigem ao rei Pelasgo não é simplesmente por asilo, mas sim por não serem entregues aos filhos de Egito se estes a pedirem (Su. 341). O que poderia então haver de

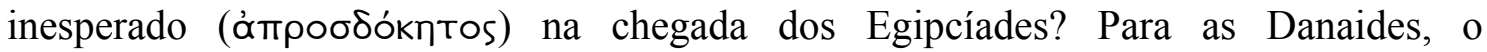
inesperado só pode ser o fato de que sua reiterada súplica para que os Egipcíades se afogassem no mar (Su. 23-39; 524-35) não foi atendida.

Zeus foi-lhes benevolente ao fazer com que suas súplicas fossem atendidas por Pelasgo e seu povo, mas nem ele nem as demais divindades evocadas pelas Danaides atenderam às suas preces de que seus perseguidores morressem no mar. Como observa Mikalson (1989, p. 93), embora ambas as preces sejam formais e dirigidas a grandes divindades e ambas sejam feitas por suplicantes em um santuário, nenhuma delas é atendida e os Egipcíades chegam pouco depois, sãos e salvos. E quanto às preces de que não desposem os Egipcíades? As Danaides pedem aos pátrios Numes de Argos, aos Deuses supremos, aos heróis e a Zeus Salvador que não permitam que elas se casem com seus primos (Su. 22a-39). O mesmo pedido elas fazem duas vezes a Épafo ( $S u$. $141-3 ; 151-3)$, duas vezes à deusa Ártemis (Su. 144-50; 1030-32) e ainda duas vezes a Zeus (Su. 1052-3; 1062-3). Embora elas não o saibam, também essas suas preces não serão atendidas: elas irão desposar os Egipcíades. 
Como se viu, as Danaides insistem na caracterização de seus perseguidores

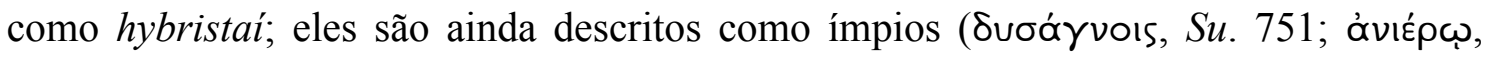

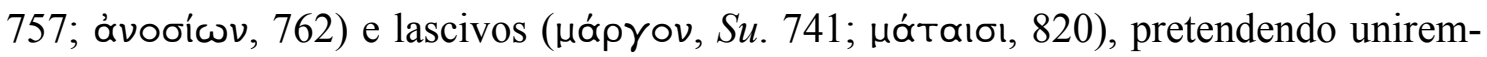

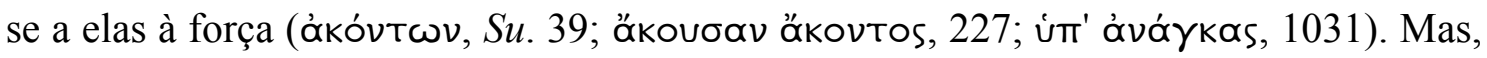
como elas declaram no párodo, os deuses, "vigilantes da justiça" (тò Síkaıov íóvtes,

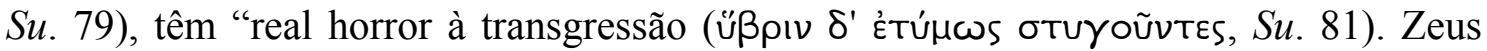
“precipita das altas torres / das esperanças perdidos mortais" (iónt

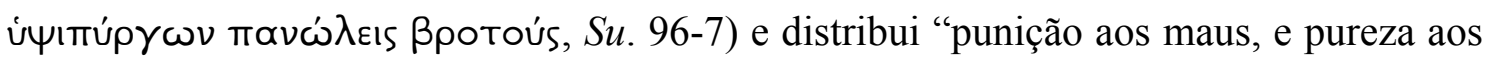

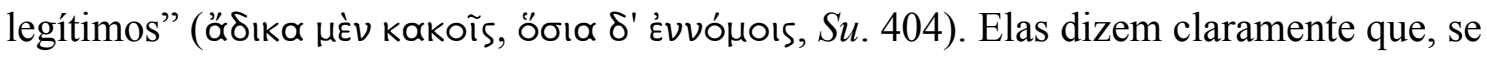
os deuses pátrios frustrassem o intento dos Egipcíades, eles seriam "justos com as

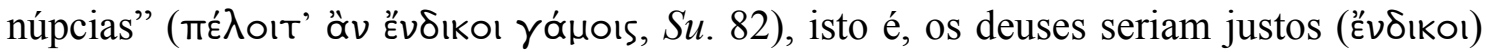
no que concerne a esse casamento, se o impedissem.

Quanto a isso, Mikalson (1989, p. 93) faz a seguinte observação:

If the Danaid trilogy developed along the lines of the Oresteia, the explanation might be that Zeus necessarily denied the Danaid's immediate wishes in accomplishing his larger purposes for Argos and justice. If Aeschylus is what most think him to be, he would hardly have left unanswered and unexplained suppliants' prayers to Zeus, Protector of Suppliants.

As preces das Danaides, no entanto, não deixam de ser respondidas; ao contrário, elas são respondidas. A negação de seus pedidos são uma resposta bastante eloquente e, enquanto resposta divina, são uma expressão dos desígnios e da justiça de Zeus. Elas, ao fugirem justamente de uma união desejada à força por homens impiedosos, acabam por exceder-se nessa recusa com sua ameaça de suicídio, que comprometeria a cidade aonde elas vêm suplicar e o povo a quem elas dirigem suas súplicas. A justiça de Zeus, embora imperscrutável para as Danaides, revelar-se-á no curso dos acontecimentos.

Ante essa chegada "inesperada", do ponto de vista das Danaides, das naus dos Egipcíades, elas ficam apavoradas. Dânao diz que irá trazer auxiliares e defensores, enquanto aconselha as Danaides a serem prudentes e a confiarem na justiça divina, uma

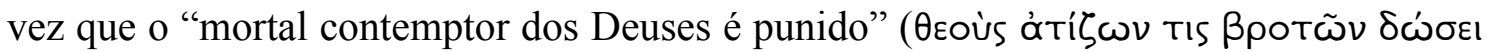

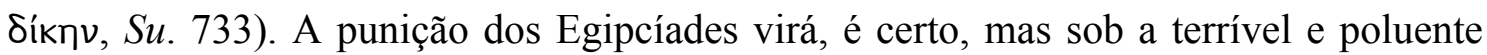
forma de um crime consanguíneo. 
Apavoradas, as Danaides expressam seu temor de que sua fuga tenha sido vã, mas Dânao, infundindo-lhes coragem, reafirma-lhes a eficiência do decreto argivo, o que implica que os cidadãos argivos hão de lutar para defendê-las. Mas as Danaides temem a sordidez e a insaciabilidade de batalha de seus perseguidores, cuja soberbia e impiedade não os faria, por temor e reverência aos deuses, afastarem delas suas mãos, e pedem que Dânao não as deixe sós, pois "mulher a sós não é nada, ausente Ares" ( $\gamma u v i ̀$

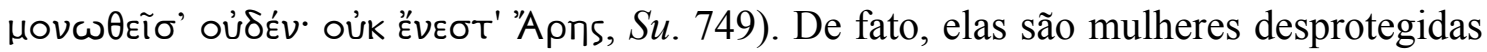
que, em sua frágil condição, não participam de Ares. Mas essa nova menção ao deus é mais um prenúncio do crime que cometerão quando, em sua noite de núpcias, participarem de Ares através do massacre de seus maridos.

No terceiro estásimo, as Danaides, entregues ao desespero, expressam, com variadas imagens, o desejo de desvanecer ou de morrer. Assim como suas preces por bens para os argivos são ao mesmo tempo um prenúncio dos males que eles sofrerão, esse desejo de morte expresso pelas jovens é ao mesmo tempo um prenúncio de morte, não delas mesmas, mas dos Egipcíades.

Dizem elas que "a morte liberta / dos lúgubres males" (

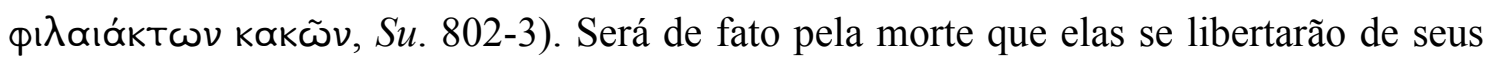
males, isto é, uma união conjugal indesejada, matando não a si mesmas e sim os seus maridos.

Desejam as Danaides morrer "antes de ter acerbas núpcias / violentas ao

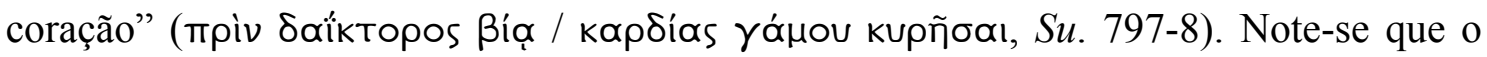

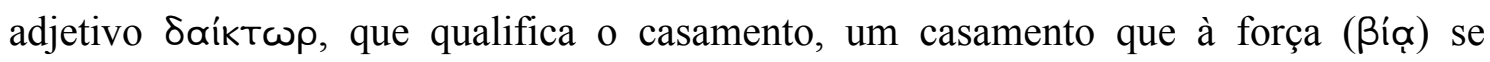

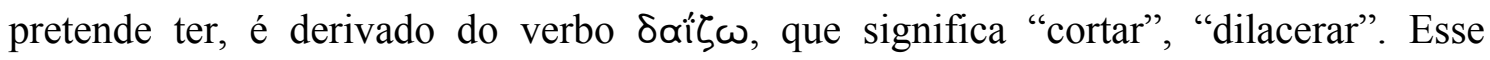
mesmo verbo aparece nas preces das Danaides quando elas pedem que nenhum massacre homicida venha a "dilacerar" ( $\delta \alpha^{\prime} \zeta \zeta \omega \nu, S u$. 680) a cidade de Argos. O que as Danaides descrevem é a profunda rejeição que elas sentem por essas núpcias, metaforicamente violentas e dilacerantes para o seu coração, mas, ao mesmo tempo, essa descrição constitui um prenúncio do que tais núpcias realmente serão, quando, rejeitando-as, elas literalmente se tornarão violentas e dilacerantes.

O mesmo se dá quando as Danaides exclamam: 


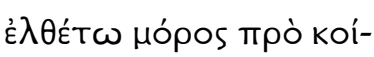

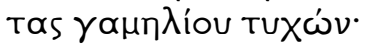

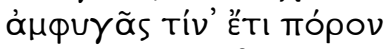

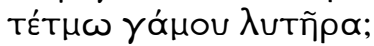

Venha a morte antes do leito nupcial, por sorte! Que via de fuga ainda corto, livre de núpcias?

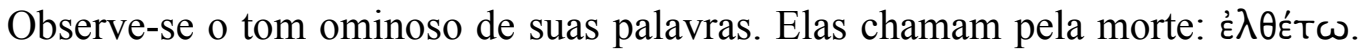
Que a morte venha "antes" (тро́) do leito nupcial. A morte pela qual elas chamam para fugir ao leito nupcial virá, mas será a morte dos Egipcíades. E a "via de fuga"

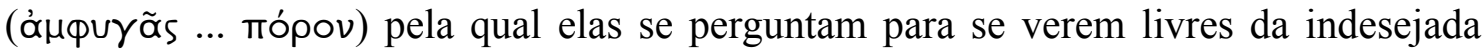
união conjugal é o assassinato de seus primos.

Ao fim do terceiro estásimo, as Danaides invocam Zeus para que, com olhos víndices, contemple a violência de seus inimigos e descrevem os Egipcíades como autores de uma intolerável transgressão ao persegui-las e ao constrangê-las a contrair forçadas núpcias. Tal transgressão ganha corpo e voz quando, no quarto episódio, o Coro dos filhos de Egito entra em cena, descrevendo a sim mesmo como "raptor" ( $\mu$ ópாттs, Su. 826) das virgens filhas de Dânao.

A atitude do Coro de Egipcíades e do Arauto que fala em seu nome é um retrato

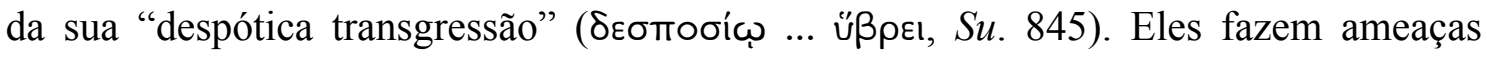
violentas para as Danaides irem imediatamente aos seus navios - "sangrenta sanguinária

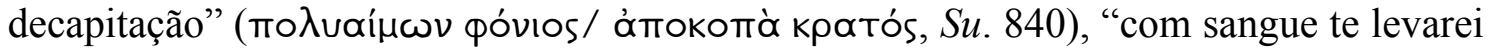

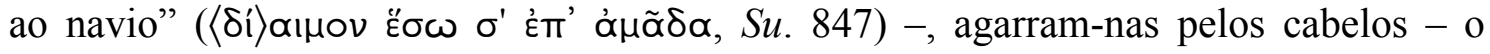

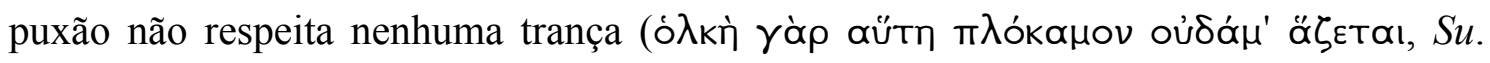
884) -, constrangem-nas - "à força, à força" (ßíạ ßíạ, Su. 863). Eles escarnecem os

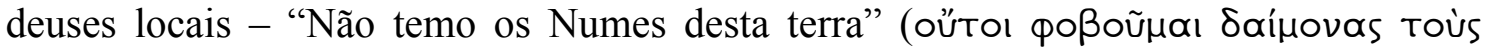

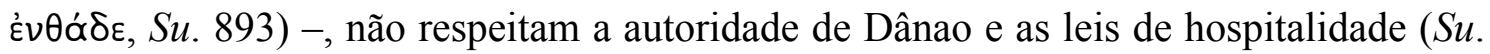
917-20), mostram-se belicosos e dispostos à guerra (Su. 935-7; 950). Essa atitude hybristés do Coro dos Egipcíades - suas palavras, suas ações - é um claro prenúncio da pesada punição que a justiça divina lhes reserva.

As Danaides respondem às palavras violentas e ameaçadoras dos Egipcíades invocando os deuses, clamando pelo auxílio do pai e do rei, vituperando seus agressores

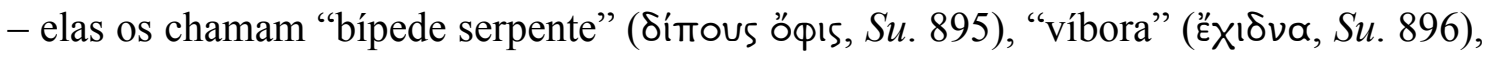
“monstro" (ס́ákos, Su. 898) - e expressando duas vezes o desejo de que eles tivessem perecido no mar (Su. 843-6; 867-71). Assim, a profunda rejeição das Danaides por seus pretendentes parece, se não se agravar, explicitar-se. E é essa rejeição, juntamente com 
o afronte agora sofrido por elas da parte dos Egipcíades, que as tornará dispostas a matá-los.

Dânao, encontrando-se a sós com suas filhas, exerce novamente o seu papel de guia do conselho $(\mathrm{Su} .11 ; 970)$, instruindo longamente as Danaides a honrar a prudência

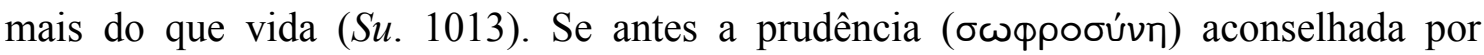
Dânao se inscrevia no âmbito de Zeus Suplicante como moderação - era aconselhável

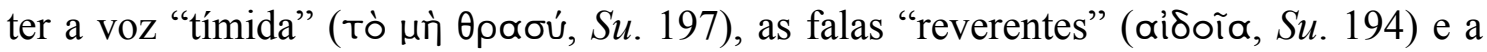

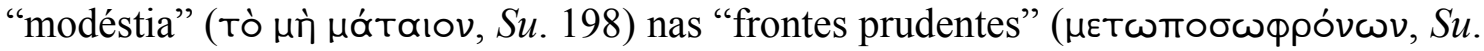

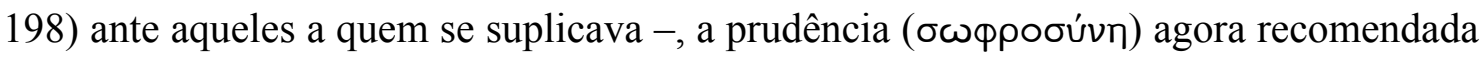
por ele diz respeito ao âmbito de Afrodite e implica castidade. Dânao reconhece em

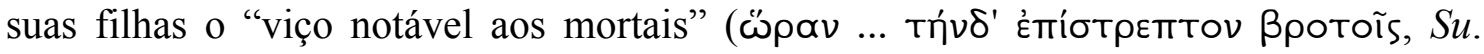

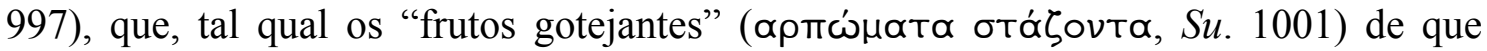

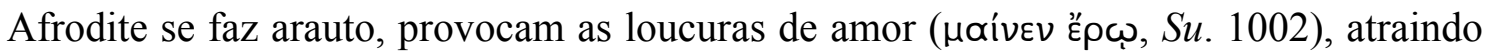

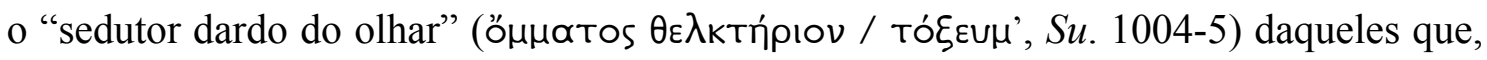

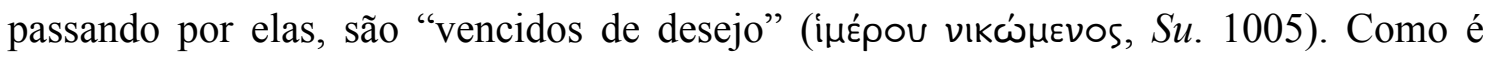

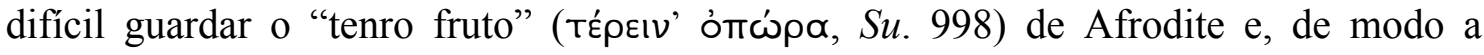
preservá-lo, vasto esforço foi preciso para cruzar o vasto mar, faz-se necessário que

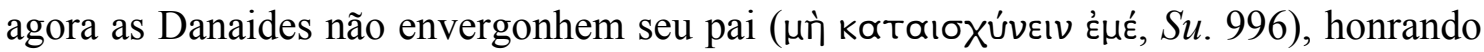

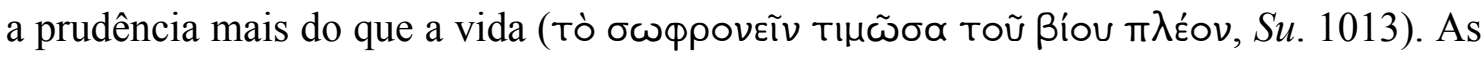

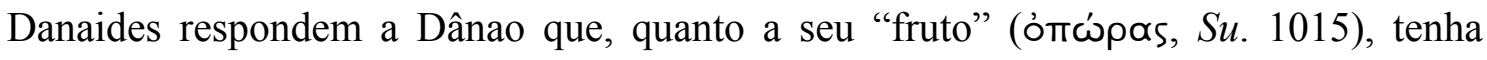
confiança.

Se a castidade, isto é, a não participação em Afrodite, deve ser preferível à vida, a questão que se coloca, tal como postula Zeitlin (1996, pp. 130-1), é ser preferível a que vida? A própria vida das Danaides ou a vida daqueles que pretendem a todo custo arrastá-las para o âmbito de Afrodite? Para a autora, a ênfase de Dânao na necessidade

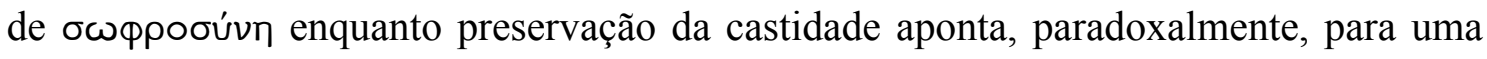

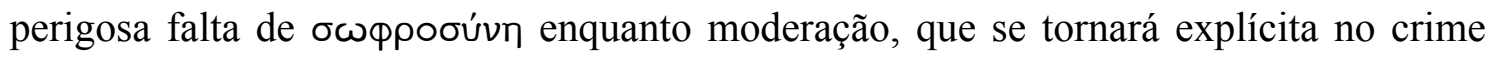
por elas cometido contra seus maridos. Assim, pode-se perceber nesse conselho de Dânao a suas filhas mais um prenúncio do assassínio dos Egipcíades. Como crê Bednarowsky (2009, p. 343), as palavras de Dânao são "a thinly veiled command to kill the Aegyptids before submitting to them”. Igualmente, Johansen \& Whittle (1980, pp. 303, vol. III) percebe na fala de Dânao "a sinister ring”. 
No êxodo, as Danaides louvam a cidade dos argivos, propondo-se a venerar com hinos não mais as vertentes do Nilo, mas os rios fecundos da região, e pedem à deusa Ártemis que vele por elas, de modo que as núpcias de Citereia não lhe venham "por

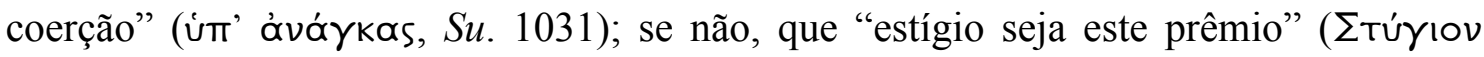

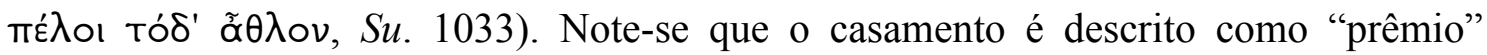
(ã $\theta \lambda \circ v)$. Na Odisseia, quando Penélope propõe aos pretendentes uma competição, diz-

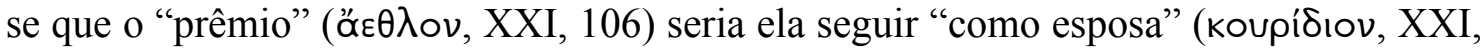
78) aquele que, dentre eles, fosse capaz de dobrar o arco de Odisseu. Para as Danaides,

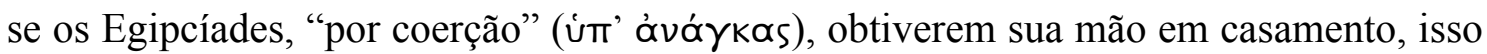
será para eles um prêmio "estígio" ( Túviov). Na Teogonia de Hesíodo, Estige nomeia o décimo braço do Oceano; enquanto os demais nove braços circundam a terra e o dorso do mar, Estige precipita-se na Noite Negra (Th. 789-92). Seu palácio, como o de Hades

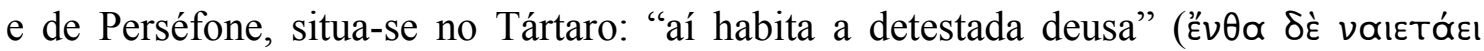

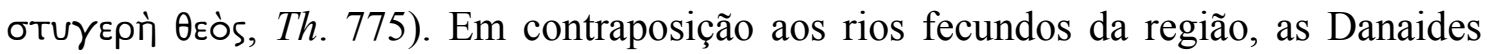
evocam a infecunda Estige, de modo que as núpcias para os seus pretendentes sejam um prêmio de morte, num claro prenúncio do futuro homicídio.

Em resposta às palavras do Coro das Danaides, o segundo Coro ${ }^{39}$ fala do poder de Afrodite, do qual não seria prudente descuidar. Afrodite é dita "astuciosa"

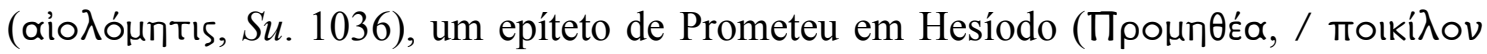

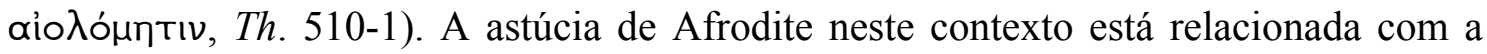

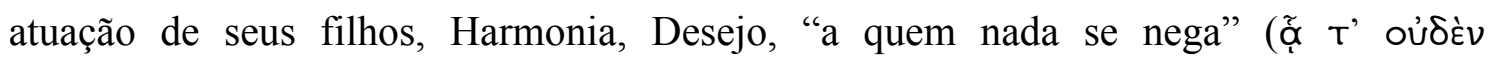

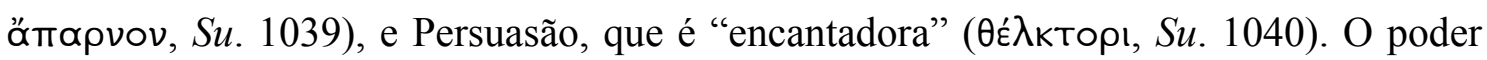
persuasório e encantatório de Afrodite seria assim capaz de encantar o sem encanto $(\mathrm{Su}$. 1055). Mas as Danaides respondem dizendo ao segundo Coro: "tu não conheces o

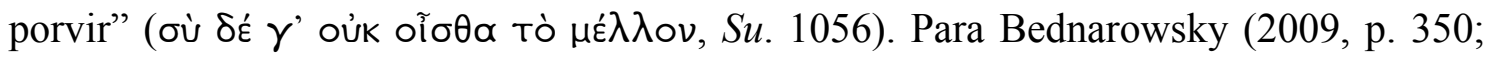
2011, p. 575), a astúcia de Afrodite aqui mencionada prenuncia o porvir, isto é, o plano executado pelas Danaides de persuadir e seduzir os Egipcíades com uma promessa de casamento para assassiná-los depois.

Ante a insistência das Danaides em sua recusa à união com os Egipcíades - "O grande Zeus afasta-me / as núpcias com Egipcíades” (Su. 1052-3), “Zeus soberano

\footnotetext{
${ }^{39}$ Especula-se que esse segundo Coro poderia ser composto pelas servas das Danaides, a quem elas se referem (Su. 975-9), conforme a opinião de Garvie (2006, pp. 194-5), Lesky (2001, p. 115), WinningtonIngram (1983, p. 60), Conacher (1996, p. 99). Especula-se ainda que o segundo seria composto pela escolta de lanceiros a que se refere Dânao (Su. 985), conforme a opinião de Taplin (1977, pp. 230-2), Sommerstein (1996, p. 140), Seaford (1987, p. 114), Johansen \& Whittle (1980, p. 307, vol. III).
} 
frustre essas / núpcias cruéis com inimigos" (Su. 1062-3), o segundo Coro aconselha o

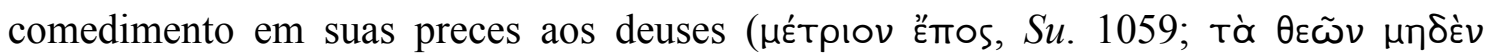

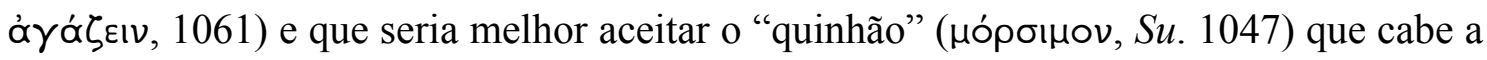
toda mulher: as núpcias. Qual o sentido, pergunta-se o Coro, de os Egipcíades terem

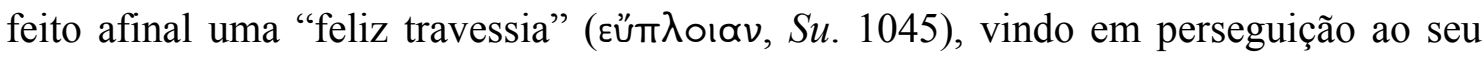
encalço? O segundo Coro evoca assim a frustrada prece das Danaides de que seus perseguidores morressem em sua travessia marítima, o que, para ele, significa que elas devem aceitar o seu quinhão, pois não se pode transgredir de Zeus "o grande espírito impenetrável” (Su. 1049). Se homens tão insolentes fizeram uma feliz travessia, escapando à morte no mar, só pode se tratar de um desígnio divino, ainda que imperscrutável, pois, como as próprias Danaides dizem, "O desejo de Zeus não se pode caçar: / as densas e sombrias sendas / do seu pensar se prolongam imperscrutáveis"

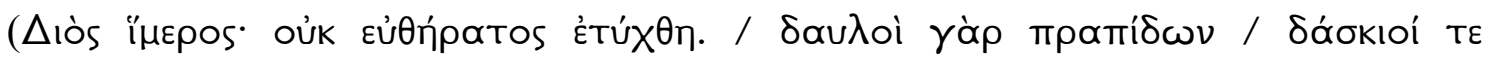

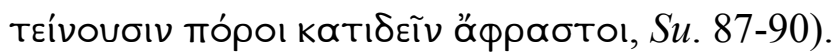

A tragédia encerra-se então, num momento de grande expectativa. Na incólume chegada dos Egipcíades, as Danaides reconhecem a possibilidade de que os deuses

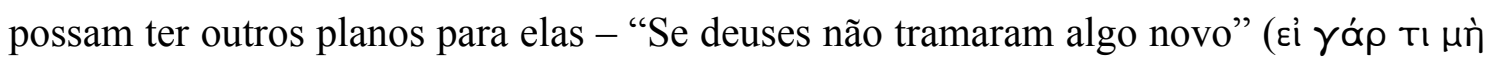

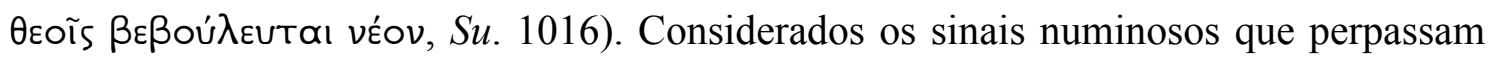
esta tragédia, tais planos apontam para uma guerra entre argivos e Egipcíades e um terrível homicídio consanguíneo - com todas as implicações advindas tanto da guerra quanto do crime -, bem como, pelo cumprimento de tais desígnios divinos, a realização da muitas vezes imperscrutável, mas sempre infalível, justiça de Zeus. 
4. ORESTEIA 


\section{ORESTEIA}

A Oresteia de Ésquilo é a única trilogia supérstite, sendo composta pelas tragédias Agamêmnon, Coéforas e Eumênides, tematicamente interligadas. Do drama satírico Proteu, que completava a tetralogia com que Ésquilo recebeu o primeiro prêmio em 458 a.C., restaram apenas escassos fragmentos.

A Oresteia narras as desgraças que se abateram sobre o palácio dos Atridas. Trata-se de um tema explorado pelos três grandes poetas trágicos. Além da Oresteia, a Electra, de Sófocles, e as tragédias Electra, Orestes, Ifigênia em Táuris e Ifigênia em Áulis, de Eurípides, também versam sobre as desventuras da casa de Atreu.

O tema das desventuras da casa dos Atridas figura já em Homero. No livro I da Odisseia (Od. I, 32-43), estando os deuses reunidos no Olimpo em assembleia, Zeus recorda-se da triste sorte de Egisto, morto pelas mãos de Orestes, vingador do assassínio do pai. E, no livro IV (Od. IV, 512-37), narra-se o assassinato de Agamêmnon durante um banquete a que, ardilosamente, Egisto convidara o recém-chegado guerreiro de Troia e seus companheiros.

Na história dos Atridas narrada na Odisséia por Homero, não há, no entanto, nenhum elemento da arte divinatória presente. A participação e a vontade divinas estão indubitavelmente mais presentes na história narrada por Ésquilo. E o sinal mais evidente disso é a presença maciça de sinais divinatórios que, ao mesmo tempo em que prenunciam os acontecimentos, oferecem deles uma interpretação.

O assassinato do líder da expedição a Troia figura na primeira tragédia, Agamêmnon. A ação dramática se passa em Argos. No prólogo (Ag. 1-39), o vigia, do alto do teto do palácio dos Atridas avista o sinal de fogo que sinaliza a tomada de Troia. O Coro de anciãos argivos entra em cena e, no párodo anapéstico ( $A g$. 40-103), ante a visão dos sacrifícios nos altares, pergunta a Clitemnestra o que a levou a realizar tais oferendas. No párodo lírico ( $\mathrm{Ag}$. 104-257), o Coro rememora a partida do exército reunida em Áulida, marcada tanto pelo auspício das aves como do terrível sacrifício da filha de Agamêmnon, Ifigênia. No primeiro episódio ( $\mathrm{Ag}$. 259-354), entra em cena a rainha Clitemnestra e, diante da incredulidade do Coro de que Troia tenha sido realmente tomada, ela descreve em detalhes o percurso do sinal do fogo e ainda a ocupação dos aqueus em Troia. No primeiro estásimo (Ag. 355-487), o Coro reflete sobre o castigo que Zeus impôs a Páris e as suas consequências, temendo que novas 
desgraças se abatam sobre os Atridas. No segundo episódio ( $\mathrm{Ag}$. 488-680), um arauto entra em cena anunciando a tomada de Troia. Clitemnestra envia ao marido uma mensagem de que encontrará em casa a mesma esposa fiel que deixou quando de sua partida. $\mathrm{O}$ arauto narra ainda a tempestade que dispersou a frota em seu retorno ao lar, dizendo que por isso desconhece o paradeiro de Menelau. O Coro, no segundo estásimo (Ag. 681-781), fala das desgraças sobrevinda a gregos e troianos por causa de Helena, finalizando seu canto com um elogio à moderação. Entra em cena, no terceiro episódio (Ag. 782-974), Agamêmnon, sendo recebido pelo Coro e por Clitemnestra, que o persuade a entrar no palácio pisando vestes púrpuras. No terceiro estásimo ( $\mathrm{Ag}$. 9751033), o Coro expressa os maus pressentimentos de seu coração. No quarto episódio (Ag. 1035-330), Clitemnestra convida a adivinha Cassandra a entrar no palácio, mas esta, muda diante da rainha, inicia, após a saída de Clitemnestra, uma série de delírios proféticos nos quais vê tantos os crimes antigos do palácio dos Atridas como os que estão prestes a acontecer, isto é, a morte de Agamêmnon e a sua própria morte às mãos de Clitemnestra e Egisto. Ante as profecias de Cassandra, o Coro, em anapestos ( $\mathrm{Ag}$. 1331-42), expressam mais uma vez o seu temor. Ouvindo os gritos de Agamêmnon, os membros do Coro, no diálogo dos coreutas (Ag. 1343-71), mostram-se indecisos quanto à ação e resolvem saber claramente o que está acontecendo com o rei. No quinto episódio ( $\mathrm{Ag}$. 1372-576), Clitemnestra entra em cena expondo seu crime e as razões que a levaram a cometê-lo e enfrenta-se com Coro, que abomina seus atos e refuta seus argumentos. No último episódio ( $A g$. 1577-673), é a vez de Egisto entrar em cena vangloriando-se de seu crime e explicitando seus motivos. O enfrentamento com o Coro é violento e Egisto desembainha sua espada, mas Clitemnestra intervém.

A ação trágica, nas Coéforas, dá-se anos depois do assassinato de Agamêmnon. O prólogo (Co. 1-21) é dito por Orestes, que retorna enfim à sua terra natal para vingar a morte do pai. No párodo (Co. 22-83), entram em cena o Coro, composto de mulheres cativas que vêm trazendo libações ao túmulo de Agamêmnon enviadas por Clitemnestra, por causa de um sonho aterrorizante. No primeira parte do primeiro episódio (Co. 84-314), Electra pergunta ao Coro o que deve dizer ao derramar as libações e é instruída a pedir o retorno de Orestes e a ruína dos assassinos de seu pai. Electra depara-se, então, com sinais que apontam para a visita de Orestes ao túmulo paterno: uma mecha de cabelos semelhantes aos seus e pegadas no chão igualmente semelhantes às suas. Orestes então se revela à irmã, oferecendo, como símbolo inequívoco de sua identidade, uma veste bordada para ele por Electra em sua infância. 
Orestes relata o oráculo recebido de Apolo, que olhe ordena vingar a morte do pai. Juntos, no kommós (Co. 315-478), os irmãos invocam o auxílio do morto na execução de sua vingança. $\mathrm{Na}$ conclusão do primeiro episódio (Co. 479-584), o Coro relata a Orestes o sonho de Clitemnestra e este o interpreta como um prenúncio da morte que dará à sua mãe. A seguir, expõe seu plano: juntamente com Pílades, aparecerão às portas do palácio como mensageiros fócios que vieram comunicar a morte de Orestes. primeiro estásimo (Co. 585-651), o Coro, estando no limiar da ação, elenca terríveis crimes cometidos por mulheres e correlaciona a Justiça com a atuação das Erínies. No segundo episódio (Co. 653-782), Orestes e Pílades são recebidos por Clitemnestra e comunicam a falsa morte de Orestes. A rainha finge pesar e a ama de Orestes, entrando em cena, exprime seu verdadeiro pesar pela morte do menino por quem teve tantos cuidados. O Coro pede à ama, que está a caminho de transmitir a Egisto a falsa notícia, que fale a Egisto que venha sem escolta ao encontro dos forasteiros. No segundo estásimo (Co. 783-837), o Coro invoca os deuses para que auxiliem Orestes na execução de sua vingança. No terceiro episódio (Co. 838-934), Egisto entra no palácio e ouvem-se seus gritos de morte, anunciada a seguir por um mensageiro. Clitemnestra entra em cena e se depara com Orestes. Suas tentativas de inspirar piedade filial no filho são inúteis. No único momento em que hesita, Pílades lembra o amigo das ordens de Apolo e este leva a mãe ao interior do palácio para matá-la. No terceiro estásimo (Co. 935-71), o Coro celebra a justiça. No último episódio (Co. 973-1076), Orestes exibe a rede na qual Clitemnestra e Egisto envolveram Agamêmnon ao matá-lo e proclama a justiça de seu ato. As Erínies aparecem diante dele, que, atordoado, parte para o santuário de Apolo em Delfos.

A ação nas Eumênides inicia-se no templo de Apolo em Delfos. A Pítia diz o prólogo (Eu. 1-139), em que narra a história da sucessão do oráculo délfico e, em seguida, entra no recinto sagrado, de onde sai horrorizada pela visão de Orestes com as mãos ensanguentadas e das Erínies adormecidas. A Pítia interpela Apolo e este, dirigindo-se a Orestes, instrui-o a dirigir-se a Atenas e abraçar a estátua de Palas como suplicante. Após a partida de Orestes, Clitemnestra aparece para as Erínies adormecidas e as incita a continuar em sua perseguição ao matricida. No párodo (Eu. 140-77), as Erínies despertam enraivecidas com os deuses novos e principalmente com Apolo. No primeiro episódio (Eu. 179-243), Apolo expulsa o Coro de Erínies de seu santuário e há um primeiro embate entre eles, em que as Erínies reafirmam seu dever de perseguir Orestes e Apolo, de defende-lo. Ao final desse episódio, há uma mudança de cenário: 
em Atenas, Orestes suplica junto à estátua de Palas Atena. No epipárodo (Eu. 244-75), o Coro entre em cena farejando Orestes. No segundo episódio (Eu. 276-98), Orestes, dizendo-se purificado, pede a proteção de Atena. No primeiro estásimo (Eu. 299-396), o Coro de Erínies canta o seu poder de punir os crimes de sangue. Atena entre em cena no terceiro episódio (Eu. 397-489) e interroga tanto as Erínies quanto Orestes; ela decide então reunir os melhores cidadãos atenienses para julgar a questão. No segundo estásimo (Eu. 490-565), o Coro canta os males que advirão caso elas não sejam respeitadas em suas atribuições. No quarto episódio (Eu. 566-777), Atena conclama a todos para, no recém-fundado tribunal do Areópago, decidirem a causa: tanto Orestes quanto Apolo são ouvidos por um lado, quanto as Erínies são ouvidas por outro. A votação dá empate e Atena decide pela absolvição de Orestes. No kommós (Eu. 778880), as Erínies, indignadas, rogam pragas contra cidade de Atenas e Atena tenta dissuadi-las de seu furor. No último episódio ( $E u$. 881-1031), Atena finalmente persuade as Erínies de renunciar à vingança e tomarem assento na cidade de Atenas, onde receberão todas as honras. No êxodo (Eu. 1033-47), uma procissão segue para instalar as Erínies em seu novo santuário.

A adivinhação se faz presente na Oresteia sob a forma de auspícios, de sonhos, de profecias, de oráculos, de pressentimentos, de palavras imprecatórias e de palavras cledomânticas, como se verá detalhadamente no exame de cada uma das tragédias.

Roisman (1986, p. 281) faz a seguinte observação a respeito dessa trilogia esquiliana: "a tendency observable in the trilogy as a whole: the first play is characterized by the most complex idioms, metaphors and syntax, all of which become simpler as the trilogy proceeds". Esse movimento de maior complexidade para maior simplicidade na Oresteia deve-se em grande medida à presença de sinais divinos, mais profícuos e mais obscuros em Agamêmnon, menos profícuos e mais claros nas Eumênides. 
4.1. AGAMÊMNON 


\subsection{AGAMÊMNON}

\subsection{1) O auspício das aves}

O prólogo inicia-se com a fala do Vigia, que, do alto do teto do palácio dos Atridas, pede aos deuses que o libertem das fadigas advindas da árdua tarefa de vigiar o céu noturno na expectativa do sinal luminoso a anunciar a captura de Troia. A sua fatigável labuta descreve-se basicamente sob três aspectos; a saber:

1) Por quem the foi imposta essa tarefa de vigília - pelo poder "do viril coração

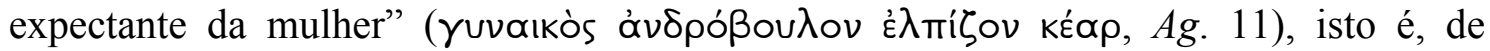
Clitemnestra.

Note-se que, em Homero, na Odisseia, o poeta menciona a existência de um vigia. O vigia homérico, no entanto, é ali posicionado não para tomar conhecimento da captura de Troia, mas sim da chegada de Agamêmnon - embora a finalidade seja a mesma: assassinar dolosamente o herói -, avistando-o no momento em que este pisa o solo da terra nativa (Od. IV, 521):

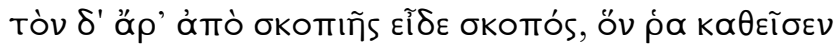

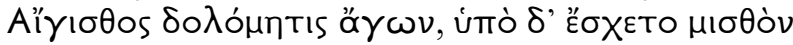

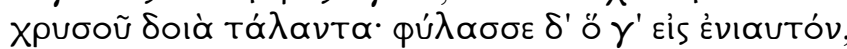

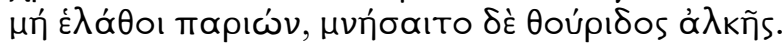

Viu-o o vigia, do ponto em que estava escondido, postado lá por Egisto traiçoeiro, que em paga promete entregar-lhe dois belos áureos talentos. De guarda o ano todo ficara; não lhe escapasse a chegada, lembrado da força impetuosa.

Contudo, há uma diferença muito mais significativa: em Homero, é Egisto quem posiciona o vigia, prometendo-lhe pagamento, enquanto aqui é Clitemnestra que, detendo o poder, ordena. O fato de uma mulher exercer o poder (кратєі̃, $A g .10$ ), quando normalmente este é exercido por homens, aponta para uma ominosa inversão de papeis, reforçada pela descrição de Clitemnestra como uma mulher de coração viril

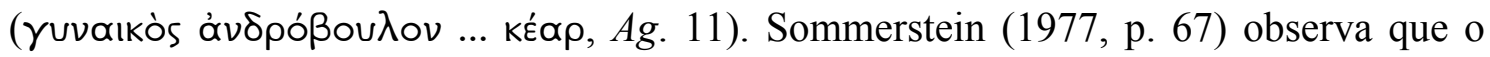

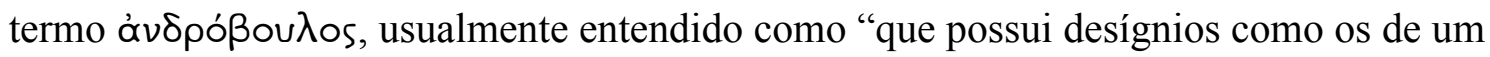
homem", possui também o sentido secundário de "que conspira contra o homem, o 


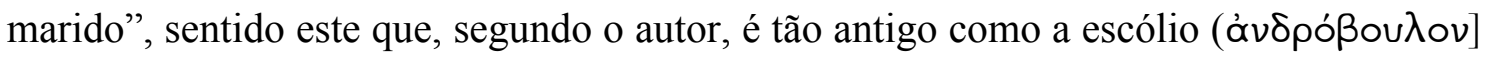

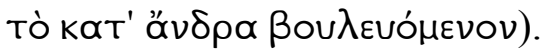

2) Pela longa duração da vigília - longo ano no qual aprendeu a conhecer os astros noturnos, cujos movimentos ascendentes e descendentes indicam o passar dos dias e das estações ${ }^{1}$. Note-se que há uma semelhança entre Homero e Ésquilo no que concerne à passagem do tempo e à duração da vigília: a vigilância "de longo ano"

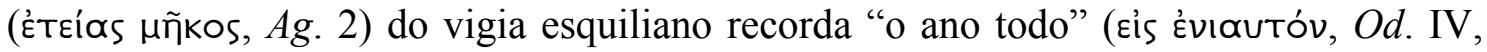
526) em que ficara a postos o vigia homérico. Assim como os astros noturnos contemplados em vigília são os que "trazem" (фépovtas, $A g$. 5) o inverno e o verão para os mortais, num movimento cíclico harmônico, o sinal de fogo "traz" (фépovođv, Ag. 9) a "voz de Troia" ('̇k Tpoías pátıv, $A g$. 9), que anuncia a captura da cidade, ou seja, a destruição, o aniquilamento, a morte, com todas as suas funestas consequências ${ }^{2}$. Essa longa vigília que Clitemnestra impõe ao Vigia é condizente com a descrição da

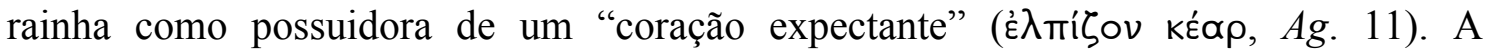
expectativa pelo retorno do marido não é, porém, a expectativa da mulher que, após longo tempo longe do esposo, deseja seu regresso, pois Clitemnestra não é uma mulher como as outras; é uma mulher de coração viril e que exerce o poder, de modo que sua expectativa pelo regresso de Agamêmnon possui um sentido outro, ominoso. Dessa forma, a longa duração da vigília do Vigia ecoa tanto a longa duração da guerra de Troia quando a longa duração da expectativa de realização de um desejo inflexível de Clitemnestra por vingança.

3) Por sua triste condição - as noites mal dormidas, sem a visita de sonhos, tomadas pelo pavor ( $\varnothing$ óßos, $A g .14$ ). O temor de que fala o Vigia, embora ele não o explicite, parece dizer respeito ao futuro de Agamêmnon, pois, em suas noites mal dormidas, ele geme e chora pela conjuntura do palácio, cuja atual administração ele julga não ser tão boa quanto à de outrora, visto que agora quem exerce o poder é uma rainha de coração expectante e de desígnios viris.

Como se atendesse diretamente à sua prece, o sinal de fogo surge nas trevas celestes, motivo de júbilo para o Vigia, que vê nesse sinal não apenas a tomada de Troia, mas também o fim de suas fadigas, o retorno do rei e, consequentemente, da boa

\footnotetext{
${ }^{1}$ Para um possível sentido ominoso dessa referência às Plêiades, que seria retomado mais explicitamente no discurso de chegada de Agamêmnon, conferir: Fisher \& Lewis (1984) "Agamemnon, Troy and the Pleiades".

${ }^{2}$ Para uma correlação entre os sinais de fogo anunciando a tomada de Troia e os sinais de fogo anunciando a captura de Atenas pelos persas, conferir o artigo "Darkness from Light: The Beacon Fire in the Agamemnon", de Tracy (1986).
} 
administração do palácio. Com um grito comunica à rainha que se levante de seu leito e transmita ao reino as boas novas - elevando pelo palácio "o alarido álacre"

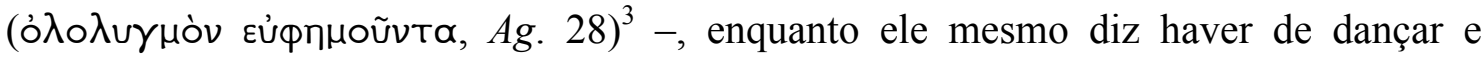
comemorar a libertação de sua vigilância noturna, fazendo votos de que lhe seja dado apertar na sua a mão amiga do rei em seu regresso ao lar.

Toda essa alegria libertadora de que o fogo mensageiro se faz sinal adquire, subitamente, um tom sinistro, quando, refreando o júbilo, o Vigia declara haver de calar-se quanto ao mais, de que fala com os que sabem e oculta dos que não o sabem. À eloquência do sinal de fogo, que é "a voz de Troia” (દ̇́ Tpoías qá tıv, Ag. 9), do grito

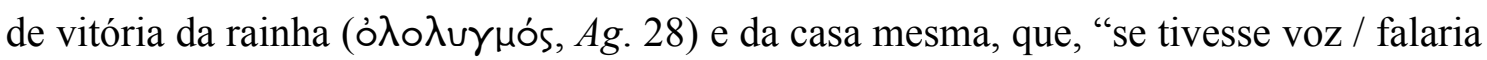

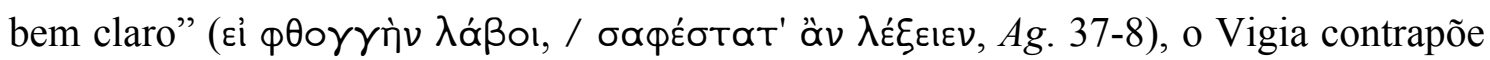
o seu silêncio e, sem dizê-lo, diz quase tudo: há algo de errado, a respeito do que não se pode falar abertamente, acontecendo no interior do palácio dos Atridas ${ }^{4}$.

O que há de enigmático, de sinistro e de temível na fala do Vigia obscurece a claridade luminosa do sinal de fogo, tornando-o um oú $\mu ß \circ \lambda \circ{ }(\mathrm{Ag}$. 8) ambíguo. Como irá ficar cada vez mais evidente ao longo da tragédia, o sinal de fogo que sinaliza a vitória em Troia também sinaliza a destruição que se prepara em Argos por vontade de

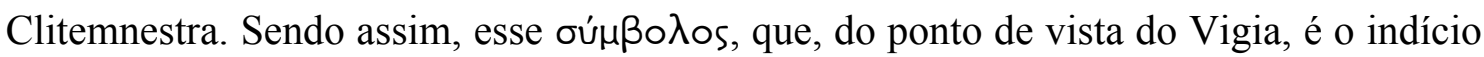

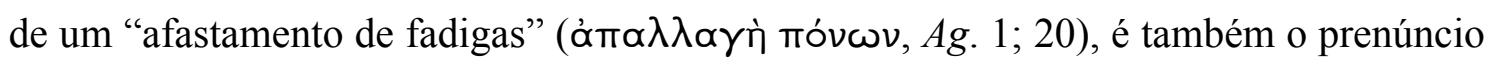
de uma aproximação de móvol: problemas, sofrimentos, dores. As dúvidas do Coro ao entrar em cena no párodo reafirmam essa ambiguidade do sinal de fogo.

O Coro de anciãos entra em cena e inicia o párodo anapéstico descrevendo, com um símile, o grande exército liderado pelos reis irmãos Agamêmnon e Menelau, que partiu há dez anos para Troia ${ }^{5}$ a fim de punir o rapto de Helena por Alexandre, infrator de mesa hóspede:

\footnotetext{
${ }^{3}$ No segundo episódio, Clitemnestra diz que "lançou um alarido" (đ́ $v \omega \lambda \lambda^{\prime} \lambda \cup \xi \alpha, A g$. 587) de alegria ao ver o sinal de fogo e que, em cada canto da cidade, cada um, à maneira de mulher, "lançava o alarido

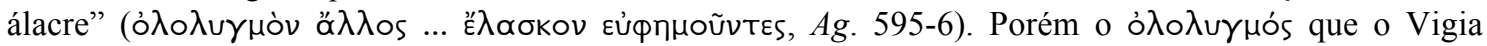
pretende que ela lance e que os demais cidadão lançam são em agradecimento pelo triunfo da expedição contra Troia, enquanto que o alarido de Clitemnestra é na verdade em agradecimento pela oportunidade que ela terá de executar a sua vingança matando Agamêmnon.

${ }^{4}$ Vaughn (1976, p. 336), em seu artigo "The Watchman at Agamemnon", faz a seguinte observação: "it is in the parenthetical or unobtrusive remarks of the Watchman that Aeschylus hides information or creates foreboding".

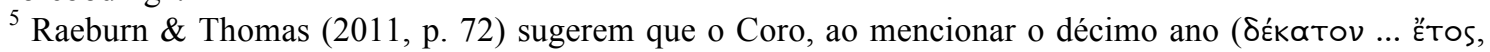
Ag. 40), mostra-se ciente da profecia de Calcas segundo a qual Troia seria capturada no décimo ano, tal como figura na Ilíada (II, 329), e que esse seria o motivo da apreensão do Coro quanto às notícias trazidas pelo fogo mensageiro. No entanto, a profecia do Calcas esquiliano está, como se verá, muito
} 


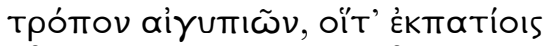

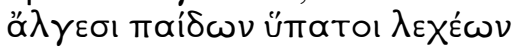

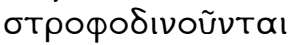

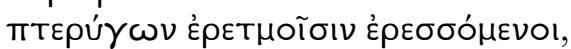

$\delta \varepsilon \mu \nu i o t n ́ \rho)$

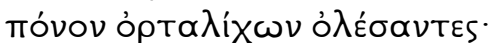

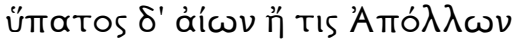

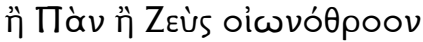

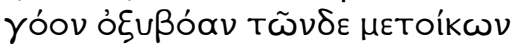

UंбTepótToIvov

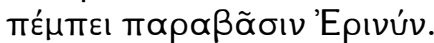

como abutres com erradias dores

por sobre os ninhos dos filhos

rodopiam

remando com remos de asas,

perdida a cuidosa

fadiga com filhotes.

Nos súperos, Apolo ou Pã

ou Zeus, ouvindo o trilado

pranto agudo destes metecos,

envia aos transgressores

depois punitiva Erínis.

Nesse símile, os reis figuram como aves de rapina, que, dolorosamente privadas de seus filhotes, rodopiam sobre seus ninhos, e cujo trilado não passa despercebido aos ouvidos dos deuses ${ }^{6}$. Tal como os deuses enviam punitiva Erínis aos que roubaram os filhotes dos abutres, assim também Zeus envia os Atridas para punir os que roubaram Helena $^{7}$. Dessa forma, essa Erínis, enviada como punição aos transgressores, manifestase sob a forma do exército liderado pelos Atridas e, mediante sua atuação, cumprir-se-á a justiça de Zeus Hóspede, cuja cólera inflexível não se pode abrandar nem com sacrifícios nem com libações. Sendo assim, nas tramas dessa imagem poética de que Ésquilo se vale aqui, articula-se uma identificação direta entre o exército enviado a Troia para punir Páris, infrator de mesa hóspede, e uma Erínis punitiva enviada por Zeus. A palavra Erínis aparece no caso acusativo ('Epıvúv, $A g .59$ ), porque é objeto de

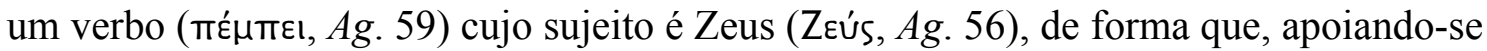
na cumplicidade poética e sintática, apresenta-se aqui a ideia de que a justiça de Zeus se manifesta, em sua face punitiva, na ação das Erínies, bem como na ação das Erínies se cumpre a justiça de Zeus.

Diante do ardor colérico do exército e de seus líderes, o Coro, já muito idoso para atividades bélicas, descreve-se vagueando como um "sonho à luz do dia" (övap

distante da profecia do Calcas homérico e o motivo do estado apreensivo do Coro diz mais respeito às possíveis consequências dessa conquista do que da conquista em si mesma.

${ }^{6}$ Observe-se que esse símile assemelha-se a um símile homérico: na Odisseia, diz-se que, no reencontro entre Odisseu e Telêmaco, ambos, emocionados, choram ruidosamente "como aves barulhentas / a águia marinha ou os abutres de garras recurvas, privados / por camponeses dos filhos, que, implumes, voar não

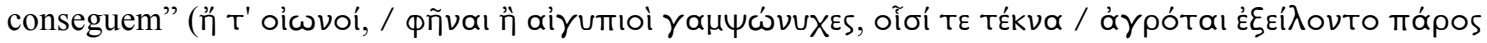

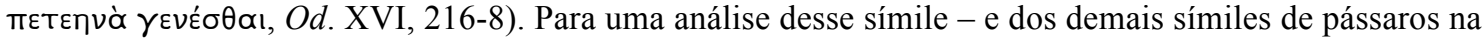
Odisseia - e sua implícita relação com a vingança, conferir o artigo de Rood (1982), "Implied Vengeance in the Simile of Grieving Vultures (Odyssey 16.216-19)".

${ }^{7}$ Schein (in: GRETHLEIN \& RENGAKOS, 2009, p. 390) faz a seguinte observação a respeito desse símile: "This humanizing of the vultures' stolen chicks and their parents' feelings is more appropriate to the loss of children by Thyestes (and the citizens of Argos) than to Menelaos' loss of Helen". 


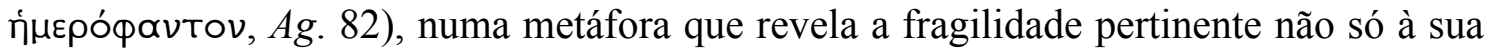
avançada idade, mas também à própria condição humana.

Tendo assim, por meio dessas imagens, descrito o exército, seus líderes e a si mesmo, o Coro indaga à Rainha Clitemnestra, cuja presença se manifesta mediante a ordem que se cumpriu: a de que todos os altares se cobrissem de oferendas e sacrifícios fossem realizados. Tais ações de graça trazem perplexidade ao Coro, pois este se encontra entre a aflição pelo exército que partiu há tanto tempo e a esperança que reluz nos altares da cidade.

É nesse momento que, para encontrar um sentido para a presente situação e para sua própria perplexidade diante desta, o Coro relembra, no párodo lírico, o auspício das aves que marcou a partida do exército a Troia:

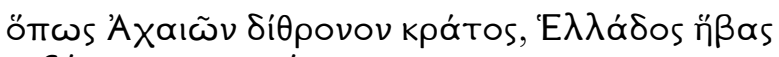

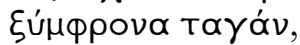

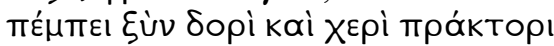

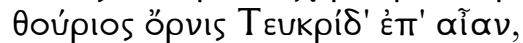

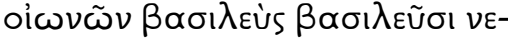

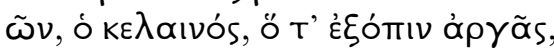

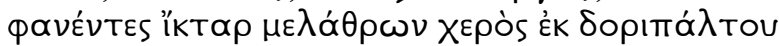

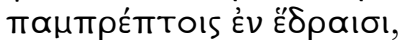

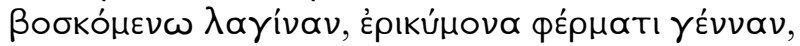

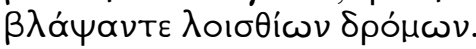

Impetuoso pássaro envia à terra têucrida

o poder aqueu de dois tronos,

o prudente império da juventude grega, com lança e braço atuante.

Os reis das aves, ante os reis das naves, - o negro e o outro alvacento atrás, vistos perto do palácio à mão da lança em bem evidentes posições, devorando a lebre prenhe com sua cria tolheram-lhe últimas corridas.

(Ag. 109-20)

O auspício (ópvis) diz-se "impetuoso" (Өoúpıos), isto é, relativo à guerra, visto

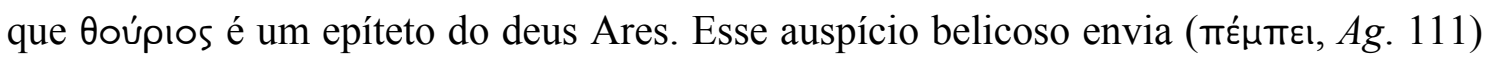

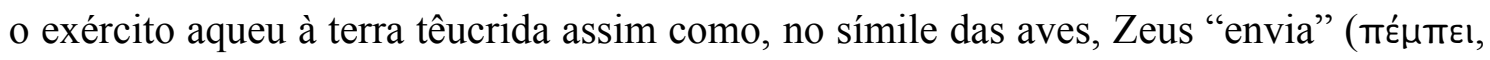
Ag. 59; 61) uma Erínis punitiva, isto é, os Atridas, contra Alexandre. Conecta-se assim o auspício à manifestação direta da vontade de Zeus.

Trata-se de uma visão clara. A descrição da espécie (águias), da coloração da plumagem dos pássaros (uma negra e outra de rabo branco), do local (perto do palácio) e da direção (à direita) de sua aparição, bem como de seu comportamento (devorando a lebre prenhe) - elementos sob cuja observação se apoia a arte augural -, deveria, a princípio, assegurar também a clareza da interpretação do auspício. Contudo, como se irá observar, essa clareza se turva com as palavras de Calcas, cuja interpretação soa tão enigmática e plurissignificativa quanto um oráculo.

Há um debate entre os helenistas a respeito do local geográfico da aparição do auspício. Sommerstein (2010, pp. 171-7) defende, na contramão de grande parte dos 
comentadores, que o auspício é avistado em Argos e não em Áulida ${ }^{8}$, onde, na Ilíada,

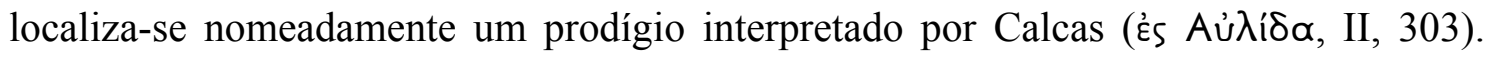
Contudo, como observa Schein (in: GRETHLEIN \& RENGAKOS, 2009, p. 390), o que realmente importa na narrativa do Coro não é o local geográfico de sua aparição e sim que o auspício foi avistado "perto do palácio" (î́к $\left.\propto \rho \mu \mu^{\prime} \alpha \dot{\theta} \theta \omega \nu, A g .116\right)$ e, portanto,

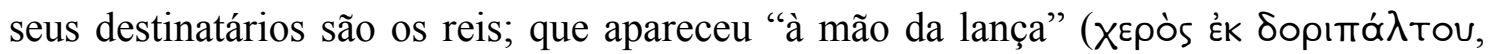
$A g$. 116), e, assim, diz respeito à guerra; que a mão que carrega a lança é a mão direita

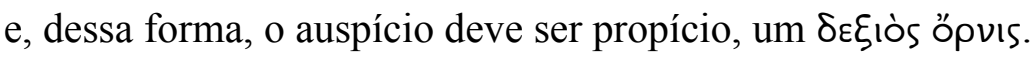

É a Calcas que aqui cabe a interpretação do auspício. Calcas é descrito pelo Coro como um sábio oтpatómavтıs, isto é, o adivinho que acompanha as expedições

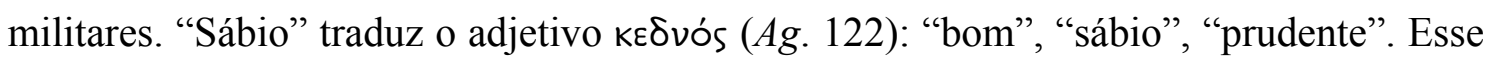
seu qualificativo influencia positivamente a apreciação que se deverá fazer a respeito de sua predição, conferindo-lhe uma marca de confiabilidade, de veracidade.

Calcas é um dos grandes adivinhos da Antiguidade e sua atuação, principalmente como áugure, está intimamente relacionada à expedição contra Troia. Sua participação na Ilíada, ainda que esporádica, é de suma importância. Como nota Bouché-Leclercq (2003, p. 306), "il est, en quelque sorte, le moteur de cette vaste ligue dont Agamemnon est le chef nominal”. É descrito por Homero como o filho de Téstor, “de longe o melhor áugure, / que conhecia o passado o presente e o futuro / e que conduziu os navios dos acaios para Ílion, / graças à arte divinatória que Febo Apolo lhe

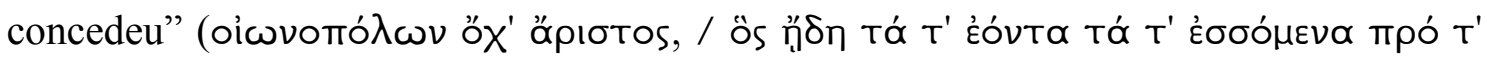

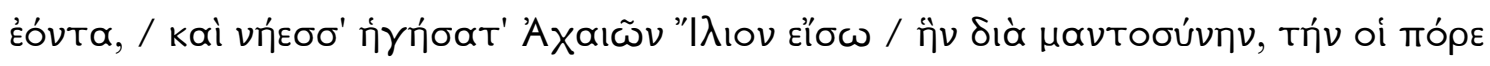
Фоїßos 'Aтó $\lambda \lambda \omega \nu$, Il. I, 69-72) ${ }^{9}$. Durante os dez anos da expedição, o adivinho aconselhou e incitou os aqueus. Nada mais se sabe a respeito da origem de seu dom profético além de que este lhe foi outorgado por Apolo ${ }^{10}$.

\footnotetext{
${ }^{8}$ Heath (2001), em seu artigo, "The Omen of the Eagles and Hare: From Aulis to Argos and Back Again" rebate os argumentos utilizados por Sommerstein, defendendo a aparição do auspício em Áulida. Conferir ainda Fraenkel (1982, p. 70, vol. II); Bollack (1981, pp. 139-42, vol. I); Raeburn \& Thomas (2011, p. 80). ${ }^{9}$ Tradução nossa.

${ }^{10}$ Sobre sua morte, no entanto, há vários relatos tardios recolhidos por Bouché-Leclercq (2003, pp. 306-9) em sua obra. Segundo o autor, há divergências sobre qual teria sido o local de sua morte: na Daunia, onde havia uma tumba e um oráculo de Calcas, ou, como aponta outra tradição, próximo a um oráculo, seja de Claros, de Malos ou de Grinion. Em Eurípides, em Ifigennia em Táurida, Orestes responde à pergunta de Ifigênia sobre o destino de Calcas dizendo apenas: "Morreu, ao que diziam os micênios" (I.T. 531-2). Ainda segundo Bouché-Leclercq (2003, pp. 773-4), o oráculo de Calcas na Daunia parece ter sido um oráculo de origem tardia, em que se praticava a incubação de forma muito semelhante ao oráculo de Anfiarau em Óropos.
} 
Note-se que o discurso de Calcas é reproduzido pelo Coro em discurso direto, o que, conforme aponta De Jong (1991, p. 174), confere à narrativa um imediatismo e uma proximidade, como se fosse a voz do próprio Calcas que os espectadores estivessem ouvindo. E essa voz diz o seguinte:

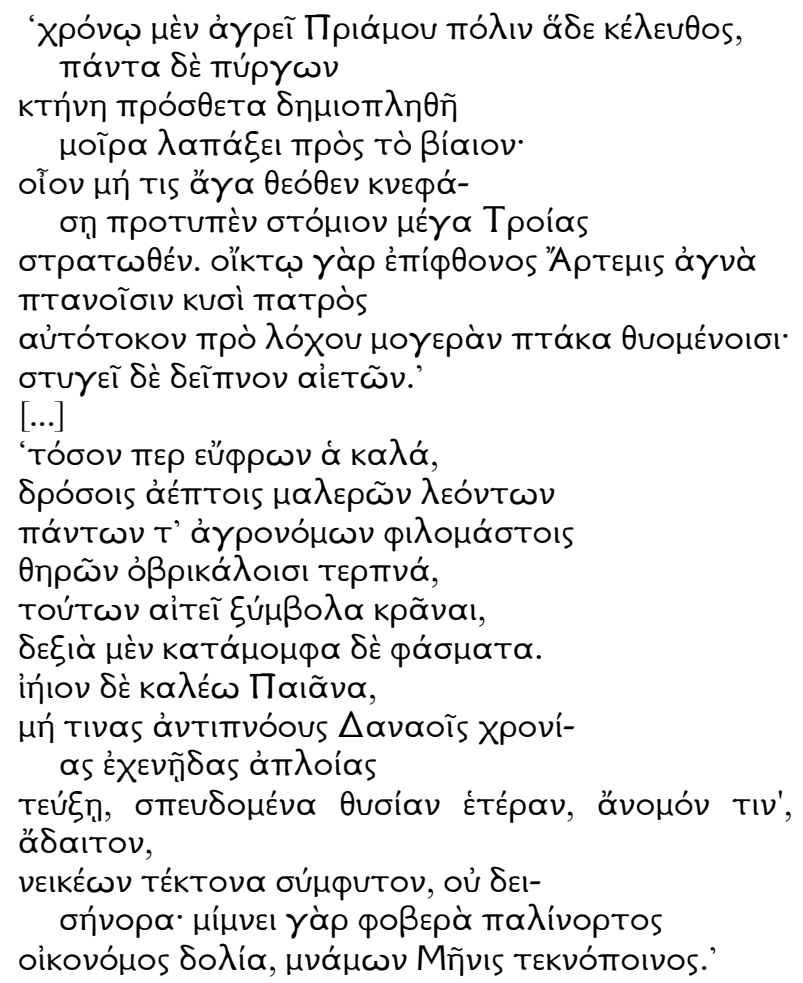

\author{
"A tempo esta incursão pilha o país de Príamo, \\ Ruína espoliará com violência \\ todas as tropas que o povo pôs \\ copiosas diante das muralhas. \\ Que a ira dos deuses não entenebreça \\ por precipitado o grande freio de Troia \\ acampado; por dó Ártemis pura se recusa \\ aos alados cães do Pai sacrificadores \\ de mísera lebre prenhe antes do parto \\ e tem horror ao repasto das águias." \\ [...] \\ "A Bela, porquanto benévola \\ com filhotes inermes de árdegos leões \\ e prazerosa com lactentes crias \\ de todos os animais selvícolas, \\ pede que deles se cumpram sinais, \\ destras mas repreensíveis visões. \\ Invoco Ieio Peã, \\ que ela não faça aos dânaos ventos adversos \\ tardios travantes inavegáveis, \\ a urgir sacrifício outro insólito impartilhável, \\ inato artesão de rixas por não temer marido, \\ pois permanece pavorosa ressurgente \\ Caseira astuta: mêmore Cólera filivíndice."
}

(Ag. 126-58)

Ao interpretar o auspício, Calcas cria uma identificação entre as duas águias,

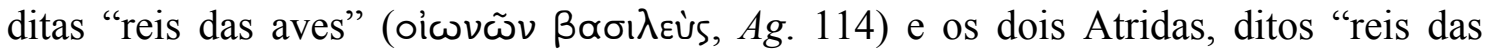
naves" ( $\beta \propto \sigma ı \lambda \varepsilon \cup \tilde{\sigma} \sigma ı \in \tilde{\nu} v, A g$. 114), identificação esta que já havia sido prenunciada no

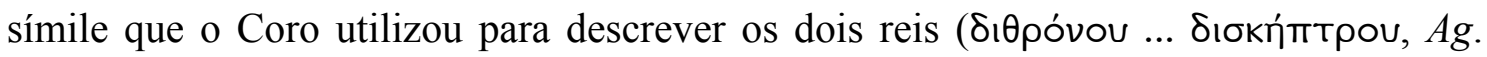
43), que, como aves de rapina ( $\alpha i \gamma \cup \pi \operatorname{\imath } \tilde{\nu} \nu, A g$. 49) privadas de sua ninhada, partem para a guerra em busca de reparação. Como se viu, a águia está entre os pássaros mais nobres no imaginário grego e é a ave mais diretamente associada a Zeus. Nesta passagem, as

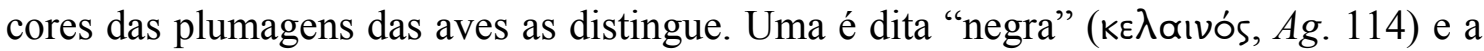

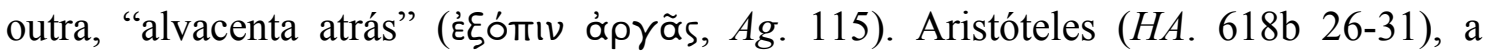

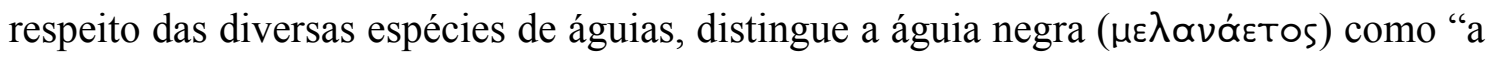

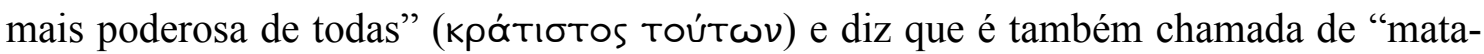

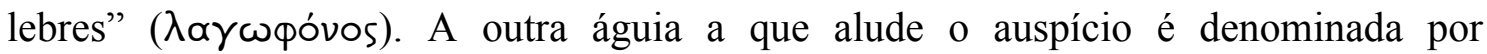
Aristóteles de "águia-rabalva" (múyapyos), devido à coloração alva de seu rabo, e, 
embora seja hierarquicamente inferior à águia negra, a esta não falta "ousadia" (Tò

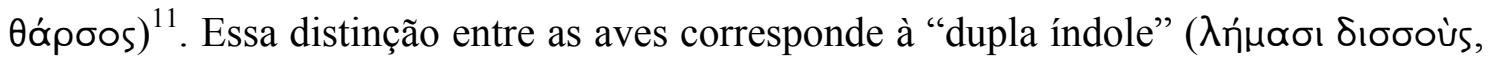
$A g$. 122) que o adivinho identifica nos reis irmãos ${ }^{12}$. Apesar da dupla índole, como distinta é a coloração das águias, ambos são ditos igualmente "belicosos, vorazes de lebre" (

Para Calcas, assim como as duas águias do auspício capturaram e devoraram a lebre prenhe, Agamêmnon e Menelau conquistarão e destruirão a cidade de Troia. Isso,

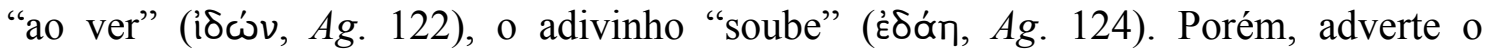
adivinho, o fato de as águias capturarem e devorarem uma lebre prenhe poderia sinalizar o perigo de o exército argivo incorrer na ira divina, porque Ártemis, ciosa dos filhotes de animais silvestres, ressente-se do festim das águias, que lhe causa horror.

Assim, se por um lado, o auspício assegura a vitória argiva - as águias surgiram na direção da mão que segura a lança, isto é, à direita, o que denota seu aspecto favorável -, por outro, o desfavor de Ártemis poderia manifestar-se em ventos impróprios à navegação, os quais criariam a necessidade de um terrível e inusitado sacrifício, fazendo que novos males se abatam sobre o palácio através do ressurgimento de uma pavorosa Cólera que não se esquece de vingar os filhos ( $\mathrm{Ag}$. 157-8).

A alusão que o texto faz ao iminente sacrifício de Ifigênia e ao futuro assassinato de Agamêmnon por Clitemnestra, ainda que bastante eloquente, constitui apenas um dos fios que compõe a intrincada trama da fala profética de Calcas. Nesse discurso do adivinho, de tão complexa urdidura, o desvelamento de fatos futuros é somente uma das dimensões de suas palavras, que abarcam não apenas o futuro, mas também o presente e o passado, cancelando-lhes as fronteiras. E, assim, o auspício alude igualmente ao pretérito crime de Atreu contra os filhos de seu irmão Tiestes, à maldição que impende sobre o palácio, ao sacrifício de Ifigênia em um futuro próximo e ao futuro assassinato de Agamêmnon. A imprecisão da localização geográfico-espacial em que o auspício foi avistado corresponde à imprecisão temporal de seu significado.

Nessa complexa trama, uma das muitas questões que a enigmática fala de Calcas suscita e que tem há muito provocado o debate entre os helenistas, é o motivo da cólera

\footnotetext{
11 Arnott (1979, pp. 7-8), em seu artigo "The Eagle Portent in the Agamemnon: An Ornithological Footnote", defende a ideia de que se trata da mesma espécie de águia e que as águias são distintas porque uma é mais jovem que outra. Para Fraenkel (1982, p., vol. II), "precise zoological identification of the species of eagle named by Aeschylus must not be attempted".

${ }^{12}$ Alguns comentadores veem na águia rabalva uma alusão ao caráter supostamente covarde de Menelau,

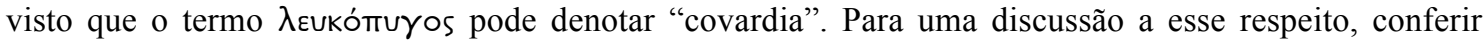
Fraenkel (1982, p. 69-70, vol. II) e Bollack (1981, p. 135-8, vol. I).
} 
de Ártemis, visto que este, ao confundir-se com a própria manifestação do auspício, não tem, para os estudiosos, seu sentido suficiente explicitado pelas palavras do adivinho, criando dessa forma a necessidade de uma hermenêutica da hermenêutica de Calcas.

Antes, porém, de se considerar a interpretação que disso oferecem os estudiosos, observe-se primeiramente como esse mitologema da demanda do sacrifício de Ifigênia por uma Ártemis encolerizada aparece nas fontes antigas.

Em outros autores, além de Ésquilo, encontra-se alusão a esse significativo episódio e, de sua leitura e análise, podem-se destacar dois pontos:

1) $\mathrm{O}$ sinal divinatório tradicionalmente associado à ocasião do agrupamento dos exércitos em Áulida antes da partida para Troia é aquele que o mesmo Calcas testemunha e interpreta no livro II da Ilíada de Homero e que é reproduzido por Odisseu em seu discurso à assembleia de guerreiros: enquanto faziam sacrifícios aos deuses num altar situado à sombra de um plátano, surgiu uma serpente, que, subindo até o ramo mais alto da árvore e encontrando ali abrigados oito filhotes de pardais mais a mãe destes, devorou-os todos, sendo a seguir transformada em pedra (Hom. Il. II, 303-19). A interpretação do Calcas homérico é de que se trata de um prodígio enviado por Zeus prenunciando a conquista de Troia (Hom. Il. II, 323-29).

No resumo de Proclo dos Cantos Cíprios, há uma referência ao mesmo sinal

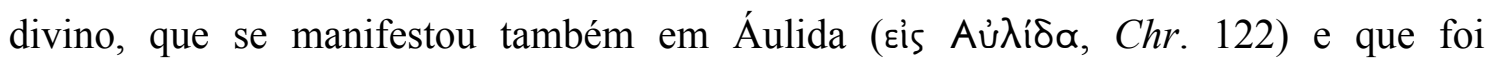
igualmente interpretado por Calcas como prenúncio da vitória argiva: "Depois disso, tendo-se reunido em Áulida, ofereceram sacrifícios. E os acontecimentos relativos à serpente e aos pardais manifestaram-se e Calcas predisse-lhes o sucesso da expedição"

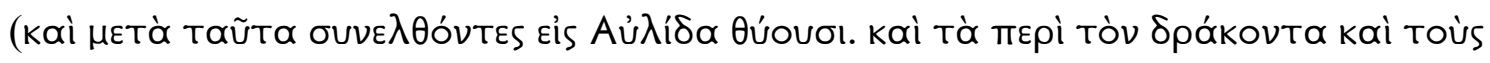

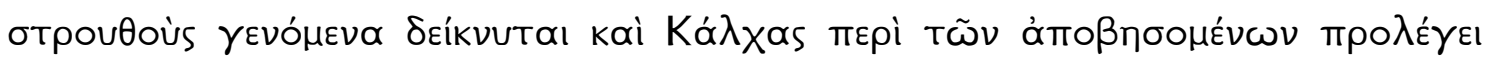
๔ưtoĩs, Chr. 122-4) ${ }^{13}$. Apolodoro, na Epítome (Epit. 3, 15-16), mantém-se fiel ao prodígio homérico - a serpente que devora os pardais -, às suas circunstâncias - a reunião do exército em Áulida - e à interpretação dada por Calcas - a vitória sobre os troianos. Diz Apolodoro:

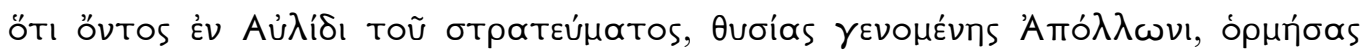

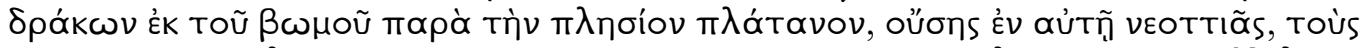

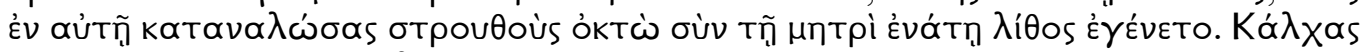

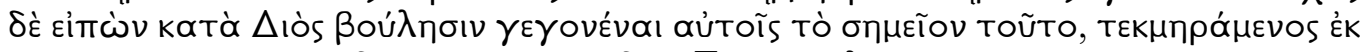

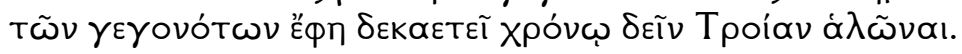

\footnotetext{
${ }^{13}$ A edição é de Severyns (1963) e a tradução é nossa.
} 
Quando o exército estava reunido em Áulida, depois de terem feito um sacrifício a Apolo, uma serpente se lançou do altar para junto de um plátano, onde havia um ninho de pássaros, e, tendo devorado oito pardais com a mãe, o nono, transformou-se em pedra. Calcas, dizendo que esse sinal lhes havia aparecido por vontade de Zeus e conjecturando sobre o fato ocorrido, anunciou que Troia seria tomada dentro de um período de dez anos. (Epit. III, 15) ${ }^{14}$

2) Encontram-se diferentes versões para justificar a cólera de Ártemis e a sua demanda pelo sacrifício de Ifigênia. Na poesia homérica não há qualquer referência a ventos adversos em Áulida, ou a Ártemis, ou ao sacrifício da jovem filha de Agamêmnon. A única alusão à Ifigênia - problemática, diga-se de passagem, visto que seu nome ali aparece como sendo Ifianassa - dá-se quando Agamêmnon oferece a Aquiles a possibilidade de desposar uma de suas filhas. Ele diz apenas: "Três filhas tenho em meu bem-construído palácio: Crisótemis, / Ifianassa e Laódice. Aquela que for do seu gosto, / sem que se veja obrigado a pagar dote algum, para casa / leve ao

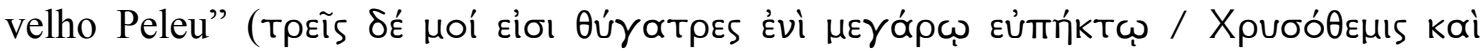

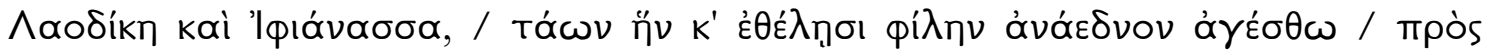

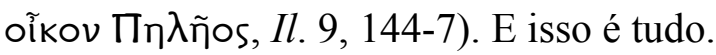

$\mathrm{Na}$ poesia trágica, na Electra sofocliana, figura um motivo pelo qual a deusa se encoleriza e exige a vida de Ifigênia. Discutindo com a mãe, a quem acusa de assassina, Electra, no segundo episódio, dirige-se a Clitemnestra com estas palavras:

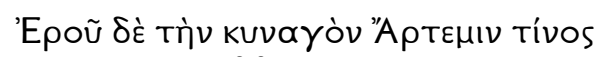

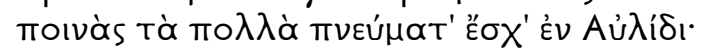

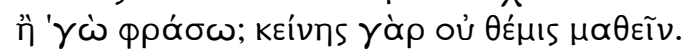

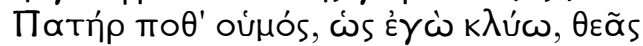

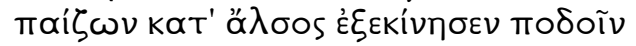

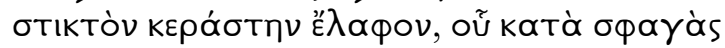

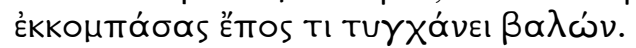

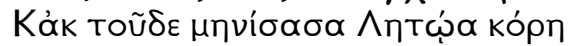

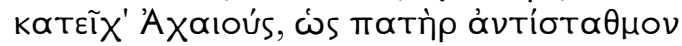

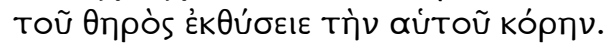

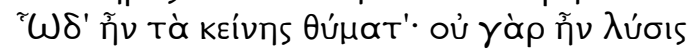

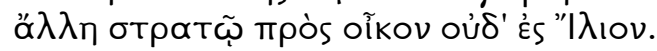

Pergunta então a Ártemis caçadora que erros [castigou ao] parar os abundantes ventos em Áulis; ou melhor, te direi eu, pois não é lícito sabermos por ela. Meu pai, segundo ouvi, caçando certa vez no bosque da deusa, desentocou com seus passos malhada e galhuda corça; por tê-la ferido, aconteceu de ele lançar uma palavra de vanglória. Encolerizada por isso, a filha de Letó reteve os aqueus e assim meu pai, em compensação pelo animal, ofereceu a própria filha em sacrifício. Por isso foi ela sacrificada, pois não seria liberado de outra forma o exército, nem para casa, nem para Ílion.

$(\text { El. 563-73) })^{15}$

Aqui, Ártemis se encoleriza ( $\mu \eta v i ́ \sigma \alpha \sigma \alpha)$ devido à atitude soberba, hybristés, de

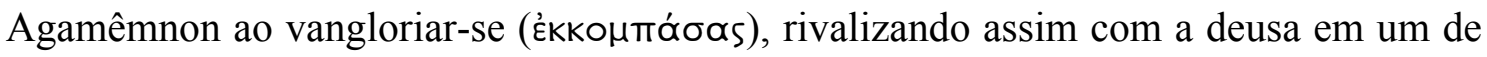
seus principais âmbitos de atuação, a caça. Trata-se de um tópos na literatura grega

\footnotetext{
${ }^{14}$ A edição é de Frazer (1921) e a tradução é nossa.

${ }^{15}$ Tradução inédita de Wilson Alves Ribeiro Jr.
} 
antiga: o mortal que se vangloria de ser superior a um deus em determinada atividade ou habilidade e, por essa razão, por essa hýbris, é duramente castigado pela divindade, como é o caso também de Níobe, por exemplo, que, tendo-se vangloriado de ter mais filhos que Leto, como punição, acabou privada de toda a sua prole.

Em Eurípides, dentre as suas tragédias supérstites, quatro tematizam as desventuras dos Atridas: Ifigênia em Táurida, Electra, Orestes e Ifigênia em Áulida. Mas, somente na primeira destas, atribui-se um motivo à demanda de Ártemis pelo sacrifício de Ifigênia. Nesse drama, a jovem, tendo sido salva do sacrifício, no último momento, pela própria deusa, vive desde então como sua sacerdotisa na região da Táurida. No prólogo, ela mesma narra as circunstâncias em que seu pai se viu confrontado com a demanda de seu sacrifício:

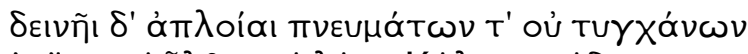

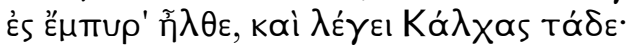

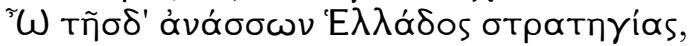

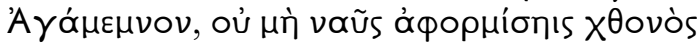

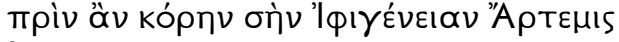

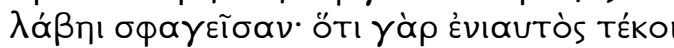

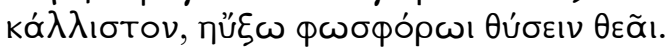

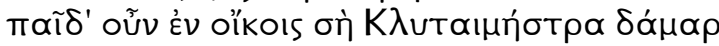

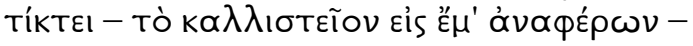

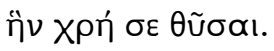

Na terrível calmaria sem lograr ventos consultou a pira e Calcas lhe diz isto: "Ó soberano chefe do exército grego "Agamêmnon, não te zarparão do solo "antes que imoles a Ártemis tua filha "Ifigênia; prometeste à Deusa lucífera "sacrificar o mais belo produto do ano. "Tua esposa Clitemnestra em casa teve "a filha - referindo-se a mim o mais belo "que deves sacrificar."

Nesses versos, encontra-se uma versão diferente para o motivo da demanda de Ártemis: o não-cumprimento de uma antiga promessa feita à deusa. A promessa feita à deusa de lhe sacrificar o mais belo fruto do ano revelou-se afinal amarga, pois a sua filha foi o mais belo fruto produzido naquele ano. Este é também um tema comum à literatura grega: o mortal que promete algo a certa divindade e, por não cumprir sua palavra, quer intencionalmente, quer por negligência, quer por não compreender o alcance de sua promessa, é castigado pelo deus. É o caso de Cassandra, que, como a própria profetisa irá contar ao Coro no quarto episódio do Agamêmnon, prometeu unirse a Apolo em troca da vidência e, não cumprindo sua promessa, foi castigada pelo deus com a perda do poder de persuasão (Ag. 1202-12).

$\mathrm{Na}$ Epítome de Apolodoro, figura uma dupla causalidade para a cólera da deusa: 


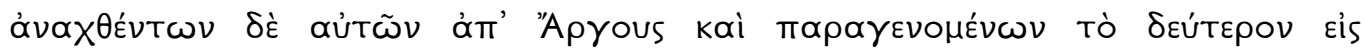

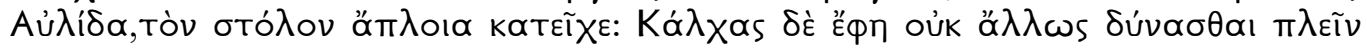

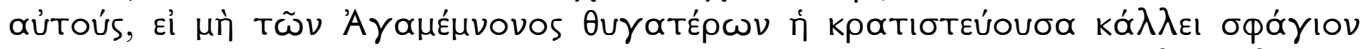

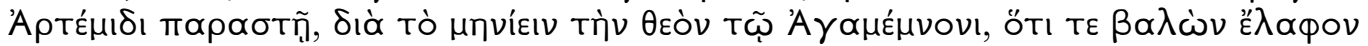

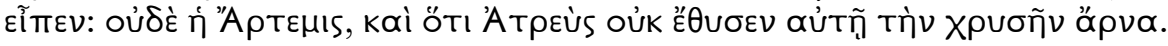

Mas quando, de Argos, eles se lançaram ao mar e se dirigiram pela segunda vez a Áulida, a frota ficou impedida de navegar, e Calcas disse que eles não poderiam fazê-lo, a menos que a mais bela das filhas de Agamêmnon fosse dada em sacrifício a Ártemis, pois a deusa estava irada com Agamêmnon, porque ele, tendo matado um veado, disse: "Nem mesmo Ártemis [faria melhor]!", e porque Atreu não sacrificou a ela uma ovelha dourada. (Epit. 3, 21)

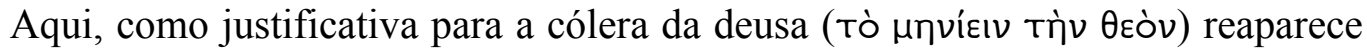
o motivo da vanglória de Agamêmnon durante a caça - o rei, ao matar uma corça, diz:

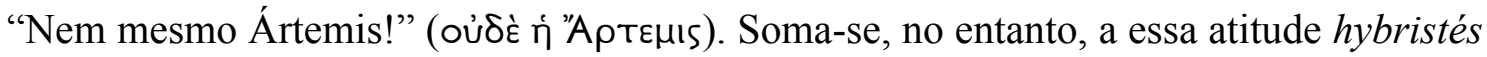
de Agamêmnon, uma antiga infração cometida por seu pai, Atreu, infração esta que é, como em Eurípides, o não cumprimento de um voto, pois ele não sacrificou à deusa uma ovelha dourada.

No resumo dos Cantos Cíprios, Proclo apresenta basicamente o mesmo motivo para a cólera de Ártemis que se viu na Electra de Sófocles:

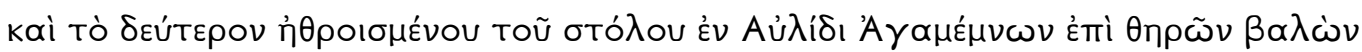

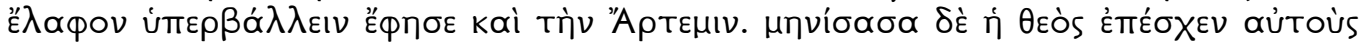

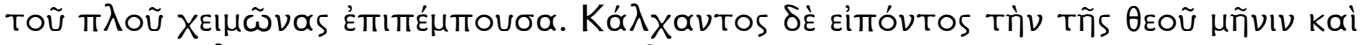

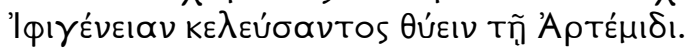

E quando a expedição se reuniu em Áulida pela segunda vez, Agamêmnon atingiu uma corça durante uma caçada e disse ter superado até mesmo a Ártemis. Encolerizada, a deusa impediu a navegação, enviando tempestades. Calcas, então, falou da cólera da deusa e exortou-os a sacrificar Ifigênia a Ártemis. $(C h r .135-40)^{17}$

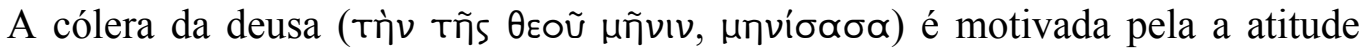

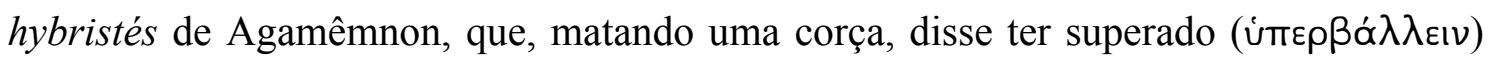
Ártemis.

Pode-se assim observar que, em nenhuma dessas narrativas, há uma conexão direta entre o sinal divino avistado em Áulida prenunciando a tomada de Troia e o motivo da cólera de Ártemis a demandar o sacrifício de Ifigênia ${ }^{18}$. O local e a

\footnotetext{
${ }^{16}$ A edição é de Frazer (1921) e a tradução é nossa.

${ }^{17}$ A edição é de Severyns (1963) e a tradução é de Wilson Alves Ribeiro Jr. (2006).

${ }^{18}$ A esse respeito, observa Peradotto $(1969$, p. 243$)$ : "Two things are noteworthy about these versions in their treatment of Artemis' anger. First, the various inciting causes are altogether prior to and wholly
} 
circunstância parecem ser os mesmos: o acampamento grego em Áulida ${ }^{19}$, de onde o exército parte em suas naus para conquistar Troia, mas se trata de acontecimentos distintos e até mesmo, como em Apolodoro e em Proclo, separados por uma distância temporal que pode chegar até a oito anos, visto que ambos os autores circunscrevem os acontecimentos relativos ao sacrifício de Ifigênia à "segunda vez" (тò Seútepov, Apoll. Epit. 3, 21; тò Seútepov, Procl. Chr. 135) em que o exército se reuniu em Áulida ${ }^{20}$.

Pode-se observar também que, apesar das variações, a versão mais recorrente para a cólera da deusa - considerando-se obviamente as pouquíssimas e muitas vezes imprecisas fontes de que se dispõe -, diz respeito a uma atitude inadequada, do ponto de vista da piedade grega, de Agamêmnon (ou de Atreu) perante Ártemis, em sua qualidade de deusa da caça, dos bosques intocados, dos animais silvestres. Agamêmnon adentra um espaço a ela consagrado - um bosque -, mata um animal sob sua proteção geralmente uma corça - e rivaliza com a deusa no manejo do arco, vangloriando-se de sua superioridade. E, como retribuição por sua atitude transgressiva, a cólera de Ártemis manifesta-se na ausência de ventos ou em ventos impróprios à navegação.

Ainda que haja geralmente uma tradicional sequência de eventos que compreendem (1) a manifestação de um sinal divino antes da partida a Troia, (2) a reunião da expedição nas praias da Áulida, (3) a cólera de Ártemis e (4) o sacrifício de Ifigênia; e ainda que essa sequência de eventos esteja indubitavelmente presente no párodo esquiliano, a forma como Ésquilo conjuga esses elementos causa um grande embaraço para os estudiosos de Agamêmnon, pois muitos helenistas procuram atribuir um sentido unívoco a uma passagem que é uma das mais representativas da tragédia esquiliana justamente por ser obscura, ambígua, complexa, polissêmica, ou seja, nãounívoca.

Veja-se, a título de exemplo e em linhas gerais, algumas interpretações que foram propostas pelos helenistas para explicar a cólera de Ártemis. Fraenkel (1983, p. 98-9) argumenta que Ésquilo e seus espectadores certamente tinham em mente a versão mais comum da história, isto é, a vanglória de Agamêmnon como causa da cólera de Ártemis, mas que Ésquilo omite intencionalmente essa informação para enfatizar a responsabilidade de Agamêmnon pelo sacrifício de sua filha e porque a vanglória do rei

unrelated to the war; second, there is not the remotest resemblance between them and the Aeschylean omen of the eagles and the hare (unless it be in the killing of an animal)".

${ }^{19}$ Isto é, assumindo-se, juntamente com a maioria dos comentadores, que de fato o auspício tenha sido avistado em Áulida.

${ }^{20}$ De acordo com esses autores, a expedição argiva, após sua primeira reunião em Áulida, perdeu-se em sua viagem a caminho de Troia. 
representaria um motivo muito pequeno diante da grandeza dos temas que a Oresteia explora. Sommerstein (1980, p. 165-169) conclui que a cólera de Ártemis não é dirigida a Agamêmnon, mas a Zeus, pois são deste as águias que devoraram a lebre prenhe, cujos filhotes estão sob a proteção da deusa. Para Whallon (1961), em artigo dedicado exclusivamente ao tema, a deusa se encoleriza por causa do vindouro massacre em Troia, mas também pelo pretérito assassínio dos filhos de Tiestes. Lloyd-Jones (1962, p. 187-199) atribui a ira de Ártemis ao significado do auspício, que é a tomada de Troia, porque se trata de uma deusa que, na Ilíada, aparece tradicionalmente ao lado dos troianos. Já para Peradotto (1969, p. 237-263), Ártemis também se ressente por causa do significado do auspício, mas não pelo fato de as vítimas dos reis Atridas serem troianas, mas sim por serem jovens e inocentes e a deusa sabe que uma guerra conduzida por tais reis causará o massacre de muitos. Lawrence (1976, p. 97-110), por sua vez, acredita que a causa do ressentimento de Ártemis é irrelevante, uma vez que se deve ver a deusa não como um princípio metafísico e sim como um recurso dramático utilizado por Ésquilo a fim de acomodar a tradição mítica à sua visão de mundo.

Ora, se a cólera de Ártemis é motivada pelo que Agamêmnon fez - a sua vanglória ou o não-cumprimento de um voto - ou se é motivada pelo que ele ainda irá fazer - o massacre de inocentes, a desmedida do ardor guerreiro; se a morte da lebre prenhe significa o sacrifício de Ifigênia num futuro próximo, ou as futuras vítimas inocentes da guerra de Troia ou as vítimas passadas, isto é, os filhos assassinados de Tiestes -, é importante, todavia, levar em consideração que o olhar do adivinho e a arte do poeta manifestam aqui uma característica própria do pensamento mítico: a capacidade sinóptica de, sem excluir os elementos distintos do conjunto, apreender a sua totalidade: apreender passado, presente e futuro e, assim, a intrincada configuração numinosa de que fala o auspício.

Em um segundo artigo sobre o tema, Lloyd-Jones (1983, p. 87) afirma que acreditar que Ártemis está irada contra os Atridas, porque estes são simbolizados pelas águias e estas águias matam a lebre prenhe, um animal sob sua proteção, seria confundir o mundo dos sinais divinos com o mundo real que estes simbolizam. Mas, na verdade, é justamente isso que a poética esquiliana faz. É nisso que reside a força dramática dessa passagem. Na obra de Ésquilo, entre a imagem poética, a imagem profética e a realidade que esta simboliza não há interrupção, descontinuidade, distinção (VERNANT, 2005, p. 230). Não é possível, portanto, separar, no discurso de Calcas, o mundo do auspício do mundo real a que ele aponta. Essas duas realidades são indissociáveis. O que as mantém 
unidas é o olhar sinóptico do adivinho e a maestria da poética esquiliana. Não há, pois, como definir qual seja o motivo da cólera de Ártemis. A sua cólera é parte integrante do auspício das aves e, por isso mesmo, é obscura, ambígua, complexa e polissêmica.

Nesse mesmo artigo supracitado de Lloyd-Jones (1983), o autor acrescenta, no entanto, um dado relevante à sua argumentação, ao dizer que o ressentimento de Ártemis é sempre associado ao aspecto benéfico da deusa enquanto protetora dos jovens, fracos e inocentes, e que dessa forma não se leva em consideração um aspecto menos dócil da deusa, a quem se costumava fazer um sacrifício sangrento preliminar à qualquer ação guerreira; geralmente, sacrificava-se uma cabra, mas, em época arcaica, segundo o autor, esses sacrifícios podiam muito bem ser humanos, como no caso de Ifigênia.

Lloyd-Jones parece resgatar assim uma abordagem fundamental quando se está diante dessa passagem de Agamêmnon: é necessário olhar para a figura da deusa e para esse aspecto fundamental do mundo de que ela se faz imagem sensível e, então, procurar perceber que questões se apresentam ao ser humano quando ele entra em interlocução com essa deusa ao adentrar os espaços ou as áreas de atividade humana que ela preside.

Vernant, em um estudo dedicado a Ártemis $(1988 b)^{21}$, diz que o exército espartano regularmente fazia suas expedições acompanhado de um rebanho de cabras, que eram sacrificadas a cada limite natural a ser transposto. Primeiramente, quando se estava para transpor os muros da cidade e penetrar no campo, sacrificava-se uma cabra e esperava-se, dentre um determinado repertório de sinais divinos, um que significasse a aceitação do sacrifício pela deusa e portanto a sua permissão para se realizar essa passagem do território da cidade, urbano, para o campo selvagem, seu domínio. Depois, realizava-se novo sacrifício quando haviam quaisquer limites naturais a serem transpostos, como um curso d'água, por exemplo. Por fim, quando se estava ante a iminência da guerra, fazia-se outro sacrifício, na linha de batalha. Igualmente, perscrutavam-se os sinais do animal sacrificado para saber se havia anuência da deusa à ordem de ataque e, assim, permissão para se atravessar essa fronteira entre a civilidade e a selvageria na qual se equilibra e se desequilibra a atividade guerreira. E Vernant (1988a, p. 29) conclui: “Ártemis opera sempre como divindade das margens, com o

\footnotetext{
21 Trata-se do artigo "Artémis et le sacrifice préliminaire au combat", publicado na Revue des études grecques, 101.
} 
duplo poder de preparar as necessárias passagens entre a selvageria e a civilização e de preservar estritamente suas fronteiras, ainda quando estão sendo atravessadas"22.

Desse modo, a partir dessa perspectiva, a necessidade do sacrifício de Ifigênia em Ésquilo parece justificar-se por si mesma: à grandeza da expedição guerreira parece corresponder a grandeza do sacrifício - não uma cabra, como era usual, mas o mais belo dom do exército, isto é, a virgem filha de seu comandante. Agamêmnon se encontra em uma dúplice fronteira: uma fronteira física entre terra firme e mar - pois Áulida é a praia de onde as naus zarparão - e uma fronteira metafísica entre a civilidade e a selvageria - pois, se o auspício das aves prenuncia a vitória bélica e, como anuncia o adivinho, Ártemis pede que dele se cumpram sinais, isto é, que ele se realize; então, esse auspício equivale a uma ordem de ataque na linha de batalha.

A grande ironia trágica aqui é o fato de que o valoroso sacrifício humano que Agamêmnon realiza como um sacrifício preliminar a Ártemis, ainda que seja uma forma de preparar a passagem entre a selvageria e a civilização, tal como sugere Vernant, não é, no entanto, capaz de preservar as suas fronteiras, visto que a violência, a matança, a sede de sangue se disseminam e contaminam todos os acontecimentos da Oresteia, fazendo sucumbir, um a um, os membros da estirpe dos Atridas. A cólera de Ártemis não prenuncia apenas o sacrifício de Ifigênia, mas também todo o ciclo de violência retributiva que se inicia ou se reatualiza com esse sacrifício.

Essa relação inadequada com os limites, que obscurece as fronteiras, apagando suas margens e tornando difícil discerni-las, pode-se ver refletida na recusa de Ártemis. Afinal, não deixam de ser questões de limites que a Oresteia irá problematizar: as fronteiras entre o que é próprio dos deuses e o que é próprio dos homens, os limites do exercício do poder, as fronteiras entre justiça divina e justiça humana, os limites entre os domínios dos antigos deuses e os dos novos deuses; os limites, enfim, da própria condição humana.

É preciso ainda considerar que o auspício das aves fala de desígnios divinos e, portanto, Calcas, ao interpretá-lo, expressa um ponto de vista divino, muitas vezes inacessível ou de difícil compreensão para os homens mortais. Não é de se admirar, portanto, que a interpretação oferecida pelo adivinho seja complexa, polissêmica, ambígua. É necessário, porém, seguir os caminhos sinalizados pelas palavras do adivinho e procurar, o mais bem possível, perscrutar-lhes o sentido.

\footnotetext{
${ }^{22}$ Estudo sobre Ártemis publicado em A Morte nos Olhos - Figurações do Outro na Grécia Antiga: Ártemis, Gorgó, traduzido para o português por Clóvis Marques.
} 
O auspício é, antes de tudo, ambíguo. Calcas fala dessa ambiguidade ao

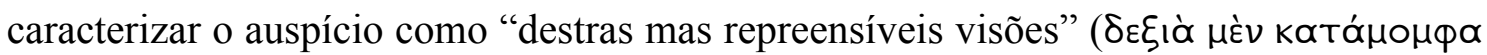

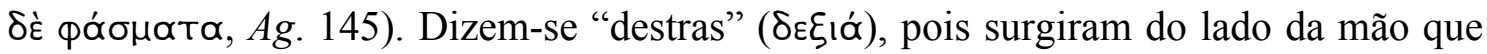
segura a lança, portanto, são auspiciosas. O aspecto favorável do auspício pertence ao domínio de Zeus, que, por meio de suas águias, dá anuência à conquista de Troia pelos Atridas. No entanto, além de destras, tais visões são também ditas "repreensíveis"

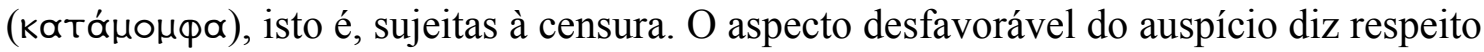
à necessidade, diante da recusa de Ártemis, de obter sua anuência ao prosseguimento da expedição guerreira mediante ventos propícios. Ventos adversos, impeditivos à navegação, trariam consigo a necessidade de um sacrifício "outro, insólito,

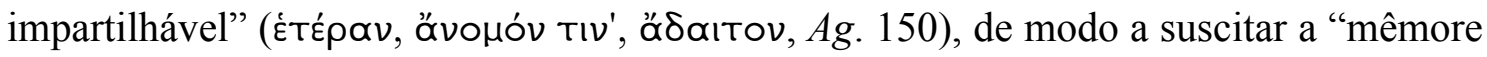

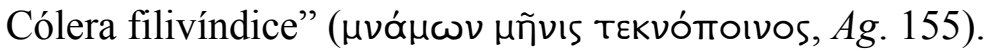

O auspício deixa, assim, entrever uma intrincada configuração numinosa. Tal configuração, como se viu, abrange tanto o passado quanto o futuro, pois esse terrível nume que habita o palácio dos Atridas é descrito como uma "caseira astuta: mêmore

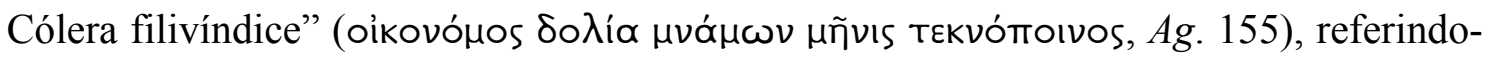
se, portanto, tanto à maldição de Tiestes, consequência da morte de seus filhos, quanto ao assassinato perpetrado por Clitemnestra para vingar a morte de sua filha Ifigênia, terrível sacrifício que as palavras do adivinho inscrevem no horizonte dos acontecimentos.

A ambiguidade do auspício é ainda sublinhada pelo estribilho três vezes

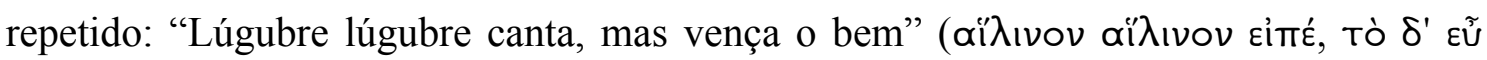

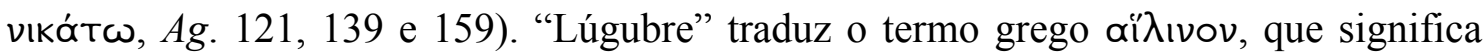
também "canto fúnebre". Esse canto fúnebre, a prantear todos os males e todos os mortos passados e prenunciados, é seguido pelo voto de que o bem vença. A narrativa do auspício das aves é pontuada por esse estribilho, que tem um caráter ritualístico. Além de sublinhar a ambiguidade do auspício, apresenta também uma função

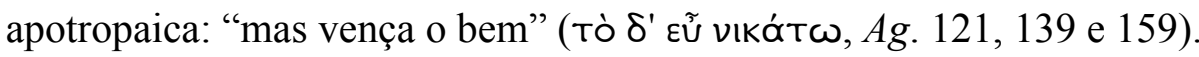

O auspício é também complexo. Um presságio favorável, a prenunciar a vitória do exército argivo, manifesta-se, mas, ao manifestar-se numa determinada forma, a da devoração de uma lebre prenhe por duas águias, gera o em nada favorável descontentamento de uma divindade, a qual deverá ser apaziguada, por meio de um terrível sacrifício de funestas consequências, de modo a garantir o 
andamento da expedição guerreira e, desse modo, o cumprimento auspicioso do presságio.

O auspício é ainda polissêmico. Na imagem das águias e a lebre prenhe, cuja aparição e comportamento compõem o auspício, há uma sobredeterminação de presságios característica de Ésquilo. Assim, a lebre prenhe é Troia capturada, mas também é, ao mesmo tempo, Ifigênia sacrificada por seu pai e os filhos de Tiestes oferecidos a este em banquete por Atreu. Às imagens advindas do auspício soma-se ainda a imagem poética na qual os reis são descritos pelo Coro como aves de rapina, raivosas e doloridas, por terem sido privadas de suas crias. Os reis, vitimados pelo rapto de Helena por Páris, assim como aves de rapina que têm roubada sua prole, sacrificam Ifigênia e atacam com excessiva violência a cidade de Príamo, assim como as águias atacam uma lebre que ainda está prenhe. Mas essa ave de rapina cujos filhotes foram roubados é também Clitemnestra. Assim, a rainha, vitimada pelo sacrifício de sua filha, age de forma excessiva em busca de vingança e comete novo crime ao assassinar seu marido. Do mesmo modo, Atreu, vitimado pelo adultério cometido por seu irmão com sua esposa, age de forma excessiva, cometendo novo crime ao assassinar seus sobrinhos e oferecê-los em banquete a Tiestes. E assim, nessa sobreposição de imagens poéticas e proféticas, delineia-se o destino da raça dos Atridas: uma sucessão brutal de crimes consanguíneos.

É interessante comparar o auspício das aves do texto esquiliano com o prodígio da serpente e dos pardais do texto homérico. De ambos aparece a descrição seguida de sua interpretação. Ambos se referem a um mesmo acontecimento, a conquista de Troia. Ambos são interpretados pelo mesmo adivinho, Calcas. Em Homero, o prodígio se dá nominalmente em Áulida; em Ésquilo, como se viu, não se nomeia o local geográfico de sua aparição ${ }^{23}$.

No livro II da Ilíada, Odisseu, em um inflamado discurso para conter as tropas gregas, que, saudosas de casa, desejavam abandonar o cerco a Troia, relembra o prodígio que lhes aparecera há dez anos quando as naus se encontravam reunidas em Áulida:

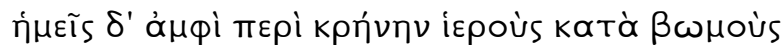

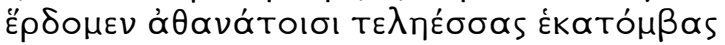

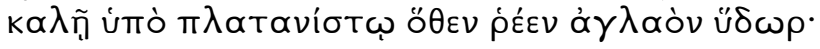

\footnotetext{
${ }^{23}$ A respeito da influência homérica no auspício das aves esquiliano, conferir o artigo de Heath (1999),

"The Serpent and the Sparrows: Homer and the Parodos of Aeschylus' Agamemnon".
} 


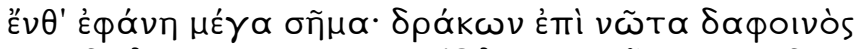

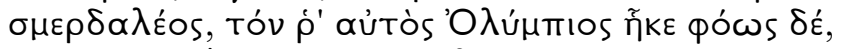

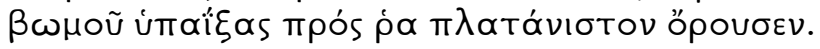

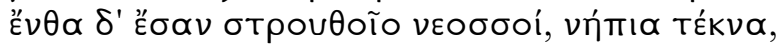

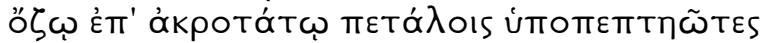

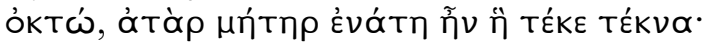

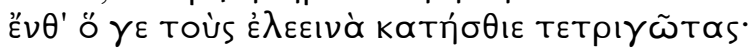

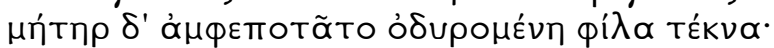

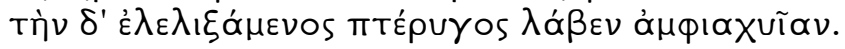

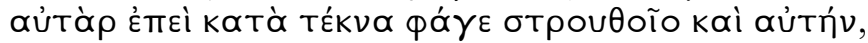

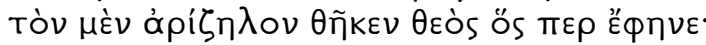

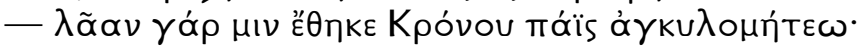

Junto das aras sagradas ao pé duma fonte nós todos às divindades do Olimpo hecatombes perfeitas fazíamos sob a frescura dum plátano donde fluía água límpida. Nisso um prodígio nos veio: uma serpe com dorso sanguíneo monstro terrível que à luz fora enviado por Zeus poderoso. Do supedâneo surgindo do altar subiu logo pela árvore onde a ninhada se achava dum pássaro míseros seres sob as folhinhas ocultos no ramo mais alto do plátano; oito eram eles incluindo-se a mãe que os gerou nove ao todo.

Por entre pios sentidos ali devorou todos eles e à própria mãe que gemente esvoaçava ao redor dos filhinhos: o bote atira-lhe o monstro apanhando-a por uma das asas. Mas após haver o dragão os filhotes e a mãe devorado foi pelo deus que o enviaram mudado num grande prodígio; petrificou-o ali mesmo o nascido de Cronos tortuoso. (Il. II, 305-19)

Odisseu prossegue em seu discurso narrando como esse acontecimento deixou perplexos e mudos a todos os presentes e conta que Calcas proferiu imediatamente sua interpretação do sinal divino:

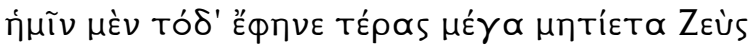

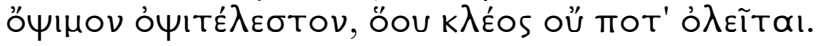

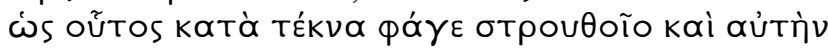

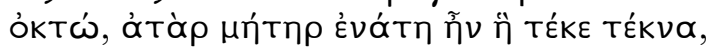

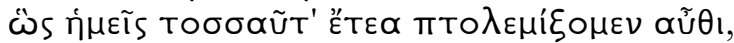

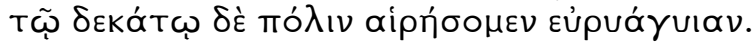

Esse prodígio por Zeus grande e sábio nos foi enviado.

Vai demorar; veio tarde; mas a fama vai ser sempiterna.

Do mesmo modo que o drago os filhotes matou e a mãe deles oito eram eles, incluindo-se a mãe, que os gerou, nove ao todo o mesmo número de anos devemos passar nesta guerra, mas no dezeno, haveremos de entrar a cidade espaçosa. (Il. II, 324-9)

A interpretação de Calcas é claríssima e unívoca. Zeus enviou um prodígio

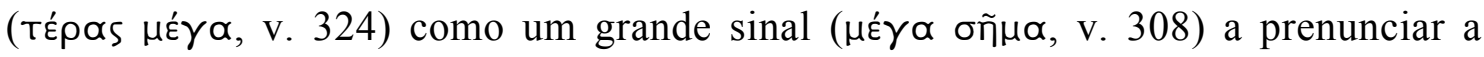
conquista de Troia e a cada pássaro devorado pela serpente corresponde um ano de 
duração da guerra, sendo, portanto, apenas no décimo que se obterá a almejada vitória, cuja fama será eterna.

Note-se que, na descrição que faz Odisseu, enfatiza-se o aspecto patético do portento: a fragilidade e a desproteção da ninhada de pardais e, principalmente, a dor da mãe e sua impotência para salvar sua prole. Como observa Schein (In: GRETHLEIN \& RENGAKOS, 2009, p. 391), nessa descrição de Odisseu, os pássaros figuram como vítimas e não como agressores, como ocorre no párodo do Agamêmnon. Observe-se ainda a clareza e a univocidade que caracterizam a interpretação do auspício homérico. A cada elemento corresponde um único significado e todos falam do mesmo: da duração e do resultado do cerco de Troia. Não há, portanto, nem ambiguidade nem polissemia e, embora a descrição feita por Odisseu enfatize o desamparo dos pequenos filhotes e principalmente o desespero e a impotência de sua mãe, não há nenhuma identificação entre a serpente e os pardais com os seres humanos que testemunham o prodígio, tal como ocorre em Ésquilo.

Enquanto no texto esquiliano as fronteiras que separam homens e animais, passado e futuro, vítima e agente, perdem a nitidez, no texto homérico esses elementos se encontram definitivamente separados. Por razões que só a arte divinatória conhece, o ataque da serpente aos pardais prenuncia a vitória sobre Troia após dez anos de batalha ${ }^{24}$. Cada pardal significa um ano de guerra. Podem-se ver refletidas na morte dessas aves as vítimas da guerra entre gregos e troianos, mas não há qualquer menção no discurso de Odisseu que induza a essa interpretação.

As aves, a relação entre pais e filhos, a perda da prole, o sofrimento gerado, a impotência dos vitimados, todos esses elementos presentes em Homero estão presentes em Ésquilo de forma pulverizada nesse diálogo divinatório que se dá mediante o símile das aves, o auspício e, como se verá, a posterior descrição do sacrifício de Ifigênia. Porém, além de o portento se configurar de forma bastante diferente, aquela interpretação clara e unívoca do Calcas homérico dá espaço a uma

\footnotetext{
${ }^{24}$ Cícero, em De divinatione, questiona a correlação que Calcas faz entre o número de pardais e a duração da guerra: "Enfim, que predição é essa, a partir de pássaros, de anos, e não meses ou dias? Mas por que faz uma conjectura sobre passarinhos, nos quais nada monstruoso havia, e se cala sobre a serpente que, coisa que não pode ter acontecido, diz-se que se tornou pedra? Por último, que semelhança tem o pássaro com os anos?" (Quae tandem ista auguratio est ex passeribus annorum potius quam aut mensuum aut dierum? Cur autem de passerculis coniecturam facit, in quibus nullum erat monstrum, de dracone silet, qui, id quod fieri non potuit, lapideus dicitur factus? postremo quid simile habet passer annis?, II, 65). A edição é de Appuhn (s/d) e a tradução é de Beatris Ribeiro Gratti (2009).
} 
complexa, ambígua e polissêmica rede de significados tecida pelas palavras do Calcas esquiliano.

Observe-se ainda que Odisseu recorre à rememoração do prodígio num momento crítico como o argumento final de um discurso cujo objetivo é persuadir os guerreiros gregos a permanecer em solo inimigo e estimulá-los a obter uma vitória que, como prenunciou Calcas, encontra-se tão próxima. Odisseu, ao terminar sua fala, é calorosamente aplaudido e os guerreiros, persuadidos e entusiasmados, dão continuidade ao cerco de Troia. A lembrança do auspício ajudou a trazer confiança na vitória e entusiasmo para obtê-la.

Em Homero, portanto, a narração do prodígio e de sua interpretação desempenha, no discurso de Odisseu, uma função motivacional. Ao relembrar os guerreiros de que Zeus prometeu-lhes e prenunciou-lhes a vitória, Odisseu busca estimulá-los e alertá-los para o fato de que juraram não abandonar o cerco a Troia sem antes tê-la conquistado. Relembrar o prodígio traria, assim, uma espécie de conforto, renovando-se a esperança, o entusiasmo e o comprometimento com a expedição, pois muitos anos já se passaram e, dessa forma, a vitória está próxima. Em Ésquilo, por outro lado, a narração do auspício e de sua interpretação não traz qualquer conforto ou estímulo, haja vista a ambiguidade do sinal divino, o seu difícil entendimento, a sua pluralidade de sentido.

Prosseguindo em sua fala, Calcas, diante de tais "destras mas repreensíveis visões" ( $A g$. 145), invoca Apolo, deus que lhe patrocina o dom divinatório, mas o invoca em seu aspecto curador, que também lhe é próprio, mediante o epíteto de "Ieio Peã" (ińıv ... П๔ı̃̃va, Ag. 146), de modo que tal situação encontre cura, ou seja, que Ártemis não mande ventos adversos a urgir consequências funestas para o palácio real.

O Coro, por sua vez, ante a aflição provocada pela rememoração do que foi pressagiado, invoca Zeus com um hino, mediante o qual busca alcançar serenidade de ânimo, pois Zeus é o deus dos deuses, o fundamento dos fundamentos, o único que o Coro pode imaginar para se livrar do peso das aflições. E, ao celebrar Zeus, fala da importância da prudência, essa prudência que, mesmo não desejada, impõe-se pela

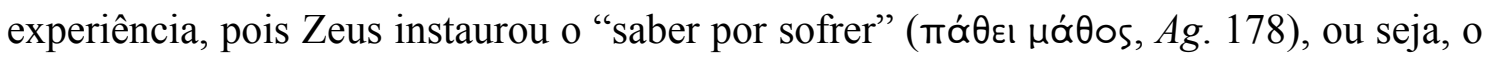
homem aprende pela experiência de que ele é sujeito paciente e, assim, mesmo que não o queira, aprende a ter prudência em tudo.

Prossegue-se, então, a narrativa do que se seguiu à manifestação do auspício e o que se segue ao auspício das aves é o início de sua realização: ventos adversos 
impediam a partida do exército do porto de Áulida. A longa espera por ventos propícios era corrosiva: os víveres diminuíam, o ânimo guerreiro e a disciplina dos soldados diminuíam, as cordas e os navios deterioravam.

Trata-se de uma situação numinosa, porque é a exata realização da previsão feita por Calcas quando da hermenêutica do auspício. Assim, ante a recusa de Ártemis, que se manifesta nos ventos tempestivos que retardam a expedição guerreira, o adivinho

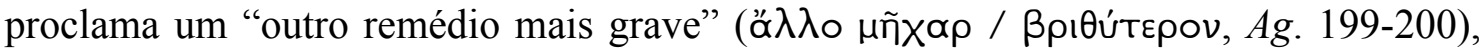

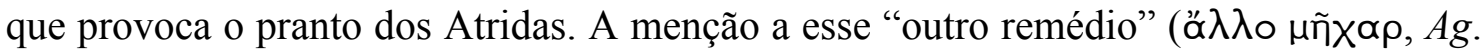

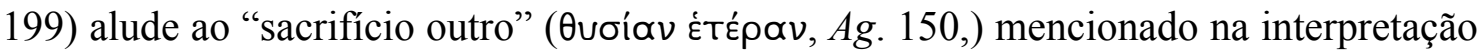
do auspício. Assim, esse outro remédio é mais grave porque se trata de um sacrifício

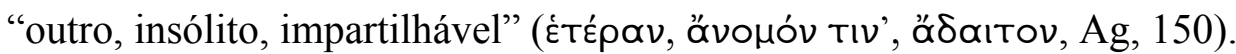

Como se viu, no sacrifício comumente realizado em campanhas militares, procurava-se obter a anuência divina à transposição de fronteiras, rios e mar e à ordem de ataque. O sacrifício esperado - ou seja, que não fosse "outro" (غ́тépav, $A g .150$ ) -, que estivesse de acordo com os costumes - e portanto não fosse "insólito" (åvo 150) - e que fosse partilhável em um banquete - e, dessa forma, não fosse

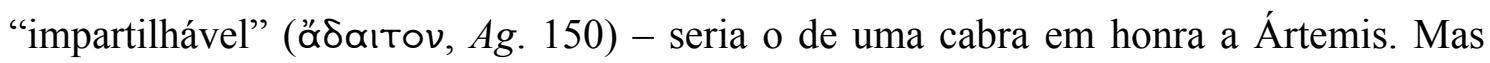
aqui não se está diante de uma situação ordinária a requerer um sacrifício ordinário, de modo que, para se obter a anuência de Ártemis e, dessa forma, a vitória favoravelmente prenunciada em Troia, faz-se necessário o sacrifício de algo muito mais valioso: Ifigênia, a virgem filha do grande líder da expedição.

O Coro descreve então o dilema de Agamêmnon ante essa situação numinosa, em que a prenunciada recusa de Ártemis manifesta-se nos ventos tempestivos que retardam a expedição guerreira, e ilustra como ele, ponderando entre dois males frustrar a aliança bélica, tornando-se um desertor das naus, ou sacrificar Ifigênia, poluindo suas mãos com o sangue da própria filha - decide pela realização do sacrifício:

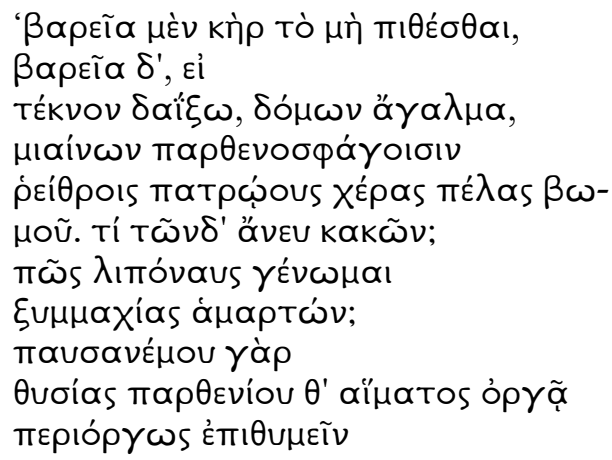

\author{
Grave cisão é não confiar, \\ grave cisão, se eu trucidar \\ a filha, adorno do palácio, \\ poluindo de filicidiais fluxos \\ paternas mãos ante altar. \\ Que há sem estes males? \\ Como ser desertor das naus \\ por frustrar o bélico pacto? \\ O sacrifício de cessar-vento \\ e o virgíneo sangue, desejá-los
}




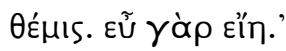

com superfurioso furor,

é lícito, pois que bem seja!

(Ag. 206-17)

Trata-se, assim, de um reconhecimento, por parte de Agamêmnon, da inelutabilidade da situação em que se encontra: é necessário escolher entre dois males e ele faz a sua escolha. Ao fazê-lo, curvando-se assim ao "jugo da coerção" (ávó $\gamma$ kas

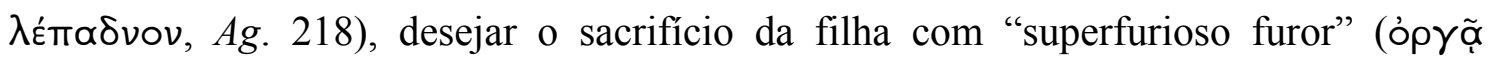

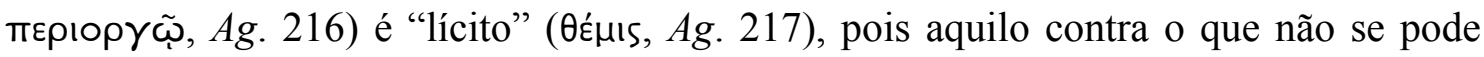
lutar, aquilo que não pode ser evitado, passa então a ser querido, desejado, e o que resta

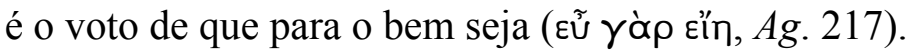

Agamêmnon é assim confrontado com essa situação numinosa em que o sacrifício de sua filha the é demandado como o único, embora amargo, remédio. Enquanto o Agamêmnon esquiliano, diante das palavras de Calcas, não vitupera o

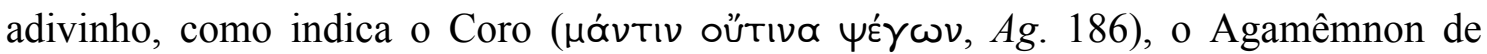
Eurípides, em Ifigênia em Áulida, expressa desprezo pelos adivinhos, dizendo que

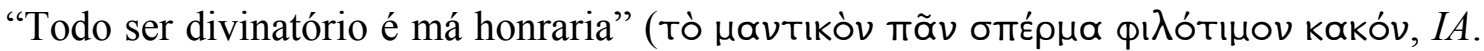
520), o que evoca seu comportamento em Homero. No canto I da Ilíada, quando Calcas revela aos guerreiros reunidos em assembleia o motivo da peste enviada por Apolo, Agamêmnon levanta-se colérico e o injuria, acusando-o de profetizar somente males aos gregos (Il. I, 101-120). Apesar das invectivas do Agamêmnon homérico e euripidiano, ambos não deixam de cumprir os desígnios divinos que se expressam por meio do adivinho: na Ilíada, Agamêmnon ordena que Criseida seja restituída a seu pai e, em Ifigênia em Áulida, após muito relutar, o Atrida decide sacrificar sua fillha ${ }^{25}$.

25 Essa decisão do Agamêmnon euripidiano advém igualmente do reconhecimento do jugo da necessidade; assim como o Agamêmnon esquiliano, o Agamêmnon euripidiano vê-se confrontado com uma situação numinosa, cuja inexorabilidade ele descreve em termos semelhantes: "Mísero! Que dizer?

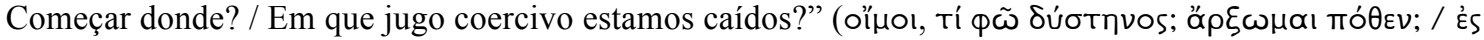

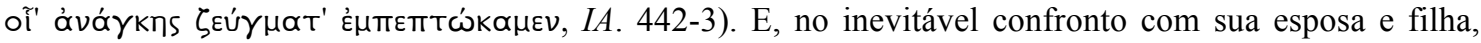
ponderando a respeito de sua situação, as palavras de Agamêmnon também ecoam os versos com que, em Ésquilo, o rei explicita seu dilema: "Terrível para mim esta ousadia, mulher, / terrível ainda é não ter,

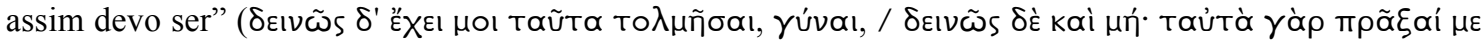
$\delta \varepsilon \tilde{I}, I A$. 1257-8). Todavia, diferentemente do que se vê no texto esquiliano, o enunciado profético de Calcas - que nessa tragédia é descrito apenas como ó $\mu$ óvtıs, "o adivinho" (IA. 89) - é bastante claro e objetivo: "Calcas o vate diante deste impasse / vaticinou sacrificar Ifigênia minha / filha a Ártemis residente neste solo / e termos navegação e ruínas frígias / se sacrificarmos; não, sem sacrifício."

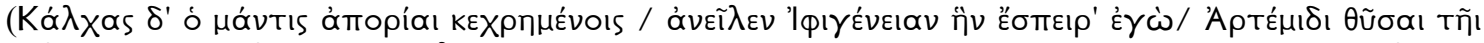

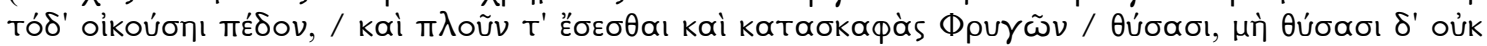

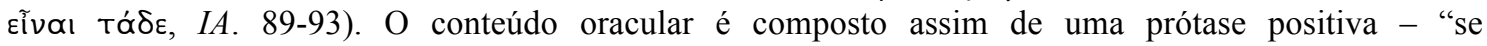

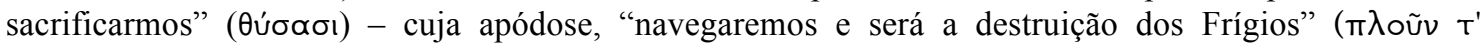

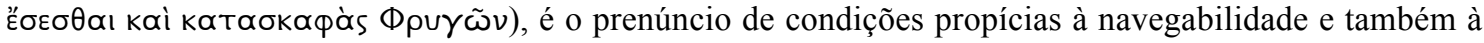

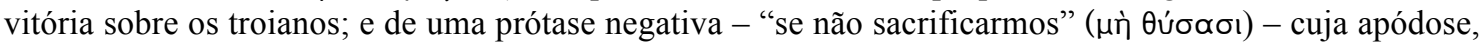


Aquilo que, sob o jugo da necessidade e do ponto de vista heroico, Agamêmnon

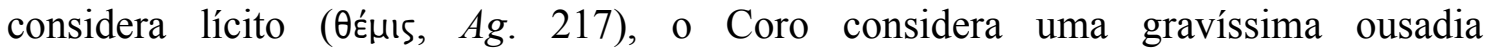

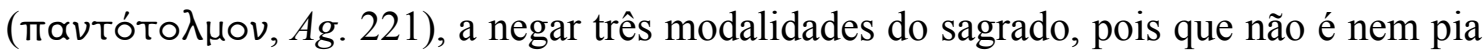

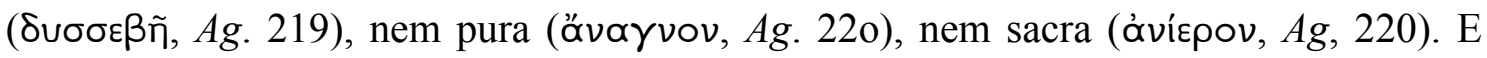
assim o considerando, descreve com grande dramaticidade o momento em que Ifigênia é levada ao altar "ao modo de cabra" (סíkav xıнaípas, Ag. 232). Tem-se o cuidado de

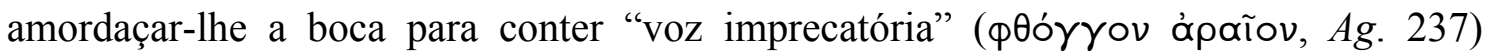
contra o palácio, embora, como explicitará Egisto ao fim da tragédia, seu pai Tiestes já tenha lançado imprecações contra os Atridas (Ag. 1600-1). Os apelos da jovem ao amado pai, suas belas vestes açafroadas a cobrir o chão, seus brilhantes olhos súplices a trazer a lembrança aos seus presentes sacrificadores das inúmeras vezes em que cantou e encantou os salões do palácio real, nada impediu os belicosos guerreiros.

O sacrifício em si, o Coro não ousa descrevê-lo, finalizando abruptamente o comovente relato dos últimos momentos de Ifigênia com a assertiva de que o que aconteceu depois ele não viu e não dirá. E, de tudo o que até agora foi rememorado em seu canto, o Coro chega a duas conclusões: "artes de Calcas não são sem efeito"

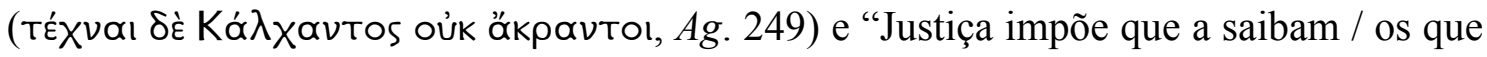

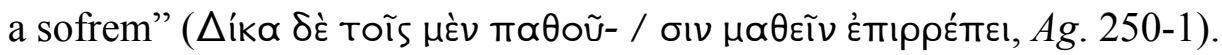

Essa justiça divina é ineludível. O Coro, ao afirmar que as previsões de Calcas são efetivas, refere-se tanto ao que já se realizou do que fora prenunciado pelo adivinho no auspício das aves - a recusa de Ártemis e a necessidade de um sacrifício outro -, quanto ao que ainda está por se realizar, pois, uma vez garantida a continuidade da expedição, garante-se também a vitória argiva, tal como o auspício anunciara. Mas resta ainda por se cumprir um aspecto da previsão feita pelo adivinho: as consequências funestas que esse sacrifício outro poderia trazer ao palácio. Dessa forma, a justiça há de se impor e se dar a conhecer tanto àqueles que, desrespeitando Zeus Hospitaleiro, raptaram Helena, quanto àquele que, nas palavras do Coro, "concebeu pensar toda

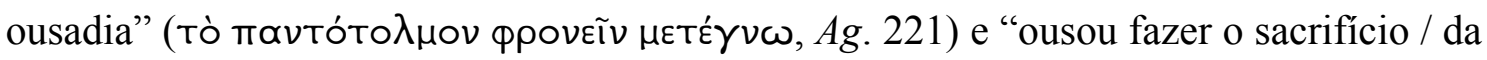

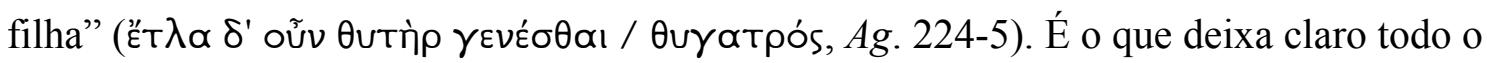

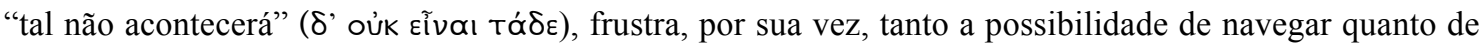
conquistar a vitória. Sendo assim, ainda que o sacrifício de Ifigênia seja apresentado como uma condição sine qua non para a tomada de Troia, as palavras proféticas de Calcas dão margem, de forma bastante clara, à possibilidade de a expedição não acontecer, já que Ifigênia deve ser sacrificada somente se a expedição for levada a cabo. E essa possibilidade - tanto de não haver sacrifício quanto de não haver expedição - diferentemente do que acontece em Ésquilo, é explorada ao máximo por Eurípides ao longo dessa tragédia.
} 
desenvolvimento subsequente desta tragédia e das demais tragédias que compõem a Oresteia.

O Coro, no entanto, abandona essa reflexão e, desse modo, os caminhos tenebrosos a que tal reflexão conduz, despedindo-se do pranto antecipado e fazendo votos de que o porvir, quando vier, seja um feliz acontecimento. Mas, porque a arte divinatória de Calcas é efetiva e a justiça de Zeus é ineludível, o porvir se tinge de fatalidade.

\subsection{2) Palavras, imagens, sentimentos pressagos}

No primeiro episódio, o Coro tem enfim a oportunidade de perguntar diretamente à Clitemnestra se os sacrifícios que estão sendo realizados mediante sua ordem, e que lhe causaram tal perplexidade de modo a fazê-lo refletir sobre acontecimentos passados, são sacrifícios de ação de graças - "Se sacrificas por saberes

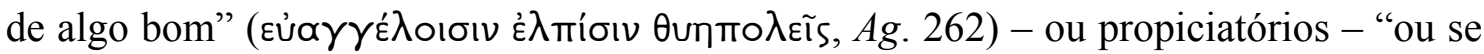

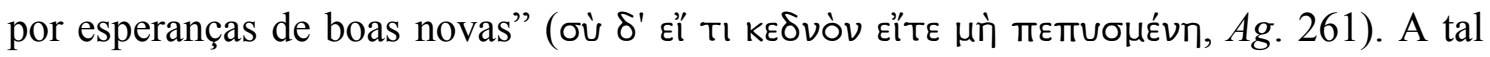
questionamento, Clitemnestra responde anunciando as boas novas: "argivos capturaram

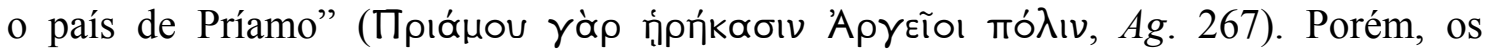
sacrifícios ordenados por Clitemnestra são tão ambíguos quanto o sinal de fogo anunciando a captura de Troia: se, por um lado, são de ação de graças pela conquista da cidade, por outro lado, são propiciatórios para a armadilha que ela prepara para o conquistador.

O Coro recebe a notícia da captura de Troia com incredulidade, indagando se a

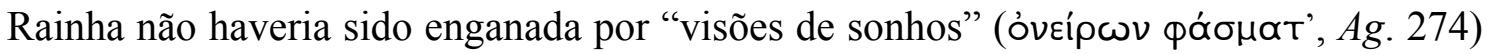
ou falsos rumores. Mas Clitemnestra refuta tais conjecturas do Coro, alegando não ser criança para acreditar em palavras inconsistentes nem tampouco possuir o espírito dormente de modo a se deixar iludir por visões de sonhos. Ironicamente, a Rainha há de experimentar, nas Coéforas, quão verdadeiras podem ser essas agora desprezadas visões de sonhos.

Ainda incrédulo, o Coro indaga que mensageiro seria capaz de trazer tão rapidamente tal notícia. Pelo prólogo, sabe-se que o mensageiro a anunciar a tomada da cidadela de Príamo foi um muito aguardado sinal de fogo. Clitemnestra, no entanto, responde que foi Hefesto. Hefesto, neste contexto, significa obviamente fogo, uma vez 
que esse elemento pertence ao deus metalúrgico, mas a palavra fogo não é usada aqui, pois não se trata de um fogo banal, mas sim de um fogo em cuja aparição se manifesta o cumprimento de um desígnio divino: a captura de Troia, tal como Calcas previra.

Trata-se, de fato, de um sinal eloquente. O que o fogo sinaliza não se esgota na mensagem da vitória argiva, assim como na vitória argiva não se esgota a realização do auspício das aves interpretado por Calcas. Dessa forma, ao mesmo tempo em que o sinal de fogo anuncia a conquista de Troia, ele também prenuncia o ressurgimento da

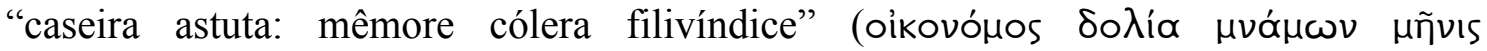
тєкvótтoıvos, $A g$. 155) na forma da tão esperada vingança de Clitemnestra, ou seja, o assassinato de Agamêmnon.

É com grande domínio das distâncias espaciais que a Rainha descreve, então, o caminho percorrido pelo fogo de Hefesto, nomeando os noves cumes em que o reluzente núncio brilhou: o monte Ida, a pedra de Hermes na ilha de Lemno e o monte Atos; em seguida, o mirante do Macisto, o monte Messápio e o monte Citéron; por fim, o monte das cabras errantes, o monte Aracneu e o teto do palácio dos Atridas. O seu domínio sobre esse processo é tão completo que ela sabe dizer até mesmo a qualidade da madeira queimada no monte Messápio, "velha urze" (Ypaías ḱpeíkns, Ag. 295), a prontidão dos que acendem o luzeiro no monte Macisto ("sem tardar", oüTı $\mu \varepsilon ́ \lambda \lambda \omega \nu$,

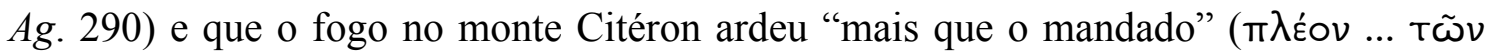

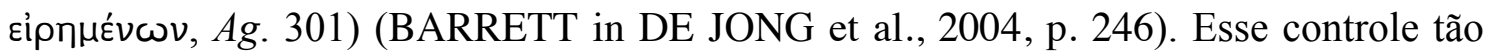
absoluto sobre a notícia da tomada de Troia, e, consequentemente, sobre a notícia do regresso de Agamêmnon, através de um elaborado sistema de sinais de fogo, revela a astúcia de Clitemnestra, fazendo assim refletir sobre sua figura a "caseira astuta"

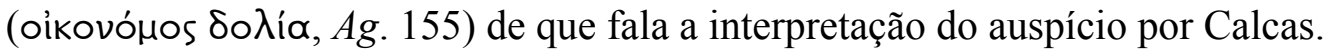

Mediante esse catálogo, de clara tradição épica, vê-se o fogo percorrendo seu caminho e aproximando-se cada vez mais do palácio - "Facho envia facho de

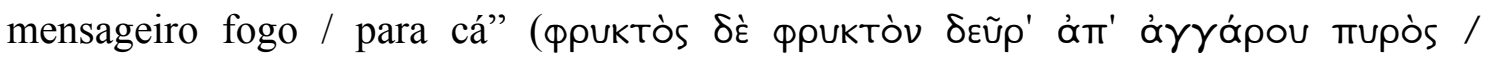

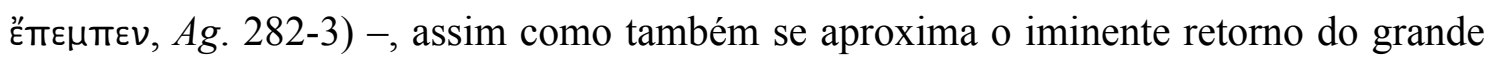
conquistador de Troia e, com ele, o momento em que Clitemnestra terá a oportunidade de vingar o sacrifício de sua filha. Como conjectura Gantz (1977, p. 31), na imagem da sucessão de sinais de fogo, que se acendem um após o outro, pode-se perceber um 
prenúncio para a sucessão de crimes e retribuição, que, como o fogo que passa de um monte para o outro, passa de geração a geração na raça dos Atridas ${ }^{26}$.

Admirado com o relato do trajeto percorrido pelo mensageiro de fogo, o Coro pede à Rainha que prossiga. Clitemnestra demonstra uma vez mais domínio das distâncias espaciais, pois descreve acontecimentos que, mesmo ela estando em Argos, não se ocultam à sua percepção. Diz ela: "Neste momento aqueus ocupam Troia"

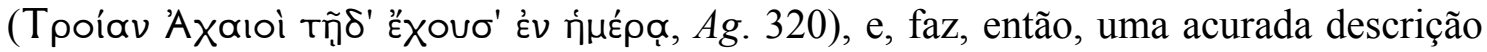
do dia da queda de Troia: ouvem-se os gritos de júbilo dos vencedores e os gritos de dores dos vencidos, assim como o pranto dos que se prostram junto aos corpos de seus entes queridos; para os sobreviventes, submetidos à escravidão, só resta a fome e o caos, pois o que há de víveres e habitações pertence agora aos conquistadores.

E, assim como não se oculta para ela o que a distância espacial encobre, também não se oculta para ela o que a distância temporal encobre, pois Clitemnestra demonstra também um domínio temporal ao falar do futuro, quando declara que os vencedores só permanecerão nessa condição e farão um seguro retorno ao lar se, não atraindo para si a cólera divina, não pilharem, movidos pela ganância, os templos, os altares e as estátuas dos deuses tutelares da cidade conquistada (Ag. 338-44). Suas palavras são mais do que uma admonição; trata-se de um prenúncio: a rainha prenuncia o comportamento sacrílego das tropas, tal como será confirmado pelas palavras do Arauto no segundo episódio.

Clitemnestra acrescenta: "Se viesse o exército sem ofensa aos Deuses, / poderia ser desperto o suplício dos mortos, / se não irrompessem repentinos males" ( $\theta$ Eoĩs $\delta^{\prime}$

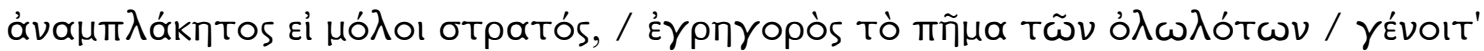

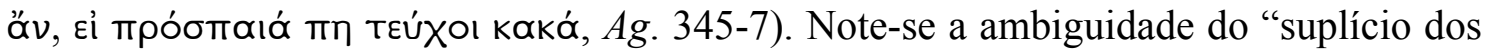

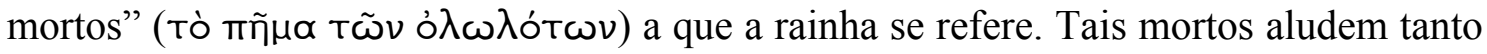
às vítimas da guerra, sejam gregos ou troianos, como também à morte de Ifigênia, mortes estas que cobram vingança, como aponta a imagem de "despertar o suplício dos mortos" ${ }^{27}$. Dessa necessidade de vingança não há escapatória: nessa oração, ela é a única apódese a duas prótases. Igualmente ambíguos são os "repentinos males"

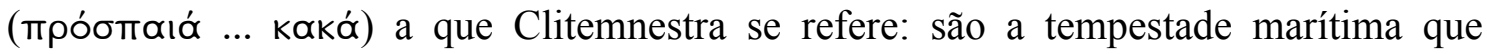

\footnotetext{
${ }^{26}$ Para uma análise da imagem do fogo na Oresteia e suas implicações, conferir o artigo de Gantz (1977), "The Fires of the Oresteia".

27 Para uma interpretação aprofundada desses versos de sentido ominoso, considerados por Fraenkel (1982, p. 177, vol. II) como "a very difficult passage", conferir o artigo de Roisman (1986), "Clytaemnestra's Ominous Words: Aeschylus, Agamemnon 345-347”.
} 
atingiu a grota argiva em seu retorno e, ao mesmo tempo, o assassinato de Agamêmnon. O Coro, no entanto, não alcança essa dimensão velada e profética do discurso de Clitemnestra e, elogiando-o pela prudência, põe-se a orar aos deuses, crendo, por fím, na veracidade da notícia da tomada de Troia.

No entanto, mesmo depois de se mostrar convencido, o Coro, ao final do primeiro estásimo, volta a desconfiar de que tal notícia seja realmente verdadeira. O que o leva a retroceder em sua convicção?

No primeiro estásimo, o Coro faz uma análise do crime de Páris, da guerra e das suas consequências. Nessa análise, torna-se manifesta a doutrina, particularmente evidente em Ésquilo, de que o excesso de riqueza, a opulência produz a hýbris, a transgressão. Como se viu, a hýbris, por sua vez, suscita a recusa dos deuses, que enviam a áte, impossibilitando aos mortais o discernimento e os fazendo agir contra seus próprios interesses, para assim conduzi-los à ruína. Dessa forma, o crime de Páris é caracterizado como uma hýbris, fruto da opulência de sua cidade, "por arderem palácios

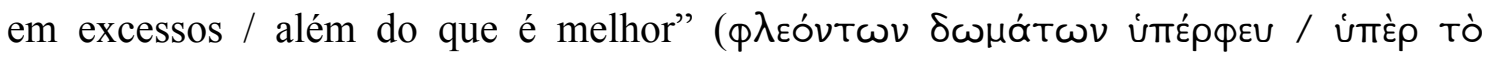

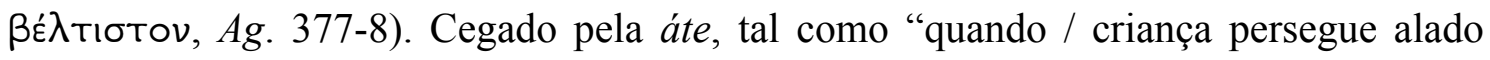

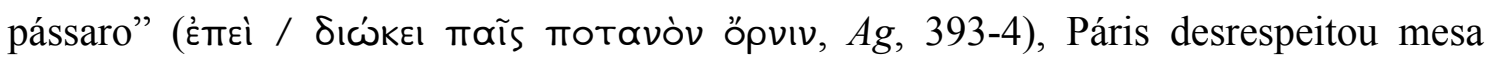

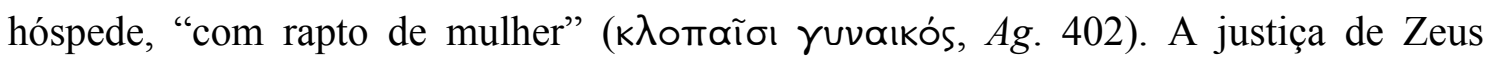
cumpriu-se na guerra que, movida contra Troia, destruiu-a inteiramente.

A guerra, no entanto, tem consequências funestas. O luto de Menelau por sua

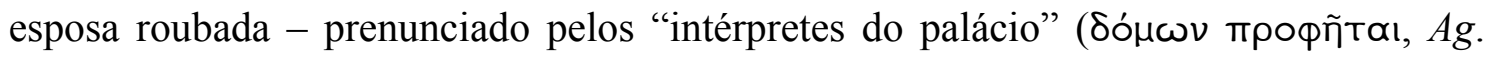
$409)^{28}$ - transbordou as fronteiras de seu palácio e se converteu no luto pela morte de

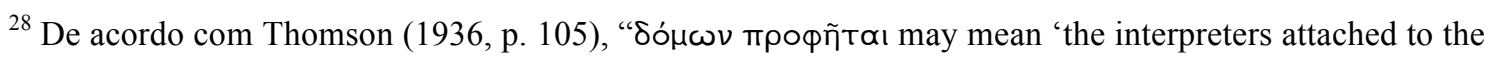
palace', 'the royal interpreters', or, if you like, 'the king's prophets". Tais adivinhos, a serviço do palácio, são consultados sempre que necessário e é plausível associá-los com os intérpretes de sonhos kpıтaí óveıpót $\omega v$ (Co. 38), que, nas Coéforas, interpretam o sonho de Clitemnestra. Quando o Coro fala da partida de Helena, ele reproduz as palavras desses adivinhos, que lamentam a sorte do palácio e de seus senhores. Essa passagem é controversa por vários motivos e um deles é o fato de que os adivinhos falam mais do estado mental e emocional de Menelau do que prenunciam algum acontecimento. Para Athanassaki (1993/1994, p. 153), "while the speech is mainly a description of Menelaus' state of mind, it does contain at least one prediction, namely, Menelaus' future visions of Helen, as is evident from the future $\delta o ́ \xi \varepsilon ı " ~(A g . ~ 415)$. A autora propõe, no entato, que o fim do dicscurso indireto reproduzido pelo Coro se dê ao final da terceira estrofe: "If we attribute the description of the evil consequences of war to the prophets, the resulting prophecy ranges far and wide. The prophecy begins with a prediction of the

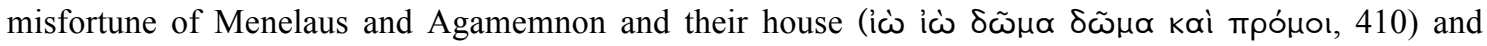
continues with an account of evils, which illustrates the nature and the extent of the initially prophesied misfortune. Menelaus, abandoned and dishonored, will have to content himself with dreams of Helen

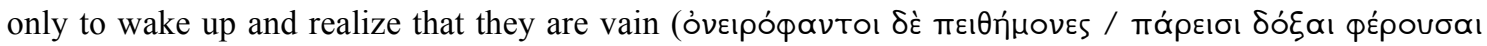
Xápıv uataíav, 420-21). This is one aspect of his sufferings, but there are evils to come which go

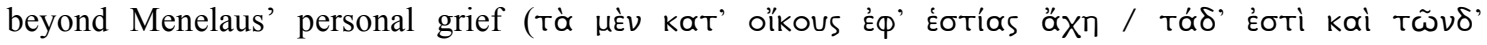

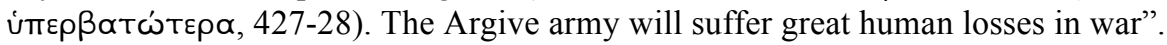


tantos homens perdidos na guerra. Da dor do luto, surge o ressentimento contra os

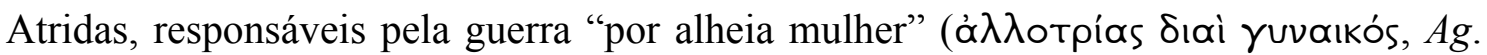
448-9), os quais se acusam com vozes veladas ${ }^{29}$. E a imprecação pública deve ser temida, pois, tal qual uma maldição, traz consigo um nume que faz com que ela se cumpra.

Assim, os Atridas, ao punirem a hýbris de Páris, tornaram-se "matadores de

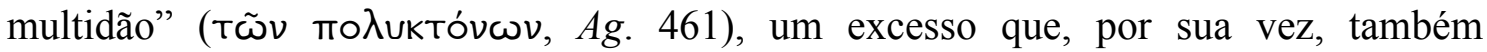
configura uma hýbris e, como tal, necessita igualmente de punição, atraindo para si a cólera divina. Portanto, de acordo com a reflexão do Coro, aceitar a notícia da vitória em Troia é também aceitar o preço que se tem de pagar por ela. Dessa forma, recusando o temor que essa reflexão lhe inspira, uma vez que põe em risco o rei, a quem o Coro mostra fidelidade, ele volta a desconfiar da veracidade da notícia trazida pelo fogo mensageiro.

No entanto, a chegada do Arauto no segundo episódio do Agamêmnon confirma o que a rainha Clitemnestra tão seguramente afirmara até então e o Coro de anciãos argivos tão relutantemente aceitara: Troia foi enfim tomada pelo exército argivo. Mas essa notícia, se, por um lado, põe fim às incertezas do Coro quanto ao sinal de fogo, por outro lado, torna ainda mais sombrio, a seus olhos e aos olhos dos espectadores, o destino do herói conquistador da cidade de Príamo.

O discurso do mensageiro se divide em três partes. Na primeira parte ( $\mathrm{Ag}$. 50337), ele inicia sua fala com uma saudação aos deuses, à sua terra e aos seus heróis, seguida da notícia do iminente retorno de Agamêmnon e da captura e da destruição de Troia. Na segunda parte ( $A g .551-82)$, ele descreve seus sofrimentos no curso da guerra, mas termina rejubilando-se da vitória por fim conquistada. Na terceira parte ( $\mathrm{Ag}$. 63480), respondendo à pergunta do Coro sobre o paradeiro de Menelau, ele relata o que sucedeu após a tomada de Troia: a terrível tempestade que destruiu e dispersou a frota grega em seu retorno à pátria.

O mensageiro chega em cena sendo extensamente anunciado pelo Coro ao longo de quatorze versos, mediante os quais os anciãos argivos reformulam suas dúvidas quanto à veracidade do sinal de fogo, prolongado e ampliando assim a expectativa sobre

\footnotetext{
${ }^{29}$ Leahy (1974, p. 14) faz a seguinte observação a esse respeito: "The people are not pictured as planning revolt against their rulers but as cursing them. And as a consequence the loyal Chorus fear not political action but something shrouded in night; and what gives shape to their anxiety is the thought that the gods mark those who are responsible for the deaths of many [...], which has sinister implications for Agamemnon".
} 
as notícias a serem proclamadas pelo Arauto. A referência à poeira que levanta sob seus passos alude à pressa e à urgência do que ele vem narrar.

Antes porém de fazer seus anúncios, o Arauto faz uma emotiva saudação à sua terra, aos deuses, aos heróis, ao palácio de seus senhores e às estátuas sagradas, saudação esta em que se exprimem a gratidão pelo retorno à pátria e os votos de melhores dias e de boa acolhida a seu senhor, o rei Agamêmnon.

O solo de sua pátria é seu primeiro interlocutor. Nesse ansiado retorno, o Arauto vê cumprir-se a esperança de que, "morto, teria parte no túmulo dos meus" ( $\theta \alpha v \omega \dot{v}$

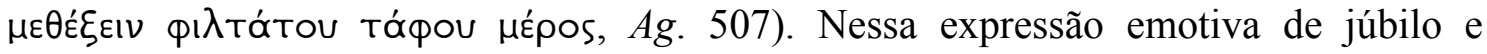

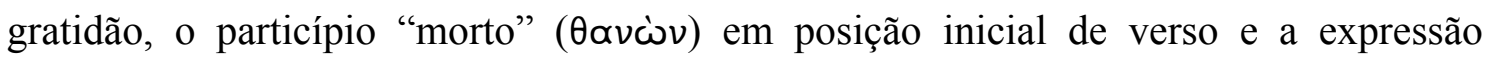
"túmulo dos meus" ( $\phi ı \lambda$ тótou tó $\phi \circ)$ ecoam as expectativas sombrias que pairam desde o início da tragédia sobre o retorno de Agamêmnon, carregando-se, dessa forma, de um sentido ominoso.

Em seguida, o Arauto dirige-se à terra, ao Sol, a Zeus e a Apolo, denominando-o

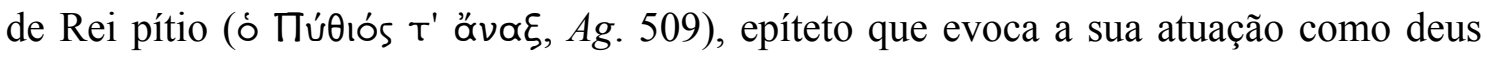
adivinho, senhor do oráculo de Delfos, uma atuação fundamental no desenvolvimento da trilogia. O Arauto roga que o deus não seja tão adverso quanto fora em Troia - numa alusão a acontecimentos passados, que evocam os relatados no livro I da Ilíada, quando Apolo com suas flechas disseminou a peste entre o exército - e que "agora" ( $v \tilde{v} \nu, A g$.

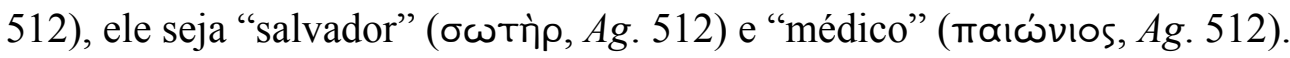

Como observa Roberts (1984, p. 65), nestes versos do Arauto se justapõem duas faces do deus: uma funesta - que aqui vemos que encontra referência num acontecimento passado: a peste que assolou o exército argivo - e uma benévola - que é a que se espera que ele mostre agora, quando do retorno à pátria desse mesmo exército. Ambos os aspectos do deus a que neste momento o Arauto alude - tanto o benfazejo quanto o funesto - irão estar presentes ao longo da Oresteia, de modo que essa evocação de Apolo pelo Arauto é bastante significativa, porque prefigura a importância e a atuação do deus na trilogia.

Prosseguindo, o Arauto interpela o próprio palácio, os assentos dos reis e as estátuas sagradas voltadas para o nascente, que adornam a fachada do palácio, pedindolhes que recebam bem, depois de tanto tempo, o rei. Só então o Arauto se dirige aos seus interlocutores em cena, exortando o Coro de anciãos argivos a bem saudar o rei, pois que, levando justiça e auxiliado por Zeus, ele destruiu Troia: 


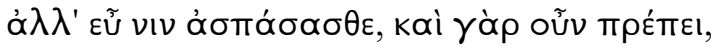

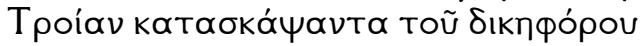

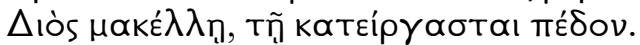

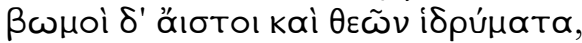

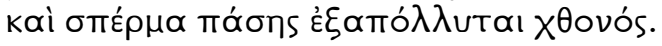

Eia, bem o saudai, pois assim convém, ele revolveu Troia com a enxada de Zeus portador de justiça, lavrado está o solo. Altares desaparecidos e estátuas de Deuses, e semente da terra toda está perecendo:

(Ag. 524-8)

O Arauto anuncia finalmente a tomada de Troia e o faz mediante o uso de uma metáfora agrícola, em cujas imagens, quase que inadvertidamente, evidencia-se e enuncia-se uma grave ofensa aos deuses: o comportamento sacrílego do exército e de seu comandante ${ }^{30}$, conforme prenunciara Clitemnestra no primeiro episódio ( $\mathrm{Ag}$. 33844). Em vista disso, pode-se dizer que o Arauto, sem o saber e utilizando-se de uma mesma imagem poética, anuncia simultaneamente a vitória e a condenação de seu rei: o solo está lavrado, mas a semente da terra toda, em vez de brotar, perece. A destruição de Troia é tão completa que, através de suas palavras, vê-se um triste retrato da cidade conquistada: apenas a terra, estéril e revolvida, no lugar onde outrora estava construída uma cidade com seus templos e estátuas de deuses.

Seu discurso, no entanto, como porta-voz do rei, é feito da perspectiva da conquista guerreira, de modo que, para ele, o fato de ter obtido a vitória em Troia significa favor divino, por isso ele afirma que seu rei retorna à pátria com "bons

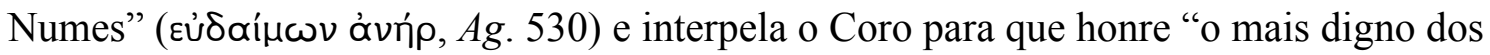

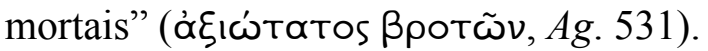

Ora, da perspectiva de seus interlocutores - o Coro e a rainha -, dificilmente se poderia crer que Agamêmnon, em vista do que acabou de ser dito, retorna ao palácio com bons numes e a exaltação excessiva que o Arauto faz do rei soa mais ominosa que auspiciosa, porque, conforme o Coro refletira no primeiro estásimo, "grave é o grande

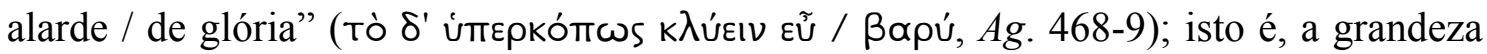
excessiva é vista como intrinsecamente má, suscitando a recusa dos deuses.

O motivo, porém, de o Arauto solicitar que assim se honre Agamêmnon é porque Páris e seu país foram duplamente castigados tanto ao perderem sua presa, isto é, Helena, como ao terem sua cidade devastada:

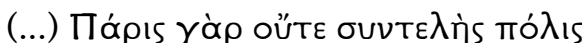

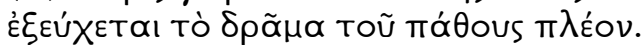

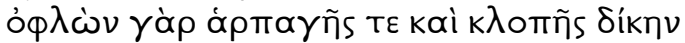

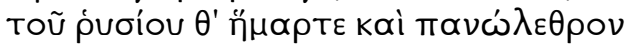

(...) Nem Páris nem o consorciado país alardeiam feito maior que o sofrido, pois condenado por rapina e furto

\footnotetext{
${ }^{30}$ É esse mesmo comportamento sacrílego que, nos Persas, figura como causa dos males sofridos e ainda por sofrer pelo exército comandado por Xerxes em seu retorno à pátria ( $P e .809-14)$.
} 


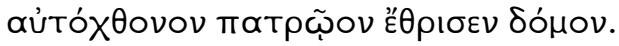

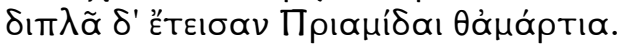

perdeu sua presa e colheu devastados o palácio ancestral e a terra mesma: os Priâmidas tiveram duplo castigo.

Uma vez mais, há um vislumbre da totalidade da devastação de Troia: vê-se novamente uma cidade vazia, uma cidade-fantasma, em que o palácio - isto é, a moradia dos Priâmidas e também a sede do governo - assim como a terra mesma estão devastados. Porém, da mesma forma que Páris e os troianos foram tão violenta e completamente punidos por sua transgressão, não seria a violência e a completude dessa punição uma transgressão em si mesma? Agamêmnon estaria assim retornando à sua pátria tanto na condição do rei vitorioso que pune a transgressão como na condição do transgressor aguardando punição ${ }^{31}$.

Note-se que o Arauto diz que nem Páris nem sua cidade poderiam alardear "feito

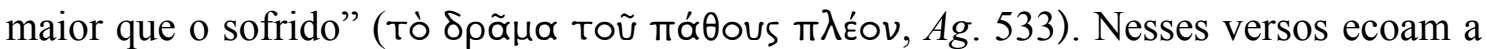

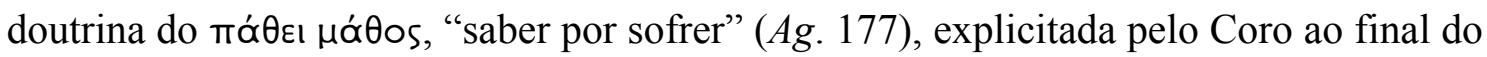
párodo lírico ( $A g$. 250-1); e que, ao final da tragédia, no quinto episódio, adquire um

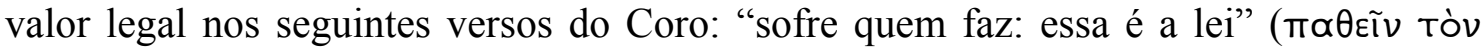

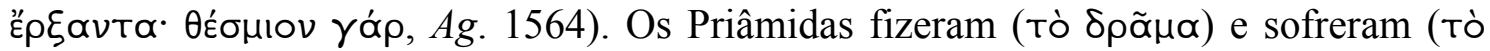

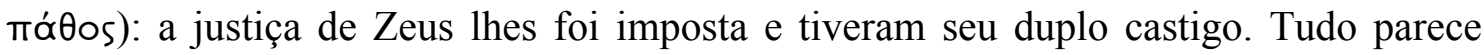
apontar para que também Agamêmnon pague por seus feitos: essa é a lei.

O Arauto, no entanto, inadvertido das funestas consequências que suas palavras prenunciam, considera a chegada à pátria a salvo junto de seu vitorioso rei um bem tão grande que aceitaria de bom grado a morte, como informa ao Coro: "Alegro-me e a

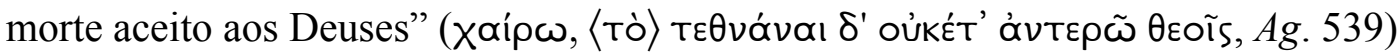

$\mathrm{Na}$ breve esticomitia entre o Arauto e o Corifeu, este último transmite uma mensagem velada, a de que, ausentes rei e tropas, a situação no palácio é tal que o silêncio tem sido a melhor forma de evitar o mal. Quando o Arauto pergunta se o Corifeu temia alguém durante a ausência de Agamêmnon e o Coro, retomando a frase dita pelo Arauto, mas ressignificando-a, responde "A ser, disseste, grande graça a morte

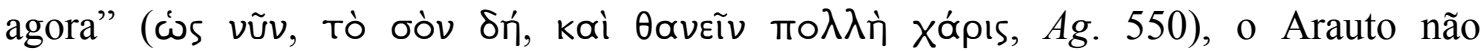

\footnotetext{
${ }^{31}$ A esse respeito, Goldhill (2004, p. 26) faz a seguinte observação: "Paris' crime has led to his destruction. The Greek fleet's crime has led to its destruction. Agamemnon's killing of his daughter awaits requital. As Agamemnon returns to Clytemnestra's trap, then, he has been depicted both as a victor punishing transgression and as a transgressor awaiting punishment. From the first ode's representation of the sacrifice of Iphigeneia, Agamemnon is locked into a narrative of revenge and reversal: revenge which punishes wrongdoing, but which, in turn, establishes the revenger as a wrongdoer in need of punishment".
} 
compreende o novo sentido das palavras do Corifeu e interrompe o diálogo, ignorando os temores do Coro.

O Arauto inicia então a segunda parte de seu discurso com a assertiva de que "está bem feito" ( e que veicula uma visão trágica do mundo, sobre a instabilidade da condição humana, pergunta quem, exceto os deuses, não está sujeito, com o passar do tempo, às vicissitudes da vida e aos revezes da sorte. Essa reflexão é sinistramente apropriada ante a atual conjuntura: nada é estável para os mortais; como bem prevenira ou previra Clitemnestra, o vencedor, vencendo, pode se tornar por sua vez vencido ( $A g$. 340). Mas essa consideração a respeito das vicissitudes a que estão sujeitos os mortais serve também de ocasião para que o Arauto relate os seus próprios padecimentos durante a guerra e, através desse relato, narra-se, em breves cenas sucessivas que se alteram rapidamente, a expedição a $\operatorname{Troia}^{32}$.

Apesar de narrar as mazelas sofridas, o Arauto faz uma reflexão acerca desses males e os relativiza: "Por que pranteá-lo? Pretéritos males, / pretéritos, de modo a nem

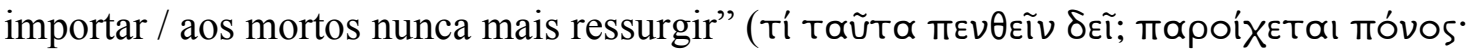

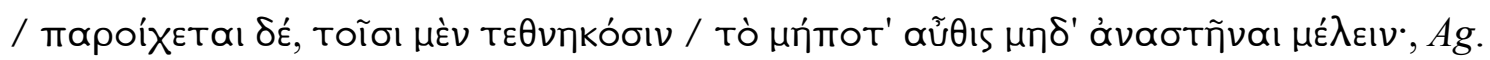
567-9). A repetição é enfática: do ponto de vista do Arauto, trata-se de males passados. Todavia, como notabilizou Jacqueline de Romilly em seu estudo sobre o tempo na tragédia grega (1971, p. 28), “dans le théâtre d'Eschyle [...] le passé n'est pas entièrement passé”. Essa asserção do Arauto contrasta ironicamente com os temores do Coro, que, justamente pelos fatos passados, teme o porvir, e contrasta com as palavras pronunciadas por Calcas na sua interpretação do auspício das aves, nas quais se diz que “permanece pavorosa ressurgente / Caseira astura: mêmore Cólera filivíndice” (Ag. 1545); ou seja, os males estão longe de encontrar seu termo e de serem esquecidos no passado. E, quanto ao fato de os mortos nem se importarem em não mais ressurgir, é preciso lembrar que entre esses mortos está Ifigênia, de cuja morte Clitemnestra está prestes a se vingar, e que, curiosamente, essa declaração do Arauto encontrará refutação nas palavras do servo no terceiro episódio das Coéforas ao comunicar a morte de

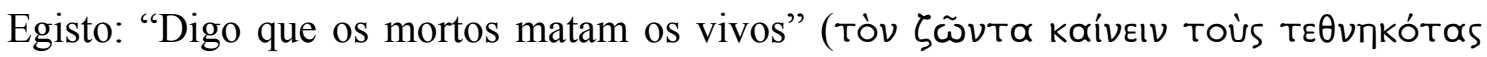
$\lambda \varepsilon ́ \gamma \omega$, Co. 886).

\footnotetext{
${ }^{32} \mathrm{O}$ relato do Arauto da guerra de Troia é considerado "realista" por muitos comentadores. A respeito do realismo do discurso do Arauto e quais os efeitos que acarreta para o segundo episódio e para a tragédia como um todo, conferir o artigo de Leahy (1974), "The Representation of the Trojan War in Aeschylus' Agamemnon".
} 
Para os que sobreviveram, observa o Arauto, "o ganho prevalece, dor não

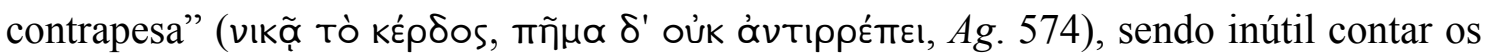
mortos e lamentar-se da sorte. Note-se que, ao ponderar sobre os dissabores da vida humana e da guerra, mas ao final concluir que tudo valeu a pena em vista da vitória conquistada, o Arauto expressa a perspectiva dos vencedores, que vai tomar forma e voz na entrada em cena do próprio Agamêmnon. E, assim, o Arauto finaliza o seu discurso

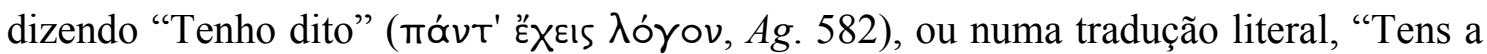
palavra toda" 33 .

Clitemnestra entra então em cena, escarnecendo dos que não acreditaram, como ela, na veracidade do sinal de fogo a anunciar a vitória argiva e, desdenhando da mensagem trazida pelo Arauto, diz que do próprio rei há de ouvir "a palavra toda"

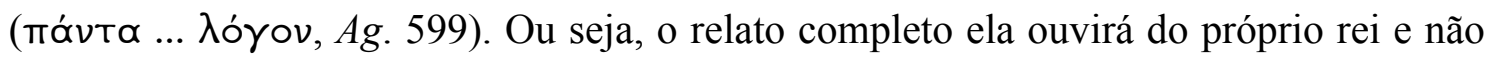
de um mensageiro, pois tem a convicção da veracidade do sinal de fogo. No momento, em vez de ouvir a mensagem enviada por Agamêmnon através do Arauto, ela prefere enviar uma mensagem a Agamêmnon através dele. Ela então comanda: "Anuncia ao

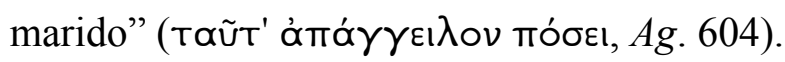

A mensagem que Clitemnestra ordena que seja entregue ao marido, como se sabe, é marcada pela ambiguidade. Vernant, com relação a este e ao discurso de boasvindas a Agamêmnon feito pela rainha, demonstrou sua exemplaridade para entender um tipo de ambiguidade trágica: "Trata-se de subentendidos utilizados de maneira plenamente consciente por certas personagens do drama, para dissimular, no discurso que elas dirigem a seu interlocutor, um segundo discurso, contrário ao primeiro, cujo sentido é perceptível por aqueles que dispõem, na cena e no público, dos elementos de informação necessários" (2005, p. 75).

$\mathrm{Na}$ mensagem de Clitemnestra a Agamêmnon, a ambiguidade de suas palavras ${ }^{34}$ reveste seu discurso de um sentido ominoso. Ela pede que se anuncie ao marido que

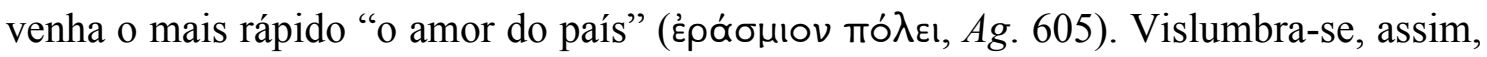
a sua falta de comprometimento com o marido, visto que Agamêmnon é o amor do país e não o seu amor. Ao chegar, diz Clitemnestra, Agamêmnon encontrará no palácio "fiel

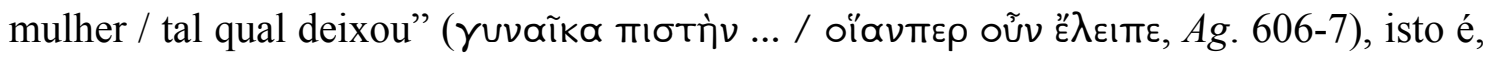

${ }^{33}$ Como aponta Barrett (2002, p. 25-6; 56), uma das marcas do mensageiro épico que sobrevive no trágico é a de que ele diz, disse ou dirá tudo. A completude da mensagem transmitida é um sinal tanto de que o mensageiro executou apropriadamente a sua missão quanto um indicativo da veracidade de suas palavras. Dizer tudo é dizer toda a verdade.

34 Conferir o capítulo 10, "Agamêmnon", da obra de Stanford (1939), Ambiguity in Greek literature: studies in theory and practice, em que o autor analisa a ambiguidade da fala de Clitemnestra. 
ainda desejosa de vingança e fiel somente a esse propósito; "cão do palácio"

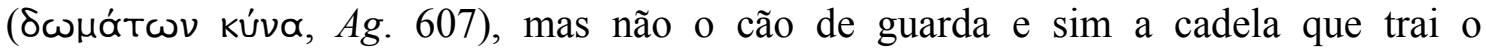

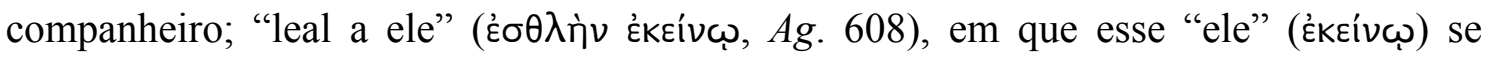

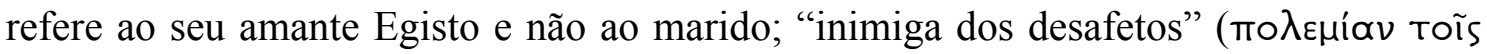

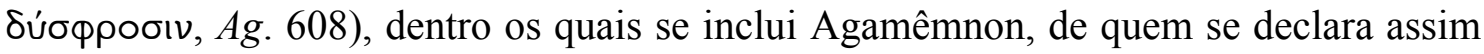
inimiga. Diz por fim que de prazeres adúlteros e de má reputação sabe tanto quanto de

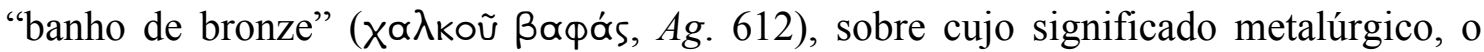
procedimento da têmpera do aço, sobrepõe-se o sentido do assassinato por arma de bronze, prenunciando-se, assim, a morte de Agamêmnon. Como observa Roisman (1986, p. 282) "the ambiguity of her language is part of her larger murder-plan".

Note-se que ela encerra seu discurso reclamando a veracidade de suas palavras:

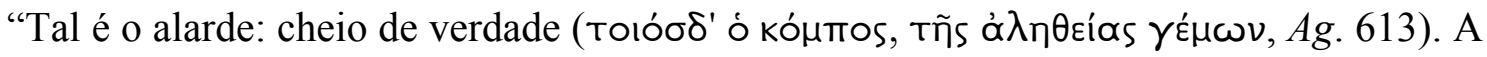
ambiguidade ominosa da fala de Clitemnestra não passa despercebida ao Coro, que diz: "Ela assim falou transparente palavra / se por claros intérpretes a entendes" ( $\propto$ ứTฤ $\mu \varepsilon \dot{\nu}$

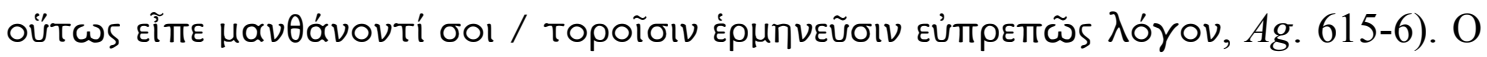
Coro, dessa forma, compara o discurso dela a um enigma, cujo sentido verdadeiro só se

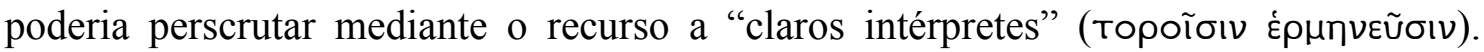
Curiosamente, o Coro, ante o silêncio enigmático de Cassandra, no quarto episódio, acredita que também a profetisa precisaria de um intérprete, ao dizer que ela parece

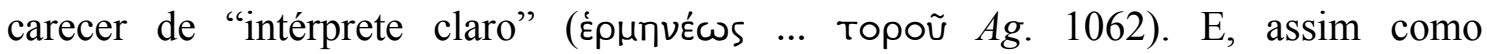
Clitemnestra, Cassandra também reclama a veracidade de suas palavras. Ela quer provar

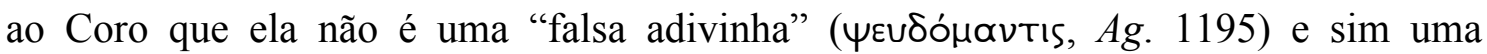

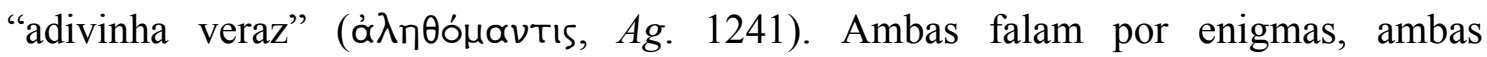
reivindicam a verdade de seu discurso, ambas falam do mesmo: a morte do rei.

O Coro, no entanto, ainda que ciente do que existe de ameaçador e sombrio nas palavras de Clitemnestra - assim como o Vigia, no prólogo, mostra-se ciente do que existe de ameaçador e sombrio no palácio -, prefere, como aquele, calar-se, pois, como

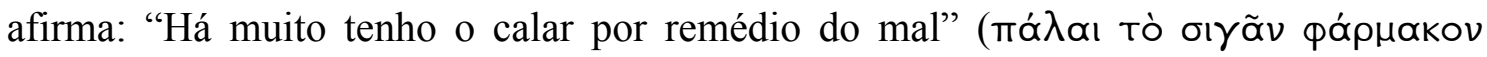

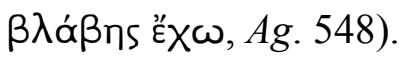

Apesar de o Arauto ter afirmado que entregou a "palavra toda" a seus interlocutores, há mais a ser dito. Quando o Coro pergunta se Menelau retorna juntamente com o exército, o Arauto titubeia, mas informa que Menelau e seu navio se perdeu do restante da esquadra argiva. O Coro, certeiro, pede que o Arauto narre o que 
aconteceu, perguntando "Procela veio à esquadra / e deu-lhe fim, pelo rancor dos

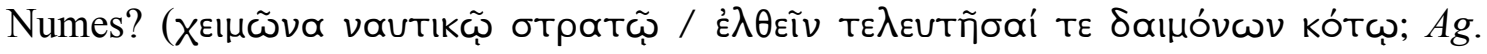
634-5). O Arauto irá confirmar isso: "procela por ira divina contra aqueus" ( $\chi \varepsilon ı \mu \tilde{\omega} \nu^{\prime}$

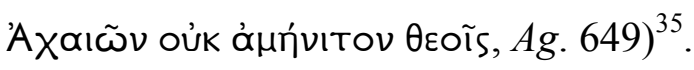

O Arauto inicia então a terceira parte do seu discurso, relutando conspurcar um

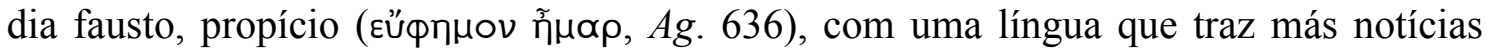

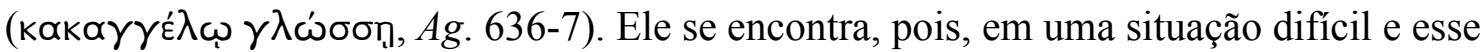
é o principal objeto de sua reflexão: como um bom mensageiro como ele, um

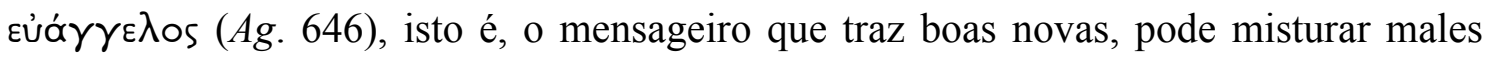
aos bens que veio anunciar ao falar da tempestade que, por cauda da ira divina, abateuse sobre os aqueus? Essa foi a dificuldade em que a pergunta do Coro sobre o paradeiro de Menelau o colocou. Ele próprio, no diálogo com o Coro que antecede esse seu

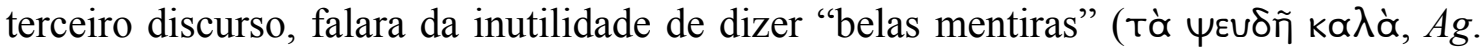

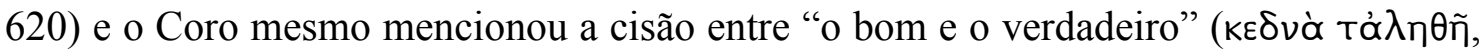
Ag. 622). E isso após o discurso de Clitemnestra, que nada mais é que "belas mentiras" e que se fundamenta na cisão entre "o bom e o verdadeiro".

Note-se que o temor do Arauto de conspurcar com más notícias um dia jubiloso pelas boas notícias que ele traz é um temor que, dentro de tudo que foi dito até então, é ironicamente dramático. Sem o perceber, ele já conspurcou o dia com más notícias ao narrar a destruição dos templos e das estátuas dos deuses. Ele já fez o que agora mais

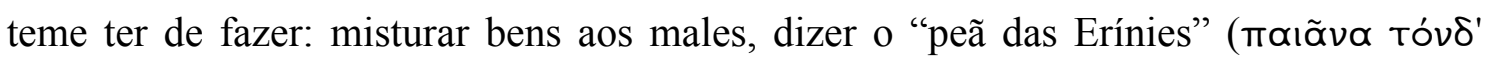
'Epıvúwv, Ag. 645). Essa difícil tarefa de trazer a notícia da vitória e em seguida ter de falar de uma tragédia marítima que se abateu sobre o exército vitorioso e fez desaparecer Menelau, separando o "par de Atridas honrado / por Zeus com dois tronos e

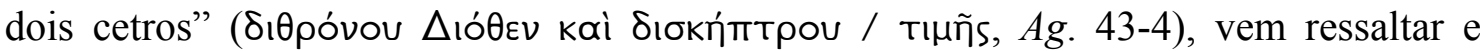

\footnotetext{
${ }^{35}$ A ideia de que aqueles que ofenderam os deuses de alguma forma encontram punição durante uma viagem marítima com uma tempestade que destrói os navios e afoga os homens é um tópos na literatura grega antiga e um tópos particularmente associado ao retorno à pátria dos heróis conquistadores de Troia como castigo por comportamento sacrílego. Assim, na Odisseia, Nestor narra a Telêmaco a destruição da

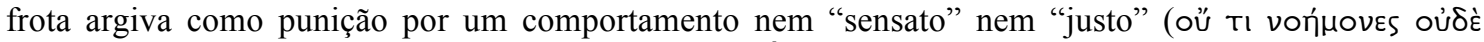

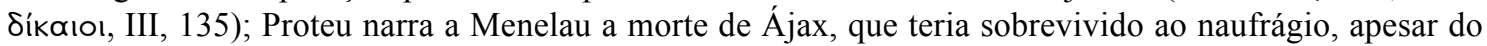

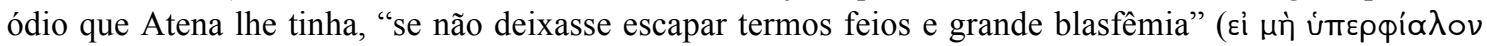

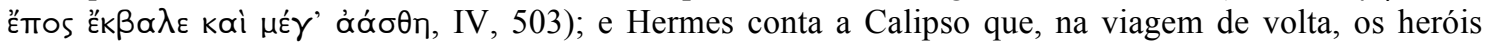

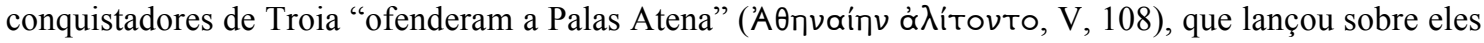
uma tempestade marítima. Nas Troianas, de Eurípides, o mesmo motivo aparece no diálogo entre Atena e Posídon, no prólogo, em que a deusa lhe pede que, juntamente com a tempestade e os raios de Zeus, cause a ruína da esquadra grega no mar, pois os gregos, principalmente Ájax, tiveram um comportamento hybristés para com ela e seus templos. A deusa pergunta a Posídon: "Ignoras o ultraje a mim e ao

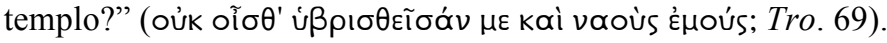


reafirmar a ambiguidade da vitória grega sobre Troia, uma ambiguidade que está presente desde o início da tragédia, tanto nas reflexões do Coro quanto no auspício das aves interpretado por Calcas.

O Arauto passa então à narrativa propriamente dita dos fatos: a cólera divina se manifestou na fúria dos elementos - fogo e mar -, que, agindo conjuntamente, destruíram a esquadra argiva, fazendo "florir o mar Egeu com cadáveres / de aqueus e

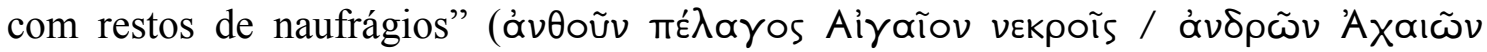
vautıkoĩs T' દ́peıтíoıs $A g$. 658-9). Ele atribui a própria salvação e a salvação de seu rei

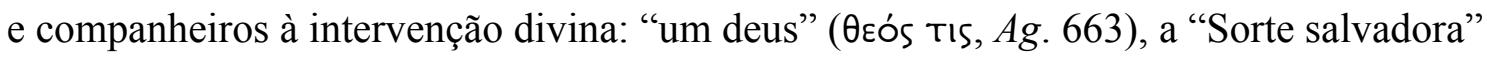

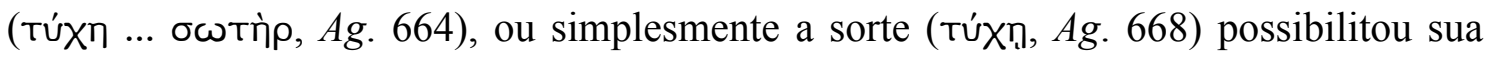
sobrevivência. Mas ele afirma desconhecer o paradeiro de Menelau e do restante de seus companheiros, restando-lhe apenas os votos de que aconteça o melhor e de que, se Menelau ainda vive, Zeus permita que ele regresse ao palácio.

O Arauto finaliza seu discurso com a assertiva: "Tanto ouviste e sabe: ouviste a

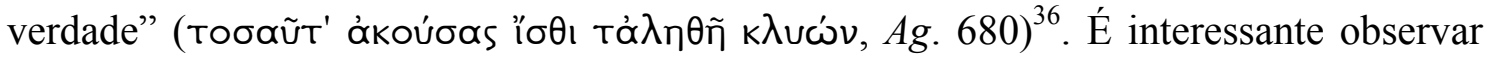
que, até o início do segundo episódio, o Coro questiona a veracidade dos sinais de fogo controlados por Clitemnestra que trazem a mensagem da conquista de Troia, de modo que, para os anciãos argivos, o Arauto é quem determinará de uma vez por todas se os sinais de fogo são verazes ( $\dot{\alpha} \lambda \eta \theta \varepsilon i ̃ \varsigma, ~ A g .491)$, como o Coro diz ao avistar o Arauto: "Logo saberemos se o fulgor dos lampejos / luminosos e as transmissões do fogo / são

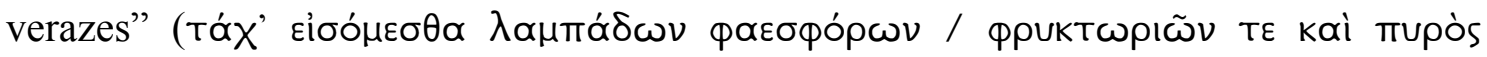

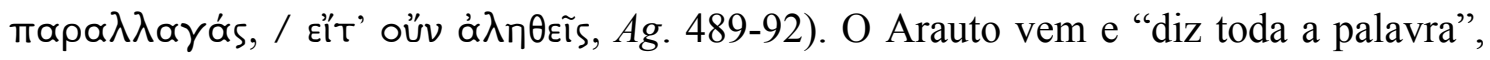
de forma que, quem ouve, ouve a verdade, e opõe-se assim à incerteza e à falta de confiabilidade que o Coro atribui ao sinal de fogo, ao qual faltam palavras. A mensagem que ambos trazem é a mesma: a vitória do exército argivo em Troia. Ironicamente, mesmo após ouvir o confiável Arauto e de ter portanto se certificado da veracidade dos sinais de fogo, o temor pelo destino de Agamêmnon, ao invés de diminuir, aumenta, porque o que o Coro pode perceber em suas palavras, mas do que o

\footnotetext{
${ }^{36}$ Como observa Barrett (2002, p. 11), essa conclusão sugere que a alegação de que sua narrativa é

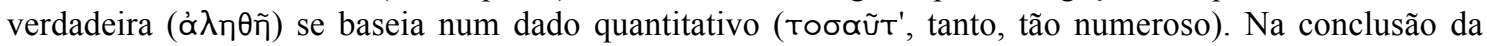

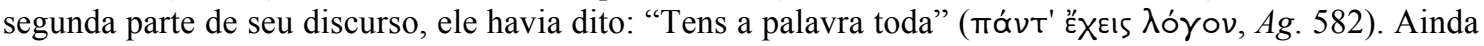
que agora, ao concluir a terceira parte de seu discurso, ele não declare ter contado a história toda, ele no entanto continua a basear o valor de sua narrativa em seu aspecto quantitativo. A verdade de seu discurso se apoia na completude de sua narrativa, que por sua vez se baseia na sua condição de testemunha ocular

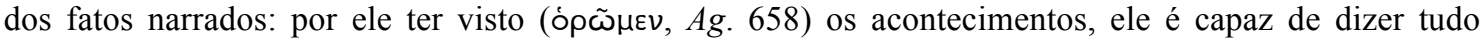

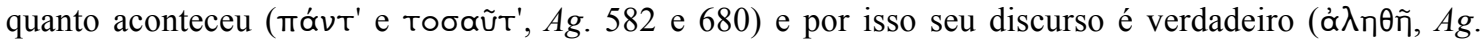
680 ).
} 
Arauto mesmo mostra-se profundamente inconsciente, são os sinais divinos que prenunciam males para o Atrida e, consequentemente, para o palácio.

Através do Arauto expressa-se, assim, um ponto de vista humano e mortal, que anuncia uma grande conquista, narrando a vitória esmagadora de seu rei e que, apesar dos males padecidos, veicula uma perspectiva otimista da guerra e de suas consequências, mas expressa-se também, de forma inadvertida, um ponto de vista numinoso, que prenuncia o destino de Agamêmnon, o cumprimento da justiça divina e as consequências funestas para o rei, consequências estas que já começaram a se revelar, como o confirma a narrativa da tempestade que atingiu as naus em seu retorno à pátria e fez desaparecer Menelau.

O Coro então, no segundo estásimo, volta-se às causas da guerra - à figura de Helena, responsável por tantos males padecidos e pressentidos -, constatando quão

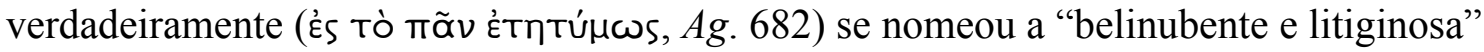

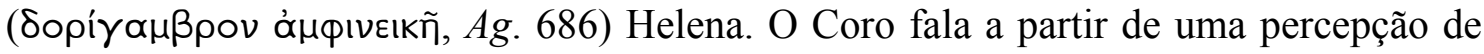
que a palavra - ou, no caso, o nome próprio - possui, como se viu, um nume que se cumpre e se revela no curso dos acontecimentos e o Coro aqui confirma a veracidade dessa percepção: "não o vemos a dirigir / com previsão do destino / a acertada língua?"

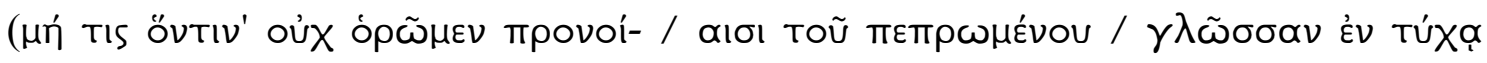
vé $\omega \omega \nu ; A g .683-5)$.

Assim, na etimologia que o Coro faz do nome de Helena ${ }^{37}$, revela-se nitidamente como se cumpriu a previsão do destino expresso por meio dele. Helena ('E $\lambda$ évav, $A g$.

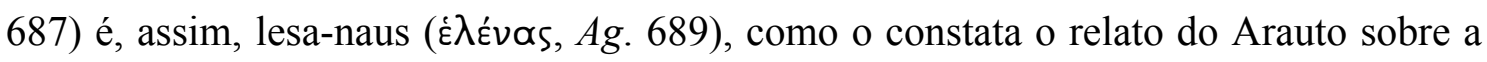
perda dos navios ocasionada pela terrível tempestade em seu retorno ao lar; é lesa-

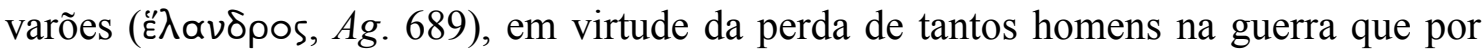

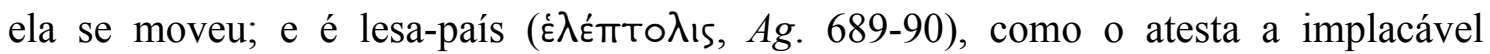
destruição a que seu país foi submetido $(\mathrm{Ag} .688-90)^{38}$.

Também na ambiguidade do termo kñסos, com que se designam as núpcias entre Páris e Helena, o Coro aponta a veracidade do kledón: diz-se da "aliança" (кñठos, Ag.

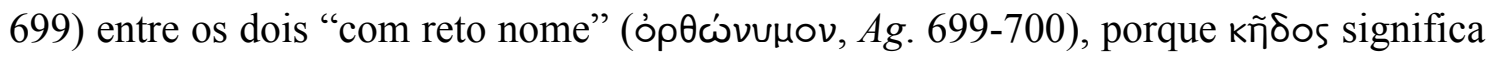

\footnotetext{
${ }^{37}$ Skutsch (1987), em seu artigo "Helen, Her Name and Nature", analisa com minúcia as possiblidades etimológicas do nome de Helena e suas implicações.

${ }^{38}$ Eurípides, nas Troianas, retoma esse jogo etimológico de palavras que associa o nome de Helena com o verbo đipéc. Hécuba, a respeito de Helena, diz o seguinte a Menelau: "Evita vê-la, não te domine pelo

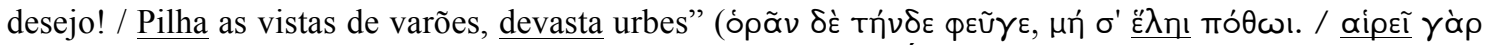

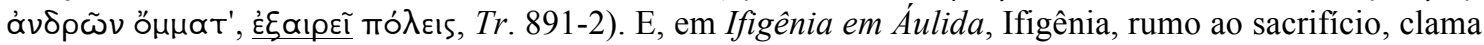

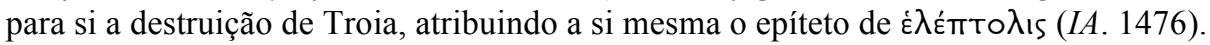


tanto "aliança", "núpcias", quanto "funerais", "luto", e o aspecto funesto dessa união

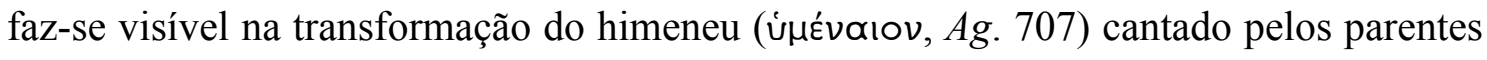

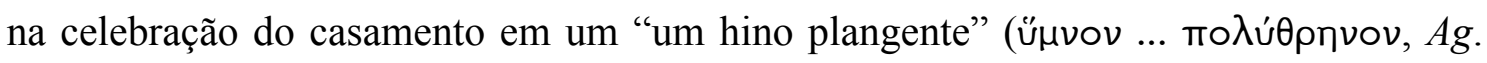
709-11) cantado pelo país de Príamo. Assim, a bela Helena, filha de Zeus, ao chegar a Troia levando atrás de si o terrível e destruidor exército argivo, mostra sua face sombria, que é a Erínis ('Epıvús, $A g$. 749), pois que ela leva morte, ruína e destruição a Troia.

De caráter pressago é também a parábola, contada pelo Coro, do homem que trouxe para sua casa um filhote de leão. Gracioso e afável quando pequeno, o leão mostrou na maturidade a índole de seus pais, banqueteando-se com o rebanho da casa e retribuindo dessa maneira todos os cuidados que lhe foram dispensados pelos seus donos. O contexto em que essa parábola é contada sugere que o leãozinho é Helena. Páris ou Troia inteira seriam o homem para cuja casa se trouxe esse adorável filhote de leão. Assim como o leãozinho trouxe destruição e dor para a casa de seu dono, também Helena trouxe destruição e dor para aqueles que a acolheram.

No entanto, como bem observa Knox (1952, p. 17-25), esse homem que acolhe o filhote de leão é também Menelau, pois, ao tomar Helena como esposa, trouxe para sua casa incontáveis males. É ainda Agamêmnon, que, tomando Clitemnestra como esposa, trouxe para dentro de casa sua futura assassina. Do mesmo modo, o leãozinho é não somente Helena, mas também Agamêmnon, que trouxe ruína aos seus ao devastar Troia e ao sacrificar a sua filha. É ainda Egisto, que, vindo habitar o palácio de Agamêmnon, conspira sua morte. E também é Orestes, que, sendo introduzido para dentro do palácio, comete matricídio. Há, dessa forma, uma semelhança entre a parábola do leãozinho e o auspício das aves, uma vez que, na tragédia de Ésquilo, as imagens poéticas se revestem continuamente de um aspecto profético. Em ambos, pois, encontra-se a mesma polissemia significativa, a mesma sobredeterminação de presságios, e através de ambos se prenuncia o mesmo destino para o palácio dos Atridas - uma cadeia de sucessivos crimes consanguíneos.

O Coro, ao fim de suas reflexões sobre o poder destruidor de Helena, faz um elogio à moderação, ao condenar o excesso, aqui visto sob forma de uma "grande

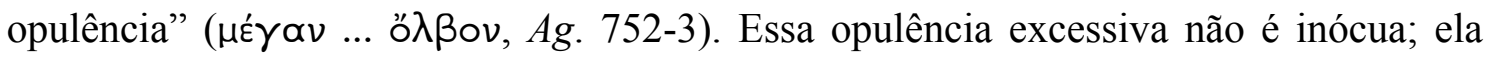

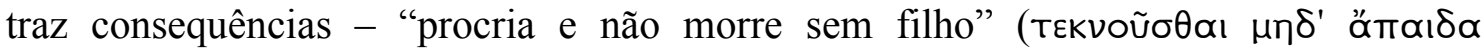

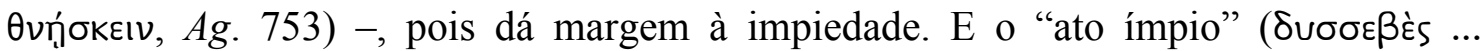




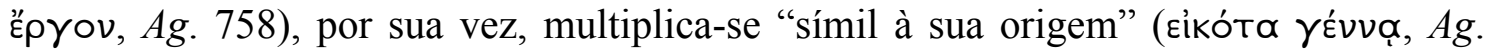
760):

 $\mu \grave{v} v \pi \alpha \lambda \alpha ı \dot{\alpha} v \varepsilon \alpha \dot{\alpha}-$

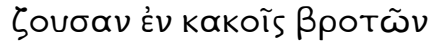
ÜßpIv TóT' ที Tó $\theta$ ', ÖTE Tò Kú-

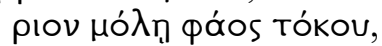

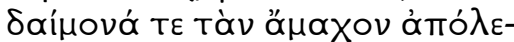

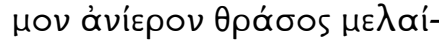

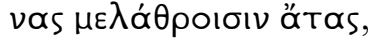

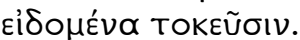

\author{
Soberbia antiga sói \\ parir soberbia nova \\ entre os males dos mortais \\ cedo ou tarde, ao vir \\ o dia próprio do parto: \\ o Nume indômito invicto, \\ a ímpia audácia \\ da negra fúria no palácio \\ parecida com seus pais.
}

A hýbris, cedo ou tarde, gera nova hýbris. Assim, a hýbris de Páris, ao ofender mesa hóspede, gerou por sua vez a hýbris de Agamêmnon. Note-se que o Coro

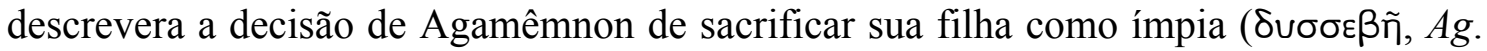

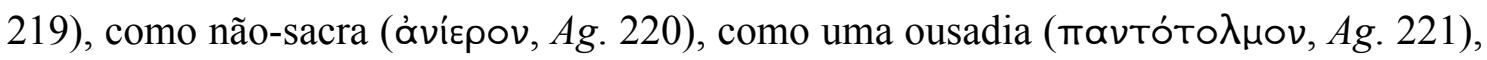
isto é, com os mesmos termos com que agora ele faz essa reflexão de caráter geral e, por ser uma reflexão de caráter geral, é aplicável tanto a Páris e aos seus quanto a Agamêmnon. O problema é que, como observa o Coro, a hýbris, cedo ou tarde, gera nova hýbris; assim, o que o Coro não diz, mas teme, é que a transgressão de Agamêmnon dê margem a uma nova transgressão, a de Clitemnestra. Observe-se que as relações de causa e consequência e de sucessão são descritas mediante a imagem da

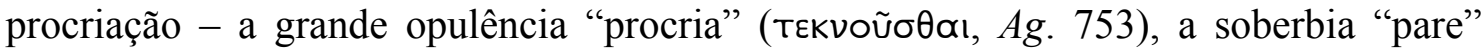
(Tíktєıv, $A g$. 763) - e da similaridade entre pais e filhos - o ato ímpio é "símil à sua

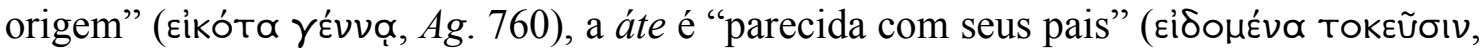
Ag. 771). Essas imagens de maternidade e de parentesco evocam a figura de Clitemnestra, cujo rancor pela morte da filha gerada legitimamente dentro de um casamento, e por isso símil aos pais, irá levá-la a perpetrar o assassinato de seu marido, de forma que essa reflexão do Coro, ao mesmo tempo em que aponta para a transgressão de Páris e de Agamêmnon, prenuncia a de Clitemnestra.

No terceiro episódio, a tão aguardada chegada de Agamêmnon finalmente acontece: o rei conquistador de Troia entra em cena. O Coro, ao procurar a justa medida ao saudar Agamêmnon, faz uma condenação daqueles que preferem as aparências e a adulação, dissimulando seus reais sentimentos: "os de aparência benévola / adulam com

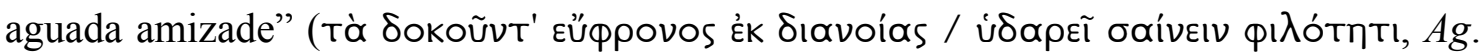


797-8). Trata-se de um aviso. O Coro mesmo confessa ter condenado o feito de Agamêmnon como uma demência (таракота́, $A g$. 223), de quem não bem dirige o

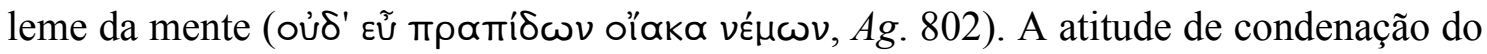
Coro, no entanto, passa a ser de louvor e a façanha de Agamêmnon, antes vista como uma demência, passa a ser vista como um "benefício" (xópıтos, $A g .787$ ), uma vez conquistada a vitória. Quanto aos demais, porém, o Coro recomenda ao rei procurar saber quais, dentre os cidadãos, agem e falam com justiça, de modo a conhecê-los "com o tempo" ( хрóvœ, Ag. 807). Ironicamente, tempo é justamente aquilo de que Agamêmnon não dispõe e, sendo incapaz de perceber por trás da aparência benévola de Clitemnestra os seus reais intentos, tal como o Coro dissimuladamente o adverte, sucumbirá.

Do discurso de Agamêmnon, ressalta-se o retrato de um homem cuja confiança em seu próprio poder e na amizade que os deuses lhe devotam é perigosamente excessiva. E esse perigo assoma novamente quando ele descreve o ataque do exército a

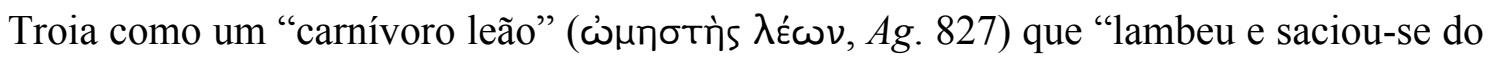

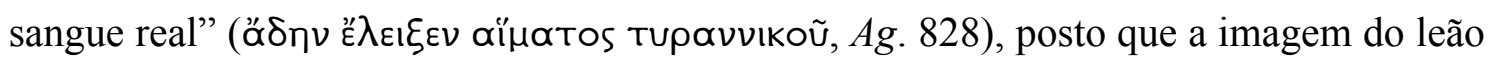
em um banquete sangrento remete à parábola do leãozinho e, assim como este, Agamêmnon também se revela um "sacerdote de Furor" (iєpeús tis ătas, Ag. 735-6). Tendo em vista essa excessiva confiança, mais trágica se torna a ironia quando, aceitando o conselho do Coro, Agamêmnon diz que, reunindo o povo em assembleia, há de deliberar "como o que está bem / ficará bem com o passar do tempo" (kaì Tò $\mu \varepsilon \dot{\nu}$

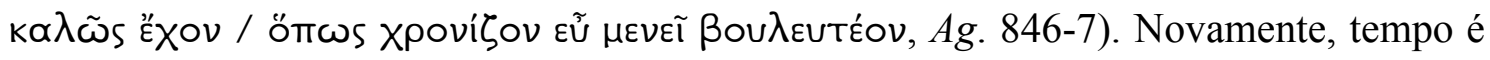
tudo que o rei não tem.

Clitemnestra, em seu discurso de saudação a seu marido, dirigido primeiramente ao Coro e só depois a Agamêmnon, fala do sofrimento pelo qual passou durante a ausência do esposo: a solidão, os constantes rumores sobre a morte de Agamêmnon que a levaram a tentar cometer suicídio, a preocupação com a segurança de Orestes frente à possível morte do rei e a derrubada do Conselho, motivo pelo qual o filho encontra-se na Fócida, do choro e das noites mal dormidas, e, por fim, do grande alívio e alegria que a volta de Agamêmnon traz. Diante disso, ela deseja homenageá-lo, cobrindo o chão a ser pisado por seus pés com vestes púrpuras.

Trata-se de um discurso plenamente condizente com uma esposa fiel e uma mãe zelosa que vê no tão ansiado retorno de seu marido o fim de todos os seus sofrimentos. 
Clitemnestra, no entanto, não é essa esposa e nem essa mãe: ela é uma mulher de "viril

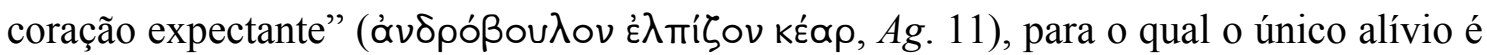
a realização da vingança que, por uma década, vem sendo ardentemente almejada e traiçoeiramente planejada. Por isso o seu discurso não é apenas mentiroso, ao omitir seus verdadeiros sentimentos e a verdadeira causa da ausência de Orestes, mas também é repleto de uma ominosa ambiguidade.

Assim, ao falar das angústias padecidas durante a ausência do marido, diz que, se Agamêmnon tivesse recebido tantas feridas quanto insinuavam os rumores, ele teria

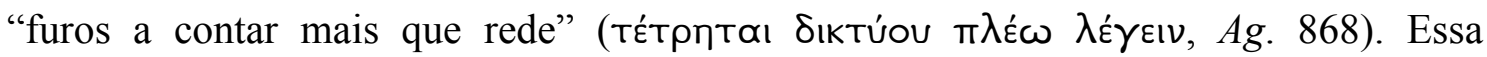
imagem que aqui Clitemnestra usa das feridas como furos em uma rede tem um sentido ominoso, uma vez que é justamente dessa forma que o rei será assassinado: envolto em uma rede (Ag. 115-6, 1382; Co. 984).

Dando continuidade ao seu discurso, Clitemnestra, ao convidar Agamêmnon a descer do carro, diz: "desce desse carro, sem pôr no chão / o teu pé devastador de Ílion,

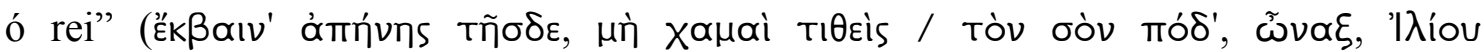
порөท́тора, $A g$. 906-7). Aqui também se pode perceber uma ambiguidade ominosa, pois "sem pôr no chão o teu pé" não significa apenas pisar nas vestes púrpuras em vez de no chão nu, mas também não ter apoio para o pé, não poder firmar-se, estabelecer-se com firmeza.

Igualmente, a rainha, dando ordem às servas, pede que "rápido se cubra de

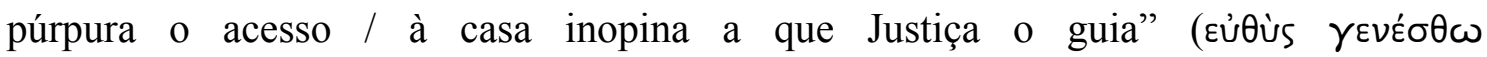

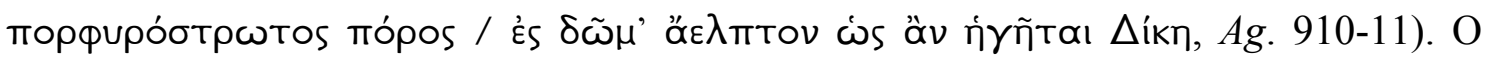
sentido literal é de que se cubra de vestes cor púrpura o caminho até a casa, ou seja, o palácio dos Atridas, ao qual o rei é guiado pela Justiça, isto é, a justiça da qual Agamêmnon se fez executor ao punir os troianos pelo rapto de Helena. Mas das entrelinhas assoma o sentido ominoso de suas palavras: cobrir o caminho de púrpura

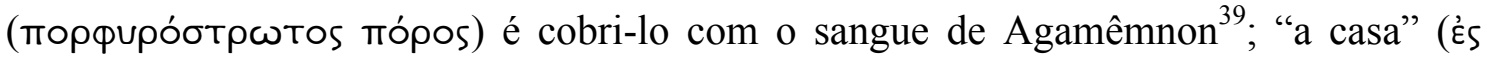
$\left.\delta \tilde{\omega} \mu^{\prime}\right)$ a que se tem acesso não é o palácio dos Atridas, mas sim o de Hades; e a Justiça $(\triangle i ́ k \eta)$ que o guiará ao Hades é a justiça da qual Clitemnestra se fará executora ao vingar o sacrifício de sua filha em prol da expedição guerreira.

Agamêmnon, no entanto, não é capaz de perceber os males que se prenunciam através das palavras ambíguas da rainha. O rei não consegue interpretar os sinais que

\footnotetext{
${ }^{39}$ Note-se, em Homero, o adjetivo порфúpєos, "rubro", "púrpura" para qualificar Өávatos, "morte":

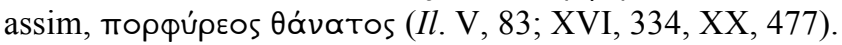


povoam a sua chegada - não capta a dimensão do aviso que o Coro lhe dá à sua chegada para que desconfie da adulação e da aparente benevolência, não distingue a ambiguidade do discurso de boas-vindas de Clitemnestra, não percebe todas as implicações do símbolo do tapete de púrpura. Ele é, por assim dizer, um mau intérprete de sinais.

Para o Coro, ele responde dizendo que "poucos entre os homens têm congênito /

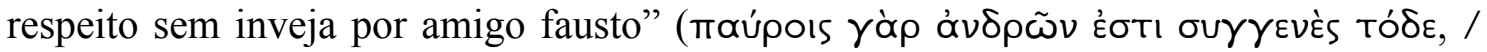

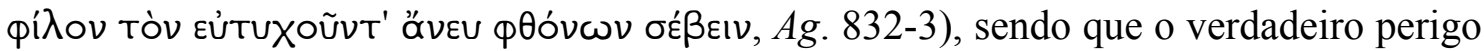

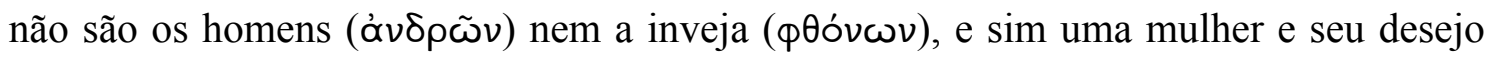
de vingança; diz que irá em assembleia deliberar "como o que está bem / ficará bem

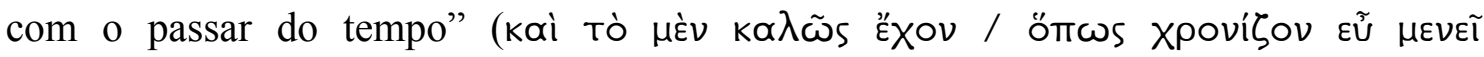

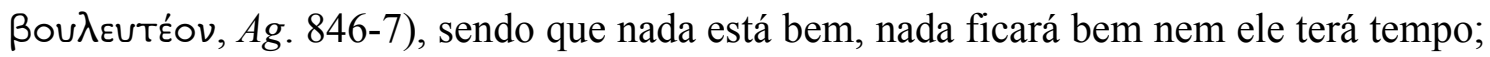
diz por fim que, se alguma questão tiver de ser remediada, será preciso tentar "reverter o

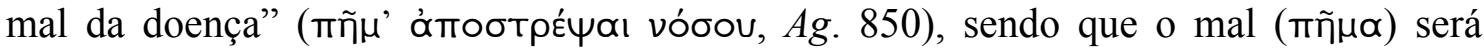
proveniente não da doença e sim da morte, e, como dirá o Coro no terceiro estásimo, não há encantamentos que possam chamar o morto de volta à vida ( $A g .1019-21)$.

Para Clitemnestra, de seu discurso ele diz apenas que é conveniente, ainda que extenso, à sua prolongada ausência. Quanto a ser honrado pisando um caminho de vestes púrpuras, ele diz não crer ser conveniente, pois se trata de uma honraria que deve ser prestada somente aos deuses e correria, portanto, o risco de, ao aceitá-la, incorrer na

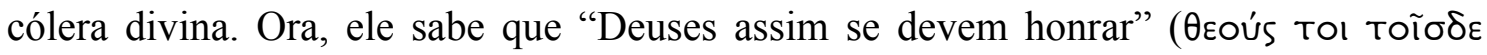

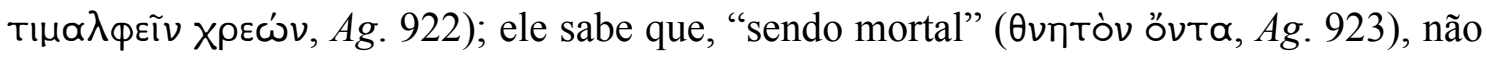
poderia pisar em tais ornamentos "sem pavor" (åveu фóßou, $A g$. 924); ele sabe que a

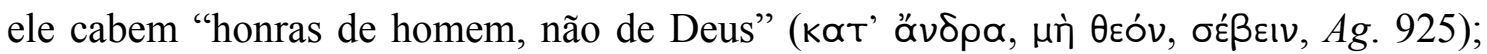

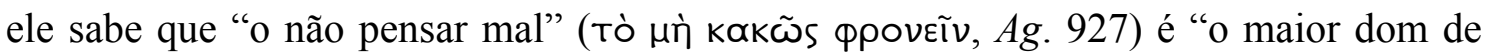

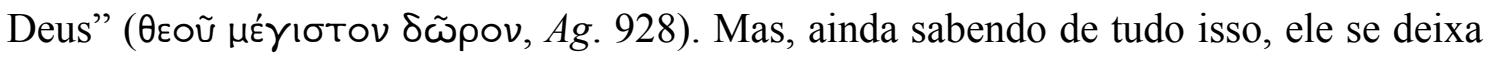
convencer por Clitemnestra e pisa nas vestes púrpuras, selando por fim o seu destino de morte.

Clitemnestra não precisa de muito esforço para persuadir Agamêmnon a satisfazer seu desejo. Ela rebate as razões apresentadas por Agamêmnon para não se

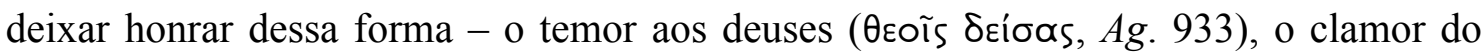

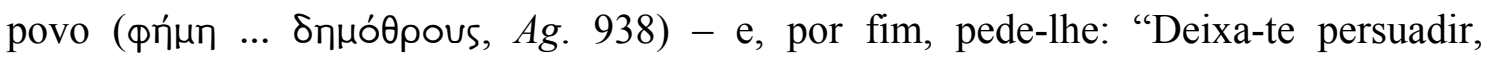

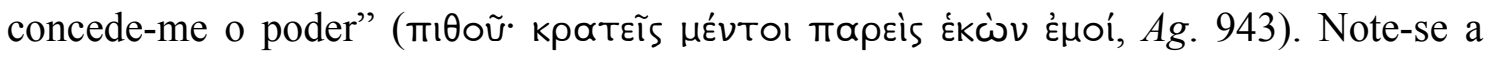


ambiguidade de suas palavras: conceder-lhe o poder significa satisfazer, nessas circunstâncias, o seu capricho de fazê-lo caminhar sobre vestes púrpuras, mas o sentido ominoso é o de que esse poder lhe será concedido por usurpação mediante a morte do rei.

Por que Agamêmnon, que se mostra tão ciente das consequências do gesto de pisar vestes púrpuras, deixa-se convencer a fazê-lo? Porque Agamêmnon está, afinal, cegado pela áte $e^{40}$. E esse domínio da áte sobre si se explicita na sua aquiescência em pisar as purpúreas vestes tirando, para isso, as sandálias - "descalcem-me logo / os

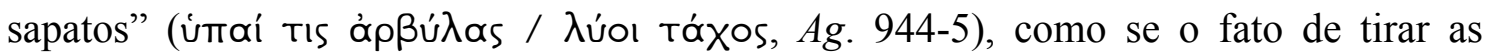
sandálias diminuísse a gravidade de seu ato sacrílego - "não me atinja de longe a inveja

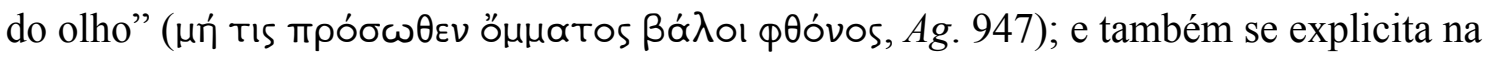
recomendação que ele faz à sua esposa para conceder benévola acolhida à sua amante -

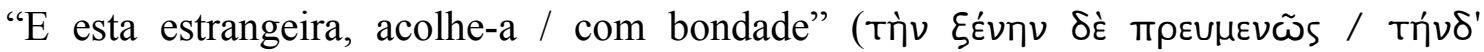

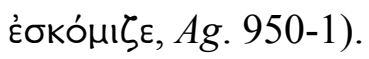

Enquanto o marido comete o sacrilégio de caminhar pelo tapete de púrpura, Clitemnestra continua a discursar e, uma vez mais, pode-se perscrutar em suas palavras um sentido ominoso, quando diz que muito mais tecidos tingidos de púrpura ela pisaria

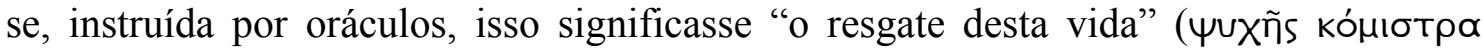

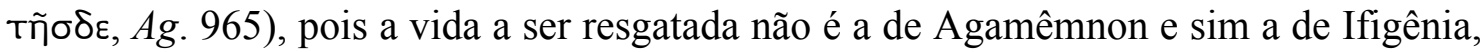
ao se executar a sua vingança. Igualmente, ao se referir ao marido como "o perfeito

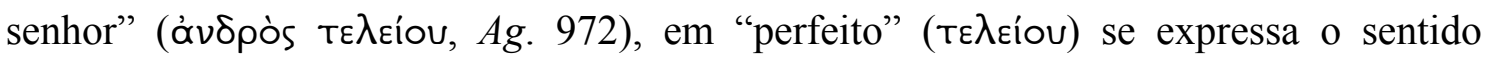
ominoso de "acabado", “morto". E em sua prece a Zeus - "Zeus, Zeus Perfectivo,

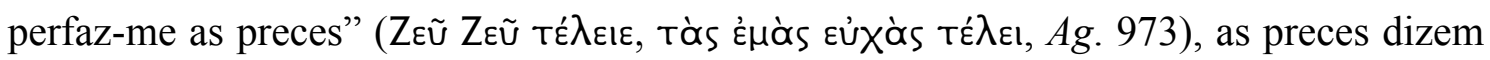
respeito à morte de Agamêmnon; é a morte dele que a rainha pede que seja cumprida.

As palavras de Clitemnestra, repletas de uma ambiguidade ominosa, têm um valor oracular, prenunciando o iminente assassinato de Agamêmnon ${ }^{41}$. Mas o rei é um

\footnotetext{
${ }^{40}$ Leahy $(1974$, p. 22) faz a seguinte observação a esse respeito: "For one desperate moment, when Agamemnon rebuffs Clytemnestra, it appears that he may perhaps after all refute the misgivings which the audience have been made to feel; but the hope passes as quickly as it came, and Agamemnon finally demonstrates for all to see that he can recognize hybris for what it is and yet, possessed by Ate, still choose to commit it. The sense of uneasiness which Aeschylus has so carefully built up is at last seen to be justified, and disaster is now inevitable".

${ }^{41}$ McClure (1997, p. 132), analisando o último discurso de Clitemnestra, chama a atenção para o aspecto encantatório de sua fala: "one of the salient characteristics of Clytemnestra's speech is the polysemy created by an abundance of metaphors. But this stylistic feature can be specifically linked to the incantatory nature of the speech. Metaphor allows Clytemnestra to say what she means in a way that eludes the other characters, particularly the chorus, who are continually baffled by her words. Given the belief in the efficacy of language which reappears at several critical junctures in the play, the repeated use
} 
mau intérprete de sinais e, assim, cegado pela áte e preso na rede tecida pelas palavras ominosas de Clitemnestra, caminha para dentro do palácio e para a sua inevitável morte.

O Coro, no entanto, não deixa de perceber em Clitemnestra uma ameaça e, diante da ação sacrílega perpetrada por Agamêmnon, tem mais um motivo para temer pelo pior. Assim, no terceiro estásimo, o Coro de anciãos fala de seu temor:

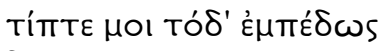

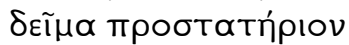

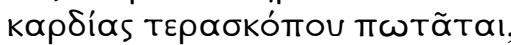

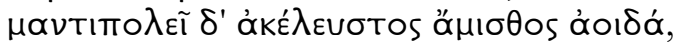

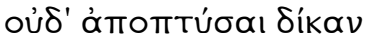

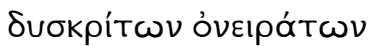

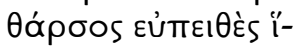

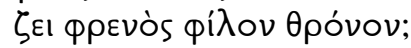

Por que este perpétuo

temor diante do vaticinante coração esvoaça?

Um canto sem convite nem paga profetiza e para desprezá-lo como a indiscerníveis sonhos nenhuma audácia persuasiva senta-se no trono do espírito.

O temor do Coro se deve a um coração que é descrito como "vaticinante". Vaticinante traduz o termo grego терхоко́тоо ( $A g$. 977), isto é, que sonda signos. Sendo o coração aquele que sonda signos, o Coro se refere, portanto, a um sentimento divinatório. Trata-se, portanto, da descrição de uma forma de adivinhação em que, como se viu, os sinais divinatórios manifestam-se por meio de um sentimento vaticinante que possui e domina a quem o tem e de que o homem não é o sujeito agente, e sim o sujeito paciente. Esse sentimento divinatório é descrito pelo Coro como um

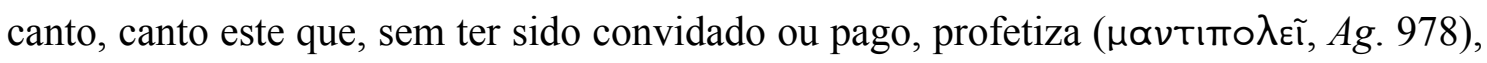
e, por mais que se deseje, não se pode desprezá-lo como se fossem "indiscerníveis

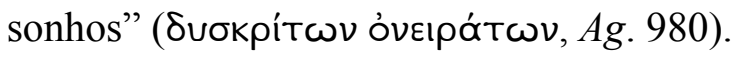

De que fala esse coração vaticinante? $\mathrm{O}$ que canta esse sentimento divinatório descrito como um canto (áoı́์́a, Ag. 979)? O Coro diz que seu "íntimo ímpeto"

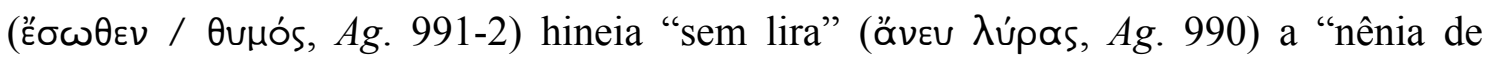

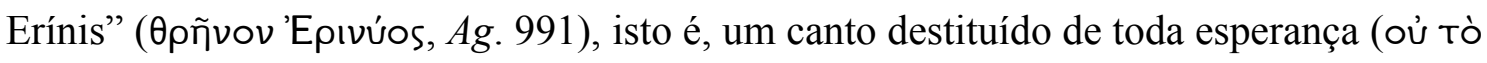

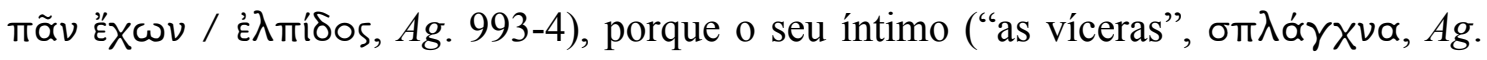

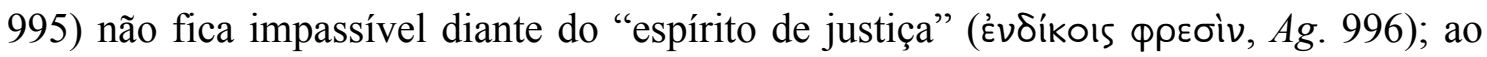
contrário, ele volteia. Essa justiça, conforme ele dissera, "impõe que a saibam / os que a

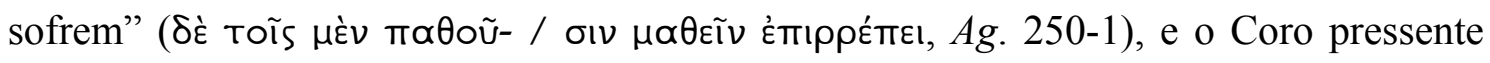

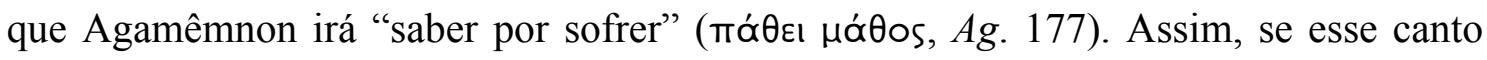


vaticinante do coração é associado pelo Coro a uma nênia de Erínis, esse sentimento divinatório fala, pois, de morte:

Tò $\delta^{\prime} \varepsilon \dot{\pi} \pi \dot{\gamma} \gamma \tilde{\alpha} \nu \pi \varepsilon \sigma o ̀ v ~ a ̈ \pi \alpha \xi$

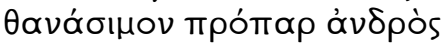

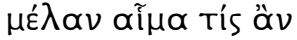

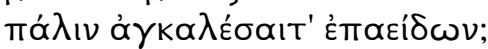

Caído por terra, morto precoce, o negro sangue viril, quem de volta o chamaria por encantos?

(Ag. 1019-21)

A imagem do corpo morto caído cujo sangue é irresgatável é uma antevisão da morte de Agamêmnon. O Coro, no entanto, crê estar falando da morte de uma maneira geral, pois ele não deseja que o seu coração se antecipe à sua língua $(A g$. 1028) e que os signos sondados por seu coração vaticinante se cumpram.

\subsection{3) Cassandra, a voz do palácio}

Ao fim do terceiro episódio, Agamêmnon introduz a personagem de Cassandra, que, silenciosa, permanecera junto ao rei em seu carro:

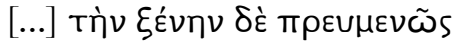

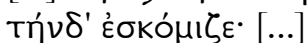

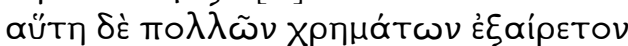

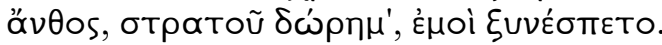

(...) E esta estrangeira, acolhe-a com bondade. (...)

Escolhida dentre muitas riquezas esta flor, dom do exército, veio comigo.

(Ag. 950-1; 954-5)

Cassandra é a profetisa de Apolo, filha de Príamo, a "flor" (ơvӨos) escolhida dentre os ricos despojos de guerra por Agamêmnon. Sua beleza já chamara a atenção do

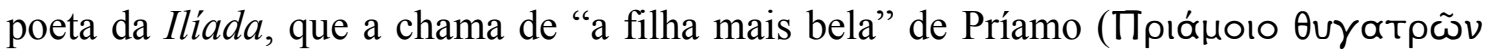

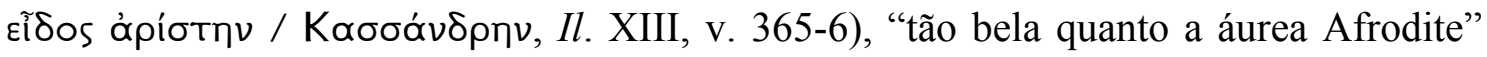

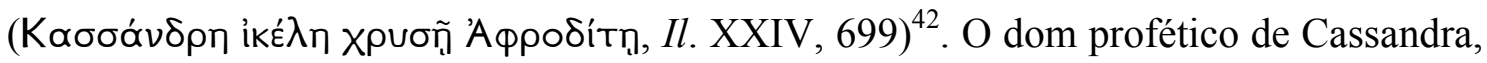
no entanto, é desconhecido de Homero. Mesmo quando a sombra de Agamêmnon narra, na Odisseia (XI, 421-4), o triste fim que encontrou ao lado da profetisa, não há qualquer menção a seus poderes divinatórios. Portanto, em Homero ela é apenas Cassandra, a bela princesa troiana, cuja mão fora prometida por Príamo a Otrioneu, de Cabeso, em troca de uma grande façanha guerreira (Il. XIII, 363-69).

\footnotetext{
${ }^{42}$ A beleza de Cassandra também é destacada num fragmento de Íbico: "Cassandra, a de olhos glaucos e

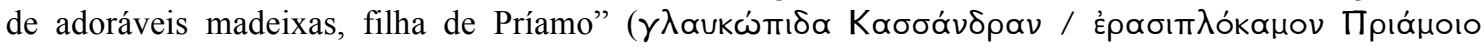
kópav, Fr. 22a.1-2). A edição é de Page, em Poetae melici Graeci (1962), e a tradução é nossa.
} 
É Píndaro quem, pela primeira vez, relaciona a bela filha de Príamo à arte divinatória, chamando-a de "virgem profetisa" ( $\mu$ óvtıv ... kópav, P. XI, v. 33). Em Ésquilo, como observa Mason (1959, pp. 84-5),

Kassandra is first and foremost the $\mu$ óvтı $v$ kópa $v$ of Pindar, and she is a full-length portrait by a master hand, and almost certainly the first in Greek literature, of the inspired prophetess who, like the Pytho at Delphi, becomes in her trance the vehicle of

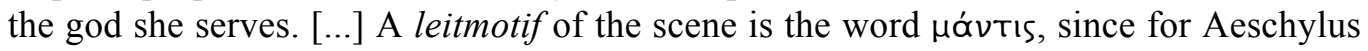
it is Kassandra's special gift which is to the fore in her portrayal.

Assim, Apolo, o adivinho (ó $\mu$ óvtıs, Ag. 1275), fez dela uma adivinha ( $\mu$ óvtıs, $A g, 1275)$, mas, ao privar-lhe do poder de persuasão, ela passa a ser considerada uma

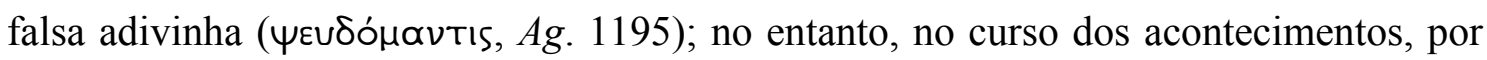
meio de seu veraz vaticínio (o’poouavteía, $A g$. 1215), ela se revelará uma adivinha

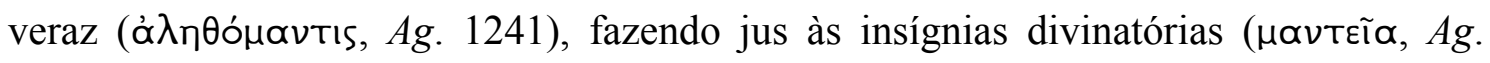
1265) que traz consigo ${ }^{43}$.

Todavia, diferentemente de Tirésias, de Anfiarau e de Calcas, Cassandra é uma adivinha que exerce um tipo de adivinhação que ficou conhecida como "inspirada", "extática", "intuitiva", isto é, em que a divindade se comunica diretamente com o adivinho, que se torna $\varepsilon^{\prime} v \theta \varepsilon O \varsigma^{44}$.

$\mathrm{Na}$ primeira cena do quarto episódio, Clitemnestra convida Cassandra para, entrando no palácio, participar das "lustrações" ( $\chi \varepsilon \rho v i ́ ß \omega \nu, A g .1037)$. A ironia de tal convite encontra-se no fato de que Cassandra não está sendo chamada a participar das lustrações como conviva, mas sim como vítima sacrificial. Cassandra, porém, ignorando o convite da rainha, permanece em silêncio, como em silêncio permanecera durante a cena de boas-vindas a Agamêmnon.

\footnotetext{
${ }^{43}$ Mason (1959, pp. 89-90) observa que, diferentemente de Ésquilo, Eurípides retrata Cassandra tanto como uma profetisa de Apolo quanto como uma mênade. Em Hécuba, no párodo, o Coro se refere a

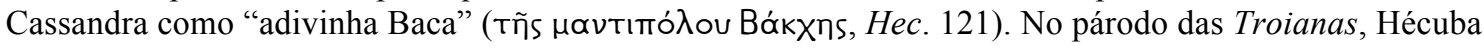
se refere à filha como uma mênade ( $\mu$ aıvó $\delta ', T r .172$ ) e, aos seus delírios, como um frenesi báquico

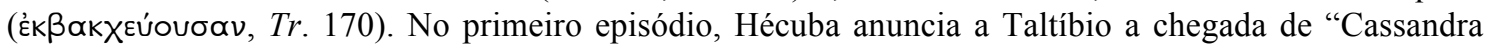

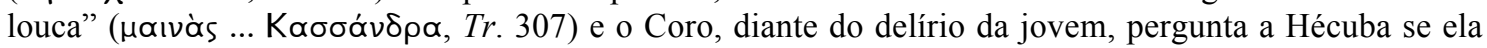

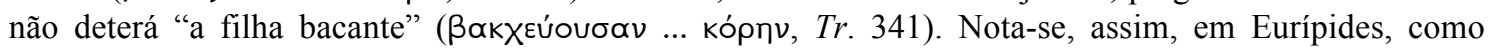
observa o autor, uma ênfase em "the new Dionysiac vocabulary of possession which is Euripides' substitution for the $\mu$ óvtis-terminology of Aeschylus".

${ }^{44}$ Conferir, entre outros, Bouché-Leclercq (2003), Halliday (2003), Dodds (1951), Flacelière (1965), Bloch (1991). Como observa Mazzoldi (2002, p. 145), “[...] it is true that Cassandra's figure falls consistently within the divination, historically attested, of the ecstatic and visionary type, and that some texts, which describe her or attribute her prophecies, become a precious reflection of an historical phenomenon - so prominent in the Mediterranean and Near East cultures".
} 
O Coro então se dirige à silente jovem: "Contigo ela acaba de dizer clara

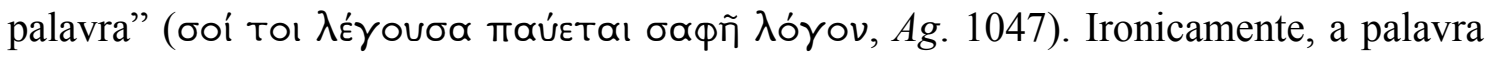
de Clitemnestra, sempre impregnada de sentidos ocultos, é, no entanto, de fato clara ( $\propto \propto \tilde{\eta})$ para Cassandra, que, dentre os interlocutores da rainha nesta tragédia, é a única que conhece realmente seus intentos e pode, por isso, perscrutar-lhes o sentido oculto, de modo que a profetisa sabe que está sendo chamada para a morte.

O Coro prossegue: "Presa dentro de fatídica armadilha / atenderias, se

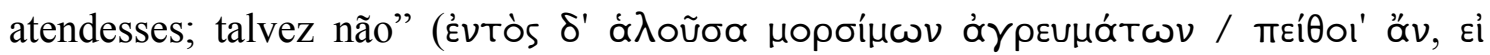

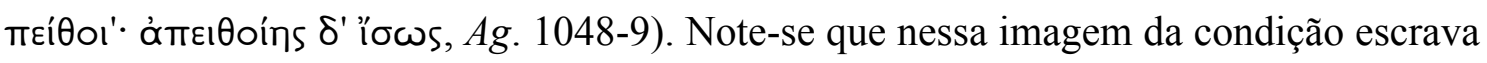

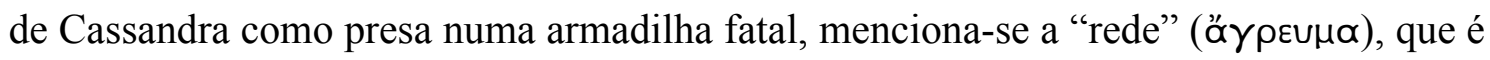
o instrumento utilizado por Clitemnestra para imobilizar Agamêmnon e matá-lo. O

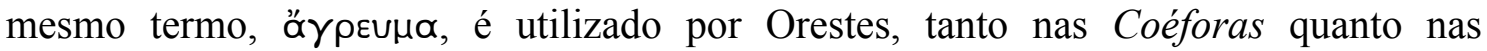
Eumênides, quando ele fala do ignóbil assassinato do pai: "malha de caçar fera"

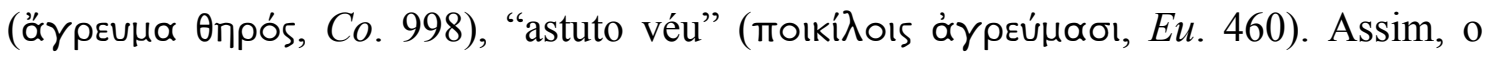
Coro, inadvertidamente, fala mais claro do que ele poderia imaginar: essa rede em que Cassandra, na condição de escrava, encontra-se presa, é também a rede que se mostrará verdadeiramente "fatídica" ( $\mu$ ópoııos) para Agamêmnon.

O persistente silêncio de Cassandra é entendido por Clitemnestra e pelo Coro como desconhecimento da língua grega, quando a rainha a compara a uma "andorinha /

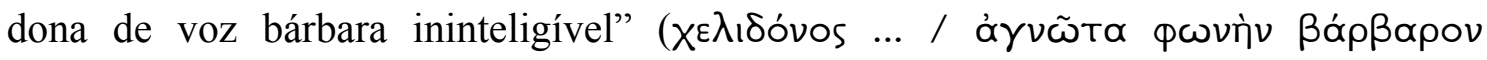

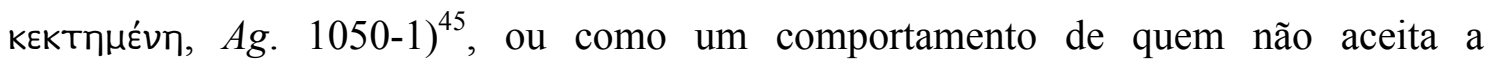
submissão, quando o Coro a compara a uma fera recém-capturada. O Coro expressa a

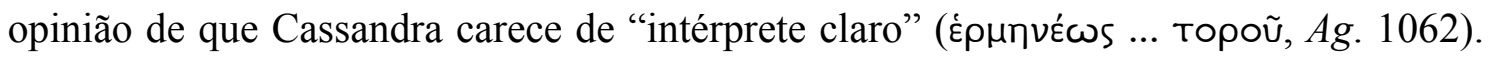
Sim, o silêncio da jovem é de fato enigmático e suas palavras se mostrarão tão enigmáticas para o Coro quanto as de Clitemnestra, para as quais o Coro também disse

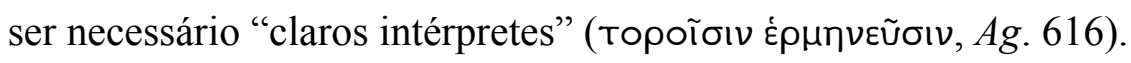

Clitemnestra, todavia, diz não ter tempo a perder, pois as ovelhas já estão prontas para o sacrifício, como nunca antes esperava obter essa "graça" ( $\chi \alpha ́$ ó 1058). A graça obtida é o retorno de Agamêmnon, mas esse retorno é uma graça apenas

\footnotetext{
${ }^{45}$ A língua bárbara costuma ser poeticamente associada ao canto dos pássaros. Aristófanes, nas Rãs (v. 679-82), diz de um certo estrangeiro que uma andorinha trácia estava empoleirada em seus lábios. Também Heródoto, sobre a chegada de uma mulher bárbara em Dodona, diz que "em minha opinião essa mulher foi chamada de 'pomba' pelos dodônios por ser bárbara, e os dodônios pensavam que a língua por

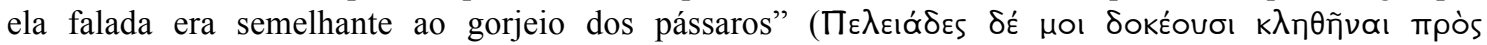

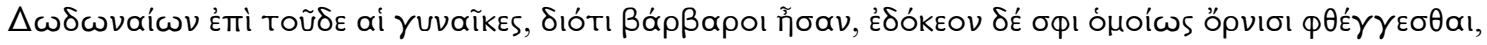
II, 57).
} 
no sentido de que representa a oportunidade de matá-lo e de se obter assim a tão acalentada vingança. O sacrifício a que ela se refere, no entanto, tem conotações mais sinistras: assim como Agamêmnon sacrificou Ifigênia no lugar de uma cabra, como costumeiro, também Clitemnestra sacrificará Agamêmnon e Cassandra, no lugar de ovelhas. Assim, sem mais delongas, a rainha se retira de cena em direção ao palácio e à realização de sua vingança.

A sós com o Coro, que se mostra piedoso ante a situação da jovem cativa - o

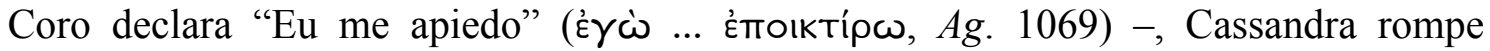
bruscamente o silêncio, invocando repetidamente e plangentemente o deus Apolo $^{46}$ :

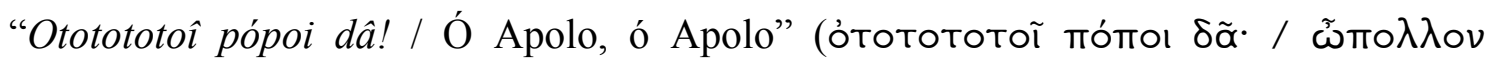

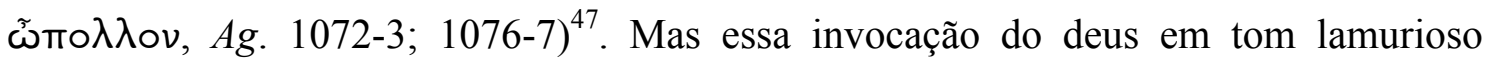
surpreende o Coro, pois, tal como ele afirma, trata-se de um deus "a quem não convém

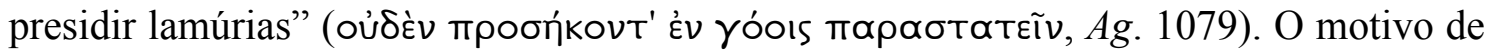
tal lamúria se revela quando, invocando-o novamente, Cassandra faz um jogo de palavras etimológico com o nome do deus:

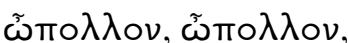

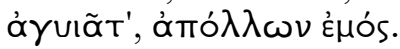

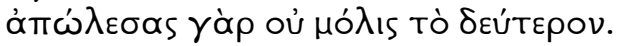

Ó Apolo, ó Apolo

viário, abolitivo meu, aboliste-me sem esforço outra vez.

(Ag. 1080-2)

Nesse trocadilho, em que se associa o nome do deus (Aтó $\lambda \lambda \omega \nu$ ) ao verbo “abolir", "destruir" (ámó $\lambda \lambda \cup \mu \mathrm{i})^{48}$, explicita-se o aspecto destrutivo da relação de Cassandra com Apolo e prenuncia-se, veladamente, a morte que ela em breve

\footnotetext{
${ }^{46}$ De acordo com Mazzoldi (2002, p. 146), esse seria o primeiro momento do processo divinatório de Cassandra: "The first stage, preceded by silence and immobility, is characterized by the phenomenon of glossolalia, which in fact appears usually in the ecstatic states; its function is to put the person in communication with the divinity and to give expression to his non-mediate presence. In Cassandra's divining process this stage constitutes the initial part of the clairvoyance, that is the contact with divinity, and it introduces the mantic visions. The cries, only apparently incoherent, seem to mark out the beginning of her clairvoyance; they develop into invocations to Apollo of ritual type and then into rhetorical questions characterized by monological modulation".

${ }^{47}$ Heirman (1975, pp. 250-261), a respeito da glossolália de Cassandra, observa o seguinte: "In general оттотототої seems to introduce a lamentation over death and destruction, out of fear and sorrow. When, however, in Aeschylus' Agamemnon Kassandra utters these shouts, they do not arise as unintentional surges of horror or gushes of fear and dismay, i.e. as mere interjections. [...] Kassandra utters these syllables [...] not as a pathetic expression of an emotional breakdown foreboding her violent death, but as a device which serves to change the quality and level of her own consciousness into clairvoyance".

${ }^{48}$ No Crátilo (404e), de Platão, alude-se a essa etimologia popular que associa o nome de Apolo com o

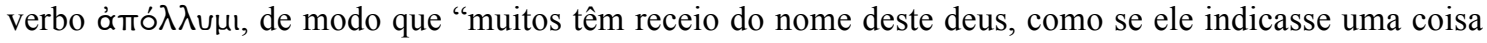

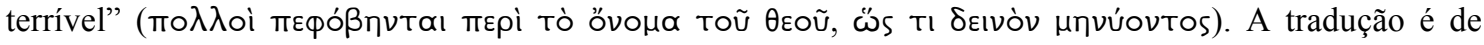
Maria José Figueiredo (2001).
} 
encontrará às mãos de Clitemnestra e Egisto. Essa destruição ela diz sofrer "outra vez"

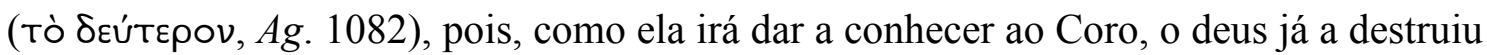
quando, tendo lhe concedido o dom divinatório, privou-a da capacidade de persuasão (Ag. 1012).

O Coro então diz: "Parece vaticinar seus próprios males: / o divino perdura no

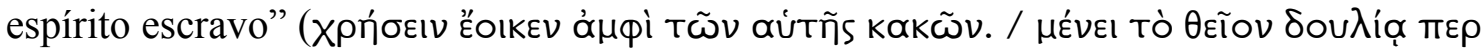
દ̇v

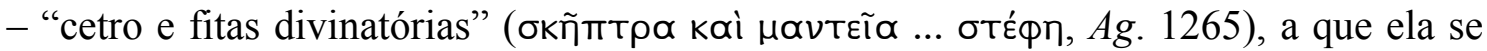
refere ao final do episódio -, de modo que o Coro reconhece nela uma adivinha. $\mathrm{O}$ fato

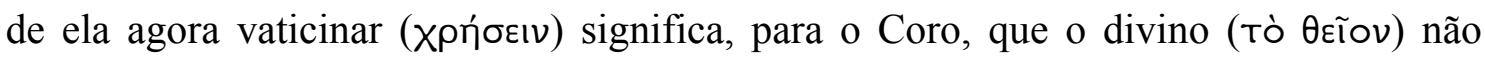
abandonou seu espírito ('่v $\phi \rho \varepsilon v i ́)$, mesmo que nas atuais circunstâncias ela se encontre submetida à condição de escrava, tendo perdido a sua liberdade e suas prerrogativas principescas. Porém, o que o Coro em breve irá descobrir é que ela não vaticina apenas

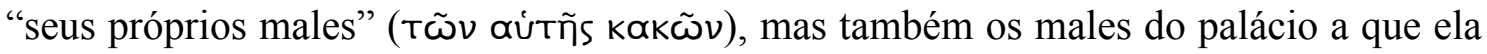
foi levada.

Cassandra então, interpelando novamente Apolo, pergunta-lhe: " $\hat{a}$ ! Onde me

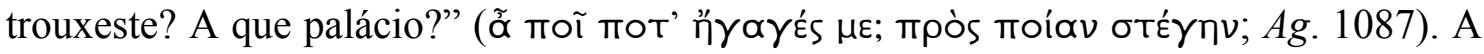
jovem profetisa não está perguntando pelo lugar físico a que ela chegou, mas sim pelo sentido de sua vida: que sentido tem a sua vida para que Apolo a levasse até ali? Somente Apolo poderia lhe esclarecer esse sentido, uma vez que ela é sua sacerdotisa e, assim, sua vida é presidida pelo deus, de modo que, se ela chegou até esse lugar, foi por desígnio de Apolo. O Coro, no entanto, responde que ela chegou ao palácio dos Atridas

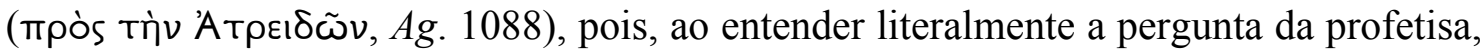
ele responde sob a perspectiva de quem vê o que está sob o olhar de todos: trata-se evidentemente do palácio dos Atridas. Evidencia-se, assim, o contraste entre o ponto de vista de Cassandra, que é um ponto de vista divino, e o ponto de vista do Coro, que é um ponto de vista humano. E esse contraste, aqui explicitado pela primeira vez, é uma característica marcante do longo diálogo que se dá entre esses dois personagens.

Cassandra aceita e confirma a resposta dada pelo Coro: sim, trata-se do palácio dos Atridas, mas o que ela vê, a partir de seu ponto de vista divino, não é apenas o aspecto físico do palácio e sim o seu aspecto numinoso: 


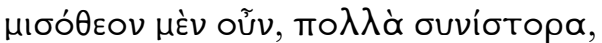

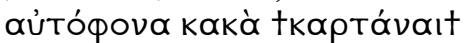

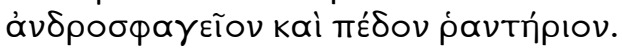

Sim, odeia Deus e conhece muitos malignos massacres dos seus, com homicídios e umedecido chão.

Nessa referência a crimes consanguíneos - os "massacres dos seus" (aủtóqova ... карта́vaı), sob cuja forma se manifesta um desrespeito ao divino, e por isso diz-se do palácio que "odeia Deus" ( $\mu$ $\sigma o ́ \theta \varepsilon \circ v)$-, Cassandra mostra-se ciente dos homicídios

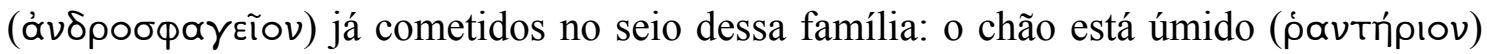
de sangue. Esse conhecimento profético não limitado temporalmente é explicitamente atribuído a Calcas em Homero, do qual se diz conhecer o presente, o passado e o futuro (Il. I, 60-70). No entanto, como observa Schein (1982, p. 11), diferentemente de Calcas, que conhece o presente, o passado e o futuro por intermédio do voo dos pássaros, Cassandra vê sem mediação o presente, o passado e o futuro. Essa menção ao chão do palácio umedecido de sangue descreve uma visão numinosa, em que crimes consanguíneos pretéritos se presentificam ante os olhos da profetisa ${ }^{49}$.

O Coro então compara Cassandra a um cão sagaz que fareja morticínios e que acabará por encontrá-los. De fato, a visão da profetisa de antigos crimes consanguíneos, antes geral - apenas o sangue derramado no chão -, agora se focaliza:

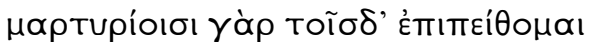

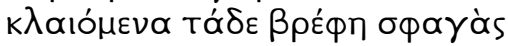

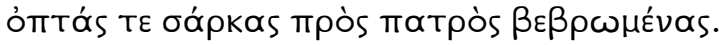

Por estas testemunhas acredito que estas crianças prateiam a morte e carnes cozidas devoradas pelo pai.

(Ag. 1095-7)

Assim, Cassandra vê o crime de Atreu, que, assassinando os filhos do irmão Tiestes, serviu suas carnes ao próprio pai em um banquete funesto. Ela vê as crianças pranteando - note-se o uso do particípio presente: $k \lambda \propto$ ๔ó $\mu \varepsilon v \alpha-$ a própria morte e como essa morte se deu: as suas carnes cozidas e devoradas pelo pai. O uso dos dêiticos

\footnotetext{
${ }^{49}$ Esse seria, de acordo com Mazzoldi (2002, pp. 146-7), um segundo estágio do processo divinatório de Cassandra: "The second stage consists of the visionary-access, which allows the knowledge of the past and of the future. In this stage the clairvoyant perceives the past and future reality through her whole person and her senses (sight, hearing, smelling, taste, touch) and she conveys it without mediation and interpretation, that is without using rationality. The conveyance of the visions is simultaneous with the perception; so the visions themselves seem present and actual, and there is no separation between the different temporal levels. [...] Since the difference between the divine language and the human language is by no means minimized, the oracular message appears obscure and ambiguous in the highest degree and so any interlocution with the chorus is impossible: in fact the verbal modulation of Cassandra appears substantially monological".
} 


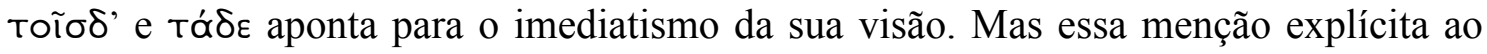
crime de Atreu faz o Coro recuar, dizendo: "De tua glória como adivinha estamos /

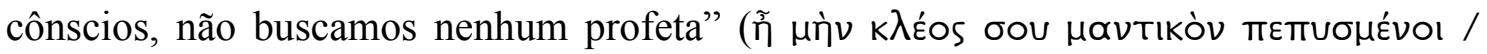

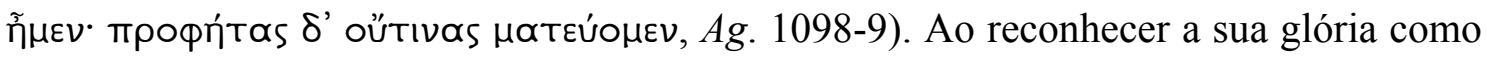
adivinha, o Coro parece reconhecer a veracidade da visão numinosa de Cassandra, mas o Coro não quer tomar conhecimento das profecias de Cassandra - tal como afirma: "não buscamos nenhum profeta" (Ag. 1099) -, assim como não quer escutar o canto vaticinante de seu coração, ou como prefere se calar quando suas reflexões o levam à conclusão de que a justiça divina tem contas a acertar com seu rei.

De uma visão do passado, Cassandra passa para uma visão do futuro:

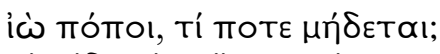

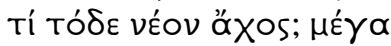

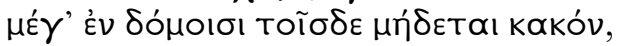

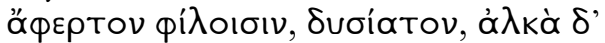

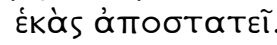

Iò pópoi! O que se trama?

Que nova dor é esta? Grande, grande mal se trama neste palácio insuportável para os seus, incurável, a defesa ausente está longe.

Nesse primeiro momento, ela pressente um novo mal - enfaticamente dito "grande" ( $\mu \varepsilon ́ \gamma \propto, A g .1101 ; \mu \varepsilon ́ \gamma ', A g .1102)$-, um mal que é tanto insuportável quanto

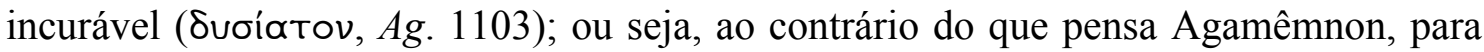

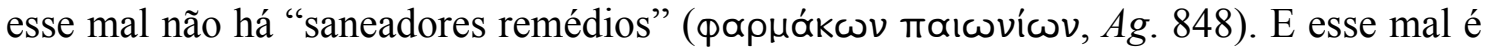
tanto mais inevitável pelo fato de a "defesa" ('่̊ $\left.\lambda_{\kappa} \alpha \dot{\alpha}, A g .1104\right)$ encontrar-se ausente (ámoотатвĩ, Ag. 1104). Há assim uma referência a Orestes. Note-se que, em seu discurso de boas-vindas, Clitemnestra, justificando a seu recém-chegado marido a

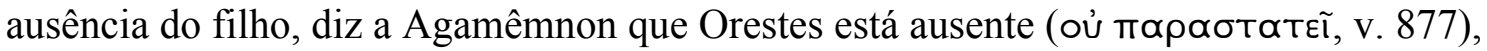
sendo criado em terra estrangeira por Estrófio da Fócida.

A referência ao crime de Atreu o Coro reconhece como verdadeira, mas declara ignorar qual seja esse grande novo mal que se prenuncia mediante as palavras da profetisa; ele, ao contrário dela, desconhece a instância do futuro. Esse novo mal pressentido por Cassandra começa a se delinear e tomar a forma de uma visão:

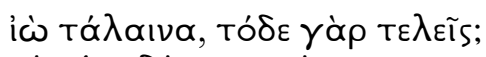

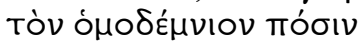

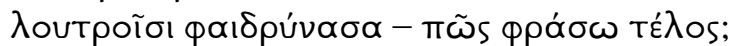

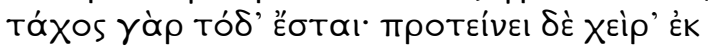

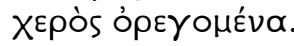

Iò! Mísera, isto farás?

Ao lavares no banho

o teu marido - como direi o fato?

Logo isto será: ela estende mão após mão alcançando. 


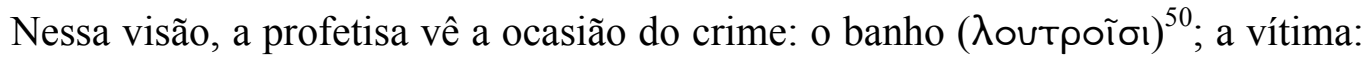

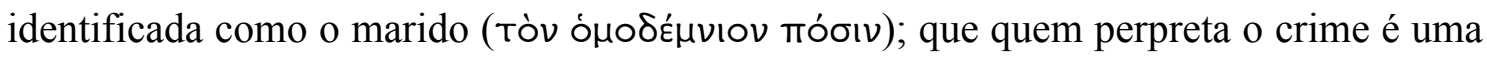

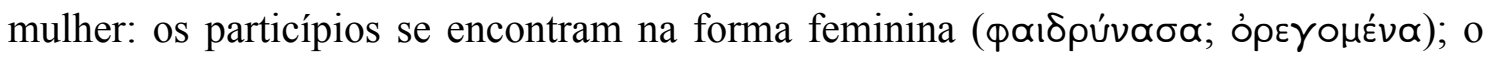

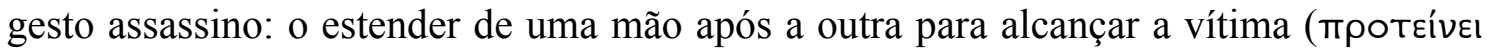

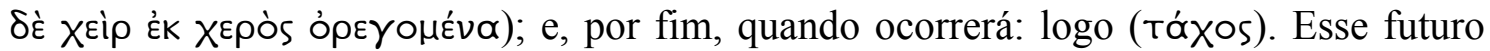
próximo, no entanto, na visão numinosa de Cassandra, faz-se presente a seus olhos,

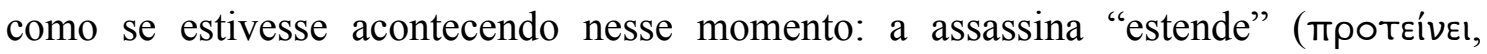

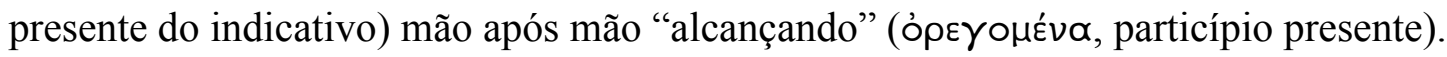

O ponto de vista numinoso expresso por Cassandra é, porém, incompreensível

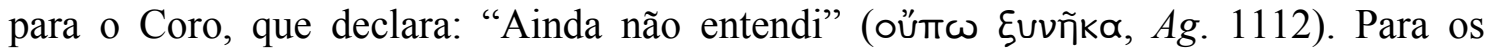
anciãos, limitados por seu ponto de vista, o prenúncio de que um grande mal se trama

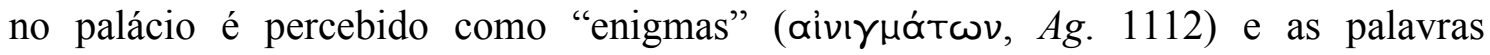
visionárias de Cassandra sobre o assassinato de Agamêmnon no banho, como "oráculos

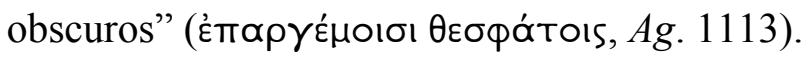

Cassandra, ignorando as palavras do Coro, prossegue:

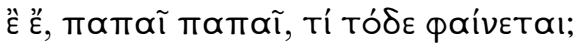

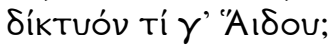

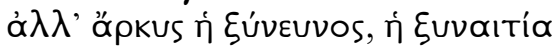

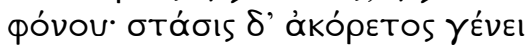

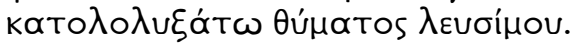

È è papaî papaî! O que se vê aqui?

É um laço de Hades?

Mas é a rede é o seu cônjuge, a co-autora do massacre. Sedição sôfrega da família alarideia pelo apedrejável sacrifício.

Nessa nova irrupção de uma visão numinosa, a profetisa vê uma rede (ơpkus),

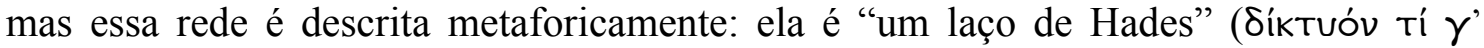

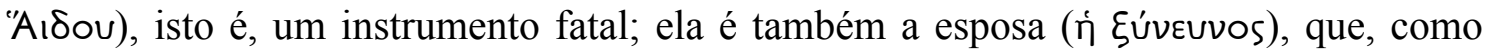

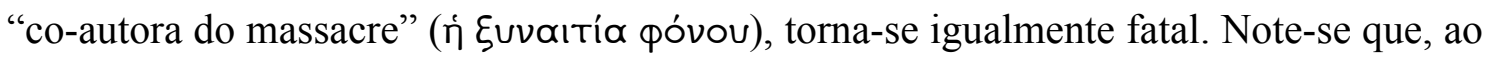
se descrever Clitemnestra como co-autora, faz-se uma velada alusão a participação de outra pessoa nesse assassinato, ou seja, Egisto. O crime, descrito como sacrifício

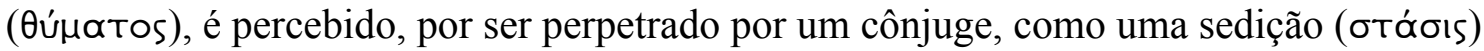

\footnotetext{
${ }^{50}$ Para uma associação entre o momento do banho aqui descrito e o banho como parte do ritual fúnebre, conferir o artigo de Seaford (1984), "The Last Bath of Agamemnon". Para uma relação com outros assassinatos igualmente perpetrados durante o banho, conferir "Agamemnon's Death in the Bath: Some Parallels", uma breve nota de Bremmer (1986), e "Murder in the Bath: Reflections on the Death of Agamemnon", artigo de Duke (1954).
} 


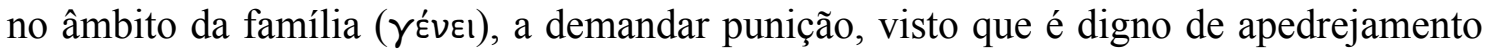
( $\lambda \varepsilon v \sigma i ́ \mu o v)$.

Ante o imperativo de Cassandra ${ }^{51}$, "Alarideia pelo apedrajável sacrifício", o Coro pergunta à jovem: “Que Erínis mandas tu estrondar / no palácio?” (moíav 'Epıvùv

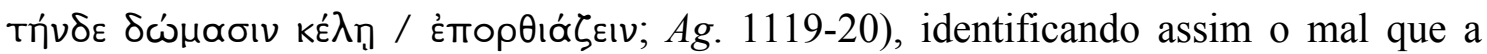
profetisa prenuncia com uma Erínis. Isso não alegra: "Não me alegra a palavra" (ou้ $\mu \varepsilon$

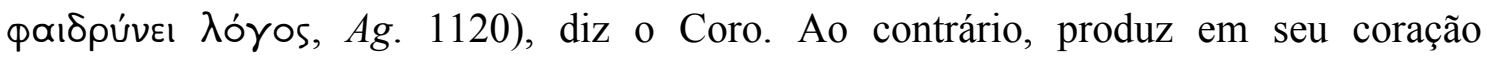

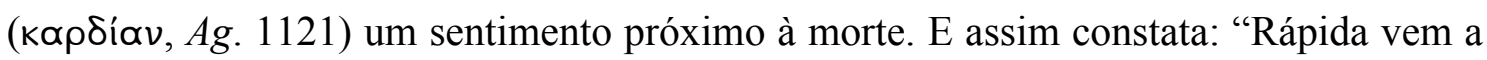

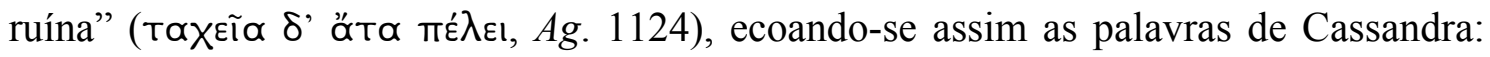

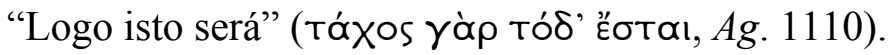

Cassandra prossegue descrevendo mais uma visão:

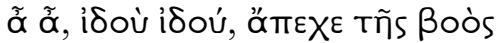

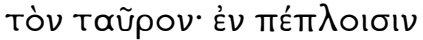

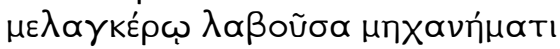

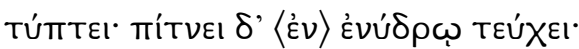

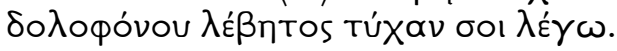

$\hat{A} \hat{a}$ ! Olha, olha! Põe longe da vaca o touro. Na túnica com negricórnio ardil ela captura e fere e ele tomba na banheira cheia d'água. Narro-te o caso de dolosa homicida bacia.

(Ag. 1125-9)

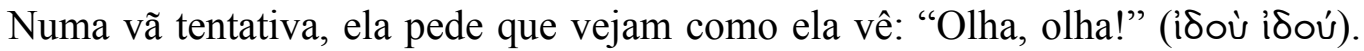
Ela vê a assassina próxima de sua vítima e por isso pede que se ponha o touro longe da vaca. A imagem do touro e da vaca e a do ardil como negricórnio fazem parte da linguagem profética de Cassandra, enigmática por natureza ${ }^{52}$. A profetisa então vê a consumação do assassinato de Agamêmnon e o descreve em uma linguagem clara. A

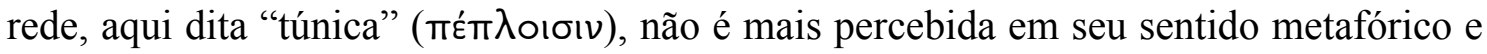
sim literal, pois com ela se captura a vítima, que, ferida, cai na banheira cheia d'água. Novamente, ela descreve o crime como se ele estivesse acontecendo na sua frente:

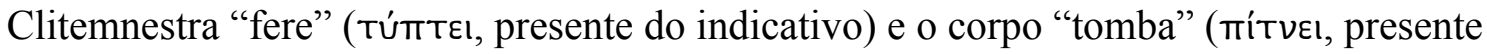
do indicativo) na banheira. Dessa forma, em visões que se sucedem e se clarificam, Cassandra passa do prenúncio de uma grande mal que se trama no palácio para a afirmação de que acontecerá um homicídio entre cônjuges que será perpetrado durante o banho: "Narro-te o caso de dolosa homicida bacia".

\footnotetext{
51 Mason (1959, p. 84) chama a atenção para o fato de que é somente a partir deste momento que Cassandra mostra-se consciente da presença do Coro.

52 Como observa Mazzoldi (2002, p. 148), "the use of metaphors and similes in her communication, typical of oracular language represents the claivoyant's attempt to approach the meaning of visions step by step and through the association of ideas".
} 
A atitude do Coro ante as palavras de Cassandra permanece a mesma: a sua fala

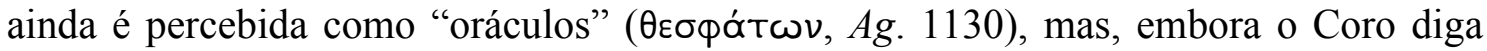

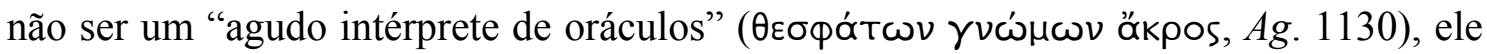

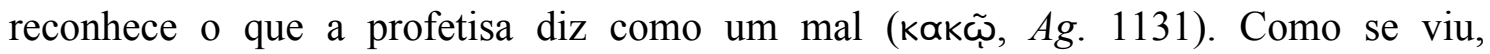
entretanto, o Coro não busca por profeta; dessa maneira, como uma forma de negar o mal que as profecias de Cassandra tornam cada vez mais fatídico, o Coro desdenha da arte divinatória:

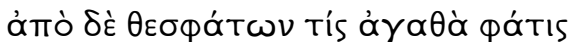

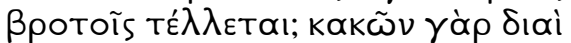

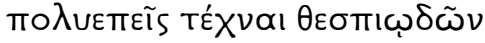

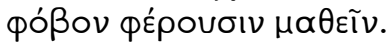

De oráculos, que bom anúncio vem aos mortais? Por meio de males as multíloquas artes dos vaticinadores trazem a compreensão do pavor.

(Ag. 1132-5)

Mas essas afirmações fazem parte da sua recusa em conhecer o futuro, por temêlo; pois, ao fim do párodo lírico, após rememorar o auspício das aves, ele conclui que

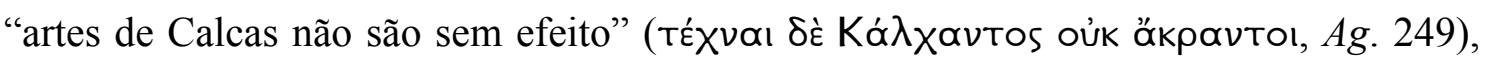
ou seja, confirma a arte divinatória como algo válido e efetivo. Além disso, deve-se considerar que o Coro encontra-se numa situação extremamente desconfortável. Mesmo tendo silenciado a voz de seu coração pressago e de suas reflexões, encontra-se diante de uma profetisa e essa profetisa não apenas ignora o desejo do Coro de manter o futuro velado como também tem a urgência de se fazer acreditar, uma vez que sua própria vida está implicada nesse futuro que ela insiste em desvelar:

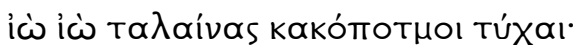
тò үà

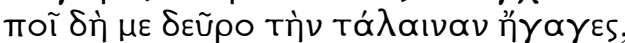

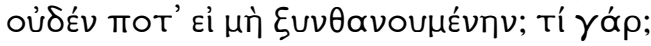

Iò iò! Malfadada sorte da mísera!

Clamo minha própria dor a transbordar. Por que aqui me conduziste a mim, infeliz, para nada senão para morrer junto? Por quê?

(Ag. 1136-9)

Cassandra lamenta sua própria sorte e interpela Apolo, perguntando-lhe novamente pelo sentido da sua vida, e, ao fazê-lo, prenuncia a sua própria morte. Notese que, nesse prenúncio de sua própria morte, a morte de Agamêmnon está implicada:

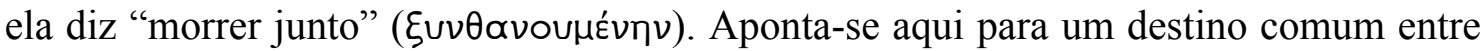
ela, a escrava troiana, e Agamêmnon, seu argivo senhor. Do mesmo modo, quando Cassandra prenuncia o retorno de Orestes, diz que ele será o vingador que há de vir por

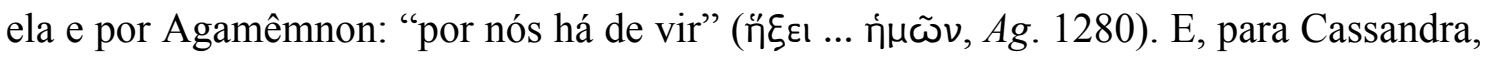


a futura morte de Clitemnestra será um pagamento pela sua morte e, a de Egisto, pela morte de Agamêmnon ( $\mathrm{Ag}$. 1318-9).

Note-se que, no início do episódio, o Coro diz que Cassandra, em cujo espírito

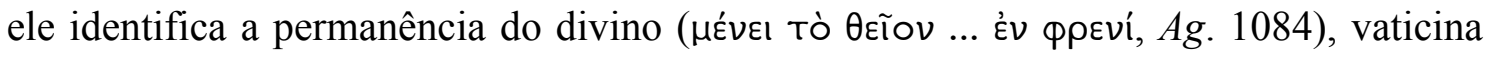

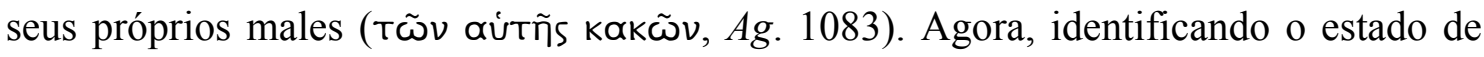

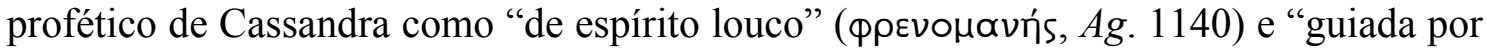

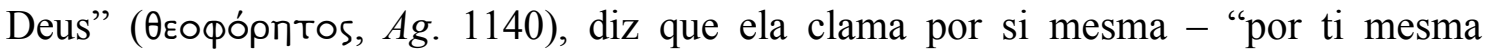

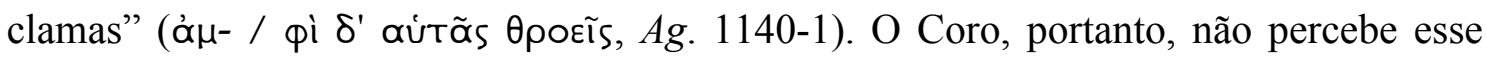
destino comum entre a jovem e seu senhor, que se expressa, mediante o delírio profético de Cassandra, no prenúncio da morte de ambos pelos mesmos assassinos ${ }^{53}$.

O Coro compara o canto lamentoso da profetisa ao canto triste do rouxinol, evocando-se assim a história de Procne, Tereu e Filomela, mas, para Cassandra, os seus males são muito maiores, porque, enquanto os deuses deram ao rouxinol asas e um

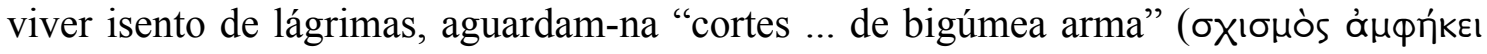
Sopí, Ag. 1149). Nesse novo prenúncio de sua morte, Cassandra explicita como esta se dará: por cortes provocados pelos golpes de bigúmea arma.

A reação do Coro ante essa afirmação é perguntar pela origem, pela causa

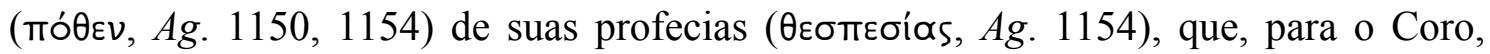

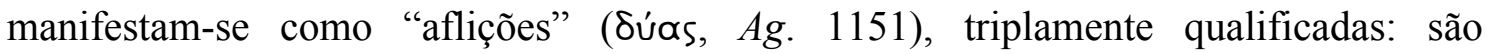

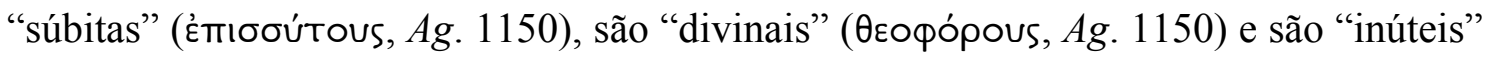
(uataíous, Ag. 1151). Observe-se a assertividade nessa descrição do Coro dos delírios proféticos de Cassandra. Como a própria profetisa observa, seus vaticínios são

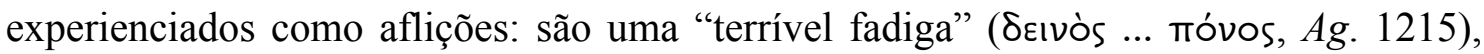

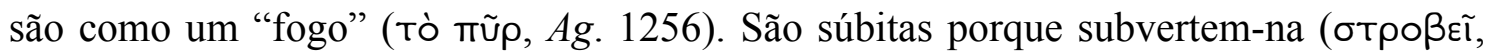

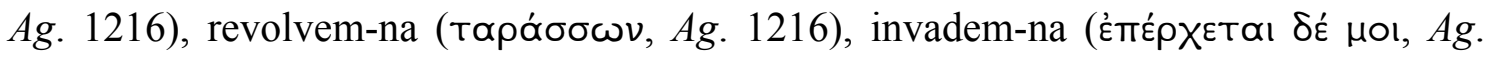
1256). São divinais, porque têm sua origem em Apolo ( $A g$. 1202), por quem ela

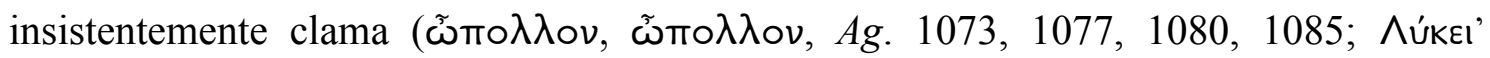

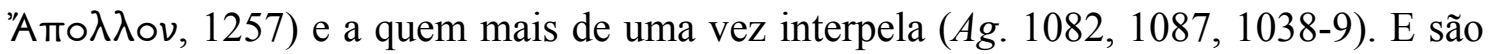

\footnotetext{
53 Fraenkel (1982, p. 539, vol. III) observa que, após ter prenunciado o momento da morte de Agamêmnon ( $\mathrm{Ag}$. 1128), "from now onwards to the end of the lyrical part the lamentations of the prophetess are solely concerned with herself and her kin". Deve-se, no entanto, levar em consideração que, como se viu, o destino de Cassandra e Agamêmnon encontra-se intimamente relacionado e que os lamentos da profetisa sobre as núpcias funestas de Páris e sobre a destruição de Troia implicam igualmente a atuação do rei, visto que foi ele quem, para punir Páris, destruiu Troia.
} 
inúteis, porque, privada do poder de persuasão por Apolo ( $A g .1212)$, ninguém nunca acreditou nelas ( $\mathrm{Ag}$. 1269-74).

Cassandra, porém, não responde às perguntas do Coro e segue prenunciando sua própria morte - "à beira do Cocito e das ribas / do Aqueronte creio logo vaticinarei"

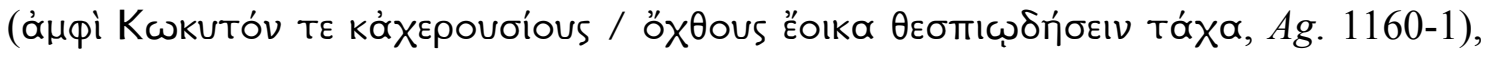

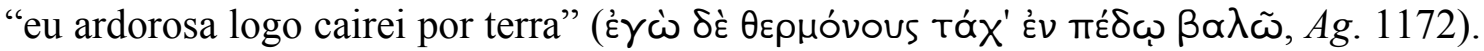
O prenúncio de sua morte, no entanto, vem acompanhado do lamento pela sua sorte, pela destruição de seu país, ao qual ela nunca há de retornar, pelas núpcias funestas de Páris ${ }^{54}$. Esse lamento o Coro pode compreender claramente - ele diz: "Que palavra tão

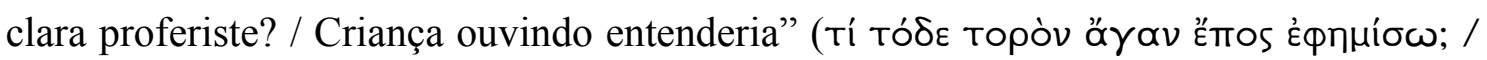

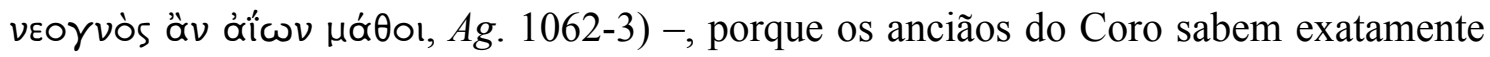
quão funestas foram as consequências das núpcias de Páris (como deixam claro no segundo estásimo), eles sabem quão completa e excessiva foi a destruição de Troia (como ouviram do Arauto no segundo episódio), e, dessa forma, podem apiedar-se da dolorosa sorte de Cassandra (Ag. 1164-6). No entanto, das "deploráveis dores mortais"

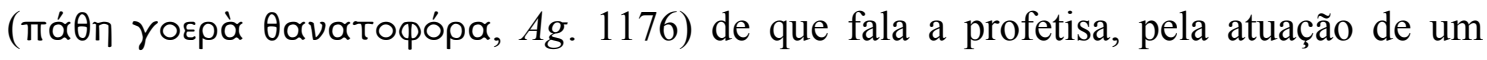

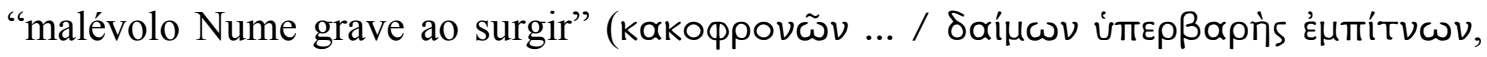

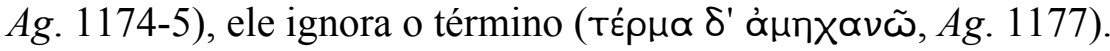

Cassandra então abandona seu canto lírico e dá início a uma rhésis. Essa mudança no ritmo de sua fala corresponde a uma mudança no estilo de seu discurso profético, uma mudança para a qual ela mesma chama a atenção ao dizer: "O oráculo

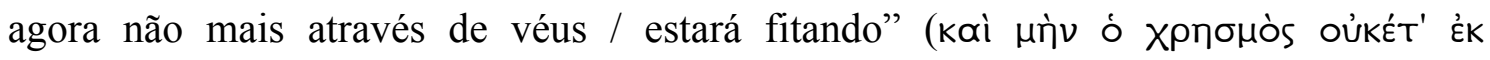

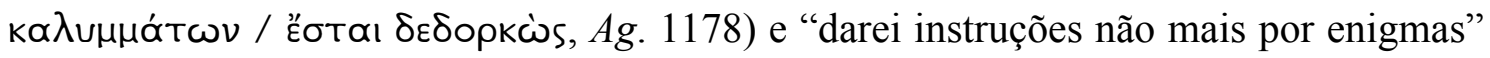
( ao falar novamente de crimes outrora perpetrados no palácio:

\footnotetext{
${ }^{54}$ Em Eurípides, as profecias de Cassandra remontam ao nascimento de Páris. Assim, em Andrômaca, o Coro conta como a profetisa vaticinou os males que o recém-nascido príncipe causaria a seu país: "Lançasse-o por cima da cabeça / a que o gerou com má sorte, / antes que habitasse o monte Ida, / quando perto de loureiro vaticinante / Cassandra clamou que o matassem / por grande dano à urbe de Príamo! / A

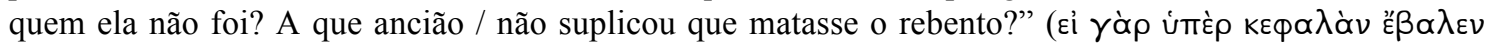

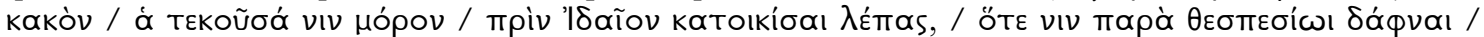

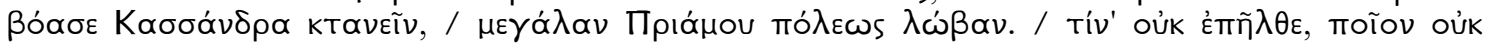

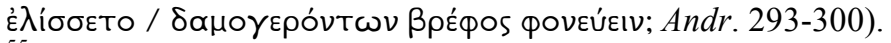

${ }^{55}$ Para Mazzoldi (2002, p. 148), esse seria o momento da real profecia: "Cassandra turns ail her attention to the communication and intervenes by rationality to render the message as understandable as possible. The exposition of prophecies in a clear style is the result of programmatic choices and statements and corresponds to the return of a normal use of verbal tenses and to a complete autonomy of interpretation and judgement. The predicted events are connected by strong temporal and causal consequence. The dialogue with the chorus becomes closer and closer".
} 


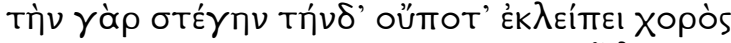

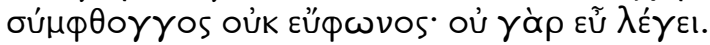

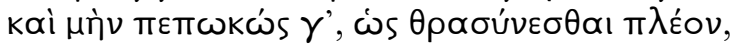

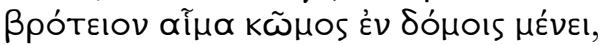

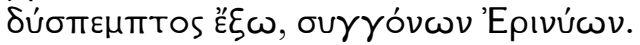

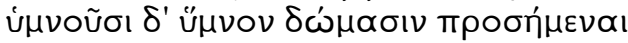

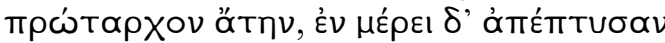

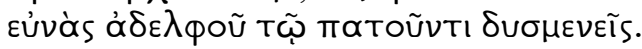

Um coro nunca abandona esta morada consoado, não suave, pois suave não fala. Para maior ousadia, bêbado de sangue humano, o bando perdura no palácio, cortejo difícil de sair, congêneres Erínies. Assíduas na moradia, hineiam num hino o primeiro error, e uma após outra abominam o leito do irmão, hostis a quem o pisou.

(Ag. 1186-93)

Cassandra identifica o nume que habita o palácio com um coro de Erínies. Esse coro de Erínies, bêbado de sangue, em vez de vinho, permanece no palácio, em vez de ir bebendo de casa em casa, sendo portanto um cortejo difícil de sair. As Erínies são ditas

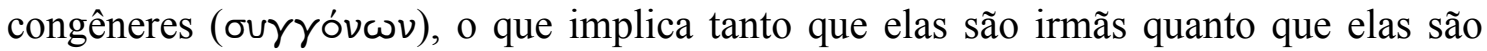
congênitas ao palácio ${ }^{56}$. Esse coro canta - em uníssono, mas de fala áspera - o primeiro

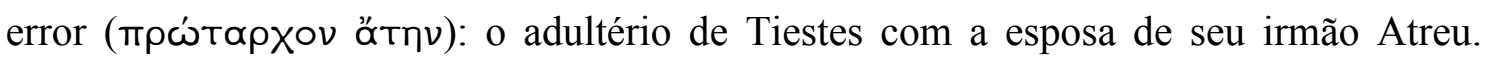
Assim, a profetisa, cônscia da veracidade de suas palavras, pede que o Coro seja testemunha de que ela tem conhecimento desse antigo crime ocorrido no palácio:

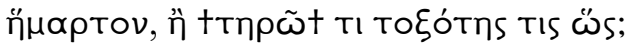

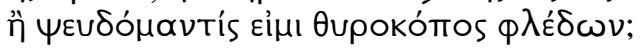

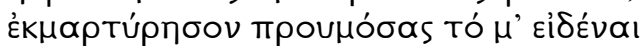

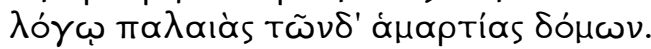

Falhei ou atinjo algo qual um arqueiro? Ou sou falsa adivinha mendiga faladeira? Sê testemunha jurada de que conheço os prístinos desacertos deste palácio.

(Ag. 1194-7)

O Coro responde afirmativamente dizendo admirar-se com o conhecimento de que ela, recém-chegada estrangeira, tem do país. Trata-se de fatos cujo conhecimento,

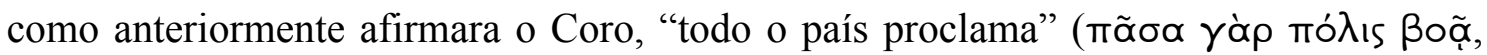
Ag. 1106). Ante a admiração do Coro com o conhecimento de Cassandra dos antigos desacertos (ஷ̊丿 $\mu \rho$ prías) do palácio, a profetisa fala a respeito da origem de seu dom

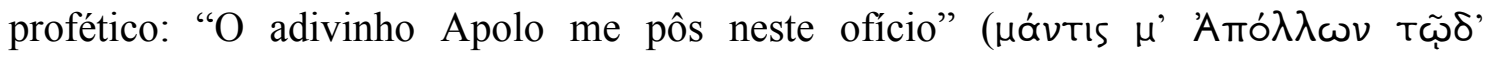

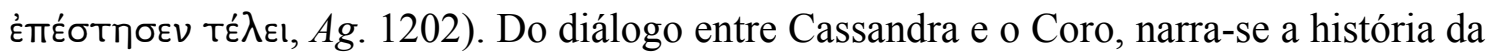
relação da profetisa com o deus: Apolo, atingido pelo desejo, requisitou favores amorosos de Cassandra, aos quais a jovem deu consentimento, mas, uma vez agraciada com o dom divinatório que lhe fora presenteado pelo deus, recusou-se a unir-se a ele:

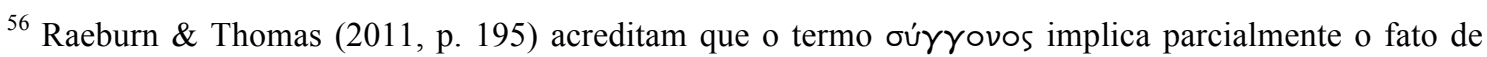
elas serem irmãs, mas principalmente o fato de elas serem responsáveis por vingar crimes consanguíneos.
} 


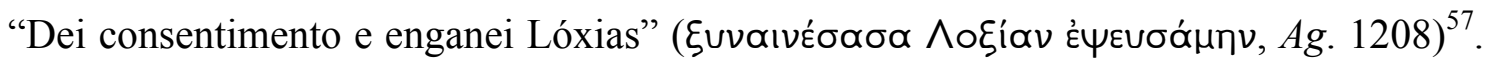
Assim enganado e tomado pelo rancor, Apolo puniu a jovem privando-a do poder de persuasão, de modo que, a partir de então, ninguém acreditasse em suas profecias.

Após o Coro lhe conceder um voto de fé, Cassandra volta a ser tomada pelo delírio profético. Nesse novo delírio, a primeira imagem que a profetisa vê é a do crime de Atreu:

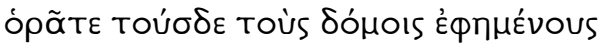

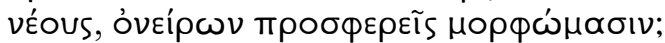

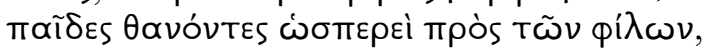

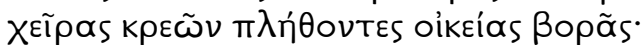

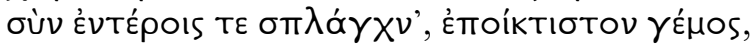

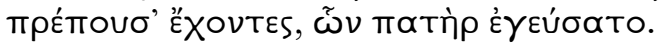

\begin{abstract}
Vede sentados perto do palácio estes jovens similares a figuras de sonhos: crianças como se morta pelos seus, as mãos cheias de carnes, pasto próprio, com intestinos e víceras, mísero peso, parecem ostentar o que o pai desgustou.
\end{abstract}

(Ag. 1217-22)

O crime de Atreu é uma vingança pelo adultério de Tiestes. O que Cassandra vê é o resultado dessa vingança: um crime hediondo, como hediondas são as imagens descritas por Cassandra. As crianças estão perto do palácio, figuras mudas, fantasmagóricas, segurando em suas mãos as próprias vísceras, como se, com esse gesto eternalizado, demandassem, por sua vez, vingança. E é justamente dessa vingança de que fala a seguir Cassandra, indo do passado para o futuro:

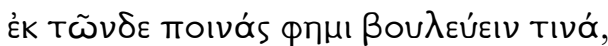

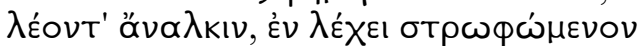

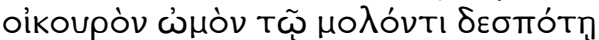

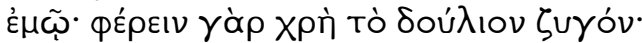

Digo que trama punição por isto um leão covarde a rolar no leito, caseiro, contra o recém-vindo senhor meu, pois devo suportar o jugo servil.

(Ag. 1223-6)

Esse leão a que a profetisa se refere é Egisto. Covarde, ele rola no leito, imagem que evoca a relação adúltera entre Egisto e Clitemnestra, e permanece em casa, enquanto os demais vão à guerra, tramando punição pela morte de seus irmãos. Essa imagem de Egisto como um leão "caseiro" (oikoupós) evoca ainda o sentido ominoso da parábola do leãozinho: trazido para dentro de casa e ali permanecendo, Egisto, tal qual o filhote de leão, revela-se, com o tempo, uma verdadeira fonte de males.

\footnotetext{
${ }^{57}$ A esse respeito, Debnar (2010, p. 133) faz a seguinte observação: "Exactly how she deceived him, Cassandra never explicitly reveals. The usual (and most plausible) interpretation of this exchange is that she lied: she agreed to have sexual intercourse with him and then broke her word. That is to say, she never had sex with Apollo, at least in any usual, human sense of the act". Note-se que a pergunta do Coro a respeito da natureza da relação entre Cassandra e Apolo é bastante específica: "Foram ambos juntos ao

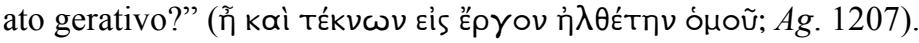


Se, para descrever Egisto, a imagem de um leão covarde parece adequada, para descrever Clitemnestra e seus ímpios intentos, Cassandra encontra dificuldade: trata-se de um monstro tão odioso que se faz difícil nomeá-lo com justeza, pois tem a ousadia de, sendo mulher, matar um homem $(A g$. 1231). Esse inominável monstro, para cobrir

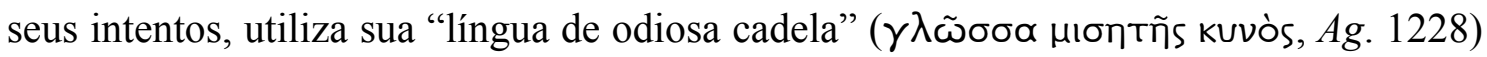
e, assim ludibriando sua vítima, parecendo alegre com o retorno do marido, "logrará

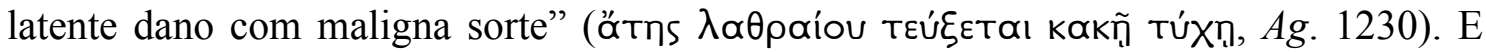
Cassandra finaliza:

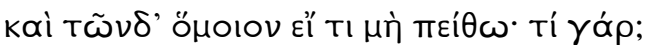

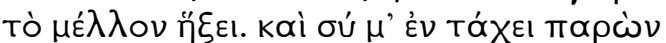

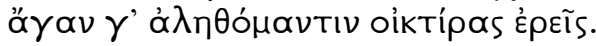

Dá no mesmo, se disto não vos persuado. O futuro virá. E tu presente logo me dirás por lástima adivinha por demais veraz.

(Ag. 1239-41)

O Coro reconhece como verídicas e é capaz de compreender as palavras da adivinha que dizem respeito ao crime de Atreu, ou seja, ao passado, mas não consegue compreender as que dizem respeito ao assassinato de Agamêmnon, isto é, ao porvir -

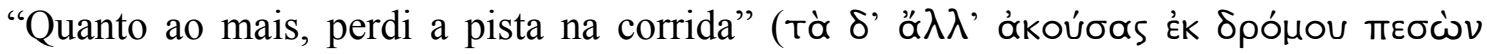

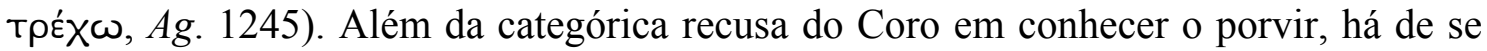
considerar ainda que o que define a arte divinatória exercida por Cassandra é a falta do poder de persuasão: essa é a punição de Apolo pela falta cometida pela profetisa. Como

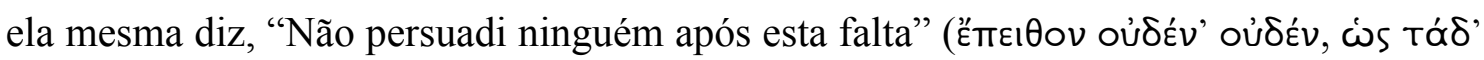

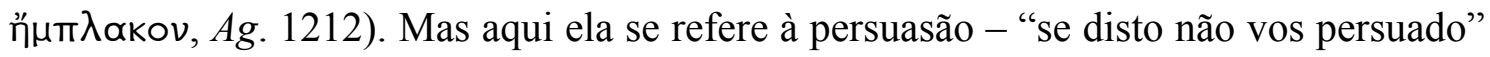

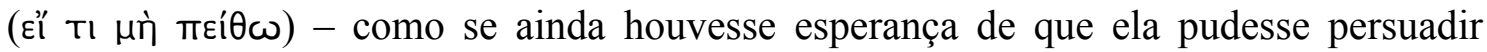

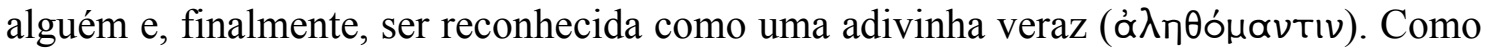
observa Mason (1959, p. 85): "all she says is meant to convince the chorus that this time, as always, she has spoken truly, as if the one thing she must do before her death is to break through the barrier of disbelief which has always been her fate".

Diante dessa necessidade de persuadir o Coro, Cassandra afirma: "Digo que

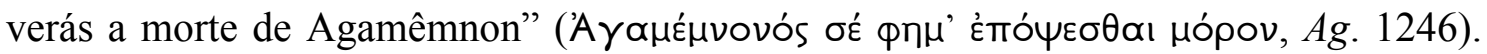
Observe-se que, nesse momento, Cassandra abandona a linguagem oracular mediante a qual vinha profetizando até então. Trata-se de uma enunciação, uma denúncia, uma afirmação categórica. A enunciação clara e direta dos fatos é algo, na maior parte das vezes, estranho à linguagem oracular, uma vez que esta tende mais comumente a descrever o sentido geral de uma determinada situação. 
Confrontado com esse anúncio da morte de Agamêmnon, o Coro primeiramente pede que ela modere sua fala, não pronunciando palavras de mau augúrio a engendrar males futuros. Para neutralizar o que há de ominoso nas palavras de Cassandra, o Coro

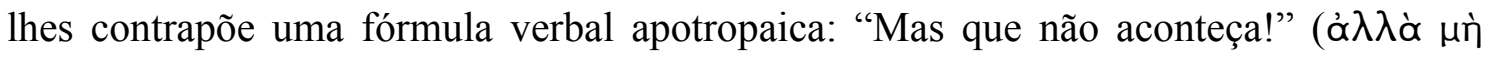

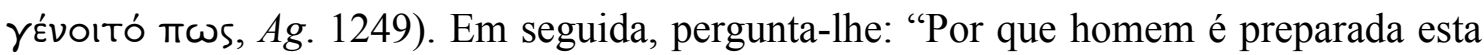

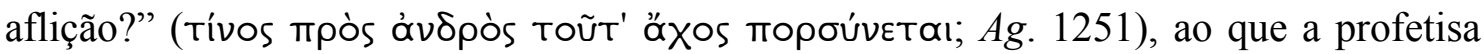

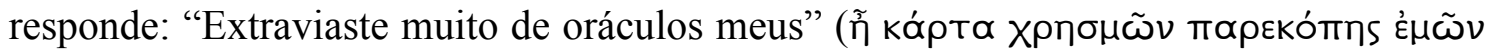
ơpa, $A g .1252)$, já que o que ela vem prenunciando até então é que um crime será

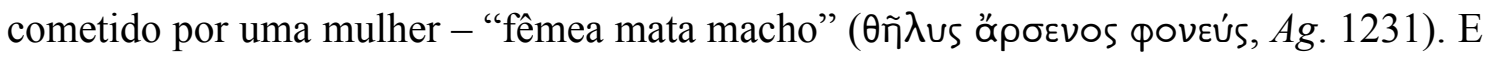
o Coro mostra-se realmente extraviado: "Não entendi o ardil de quem executa" (тoũ

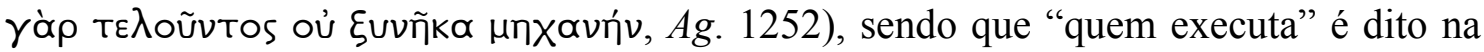
forma masculina, Toũ TEגoũvtos.

Aqui se explicita uma vez mais a disparidade do ponto de vista divino, de que fala Cassandra, e do ponto de vista humano, de que fala o Coro. Se em momentos coincidem e se confundem, em outros momentos, como agora, tornam-se radicalmente distintos, impossibilitando, neste caso, a comunicação entre Cassandra e o Coro. Ciente

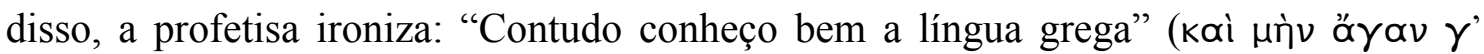

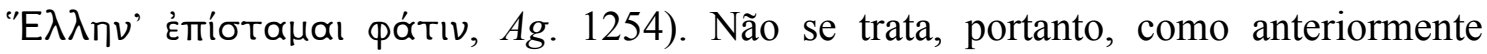
conjecturaram Clitemnestra e o Coro, de um desconhecimento da língua grega ( $\mathrm{Ag}$.

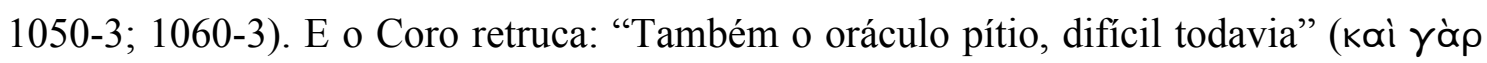

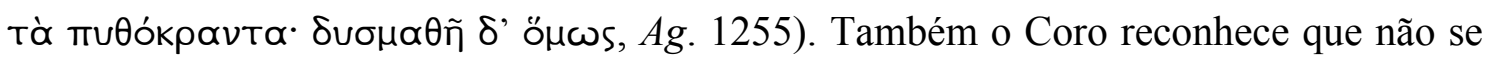
trata de uma ignorância da língua grega, mas do modo de sua elocução, difícil de

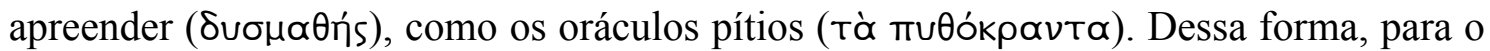
Coro, as palavras de Cassandra têm a qualidade própria da enunciação oracular délfica $^{58}$.

Acometida por mais um delírio profético, Cassandra volta a descrever as imagens com que se prenunciam a sua morte e a de Agamêmnon:

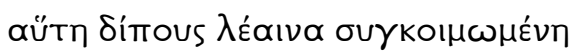

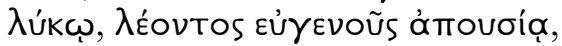

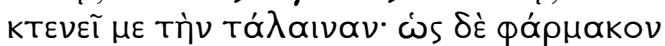

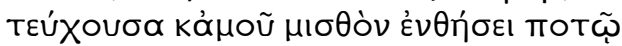

Essa leoa bípede junto com o lobo deitada na ausência do nobre leão matar-me-á mísera: como remédio porá ainda a minha paga na poção.

\footnotetext{
${ }^{58}$ Dodds (1951, pp. 70-3) observa que a diferença entre os enunciados proféticos de Cassandra, e de outras figuras semelhantes, e os da Pítia em Delfos é que, enquanto os primeiros ocorrem sob a forma de visões espontâneas e imprevisíveis, os enunciados pítios advém do "entusiasmo", que se atinge mediante um processo de autoindução.
} 


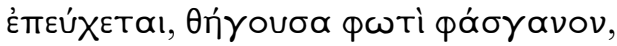

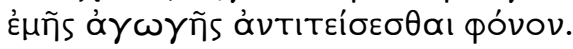

Aguçando o gládio para o marido gloria-se

de puni-lo com morte por ter-me trazido.

(Ag. 1258-63)

A linguagem de Cassandra torna-se novamente enigmática. A imagem do leão

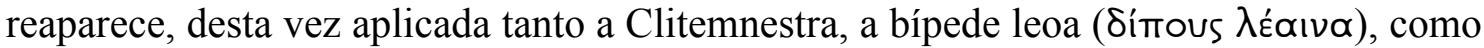

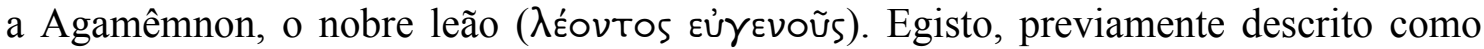
um leão, reaparece dessa vez como um lobo ( $\lambda$ úkผ), diferindo-se, na imagética animal, de Agamêmnon e Clitemnestra, pois ele é tanto o outro, o elemento discordante na relação entre marido e mulher, como aquele que é hierarquicamente inferior. A morte de Cassandra surge como um pagamento ( $\mu$ เöós) na poção que Clitemnestra prepara para o marido enquanto afia a espada ( $(\alpha$ ó $\gamma \alpha v o v)$ com que vai matá-10 ${ }^{59}$ como punição por ter trazido a profetisa de Troia.

Cassandra, confrontada uma vez mais com a imagem de sua própria morte, destrói suas insígnias divinatórias. Nesse gesto de desespero se vê representada sua própria destruição. Cassandra diz que é Apolo mesmo quem a despe de suas insígnias "Eis Apolo mesmo despindo-me / as vaticinas vestes" (íoù $\delta$ ', 'Aтó $\lambda \lambda \omega \nu$ aủtòs

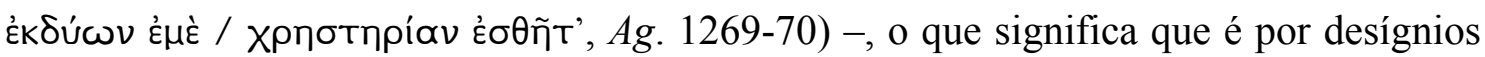
do deus, ao conduzi-la diretamente às mãos de sua assassina, que ela será destruída: “O

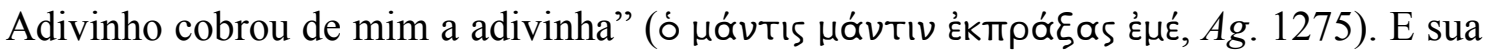
morte será tão cruel quanto terrível foi a sua vida de adivinha, tendo de suportar o escárnio e a hostilidade dos amigos e sendo chamada de pedinte e de famélica.

A destruição de suas insígnias, no entanto, não representa o fim de seu dom divinatório. Assim, Cassandra profetiza a chegada de um futuro em que sua morte e a de Agamêmnon encontrarão justa vingança:

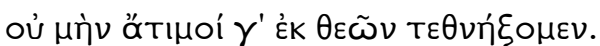

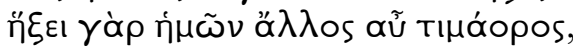

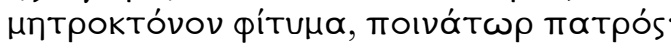

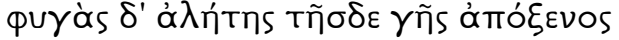

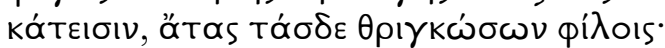

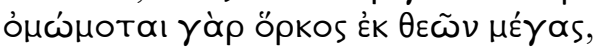

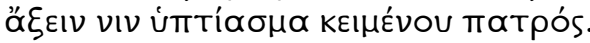

Não sem honra aos deuses morreremos: um outro punidor por nós há de vir, matricida rebento, vingador do pai. Exilado errante estranho a esta terra voltará para coroar a ruína dos seus. Há de conduzi-lo o pai supino em jazigo.

(Ag. 1279-84)

Note-se que o que Cassandra descreve é exatamente o que irá acontecer nas Coéforas: Orestes é o punidor que há de vir para vingar a morte do pai, em cujo túmulo

\footnotetext{
${ }^{59}$ Há uma discussão a respeito da arma utilizada por utilizada por Clitemnestra para matar Agamêmnon. A esse respeito, conferir Sommerstein (1989).
} 
ele pede auxílio, voltando à sua terra na condição de exilado, errante, estranho à terra, pois de fato ele foi exilado de sua pátria, volta para ela ainda na condição de estranho, visto que chega disfarçado de estrangeiro, e, após o matricídio, tem de se exilar novamente ${ }^{60}$.

Resta à trágica profetisa suplicar por um golpe certeiro às portas de Hades - o limite inerente à vida dos mortais -, aqui representadas pelas portas do palácio ao qual, adentrando, ela perderá sua vida. A sua determinação em caminhar para a morte causa a admiração do Coro, para quem, afinal, Cassandra revelou ser uma "demasiado sábia

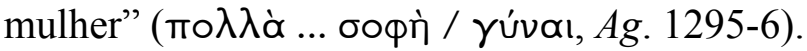

Algo, no entanto, refreia momentaneamente seus passos: "O palácio respira

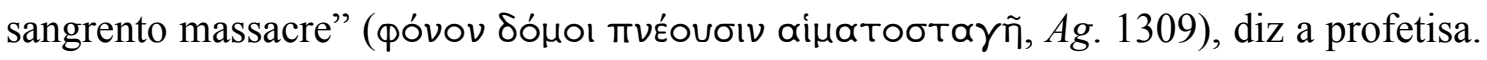
Cassandra fala de uma percepção olfativa de caráter numinoso: ela sente o cheiro do sangue de crimes passados e futuros recender pelo palácio e esse cheiro se assemelha ao odor que emana do túmulo. Essa percepção, no entanto, é inacessível ao Coro, que tem uma percepção olfativa ordinária e para quem o cheiro que ela distingue é apenas o que emanam os sacrifícios no altar.

Antes de prosseguir em seu caminho para o interior do palácio, Cassandra profetiza ainda a morte de Clitemnestra e de Egisto, pedindo então ao Coro que, "quando por mim, mulher, a mulher morrer / e, por malcasado homem, o homem cair"

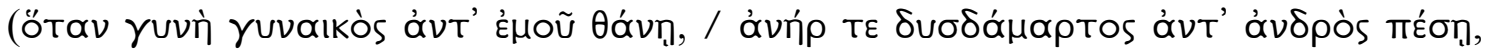
Ag. 1318-9), eles, como um presente de hospitalidade, sejam testemunhas de que ela profetizara acertadamente.

As últimas falas da profetisa são um lamento pela precariedade de sua condição humana e um pedido de vingança: "suplico que os inimigos paguem / aos vingadores do

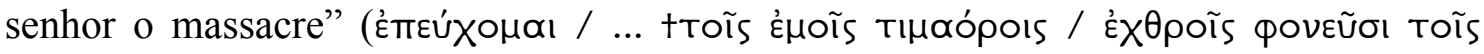
ĖHoĩs Tíveıv ónoũt, $A g$. 1323-5).

Cassandra revela-se, assim, ser a voz do palácio, a que o Vigia, no prólogo, aludiu (Ag. 37-8). Por meio de sua voz, passado, presente e futuro se descortinam, lançando luz no que até então permanecia obscuro e desfazendo as ambiguidades de todos os sinais numinosos, tanto os que já se manifestaram quanto os que ainda estão por vir. E o que essa súbita claridade advinda de sua voz profética ilumina e revela é a

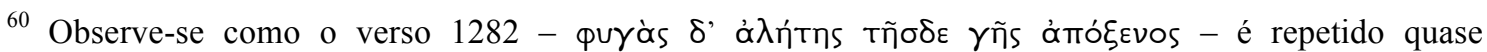

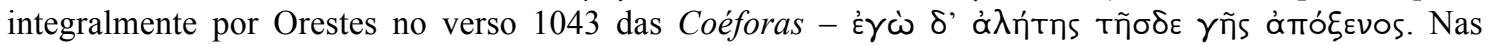
Coéforas, no entanto, o exílio a que Orestes se refere é o exílio após o assassínio de Clitemnestra e de Egisto. 
compleição do nume que habita o palácio. Para percebê-lo, no entanto, é necessário olhá-lo através dos olhos de Cassandra.

\subsection{4) O prenúncio da vingança}

Após a saída de cena de Cassandra, o Coro faz uma breve reflexão sobre a precariedade da condição humana, na qual o destino de Agamêmnon é contemplado: honrado pelos deuses, que lhe concederam a captura de Troia e um seguro retorno ao lar. No entanto, pondera o Coro,

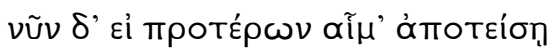

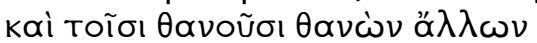

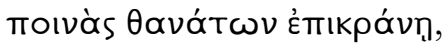

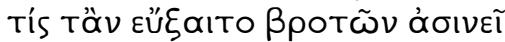

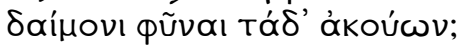

Se agora responder por sangue antigo e morto pelas mortes cobrar punição com outras mortes, que mortal ouvindo isso alardearia ter nascido com incólume destino?

(Ag. 1338-42)

Ainda que o Coro não tenha podido compreender as profecias de Cassandra, é notável como, nessa sua reflexão sobre a precariedade da condição humana, o Coro sintetiza de certo modo tudo que foi dito pela profetisa, só que sob a forma de uma oração condicional: se (Ei) agora Agamêmnon tiver de responder por "sangue antigo"

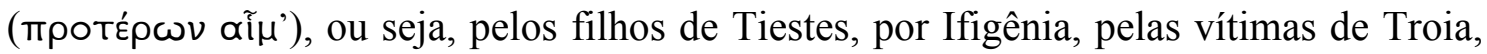
e, uma vez morto, "pelas mortes" (тоர̃oı Өavoũoı), isto é, a sua e a de Cassandra, cobrar

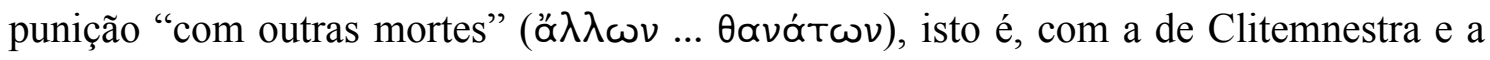
de Egisto, nenhum mortal, ouvindo isso, poderia dizer ter nascido com um destino incólume. Assim, o que Cassandra vê, através de seu dom profético, o Coro apreende mediante seu raciocínio, mas, enquanto, para Cassandra, o ciclo de morte e retribuição que assola o palácio dos Atridas é uma realidade nua e crua, para o Coro, é uma temível possibilidade.

Essa possibilidade, todavia, imediatamente se faz real quando as reflexões do Coro são interrompidas pelos gritos moribundos de Agamêmnon: “Ómoi! Um golpe

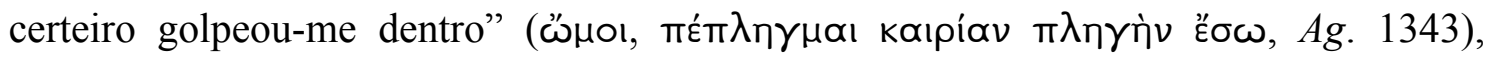

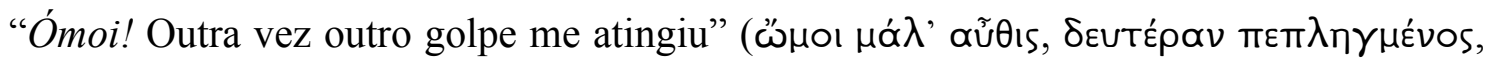
$A g$. 1345) Claramente ineptos para a ação, os membros do Coro debatem entre si de forma a descobrir qual seria a melhor atitude a tomar e chegam à conclusão de que é 
necessário, antes de tudo, saber claramente o que está acontecendo com o rei. Observese que, nessa confusão em que se encontram os anciãos do Coro, explicita-se uma vez mais a sua incapacidade de compreender as profecias de Cassandra ${ }^{61}$ : eles associam a morte do rei não a uma vingança de Clitemnestra e de Egisto por questões familiares, mas a um golpe de estado, a uma tentativa de instauração de tirania. Assim, eles falam

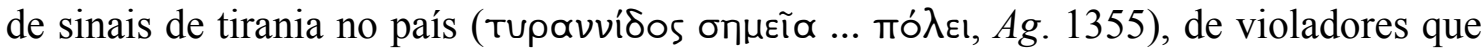

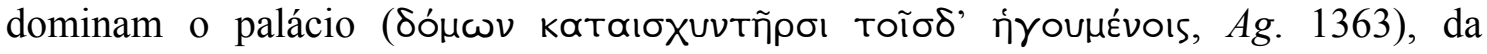

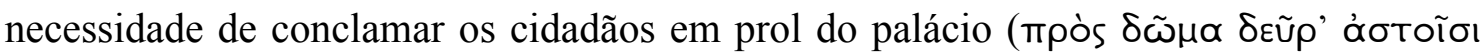

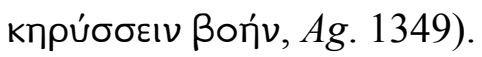

É nesse momento que, no quinto episódio, Clitemnestra entra em cena anunciando o assassinato de Agamêmnon. Primeiramente, ela admite que suas palavras

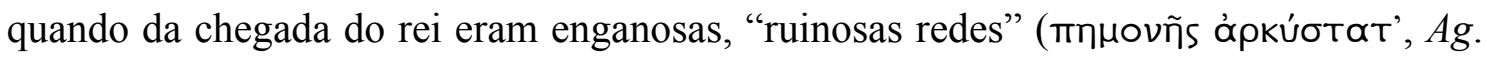
$1375)^{62}$ para capturar o inimigo ${ }^{63}$. Ela então não apenas declara ter matado o marido, mas também narra como o fez:

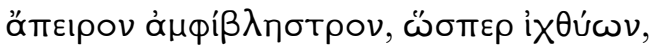

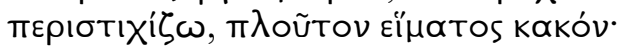

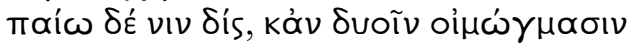

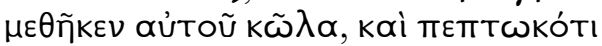

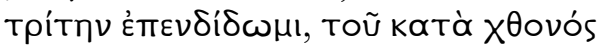

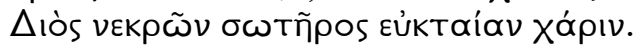

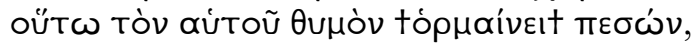

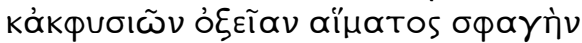

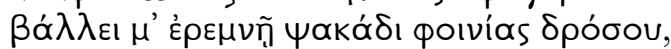

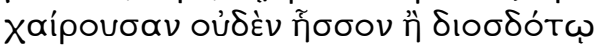

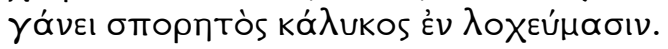

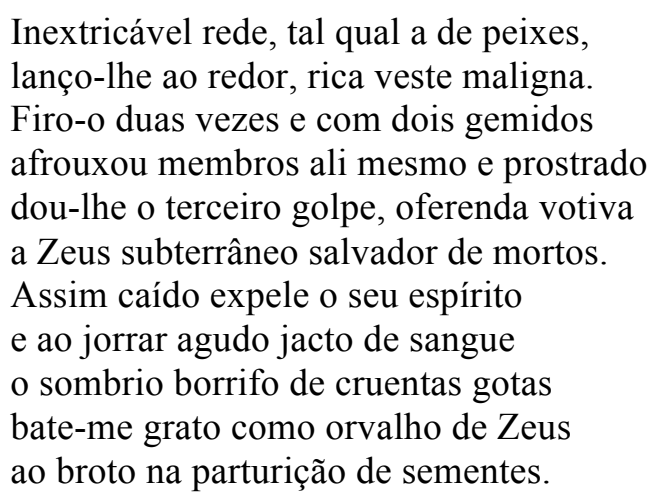

(Ag. 1382-92)

Clitemnestra descreve o regicídio como um sacrifício: o terceiro golpe é uma oferenda votiva (Eứctaíav Xápıv) a Zeus subterrâneo (Toũ katà X Xovós $\Delta$ ı̀̀s), o que o torna uma contrapartida do sacrifício de Ifigênia, feito por Agamêmnon a Ártemis, uma deusa olímpica. No entanto, assim como o sacrifício de Ifigênia trouxe a morte a seu

\footnotetext{
${ }^{61}$ A essa incapacidade do Coro de compreender as profecias de Cassandra parece corresponder a sua capacidade de adivinhar. O Coro, ouvindo os gemidos de Agamênon, diz: "Por indícios vindos de gemidos / adivinharemos que é morto o rei?" (ก̃ yà

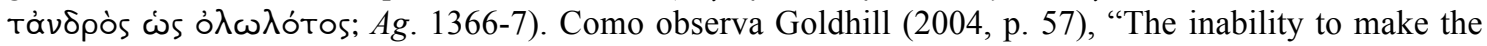
gestures of foretelling with certainty is depicted as leading to an inability to act. [...] Lack of knowledge an inability to prophesy accurately from the evidence - leads to an incapacity for action".

${ }^{62}$ Para Raeburn \& Thomas (2011, p. 213), "here, Clytemnestra makes it clear that words have been her prime weapon in the entrapment of Agamemnon".

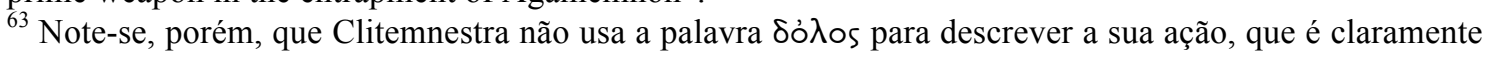
dolosa.
} 
executor, também esse sacrifício trará a morte a seus executores. Observe-se que, enquanto o sacrifício de Ifigênia não é descrito, o de Agamêmnon é descrito em

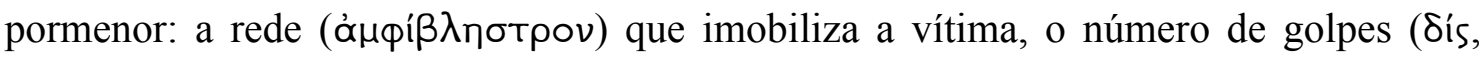

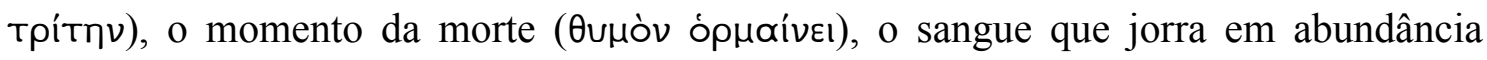

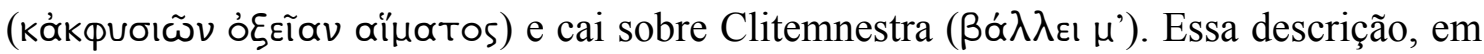
que se ressalta a natureza dolosa, violenta e cruel do assassinato de Agamêmnon, é comparável com a descrição feita por Cassandra do crime de Atreu, de forma que, assim como aquele crime clamava por vingança, uma vingança que por fim se realizou, também este crime clama por vingança.

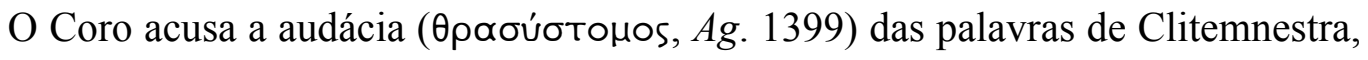
que lhe causam espanto, mas Clitemnestra desdenha da opinião do Coro e se reafirma como a autora da morte de Agamêmnon: "façanha desta mão / destra, justo artífice"

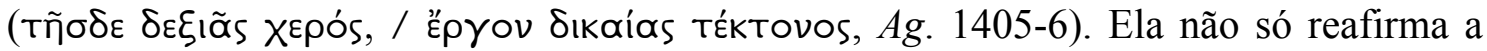
autoria do crime como o justifica, falando de como Agamêmnon,

oủ $\pi \rho \circ т$

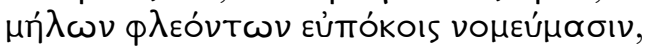

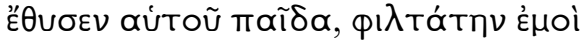

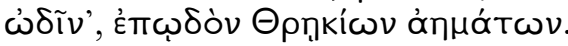
desatento como da sorte de uma rês, sobejando ovelhas nos lanosos rebanhos, sacrificou a própria filha, meu dileto parto, encantador dos ventos trácios.

(Ag. 1415-8)

O sacrifício de Ifigênia, que desde o párodo não foi mais explicitamente mencionado, ressurge neste momento como uma atitude mundana e inconsequente da parte de Agamêmnon, visto que Clitemnestra desconsidera as conjunturas divinas e humanas que levaram o rei a sacrificar a filha. Toda aquela intrincada configuração numinosa de que o Coro fala no párodo reduz-se, do ponto de vista de Clitemnestra, a

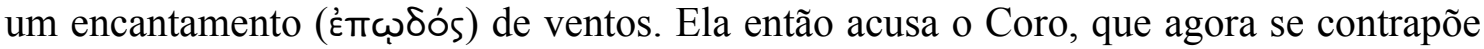
a ela, de não ter na ocasião se contraposto a Agamêmnon. Mas, para o Coro, o crime de Clitemnestra é injustificável e suas palavras à rainha são proféticas: "Retaliada, carecida

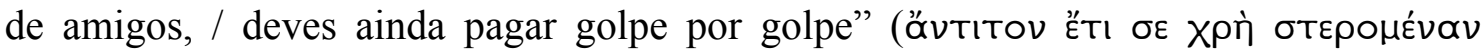

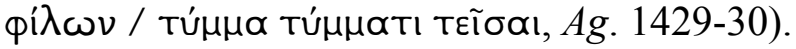

Clitemnestra, no entanto, diz não temer, porque ela tem Egisto ao seu lado e, ao falar de seu amante, fala também da amante de Agamêmnon:

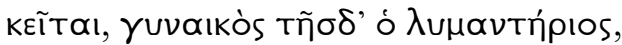

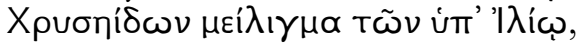

Jaz quem ultrajou esta mulher, quem deleitava as Criseidas em Ílion, 


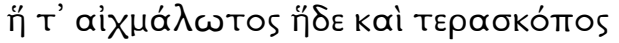

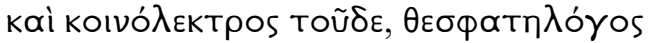

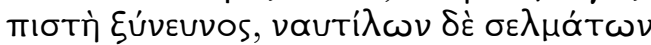

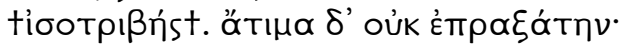

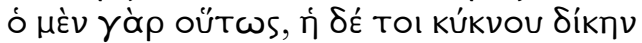

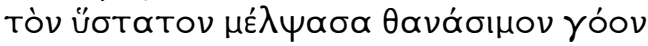

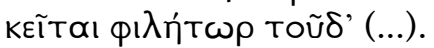

jaz esta prisioneira e adivinha, sua concubina e profetisa, fiel consorte e co-usuária dos bancos do navio, obtiveram ambos o devido, ele desse modo, ela como o cisne entoou o último lamento de morte e jaz amante sua (...).

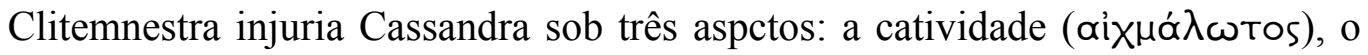

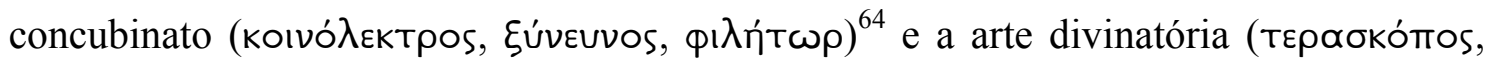

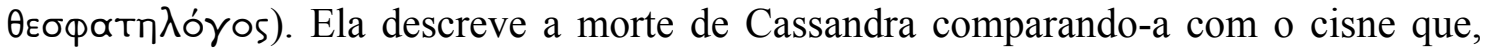
presciente de sua morte, canta um triste lamento, de forma que também Cassandra, presciente de sua morte, entoou o último lamento ${ }^{65}$. No entanto, o "lamento do cisne" de Cassandra é um canto profético que fala mais do que de sua própria morte: ele fala de

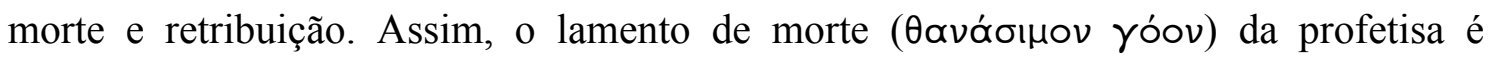
também o prenúncio da vingança de que serão vítimas Clitemnestra e Egisto.

O Coro, lamentando a sorte de Agamêmnon, evoca o nume que surge no palácio e preside o destino dos Atridas, assim descrito por Clitemnestra:

Tòv трıт์̛́ XUvTov

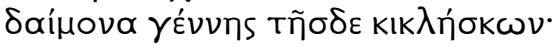

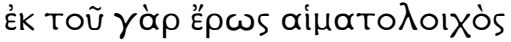

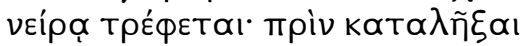

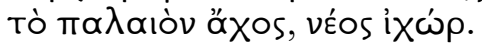

(...) o Nume

trinutrido desta estirpe:

por ele o desejo sanguinolento

na víscera se cria, antes de cessar

a antiga dor, novo cruor.

(Ag. 1476-80)

Clitemnestra qualifica o nume da estirpe de "trinutrido" (трıто́́ Xuvтov), numa alusão à morte dos filhos de Tiestes, de Ifigênia e de Agamêmnon. No entanto, como a própria rainha observa, esse nume é insaciável, sendo sempre acometido pelo desejo de sangue, um desejo que se manifesta na "víscera" (veípạ) e que se concretiza como "novo cruor" ( véos ið $\omega ́ p)$. O Coro reforça esse aspecto do nume, dizendo-o "grave na

\footnotetext{
${ }^{64}$ Em Eurípides, a relação amorosa entre Agamêmnon e Cassandra é bastante explícita. Nas Troianas, Taltíbio, no primeiro episódio, anuncia a Hécuba o destino de sua filha: coube como escrava a

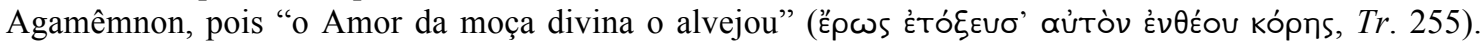
Em Hécuba, a esposa de Príamo, no terceiro episódio, diz a Agamêmnon: "Junto às tuas costelas dorme

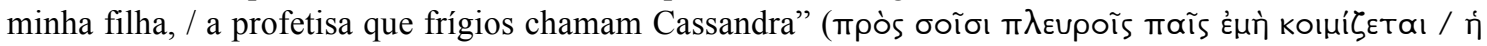

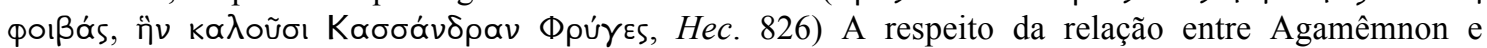
Cassandra em Ésquilo, conferir o artigo de Debnar (2010), “The Sexual Status of Aeschylus' Cassandra”. ${ }^{65}$ Para uma análise sobre essa comparação entre Cassandra e o cisne que canta sua própria morte, conferir o artigo de Harris (2012), “Cassandra's Swan Song: Aeschylus' Use of Fable in Agamemnon”.
} 


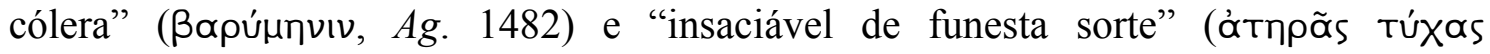
ớкópєoтоv, $A g .1484)$.

A rainha, então, identifica-se com esse nume:

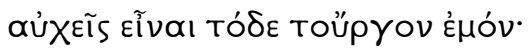

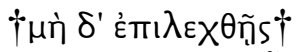

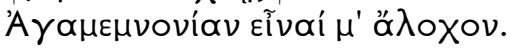

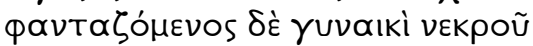

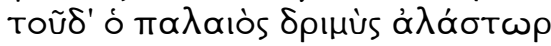

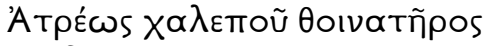

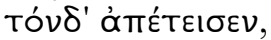

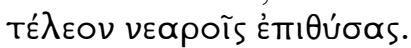

\author{
Julgas ser minha esta façanha \\ mas não contes que seja \\ eu a esposa de Agamêmnon, \\ mas, na figura da mulher deste morto, \\ o antigo áspero Nume, sem oblívio \\ de Atreu cruel festeiro, \\ fez deste homem feito a paga \\ dos jovens, noutro sacrifício.
}

(Ag. 1497-504)

Dessa forma, a ação de Clitemnestra se converte na atuação do terrível nume que habita o palácio. Porém, esse nume que se manifesta através de Clitemnestra não se

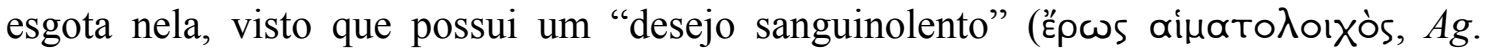
1478), é “insaciável de funesta sorte” (átnpãs тúxas ákópєotov, Ag. 1484), e, antes que a dor antiga cesse, provoca "novo cruor" ( véos ix

Mas a rainha quer fazer um pacto com esse nume que ela percebe estar atuando por meio dela, de modo que, abandonando o palácio, cause a ruína de outros com crimes recíprocos (Ag. 1568-76): “a loucura das mortes mútuas” ( $\mu$ avías ... á $\lambda \lambda \eta \lambda$ oqóvous, $A g$. 1576). Porém, como explicita o Coro, "Pêgo quem pega, quem mata paga. / Detendo o trono Zeus, / sofre quem faz: essa é a lei” (фépeı фépovT',

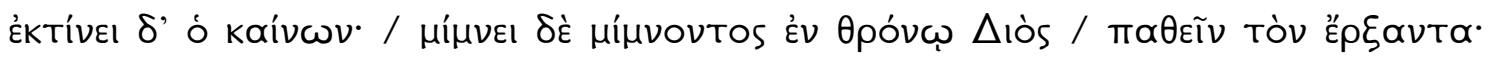

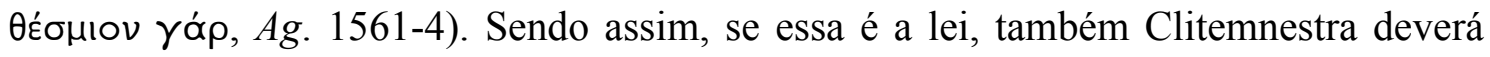
sofrer as consequências pelo que fez. Essa lei divina evocada pelo Coro prenuncia o que ainda está por vir: a morte de Clitemnestra e de Egisto.

Embora Clitemnestra defenda a justiça de seu ato - "justo, mais do que justo"

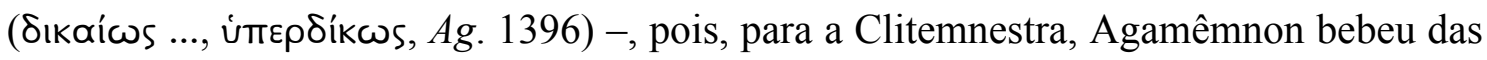
taças que ele mesmo encheu de ominosos males ao sacrificar sua própria filha para encantar os ventos em Áulida e, ao mesmo tempo, pagou pelo crime de seu pai, Atreu; para o Coro, conforme ele canta em estribilho, a morte de Agamêmnon foi uma morte

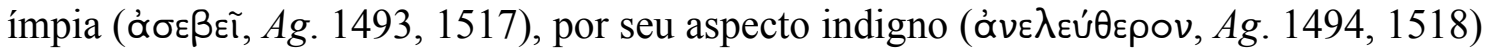

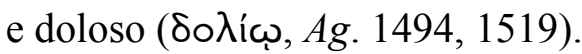

Também Egisto, ao entrar em cena no último episódio, reivindica justiça para

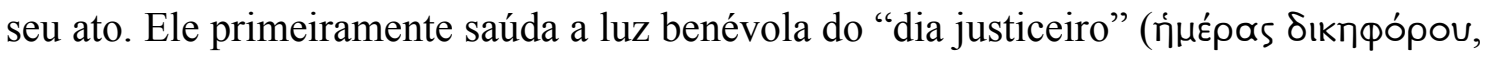


Ag. 1577), pois nesse dia Agamêmnon morreu "em paga de ardis da paterna mão"

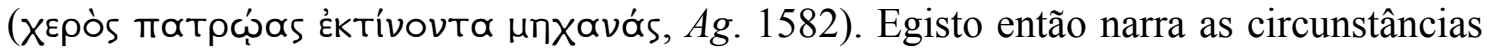
do banquete de Atreu e a maldição lançada por Tiestes - "assim pereça toda a prole de

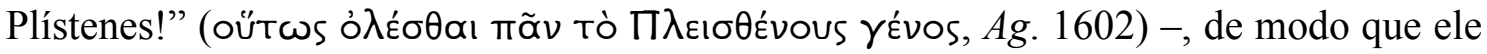

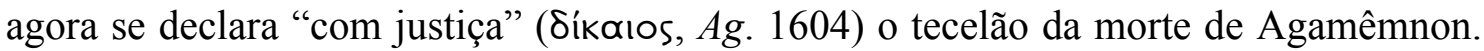
Foi a Justiça ( $\delta i ́ k \eta, A g .1607)$ que o trouxe, já adulto, de volta do exílio em que passou sua infância, e tramando o ardil, pode agora ver o rei pego "nas redes da Justiça" (Tñs

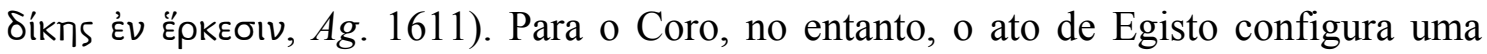

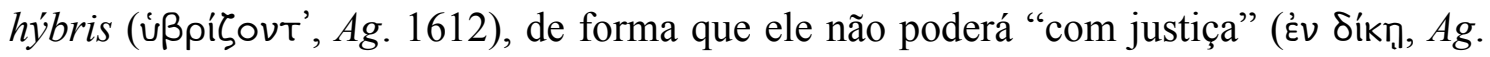
1615) livrar-se das pragas do povo.

Note-se que o próprio destino de Egisto - a infância passada no exílio, o retorno à terra pátria depois de adulto, a trama executada para vingar a morte do pai - prenuncia o destino de Orestes. O Coro também prenuncia o destino do filho de Agamêmnon como uma ameaça a Egisto: "Orestes algures vê a luz, / há de regressar com próspera

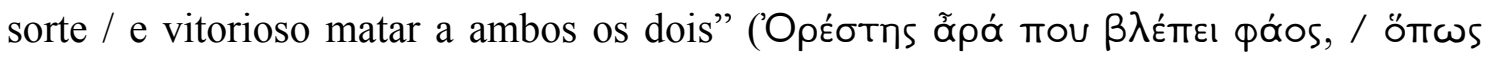

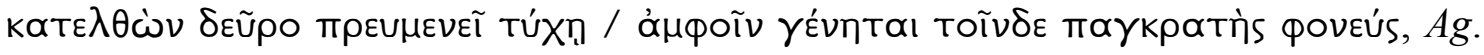
1646-8).

Irritado, Egisto ameaça o Coro com sua espada, mas Clitemnestra intervém:

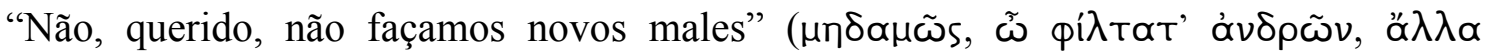

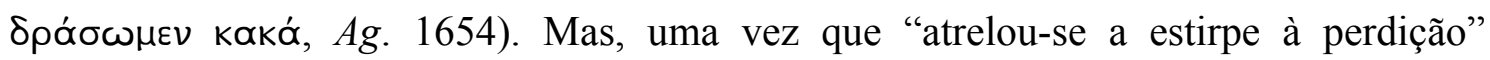

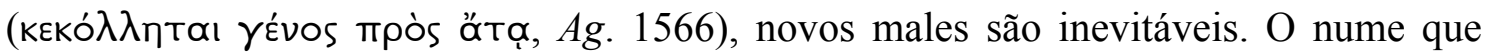
preside o destino dos Atridas e se revela na consumação de recíprocos crimes consanguíneos ainda não abandonou o palácio, pois, conforme profetizou Cassandra, um vingador há de por eles vir ( $A g .1280)$. 
4.2. COÉFORAS 


\subsection{COÉFORAS}

\subsection{1) O sonho de Clitemnestra}

Os últimos versos de Agamêmnon são ditos por Clitemnestra a Egisto, quem, no êxodo, discute com o Coro de anciãos e ameaça puni-los por suas palavras insolentes. A rainha, tentando aplacar a contenda, diz a seu companheiro: "Não cuides mais destes

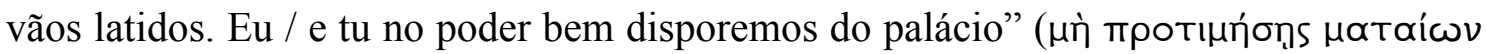

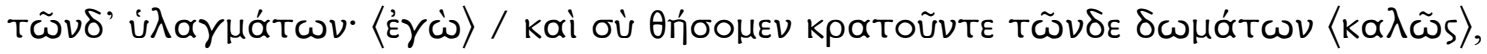
Ag. 1672-3).

De fato, Clitemnestra e Egisto tomaram o poder e dispuseram do palácio como bem lhes aprouve. Há, porém, uma ironia nesses últimos versos: o que Clitemnestra

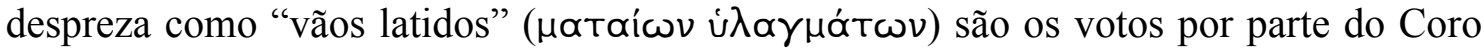
de que Orestes, auxiliado pelo nume, regresse para vingar a morte de Agamêmnon: "se

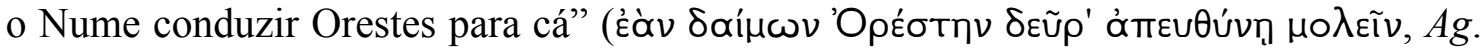
1667). Ora, esses votos são pronunciados pelo Coro, que é composto de anciãos argivos

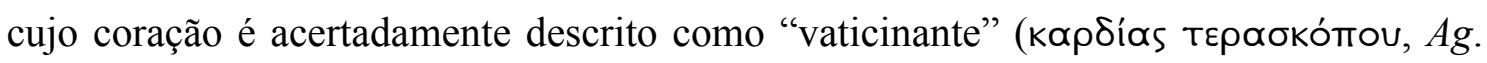
977). Trata-se, portanto, da expressão de um voto que é ao mesmo tempo um vaticínio: "Orestes algures vê a luz, / há de regressar com próspera sorte / e vitorioso matar a

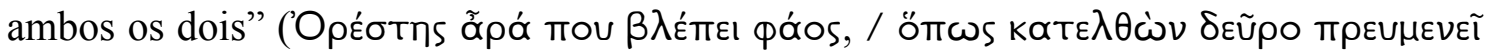

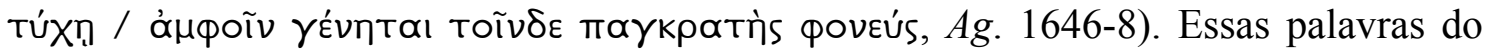
Coro são ainda mais expressivas porque ecoam as predições de Cassandra, que, como se viu, prenunciou o retorno de Orestes: "um outro punidor por nós há de vir, / matricida

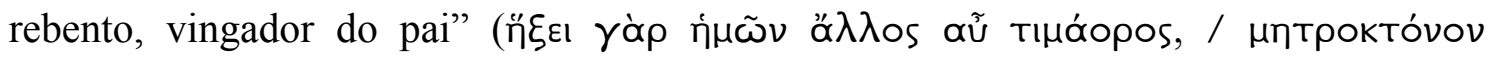

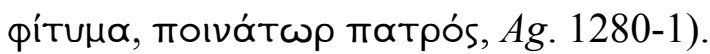

O fragmentário prólogo das Coéforas ${ }^{1}$ inicia-se com a presença em cena de

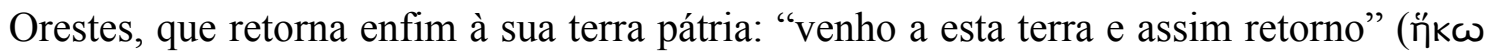

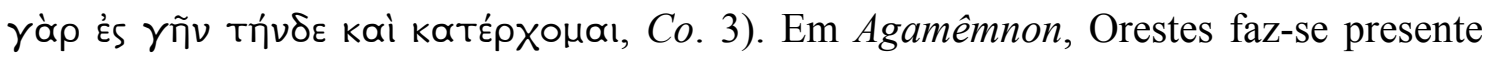

\footnotetext{
${ }^{1}$ Os primeiros nove versos que compõem o prólogo das Coéforas encontram-se ausentes do manuscrito Mediceu e provêm de citações de outros autores. Os quatro versos iniciais são citados pelo personagem de Ésquilo nas Rãs de Aristófanes - e seu sentido é debatido entre os personagens de Ésquilo, Eurípides e Dioniso ( $R a$. 1119-74) -, enquanto os demais provêm de escólios ao verso 145 da Pítia IV de Píndaro e ao verso 786 de Alceste de Eurípides.
} 
através de sua ausência. Ele é o filho que está sendo criado no exílio, é aquele que está

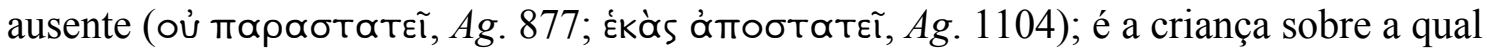
impende o destino profeticamente enunciado de ser o vingador do pai. Assim, nas Coéforas, sua própria presença reveste-se de um caráter numinoso, uma vez que o seu retorno foi determinado por Apolo, como será relatado por Orestes no primeiro episódio $^{2}$, e põe em ação o cumprimento de um destino a que, por desígnios divinos, o palácio dos Atridas está fadado.

Junto ao túmulo de seu falecido pai, Orestes pede a Hermes Ctônio ('E $\rho \mu \tilde{n}$

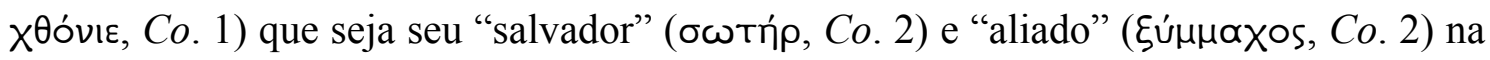
tarefa que se lhe impõe: vingar a morte de Agamêmnon. Essa invocação inicial a Hermes é significativa, pois evoca as várias facetas do deus que são contempladas ao longo desta tragédia. Ele, como arauto dos deuses súperos e ínferos - "dos sobre e dos

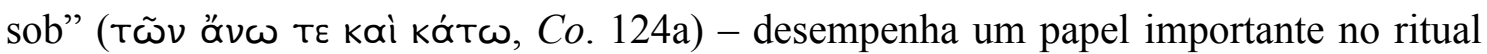
de libação executado por Electra, transmitindo aos numes subterrâneos as suas preces, assim como no kommós; em seu papel de deus do engano, ele auxiliará Orestes na execução de seu plano (Co. 727-8; 813-4), ao ajudá-lo a ludibriar Clitemnestra e Egisto; além disso, em seu papel de guia (тонтаĩos, Eu. 91), Hermes é quem, nas Eumênides, conduzirá Orestes de Delfos a Atenas ${ }^{3}$.

Orestes, tendo sido exilado de sua terra, lamenta o fato de não poder ter estado

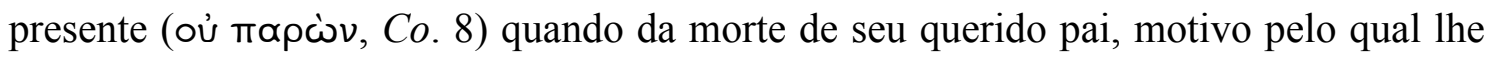
dedica agora uma mecha de seus cabelos, um sinal concreto de sua numinosa presença em solo pátrio: “Ofereci trança a Ínaco pelo alimento / e esta segunda, por lutuoso

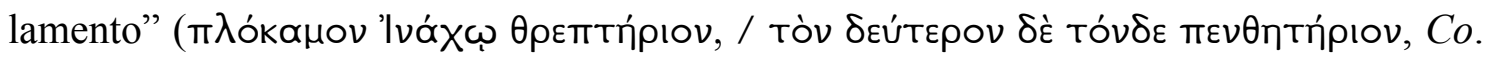
$6-7)^{4}$.

Nesse momento, Orestes avista um grupo de mulheres vestidas de preto - entre as quais distingue, por sua dor, a presença de sua irmã - trazendo libações funerárias ao

\footnotetext{
${ }^{2}$ Especula-se que uma menção ao oráculo de Apolo tenha sido feita, provavelmente, já no prólogo.

${ }^{3}$ Garvie (1986, p. 48) observa ainda o seguinte: "Belonging then to both the lower and the upper worlds, he [Hermes] is appropriate to this transition from the world of Agamemnon, dominated as it was by Zeus, to that of Choephori, in which the chtonic powers have so large a part to play". Note-se, no entanto, que Orestes, alguns versos depois, pede a aliança também de Zeus na execução de sua vingança. Ele pede

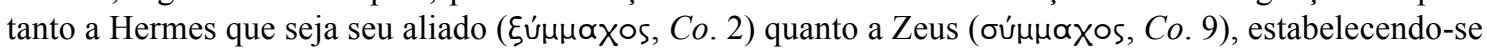
assim uma relação entre os deuses súperos e os deuses ínferos.

${ }^{4}$ A dedicação de uma mecha de seus cabelos ao deus-rio Ínaco representa o fato de Orestes ter atingido a puberdade. Era costume entre os jovens gregos dedicarem uma mecha de cabelo a um deus ou a uma divindade fluvial como forma de recompensa por sua criação. Esse gesto simboliza, dessa forma, o fim da infância. A esse respeito, conferir Nilsson (1949, pp. 96-7); Garvie (2002, pp. 50-1); Mikalson (2010, p. 185). Como Orestes a dedica a Ínaco, rio da Argólida, expressa-se a ideia de retorno e reintegração à sua terra natal, da qual fora exilado.
} 
túmulo de Agamêmnon. Ante essa visão inusitada, Orestes suplica a Zeus que, sendo

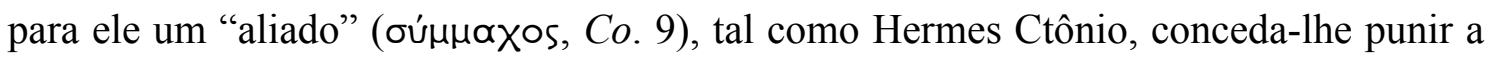
morte de seu pai: “Ó Zeus, dá-me punir a morte / do pai, sê aliado anuente comigo!” (డ̃

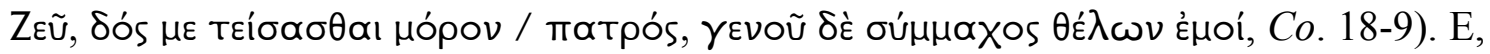
assim, juntamente com Pílades, o silencioso amigo que lhe acompanha, afasta-se para informar-se melhor sobre essa procissão de mulheres.

No párodo, o Coro, composto de mulheres cativas, exprimindo o seu luto ${ }^{5}$, enuncia o motivo pelo qual veio ao túmulo do falecido rei portar-lhe libações fúnebres:

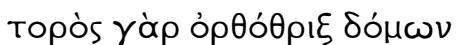

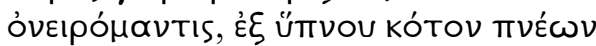

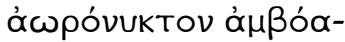

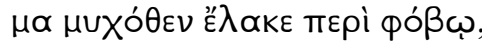

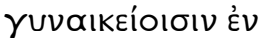

$\delta \omega \dot{\mu \alpha \sigma i v ~ \beta \alpha \rho u ̀ s ~ \pi i ́ t v \omega v ~}$

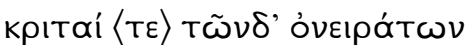

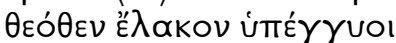

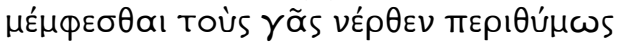

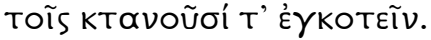

Claro, arrepiante, no palácio,

o Adivinho de sonho, tirando sono, a respirar rancor, alta noite, no recôndito, bramiu

um grito terríssono,

grave ao reboar

nos aposentos femininos.

Os intérpretes deste sonho

garantidos pelo Deus bramiram

que os ínferos irados repreendem

os que mataram e lhes têm rancor.

Uma questão que se coloca com relação a essa primeira antístrofe é a da identidade desse "Adivinho de sonho" (óveıpó $\mu$ avtıs) a que se refere o Coro. Trata-se de uma questão debatida, em virtude de um problema de estabelecimento textual do

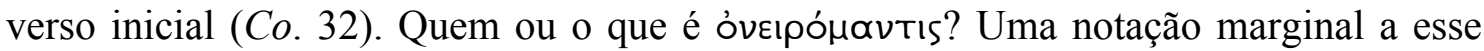
trecho do texto, comumente suprimida pelos editores, pois torna o verso metricamente problemático, traz a palavra Фoĩßos, criando-se assim uma identidade entre Фoĩßos e

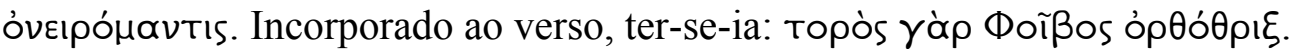

Para Garvie (1986, p. 57), contudo, "Apollo has nothing to do with the interpretation of dreams in the palace of Argos, or with the uttering of cries through Clytaemestras's mouth". O autor considera, no entanto, mais pertinente a emenda em que se corrige Фoĩßos por фóßos, sendo planteadas, de acordo com alguns editores, as

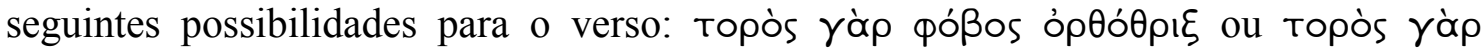

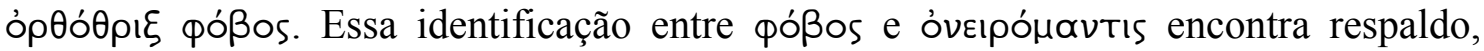

\footnotetext{
${ }^{5}$ Embora sejam cativas (a princípio, tendo sido trazidas de Troia por Agamêmnon, sendo, no entanto, impossível determinar com segurança sua origem), elas, como Cassandra, demonstram lealdade e compaixão a seus senhores, o que aqui se explicita pelo sincero luto que elas demonstram. $O$ fato de que elas, ainda que estrangeiras, sejam leais à memória de Agamêmnon e a seus filhos acentua a frieza e a crueldade de Clitemnestra e Egisto, aos quais, tanto como compatriotas quanto como membros da família, caberia lealdade e compaixão.
} 
segundo Garvie, no fato de que Clitemnestra, ao perceber a veracidade de seu sonho,

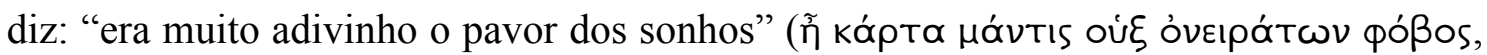
Co. 929) ${ }^{6}$. Para Bowen (1986, p. 36), a identidade do óveıpómavtıs é suficientemente clara: "Probably fear itself, implicit, not mentioned till пєрі фó $\beta \omega$ and then almost casually, as if obvious". E assim explica a emenda do verso: "M has Фоïßos in the sentence, appropriate subject of $\varepsilon^{\prime} \lambda \propto \kappa \varepsilon$, but it mars the metre, and may derive from the marginal comment of someone who saw that fear is effectively the subject and made himself a little note: фóßos" ${ }^{7}$. Meneses (2002, p. 119), a esse respeito, faz a seguinte observação: "Phoibos/Phobos: importaria precisar qual o termo originalmente empregado? É irretorquível que as duas ideias, de oráculo e de medo, em sua interassonância no original grego, estão intensamente presentes e respaldadas pelo contexto". Lloyd-Jones (1979, p. 134), por outro lado, afirma que se trata simplesmente do nume do palácio: "the 'dream-prophet' is the Daimon of the house, the personified curse upon it, who has caused the dream"^. A tradução dessa passagem por Mazon (1949) vem acompanhada de uma nota explicativa em que o tradutor identifica óveıpónavtıs com o remorso de Clitemnestra: “Ce 'prophète', c'est le remords anxieus qui habite Clytemnestre" ${ }^{9}$. Outra possibilidade, que se depreende da tradução de

\footnotetext{
${ }^{6}$ Além disso, há duas possíveis edições para um escólio ao verso 35, que diz: "O claro Febo, profetizando

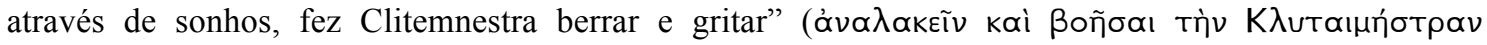

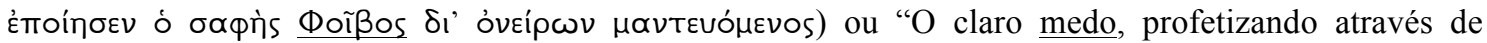

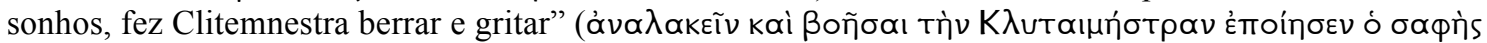

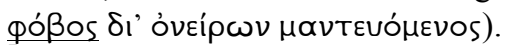

${ }^{7}$ Essa interpretação revela-se presente nas traduções de Grene \& Lattimore (1991): "Terror, the dream diviner of / this house, belled clear, shuddered the skin, blew wrath / from sleep, a cry in night's obscure watches, / a voice of fear deep in the house, / dropping deadweight in women's inner chambers". Embora os autores traduzam a partir da edição de texto de Smyth (1960), que mantém Фoĩßos no verso 32,

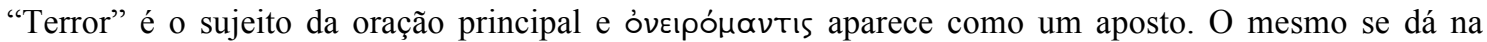
tradução de Burian \& Shapiro (2003): "For terror, dream-seer of the house / with every hair-end bristling, every / sleeping breath now breathing wrath, / cried out its shrill cry in the dead / of night, deep from within the palace / falling heavy on the women's quarters".

${ }^{8}$ Essa interpretação de Lloyd-Jones não afeta, no entanto, a sua tradução desses versos: "For shrill, making the hair to stand on end, / the dream-prophet of the house, in sleep breathing anger, / uttered a midnight shriek / of terror from the heart of the palace / in grievous assault upon the women's chambers". Morales (1986) parece seguir a mesma interpretação de Lloyd-Jones, o que se reflete mais claramente na sua tradução desses versos: "Con voz estridente que eriza el cabello, el genio maléfico de esta morada, profetizando en pesadillas, salió a deshora del sueño y exhaló ira en plena noche. Y, de pavor, lanzó un grito que se elevó desde lo hondo del palacio y fue cayendo con terror en las estancias de las mujeres".

${ }^{9}$ A tradução de Mazon (1949) diz o seguinte: "En un trop clair langage, auquel se dressent les cheveux, le prophète qui, dans cette demeure, parle par la voix des songes, soufflannt la vengeance du fond du sommeil, en pleine nuit, au coeur du palais, proclamant son oracle en un cri d'épouvante, lourdement vient de s'abatre sur les chambres de femmes".
} 


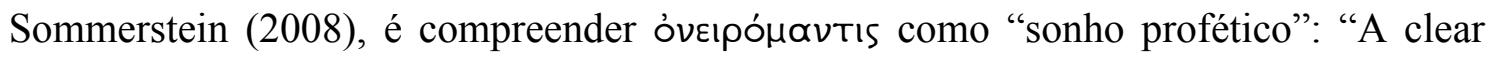
prophetic dream [..] raised a loud cry of terror [..]"

Como observa Bowen (1986, p. 36), a estrutura dessa longa frase é simples -

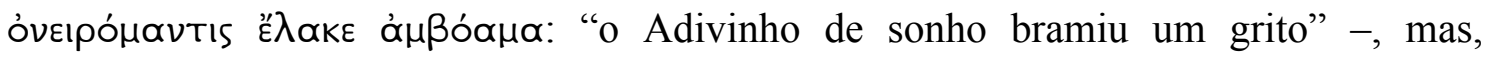
prossegue o autor, muitos detalhes são acrescidos a essa oração principal e a maior parte do vocabulário é exótica. Para o autor, "the implication is that this is no ordinary dream". De fato, não se trata de um sonho ordinário. Em primeiro lugar, diz-se "claro" (тopós, Co. 32). Essa nitidez que distingue o sonho é um indício de que se trata de um sonho significativo, isto é, profético. Como se viu, quando a Rainha, nos Persas, inicia o relato de seu sonho profético, ela o distingue dos demais sonhos com os quais convive desde a partida de Xerxes por sua claridade (દ̇vapyès, Pe. 179). É portanto um sonho que não se pode, como pretende o Coro no Agamêmnon, desprezar por ser indiscernível

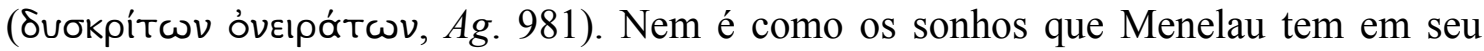
luto pela mulher perdida, imagens frustrâneas de Helena que escapam de seu abraço:

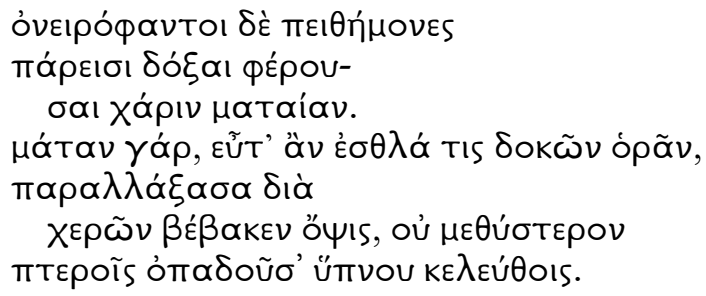

\author{
"Surgidas em sonho dolorosas \\ "apresentam-se aparências \\ "trazendo graça frustrânea: \\ "frustrânea, quando se crê bem ver, \\ "através dos braços espaca \\ “e vai-se a visão sem mais \\ "seguindo alados caminhos de sono."
}

(Ag. 420-6)

Ao contrário, o sonho de Clitemnestra, como bem dirá Orestes, não é vão: "Esta

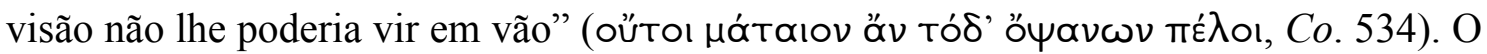
seu sonho se distingue por sua qualidade amedrontadora, que se manifesta no efeito que

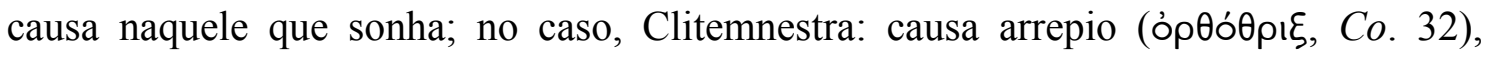

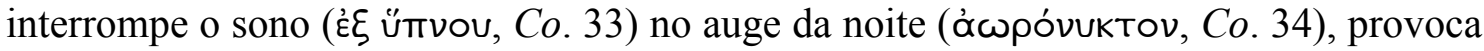
terror (тєрі фóß५, Со. 35). Mais do que um simples sonho, esses versos descrevem

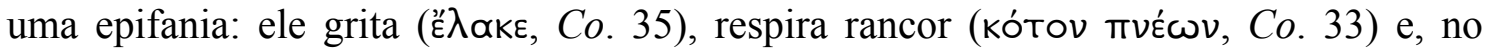
interior do palácio ( $\mu \cup \chi o ́ \theta \varepsilon v$, Co. 35), cai pesadamente (ßapús, Co. 36) sobre os aposentos femininos.

\footnotetext{
${ }^{10}$ A tradução completa dessa passagem por Sommerstein (2008) diz o seguinte: "A clear prophetic dream, breathing out wrath in sleep, / which made the houses's hair stand on end, / raised a loud cry of terror at dead night in the innermost part of the house, / making a heavy attack / on the women's quarters".
} 
Garvie (1986, p. 57) observa que o uso do termo uvхó日ev (Co. 35) evoca o

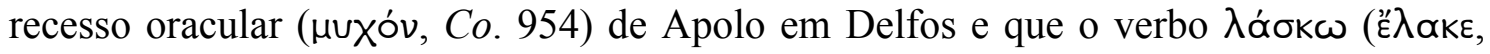

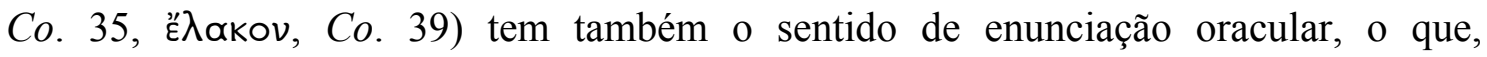
juntamente com a ideia de que se trata de um sonho divinatório, "may have misled a scribe (perhaps through the intermediary of a scholion) into this identification of the

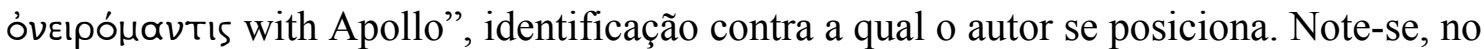
entanto, outro elemento que contribuiria para a identificação de Apolo com

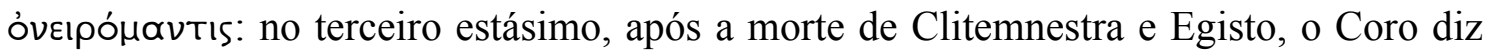
que a Justiça "respira rancor" (пvéous' ... kótov, Co. 952) e quem a proclamou de seu recesso ( $\mu$ uXóv) foi Apolo (Co. 953-4).

O Coro se refere, nessa passagem, ao oráculo proclamado pelo deus em Delfos de que Orestes vingasse seu pai dando morte a seus assassinos. É em função desse oráculo que ele retorna a Argos e se dirige ao túmulo de Agamêmnon. Clitemnestra tem um sonho cuja interpretação, de que os mortos se ressentem dos que os assassinaram, leva-a a enviar libações ao túmulo de Agamêmnon. Há assim uma correlação entre a chegada de Orestes em solo pátrio, motivada pelo oráculo de Apolo, e o envio de libações ao túmulo de Agamêmnon, motivado pelo sonho profético da rainha.

Smyth (1926), em sua tradução das Coéforas, faz a seguinte observação a respeito dessa primeira antístrofe do párodo:

The language of the passage is accommodated to a double purpose: (1) to indicate an oracular deliverance on the part of the inspired prophetess at Delphi, and (2) to show the alarming nature of Clytaemestra's dream; while certain limiting expressions (as

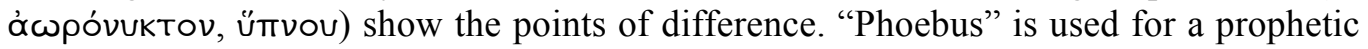

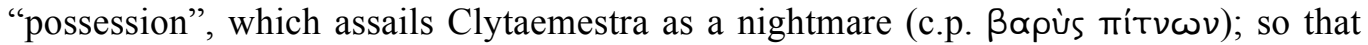
her vision is itself called an óveıpó $\mu \alpha v т ı s$.

Ainda que se possa discordar da interpretação de Smyth, é interessante e válida a relação de simultaneidade que ele estabelece entre o oráculo de Apolo e o sonho de Clitemnestra. Essa simultaneidade, além de possibilitar que Orestes reencontre sua irmã e obtenha dela e das mulheres do Coro ajuda para executar a sua vingança, testemunha o fato de que tanto o oráculo de Apolo quanto o sonho de Clitemnestra fazem parte de um mesmo diálogo divinatório. São as duas faces de um mesmo desígnio divino: a justiça que se realiza através do ato punitivo. $\mathrm{O}$ oráculo desvela a necessidade de punir e o sonho, a iminência da punição. Cada sinal divinatório tem o seu destinatário e cada destinatário age de acordo com o sinal que recebe: Orestes parte para Argos para punir e 
Clitemnestra envia libações para escapar à punição. No tempo presente da tragédia, esses acontecimentos se fazem não apenas correlatos mas também simultâneos.

Embora o conteúdo do sonho não seja revelado até o final do primeiro episódio, o Coro fala da interpretação que dele fizeram os intérpretes do sonho (kpıт đì

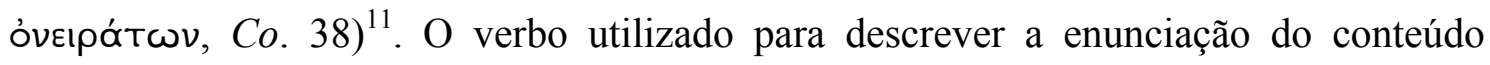

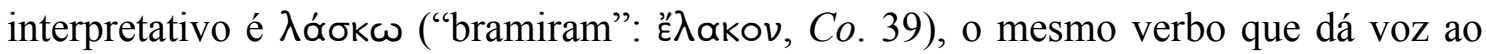

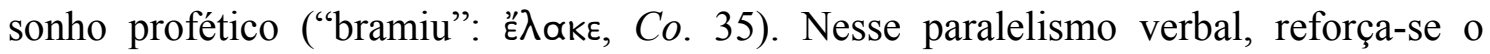
caráter divinatório do sonho de Clitemnestra. Além disso, os adivinhos do palácio falam

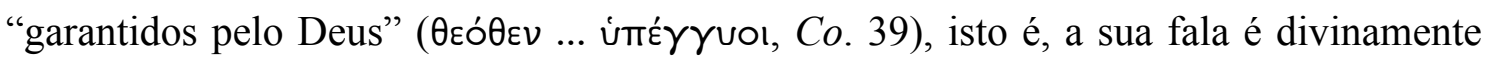
legitimada.

Os adivinhos fornecem uma interpretação que aponta para o sentido geral do sonho: "os ínferos irados repreendem / os que mataram e lhes têm rancor" ( $\mu \varepsilon ́ \mu \phi \varepsilon \sigma \theta \propto$ ।

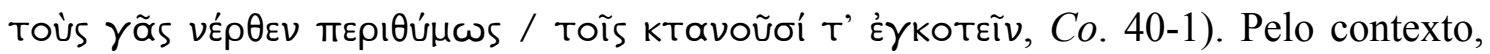

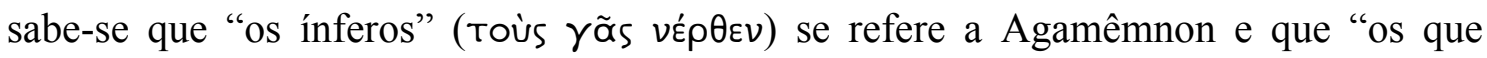
mataram" (тоĩs кта์ ỡoí) se refere a Clitemnestra e Egisto, mas, nessa interpretação, não apenas não se nomeiam mortos e matadores, como também não se prenunciam as consequências dessa ira dos mortos. É uma interpretação que fala sobretudo de uma disposição não propícia dos ínferos - visto que há repreensão ( $\mu \varepsilon ́ \mu \phi \varepsilon \sigma \theta \propto$ เ, Co. 40), ira

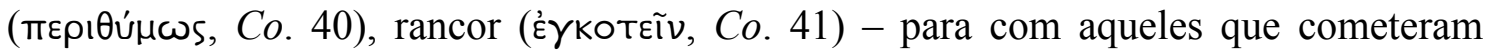
assassinato. Ora, o rancor dos mortos é algo temível e, portanto, mesmo que a interpretação do sonho feita pelos adivinhos do palácio não prenuncie claramente a morte de Clitemnestra e de Egisto, esse sonho prenuncia um mal, um mal cuja proveniência é identificada com os ínferos irados.

Numa tentativa de tornar propícios os não propícios ínferos, Clitemnestra envia libações ao túmulo do marido, para, por meio dessas oferendas fúnebres, apaziguar o rancor dos mortos e contornar, assim, o mal prenunciado em seu sonho. O Coro, no entanto, descreve as libações, que têm uma função apotropaica, pois são ditos "repelentes de males" (ámótpotrov kakẽv, Co. 44), como uma "graça não-graça" ( Xápı áxápıтov, Co. 44); ou seja, a tentativa de Clitemnestra de aplacar o rancor dos ínferos é imediatamente considerada vã, já que o sangue, uma vez derramado, é irremível. O sangue derramado clama por vingança e um terrível castigo há de cair sobre o culpado, pois, pondera o Coro, a justiça chega para todos.

\footnotetext{
11 Tais intérpretes podem, ainda que não necessariamente, ser associados aos "intérpretes do palácio"

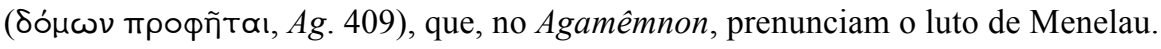


Também Orestes, ao final do primeiro episódio, observa que as dádivas enviadas por Clitemnestra são inferiores à falta cometida e, manifestando ao Coro o desejo de saber por que motivo a rainha, tantos anos depois do assassínio de Agamêmnon, ordena que sejam enviadas oferendas fúnebres a seu túmulo, diz ao Coro: "Desejo que, se é que

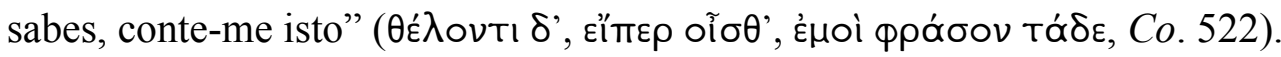

Por ter presenciado o acontecimento, o Coro pode lhe esclarecer: "por sonhos / e por noctívagos terrores sacudida / a ímpia mulher enviou estas libações" (Ék T'

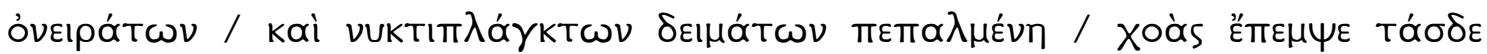

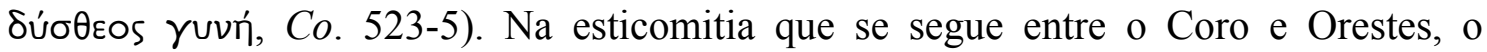
conteúdo do sonho finalmente é revelado:

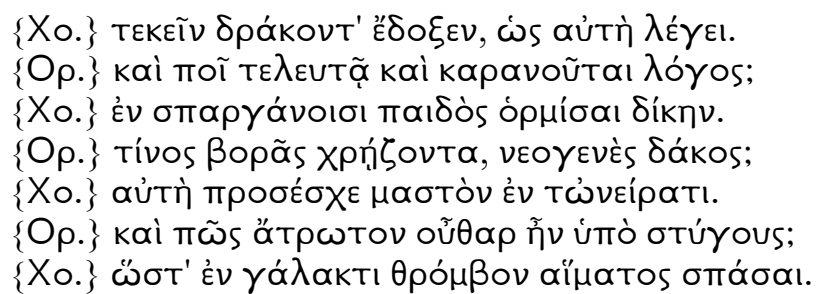

Co. Pareceu-lhe parir serpente, ela mesma fala.

Or. E aonde vai terminar e concluir a fala?

Co. Atou com faixas como a uma criança.

Or. E que nutria o recém-nascido monstro?

Co. Ela mesma lhe deu o seio no sonho.

Or. E como ficou ileso o úbere sob o horror?

Co. Sorveram-se com leite coágulos de sangue. (Co. 527-33)

Uma vez que a serpente é tradicionalmente associada aos mortos e às potestades dos ínferos ${ }^{12}$, na imagem da serpente que fere o úbere do qual se alimenta veem-se configurados a ira dos ínferos e o rancor dos mortos pelos seus matadores, isto é, a rainha Clitemnestra e Egisto. A serpente seria então o falecido rei Agamêmnon, cuja cólera, assim manifesta em sonhos, os intérpretes do sonho do palácio recomendaram que se tentasse apaziguar com libações fúnebres vertidas sobre seu túmulo.

\footnotetext{
12 Burkert (1993, pp. 380; 402) afirma que "o morto pode aparecer na figura de uma cobra" e que "uma cobra, criatura aterrorizante, pode ser encarada como manifestação de um herói”. Mesmo escrevendo alguns séculos depois, Artemidoro não deixa de ressaltar em sua Onirocrítica o aspecto ctônio da

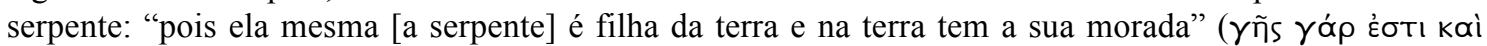

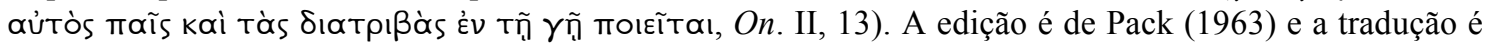
nossa. Para uma análise da serpente no imaginário antigo, conferir o capítulo de Pérez (2011), "La serpiente como símbolo en el mundo griego: escenas del 'Más Acá'”, no livro organizado por Manzano.
} 
Parece ter sido esse também o sentido do sonho de Clitemnestra na perdida Oresteia de Estesícoro ${ }^{13}$. Um fragmento dessa obra diz o seguinte: "Pareceu-lhe vir [à vista] uma serpente com o topo da cabeça manchado de sangue, e então dela surgiu o rei

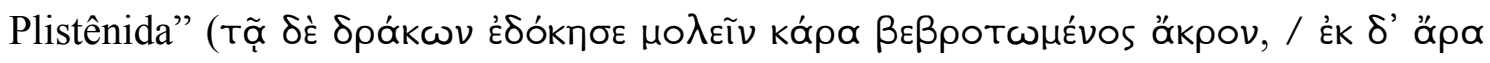

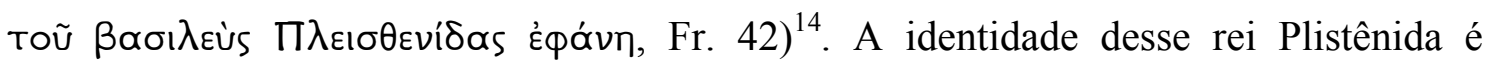
debatida: seria Agamêmnon ou Orestes? Para Devereux (1976, pp. 171-6), trata-se de Orestes, que surge da cabeça da serpente, assim como Atena nasce da cabeça de Zeus. Para Garvie (1986, p. xx), trata-se de Agamêmnon: "The snake changes into the human

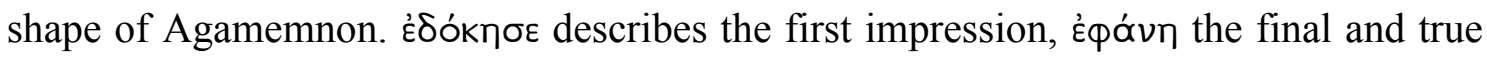
manifestation of the dead king”. Independentemente de quem seja o rei Plistênida a que o fragmento alude, o que só o contexto poderia de fato esclarecer, o imaginário onírico estabelece uma associação entre a serpente (Agamêmnon morto), o sangue (tanto o derramado no passado quanto o que será derramado no futuro) e a vingança (Orestes), de modo que o sonho prenuncia a ruína dos assassinos do Atrida como uma reparação à sua morte.

Também nas Coéforas esses mesmos elementos aparecem associados. A configuração onírica, no entanto, é diferente, de modo que se somam a esses elementos a relação entre mãe e filho através das imagens de geração (тยкє̃̃v, Co. 527), cuidado

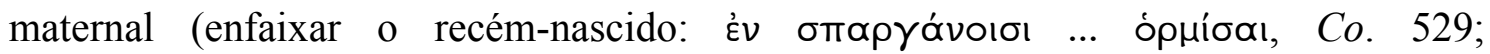

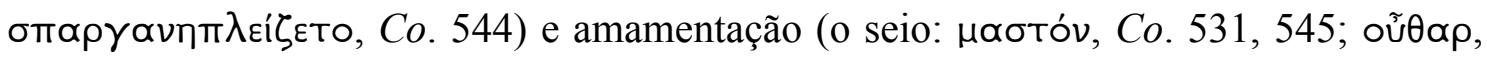

\footnotetext{
${ }^{13}$ Costuma-se atribuir o sonho profético da Clitemnestra esquiliana a uma influência dessa obra perdida de Estesícoro. Sófocles, em sua Electra, narra igualmente um sonho profético. Crisótemis diz à sua irmã o seguinte a respeito do sonho da mãe: "Disse que nosso pai reapareceu / aos olhos dela vivo e que empunhou / o cetro ancestre, o mesmo que hoje Egisto / agita. O finca ao chão e dele aflora / um

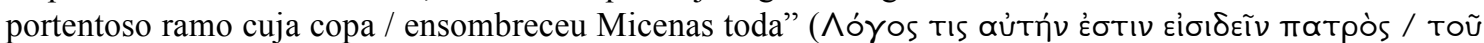

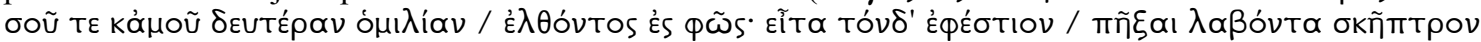

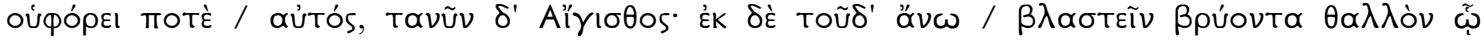

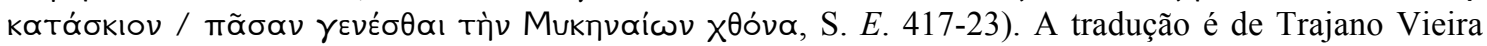
(2009). Bowman (1997, p. 138) fazendo um estudo comparativo entre o sonho de Clitemnestra nas Coéforas e na Electra sofocliana, observa o seguinte: "The use of the dream in the Elektra mirrors that of the Choephoroi in terms of the identity of the dreamer and the way in which the dream (and her fear) is used to motivate the sacrifice at Agamemnon's tomb. The content of the dream in Sophokles' play, however, is modelled rather on the two dreams of Astyages in Herodotos' Histories". Outra diferença digna de nota entre as duas tragédias é, segundo a autora, o fato de que o sonho em Electra "remains formally uninterpreted by anyone in the play, although the events of the play clearly fulfil it and resolve its terms" (p. 134). Para Lill (2003, p. 187), "The most important change in the dream elements in Sophocles is connected with the agents who are represented in the dream. In Aeschylus these are Clytemnestra and the serpent. In Sophocles the central figure is Agamemnon. Clytemnestra manipulating the serpent is in Sophocles replaced by Agamemnon manipulating his sceptre. Nurturing the serpent is replaced with putting the sceptre into the hearth. Thus, the serpent and the sceptre are in the parallel position in the two dreams". Para a autora, essa diferença reflete uma diferença na orientação da tragédia: "From the domestic, family oriented sphere in Aeschylus the interest of Sophocles is shifted towards the socially oriented themes. The sceptre in the dream is the sign of power" (p. 195).

${ }^{14}$ A edição do fragmento é de Page (1962) e a tradução é nossa.
} 


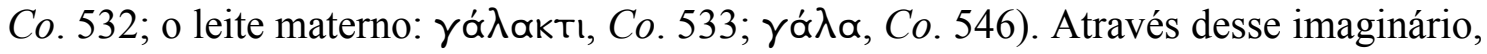
Orestes surge, portanto, não apenas como o vingador do pai, mas sobretudo como o matador da mãe.

Assim, num primeiro nível de intepretação, Agamêmnon é a serpente e o fato de essa serpente causar dor e horror ao ferir Clitemnestra é um indício da cólera do falecido rei, que deve ser aplacada. Essa é a interpretação dos adivinhos do palácio e é legítima, pois, como disse o Coro, eles falaram "garantidos pelo Deus" ( $\theta \varepsilon o ́ \theta \varepsilon v ~ . .$.

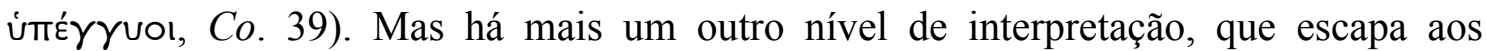
intérpretes do sonho e à própria Clitemnestra, e que somente Orestes, por ter conhecimento do oráculo de Apolo que lhe foi entregue e por ser "perito em prodígios" (тврабко́тор, Co. 551), consegue perceber: essa serpente é também Orestes. Esse é o elemento-chave de sua interpretação do sonho; é o elemento que torna o sonho

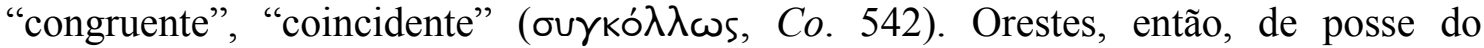
conteúdo do sonho de Clitemnestra, apropria-se do papel de intérprete, antes delegado aos adivinhos do palácio, e o interpreta (кpívw, Co. 542):

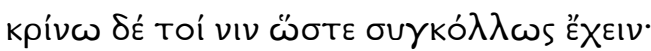

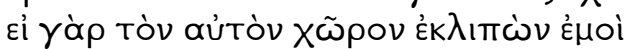

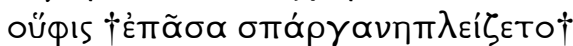

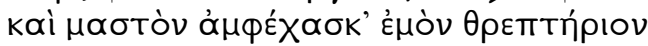

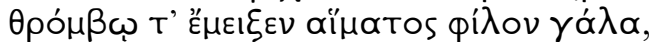

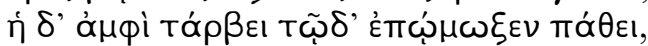

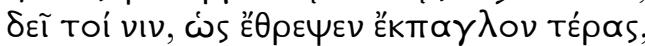

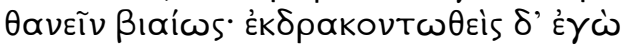

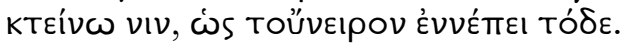

Interpreto-o de modo a ser congruente: se surgiu do mesmo lugar que eu a serpente e enfaixada como criança abocanhava o seio que me nutriu e mesclou leite a coágulos de sangue e ela apavorada pranteava este mal, porque nutriu hórrido prodígio, deve ter morte violenta e tornado serpente eu mato-a - como conta este sonho.

(Co. 542-50)

Sua interpretação estrutura-se na forma de um período hipotético - se (Eỉ, Co. 543 ) -, em que várias prótases se acumulam e cuja apódose constitui o prenúncio "deve

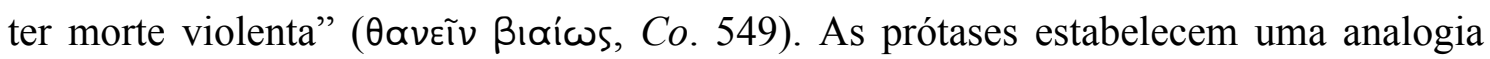
entre a serpente e Orestes. Clitemnestra deu à luz uma serpente assim como deu à luz Orestes; ela envolveu a serpente em faixas, tal como o fez com o pequeno Orestes; para alimentá-la, Clitemnestra ofereceu o leite materno, exatamente como o fizera com Orestes. Até esse momento, o que fundamenta a analogia entre Orestes e a serpente é a relação entre mãe e filho: a geração, o cuidado, a nutrição. A serpente, porém, ao sugar

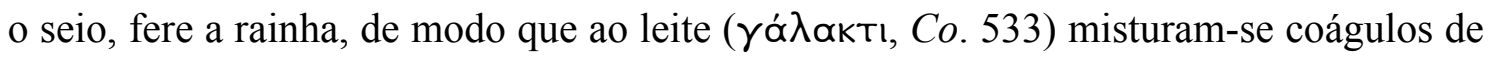

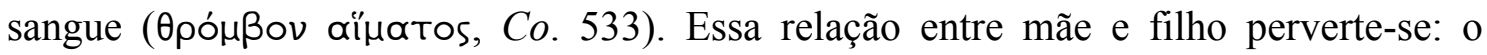


alimento materno tinge-se de sangue ${ }^{15}$. Clitemnestra apavora-se (тó $\rho \beta \varepsilon l$, Co. 547),

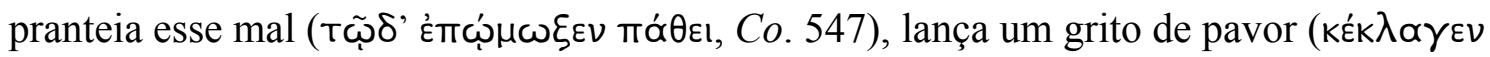

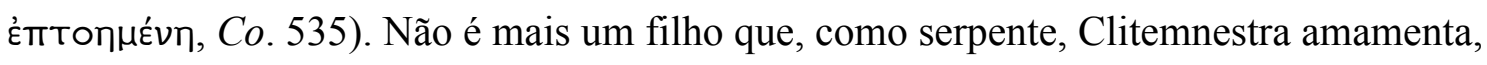

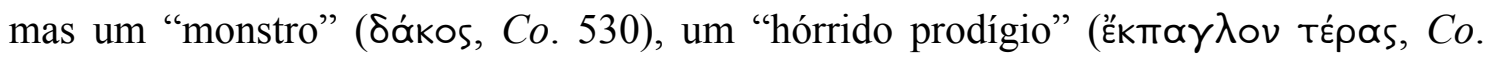
548). A analogia, no entanto, mantém-se: assim como a serpente tirou sangue de Clitemnestra, provocando-lhe pavor e horror por ter nutrido esse terrível prodígio, também Orestes tirará sangue de Clitemnestra, dando-lhe uma morte violenta. Para

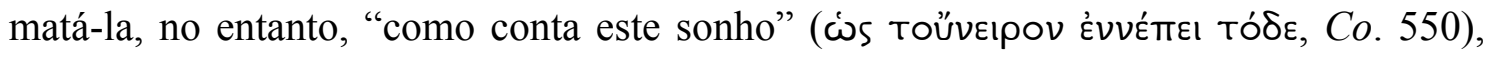
Orestes precisará não mais ser tal como uma serpente, mas sim se transformar numa

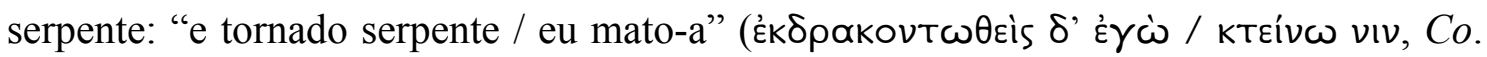
549-50). Para cumprir o que o sonho prenuncia, Orestes deve passar de uma analogia a uma identificação.

Assim identificado com esse animal que tem um forte sentido ctônio, será, portanto, através de Orestes que o rancor do morto e das potestades infernais irá se manifestar, do mesmo modo como, em Agamêmnon, através da ação criminosa da rainha se manifestou o terrível nume que habita o palácio dos Atridas ( $A g$. 1497-504).

Note-se, porém, que a imagem da serpente esteve até então associada a Clitemnestra. Pela monstruosidade de suas ações, Cassandra, em Agamêmnon,

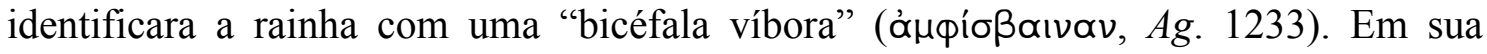
prece a Zeus, após o reconhecimento de Orestes e Electra, ele descreve Clitemnestra

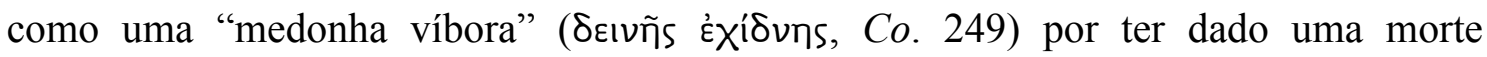
ignominiosa a seu pai. Após a morte de Clitemnestra e Egisto, Orestes chama-a "moreia

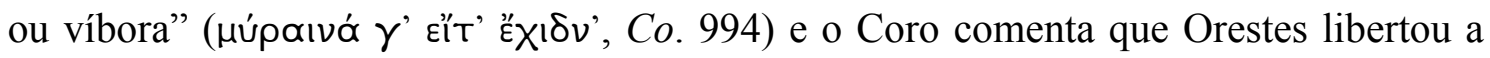

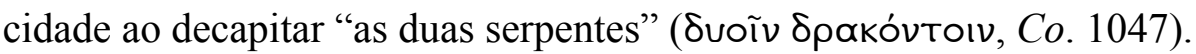

Orestes, por sua vez, associa-se à imagem da águia, inimiga tradicional da serpente $^{16}$. Na prece que dirige a Zeus no primeiro episódio, Orestes pede ao deus que, testemunhando a presente situação em que se encontram os filhos e o palácio do grande Agamêmnon, não deixe ser destruída a "geração da águia" (đỉєtoũ $\gamma \varepsilon ́ v \varepsilon \theta \lambda$ ', Co. 258). Orestes e sua irmã são assim descritos como "a prole órfã da águia" ( $\gamma$ Évvav eũvıv

\footnotetext{
${ }^{15}$ Para uma análise dessa imagem, conferir o artigo de Chiesi (2011), "Reading Aeschylean images: Matricide and the blood in maternal milk in Clytemnestra's dream".

${ }^{16}$ Aristóteles observa que "a águia e o dragão são inimigos, porque a primeira se alimenta de serpentes"

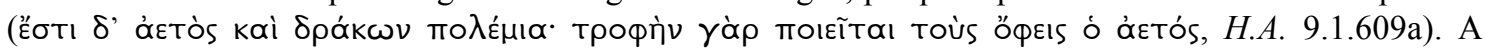
tradução é de Maria de Fátima Sousa e Silva (2008). Segundo Pérez (2010, p. 9), "It was Aeschylus who extensively used the natural symbolism of the eagle and the snake. His trilogy, especially the Libation Bearers, is one of the most important sources for the symbolism of the eagle and the snake".
} 


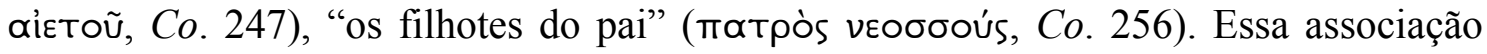
entre a águia e Agamêmnon retoma a que já havia sido feita em Agamêmnon em dois momentos: no símile em que os dois Atridas são comparados a aves de rapina cuja prole fora roubada ( $A g$. 49-54) e no auspício das aves, quando o adivinho vê nas duas águias a devorar uma lebre prenhe os dois Atridas (Ag. 123-5).

A águia, como se sabe, é um animal nobre. A serpente, por outro lado, é um animal assustador e traiçoeiro ${ }^{17}$. Orestes, enquanto vingador do pai, identifica-se com a águia de que é filho. No entanto, para executar a sua vingança, ele deve não apenas matar Egisto, mas também a sua própria mãe e, para matá-la, ele deve abandonar sua identificação com a águia e tornar-se uma serpente, de que igualmente é filho ${ }^{18}$.

A identificação de Clitemnestra com uma serpente ressalta o que há de monstruoso no crime que ela cometeu - a esposa que mata o marido - e a identificação de Orestes com a serpente ressalta igualmente o que há de monstruoso na vingança de Orestes - o filho matar a mãe. O sonho de Clitemnestra não é portanto apenas um prenúncio de uma vingança, pura e simplesmente, mas também o prenúncio de um matricídio, em que estão implicadas terríveis consequências. A imagem da serpente não se esgota, portanto, em Clitemnestra e em Orestes; as Erínies, que buscam vingança pelo matricídio, são comparadas por Orestes, nas Coéforas, e pela Pítia, nas Eumênides,

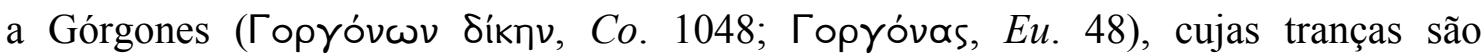
“serpentes" (Spákovoıv, Co. 1050). Nas Eumênides, o seu furor é comparável ao de

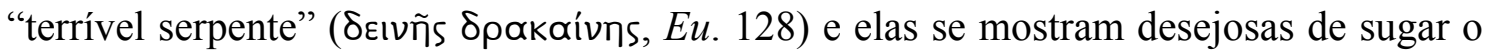
sangue de Orestes (Eu. 264-6). A vingança de Orestes, à medida que passa pelo matricídio, torna-se um crime que, assim como o de Clitemnestra e dos demais membros da família dos Atridas, demanda punição ${ }^{19}$.

\footnotetext{
${ }^{17}$ Aristóteles, ao falar sobre a diversidade de caráter dos animais, diz que as cobras são vis e pérfidas

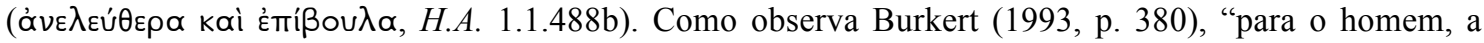
cobra é um animal pura e simplesmente aterrador, inquietante na forma e no comportamento, com aparições imprevisíveis". Pérez (2010, p. 9, n. 45), em "Contextualizing Symbols: "the Eagle and the Snake' in the Ancient Greek World", faz, no entanto, a seguinte observação: "It is worth noting that in these kind of literary similes, and also in the fables, the snake is the animal negatively characterised. To some extent, writers forgot to look on the 'bright (though not less disturbing) side' of the snake, that side in which it appeared as giver (and also thief) of life, immortality, fertility and owner of the ancestral knowledge".

${ }^{18}$ Pérez (2010, p. 10) ressalta: "For this dire act to be carried out, Orestes must irst become the mother, the snake, to avenge the eagle, the father. [...] Nevertheless, there is only one snake, Clytemnestra; Orestes becomes one in obeying Loxias' oracle but he 'is' not one. Actually this rich imagery in the Oresteia clearly relects the contradictory problems that the 'lex talionis' entails.

${ }^{19}$ Goldhill (2004, p. 56) faz a seguinte observação: "Orestes declares himself a monster, a snake, an agent of violence - all words that resonate with other moments of intrafamilial violence in the house of
} 
Tendo Orestes assim interpretado o sonho, o Coro exclama: "Elejo-te por isto

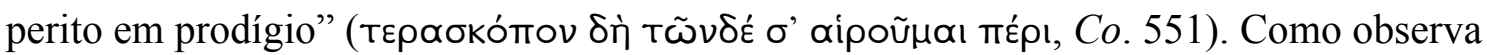
Roberts (1985, p. 283-297), o termo "perito em prodígio" (тєрабко́то৩) associa Orestes a outros personagens da trilogia que também possuem, com maior ou menor extensão, conhecimento divinatório: Calcas, que, após ver o auspício das aves, “disse o

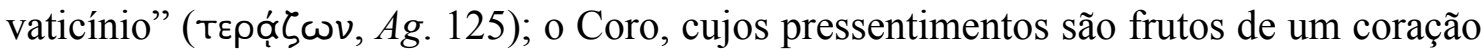

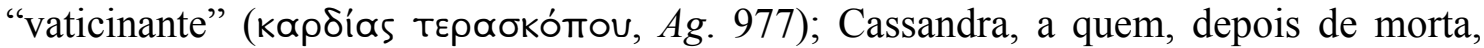
Clitemnestra se refere, entre outros atributos menos elogiosos, como "adivinha" (тєр๔бко́тоо, $A g .1440$ ); e, por fim, o próprio deus Apolo, que, dentre as qualidades que lhe são atribuídas pela Pítia, está a de "intérprete de signos" (тєрабко́тоо, Eu. 62). Orestes, no entanto, não se associa a esses personagens apenas por sua habilidade em interpretar o sonho de Clitemnestra, mas também pelo fato de, tendo sido o destinatário de um oráculo pítio, possuir conhecimento dos desígnios divinos.

Contudo, Orestes, ao mesmo tempo em que figura como um exímio intérprete de sinais divinatórios, também figura como aquele que os cumpre. É por meio dele que se cumprem a profecia que Cassandra fizera em Agamêmnon, as preces e as imprecações de Electra, o oráculo de Apolo, o sonho profético de Clitemnestra nas Coéforas e todo e qualquer sinal divinatório que, em maior ou menor grau, nesta ou na tragédia anterior, apontam na direção da morte dos assassinos de Agamêmnon. O sonho profético de Clitemnestra parece ser o último sinal numinoso de que Orestes necessitava para pôr em ação a sua vingança.

\subsection{2) Os sinais do reconhecimento}

Pode-se dizer que há duas cenas de reconhecimento nas Coéforas: a de Orestes e Electra e a de Orestes e Clitemnestra. Esses reconhecimentos se dão como o desvendar de um enigma e ambos, uma vez desvendados, prenunciam um acontecimento significativo. O reconhecimento entre Orestes e Clitemnestra, no entanto, passa antes por um desconhecimento, pois Orestes encobre sua verdadeira identidade, que só é revelada através da execução de sua vingança ${ }^{20}$.

Agamemnon. The prophecy, as it foretells the matricide, also binds Orestes into the narrative of the family curse".

${ }^{20}$ A respeito da cena de reconhecimento entre Orestes e Electra, conferir Brown (1961), Mejer (1979), Jouanna (1997), Zeitlin (2012). 
Inicialmente, a identidade de Orestes é um enigma tanto para Electra quanto para Clitemnestra. Quando Electra desvenda esse enigma, ela se depara com um acontecimento auspicioso, que prenuncia a realização de seu maior desejo, vingar o pai. Quando, todavia, Clitemnestra desvenda esse enigma, ela se depara com a própria morte.

No prólogo, Orestes avista um grupo de mulheres trazendo libações para o túmulo de seu pai. Dentre elas, Orestes reconhece sua irmã: "Não é outra! Creio

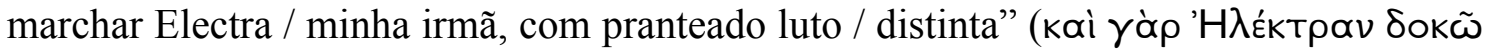

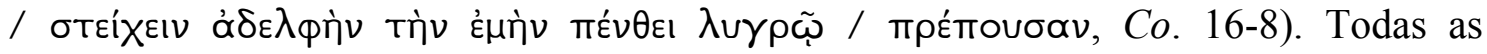
mulheres vestem-se de preto e isso chama a atenção de Orestes, pois as torna distintas

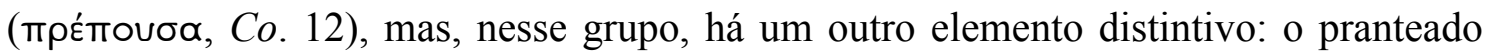

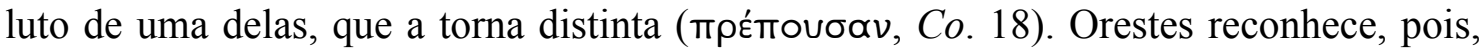
sua irmã pelo seu destacado sofrimento. E assim, Orestes, na companhia de Pílades, afasta-se para mais bem observar essas mulheres.

No primeiro episódio, diante do túmulo do pai, Electra consulta o Coro a respeito de que palavras pronunciar no momento de verter as libações: dizer, sarcasticamente, que são oferendas enviadas por uma querida esposa ao querido marido; pedir destino igual ao do morto aos que lhe enviaram essas dádivas; ou por fim derramá-las no mesmo ignominioso silêncio em que o rei foi assassinado. A preocupação de Electra em escolher palavras adequadas é compreensível quanto se tem em mente que o derramamento de libações fúnebres sobre o túmulo é um ritual solene e, por isso, deve-se atentar para o que é dito nesse momento.

O Coro sugere que ela se aproprie das oferendas e as verta em seu próprio nome, subvertendo o propósito pelo qual a rainha as enviou, de modo a adequá-las aos seus próprios interesses. Assim, ao invés de serem propiciatórias a quem as enviou, passam a ser propiciatórias aos inimigos de quem as enviou.

Primeiramente, o Coro a aconselha a pronunciar votos favoráveis aos amigos de seu pai; ou seja, àqueles que odeiam Egisto. Electra, pergunta então quem deveria ainda acrescentar a essa "sedição" (бтóoєı, Co. 114), termo em que se explicita a subversão do propósito das libações que estão para ser derramadas. Para o Coro, parece certo

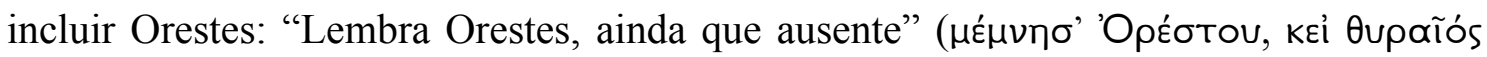

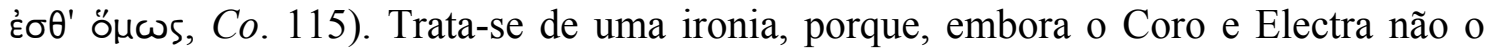
saibam, Orestes está presente. 
Em segundo lugar, tendo em mente os culpados pela morte de Agamêmnon, o

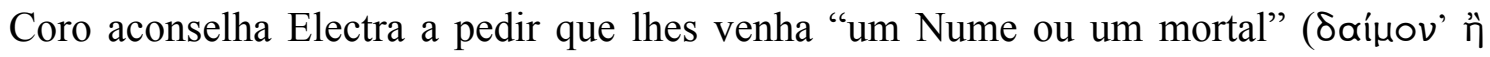

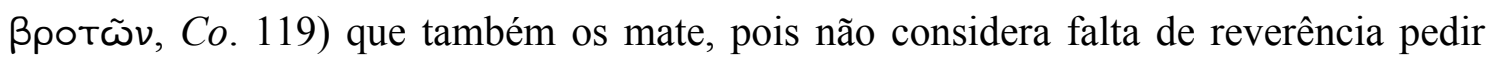
aos deuses que retribuam os males aos inimigos. Sem que o saibam, Orestes é os dois ao mesmo tempo: mortal e numinoso, visto que ele retorna a Argos tanto na condição de ser o cumprimento de uma profecia - Cassandra prenunciou que ele voltaria (Kó́tยıoıv, Ag. 1283) -, quanto na condição de dar cumprimento a uma profecia de Apolo - o deus

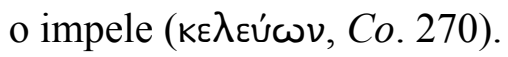

Electra, então, invoca primeiramente Hermes Ctônio, para que o deus, na condição de arauto, proclame suas preces às potestades subterrâneas. Invocando o pai, fala da terrível situação em que se encontram: ela mesma vive como uma escrava em seu palácio e Orestes foi banido do país e das riquezas paternas, das quais unicamente desfrutam os assassinos usurpadores do trono. Assim, ela suplica que o pai propicie o

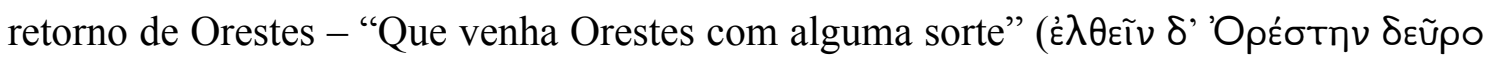
бùv Túxṇ tıvì, Co. 138). Para os inimigos de Agamêmnon, ela pede que "com justiça" ( $\delta i ́$ iṇ, Co. 144) sejam mortos pelas mãos de seu vingador.

Note-se que a prece de Electra se assemelha à de Orestes no prólogo. Ambos

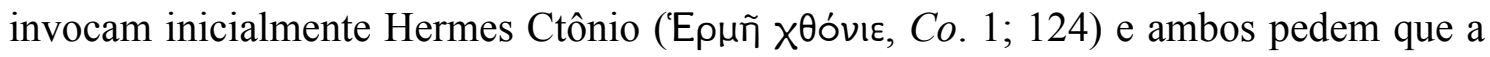

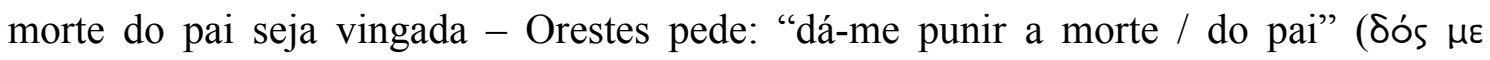

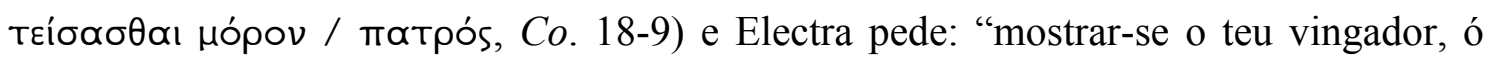

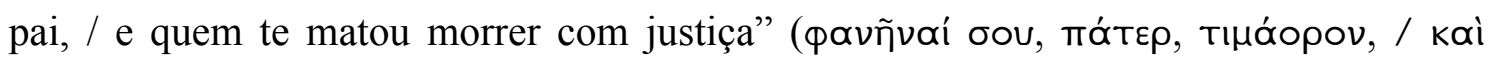

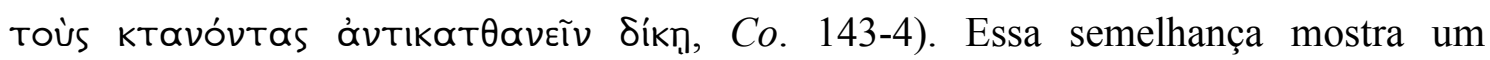
paralelismo entre os irmãos e prefigura a cena de reconhecimento, pois o reconhecimento entre eles é mais do que a descoberta de uma identidade; é também a identificação de destinos comuns.

Essa prece pela morte de Clitemnestra e Egisto, feita em meio a um ritual fúnebre, cuja solenidade é sublinhada pelo Coro ao dizer que respeita como um altar o túmulo de Agamêmnon (Co. 106), converte-se, dessa forma, em uma maldição, como bem nota Electra quando diz: "Isso ponho no meio desta bela prece / dizendo para eles

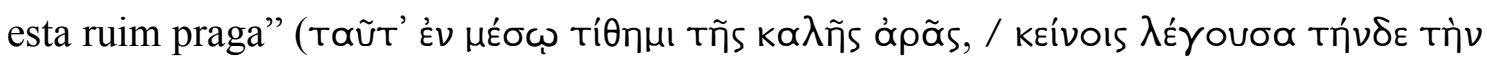
кakìv ápóv, Co. 145-6). Assim, ao poder da autoridade dos que agora reinam Electra

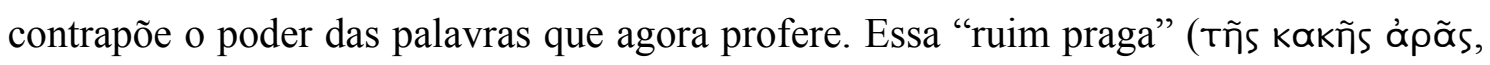


Co. 146) pronunciada por Electra, torna-se assim um sinal a prenunciar a morte de Clitemnestra e de Egisto.

O derramamento das libações é acompanhado do lamento do Coro, em que se reitera a súplica por retaliação à morte do rei com a vinda de um vingador. $\mathrm{O}$ fim do ritual fúnebre é seguido do primeiro indício de que as preces de Electra e do Coro foram atendidas:

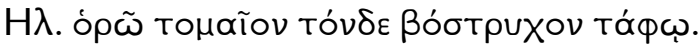

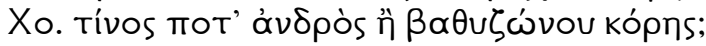

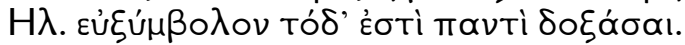

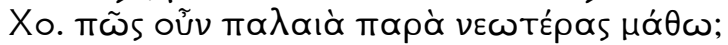

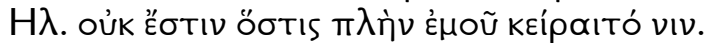

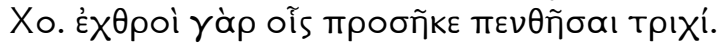

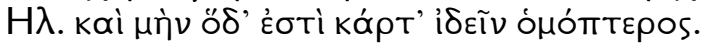

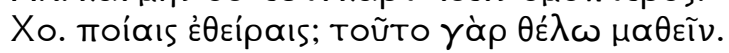

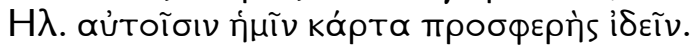

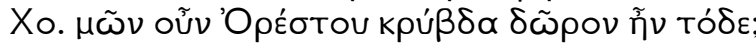

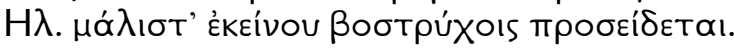

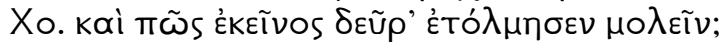

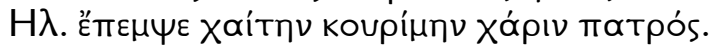

El. Vejo esta madeixa cortada na tumba.

Co. De que homem ou moça de funda cintura?

El. Bom sinal isto pode parecer a todos.

Co. Como aprender, velha junto à nova?

El. Não há quem além de mim cortaria?

Co. Tem ódio quem devia oferecer cabelo.

El. Ora, isto é pluma símil de se ver.

Co. A quais cabelos? Isto quero saber.

El. A nós mesmas muito símil de se ver.

Co. Isto seria oculta dádiva de Orestes?

El. Muito se assemelha às madeixas dele.

Co. E como teve ousadia de vir aqui?

El. Enviou a crina cortada por amor do pai. (Co. 168-80)

A primeira consideração que Electra faz ao ver uma mecha de cabelos é a de que

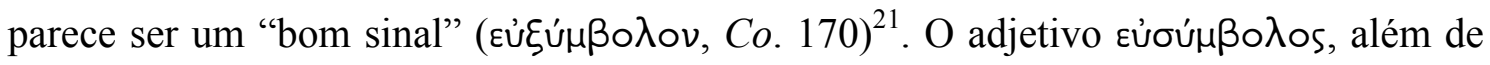
significar "auspicioso", pode significar também "fácil de adivinhar" ou "fácil de

\footnotetext{
${ }^{21}$ A mecha de cabelo como instrumento da anagnórisis parece ter estado presente na Oresteia de

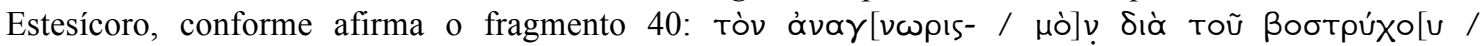

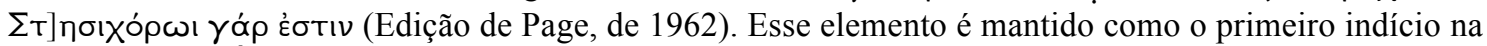
obra não só de Ésquilo, mas também de Sófocles e de Eurípides. Na Electra euripidiana, a personagem homônima desdenha, no entanto, da credibilidade desse indício encontrado pelo Ancião na tumba de Agamêmnon: "como conferir o cacho de cabelo, / o de nobre varão, crescido nos estádios, / e o feminino, penteado? Não é possível. / Em muitos verias madeixas semelhantes, / velho, e em não natos do mesmo

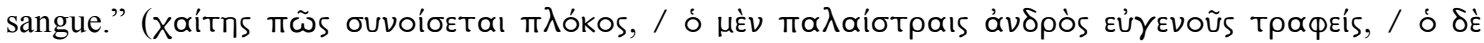

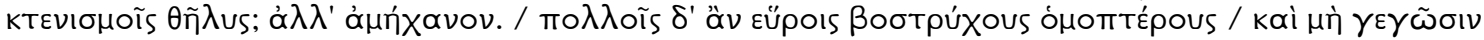

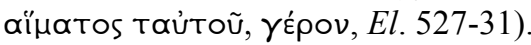


entender". Em ambos os casos, ilustra a atitude de Electra ante a mecha de cabelos que ela avista: é um sinal, um indício, um augúrio ( $\sigma u ́ \mu ß ం \lambda \circ \varsigma$ ) que ela tem de interpretar. Ela baseia sua interpretação em dois aspectos: na semelhança da mecha com seus

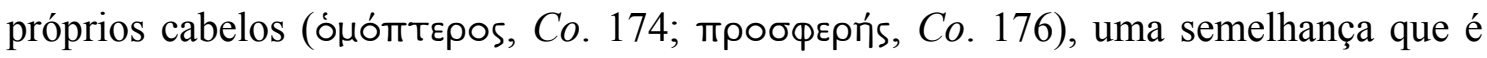

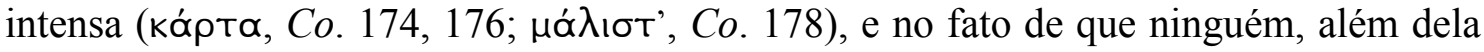
mesma, ofereceria essa dádiva ( $\delta \tilde{\omega} \rho o v, C o .177)$ ao túmulo paterno, pois "tem ódio

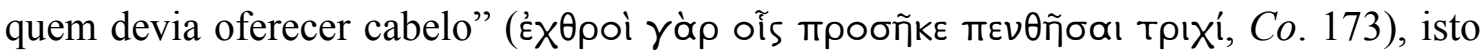
é, Clitemnestra. O Coro antecipa-se à sua dedução: seria, portanto, uma dádiva de Orestes? E, sendo de Orestes, como ele teria tido a ousadia de vir até o túmulo do pai? Electra considera então a possibilidade de ele não ter estado presente, mas ter enviado uma mecha de seus cabelos. O Coro comenta que ainda assim isso seria deplorável, "se

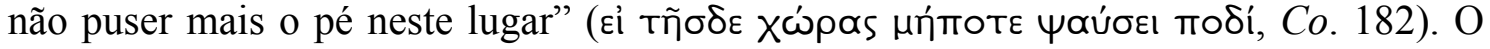
Coro, sem o saber, prenuncia o segundo indício: aquele deixado pelas pegadas dos pés de Orestes ${ }^{22}$.

Sendo assim, esse primeiro indício aponta tanto para a existência de Orestes (ou seja, ele ainda estaria vivo) quanto para a sua devoção ao pai, pois o gesto ritual de dedicar uma mecha de cabelo sobre o túmulo indica um respeito piedoso para com o

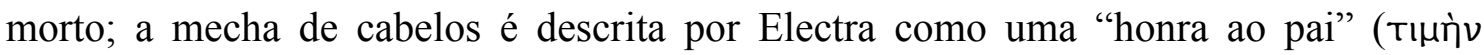
татрós, Co. 200). É assim um símbolo tanto de sua pessoa quanto de sua piedade filial. Electra também demonstra esse mesmo respeito piedoso para com o falecido pai, de modo que a semelhança física que se enfatiza entre os cabelos dos irmãos reflete uma semelhança de atitude ante a morte do pai e, principalmente, de propósito: vingar Agamêmnon.

Electra, então, é tomada por uma dúvida assoladora. Por um lado, pelo indício,

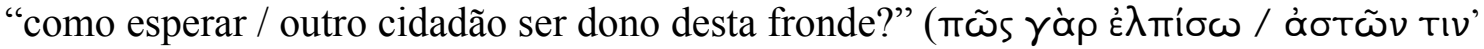

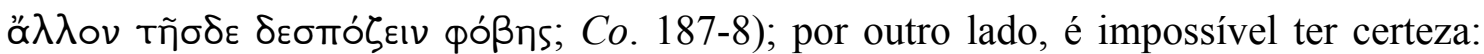
"como anuir direto a isto, / ser este adorno do mortal que eu mais / amo, Orestes?"

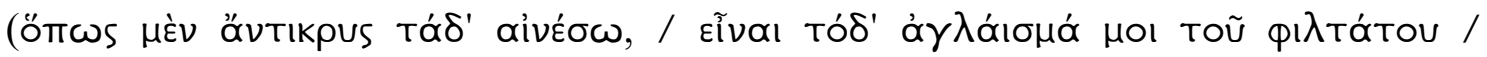

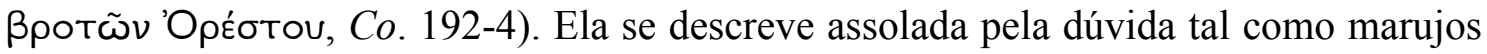
pelas tempestades e invoca os deuses, pois só estes poderiam, com seu conhecimento, propiciar-lhe a serenidade advinda da certeza. Nesse momento, ela vê mais um indício:

\footnotetext{
${ }^{22}$ Lebeck (1971) observa que "the phrase is more than heightened diction or poetic periphrasis for "if Orestes never returnes'. It is periphrasis prophetic of the action".
} 


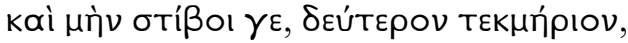

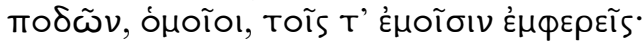

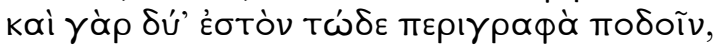

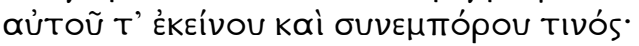

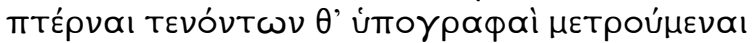

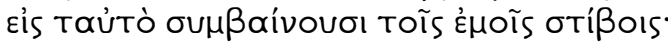

Eis vestígios - segundo indício de pés, similares, e parecidos aos meus, pois estes dois traços são de dois pés, dele mesmo e de algum companheiro; talões e traços de nervos, quando medidos, coincidem no mesmo com minhas pegadas.

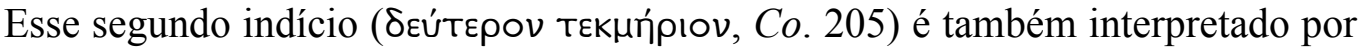
Electra tendo por base a semelhança; desta vez, entre as pegadas deixadas pelos pés do irmão com as pegadas deixadas pelos seus próprios pés. A semelhança é novamente

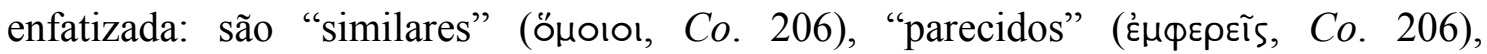
“coincidem" (oupßaívovoı, Co. 210) ${ }^{23}$. A descoberta de outro par de pegadas, que Electra conjectura, acertadamente, ainda que ela não o saiba, pertencerem a algum companheiro de Orestes, reforça, pela diferença, a semelhança entre as suas pegadas e as de Orestes. Novamente, a semelhança física reflete a comunidade de destinos entre os dois. Orestes é aquele que partiu, enquanto ela permaneceu. Esse novo indício, no entanto, é um sinal de que Orestes retornou a Argos, de que o ausente se faz presente.

O segundo indício é seguido imediatamente de sua materialização, pois, deixando o seu esconderijo em cena, Orestes surge diante de Electra, que exclama:

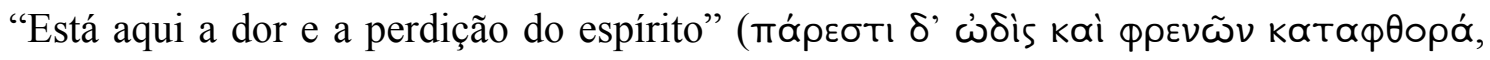
Co. 211). Lebeck (1971, p. 109) observa que esse verso é usualmente compreendido como uma expressão do conflito de Electra causado pela dúvida, mas, segundo a autora, ainda que seja certamente o que Electra quer dizer, não é o que ela realmente diz.

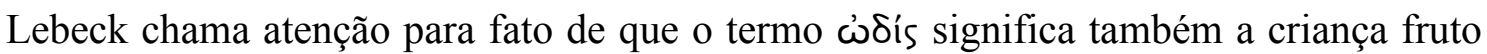
de um parto doloroso, difícil, e que, portanto, teria um sentido ominoso: "the child whose birth ends in his mother's death". Igualmente, a "perdição do espírito" ( $\phi \rho \varepsilon \nu \tilde{\omega \nu}$

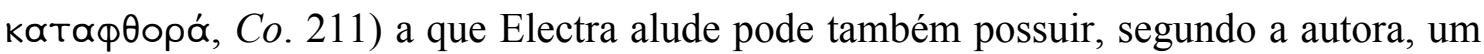

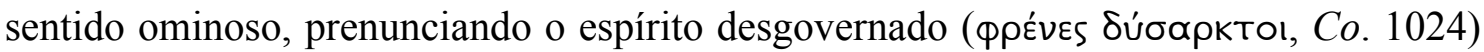
de Orestes após o matricídio.

O surgimento de Orestes ante seus olhos não é, no entanto, suficiente para convencê-la da identidade de seu irmão. Ela pergunta: "Qual ganho tenho agora dos

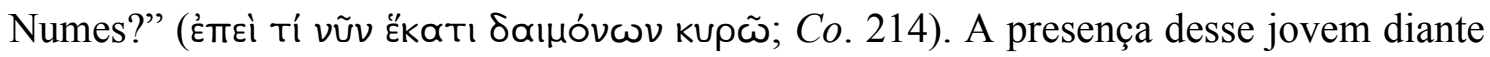

\footnotetext{
${ }^{23} \mathrm{Na}$ Electra de Eurípides, a personagem homônima também desdenha desse segundo indício: "Como haveria no chão rochoso da terra / as impressões dos pés? Se há pegadas, / não seriam iguais os pés de

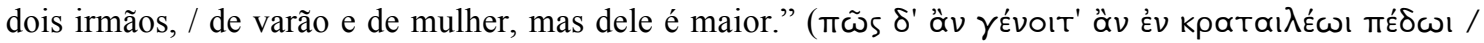

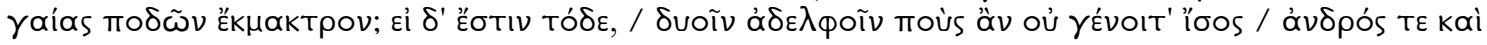

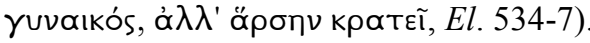


dela é-lhe tão enigmática quanto os indícios por ela encontrados e, por essa razão, Electra atribui isso aos numes.

Embora Orestes lhe diga que suas preces foram atendidas, que ele é o mortal por quem ela clamava, e que diga claramente: "Sou ele, não busques mais perto que eu"

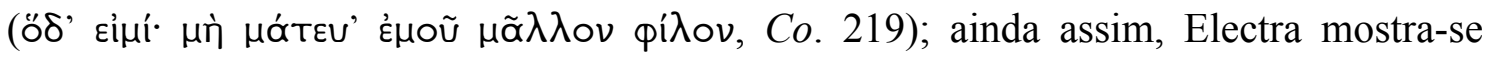

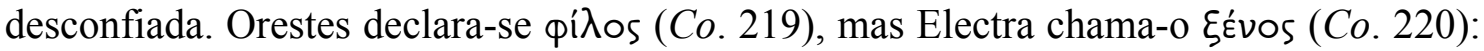

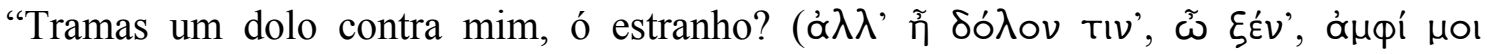

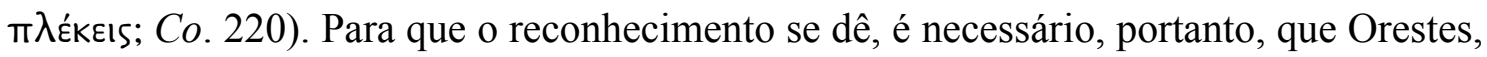

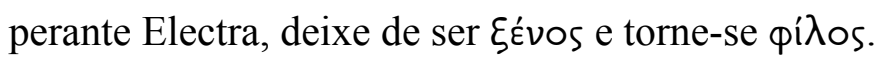

O reconhecimento entre eles não é apenas um reconhecimento de identidade, mas de um destino comum. É esse destino comum que se enfatiza nas palavras de

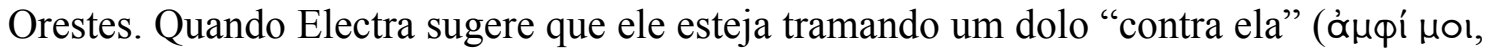
Co. 220), Orestes diz que, se assim o fizesse, estaria tramando "contra mim mesmo" (aútòs kat' aútoũ, Co. 221). Da mesma forma, quando Electra sugere que ele deseja rir dos males dela - "Mas no meio de meus males queres rir?" (á $\lambda \lambda$ ’ '́v kakoĩoı Toĩs

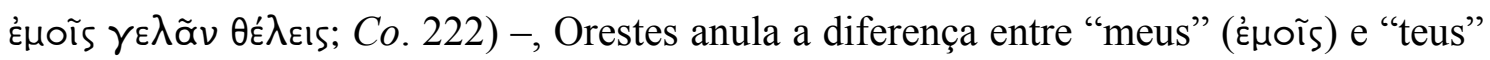

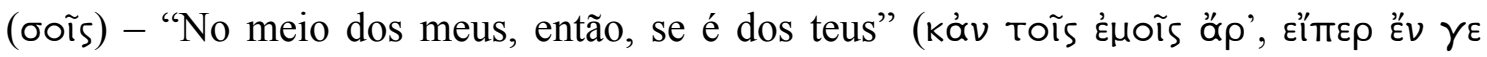
тoĩol бoĩs, Co. 223). E, finalmente, ao falar dos parentes, ele recorre ao pronome

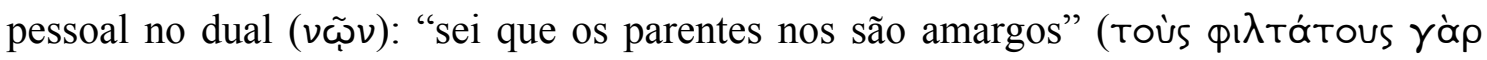

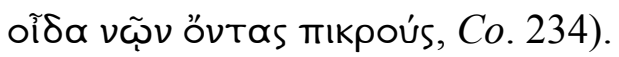

A prova cabal desse destino comum vem sob a forma de um terceiro indício, apresentado após uma recapitulação dos indícios anteriores, cuja assertividade é validada:

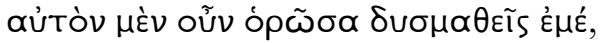

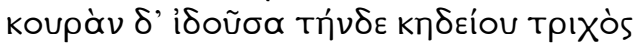

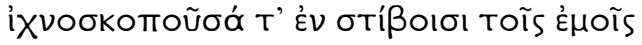

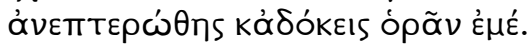

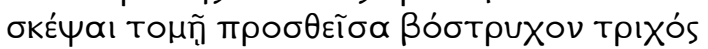

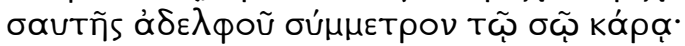

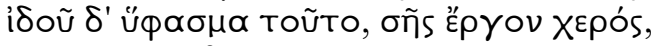

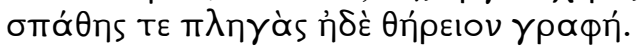

Quando vês a mim mesmo, mal reconheces, mas ao vires esta mecha de cabelo na tumba, e sondares vestígios de minhas pegadas, arrepiaste as asas e creste que me vias. Examina perto do corte a madeixa de teu irmão, parecida com tua cabeça. Vê esta veste trabalhada por tua mão, a imagem animal da espátula e batente.

(Co. 225-32)

Orestes aponta para uma contradição, fruto da desconfiança e da dúvida de

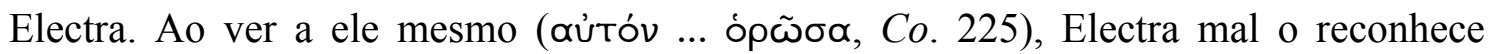

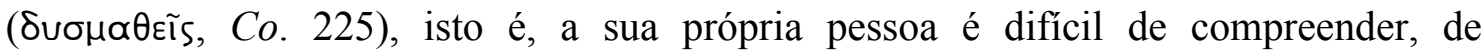


reconhecer. Porém, quando Electra viu os indícios de sua pessoa - a mecha de cabelos e

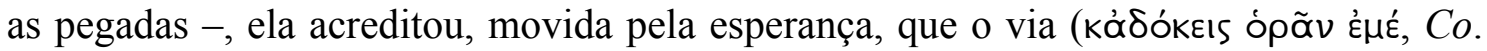
228). Assim, o terceiro indício é apresentado por ele mesmo em pessoa: Orestes lhe mostra uma veste bordada por Electra ${ }^{24}$.

Esse terceiro indício, além de ser apresentado pelo próprio Orestes, estabelece uma conexão irrefutável entre eles, pois a veste que está agora em suas mãos foi

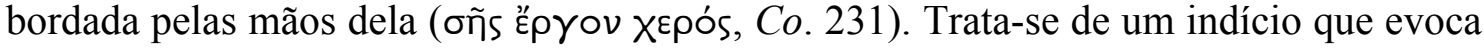
uma infância compartilhada por ambos. Só então Electra se convence da verdadeira identidade de seu irmão, a única que lhe seria possível reconhecer: a de um Orestes criança, a quem ela, irmã mais velha, tecera uma veste ${ }^{25}$. A partir desse momento,

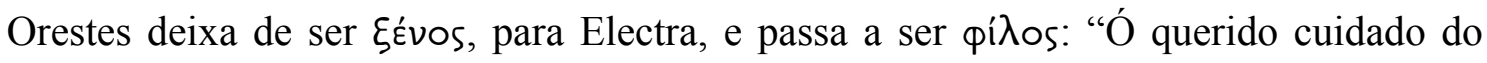

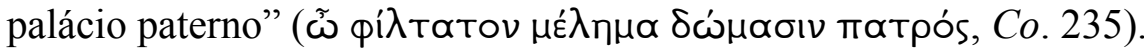

Esse reconhecimento/reencontro entre os irmãos é um acontecimento auspicioso. Ao mesmo tempo em que se tornou possível em função de dois sinais divinos - o oráculo de Apolo, que ordenou que Orestes retornasse a Argos para vingar o pai, e o sonho profético de Clitemnestra, que fez com que Electra saísse do palácio e fosse até o túmulo do pai levar libações - e que é a realização das preces de Electra de que Orestes

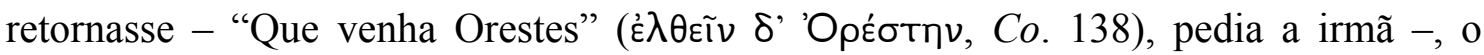
reconhecimento/reencontro em si torna-se um sinal divino a prenunciar o cumprimento tanto do oráculo de Apolo quando do sonho de Clitemnestra.

Há de se lembrar novamente que o retorno de Orestes é o cumprimento das profecias de Cassandra. A profetisa menciona, primeiramente, o filho de Agamêmnon

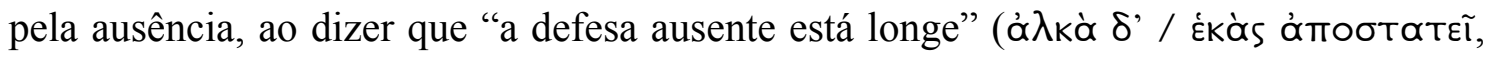
Ag. 1103-4). Essa ausência, no entanto, findará, pois, diz Cassandra:

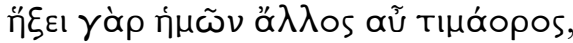

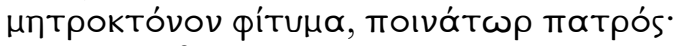

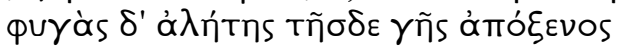

um outro punidor por nós há de vir, matricida rebento, vingador do pai. Exilado errante estranho a esta terra

\footnotetext{
${ }^{24} \mathrm{Na}$ Electra de Sófocles, o terceiro e definitivo indício da identidade de Orestes é um anel pertencente a

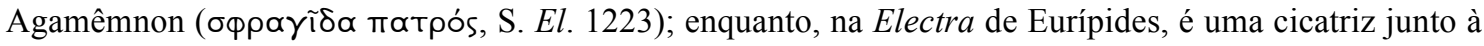

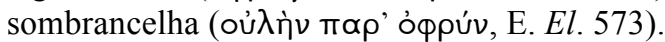

${ }^{25}$ É impossível determinar a idade de Orestes ao ser exilado, assim como é impossível determinar quanto tempo se passou entre o assassinato de Agamêmnon e o retorno de Orestes. Na Odisseia, diz-se que

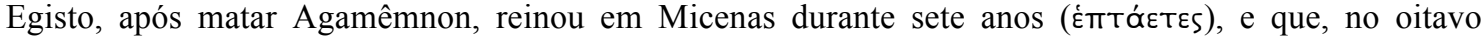

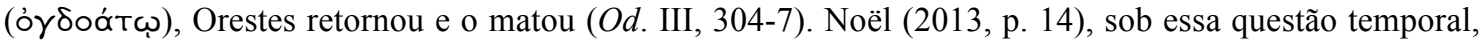
observa o seguinte: "La gradation des indices donne à voir le mouvement même par lequel Oreste revient vers Électre et se matérialise littéralement devant elle: la mèche, puis le pas, qui est présenté comme un moulage du pied, puis Oreste en personne, porteur du tissu cadeau d'Électre autrefois. Il s'agit d'une solution dramaturgique pour montrer au spectateur la temporalité de ce retour".
} 


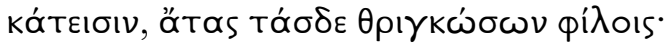

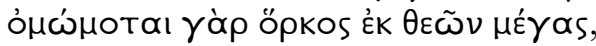

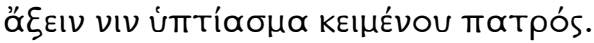

voltará para coroar a ruína dos seus.

Há de conduzi-lo o pai supino em jazigo. (Ag. 1279-84)

Forma parte da profecia de vingança de Orestes a condução de Agamêmnon de seu túmulo. Esse é, pois, o objetivo do longo kommós. Esse canto fúnebre, aqui entoado pelo Coro, por Electra e por Orestes, tem por finalidade estabelecer uma comunicação com o falecido Agamêmnon e formar com ele uma aliança, pedindo-lhe auxílio e proteção na execução de sua vingança.

Uma das atribuições do Coro que podem ser observadas no kommós é guiar as invocações e as súplicas dos dois irmãos, mostrando-se sempre atento ao aspecto auspicioso ou ominoso das palavras pronunciadas por Orestes e Electra ${ }^{26}$. Assim como no ritual em que Electra verte as libações sobre o túmulo de seu pai, também neste canto fúnebre, igualmente realizado junto ao túmulo de Agamêmnon, deve-se atentar às palavras pronunciadas. Como observa o Coro, "o lamento legítimo busca / punição,

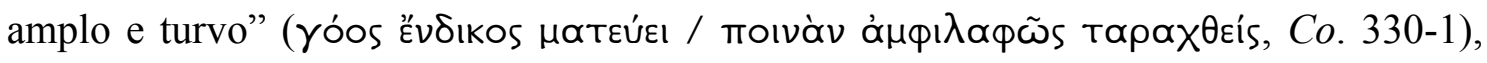
isto é, o lamento fúnebre é uma forma assegurar a punição aos assassinos de Agamêmnon.

Os irmãos principiam, assim, lamentando a morte de Agamêmnon e lhe descrevendo como eles, seus filhos, encontram-se em uma terrível situação, exilados de seu próprio lar. A essa lamúria o coro contrapõe palavras mais auspiciosas, indicando a possibilidade de que o atual pranto pode, por vontade divina, ser convertido em celebração. Orestes expressa o desejo de que seu pai tivesse sucumbido na guerra de Troia, legando assim uma bela glória a seu palácio e a seus filhos. O Coro comenta que não só foi rei em vida, mas continua a sê-lo depois de morto. Electra, por sua vez, expressa o desejo de que na distante Troia tivessem sucumbido, em vez de Agamêmnon, seus homicidas ${ }^{27}$. O Coro, embora considerando que, se assim tivesse sido, seria uma grande sorte, chama atenção à realidade: além de não estarem mortos, os inimigos detêm o poder do palácio. Assim confrontado com a realidade, Orestes formula, enfim, um pedido de vingança a Zeus: que ele envie dos ínferos "punitiva erronia" (ن́отерótтoıvov ătav, Co. 383) aos assassinos de seu pai. Esse voto é secundado pelo Coro, que expressa seu desejo de celebrar com um poderoso grito a

\footnotetext{
${ }^{26}$ Para uma análise a respeito da identidade e das funções do coro das Coéforas, conferir o capítulo "The Chorus of Aeschylus' Choephori”, de McCall (1990), no livro organizado por Griffith \& Mastronarde.

${ }^{27}$ Orestes e Electra expressam aqui o ideal homérico da "bela morte" e da "bela glória".
} 


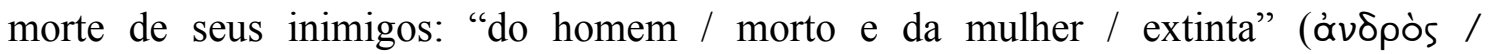

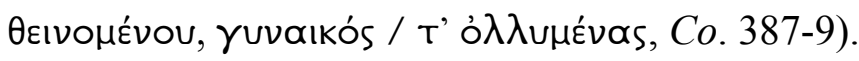

Invocando a Terra e os poderes ctônios, Electra pede que Zeus deixe cair suas mãos sobre os inimigos, de modo a partir-lhes o crânio. O Coro, porém, adverte a jovem de que o sangue derramado clama por mais sangue, sucedendo-se erronia após erronia:

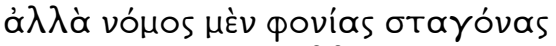

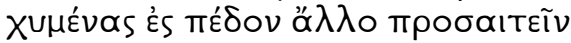

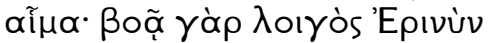

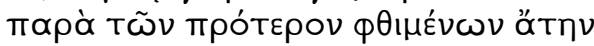

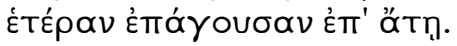

\begin{abstract}
Mas sói que gotas sangrentas vertidas no chão pedem outro sangue: exício grita por Erínis a trazer dos anteriores finados outra erronia à erronia
\end{abstract}

Trata-se de uma advertência que é ao mesmo tempo um prenúncio. Orestes, ao matar sua mãe, fará verter sangue novamente, provocando uma ruína que "grita por Erínis" (ßo ̃⿱ ... 'Epıvùv, Co. 402).

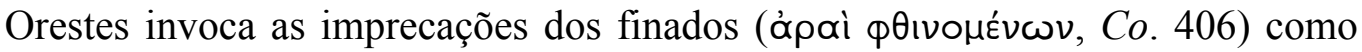
testemunhas do porvir dos Atridas: sem recursos, desonrados, banidos do palácio. A essas palavras de Orestes, o Coro responde:

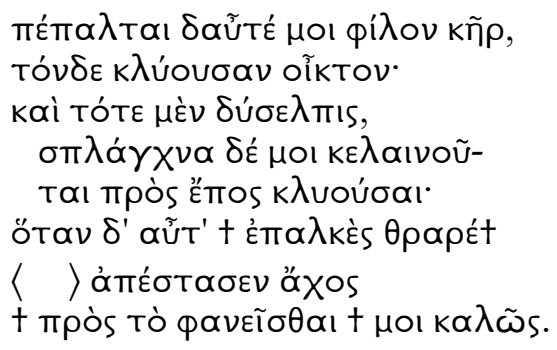

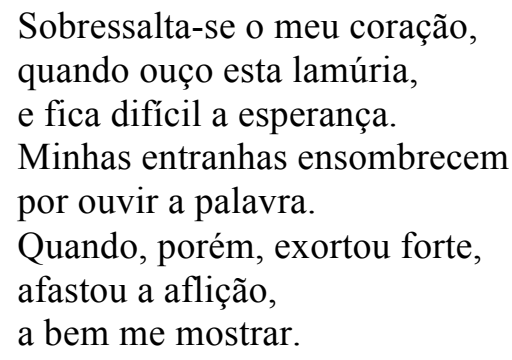

Sobressalta-se o meu coração, quando ouço esta lamúria, e fica difícil a esperança. Minhas entranhas ensombrecem por ouvir a palavra. Quando, porém, exortou forte, afastou a aflição, a bem me mostrar.

(Co. 410-7)

Esse sombrio temor que domina o coração do Coro surge ante essa invocação feita por Orestes repleta de palavras de mau augúrio. Essas palavras agourentas, ao pressagiarem um destino adverso - o desprovimento, a desonra, o exílio -, tornam difícil que se tenha esperança num porvir mais auspicioso. Essa aflição, no entanto, afasta-se do coração do Coro quando Orestes usa palavras de bom augúrio, a prenunciar um destino em que a justiça se cumpre na morte dos assassinos do falecido rei.

Assim advertido e incentivado, Orestes, após a rememoração feita por Electra das aflições sofridas e da ousadia da mãe ao sepultar o marido sem as devidas honras -

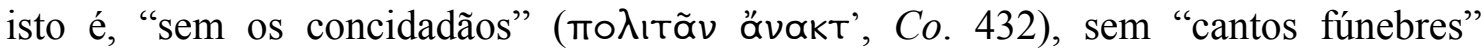




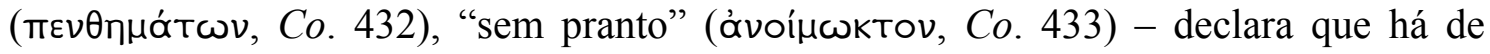
fazê-la pagar por essa desonra com a morte, graças tanto ao nume que o impele quanto ao seu próprio braço.

O Coro menciona então a mutilação a que foi submetido o cadáver de

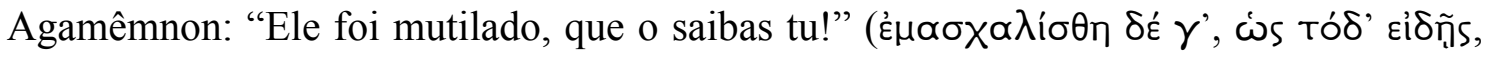
Co. 439). Não se descreve em que consistiu essa mutilação, mas o verbo utilizado, $\mu \alpha \sigma \chi \alpha \lambda i \zeta \omega$, de $\mu \alpha \sigma \chi \alpha \dot{\alpha} \lambda \eta$, "axila", designa a ação de se cortarem as extremidades dos membros e colocá-las sob as axilas ${ }^{28}$, a fim de que o morto não pudesse, dessa forma, nem andar nem agir e, assim, ficar incapacitado de prestar auxílio àqueles que desejassem vingá-lo. No entanto, a mutilação é mencionada não para mostrar que as súplicas que se dirigem a Agamêmnon são infrutíferas e sim para mostrar como o cadáver do rei recebeu um tratamento ignominioso e, dessa forma, mais fortemente se deve desejar a vingança e pedir por ela ${ }^{29}$. E assim, unidos nesse propósito, Electra, Orestes e o Coro pedem a assistência de Agamêmnon e dos deuses no cumprimento da

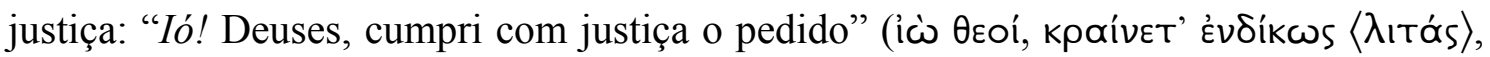
Co. 462).

Antes de suas palavras finais, o Coro comenta que um tremor lhe invade ao ouvir as preces feitas, pois, "O fatídico demora há muito / e por nossas preces poderia

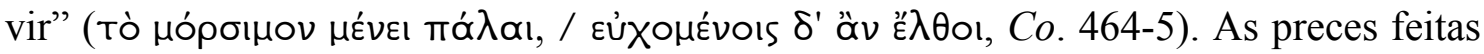
nesse canto fúnebre ante o túmulo de Agamêmnon, igualmente como ocorrera com as palavras de Electra ao verter as libações sobre o túmulo do pai, adquirem toda a força de uma imprecação. O nume que habita a palavra imprecatória assegura o cumprimento do destino prenunciado por ela. E a percepção da iminência do cumprimento desse destino pelo qual tanto se aguardou é o que causa o tremor do Coro. Contudo, isso não o impede de prosseguir e, assim, constatar que esse destino encontrará realização por meio de

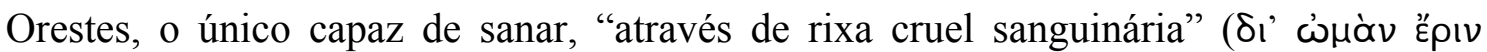

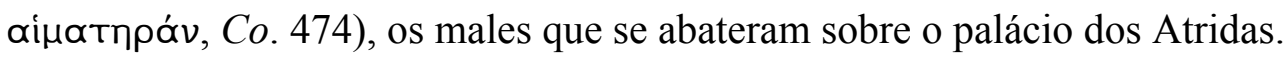

\footnotetext{
${ }^{28}$ Kittredge, em seu artigo "Arm-Pitting among the Greeks" (1885, pp. 151-3), explica da seguinte forma

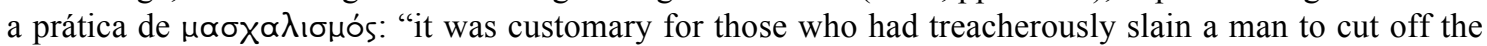
extremities of his limbs, string the pieces together, and fasten them under the armpits of the corpse by a band or girdle round the neck. [...] The atrocity was committed on the bodies of men slain by treachery, or, in general, on the bodies of murdered kinsmen".

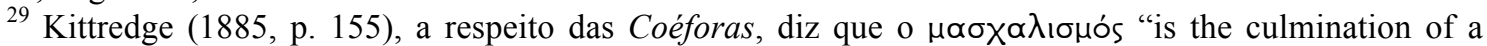
series of atrocities - among which are the shameful murder and the neglect of proper burial rites - which rob Agamemnon of his just rank in Hades and make his shade weak and miserable, and if weak, unable therefore to take vengeance on his murderers".
} 
Findo o canto fúnebre, Orestes e Electra prosseguem em suas súplicas, pedindo ao pai que lhes concedam o poder do palácio e que vigie Orestes na batalha que ele está a ponto de travar. Lembrando-lhe das injúrias sofridas - o banho, a rede, o dolo -, atiçam-lhe a cólera e intentam fazê-lo despertar. As pungentes invocações que se seguem atingem um clímax do qual se poderia esperar que o espectro de Agamêmnon, assim como o de Dario nos Persas, emergisse de seu túmulo ${ }^{30}$. O Coro então considera terminado o momento das súplicas, sugerindo a Orestes que, estando agora disposto a agir, avance de outra forma na realização seus propósitos, pondo em movimento o destino fatídico traçado para seus inimigos pelo oráculo de Apolo e por suas palavras imprecatórias.

Nesse momento, Orestes busca esclarecimentos sobre o motivo de Clitemnestra ter enviado oferendas ao túmulo do falecido marido. Informado do sonho da mãe e, tendo-o interpretado, Orestes instrui Electra a recolher-se ao palácio e confidencia ao Coro o que pretende fazer a seguir: com suas armas, ele, na companhia de Pílades,

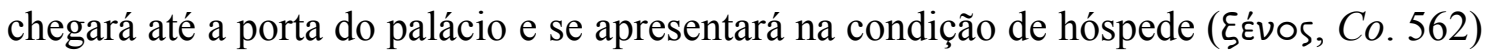
proveniente da Fócida, cujo modo de falar ele e Pílades imitarão ao serem recebidos. Contando com a possibilidade de que, mesmo com relutância, pois "a casa é de maus

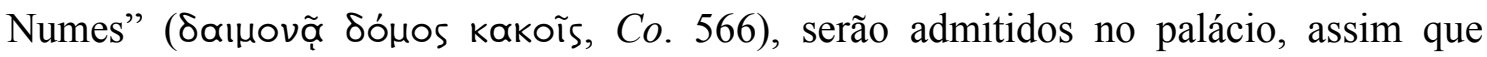
Orestes vir Egisto sentado no trono de seu pai ou caso ele venha a ter consigo, mata-lo-á imediatamente.

Para que seu plano funcione, é necessário, observa Orestes, que Electra mantenha-se alerta dentro do palácio e o Coro conserve "a língua propícia" ( $\gamma \lambda \tilde{\omega} \sigma \sigma \alpha \nu$

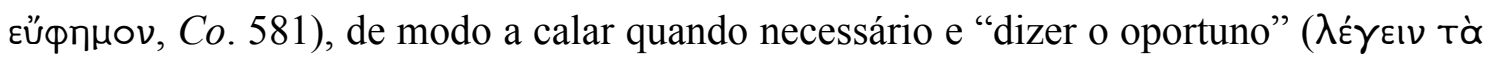
kaípıа, Co. 582). Assim, o que Orestes exorta o Coro a fazer é evitar pronunciar palavras ominosas que possam prenunciar acontecimentos adversos ao plano que agora se coloca em ação. Para garantir que tudo ocorra bem, portanto, o Coro deve silenciar quando preciso e pronunciar somente palavras auspiciosas.

Encontrando-se no limiar da ação, o Coro, no primeiro estásimo, reflete a respeito dos terrores nutridos pela deusa Terra: os monstros marinhos, os meteoros, as tempestades. Destes poderiam falar os pássaros e os que caminham sobre a terra. Do que parece ser o pior desses terrores, "o soberbo pensamento do homem / e ousados

\footnotetext{
${ }^{30}$ Seria infrutífero tentar responder acerca do motivo pelo qual o espectro de Agamêmnon não surge em cena. Contudo, não deixa de ser curiosa a observação de Bouché-Leclercq (2003, p. 251) a esse respeito, quando afirma que havia uma crença generalizada entre os antigos de que a alma cujo corpo fora mutilado não poderia deixar jamais o outro mundo.
} 


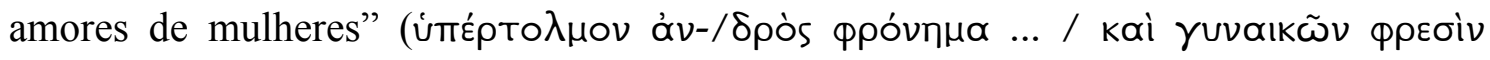
$\tau \lambda \eta \mu o ́ v \omega v$, Co. 594-6), falam as histórias dos crimes de Alteia, de Cila, das mulheres lêmnias $^{31}$ e o da própria Clitemnestra. A essa lista de crimes "sem justiça" (oưk

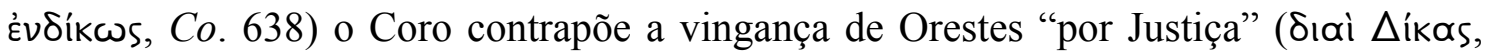
Co. 341): "Eis um punhal perto dos pulmões / pontiagudo vai perfurar o flanco / por

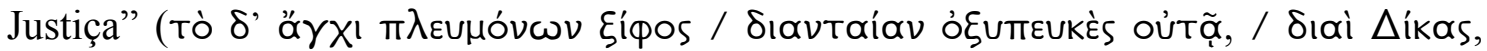
Co. 369-41). Trata-se de uma antevisão da morte de Egisto e de Clitemnestra.

Orestes, no segundo episódio, chega às portas do palácio e é recebido por um

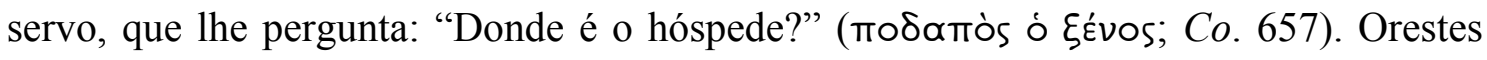
assume, portanto, novamente a condição de Ǵ́vos. A sua verdadeira identidade, com todas as suas implicações, está assegurada pelo silêncio de Electra, que se retirou de cena e não mais retornará, e pela fidelidade do Coro à sua causa. O servo, obviamente, não é capaz de reconhecê-lo e por isso o interpela como Ł̇́vos. Orestes não responde à pergunta pela sua procedência e pede que o servo chame algum dos senhores do palácio, e o faça rápido, pois, diz ele, “o carro da Noite se apressa tenebroso" (vUKTòs ăpu'

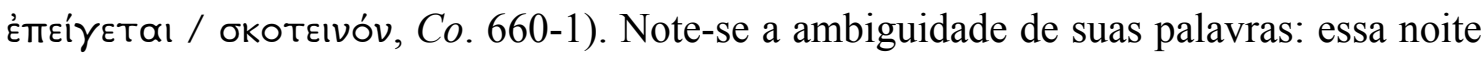
que se aproxima é tanto a noite em seu sentido sensível, isto é, que denota uma parte do dia, quanto a noite em seu sentido inteligível, ou seja, que denota um aspecto do mundo que é o da privação de ser. Essa noite, em todos os seus sentidos, urge.

Nesse momento, Clitemnestra entra em cena. Também ela não reconhece

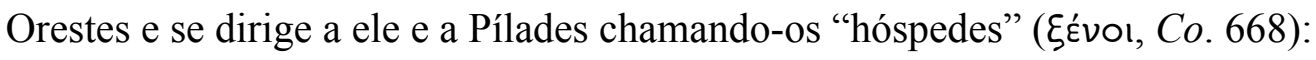

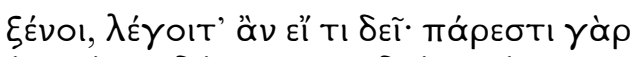

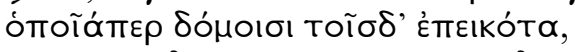

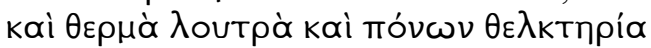

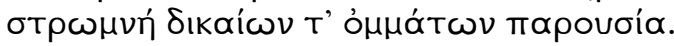

Hóspedes, dizei-me se precisais de algo, pois há neste palácio o que vos convém, banhos quentes e lenimentos de males, agasalho e a presença de olhos justos.

(Co. 668-71)

Clitemnestra desempenha bem seu papel de anfitriã, oferecendo acolhida aos estrangeiros em seu palácio. Tendo-se em mente, no entanto, a boa acolhida que ela

\footnotetext{
${ }^{31}$ Lebeck (1967, p. 184), em seu artigo "The First Stasimon of Aeschylus' Choephori: Myth and Mirror Image", observa como essa lista de crimes consanguíneos espelha os crimes consaguíneos da Oresteia: "the three paradigms are relevant not only in so far as each deals with a woman's crime; taken together they play upon the various combinations of kin murder which beset the seed of Atreus. In the first, child is slain by parent, as in the generation of Agamemnon. The second reverses this: parent is slain by child, as in the generation of Orestes. The last alludes to one wrong followed by another, its mirror image. Wives slay their husbands, husbands their wives. And so the myths chosen by the poet at this central point reflect the three crimes of the trilogy". A respeito desse primeiro estásimo, conferir ainda o artigo de Stinton (1979), "The First Stasimon of Aeschylus' Choephori”.
} 
ofereceu a Agamêmnon quando de sua chegada, há algo de perturbador em suas

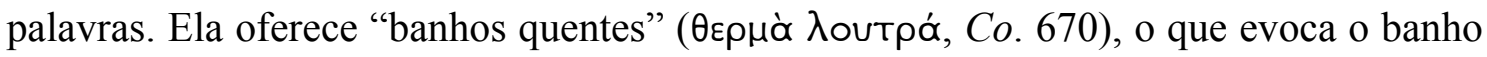
(入outpoĩoı, Co. 1109) em que ela assassinou seu marido. Em Agamêmnon, Clitemnestra recebe o marido como a um amigo - ela se dirige a ele chamando-o "ó cabeça querida" ( фí̉ov kópa, Ag. 905) - e o trata como a um inimigo, matando-o. Nas Coéforas, Clitemnestra recebe o filho como a um desconhecido - um Ġ́vos - e, por sua vez, é tratada como uma inimiga, sendo morta por ele. Agamêmnon entrou no palácio para morrer e agora seu filho entra no palácio para matar.

Orestes, ao responder a Clitemnestra, reforça a sua condição de छ̇́vos: "Hóspede

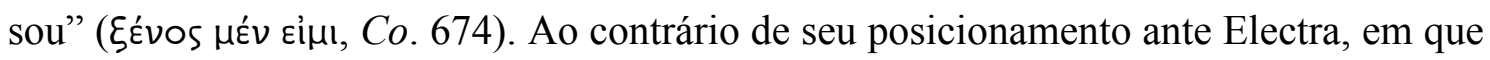
ele oferece provas de sua identidade para que haja um reconhecimento e deixe de ser a

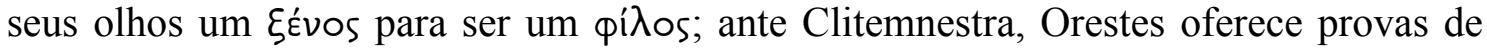
sua falsa identidade, de modo que haja um desconhecimento entre ele e a mãe e ele não deixe de ser um Ǵv́vos a seus olhos.

Assim, ele se apresenta como um dauliense que, vindo da Fócida e prestando um favor a um desconhecido chamado Estrófio, traz a notícia da morte de Orestes e indaga a respeito do destino que se deve dar às cinzas do falecido: se devem ser transladas a Argos ou sepultadas na Fócida mesmo, na condição de meteco, "em tudo sempre

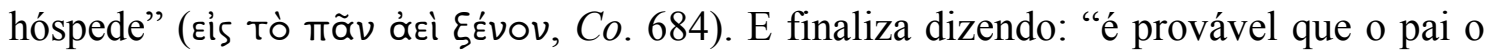

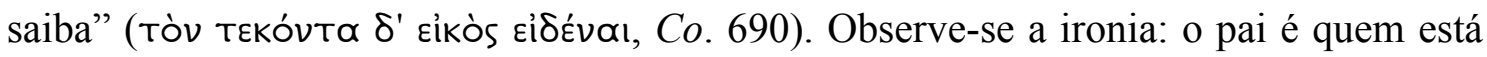
morto e não Orestes.

Clitemnestra deplora a morte do filho, ainda que seja somente para manter as

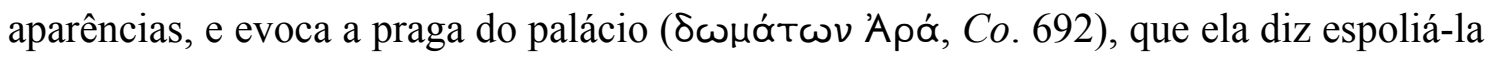
dos que lhe são caros ( e a reação de Clitemnestra são falsas, a conclusão a que ela chega em seu discurso é, por

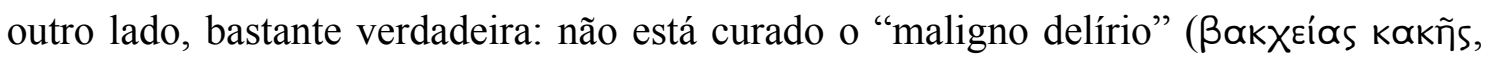
Co. 699) que atinge o palácio. Mas a rainha, assim como falha em reconhecer Orestes, também falha em reconhecer os sinais: não é a morte de Orestes que anuncia mais um mal decorrente da maldição do palácio e sim a sua própria morte e a de Egisto. Ela, portanto, será espoliada de quem verdadeiramente lhe é "caro" (фí̉os): Egisto e não Orestes.

Na fala seguinte de Orestes, mantém-se esse jogo de enigmas que se dá entre a identidade de quem é estranho, estrangeiro, hóspede e de quem é amigo: 


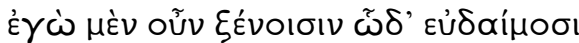

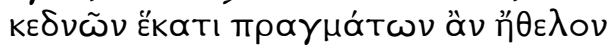

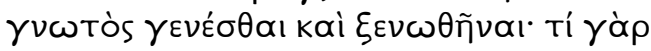

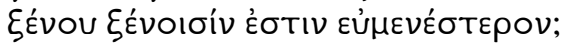

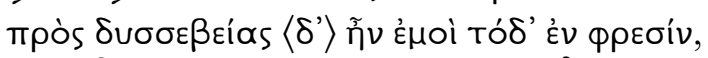

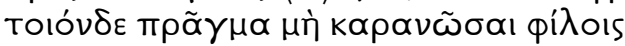

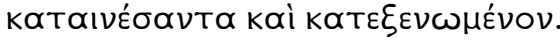

Eu junto a hóspedes tão prósperos queria por auspiciosas notícias ser conhecido e hospedado. O que é mais grato aos hóspedes que o hóspede? Impiedade seria isto em meu espírito: não cumprir tal promessa a amigos quando prometi e estou hospedado.

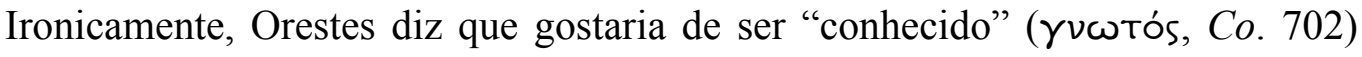
por trazer notícias auspiciosas - quando na verdade ele será conhecido através de seus

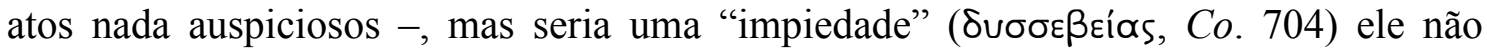

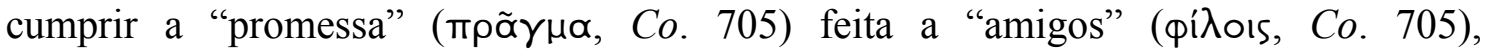
encontrando-se agora hospedado. A promessa feita, no contexto do discurso falso de Orestes, é a de transmitir a mensagem da sua morte e os amigos a que ele se refere seria

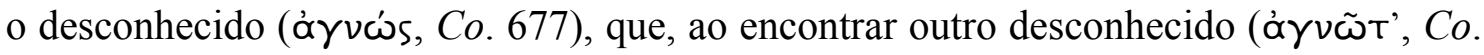
677), pediu que transmitisse uma mensagem. Porém, verdadeiramente, a promessa feita diz respeito à sua vingança; os amigos, sua irmã e o Coro; e impiedade seria não cumprir o oráculo de Apolo e assim não vingar a morte do pai. As palavras de Orestes são, portanto, tão ambíguas e equívocas quanto as palavras de Clitemnestra ao receber Agamêmnon. E, assim como o rei, ela também não é uma boa intérprete de sinais, pois diz a Orestes: "Não obterás algo menos digno de ti, / nem serias menos amigo do

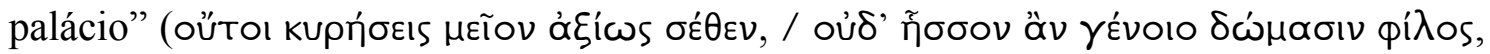
Co. 707-8). Sem o saber, ela confirma os intentos do filho: sim, ele obterá algo digno dele ao vingar o pai, mostrando assim realmente sua identidade; não a de um estranho

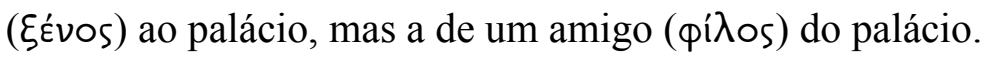

O Coro, ante tais circunstâncias e aconselhado como fora a "dizer o oportuno"

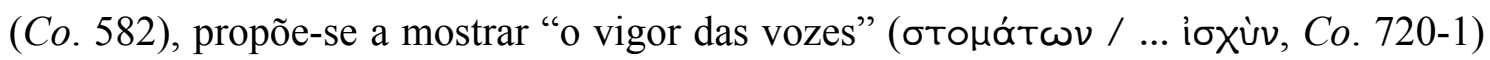
por Orestes, evocando a senhora Terra e a senhora orla da tumba de Agamêmnon, para que a persuasão dolosa e Hermes noturno se manifestem e assegurem a execução da vingança de Orestes.

Nesse momento, o Coro avista a Ama de Orestes, saindo do palácio em prantos. Questionada, a ama explica que Clitemnestra lhe ordenou chamar Egisto para se inteirar e procurar saber mais da notícia trazida pelos estrangeiros. Ela revela que o luto que 
Clitemnestra expressa pela dor do filho é fingido ${ }^{32}$. A esse luto fingido de Clitemnestra e à alegria que sentirá Egisto ao saber da morte de Orestes, a Ama contrapõe sua dor e seu luto verdadeiros, chamando-o "meu Orestes" ( rememorando as fadigas e os cuidados que teve ao criá-lo. A sua descrição de como o

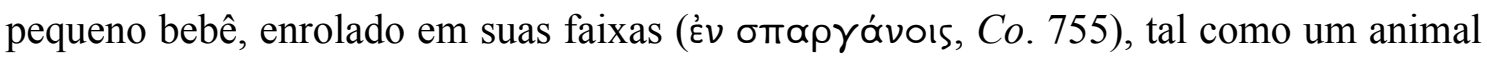
(ßotóv, Co. 453), deve ser nutrido (тре́фєıv, Co. 754), evoca as imagens do sonho profético de Clitemnestra, prestes a ser realizado.

O Coro, então, pede-lhe que, mudando seu estado de ânimo, transmita, contrariamente ao que lhe fora ordenado, a mensagem de que Egisto deve vir desacompanhado de lanceiros ao palácio. Ao estranhamento da ama o Coro responde que Zeus pode transformar os atuais males em alegrias e, quanto a Orestes estar morto,

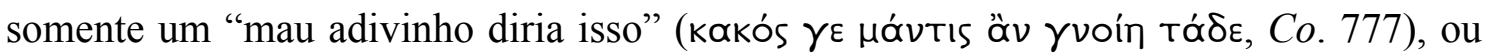
seja, só alguém que não consegue interpretar bem os sinais, que não consegue

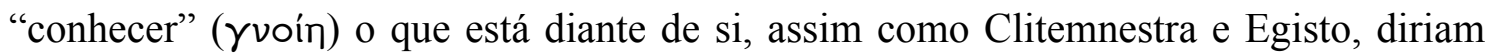
Orestes estar morto. E assim, sem lhe entregar maiores informações, convence a ama a aquiescer a seu pedido.

No segundo estásimo, o Coro dirige suas preces a Zeus, para que garanta o bom sucesso da ação; aos deuses que habitam o palácio, para que ponham fim à cadeia de crimes sucessivos - dissolvendo "sangue das façanhas / antigas com as recentes

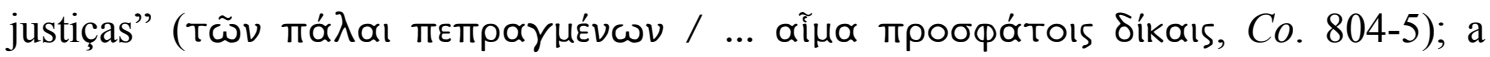
Apolo, para que, dissipando as trevas do palácio, este volte a ver a luz da liberdade; e a Hermes, para que auxilie no aspecto doloso da ação que está para ser executada. O Coro ainda exorta Orestes a não vacilar nem temer quando estiver frente a frente com Clitemnestra, antevendo o que de fato acontecerá. Quando ela gritar "filho" (тદ́kvov,

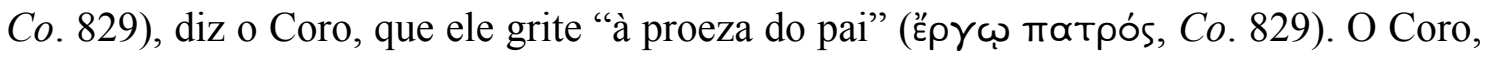
assim, antevê a hesitação de Orestes. E recomenda ainda que ele, "mantendo no peito /

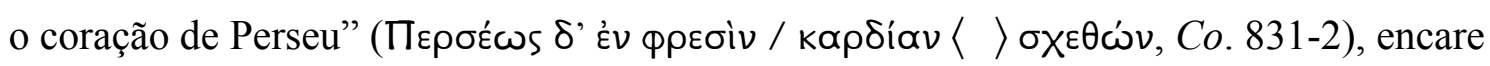
e destrua os culpados.

Perseu é o herói que mata seu inimigo sem olhá-lo diretamente nos olhos. Assim como Perseu, que matou a Medusa sem encará-la, Orestes deve fazer o mesmo com sua mãe. Porém, o mito de Perseu conta ainda como, depois de matar a Medusa, ele foi perseguido pelas outras Górgones, de modo que a perseguição de Orestes pelas Erínies,

\footnotetext{
${ }^{32}$ Sobre a visão da Ama a respeito do luto de Clitemnestra por Orestes, conferir Margon (1983).
} 


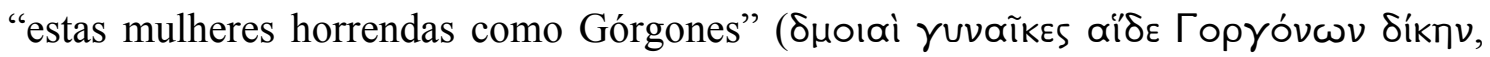
Co. 1048), é prenunciada nessa alusão ao mito de Perseu, com observa Garvie (1986, pp. 271-2).

Egisto, no terceiro episódio, entra em cena dizendo ter vindo informar-se acerca da notícia trazida pelos hóspedes, cuja veracidade, uma vez comprovada, tornar-se-ia um terrível acontecimento para o palácio. Do mesmo modo que Clitemnestra fizera, Egisto discursa com o intuito de manter as aparências, não revelando o quão propícia seria a morte de Orestes a seus interesses. Ele, no entanto, ainda duvida da veracidade

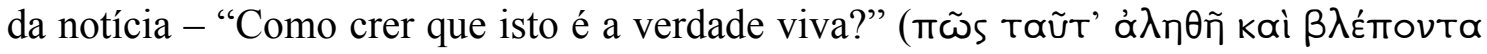

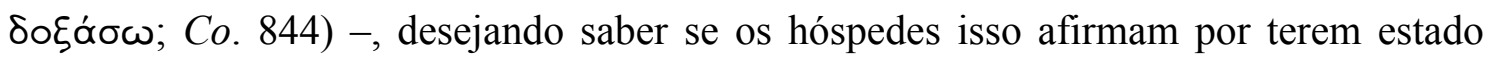
presentes à morte de Orestes ou se por ouvirem dizer. O Coro, então, instiga-o a entrar no palácio e a informar-se diretamente com os portadores da notícia. E assim Egisto, ironicamente dizendo como os hóspedes "não enganariam um espírito perspicaz" (oủтo।

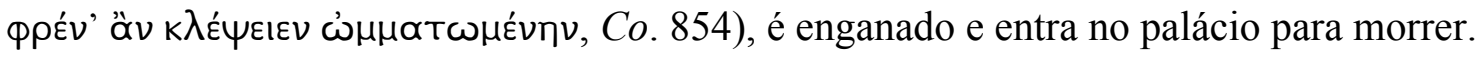

Após uma breve evocação a Zeus e aos deuses, o Coro ouve gemidos advindos de palácio. Em seguida, um servo anuncia a morte de Egisto e, atordoado, pergunta pela rainha, cujo pescoço ele crê já estar próximo da navalha. Clitemnestra logo surge, indagando o motivo da gritaria, ao que o servo, atônito, responde de forma enigmática:

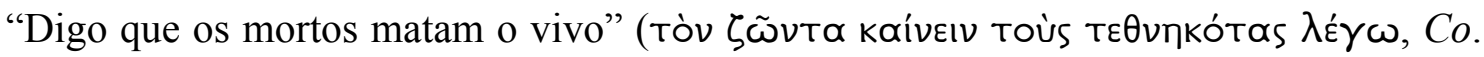

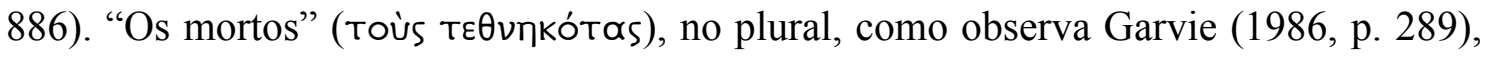
indica mais do que uma generalização, pois Agamêmnon, através de Orestes, também estaria envolvido na vingança.

Esse enigma Clitemnestra consegue imediatamente compreender: "Ai!

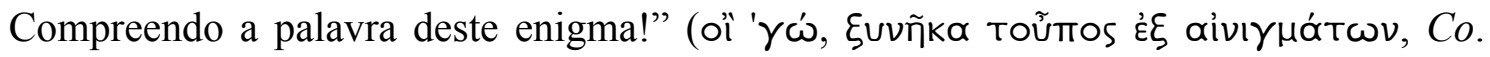

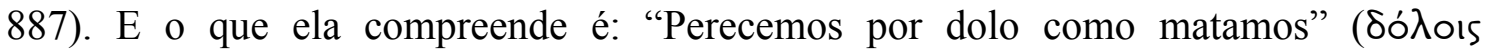

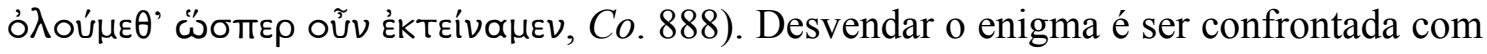
o fato de que Orestes não se encontra no palácio da condição de छ́ćvos, como ela

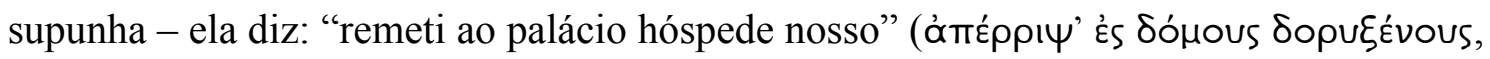
Co. 914) -, mas na condição de qí̉os. O reconhecimento é imediato - ela interpela Orestes chamando "fillho" ( $\pi \propto \tilde{i}$, Co. 896) - e é um reconhecimento cujas consequências ela prevê serem adversas, pois pede que lhe deem um machado, numa vã tentativa de se defender. Mas, de fato, só há uma arma de que Clitemnestra realmente dispõe: apelar 
para o sentimento filial de Orestes. Assim, a rainha lhe mostra o seio nu ${ }^{33}$, suplicandolhe:

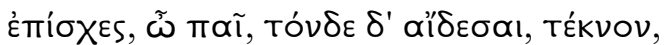

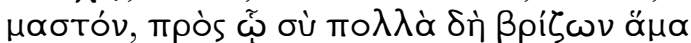

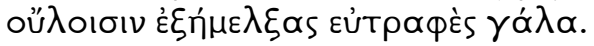

Para, filho, e respeita, criança, este seio em que muitas vezes já sonolento sugaste com as gengivas nutriente leite.

(Co. 896-8)

A visão do seio materno é uma visão encantatória, uma vez que paralisa imediatamente Orestes. E, como se respondesse ao poder das palavras que designam os

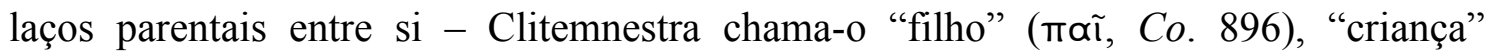
(тÉkvov, Co. 896) -, Orestes pela primeira e única vez durante a cena do matricídio usa o termo "mãe" referido à Clitemnestra, quando, voltando-se para Pílades, pergunta o

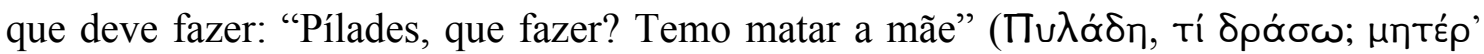

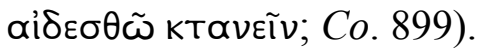

Pílades permaneceu em silêncio durante toda a tragédia e, por assim ter permanecido, quando ele finalmente fala, suas palavras adquirem uma especial dimensão dramática. Assim, ao advertir o amigo da obediência que ele deve ao deus adivinho, é como se o próprio Apolo se manifestasse mediante suas palavras:

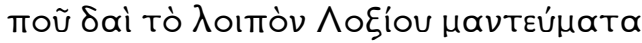

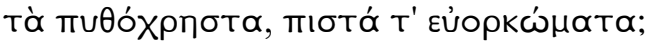

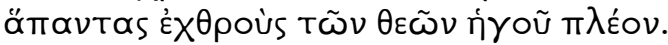

Onde no porvir os vaticínios de Lóxias dados em Delfos e os fiéis juramentos? Tem por hostis a todos mas não aos Deuses.

(Co. 900-2)

A fala de Pílades, que, como uma manifestação de Apolo, constitui um sinal numinoso, tem o poder de quebrar o fascínio da imagem do seio materno e das palavras de Clitemnestra que remetem à estreita consanguinidade entre ambos e de libertar, assim, Orestes dessa dimensão tão humana na qual ele se viu subitamente enredado.

Orestes decide-se então obedecer às palavras oraculares de Apolo, sobrepondo, dessa forma, o dever para com o deus ao dever filial, visto que, como lhe advertira Pílades, deve-se temer, sobretudo, a hostilidade divina. Imbuído dessa convicção, Orestes não se deixa persuadir pelos argumentos de Clitemnestra. O poder de persuasão

\footnotetext{
${ }^{33}$ Essa cena evoca a cena homérica de Hécuba mostrando o seio materno a Heitor e suplicando-lhe que evite o confronto com Aquiles (Il. 22, v. 82-5). O'Neill (1998, p. 216-229), em seu artigo "Aeschylus, Homer, and the Serpent at the Breast", observa que existe até mesmo uma similaridade linguística entre ambas as cenas. No entanto, a intenção de Hécuba é a de salvar o filho e a de Clitemnestra é a de salvar a própria vida. Além disso, enquanto o amor maternal de Hécuba é indubitável, o de Clitemnestra é suspeito.
} 
que outrora a rainha possuíra ao convencer Agamêmnon a andar sobre as vestes púrpuras mostra-se agora ineficaz.

Diante da inflexibilidade de Orestes, Clitemnestra adverte-o das consequências do ato que está prestes a realizar: "Cuidado com rancorosas cadelas da mãe" (öpa,

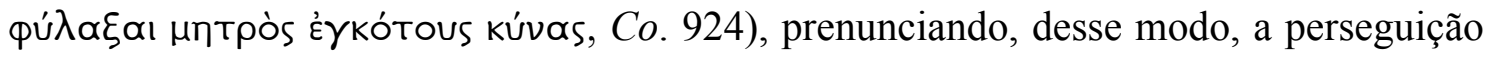
de Orestes pelas Erínies. Mas Orestes sabe que, se não cumprir as ordens de Apolo, será perseguido pelas Erínies do pai: "E as do pai, como as evito, omisso aqui?" (Tàs toũ

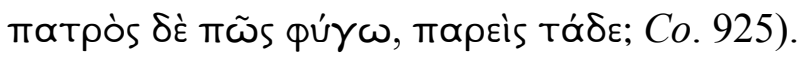

Vendo-se vencida, Clitemnestra reconhece como fora profético seu sonho - "Era

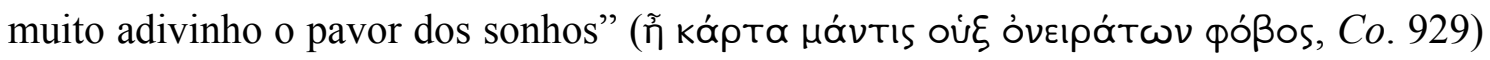
- e, ao identificar Orestes com a serpente, interpreta-o agora do mesmo modo que

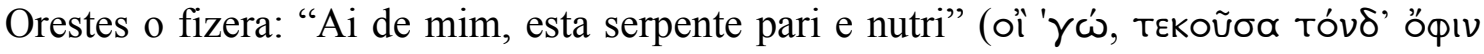

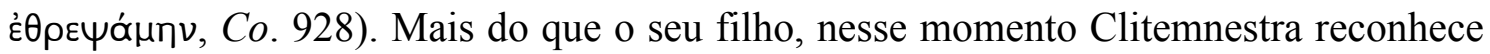
o seu destino, pois ela sabe que essa identificação entre Orestes e a serpente significa a sua morte. E assim se cumprem os desígnios divinos.

\subsection{3) Orestes e o oráculo de Apolo}

Nas Coéforas, há uma associação direta entre o deus Apolo e a vingança pela morte de Agamêmnon. Essa relação íntima entre Orestes e o deus Apolo encontra-se ausente em Homero. Na Odisseia, Zeus, refletindo a respeito do triste fim de

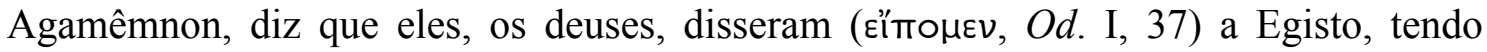

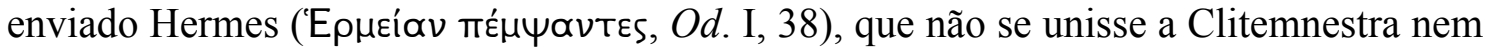
matasse seu marido, "pois a vingança do filho de Atreu lhe viria de Orestes, / quando

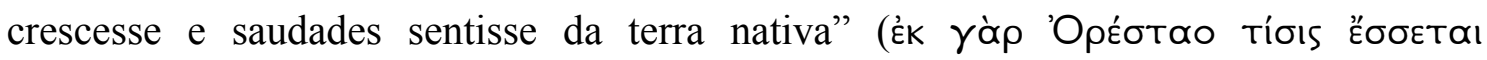

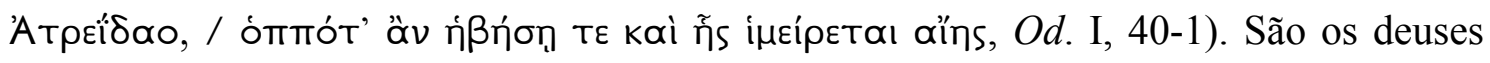
que, através de Hermes, dizem a Egisto que Orestes vingaria o pai: "Hermes assim o

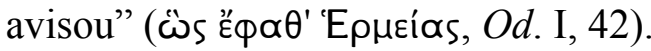

Em Píndaro, na Pítia XI, em que o poeta narra a morte de Agamêmnon e a vingança de Orestes, também encontra-se ausente Apolo. É Ares quem auxilia Orestes em sua vingança ${ }^{34}$ : “mas, com a posterior ajuda de Ares, matou a mãe e fez verter o

\footnotetext{
${ }^{34}$ Para um estudo detalhado e uma edição comentada da Pítia XI, conferir Finglass (2008).
} 


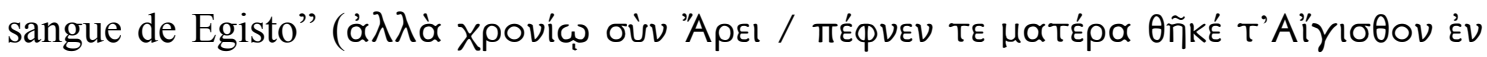
povaĩs, $P$. XI, 36-7) $)^{35}$.

$\mathrm{Na}$ perdida Oresteia de Estesícoro, sabe-se somente que Orestes, após a execução de sua vingança, teria recebido um "arco" (Tógov, Fr. 40) como "um presente

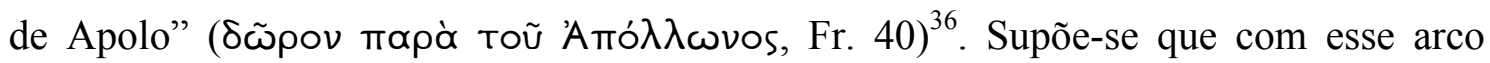
Orestes teria recebido o auxílio do deus para proteger-se das Erínies, que não estão presentes na história nem em Homero nem em Píndaro ${ }^{37}$.

Hermes e Ares se fazem presentes nas Coéforas: Hermes, ao possibilitar a comunicação entre o mundo dos vivos e o mundo dos mortos e ao velar sobre aspecto doloso do plano de Orestes; e Ares, na dupla matança. É, no entanto, Apolo, através de seu oráculo e do sonho profético de Clitemnestra, que ganha proeminência nessa tragédia, uma proeminência que culmina com sua aparição em cena nas Eumênides. $\mathrm{O}$ mesmo se dá com as Erínies.

A primeira menção ao oráculo de Apolo é feita por Orestes logo após o reconhecimento entre ele e Electra, no primeiro episódio. O Coro pede que eles silenciem seu júbilo, para que a notícia do retorno de Orestes não chegue aos ouvidos dos algozes de seu pai e assim o Coro possa vê-los um dia mortos (Co. 264-8). Ao temor do Coro, Orestes contrapõe a confiança no oráculo de Apolo, dizendo:

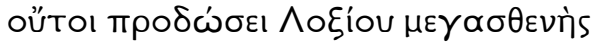

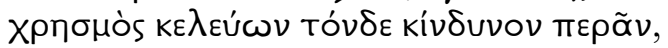
кå̉

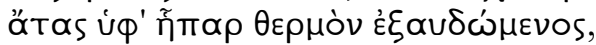

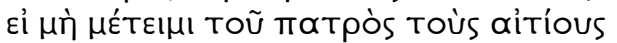
тро́то

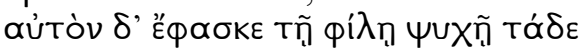

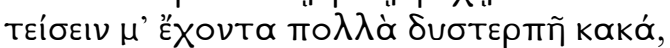

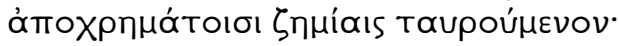

Não nos trairá o oráculo plenipotente de Lóxias, ao impelir a este perigo com muitos brados e ao proclamar tormentosa erronia no cálido fígado, se não punir os culpados de meu pai dando-lhes por sua vez a mesma morte, e disse que em minha própria pessoa eu o pagaria com muitos tristes males, feito um touro sem bens por castigo.

(Co. 269-77)

Embora Orestes não reproduza ipsis litteris as palavras oraculares de Apolo, pode-se perceber que se trata de um oráculo que, além de eloquente, é bastante claro, como o sugere o entendimento que dele tem o seu destinatário ao relatá-lo.

\footnotetext{
${ }^{35}$ A edição é de Puech (1955) e a tradução é nossa.

${ }^{36}$ A edição dos fragmentos é de Paige (1962).

${ }^{37}$ Eurípides, em Orestes, faz referência a esse arco. Diz Orestes à irmã: "Dá-me o arco de chifre, dom de

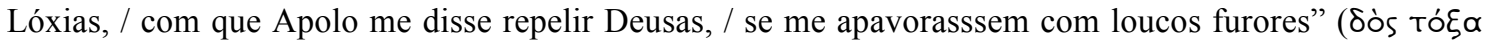

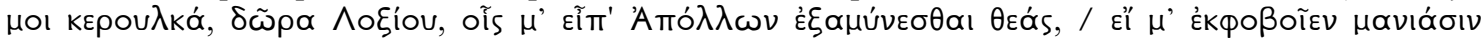

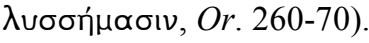


Ora, uma das características dos oráculos pítios é justamente a obscuridade, a ambiguidade e, por isso, a dificuldade que se tem de interpretá-los. Tal característica é tradicionalmente conhecida, como o revela a etimologia popular que associa o epíteto

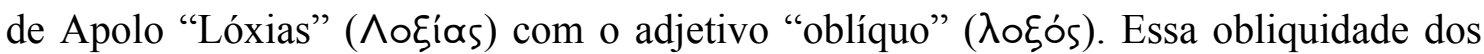
oráculos do deus decorre do fato de estes serem a expressão de um ponto de vista divino, cujo sentido escapa ao homem, confinado como está ao ponto de vista limitado por sua finitude humana. Essa obliquidade é apontada em Agamêmnon, quando o Coro de anciãos compara as palavras proféticas de Cassandra ao oráculo pítio, que ele considera difícil de compreender ( $\delta v \sigma \mu \alpha \theta \tilde{\eta}, A g .1255)$.

Nas Coéforas, porém, a clareza do oráculo pítio se mostra condizente com o

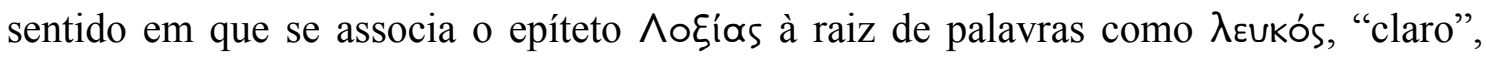
"brilhante", e $\lambda \varepsilon \cup ́ \sigma \sigma \omega$, "ver algo brilhante", e que equivale ao significado de seu outro epíteto, Febo (Фoĩßos), “luminoso” (TORRANO, 2004, p. 33). Não há assim, nessa tragédia, nada mais claro do que esse oráculo de Apolo.

Há vários aspectos sob os quais essa clareza aparentemente incomum do oráculo apolíneo poderia ser observada. Poder-se-ia considerar, assim, o estatuto heroico da personagem a que o oráculo foi entregue, que se caracteriza justamente pela proximidade com o divino e por uma relação individual com os deuses. Poder-se-ia considerar ainda a comunidade de interesses, da qual fala Orestes, entre a ordem do deus, expressa por meio de seu oráculo, e as necessidades e obrigações do seu destinatário. Poder-se-ia também argumentar que a clareza está na interpretação do oráculo por Orestes - já que a sua interpretação do sonho de Clitemnestra lhe fará ser eleito pelo Coro um "perito em prodígios" (тєрабко́тоо , Co. 551) - e não necessariamente nas palavras oraculares de Apolo.

Parece, contudo, ser mais interessante analisar essa clareza do oráculo pítio tendo em perspectiva não somente a tragédia na qual este sinal divinatório se insere, mas toda a trilogia. O que se observa, dentro dessa perspectiva maior, é que existe um movimento descendente no que diz respeito à ambiguidade e à complexidade dos sinais divinatórios na Oresteia.

Como se viu, no párodo do Agamêmnon, o auspício das aves, que prenuncia tanto o sacrifício de Ifigênia quanto a morte de Agamêmnon, acontecimento central para a tragédia, é de uma complexidade assombrosa e, por essa mesma razão, não apenas difícil de interpretar, mas também aberto a múltiplas interpretações. Nas Coéforas, por sua vez, o oráculo de Apolo e o sonho de Clitemnestra, que prenunciam a morte desta e 
de Egisto, são, comparativamente, muitíssimo mais dóceis à interpretação e, por isso mesmo, muito mais unívocos em seu sentido numinoso. Já nas Eumênides, eliminam-se quaisquer intermediários e, portanto, qualquer necessidade de interpretação, pois são os deuses, in persona, que agem e, agindo, determinam o curso dos acontecimentos.

De que fala, então, tão claramente o oráculo de Apolo? Nessa primeira menção ao oráculo, fala da necessidade de "punir os culpados de meu pai / dando-lhes por sua

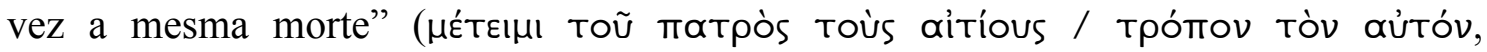

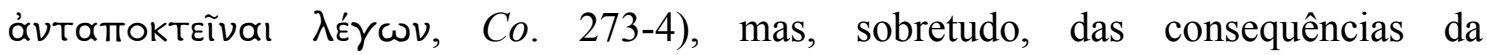

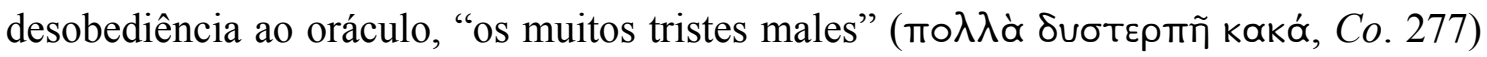
que ele sofreria em sua própria pessoa:

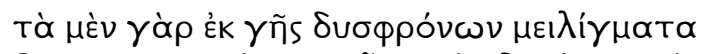

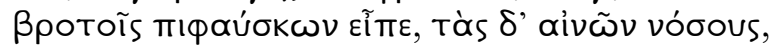

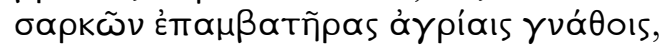

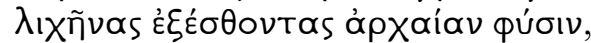

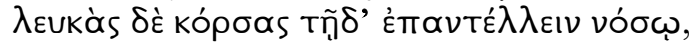

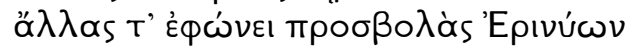

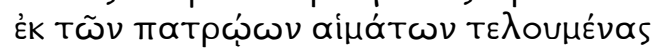

Anunciando disse as delícias dos díscolos da terra aos mortais, disse as doenças atacarem a carne com ferozes maxilas, lepras devorarem a originária natureza, cãs pungirem nas têmporas com esta doença, e falou que outros assaltos de Erínies perpetram-se pelo paterno sangue.

(Co. 278-84)

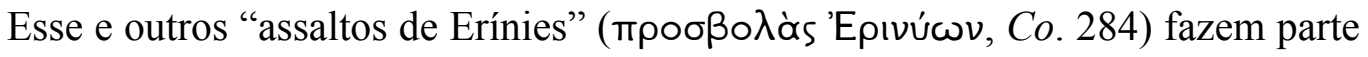
da enunciação oracular. Observe-se a ênfase nos versos de enunicação, cujo sujeito é "o

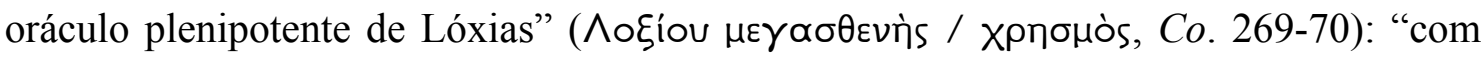

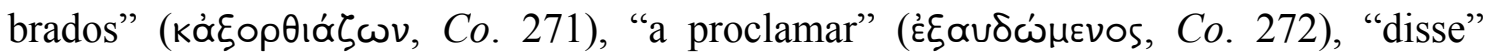

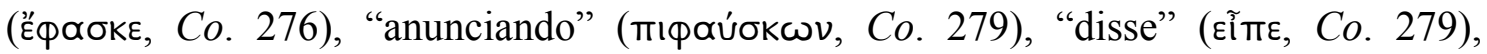

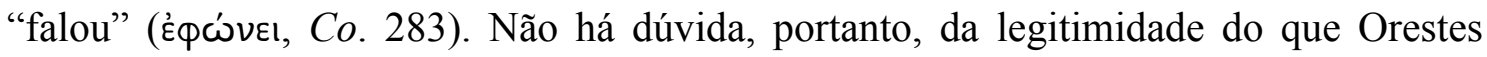

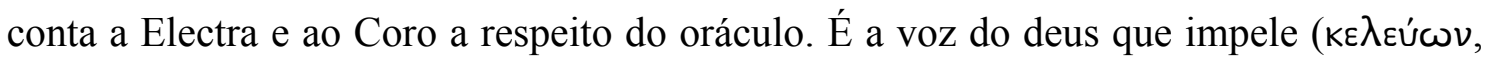
Co. 270), essa voz que brada, proclama, anuncia, diz, fala.

Orestes prossegue:

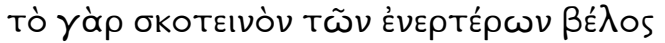

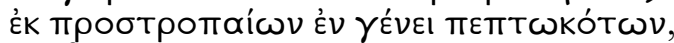

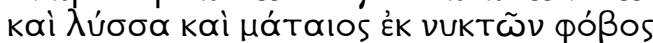

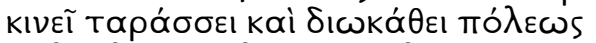

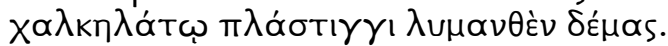

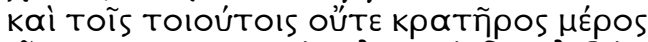

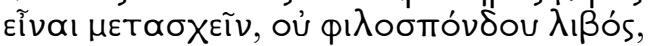

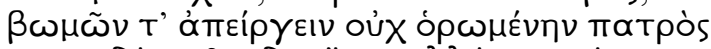

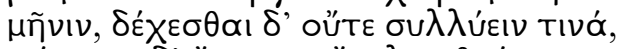

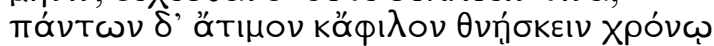

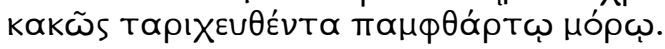

O dardo tenebroso de sob a terra vindo de súplices parentes caídos e a fúria e o inane pavor noturno aturdem, atordoam, expulsam da cidade com brônzeo açoite quem se poluiu. E assim não lhes ser possível participar nem do vinho nem do fluxo libatório e afastá-los de altares não vista cólera paterna, nem receber nem hospedar-se, e de todo sem honras nem amigos morrer em má hora ressecado por ruinosa morte.

(Co. 286-96) 
Às doenças que atacam o corpo seguem-se os males do espírito - a fúria

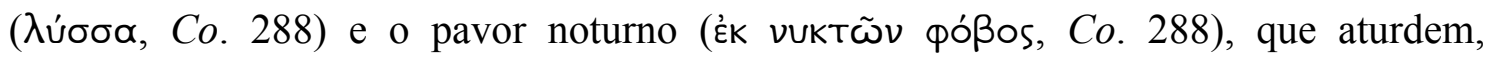
atordoam - e o banimento do convívio social - o exílio, a não-participação nos rituais religiosos, a desonra, a solidão, a morte. Isso é o que acontece com aquele que descuida

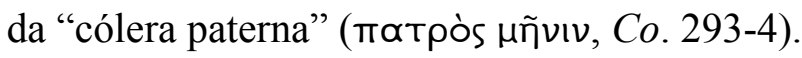

Por serem assim tão claros e assertivos, "Não se deve confiança a tais oráculos?"

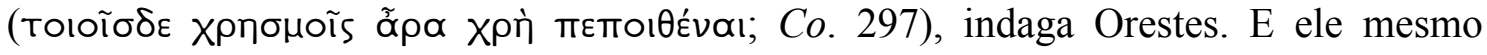

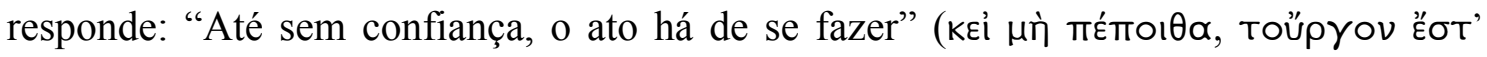

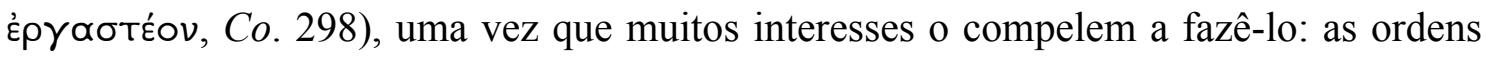
de Apolo, a dor pela perda do pai, a carência de recursos em que se encontra e a desonra que significa estarem submetidos cidadãos tão ilustres, responsáveis pela tomada de Troia, a uma mulher e a um homem cujo espírito fêmeo faz dele uma mulher.

Ao revelar seu plano de ação a Electra e ao Coro, Orestes menciona novamente o oráculo de Apolo:

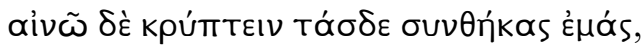

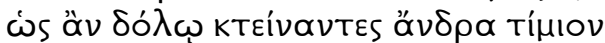

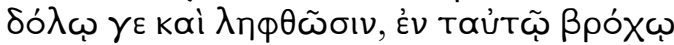

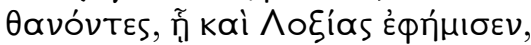

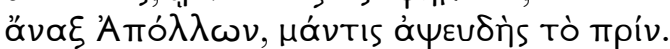

Exorto-os a ocultar este pacto comigo para que os dolosos matadores do bravo com dolo sejam pegos e no mesmo laço morram como também proclamou Lóxias rei Apolo, adivinho sem mentira antes.

(Co. 555-9)

Ressalta-se novamente a exigência de paridade entre as mortes de Agamêmnon e a de seus assassinos. Assim como eles mataram de forma dolosa ( $\delta$ ó $\lambda \omega$, Co. 556)

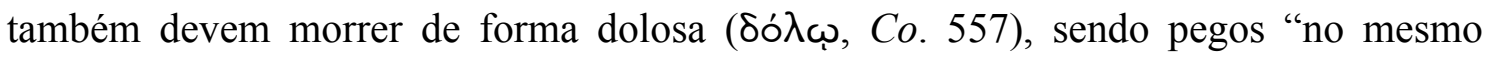

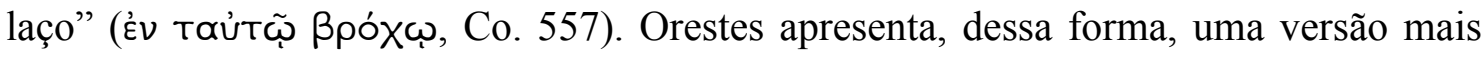
estendida do comando proclamado por Apolo de "punir os culpados de meu pai / dando-

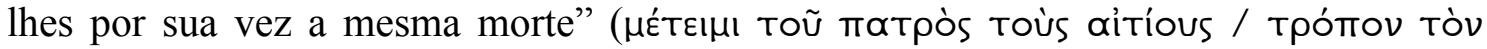
aủtóv, ávtatтоктеĩvaı $\lambda \varepsilon ́ \gamma \omega v$, Co. 273-4). Que essa punição seja de forma dolosa, isso também o deus proclamou (

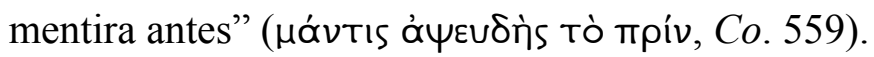

Ao dizer que Apolo como adivinho não mente, Orestes reforça a confiança que se deve ter em seus oráculos e a gravidade desses oráculos. As palavras do deus têm a força de um comando. Como se viu, Orestes se refere a elas como "as ordens do deus"

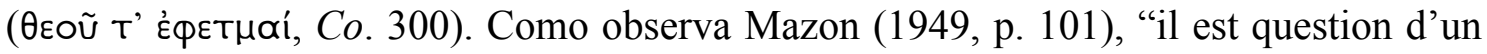


ordre, non d'une prophétie; mais lorsqu'il s'agit d'une oracle, les deux notions sont souvent confondues".

Orestes cumpre o comando do deus no terceiro episódio. Primeiramente, ele mata Egisto e, quando Clitemnestra percebe que o momento da punição chegou, ela

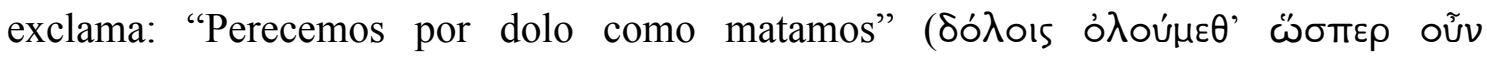

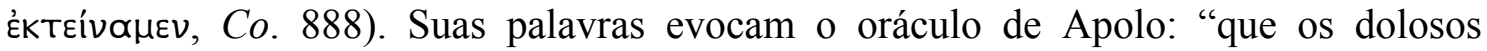

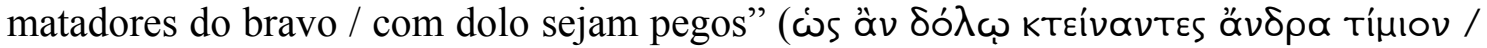

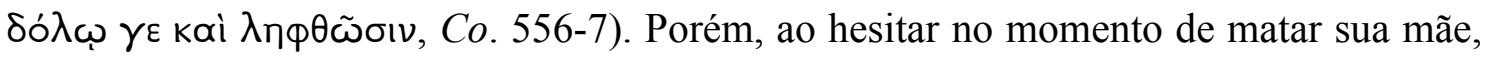
Orestes coloca em risco o cumprimento do oráculo de Apolo. Faz-se então necessária a intervenção do até então silencioso Pílades:

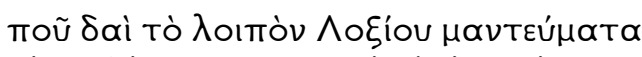

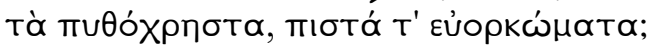

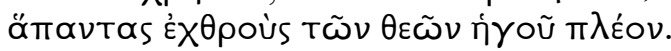

Onde no porvir os vaticínios de Lóxias dados em Delfos e os fiéis juramentos? Tem por hostis a todos mas não aos Deuses.

(Co. 900-2)

Suas palavras têm a função de lembrar Orestes, preso ao sentimento de pudor ante a visão do seio nu de sua mãe, de seu dever para com o deus. Ao mencionar a gravidade da hostilidade divina, as palavras de Pílades evocam todos "os muitos tristes

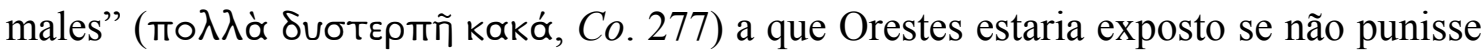
os assassinos de seu pai. Além disso, o que seriam dos vaticínios do deus e dos fiéis juramentos se ele os descumprisse? Palavra divina e palavra humana encontram-se em risco nesse momento de hesitação. No entanto, como observa Roberts (1984, p. 44), "he does not ask what will become of Orestes, but what will become of Apollo's oracles. Their fulfillment matters as much as Orestes' obedience, and Orestes' responsability to that fulffilment is stressed here as the god's was before".

Ao se enfatizar a responsabilidade de Orestes pelos vaticínios de Apolo e pela fidelidade dos juramentos, explicita-se a relação de reciprocidade entre deuses e mortais

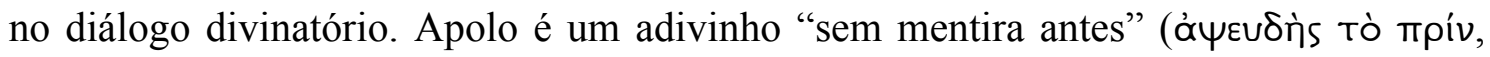
Co. 559) e cabe a Orestes, ao dar cumprimento a seus oráculos, que ele continue a ser um adivinho veraz ${ }^{38}$.

\footnotetext{
${ }^{38}$ Essa mesma relação de reciprocidade entre deuses e homens no diálogo divinatório pode ser percebida quando, no primeiro episódio, em sua prece a Zeus, Orestes diz que "Destruída a geração da águia, de

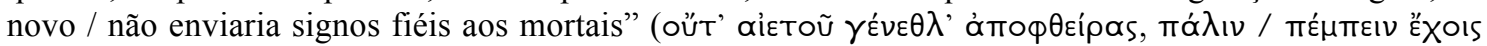

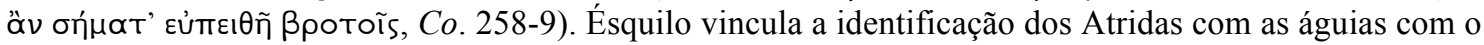
fato de as águias serem as aves mediante as quais Zeus envia signos ( explicita-se essa relação de reciprocidade entre deuses e mortais no que concerne à adivinhação. Ela é
} 
A intervenção epifânica de Pílades é bem-sucedida e Orestes consegue sobrepujar o seu pudor: ele mata a mãe, cumprindo assim a sua vingança. O Coro, no terceiro estásimo, celebra nesse acontecimento o cumprimento da Justiça divina: primeiro, ela se manifestou na punição sofrida pelos Priamidas e depois na punição sofrida por Clitemnestra e Egisto por meio de Orestes. Orestes é dito "o exilado emissário de Delfos / impelido por instruções do Deus" (ó muӨóxpnotos quyàs /

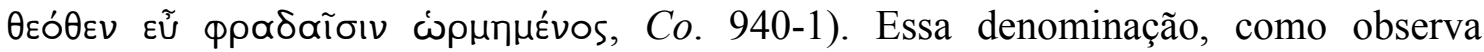
Roberts (1984, p. 47), é aplicável tanto ao passado quanto ao futuro. Ele retornou do exílio instruído por Apolo e partirá para o exílio igualmente instruído pelo deus.

A enunciação oracular de Apolo é, assim, identificada com a expressão da

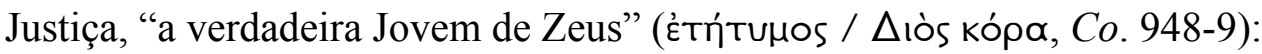

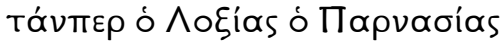

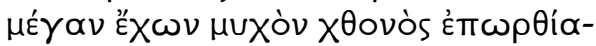

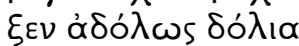

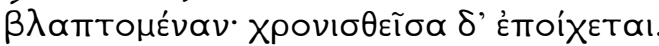

Lóxias senhor do grande recesso da terra parnásia proclamou-a sem dolo com dolo ofendida, mas com o tempo ela ataca.

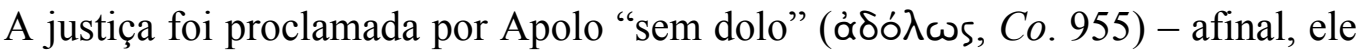
é um "adivinho sem mentira antes" -, mas por ter sido a justiça ofendida "com dolo"

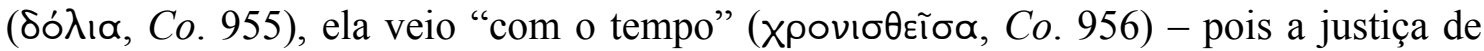
Zeus se manifesta no horizonte temporal, no curso dos acontecimentos - e veio sob a

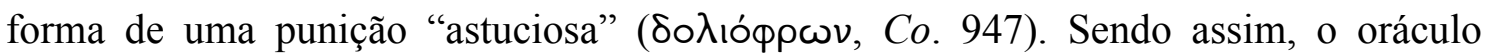
apolíneo é uma expressão da justiça de Zeus, uma vez que ele revela o curso dos acontecimentos e é no curso dos acontecimentos que a justiça de Zeus se realiza.

No último episódio, Orestes menciona uma vez mais o oráculo que lhe fora entregue:

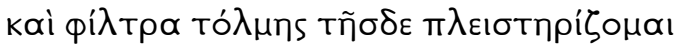

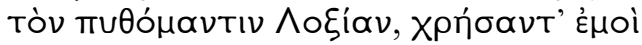

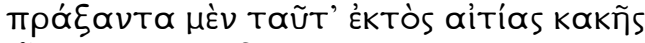

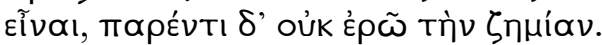

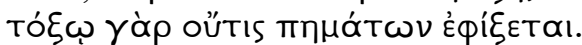

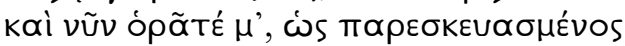

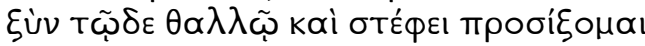

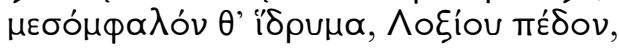

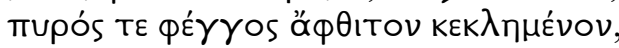

Encareço como estímulo desta audácia o pítio Lóxias, ao dar-me o oráculo de assim agir isento de maligna culpa, mas não direi o castigo se me omitisse: com arco algum as dores serão atingidas. Vede-me agora, partirei adornado com este coroado ramo ao templo no umbigo do meio, terra de Lóxias,

colocada no mesmo nível que a relação de reciprocidade que se dá no sacrifício: "uma vez seca toda esta

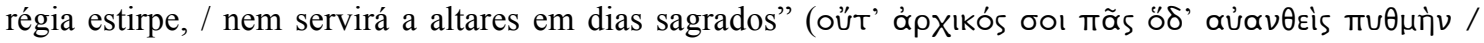

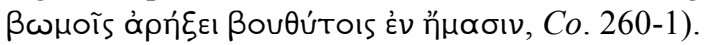




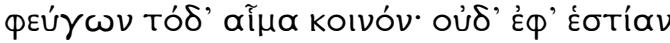

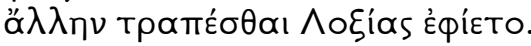

luminoso fogo chamado imperecível, a fugir deste sangue comum. Não permitiu Lóxias voltar-me a nenhum outro lar.

(Co. 1029-39)

Suas palavras trazem duas novas significativas informações a respeito do oráculo do Apolo. Primeiramente, a de que, ao matar a mãe, ele estaria "isento de maligna culpa" ('̇kтòs aítías kakñs, Co. 1031) e, em segundo lugar, de que ele deveria, após realizar sua vingança, dirigir-se a Delfos na condição de suplicante. Portanto, apenas uma parte do oráculo foi realizada: "since the oracle promised that Orestes, if he did as commanded, would be free of blame, it is not completely fulfilled until the final acquittal towards the end of the Eumenides" (ROBERTS, 1984, p. 27).

Se Orestes não vingasse a morte de seu pai, dando a seus assassinos a mesma morte, tal como ordenou o oráculo pítio, ele estaria exposto aos "assaltos de Erínies"

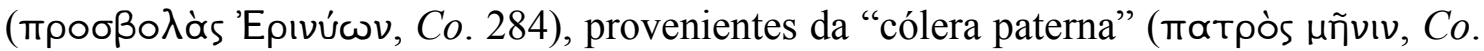
293-4). Por outro lado, se Orestes vingasse a morte de seu pai, o que implica cometer matricídio, ele estaria livre de culpa. No entanto, ficar livre de culpa não é algo que se realiza imediatamente e por si mesmo; é um processo, como o sugere a jornada até Delfos como suplicante para “fugir deste sangue comum” ( Co. 1038), isto é, o exílio autoimposto em função do derramamento de sangue consanguíneo; é algo que deve ser conquistado, como o sugere a ênfase de Orestes na

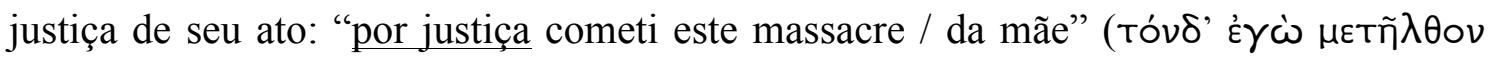

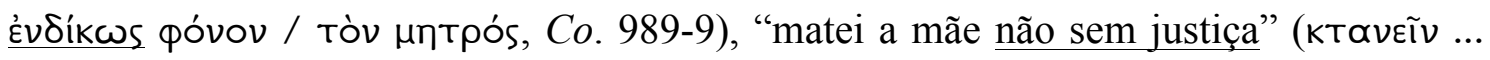

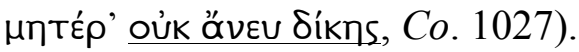

Orestes, através da utilização de um vocabulário jurídico, parece mesmo antever e prenunciar o seu julgamento. Ele exibe a rede maculada de sangue na qual seu pai foi

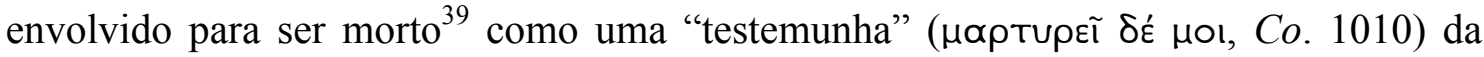

\footnotetext{
${ }^{39}$ É interessante observar o desenvolvimento dessa imagem da rede ao longo da Oresteia. Essa imagem da rede foi utilizada pelo Coro, em Agamêmnon, para, no primeiro estásimo, descrever a atuação do exército e a captura de Troia como uma "rede" (Síktvov, $A g$. 358) que Zeus rei e Noite amiga lançaram sobre suas torres. Clitemnestra, ao discursar para Agamêmnon no terceiro episódio, falando dos rumores que ouvira, diz que, se verídicos, Agamêmnon teria em seu corpo mais furos do que uma "rede" (Siktúou, $A g$. 868). Cassandra, no quarto episódio, prenunciando o assassinato de Agamêmnon, descreve como Clitemnestra, evolvendo o marido em uma "rede" (äpkus, $A g$. 1116), mata-o. A própria Clitemnestra, no quinto episódio, ao confessar o homicídio, relata como matou o marido: lançando-lhe ao

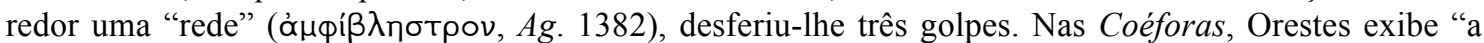

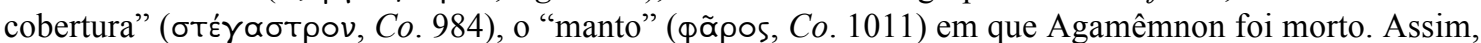
num primeiro momento, a imagem da rede é apenas uma metáfora para a punição divina que se abateu sobre Troia. Num segundo momento, através do discurso de Clitemnestra, ela adquire uma conotação ominosa. Em seguida, passa a ter um caráter inequivocamente profético mediante as profecias de
} 
vileza de seu assassínio e da culpabilidade de Egisto e pede que o Sol esteja presente

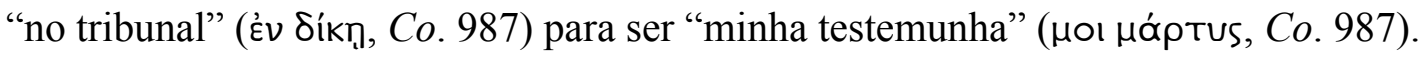

Porém, por uma ironia divina, até que ele seja absolvido da culpa, ele se encontra igualmente exposto aos assaltos de Erínies; se não às do pai, às das

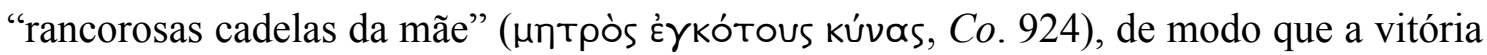
que obteve ao vingar o pai é descrita por Orestes como uma "indesejável poluência"

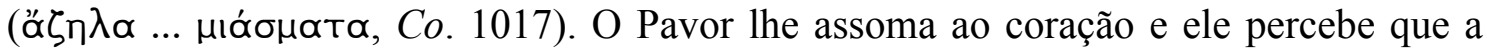
lucidez está prestes a lhe abandonar.

Ao descrever a condição em que se encontra - "Eis-me erradio, banido desta

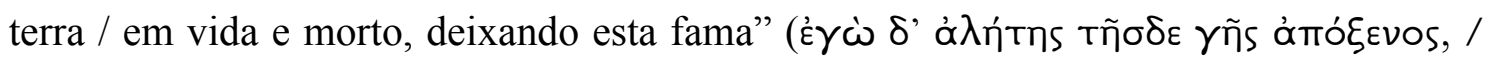

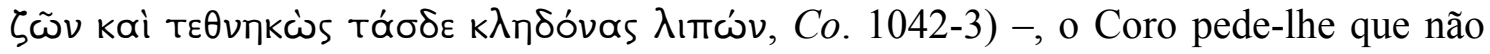
pronuncie palavras de mau augúrio - "não subjugues a boca / à palavra perversa, nem

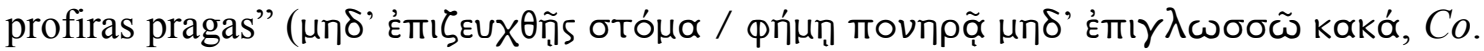
1044-5) - e, buscando consolá-lo, diz ter agido bem libertando a cidade de Argos ao decapitar "as duas serpentes" (Co. 1047).

As palavras do Coro encontram realização imediata: ao nomear as serpentes, elas se tornam presentes à visão de Orestes, que assim descreve as Erínies de sua mãe:

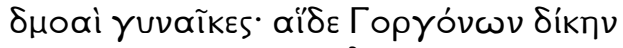
фaı

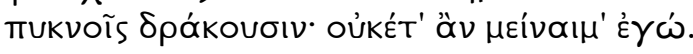

Estas mulheres horrendas como Górgones, vestidas de negro, com as tranças de crebas serpentes, eu não ficaria.

O Coro, não podendo vê-las, tenta interpretar a visão de Orestes como uma perturbação de espírito, fruto das dores e do sangue recente em suas mãos, dizendo-lhe: "Novo é o sangue ainda em tuas mãos, / disso provém o turvo ao teu espírito"

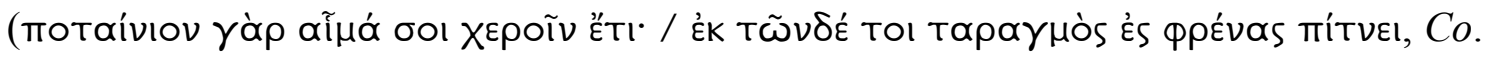
1055-6). Mas, para Orestes, trata-se de uma visão objetiva: "Não são visões destas

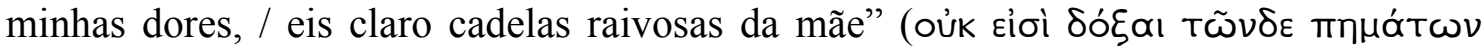

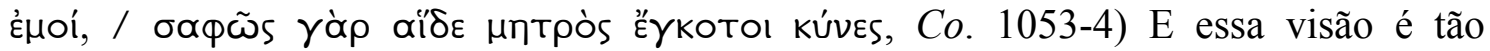
inequívoca em sua objetividade e tão poderosa pelo terror que inspira em Orestes que

Cassandra. Depois, realizando-se o que fora prenunciado, adquire toda a concretude nas mãos assassinas de Clitemnestra. Por fim, nas Coéforas, é novamente exibida, mas agora como um testemunho da culpa dos assassinos de Agamêmnon. Assim, o nume que preside o destino dos Atridas é, pois, como uma rede da qual não se pode escapar: a vítima, ao punir o crime de que foi vítima, incorre em uma falta que, por sua vez, também demanda punição. 
lhe demanda a partida imediata a Delfos, pois, como afirma o Coro, somente Lóxias poderá livrá-lo desses males.

Ao Coro só resta ponderar sobre a inexorabilidade do destino reservado à estirpe dos Atridas e indagar quando as sucessivas tempestades hão de parar de se abater sobre o palácio:

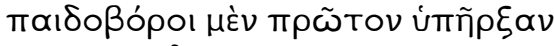

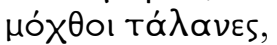

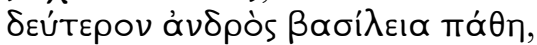

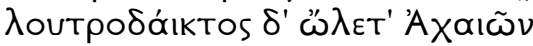

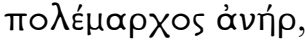

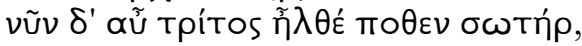

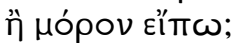

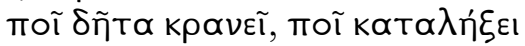

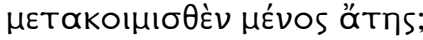

Primeiro foi a mísera devoração de criança. Depois a morte do marido, trucidado no banho pereceu o rei guerreiro dos aqueus. Agora veio o terceiro salvador ou devo dizer: trespasse? Onde concluirá? Onde repousará adormecida a cólera de Erronia?

(Co. 1068-1076) 
4.3. EUMÊNIDES 


\subsection{EUMÊNIDES}

\subsection{1) O oráculo de Apolo em Delfos}

Na primeira cena do prólogo das Eumênides, a Pítia anuncia, diante do templo de Apolo em Delfos, a abertura de um dia de consulta ao oráculo ${ }^{1}$. Primeiramente, ela faz uma prece aos deuses fundadores do oráculo e, nessa prece, tece-se a história de sua sucessão até o estabelecimento de Apolo no trono de Delfos:

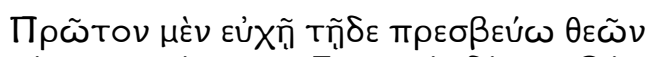

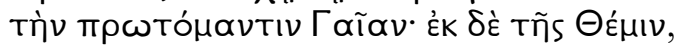

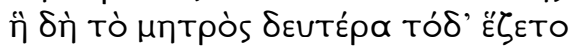

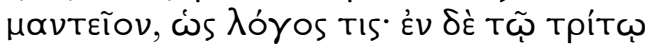

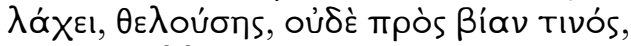

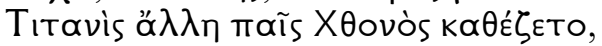

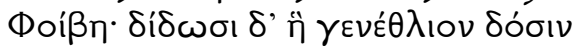

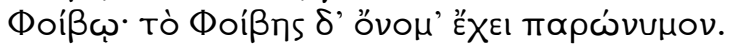

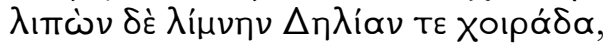

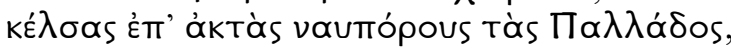

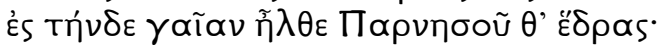

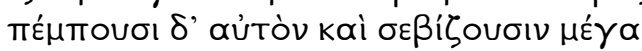

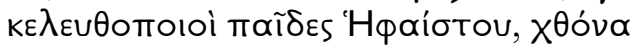

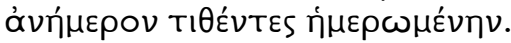

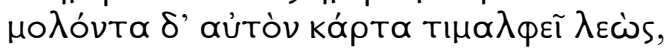

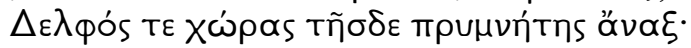

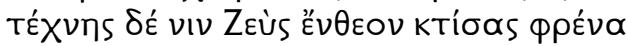

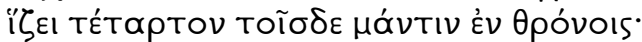

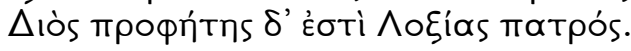

Primeiro dos Deuses nesta prece venero Terra, primeira adivinha. Dela provém Têmis, essa após a mãe sentava-se neste oráculo, como contam. No terceiro sorteio, porque ela anuiu, e não por violência, outra Titânida filha da Terra teve assento, Febe, e essa o doa, natalícia dádiva, a Febo. Ele tem de Febo o cognome. Deixou a lagoa e o penhasco délio, aportou nas costas navegáveis de Palas e veio a esta terra e sede do Parnaso. Abrindo caminho os filhos de Hefesto fazem-lhe escolta, prestam-lhe culto, sendo amansadores da terra bravia. Delfo, o rei timoneiro desta região, e o povo muito honram a sua chegada. Zeus o torna pleno de divina arte e põe quarto adivinho no trono, e Lóxias é profeta de Zeus Pai.

(Eu. 1-19)

\footnotetext{
${ }^{1}$ Como observa Bowden (2005, p. 17), há uma grande discussão entre os estudiosos a respeito da frequência com que o oráculo de Delfos funcionava. Acreditava-se que Apolo residia em Delfos durante apenas nove meses ao ano, indo passar o inverno junto aos hiperbóreos, e que o oráculo funcionava um dia em cada um desses noves meses, o que implica que as consultas eram realizadas durante somente nove dias ao ano. Não há, no entanto, suficientes evidências para se determinar com precisão a frequência de seu funcionamento, principalmente em vista do extenso período em que o oráculo esteve em atividade. Amandry (1950, pp. 84-5), em sua obra "La mantique apollinienne à Delphes - Essai sur le fonctionnement de l'oracle", chega à seguinte conclusão a esse respeito: "il est plus vraisemblable que l'oracle, accessible à tous sans conditions les jours de consultation publiques, annuelles dans les premiers temps de l'oracle, mensuelles à partir d'une époque impossible à déterminer exactement, s'ouvrait en outre en tout temps - sauf à certains jours de l'année tenus pour néfastes par le calendrier liturgique - aux seuls bénéficiaires d'un privilège concédé par la ville de Delphes".
} 
A primeira detentora da sede oracular foi a deusa Terra, descrita pela Pítia com o

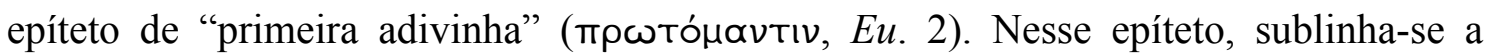
primordialidade e a inerência do caráter profético da Terra.

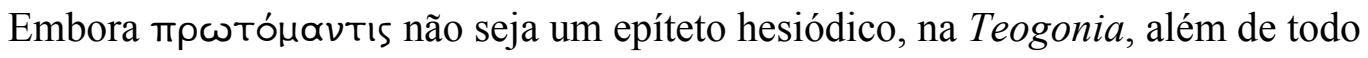
o ser e o devir dos deuses serem uma manifestação do ser da deusa Terra, ela também está presente em todos os momentos decisivos da organização do mundo, aconselhando e prenunciando ao mesmo tempo. Como observa Iriarte (1990, p. 38):

En este canto inspirado por las Musas que es la Teogonía, se encuentra la huella de un saber profético - que circula exclusivamente en el universo divino - cuya detentora es Gea, y al que se alude mediante el empleo de verbo $\phi \rho \alpha ́ \zeta \zeta \omega$, "dar a conocer", "hacer entender", o del término $\phi \rho \propto \delta \mu \circ \sigma u ́ v \eta$, que designa la expresión de la Sabiduría.

É a deusa Terra quem planeja o ardil pelo qual o Céu, seu esposo, vê-se privado

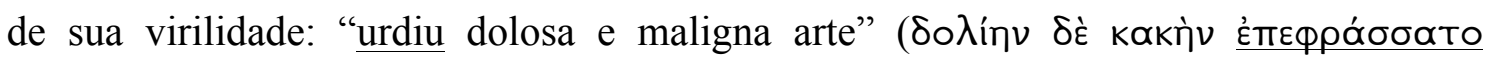
тÉXvๆv, Th. 160) ${ }^{2}$. É ela, junto ao Céu constelado ${ }^{3}$, quem prenuncia a Crono que ele haveria de ser destronado por um filho seu: "[Crono] soube da Terra e do Céu constelado / que lhe era destino por um filho ser submetido / apesar de poderoso"

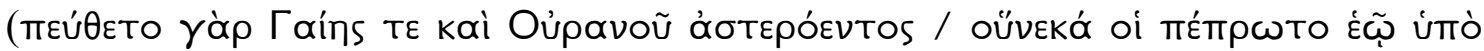

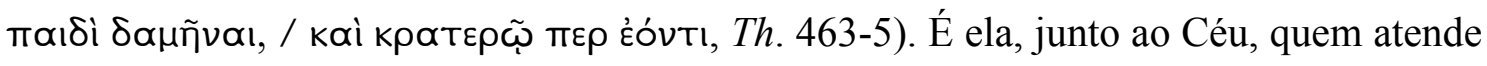

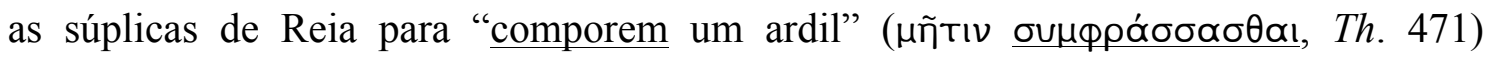
mediante o qual Zeus não fosse engolido pelo pai e, assim, eles "indicaram quanto era

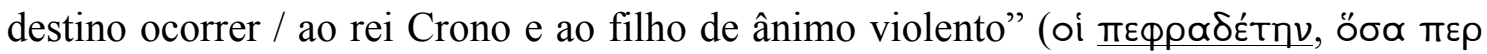

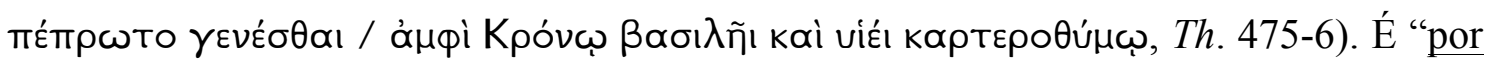

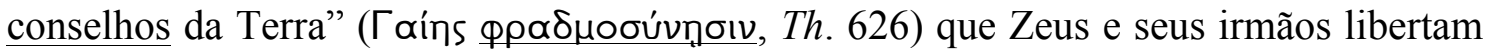
de sob a terra os Centímanos, pois Terra "Ihes revelou clara e plenamente: / teriam com

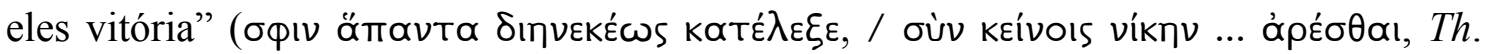

\footnotetext{
${ }^{2}$ Iriarte (1990, p. 38) chama atenção para o fato de que o poder de predição da deusa Terra é indissociável de seu poder de ação: "El poder profético de la Tierra se confunde con um modo de reflexión y de savoirfaire caracterizados por ese tipo de inteligencia 'astuta' que el griego denominaba métis". Quantin (1992, p. 188), porém, nega a efetividade e a eficácia da palavra profética da Terra: "Il s'agit presque d'une discours sans locuteur: ce qui l'apparente plus à une rumeur transmettant un savoir commun qu'à une parole active et efficace. [...] Le savoir qu'a Gaia du destin n'est pas une maîtrise, elle ne fait qu'avertir ses enfants des lois du destin. Sa parole est un avertissement, une connaissance donnée: Gaia informe, indique; ele ne dit rien, elle "répète'".

${ }^{3}$ Quantin (1992, p. 188) observa que o Céu compartilha do saber da Terra e que, portanto, "la Terre n'a pas l'exclusivité de la fonction prophétique; on peut donc douter que cette fonction soit dès l'origine étroitement liée à la féminité de Gaia". Iriarte (1990, p. 38), por outro lado, admite que o saber da Terra é compartilhado pelo Céu, mas observa que o Céu é uma "potencia que ella misma ha engendrado y que es, de hecho, su propio doble: "un ser igual a sí misma'".
} 


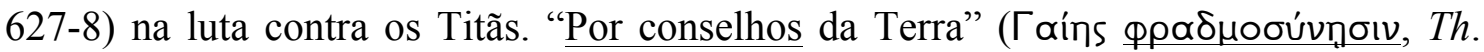
884), os deuses olímpios exortavam Zeus a assumir o poder e "por conselhos da Terra e

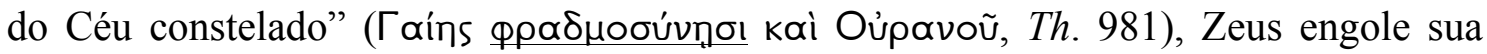

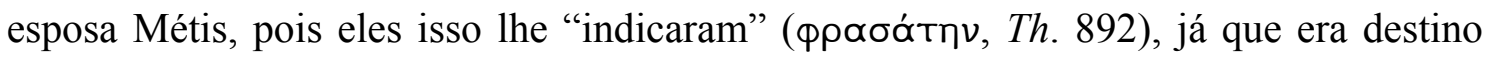
que Métis parisse um filho que ameaçaria a soberania de Zeus.

No relato da Pítia, a segunda deusa na linha sucessória do oráculo délfico foi Têmis, que, conforme os versos hesiódicos (Th. 126-135), é filha da Terra e do Céu. O caráter profético de Têmis se explicita principalmente mediante sua filiação à deusa Terra, com a qual muitas vezes se confunde, tal como quando, no Prometeu Cadeeiro, o Titã, ao dizer que sua mãe lhe profetizava o porvir, chama-a Terra e Têmis, "de muitos

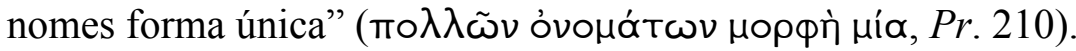

A terceira deusa a presidir a sede oracular foi Febe, "outra Titânida filha da

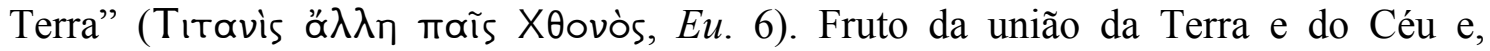
portanto, irmã de Têmis, Febe é ainda avó de Apolo, como indica Hesíodo (Th. 126-36; 404-8; 918-20). Assim, é também mediante sua genealogia que se explicita o aspecto profético dessa deusa ${ }^{4}$.

Por fim, encerrando a história de sucessão do oráculo, figura Febo, que "tem de

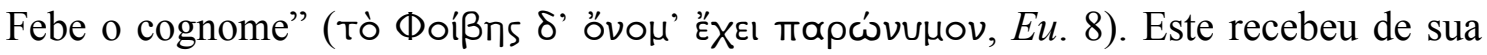
avó o oráculo délfico como um presente de nascimento, "natalícia dádiva" ( $\gamma \varepsilon v \varepsilon \varepsilon \lambda_{\imath} \circ \nu$

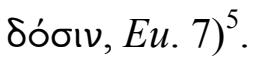

A principal característica desse breve relato feito pela Pítia sobre a sucessão divina do oráculo de Delfos é o aspecto harmonioso, pacífico e não-violento dessa sucessão. Este é triplamente enfatizado ao se descrever a transição do oráculo de Têmis

\footnotetext{
${ }^{4}$ Para Robertson (1941), a inclusão de Febe no processo sucessório do oráculo de Delfos é uma invenção de Ésquilo, a qual, segundo a autora, justifica-se pela tentativa do tragediógrafo de criar um paralelo entre as três primeiras possessões do oráculo com as três distribuições de honrarias feitas respectivamente por Céu, Crono e Zeus. Para Sommerstein $(1989$, p. 81), Ésquilo introduz Febe para evitar uma transição direta do oráculo de Têmis a Apolo, tradicionalmente não-pacífica. Podlecki (1989, p. 129), por sua vez, afirma que a introdução da deusa Febe, ao alongar o processo sucessório, torna-o mais venerável, ao mesmo tempo em que se enfatizam os vínculos familiares, já que Febe, como avó de Apolo, transmite o oráculo como um presente de aniversário. Para Ruiz (2010, p. 10), "el mito de la sucesión en el santuario es una reelaboración del mito tradicional de la sucesión divina, en el que un dios primigenio es vencido por un dios joven que trae el orden y la ley: en el caso de Delfos han sido vencidos los aspectos ctónicos, peligrosos y desordenados del cosmos y subordinados a un guía celestial, legislador. En el Himno a Apolo aparece también un mito de fundación, que se refiere a la misma idea de llegar a un nuevo orden, el de Zeus. La serpiente que es vencida supone la misma idea que Gea: aunar en una figura mítica los aspectos terribles y desordenados del mundo. Luego se introducirá la figura de Temis, un paso intermedio que hace menos abrupta la sucesión. En el caso de Esquilo la figura intermedia es Febe, más positiva pero con la misma función de transición".

${ }^{5}$ Amandry (1950, pp. 201-14) dedica um capítulo de sua obra às histórias de sucessão da sede oracular délfica, recolhendo todas as suas variantes.
} 


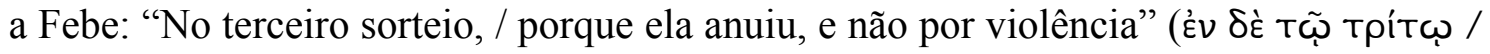

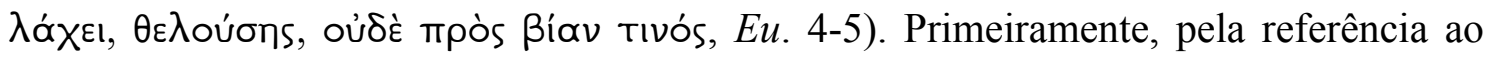
sorteio ( $\lambda$ á $\chi \bigcirc \varsigma$ ), que, como se viu, é uma forma legítima e pacífica de se distribuir bens

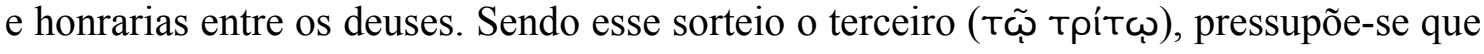
até então a transição da sede oracular entre as divindades tenha se dando igualmente através da tiragem à sorte. Em segundo lugar, pela referência ao caráter voluntário da transição: a deusa anuiu ( $\theta \varepsilon \lambda$ oúons). Por fim, pela expressão mesma da ausência de violência (oủঠè mpòs ßíav tıvós). Essa harmoniosa transição também se deixa perceber na paronímia entre Febe e Febo, a que se faz menção (Eu. 8), e ainda ao se retratar a passagem do oráculo entre esses dois deuses como um presente de aniversário da avó para o neto (Eu. 7).

Observe-se que essa ênfase que se dá ao processo harmonioso da sucessão divina do trono pítio está presente não apenas no que é relatado a respeito de tal sucessão, mas também no que é omitido nesse relato. O embate entre Terra e/ou Têmis, divindades notadamente ctônias, com uma divindade olímpia pela posse da sede oracular parece ter sido um aspecto recorrente dos mitos relativos ao oráculo de Delfos. Quanto a isso, Bouché-Leclercq (2003, p. 578) faz a seguinte observação:

[...] la tradition recueillie et retouchée par Eschyle n'est qu'une des nombreuses combinaisons de légendes essayées par les mythographes pour reconstituer l'histoire primitive de l'oracle, et ce n'est probablement pas la plus conforme à la foi populaire. [...] La plupart des récites mythiques mettent en conflit direct avec Gaea au moins deux usurpateurs successivement attirés par les séductions du lieu, Poseidon et Apollon.

Esse embate entre divindades ctônias e olímpias deixa-se entrever no embate entre Apolo e a serpente Píton, de cujo nome a sacerdotisa do templo de Delfos parece derivar o seu. Tal mito às vezes se associa diretamente ao oráculo, fazendo-se da terrível serpente uma guardiã da telúrica sede oracular, como se vê no quarto estásimo de Ifigênia em Táurida, de Eurípides:

EüTraıs ò ^atoũs yóvos,

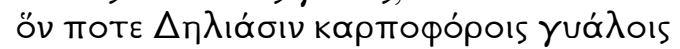

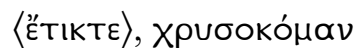

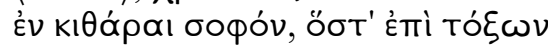

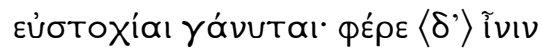

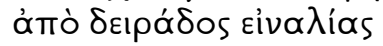

$\lambda$

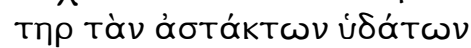

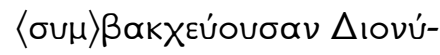

Belo filho Leto gerou no frutífero vale délio, filho de áurea cabeleira, hábil na cítara, com arco brilha por boa mira. Leva-o a mãe, das fragas do mar, do ínclito local do parto, ao cimo de inegadas águas do Parnaso, onde bacante 


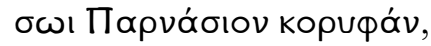

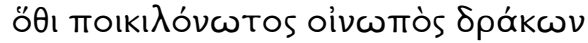

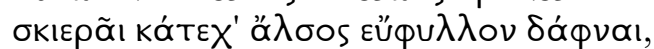

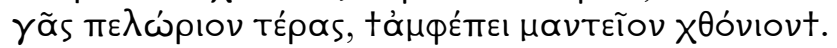

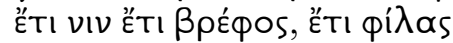

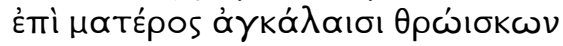

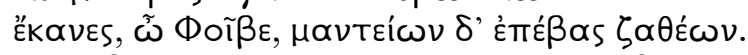

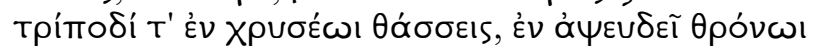

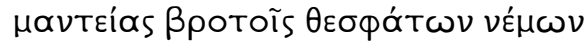

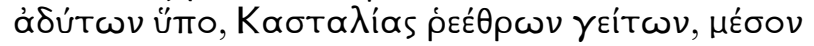

$\gamma \tilde{\alpha} \varsigma$ हैX $\chi \omega \nu \mu \varepsilon \dot{\varepsilon} \lambda \alpha \theta \rho o v$. celebra Dioniso, onde

vínea serpente de dorso vário

tinha bosque frondoso em laurácea sombria,

vasto portento da terra vigiava oráculo ctônio.

Mataste-a, ainda novo, ainda nos braços

maternos, buliçoso,

ó Febo, e tens o templo divino,

sentado no áureo tripé, trono sem mentira, dando vaticínios divinatórios a mortais, no ádito, perto da fonte Castália, no palácio do meio da terra.

(E. IT. 1234-58)

Nessa primeira estrofe, o Coro canta o nascimento de Apolo e como sua mãe, Leto, levou-o da ilha de Delos, seu local de nascimento, até o Parnaso, onde, lá

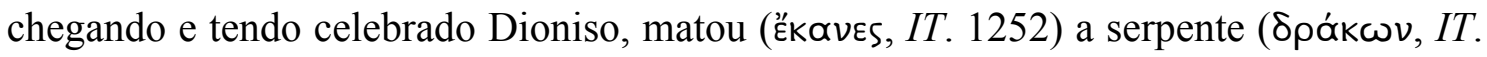

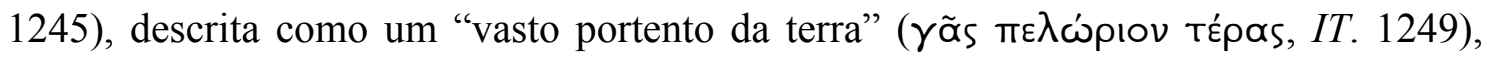

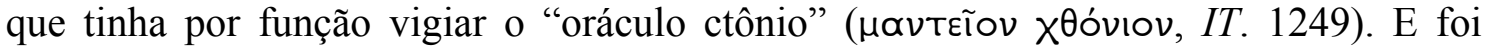

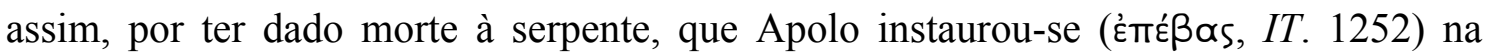
divina sede oracular. A proeza do deus é ressaltada pelo fato de ele ser "ainda novo" ('̌́tı ßpéфos, IT. 1250), ainda uma criança nos braços da mãe. Porém, a sua façanha trouxe-lhe consequências indesejadas, como o narra a antístrofe:

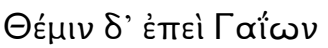

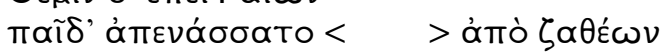

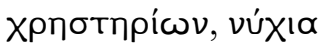

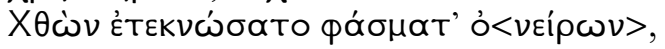

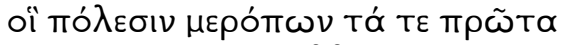

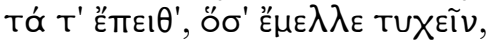

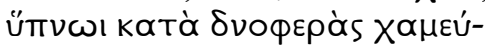

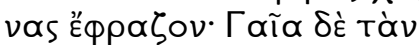 \\ $\mu \propto v T \varepsilon i ́ \omega \nu$ ơ $\phi \varepsilon i ́ \lambda \varepsilon T O$ TI-

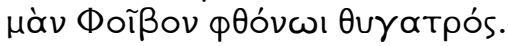

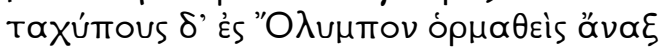

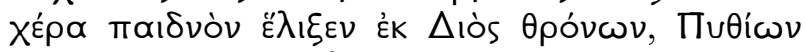

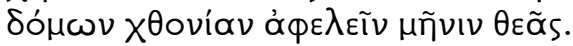

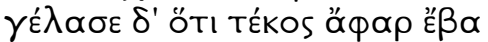

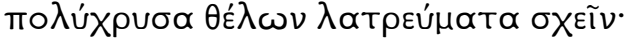

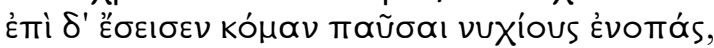

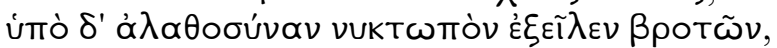

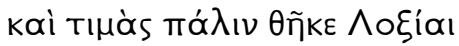

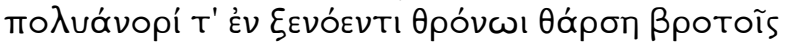

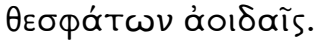

Quando Têmis, filha da Terra, foi despejada do divino sítio divinatório, Terra noturna gerou visões de sonhos que diziam a muitos mortais o antes, o depois e o porvir no sono nos leitos trevosos, Terra tirou assim o oficio de vaticínios de Apolo por recusa da filha. $\mathrm{O}$ rei a rápido passo foi ao Olimpo, deu abraço filial ao trono de Zeus, que tire da casa pítia a ira de Deusa Terra, Zeus riu porque o filho veio rápido querendo manter os auríferos cultos. Brandiu a crina cessando vozes noturnas, retirou dos mortais a verdade vista à noite, reverteu o oficio a Lóxias e a coragem aos mortais em populoso hospitaleiro trono mediante cantos divinatórios.

(E. IT. 1259-83) 
A morte da serpente representa o fim da dominação da deusa Têmis sobre o

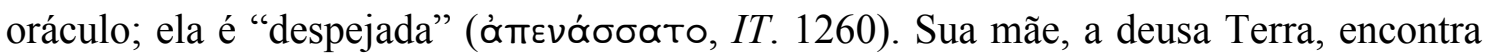

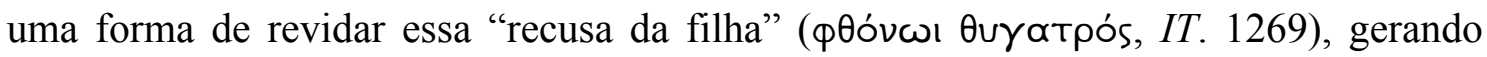
sonhos proféticos para os mortais e retirando assim de Apolo o "ofício de vaticínios"

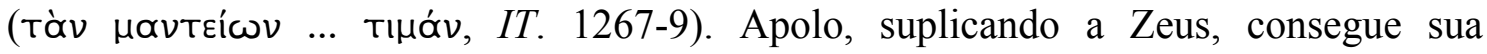
intervenção: Zeus emudece os sonhos proféticos e restitui ao filho o "ofício" (тıนás, IT. 1280).

No Hino Homérico a Apolo, narra-se que, vagueando à procura de um local para construir um templo em cujo espaço sagrado pudesse proferir seus oráculos, Apolo é aconselhado pela corrente d'água Telfusa a se dirigir ao Parnaso. Lá, depara-se com a serpente Píton:

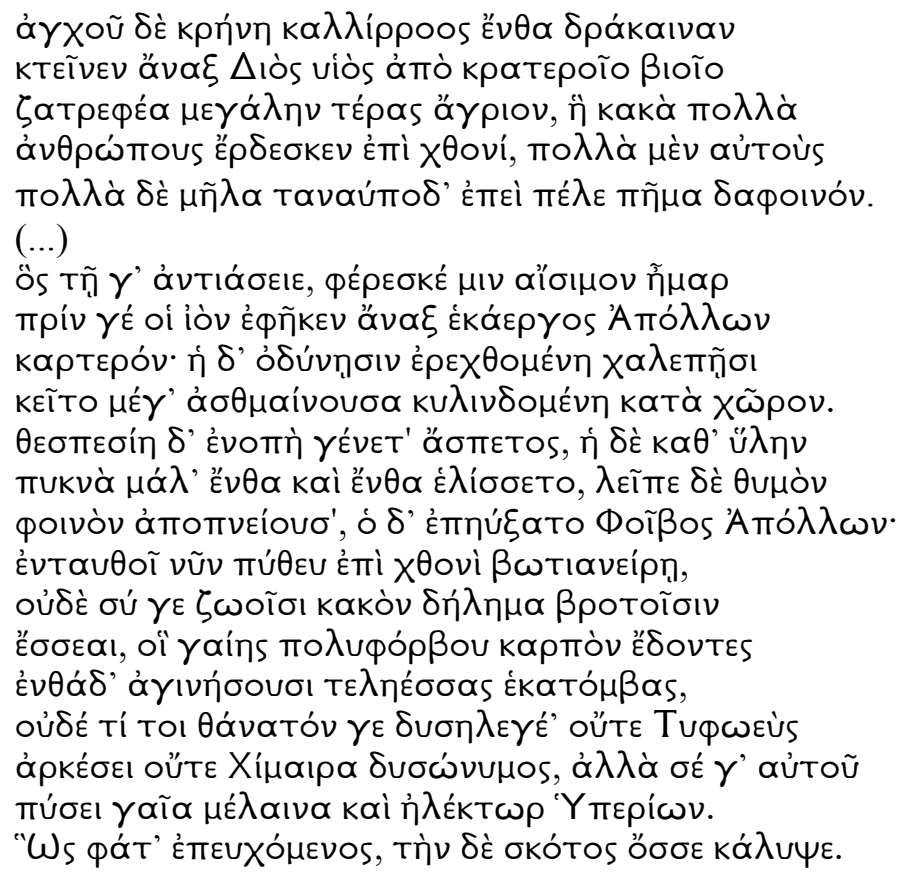

Perto ${ }^{6}$ há uma fonte de bela corredeira, ali o senhor filho de Zeus, matou, com seu arco enérgico, uma serpente robusta, grande, um monstro feroz que fazia muitos males aos homens sobre a terra; muitos males a eles, e muitos males aos carneiros de patas finas. Era um tormento de sangue.

\section{(...)}

Quem a encontrasse, o dia fatal o levava, antes que o senhor arqueiro Apolo lançasse-lhe suas flechas fortes. A serpente, dilacerada pelas dores difíceis de suportar, jazia ofegante, rolando no chão.

Um grito extraordinário surgiu imenso; sem cessar

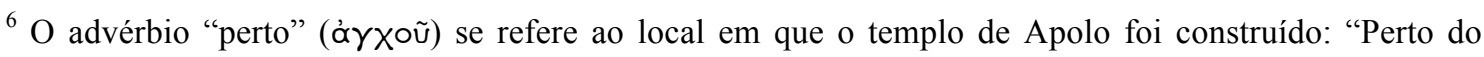
templo há uma fonte...".
} 
suplicava ela aqui e ali na floresta; depois abandonou o ânimo, exalando um sopro sanguíneo, e Febo Apolo disse:

"Que agora aqui apodreças sobre a terra nutriz de homens.

Não será mais a ruína aos mortais viventes;

eles, que comem o fruto da mui nutriz terra,

aqui me trarão perfeitas hecatombes;

nada te afastará da morte cruel, nem Tifeu,

nem Cabra de nome odioso, mas aqui mesmo

a terra negra e o brilhante Hipérion te farão apodrecer".

Assim falou vangloriando-se. E as trevas cobriram os olhos da serpente.

(h.Hom. XXI, 300-4; 356-70) ${ }^{7}$

Nesse hino homérico, narra-se a chegada de Apolo e a instauração de seu culto em Delfos. A serpente não aparece relacionada diretamente ao oráculo, no sentido de que ela não é sua guardiã ${ }^{8}$, mas está relacionada à região em que Apolo estabelece seu culto e seu templo oracular. O embate entre o deus e a serpente se associa, então, ao processo civilizador de Delfos, uma vez que Píton figura como um ser monstruoso

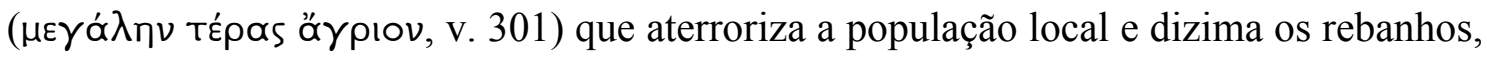
causando inúmeros males (

Quanto à chegada de Apolo em Delfos e à instalação de seu culto na cidade nos versos esquilianos, também se mostra a mesma harmonia ressaltada na descrição da sucessão divina do oráculo pítio. Assim, o deus, partindo de sua terra natal ("a lagoa e o

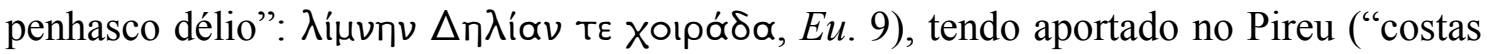

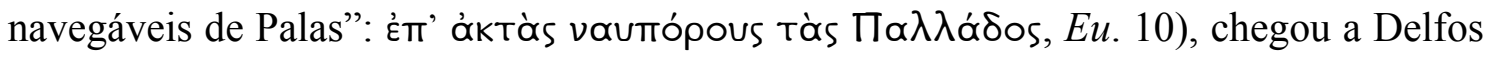

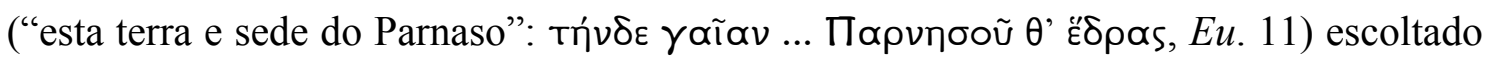

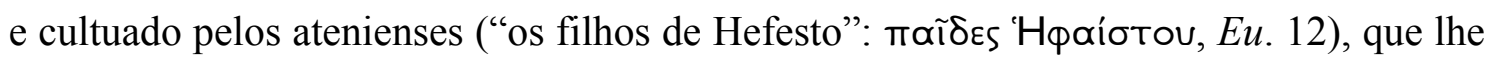

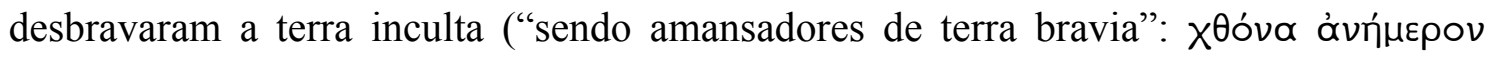

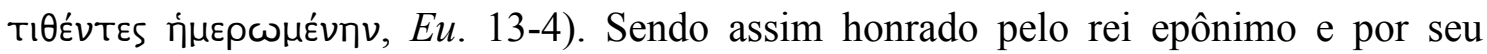
povo,

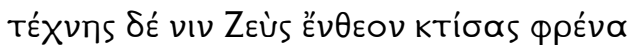

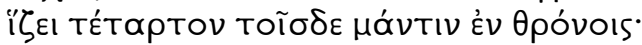

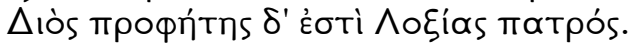

Zeus o torna pleno de divina arte e põe quarto adivinho no trono, e Lóxias é profeta de Zeus Pai.

\footnotetext{
${ }^{7}$ Tradução de Maria Lúcia G. Massi e Sílvia M. S. de Carvalho (2010).

${ }^{8}$ Chappell (2006), em seu artigo "Delphi and the Homeric Hymn to Apollo" afirma que "the connecting of the snake and the previous owners is first attested in Euripides' Iphigenia in Tauris (1234-83)", embora a morte da serpente Píton seja uma das partes mais celebradas do mito délfico. No que se refere à morte da serpente às mãos de Apolo no hino homérico, o autor observa o seguinte: "The description of the actual combat is brief: we are merely told that Apollo killed the snake with his bow, and more space is devoted to the description of her death throes and Apollo's boastful speech over the corpse. The brevity of the description may stress the ease of Apollo's victory".
} 


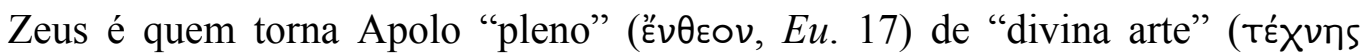

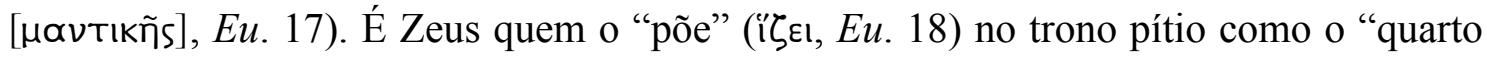

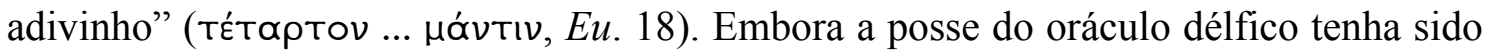

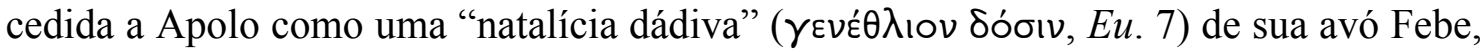
é Zeus quem sanciona e legitima o deus como adivinho em Delfos, fazendo dele seu “profeta” (профท́тпs, Eu. 19), isto é, aquele que fala em seu nome". Zeus figura, assim, como aquele que garante a veracidade e a legitimidade dos oráculos apolíneos, o que será usado por Apolo como o primeiro argumento em favor da defesa de Orestes (Eu. 616-8).

Em um segundo momento, dando continuidade à sua prece, a Pítia invoca ainda as divindades que fazem parte tanto da paisagem física quanto da paisagem divina de Delfos. Primeiramente é evocada Palas Atena, cujo templo situa-se diante do templo de Apolo e, por isso, é dita "Palas Pronaia" ( $\Pi \propto \lambda \lambda \lambda_{\alpha}$ \ Пpovaía, Eu. 21); em seguida as

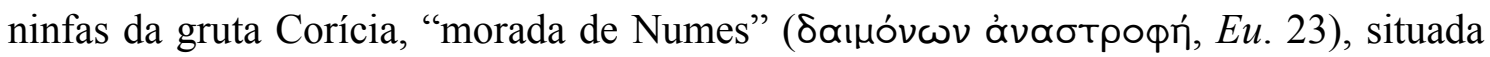
na encosta do Parnaso; Dioniso, cujo teatro se encontra bem próximo ao templo de $\mathrm{Apolo}^{10}$; Posídon, em uma de suas epifanias, o curso de água Plisto; e, por fim, "o

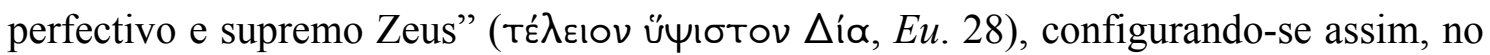
horizonte divino de Delfos, uma comunidade harmoniosa de deuses ctônios e olímpios, que coabitam nesse espaço privilegiado pela beleza e pela sacralidade.

A omissão de qualquer referência a qualquer embate entre deuses ctônios e olímpios pela posse do oráculo délfico ou à morte da serpente Píton por Apolo é extremamente eloquente. Essa profunda harmonia que se mostra no processo de

\footnotetext{
${ }^{9}$ Tanto no Hino Homérico a Apolo quanto no Hino Homérico a Hermes, Apolo desempenha o papel de profeta de Zeus. No primeiro, Apolo diz: "Revelarei, aos homens, o desígnio infalível de Zeus" (

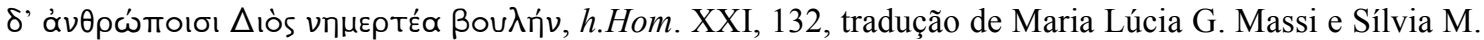
S. de Carvalho, 2010). No segundo, dialogando com Hermes, Apolo diz: "Mas a adivinhação, meu caro, que sem cessar me solicitas, / nem a ti é dado conhecer, nem a nenhum outro / imortal. Pois este saber é da mente de Zeus. Quanto a mim, / empenhei minha palavra ao assentir, com potente juramento, / em que, além de mim, nenhum outro dos imortais / conheceria de Zeus o poderoso desígnio. / E tu, irmão portador

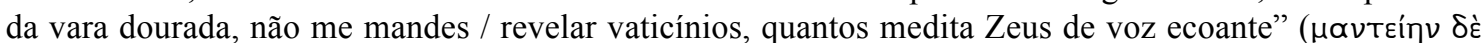

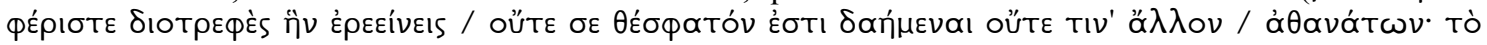

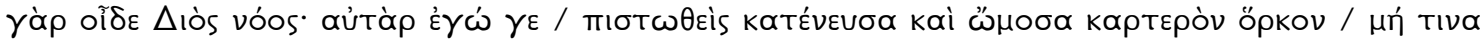

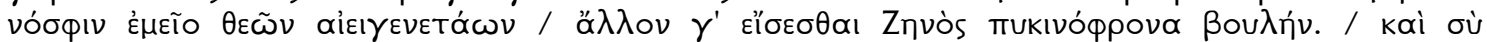

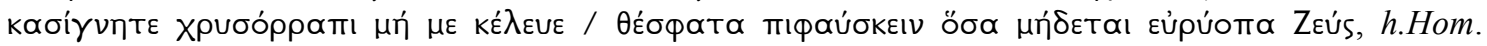
XVIII, 533-40, tradução de Maria Celeste C. Dezotti e Sílvia M. S. de Carvalho, 2010).

${ }^{10}$ Em sua evocação a Dioniso, a Pítia lembra a partida do deus com suas bacantes "tramando morte de

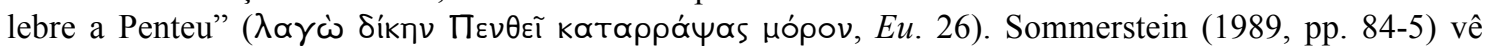
nessa menção a Penteu morto como uma lebre uma alusão à lebre morta pelas águias no párodo de Agamêmnon. A respeito dessa referência a Dioniso e Penteu, conferir o artigo de Miralles (2001), "Dioniso nel prologo delle Eumenidi".
} 
transição do oráculo e perpassa o horizonte divino de Delfos, refletindo-se na pacífica convivência entre deuses novos e antigos, mostra-se aqui, por assim dizer, como a calmaria que antecede a tempestade.

Essa harmonia que perpassa toda a primeira cena do prólogo das Eumênides torna, por contraste, ainda mais terrível e ameaçador o conflito que em breve há de se instalar: ocultos no interior do recesso oracular encontram-se um matricida e as suas perseguidoras, as horripilantes Erínies. Assim, se, por uma lado, a harmonia enfatizada por Ésquilo nessa primeira cena torna ainda mais perturbador o conflito que a presença de Orestes e das Erínies estão a ponto de deflagrar; por outro lado, essa mesma harmonia serve como um prenúncio daquela harmonia derradeira, a que há de se instaurar no fim da tragédia e da trilogia, quando o convívio pacífico e harmônico entre deuses novos e antigos, entre deuses ctônios e olímpios, é restabelecido.

A Pítia assim finaliza sua prece:

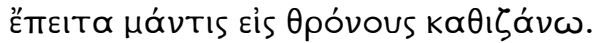

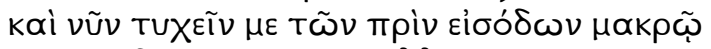

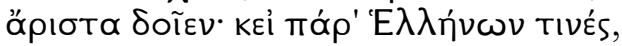

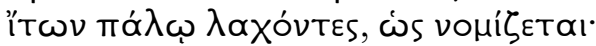

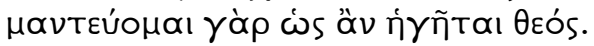

depois adivinha me sento no trono. Deem-me hoje lograr a melhor entrada que antes. Se há gregos presentes, venham, segundo sorteio, como sói ser. Vaticino como deus vai conduzindo.

(Eu. 29-33)

Ao sentar-se "no trono" (Eis Opóvous, Eu. 29), esse trono no qual Zeus estabeleceu Apolo, a Pítia torna-se "adivinha" ( $\mu a ́ v \tau$ เs, Eu. 29). Assim como Apolo vaticina em nome de Zeus, a Pítia vaticina em nome de Apolo: "vaticino como o deus

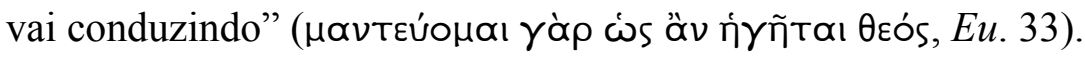

A prece aos deuses é assim finalizada com o pedido de que estes the deem

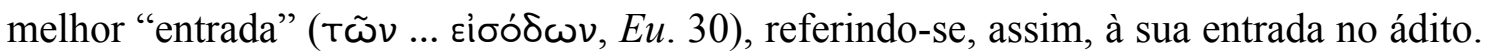
Sommerstein (1989, p. 86) observa que essa prece é justifícável porque "to become the inspired vehicle of Apollo's utterances was a dangerous act", e cita o caso narrado por Plutarco (Mor. 438a-c) da morte de uma pitonisa que, por presságios desfavoráveis, entrou no ádito relutante e, após a primeira resposta, saiu de lá aos berros, jogou-se no chão e morreu dias depois. Podlecki (1989, p. 131), por sua vez, vê nesse pedido da Pítia por uma boa entrada no ádito uma "palpable irony”, já que em breve ela sairá de lá horrorizada pela visão de Orestes e das Erínies.

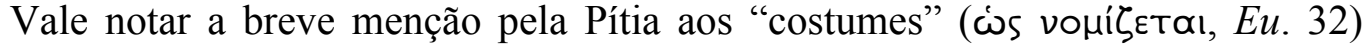
segundo os quais há um sorteio para definir, muito provavelmente, a ordem de 
consultação. No entanto, segundo Bowden (2005, p. 17), havia, no período clássico, uma ordem de consulta em parte já pré-estabelecida: a cidade de Delfos e seus cidadãos tinham o direito de serem os primeiros a consultar o oráculo; depois deles, as cidades ou os indivíduos aos quais Delfos havia garantido o privilégio da promanteía; por fim, as delegações e os indivíduos provenientes das demais cidades-estado.

Por fim, a Pítia entra no templo, para em breve de lá sair arrastando-se - "Corro

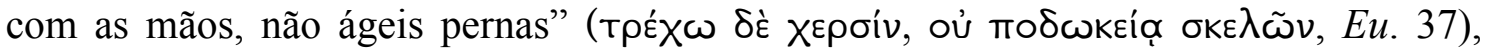

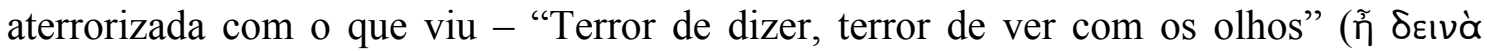

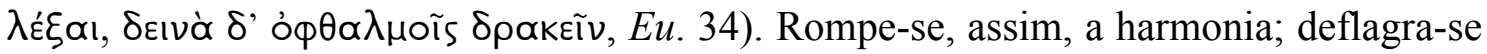
o conflito. Diz a Pítia:

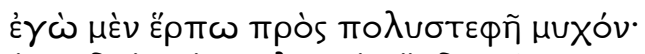

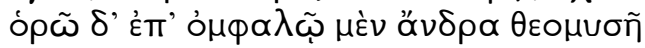

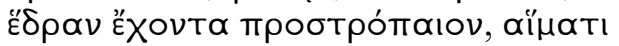

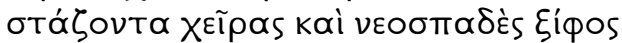

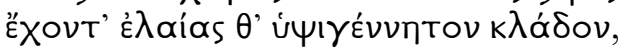

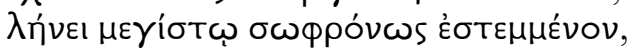

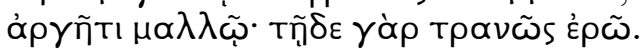

Eu me esgueiro no engrinaldado recesso, e junto ao Umbigo vejo homem horrendo aos Deuses, conspurcado, tendo as mãos sangrentas e a espada recém-puxada, portador de ramo de oliveira altaneiro com prudência coroado com largo velo, com alva lã, assim se diz claramente.

(Eu. 39-45)

A visão que a Pítia tem de Orestes, a quem descreve como um "homem horrendo

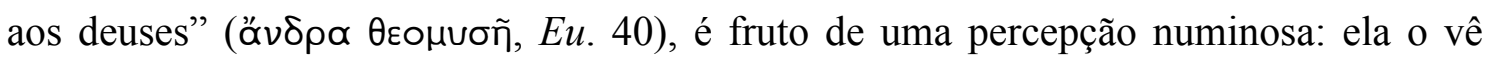

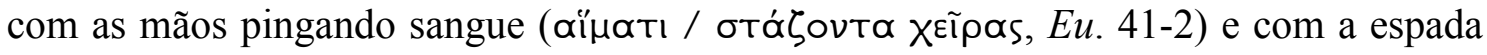

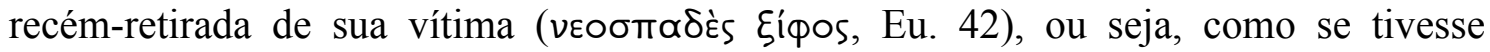
acabado de assassinar Clitemnestra. É uma visão que se assemelha em certo modo às visões de Cassandra em Agamêmnon, no sentido de que lá a profetisa vê o resultado presente de um crime passado: o chão do palácio umedecido de sangue, os filhos de Tiestes segurando em suas mãos as carnes devoradas pelo pai. Da mesma forma, a Pítia vê Orestes com as mãos e a espada ainda sujas do sangue de sua vítima. Mais do que um peregrino que, tendo percorrido longas distâncias, chegou de Argos ao templo de Apolo na condição de suplicante, ela vê um homem "conspurcado" (тробтрóтঞ๙ıov, $E u .41)$ em razão do crime que cometeu.

A visão de um homem com as mãos sujas de sangue, carregando um ramo de suplicante e uma espada, no recesso sagrado do templo de Apolo é por si mesma já bastante aterrorizante, mas, além disso, diante desse homem, jaz adormecido um bando de mulheres cujo aspecto horroroso a Pítia procura, com dificuldade, descrever: 


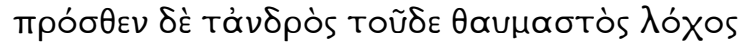

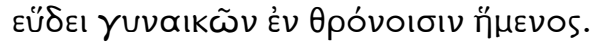

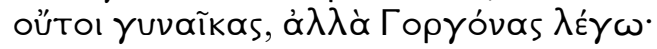

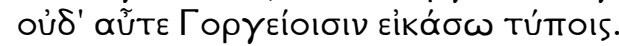

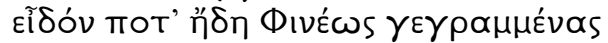

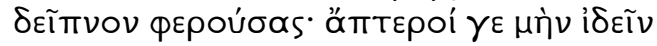

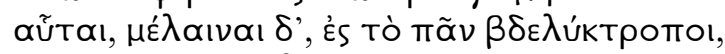

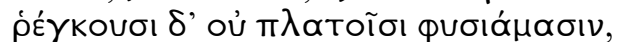

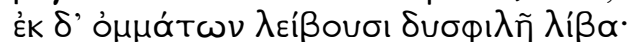

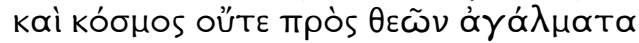

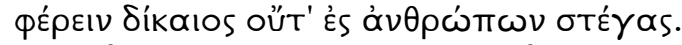

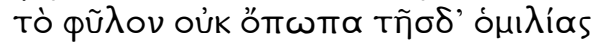

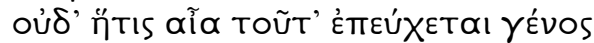

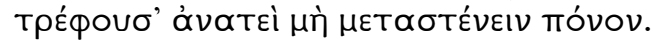

Diante desse homem, espantoso bando de mulheres dorme sentado nos bancos. Nem digo mulheres, mas Górgones. Nem as comparo às formas gorgôneas. Vi já numa pintura: elas tiravam comida de Fineu. Asas estas não têm e são negras, em tudo abomináveis, estertoram com inabordáveis hálitos e vertem dos olhos hediondo licor, o ornamento é indigno de portar-se ante imagens de Deuses e em lares de homens. A tribo deste rebanho eu nunca vi, nem que terra se diz impune nutriz desta gente sem depois gemer de dor.

(Eu. 46-59)

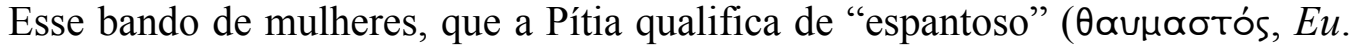
45), tem uma aparência tão abominável - assemelhando-se a Górgones ou mais bem a Harpias, obscuras, de hálito insuportável e de cujos olhos escorre um líquido hediondo ${ }^{11}$ - que ela tem dificuldade de comparar com qualquer coisa que ela já tenha visto. Esses seres, bem como sua proveniência - a terra que poderia tê-los nutrido -, são-lhe inteiramente desconhecidos. A Pítia desconhece as Erínies, pois, como sacerdotisa de Apolo, tudo o que é estranho ao âmbito desse deus também lhe é estranho. É a Apolo, portanto, a quem ela recorre ante tal situação:

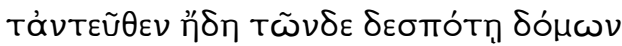

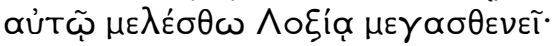

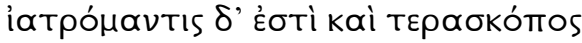

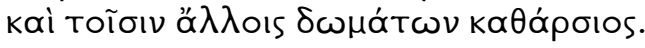

Do porvir cuide Lóxias magniforte, ele mesmo senhor deste palácio: é médico-adivinho, intérprete de signos e purificador de alheios palácios.

(Eu. 60-3)

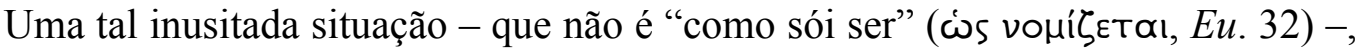
a Pítia remete a Lóxias "magniforte" ( $\mu \varepsilon \gamma \propto \sigma \theta \varepsilon v \varepsilon i ̃, E u .61)^{12}$. Essa potência do deus é evocada mediante suas atribuições de médico-adivinho, intérprete de signos e purificador.

Todas essas competências apolíneas se fazem agora concomitantemente necessárias. Observe-se que, quando, nas Coéforas, Orestes reporta ao Coro e à irmã os

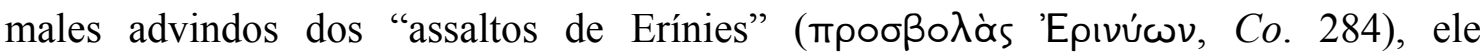

\footnotetext{
${ }^{11}$ Maxwell-Stuart (1973), em seu artigo “The Appearance of Aeschylus' Erinyes", aproxima a aparência das Erínies a morcegos.

${ }^{12}$ A Pítia usa aqui o mesmo adjetivo, $\mu \varepsilon \gamma \alpha \sigma \theta \varepsilon v n ́$ s, com que Orestes, nas Coéforas, qualifica o oráculo apolíneo (Co. 269).
} 
menciona doenças (vóoous, Co. 279; vóøฺ, Co. 282). Somente o deus, portanto, enquanto "médico-adivinho" (iatpó $\alpha$ avтs, Eu. 62), pode prover a cura para tais doenças; somente o deus pode curar o mal de Orestes. Do mesmo modo, Orestes, nas Coéforas, fala do matricídio como uma vitória que, ao mesmo tempo, traz uma indesejável "poluência" ( (тробтро́таıоv, Eu. 41), de forma que somente Apolo, enquanto "purificador"

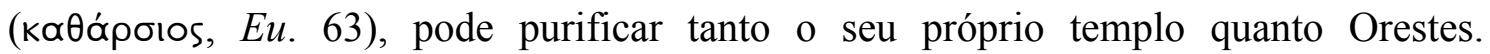
Enquanto “intérprete de signos" (тєрабкóтоos, Eu. 62), é somente Apolo quem pode interpretar esse prodígio que é, para a Pítia, a visão de Orestes, de mãos e espada ensanguentadas, e das Erínies, seres horripilantes e desconhecidos, dentro do recesso oracular do templo de Delfos.

Essas competências de Apolo designadas pela Pítia têm, portanto, um sentido imediato: como médico-adivinho, espera-se que o deus indique o remédio para a atual situação; enquanto intérprete de signos, pede-se que ele descubra e desvele o sentido do que se mostrou ante os olhos da Pítia; e, como purificador, espera-se que o deus purifique seu templo da poluência causada pela presença de um homem conspurcado. Essas mesmas competências, contudo, têm um sentido póstero: é na qualidade de médico-adivinho que Apolo irá encontrar um meio de solucionar o conflito envolvendo Orestes; sua qualidade de intérprete de signo será requisitada, pois nas Eumênides são as ações de Orestes que se tornam um sinal que tanto os deuses como o júri devem interpretar; e, como purificador, será Apolo quem enfim irá purificar o palácio dos Atridas.

Orestes entra em cena e, contrariando os usos, que requerem a intermediação da

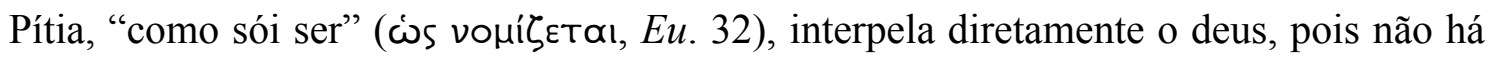
espaço para a intermediação da Pítia. Essa intermediação poderia suscitar as ambiguidades pertinentes à expressão de um ponto de vista divino. Porém, o conflito nas Eumênides não reside na divergência entre um ponto de vista divino e um ponto de vista mortal e humano, como nas demais tragédias desta trilogia, mas sim entre dois diferentes pontos de vista divinos: o de Apolo e o das Erínies.

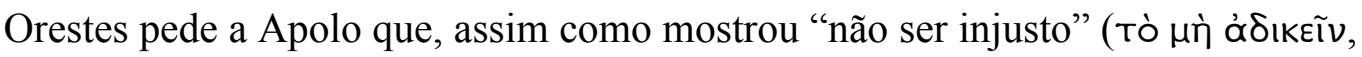
Eu. 85), mostre-se também vigilante e o apoie. Se uma parte do oráculo foi devidamente cumprida por Orestes, visto que ele deu aos assassinos de seu pai "a mesma morte" (тро́тор тòv aủtóv ávтатоктвĩvaı, Co. 274) e depois se dirigiu ao templo de Apolo 
como suplicante, falta, no entanto, que o deus dê cumprimento ao restante do oráculo, que dizia que Orestes, ao matar a mãe, estaria "isento de maligna culpa" (દ̇kTòs aítías kakñs, Co. 1031). Por essa razão, Orestes pede ao deus: "sabe ainda não descurar, / e

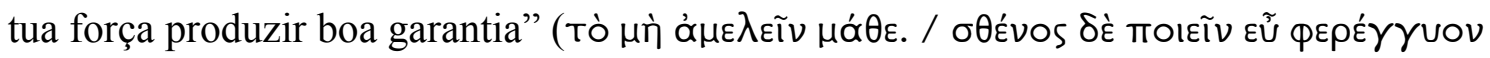
Tò oóv, Eu. 86-7).

O deus lhe responde direta e imediatamente, garantindo-lhe: "Não te trairei"

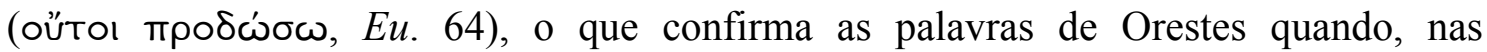

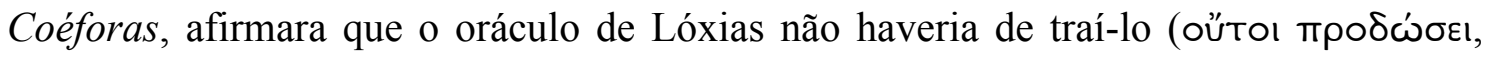
Co. 269-70). Como garantia disso, mostra-lhe as Erínies momentaneamente dominadas pelo sono. E, a seguir, faz um prenúncio, que contém novas instruções para Orestes:

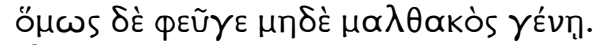

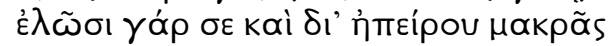

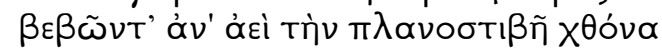

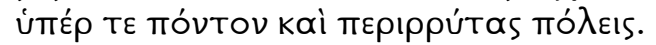

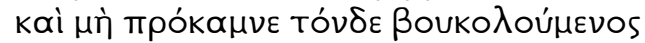

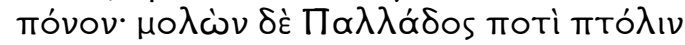

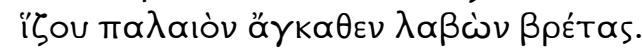

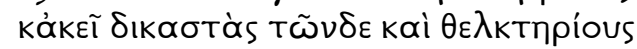

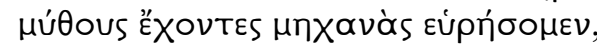

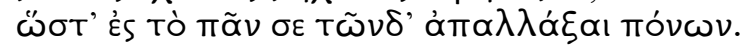

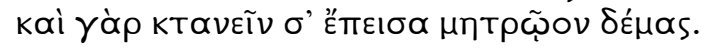

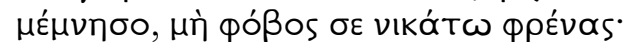

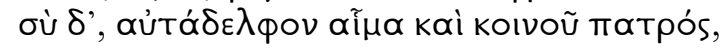

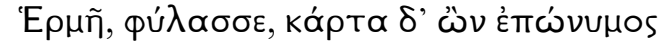

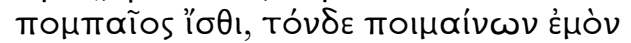

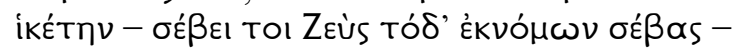

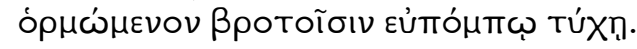

Foge, todavia, não te faças frouxo, perseguir-te-ão ainda por muitas terras, vão pelo chão pisado por tuas errâncias além do mar e dos circufusos países. Não te canses de pastorear esta fadiga. Quando chegares à cidade de Palas suplica abraçado ao antigo ícone. Lá com juízes disto e com palavras encantatórias descobriremos meios de livrar-te para sempre destes males, pois eu te persuadi a matar a mãe. Lembra-te, Pavor não vença teu âmago. Tu, consanguíneo irmão do mesmo pai, Hermes, sê o guardião, conforme cognome sê o Guia, pastoreia este meu suplicante. Zeus cultua este culto de proscritos ao irem a mortais com a sorte a guiá-los.

(Eu. 74-93)

Apolo prenuncia, assim, a Orestes os sofrimentos que as Erínies ainda lhe causarão, visto que continuarão a persegui-lo incansavelmente "por muitas terras" ( $\delta$ '

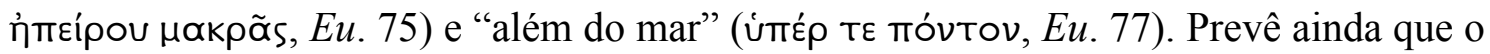
remédio para os males de Orestes passará por Hermes, que há de guiá-lo até o santuário

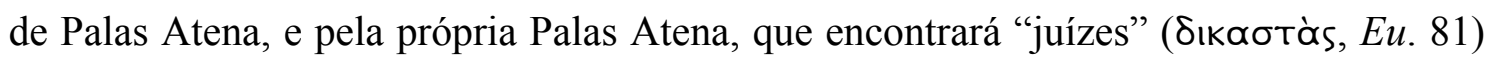

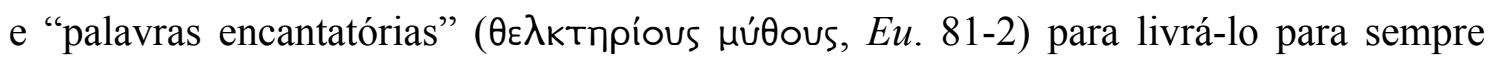
desses males. Assim, ordena a Orestes que fuja, não se deixando vencer pelo pavor, até chegar à cidade de Palas e que, na condição de suplicante, abrace a imagem da deusa. 
Esses novos comandos de Apolo, que prescindem da intermediação da Pítia, constituem um segundo oráculo que o deus entrega a Orestes ${ }^{13}$, cujo conteúdo vem esclarecer e reforçar a parte do primeiro oráculo em que Apolo the havia predito a isenção de culpa pelo matricídio. Assim, para que Orestes se torne isento de culpa e,

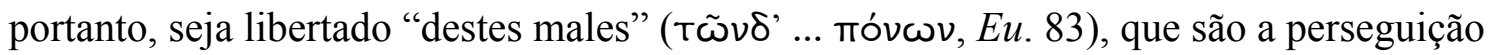
que ele sofre por parte das Erínies, é necessário que ele fuja, guiado por Hermes, até o santuário de Palas em Atenas, abraçando a estátua da deusa na condição de suplicante. Como observa Roberts (1984, p. 49), "That this added command is also considered oracular is suggested by Orestes' opening words to Athena; he says that he has come by

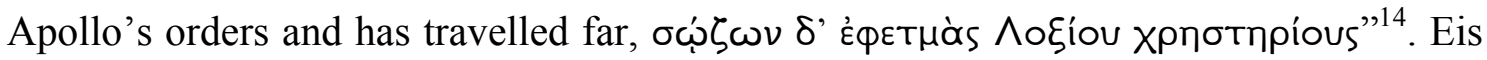
as palavras de Orestes à deusa:

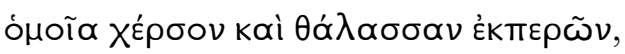

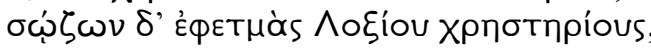

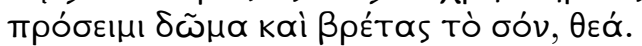

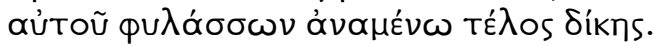

Por igual transpondo terra e mar, fiel ao comando oracular de Lóxias, chego a seu templo e imagem, ó Deusa. Aqui aguardo e espero termo de Justiça.

(Eu. 240-3)

Orestes chega, portanto, a Atenas obedecendo uma vez mais as palavras oraculares de Apolo. Ele interpela a deusa dizendo "por ordem de Lóxias / venho"

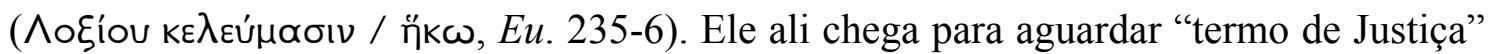

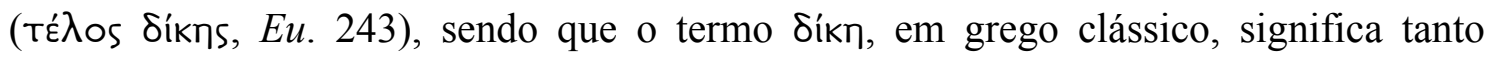
Justiça, a deusa filha de Zeus, quanto processo judiciário, julgamento. Nessa ambiguidade, percebe-se que, qualquer que seja o resultado do julgamento, este será uma expressão da justiça divina.

\footnotetext{
${ }^{13}$ Pelliccia (1993, p. 74) observa uma similaridade entre esse oráculo de Apolo a Orestes e o primeiro oráculo entregue aos atenienses quando da aproximação do exército persa: "Apollo speaks as the oracular god of Delphi, and does so in a pessimistic vein that the Athenian audience would have instantly recognized. In particular, the injunction to 'flee, for so-and-so pursues' would have struck them as familiar Delphian strains, though the suggestion that the questioner should flee to Athens must have seemed an enjoyable novelty".

${ }^{14}$ Para Pelliccia (1993), nessa passagem, "the features judged by the transposers to be anomalous are articles of its oracular clothing".
} 


\subsection{2) O sonho das Erínies}

Na última cena do prólogo, surge o espectro de Clitemnestra ante o adormecido Coro das Erínies, lamentando-se de que, tendo sido assassinada pelo próprio filho, não desperte a ira de um nume vingador, visto que as Erínies, ao invés de perseguir o matricida, dormem. Clitemnestra descreve a si mesma como um sonho (övap, Eu. 116), cuja clareza e eficácia a rainha, tendo sido ela mesma testemunha disso ${ }^{15}$, explicita ao pedir que as Erínies vejam suas chagas: "no sono os olhos da mente se iluminam, / de

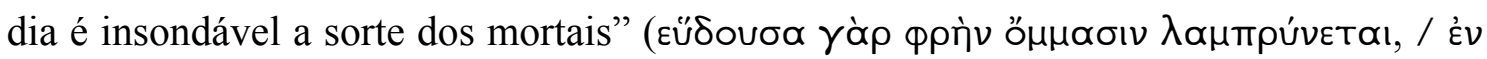

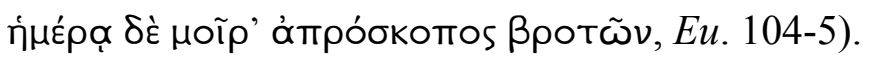

Mediante esse sonho que ela afirma ser, Clitemnestra então repreende as Erínies por terem deixado escarpar Orestes e as instiga a prosseguir em sua perseguição, exibindo-lhes, para tanto, os golpes sofridos ao ser assassinada e lhes recordando das oferendas feitas em seu nome. O Coro, então, emite murmúrios, como se, tal qual observa Clitemnestra, perseguisse em sonhos uma presa. A rainha então declara que suas justas reprimendas ao Coro, assim como aguilhões, devem ser sentidas em seu

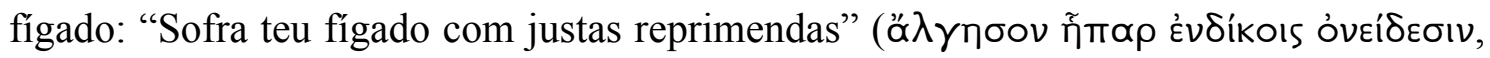
Eu. 135).

Essa cena pode ser entendida como um sonho das Erínies com Clitemnestra, pois tanto Clitemnestra identifica a si mesma como um sonho - "num sonho Clitemnestra

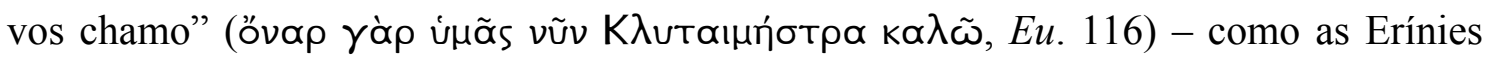

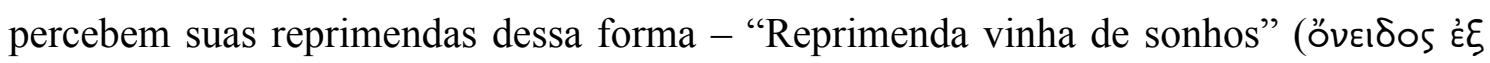

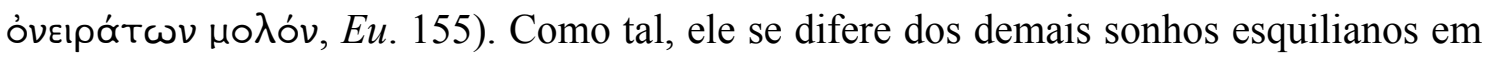
relação a alguns aspectos dignos de nota. Primeiramente, trata-se de um sonho que, em vez de ser narrado - como o da Rainhas nos Persas, como o de Clitemnestra nas Coéforas ou como o de Io em Prometeu Cadeeiro -, é encenado.

Em segundo lugar, trata-se de um sonho que aparece tendo, como uma espécie de pano de fundo, outro sonho. Pelos murmúrios das adormecidas Erínies, deixa-se entrever que elas estão sonhando com uma perseguição, pois elas murmuram "Pega!

\footnotetext{
${ }^{15}$ Como observa Mace (2004, p. 51), "Klytaimestra, who had expressly disavowed the connection between dreams and retaliatory violence in Agamemnon, but was forced by circumstance to discover her error in Choephoroi, now actually assumes the form of a dream to further the next act of counterrevenge". Winnington-Ingram (1948, p. 141) também comenta a esse respeito: "The woman who in the Agamemnon despised the 'plausible visions of a dream' (Agam. $274 \mathrm{f}$.), but in the Choephori allowed her action to be governed by a dream (Cho. 32 ff.), is now herself a dream in the minds of her avengers (116)".
} 


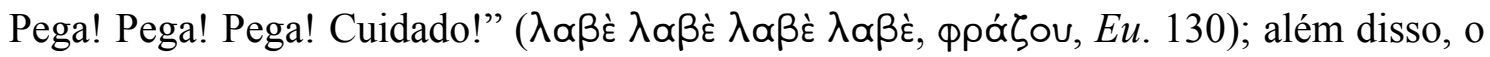

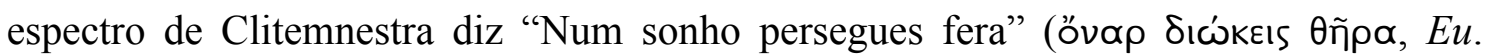
131). Assim, um sonho, que é a admoestação de Clitemnestra, sobrepõe-se a outro, um sonho de perseguição ${ }^{16}$.

Em terceiro lugar, trata-se de um sonho com características próprias aos sonhos homéricos. Como se viu, nos sonhos homéricos há a aparição de uma figura onírica, que se dirige até o sonhador, coloca-se junto à sua cabeça, chama a atenção ao estado de sono em que se encontra quem sonha e lhe profere algumas palavras. Essa figura onírica

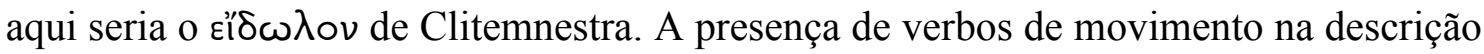
dos sonhos homéricos é substituída pela movimentação em cena, a qual, infelizmente, não se conhece $^{17}$, mas não seria de se admirar que o espectro de Clitemnestra se aproximasse do Coro das Erínies. Como nos sonhos homéricos, chama-se primeiramente a atenção para o estado de sono de quem sonha; dessa forma, as primeiras palavras do espectro de Clitemnestra são: "Dormiríeis. Oé! E que vale quem

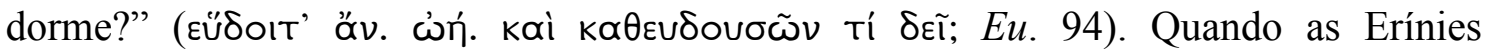
começam a murmurar, o espectro de Clitemnestra volta a chamar a atenção ao seu

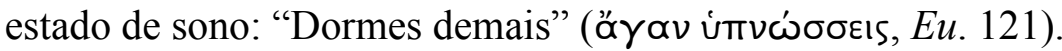

Em quarto lugar, trata-se de um sonho que, tal como os sonhos homéricos, possui um forte caráter exortativo e admoestatório. Clitemnestra diz ao Coro:

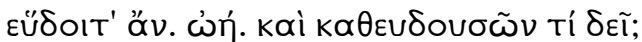

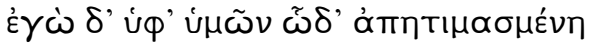

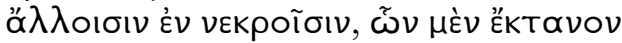

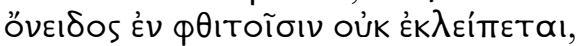

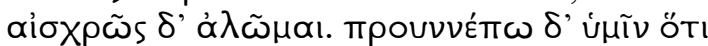

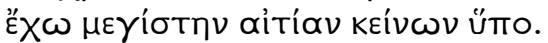

Dormiríeis. Oé! E que vale quem dorme? Eu mesma por vós tão lesada na honra entre outros mortos, entre os defuntos não cessa o vitupério dos que massacrei e vagueio ignóbil. Proclamo-vos que deles suporto a mais grave acusação.

(Eu. 94-9)

Nesse sentido, assemelha-se bastante com o sonho de Aquiles, no canto XXIII, e com o de Príamo, no canto da XXIV da Ilíada. No primeiro, Aquiles dorme quando o

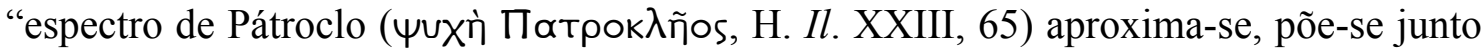
à cabeça do guerreiro e lhe diz:

\footnotetext{
${ }^{16}$ Sommerstein (1989, p. 107) diz o seguinte a esse respeito: "it is as if the Erinyes were experiencing, simultaneously, an objectively real dream in which Clytaemestra upbraided them for their failure to persue Orestes, and a subjective fantasy-dream in which they imagined themselves actually pursuing him".

${ }^{17}$ Taplin (2001, p. 366) observa o seguinte a esse respeito: "It is hard to see, given our evidence, how this strange scene, unique in surviving tragedy, was originally played".
} 


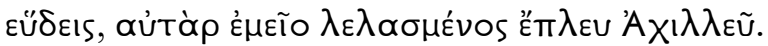

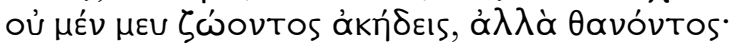

$\theta$

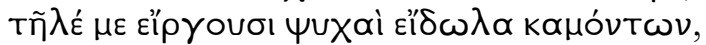

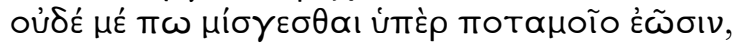

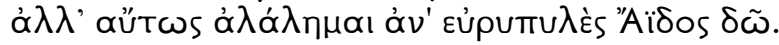

Dormes, Aquiles, o amigo esquecendo? Zeloso era antes, quando me achava com vida; ora, morto, de mim te descuidas.

Com toda a pressa sepulta-me, para que no Hades ingresse,

pois as imagens cansadas dos vivos, as almas, me enxotam,

não permitindo que o rio atravesse para a elas juntar-me.

Por isso, vago defronte das portas amplíssimas do Hades. (H. Il. XXIII, 69-74)

Note-se a semelhança da reprimenda dos espectros de Pátroclo e de Clitemnestra: ambos se queixam aos seus destinatários de que seus interesses estão sendo negligenciados e de que estão sofrendo desonra da parte de outros mortos; um, por não ter sido ainda sepultado e o outro, por não ter sido ainda vingado.

O sonho das Erínies com Clitemnestra também se assemelha ao sonho de Príamo por seu caráter exortativo. Preocupado com a segurança do velho rei de Troia, que dorme tranquilamente na tenda de Aquiles entre o exército inimigo, Hermes põe-se junto à cabeça de Príamo e lhe diz:

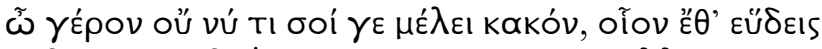

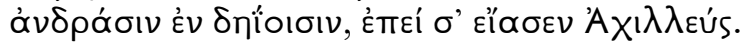

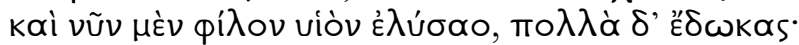

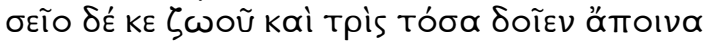

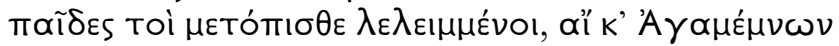

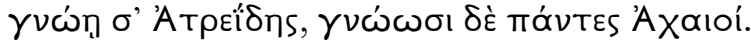

Dormes, ancião, tão sem medo, no meio de gentes imigas,

sem refletires, apenas por ter-te poupado o Pelida?

Certo, obtiveste o cadáver, mas foi com resgate vultoso;

três vezes isso, porém, os teus últimos filhos teriam

que oferecer para a vida livrar-te, se acaso Agamêmnon,

ou outro qualquer dos Acaios soubesse que aqui ora te achas. (H. Il. XXIV, 683-8)

Assim admoestado, Príamo acorda, desperta Ideu, seu companheiro de viagem, e parte imediatamente de volta a Troia. De forma semelhante, o espectro de Clitemnestra admoesta as Erínies a retomarem sua perseguição a Orestes: "Que fazes? Ergue-te! Não

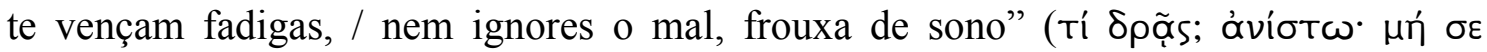

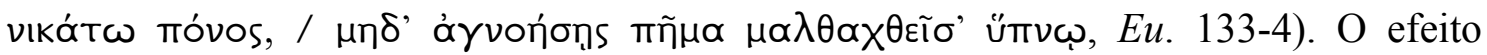


obtido é o mesmo, pois, assim como Príamo desperta de seu sonho admoestatório, também despertam as Erínies: "Desperta! E tu a ela como eu a ti. / Dormes? Ergue-te,

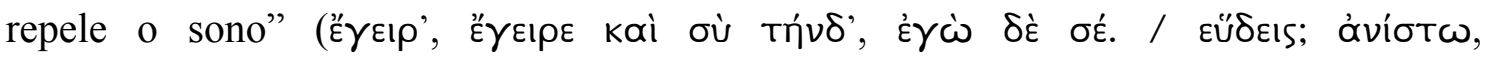

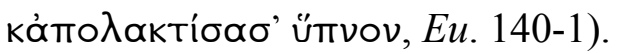

Em último lugar, trata-se de um sonho que não precisa ser interpretado. Como observa Pereira (2009, p. 8), “no caso das Euménides de Ésquilo, não se justifica o apelo a intérpretes, dado que o carácter divino das sonhadoras lhes confere uma sabedoria natural para perceber a experiência que as perturba. [...] O estatuto das Erínias fundamenta a sua clarividência". Além disso, há de se considerar o estatuto de quem transmite, em sonho, uma mensagem a deuses: é uma mortal, Clitemnestra.

A mensagem transmitida pelo sonho é a de que Orestes escapou à perseguição

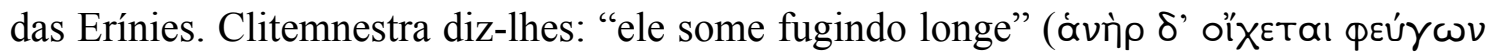

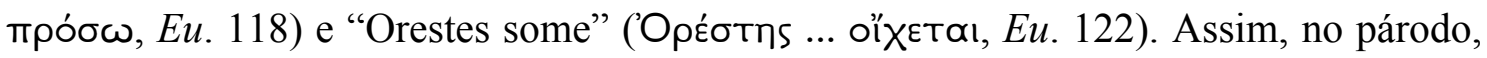

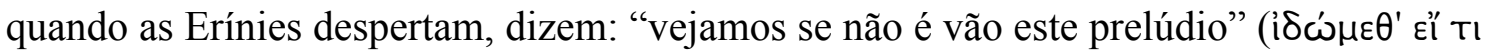

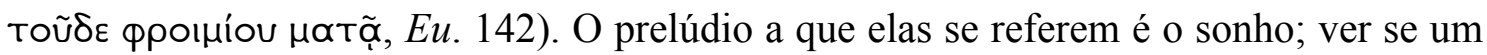
sonho é "vão" ( $\mu$ đTỡ) ou não é verificar a sua veracidade. Elas logo constatam que não foi um sonho vão, porque, de fato, Orestes sumiu: "Escapou das redes e sumiu a caça"

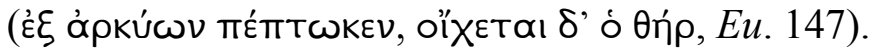

A seguir, as Erínies mencionam a dor no fígado, que, conforme o espectro de Clitemnestra lhes dissera (Eu. 135-6), elas haveriam de sentir como consequência de sua reprimenda:

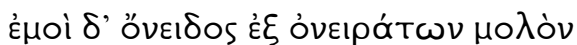

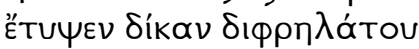

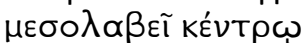

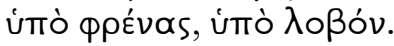

Reprimenda vinda de sonhos fere-me, como o cocheiro de aguilhão em punho, no íntimo, no fígado.

A dor sentida no fígado das Erínies oferece testemunho tanto da violenta exortação de Clitemnestra para que retomem sua perseguição a Orestes quanto do aspecto exterior e objetivo de sua experiência onírica ${ }^{18}$.

\footnotetext{
${ }^{18}$ Para Dodds (1951, pp. 105-6), "It looks as if the objective, visionary dream had struck deep roots not only in literary tradition but in the popular imagination. And that conclusion is to some extent fortified by the occurrence in myth and pious legend of dreams which prove their objectivity by leaving a material token behind them, what our spiritualists like to call an 'apport'; the best-known example in Bellerophon's incubation dream in Pindar, in which the apport is a golden bridle". A dor no fígado das Erínies, por sua objetividade, poderia ser considerada um sinal "material" deixado pelo sonho.
} 


\subsection{3) Palavra imprecatória e palavra auspiciosa}

$\mathrm{Na}$ segunda cena do primeiro episódio - em que se supõe uma mudança de cenário, visto que Orestes encontra-se ante a estátua de Palas Atenas -, o suplicante, declarando-se livre de poluência, pede à deusa que lhe seja propícia:

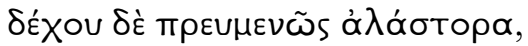

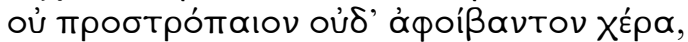

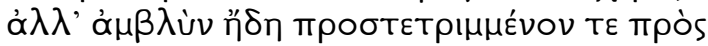

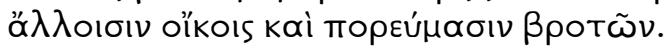

Recebe propícia o perseguido não conspurcado, nem sem pureza na mão, mas perdida a poluência já desgastada nas casas e caminhos de outros mortais.

(Eu. 236-9)

No epipárodo, porém, vêm em seu encalço as Erínies. Conforme prenunciara Apolo, as Erínies chegam tendo perseguido Orestes "por toda a terra" ( $\chi$ Өovòs yà $\rho$ mãs

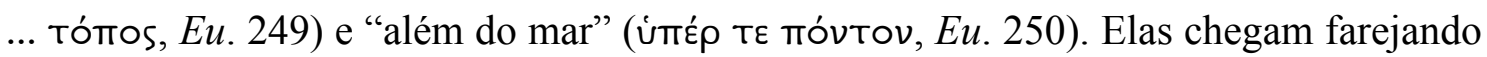
sua caça, "como um cão" ( Clitemnestra nas Coéforas como "rancorosas cadelas" ('̇үкótous kúvas, Co. 924). Dessa forma, como observa Fowler (1991, p. 99), "the imagery has come to fulfillment", ou ainda, segundo Cynthia Werner (2012), "metaphor turns into action".

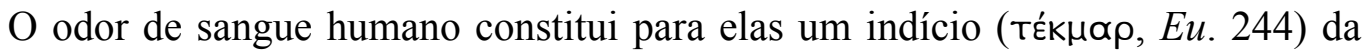
presença de Orestes no santuário de Atena, o que contrasta com a recém-declarada afirmação de Orestes de que estaria livre de qualquer poluência. Por fim, as Erínies avistam-no abraçado à imagem da deusa e reafirmam o dever imperioso de lhe dar justa punição por ter vertido no chão o irremível sangue materno.

No segundo episódio, Orestes retoma sua prece a Palas Atena, demonstrando, uma vez mais - tal como fizera nas Coéforas ao pedir que o Coro mantivesse uma língua propícia (Co. 581-2) -, a consciência a respeito do cuidado que se deve ter com as palavras: "conheço / bem cada ocasião, e quando é justo / falar e também calar"

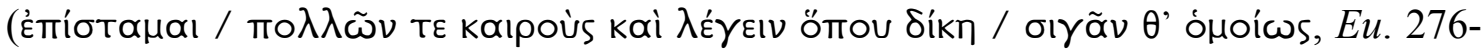
8). Orestes diz, no entanto, ter sido, em momento tão premente, instruído a falar por

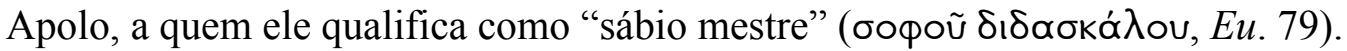

Antes, porém, de se dirigir à deusa, declara-se novamente livre de qualquer mácula, como se se defendesse da acusação das Erínies de que suas mãos ainda estariam sujas de sangue. Com lustrações de sangue suíno feitas no templo de Apolo e mediante 
a ação do próprio tempo transcorrido, afastou-se a poluência de suas mãos, tal como o comprova o contato inócuo que teve com muitas pessoas ao longo de suas peregrinações. Se, portanto, do ponto de vista das Erínies, Orestes ainda tem as mãos sujas de sangue, do ponto de vista de Apolo e de Orestes, este último foi devidamente purificado $^{19}$.

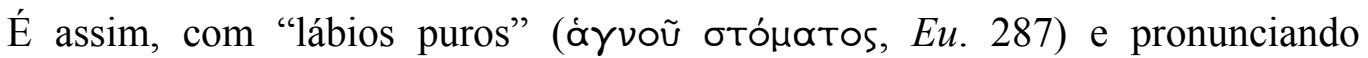

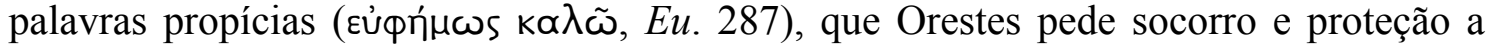
Atena, para quem ele, sua terra e seu povo hão de se tornar aliados perenes. Onde quer que a deusa agora se encontre, Orestes lhe pede que venha a seu auxílio e se torne sua libertadora.

A essa prece, enunciada por lábios puros e com palavras propícias, as Erínies contrapõem um canto amaldiçoador, que é uma manifestação da sua própria natureza, visto que, quando Atena lhes pergunta quem são, elas respondem: "Nós somos as filhas

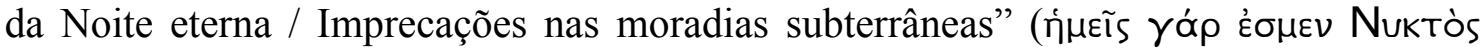
๔i̊ de proteção de Orestes, as Erínies contrapõem uma imprecação: "Nem Apolo nem a

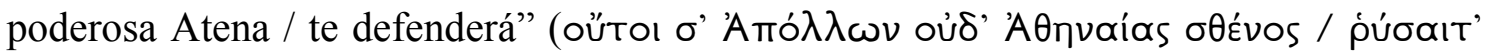
ơv,$E u$. 299-300). E, à súplica de Orestes de que Atena seja para ele libertadora, as Erínies respondem dizendo que seu canto há de acorrentá-lo: “e ouvirás como hino este

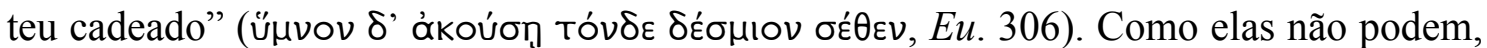
por encontrarem-se no santuário de Atena, efetivamente prendê-lo em suas redes e executar a sua punição, elas o prendem na rede tecida por suas palavras imprecatórias, que são uma explicitação de seu próprio ser:

\begin{tabular}{|c|c|}
\hline 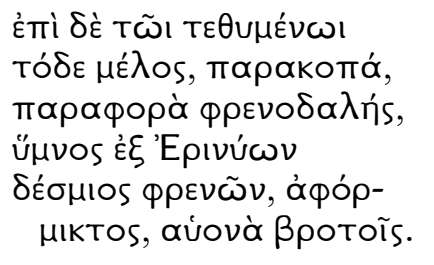 & $\begin{array}{l}\text { Sobre esta vítima } \\
\text { este canto vertigem } \\
\text { desvario aturdimento } \\
\text { hino de Erínies cadeia } \\
\text { do espírito nenhuma lira } \\
\text { exaustão dos mortais. }\end{array}$ \\
\hline
\end{tabular}

$($ Eu. 328-33)

De que fala esse hino encadeante? Do poder e da natureza de quem o canta. As

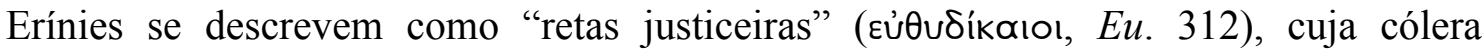

\footnotetext{
19 A respeito desse conflito a respeito da purificação e da poluência de Orestes, conferir o artigo de Sidwell (1996), "Purification and Pollution in Aeschylus' Eumenides".
} 
punitiva está reservada aos que, como Orestes, perpetram crimes contra os seus. Essa foi a atribuição que lhes foi destinada quando elas, filhas da deusa Noite, nasceram e, por terem e executarem essa atribuição, estão afastadas do convívio e dos banquetes comuns dos demais deuses imortais. Dessa prístina honra, no entanto, o filho de Leto pretende privá-las ao subtrair-lhes Orestes ${ }^{20}$.

No segundo estásimo, as Erínies prosseguem com suas imprecações, mas agora sob uma nova perspectiva, a das consequências que a absolvição de Orestes trará para a comunidade dos homens mortais por não temerem a cólera das Erínies: "muitas dores

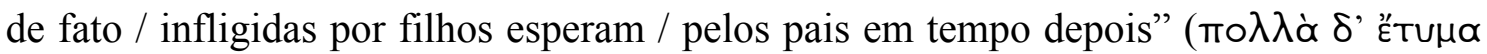

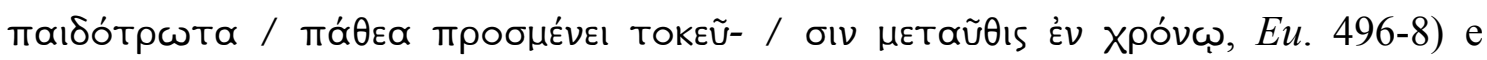

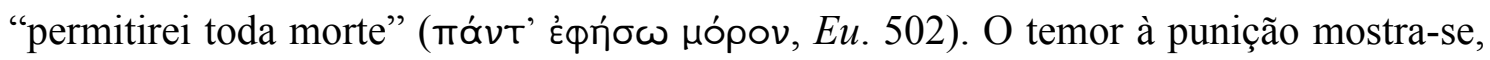
pois, necessário à observância da justiça, seja por um indivíduo ou por uma cidade, inspirando-lhes a prudência e afastando-os de atos impiedosos, cujo fruto é a soberbia, causa de tantos males para o homem mortal. É a respeito desses males que elas cantam, urdindo com suas palavras imprecatórias um futuro em que o "palácio da Justiça"

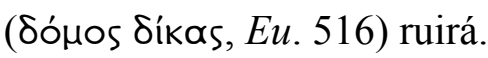

No kommós, após a absolvição de Orestes, as Erínies deploram a desonra de que foram vítimas por parte dos deuses novos ao se inocentar Orestes da acusação de matricídio. A cólera suscitada por essa derrota manifesta-se nas palavras de mau augúrio que elas lançam sobre a região. Tais palavras imprecatórias, que são a expressão de sua "grave cólera" (ßарúkotos, Eu. 780), assim como um veneno ou uma doença letal, destruirão a fertilidade do solo, dos animais e dos mortais:

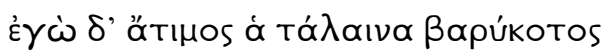

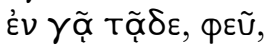
ì̀v ì̀v ávtıTrv-

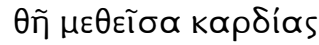

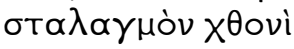
äpopov, ह̇k $\delta \dot{~}$ Toũ

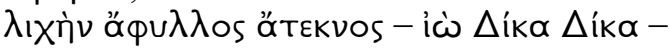

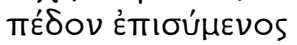

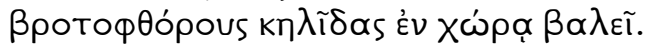

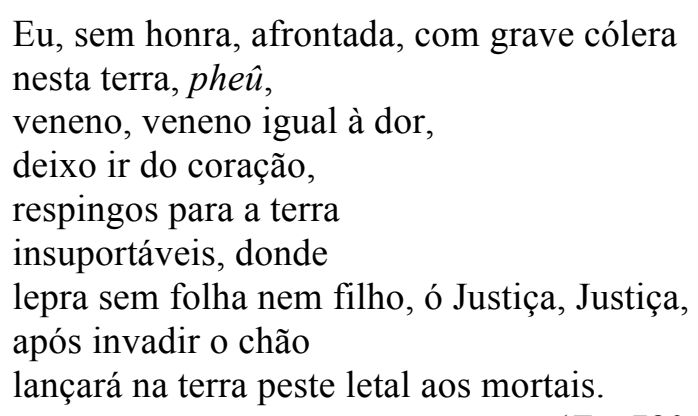
nesta terra, phêे, veneno, veneno igual à dor, deixo ir do coração, respingos para a terra insuportáveis, donde lepra sem folha nem filho, ó Justiça, Justiça, após invadir o chão lançará na terra peste letal aos mortais.

(Eu. 780-7)

O desfavor das deusas mostra-se assim intimamente ligado à infecundidade, à doença, à morte. Apolo, no prólogo, chama-as de "abomináveis virgens / anciãs,

\footnotetext{
20 A respeito desse canto das Erínies e do estatuto das deusas enquanto coro, conferir o artigo de Smitherman (2013), "Hearing the Erinyes' Voices: Thoughts on the 'Binding Song' (Eu. 307-96)".
} 


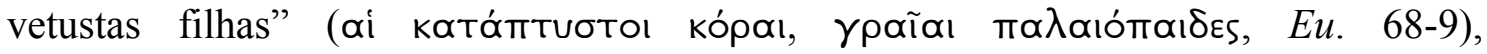
caracterizando-as, desse modo, pela velhice e pela virgindade, simultaneamente. A velhice, contudo, mais do que um sentido cronológico, tem nessa caracterização um sentido qualitativo, ou seja, trata-se de deusas ctônias, mais ligadas à morte do que à vida. Do mesmo modo, sua virgindade não significa necessariamente castidade, mas sim a negação da vida, a não-procriação, visto que a elas, diz Apolo, "não se une / nem

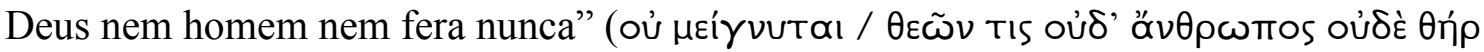
потє, Eu. 69-70). Se, portanto, o seu desfavor significa, em última instância, a infecundidade; o seu favor será, por sua vez, a fecundidade, o que fica claro quando as deusas, tendo contido sua cólera, pronunciam palavras auspiciosas para a cidade de Atenas.

A deusa Atena reconhece a gravidade das palavras imprecatórias das Erínies e como estas podem ser tão nocivas à vida em sua cidade:

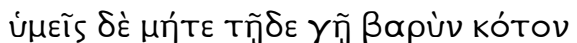

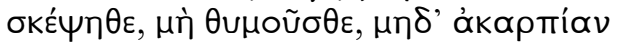

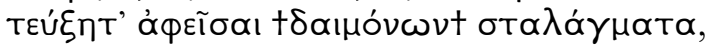

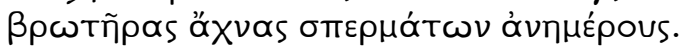

Não inflijais grave cólera a esta terra, nem vos enfureçais, nem a torneis sem frutos, por numinosos respingos, ferozes lanças devoradoras de sementes.

(Eu. 800-3)

É necessário, dessa forma, que Atena procure, por meio da persuasão, conterlhes a "grave cólera" (ßарùv kótov, Eu. 800), que se manifesta nas palavras agourentas das Erínies. A deusa argumenta primeiramente que as Erínies não foram vencidas na contenda, uma vez que houve empate e, portanto, nenhuma desonra para elas. Argumenta, em segundo lugar, que o oráculo recebido por Orestes de Apolo, no qual se prenunciava a ausência de dano se agisse em conformidade com o que lhe era exigido, era um testemunho claro da vontade de Zeus. A deusa, por fim, promete-lhes um trono em sua cidade, sentadas no qual receberão honrarias por parte dos cidadãos atenienses.

O Coro, porém, repete, na primeira antístrofe, as mesmas palavras imprecatórias que pronunciara na primeira estrofe. Atena, então, mais uma vez pede que contenham

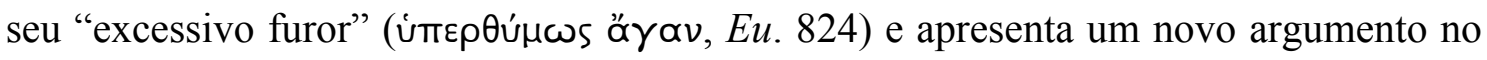
intuito de convencê-las a abrandar a sua cólera destrutiva: ela, única entre os deuses, conhece as chaves da câmara onde estão os raios de Zeus. Trata-se de um argumento de poder. Atena crê, no entanto, não haver de ser necessário recorrer a essa ameaça e reitera seu pedido de não lançar sobre a cidade palavras funestas à sua fecundidade: "não lances à terra palavras de língua vã / a estorvar o viço de toda frutificação" 


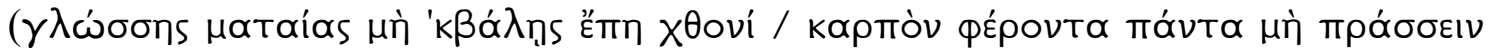
к $\alpha \hat{\omega} \varsigma, E u .830-1)$. A deusa, então, volta a prometer-lhes honrarias: as primícias da terra, ofertadas antes de casamentos e de nascimentos; isto é, exatamente o oposto daquilo que suas palavras agourentas contemplam.

Irredutíveis, as Erínies pranteiam a perda de suas antigas honras, invocando como testemunha dessa desonra por parte dos deuses novos - que se manifesta em forma de uma dor a lhe penetrarem os flancos - sua mãe, a deusa Noite. Atena, considerando a sabedoria que lhes advém de sua velhice, argumenta que Zeus também

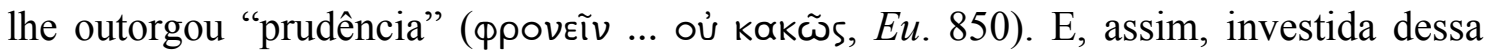
prudência divina, faz-lhes uma predição:

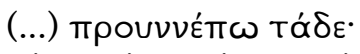

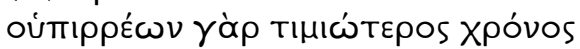

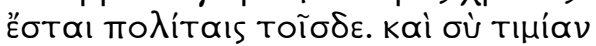

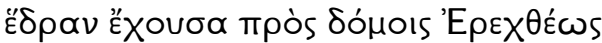

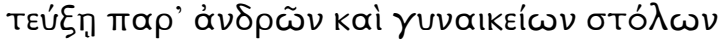

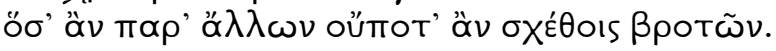

(...) Eu vos predigo:

o porvir trará maiores honras

a estes cidadãos e tu terás honroso

assento junto ao templo de Erecteu

e obterás dos varões e cortejos femininos

quanto nunca teríeis de outros mortais.

(Eu. 852-7)

Curiosamente, o que legitima a predição de Atena é a realidade vivida e compartilhada pelos espectadores, incluídos na menção da deusa a "estes cidadãos"

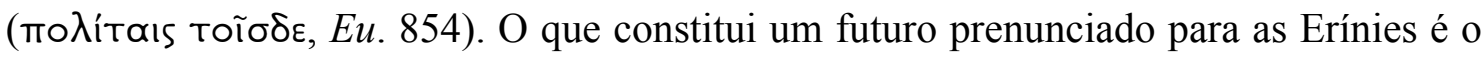
presente dos cidadãos da Atenas do século V a.C. Estes são assim evocados como testemunhas da veracidade da predição da deusa, pois a realidade em que vivem é a realização desse prenúncio.

A deusa reforça uma vez mais seu pedido de que as Erínies contenham sua cólera, cujas consequências funestas passam a contemplar também a guerra civil e a violência irrefreada entre os cidadãos:

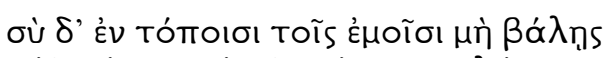

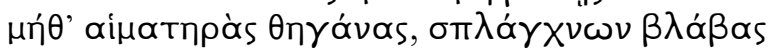

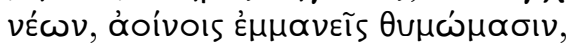

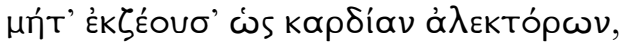
Év Toĩs દ̇uoĩs áotoĩoı í

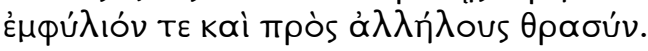

Não atires tu em meu território cruentos aguilhões ruinosos dos ânimos juvenis, por enfurecê-los sem vinho. Não instigues corações de galos nos meus cidadãos, nem instales Ares nas tribos, audácias recíprocas.

(Eu. 858-63)

A insistência da deusa em refrear a cólera das Erínies, manifesta em suas palavras funestas, oferece testemunho do poder de realização da palavra imprecatória. 
E, à menção a guerras intestinas, Atena contrapõe palavras auspiciosas, na forma de um voto de que as guerras sejam externas e por motivos nobres: "Externa seja a guerra, não escassa, / onde houver terrível amor de glória, / e não briga de ave doméstica." (Oupaĩos

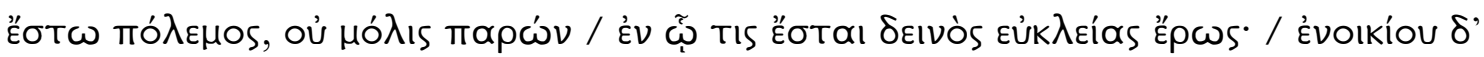

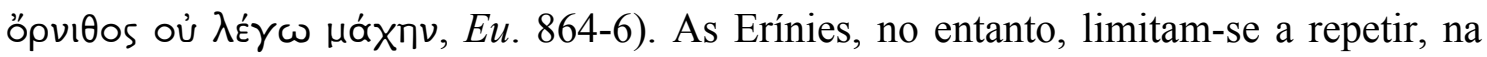
segunda antístrofe, as pranteadas palavras da segunda estrofe: elas ainda bufam "cólera

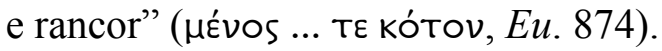

No último episódio, Atena afirma não haver de se cansar de falar sobre os bens que as Erínies receberiam dela e de seus concidadãos, de modo a não poderem dizer terem sido banidas sem honra por eles. Se as prístinas deusas venerassem a "pura Persuasão" (áyvóv ... ПદıӨంũs, Eu. 885), elas ficariam, tendo com justiça domicílio e honrarias na região, mas, se assim não o desejarem, pede-lhes que não imponham injustamente os males advindos de sua cólera a esse país.

Observe-se que Atena qualifica a sua persuasão como "delícia e encanto de

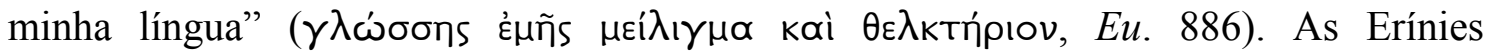
começam, então, a sucumbir ao efeito desse encantamento, pois pela primeira vez demonstram interesse em conhecer melhor as honras prometidas por Atena, questionando-lhe a respeito de sua extensão e de sua duração, até que por fim declaram:

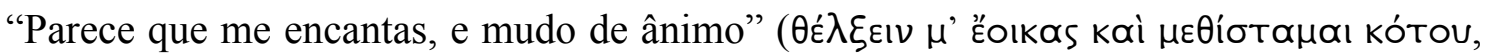
Eu. 900). Essa caracterização da persuasão como algo que tem o poder de encantar evoca o oráculo de Apolo, em que este previu a necessidade de "palavras encantatórias"

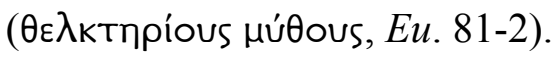

De que maneira se expressa essa mudança de ânimo das Erínies? Se, antes, seu estado de ânimo colérico expressava-se mediante palavras imprecatórias e de mau augúrio que lançavam à cidade, prenunciando-lhe um destino adverso, agora, com um

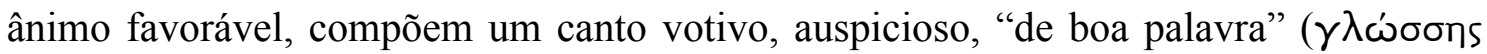
óy $\alpha \theta \tilde{n} s, E u .989)$, cujo conteúdo demandam a Atena: "O que me pedes cantar por esta

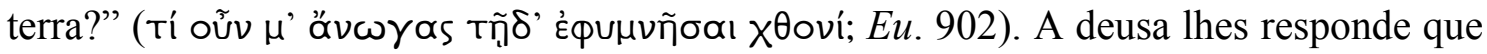
cantem o que vise a vitória imaculada, ventos serenos, fertilidade e fecundidade e ausência de sofrimentos para as famílias dos juízes reunidos no Areópago.

As Erínies, declarando então aceitar a oferta de domicílio em Atenas, fazem votos que são ao mesmo tempo predições: "Por ela suplico / e predigo propícia” (ỡ T'

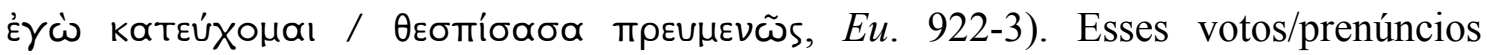
manifestam-se, assim, em palavras auspiciosas: que a luz do sol faça brotar da terra em 
profusão todos os bens propícios à vida. Tais bens se explicitam ao declararem suas dádivas de caráter ctônio: a fecundidade vegetal, a fecundidade animal, a riqueza do subsolo, a felicidade conjugal, a prosperidade, ausência de guerra civil e de violência mortífera entre os cidadãos, bem como a convivência pacífica entre eles.

Todas essas dádivas que as Erínies não só suplicam, mas prenunciam para a cidade, mostram-se como o reverso do que antes elas prenunciavam mediante suas palavras imprecatórias. Se o desfavor das deusas implicava a infertilidade, a infecundidade, a guerra civil, a violência disseminada; o seu favor implica o oposto. É interessante perceber, no entanto, como as suas atribuições, antes restritas à perseguição de matricidas $(E u$. 210, 421), mostram-se consideravelmente ampliadas tanto ao amaldiçoarem quanto ao bendizerem a cidade. Como pontua Atena, "Elas têm por sorte

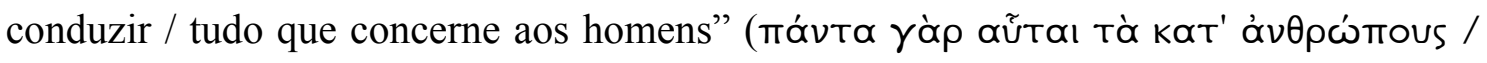

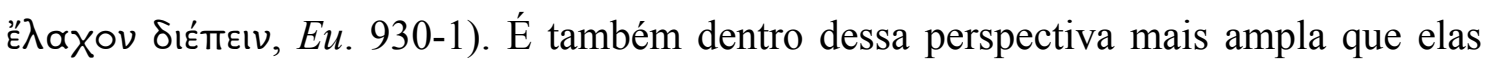
figuram em Agamêmnon e nas Coéforas. A restrição de suas atribuições nas Eumênides deve ser percebida, portanto, dentro de uma perspectiva dramática: elas estão de tal forma empenhadas na perseguição e na punição de Orestes que é como se todas as suas atribuições se resumissem a isso, como se isso fosse tudo o que lhes concernisse.

Atena, cujas falas intercalam o canto benfazejo das Erínies, louva o vasto poder das veneráveis deusas, alerta os atenienses para não ofendê-las, bendiz Persuasão e Zeus forense por ter conseguido mudar o ânimo das rancorosas deusas e assegura a seus cidadãos que, sendo benévolos com as deusas, prosperarão com honra e justiça. Por fim, Atena, aprovando as preces das Erínies, lidera e orienta o cortejo que indicará a residência das deusas, pedindo-lhes que repilam da região os males e enviem a ela somente o que for favorável à vitória da cidade. E, assim como as próprias atribuições das deusas se transformam, também suas palavras se transformam de imprecatórias para auspiciosas.

\subsection{4) Oráculo e justiça divina}

Como se viu, nas Coéforas, o oráculo de Apolo poderia ser dividido em duas partes. A primeira parte refere-se à vingança de Orestes, ou seja, ao comando de que ele deveria dar aos assassinos de seu pai a mesma morte (Co. 274). A segunda parte referese à isenção de culpa após a realização da vingança (Co. 1031). Se a primeira parte do 
oráculo foi realizada - e a sua realização é representada nas Coéforas - resta ainda por se realizar a segunda parte. A realização dessa segunda parte - que inclui a ida de Orestes até o templo de Apolo em Delfos na condição de suplicante, onde ele recebe novas instruções do deus, a de dirigir-se, guiado por Hermes, à cidade de Atenas, para que lá, colocando-se como suplicante ante a imagem da deusa Atena, descubra-se, com juízes e palavras encantatórias, uma forma de livrá-lo da perseguição das Erínies - é o núcleo ao redor do qual giram os acontecimentos representados nas Eumênides.

Para que Orestes torne-se "isento de maligna culpa" ('̇kтòs aitías kakñs, Co. 1031), ele deve ser absolvido pelo tribunal. Ser isentado da culpa pelo matricídio significa que, ao cometê-lo, Orestes agiu justamente. O que o tribunal determina, portanto, é a justiça do crime por ele cometido. Como pede Orestes à Atena, "Se agi

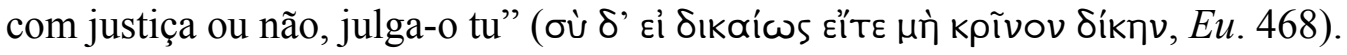

Em nenhum momento, Orestes nega ter matado a própria mãe. Ele o afirma

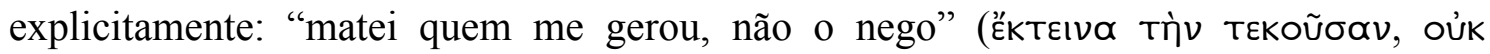

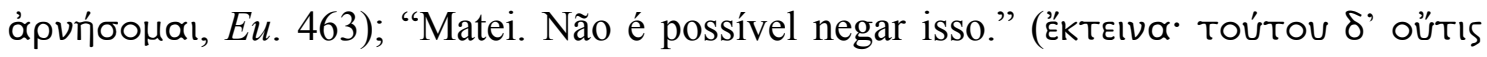

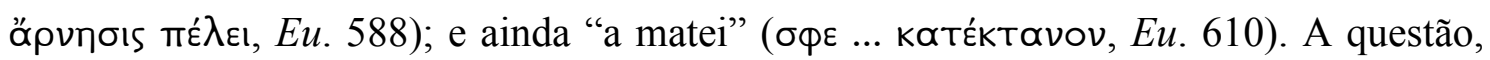
portanto, não é a de que se ele fez ou não fez, como lhe perguntam as Erínies, mas se ele o fez justa ou injustamente. É isso que ele pede também a Apolo:

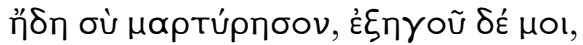

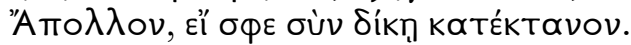

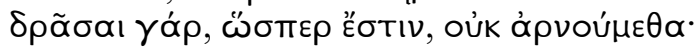

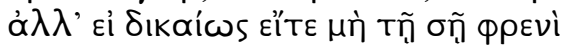

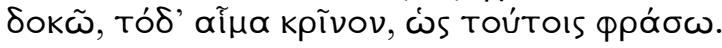

Dá testemunho já e explica-me, Apolo, se com justiça a matei. Não negamos que fiz tal como é, mas se te parece com justiça ou não, julga esta morte para eu lhes dizer.

Sim, Orestes matou a própria mãe, mas ele o fez em obediência ao oráculo de Apolo, o que é enfaticamente reforçado ao longo da tragédia. Assim, Apolo diz a

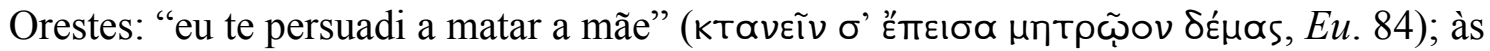

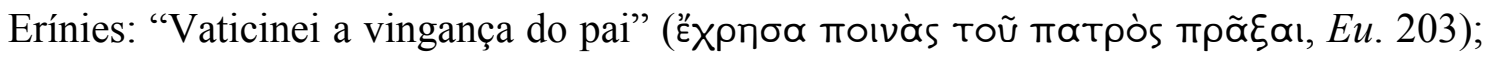

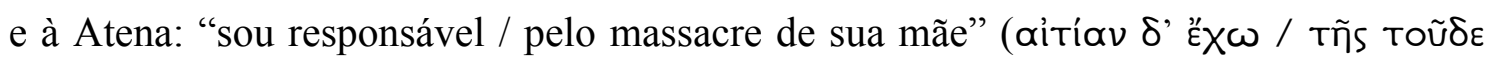

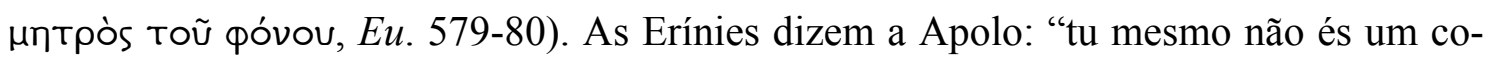

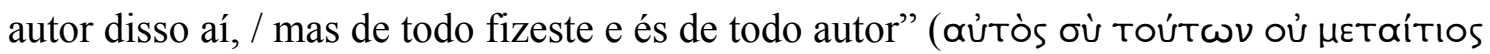

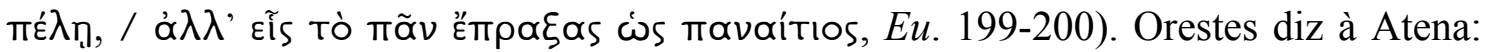
“Co-autor disso é Lóxias, ao predizer / dores aguilhoantes do coração / se eu nada

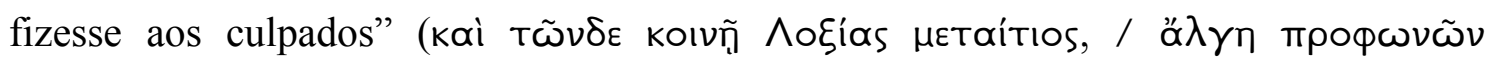




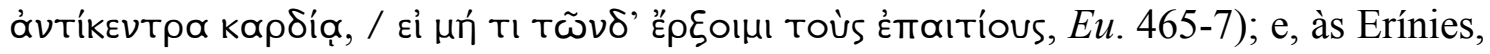
quando estas perguntam quem o persuadiu e o aconselhou a matar a mãe: "Os oráculos

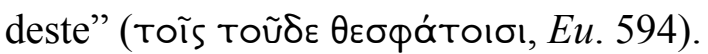

Se o ato de Orestes é, dessa forma, tão inextrincavelmente ligado ao oráculo de Apolo, não restando dúvidas de que Orestes cometeu o matricídio em obediência à palavra oracular do deus, determinar se Orestes agiu justa ou injustamente significa determinar se Apolo profetizou justa ou injustamente.

Todavia, Apolo, nesta tragédia, é caracterizado como "profeta de Zeus pai" ( $\triangle$ iòs mрофńtпs ... татрós, Eu. 19). Ser profeta de Zeus significa ser aquele que fala em nome do deus, como deixa claro o termo профńtпs: тро- (em nome de), -фń- (do verbo $ф \eta \mu i ́)$ e -tпs (sufixo de agente). O próprio Apolo o declara:

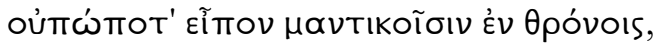

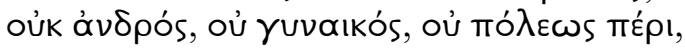

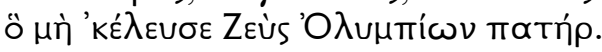

No trono divinatório, nunca disse de homem, de mulher ou de cidade senão ordem de Zeus pai dos Olímpios.

(Eu. 616-8)

Assim sendo, determinar se Orestes agiu justa ou injustamente significa, em última instância, determinar se esse desígnio de Zeus foi justo ou injusto. Coloca-se assim em questão a estreita correlação entre a palavra oracular de Apolo, mediante a qual se expressam os desígnios divinos, e a realização da justiça de Zeus.

O perigo que as Erínies representam, além de todos os males que elas enunciam mediante suas palavras imprecatórias, é o de comprometerem a absolvição de Orestes, o que, por sua vez, comprometeria a realização do oráculo de Apolo. Essas vetustas deusas colocam assim em risco os sinais divinatórios de Zeus, que são uma expressão não somente da vontade mas também da justiça divina.

Faz-se necessária, portanto, a intermediação da deusa Atena, como prenunciara Apolo no prólogo. Assim, no terceiro episódio, atendendo ao chamado de Orestes e abandonando a região da Tróade onde se encontrava, Atena chega a seu santuário e, desconhecendo os ali presentes, pede-lhes que se identifiquem. As Erínies então se declaram filhas da Noite, sendo chamadas nos ínferos de Imprecações (Eu. 416-7). Como honra lhes coube expulsar de casa os matricidas, razão pela qual estão a perseguir Orestes. E, assim, pedem à deusa que, submetendo a questão a exame, dê "reta

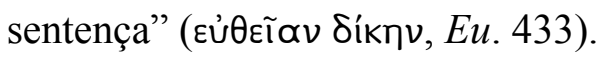


Para tanto, Atena precisa primeiramente ouvir o que a parte acusada tem a dizer a respeito de si mesmo e da acusação que lhe fazem. Encorajado por Atena, Orestes inicia seu discurso enfatizando uma vez mais o fato de não estar conspurcado e, portanto, de não haver risco de que sua presença polua o templo da deusa. A seguir, fala de sua origem, de seu pai e da morte vil que este encontrou às mãos da esposa, e de como, regressando do exílio a que fora submetido, vingou a morte do pai matando a mãe, assim instruído pelas palavras oraculares de Apolo, a quem ele declara ser coautor do crime cometido. Do mesmo modo que fizeram as Erínies, também Orestes remete à deusa a decisão de julgar o caso, determinando se agiu ou não com justiça.

A gravidade da causa que assim se apresenta à deusa impele-a a recorrer a outros meios de se julgá-la, pois como ela poderia rejeitar o pedido de acolhimento de um suplicante que ela reconhece estar devidamente purificado? Por outro lado, como ela poderia, ignorando os prístinos direitos das Erínies, expor sua terra e seu povo à cólera dessas deusas? Para resolver essa difícil situação, a deusa declara que há de convocar os melhores de seus cidadãos para atuarem como juízes dessa causa e pede que ambas as partes envolvidas reúnam testemunhas e indícios que auxiliem a justiça.

A justiça de Zeus, mesmo para Atena, não se mostra, portanto, fácil de discernir $^{21}$. Orestes, que nas Coéforas é chamado de "perito em prodígios" (тєрабко́тоv, Co. 551), agora, nas Eumênides, torna-se ele mesmo um prodígio que somente o esforço conjunto de deuses e homens pode interpretar. E, assim, no quarto episódio, Atena dá início ao julgamento.

Apolo apresenta-se como testemunha, assegurando a não-poluência de Orestes, seu hóspede e suplicante, e uma vez mais reivindicando para si a responsabilidade do matricídio. Assumindo a função de arconte-rei do tribunal do Areópago, que se institui mediante esse julgamento inaugural, Atena solicita às Erínies que exponham a sua acusação. Elas o fazem questionando Orestes, que não nega ter matado a própria mãe, cortando-lhe com uma espada o pescoço, mas que afirma tê-lo feito persuadido pelos

\footnotetext{
${ }^{21}$ Chiasson (2000, pp. 144-5) faz uma observação interessante a esse repeito: “Athena's dilemma recalls the human quandaries of Agamemnon at Aulis, forced to choose between his expedition and his daughter's life; and of Orestes at Argos, forced to choose between disobeying Apollo and killing his own mother". Para o autor, enquanto Agamêmnon e Orestes tomam sua decisão recorrendo à vontade divina, Atena, por sua vez, toma sua decisão recorrendo aos mortais ao estabelecer o tribunal do Areópago. Prossegue Chiasson: "If we look beyond the Oresteia, Athena's resolution of her "tragic dilemma" may be seen closely to resemble the course of action adopted by the Argive king Pelasgus in Supplices, who like the goddess professes a surprising inability to decide on his own authorityan issue of momentous consequence for his community".
} 
oráculos de Lóxias. É ao deus que Orestes pede que testemunhe e explique se matou a mãe justamente.

O primeiro argumento de Apolo em defesa da justiça do ato matricida é que Orestes estava obedecendo às suas palavras oraculares e que ele, deus adivinho, estava por sua vez obedecendo às ordens de Zeus ao pronunciá-las. Apolo e seu oráculo falam, portanto, em nome de Zeus ${ }^{22}$.

Como então poderia Zeus, questionam as Erínies, ordenar a vingança pela morte do pai sem considerar as honras devidas à mãe? O que as Erínies colocam em dúvida é a legitimidade do oráculo. Elas enfatizam que é Apolo quem afirma ter sido Zeus a

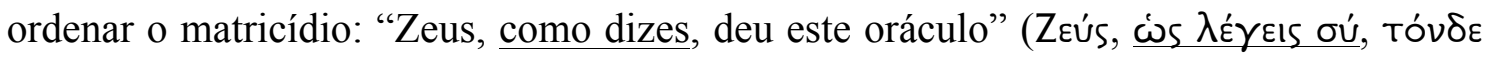

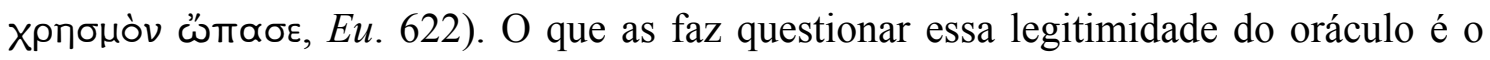
fato de lhes não parecer verossímil que Zeus possa ter ordenado algo que desconsidere a

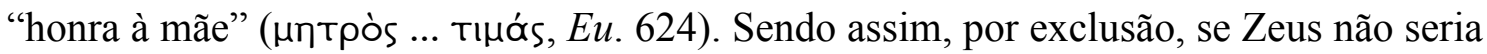
capaz de tal desígnio, o problema se encontra na competência de Apolo em transmitir os desígnios de Zeus, isto é, na sua enunciação oracular: é Apolo quem diz, como salientam as Erínies.

A essa pergunta, de como poderia Zeus desconsiderar as honras maternas, Apolo responde dizendo: "não é o mesmo" (Eu. 625). Afinal, argumenta o deus, há de se considerar, primeiramente, os atributos do varão morto: trata-se de um rei, cujo cetro lhe fora outorgado por Zeus, venerado por todos e um vitorioso guerreiro, um chefe de armada. Também devem ser consideradas as circunstâncias dolosas de sua morte: sua mulher, tendo-o recebido em casa com palavras benévolas, matou-o à hora do banho, envolvendo-o com uma rede antes de lhe desferir o golpe fatal.

Como poderia Zeus, voltam a questionar as Erínies, honrar mais o pai se ele mesmo prendeu o seu em cadeias? Uma vez mais, as Erínies questionam a legitimidade do oráculo dado por Apolo, baseando-se no que lhes parece ser inverossímil e mostrando novamente um certo ceticismo quanto à competência de Apolo em expressar os desígnios de Zeus. Que Zeus honre o lote do pai se ele mesmo acorrentou o seu é o

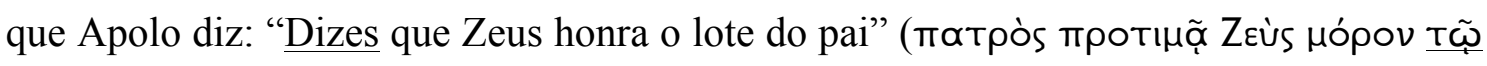

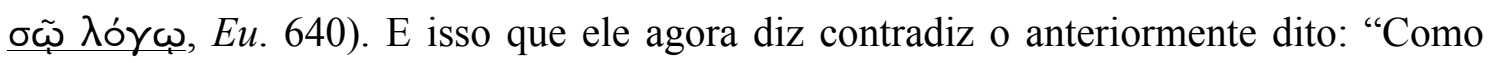

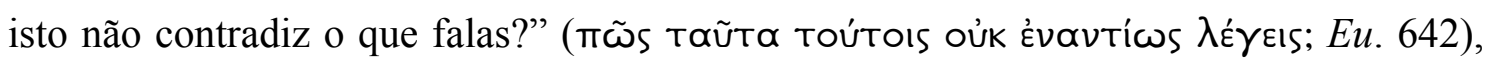
perguntam as deusas. Apolo então argumenta que se trata de situações que não se

\footnotetext{
${ }^{22}$ Trata-se de um argumento de autoridade. Como observa Roberts (1984, p. 50), “Apollo is saying that his justice and Orestes' justice rest on Zeus' will".
} 
podem comparar, visto que cadeias podem ser soltas e há muitas formas de libertação, mas o sangue derramado de um homem é irrecuperável e nem mesmo o poderoso Zeus poderia trazer um morto de volta à vida.

As Erínies, então, não obtendo sucesso em questionar a legitimidade do oráculo apolíneo como expressão dos desígnios de Zeus, voltam a insistir na poluência de Orestes, questionando como ele poderia, estando conspurcado pelo sangue materno, possuir o palácio de seu pai, ter acesso aos altares públicos ou servir-se de água lustral. Se elas não conseguiram questionar com sucesso a competência de Apolo enquanto

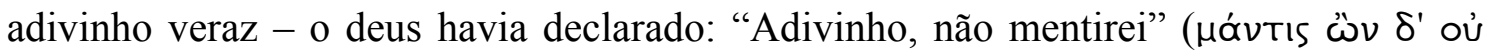

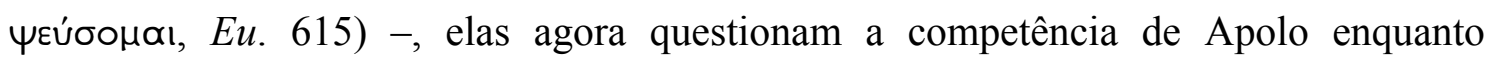
purificador, recusando-se, desse modo, a aceitar a purificação de Orestes pelo deus. Se ele, portanto, não se encontra devidamente purificado do matricídio, isso significa que elas têm o direito de persegui-lo, já que sua atribuição é expulsar de casa os matricidas (Eu. 210).

O próximo argumento de Apolo tem como objetivo demonstrar que Orestes, ao matar Clitemnestra, não derramou sangue comum e, por essa mesma razão, não se encontra, pois, conspurcado. Esse mesmo argumento tem também a função de validar o seu oráculo: se Orestes matasse a mãe, ele estaria isento de culpa. Apolo então alega que é o pai quem gera o filho e não a mãe, cujo papel se restringe apenas a hospedar a semente em seu ventre:

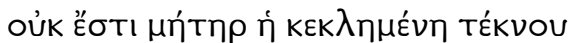

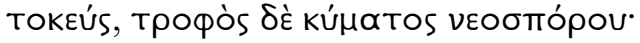

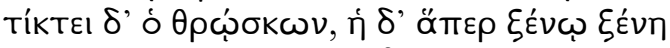

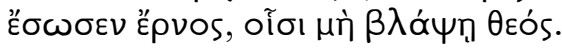

Não é a denominada mãe quem gera o filho, nutriz de recém-semeado feto. Gera-o quem cobre. Ela hóspeda conserva o gérmen hóspede, se Deus não impede.

(Eu. 658-61)

Apolo ainda oferece como prova de que é possível um pai gerar um filho sem mãe a própria existência da deusa Atena, nascida unicamente de Zeus.

Roberts (1984, pp. 52-54) propõe uma leitura bastante interessante desse tão polêmico e tão amplamente discutido argumento de $\mathrm{Apolo}^{23}$ :

I see the claim, therefore [...], as something older than the sophistry it is sometimes taken to be; it is a variant of the traditional revelation that an oracle does not mean quite what is had taken to mean. Many stories include this motif in one form or another: an

\footnotetext{
${ }^{23}$ Para uma discussão mais recente desse argumento de Apolo, conferir o artigo de Burian (2006),
} "Biologia, democrazia e donne nelle 'Eumenidi' di Eschilo". 
oracle turns out to have an unexpected sense either because its words are to be taken differently or because the facts are other than the recipient thought.

A autora cita então os exemplos dos oráculos entregues a Creso e a Édipo. Heródoto narra que Creso, rei dos medos, desejando saber a duração de sua soberania, consultou o oráculo de Delfos e a Pítia lhe respondeu que teria de fugir para salvar sua vida quando um mulo se tornasse rei dos medos ${ }^{24}$. Creso ficou exultante com a resposta da Pítia, pois pensou que, como um mulo jamais poderia ser rei dos medos, o seu reinado estava assegurado ${ }^{25}$. Após perder sua soberania para Ciro, Creso enviou alguns lídios a Delfos no intuito de cobrar explicações a respeito do oráculo recebido. A Pítia

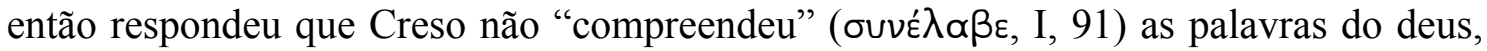
pois "o mulo" (ó njuíovos, I, 91) era em realidade Ciro, visto que era filho de duas pessoas que não eram da mesma raça. Ao ouvir a resposta da Pítia que lhe foi transmitida pelos lídios, Creso "reconheceu que o erro tinha sido seu e não do deus"

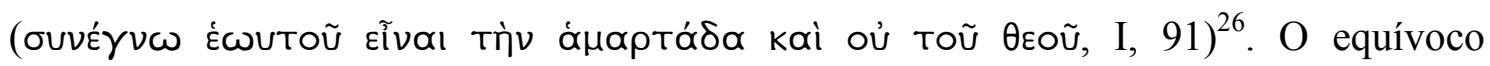
cometido por Creso foi, portanto, o de não compreender o que de fato a palavra "mulo" significava, interpretando-a literalmente: um animal e não um ser resultante do cruzamento de raças diferentes.

Já no caso do famoso oráculo entregue a Édipo, não se trata de uma má compreensão do sentido das palavras oraculares, pois o oráculo não é ambíguo: Édipo matará seu pai e desposará sua mãe. O equívoco está nos fatos, pois Édipo na verdade desconhece quem são realmente seus pais.

Roberts vê uma certa semelhança entre os casos de Édipo e Orestes, no sentido de que, em ambos os casos, os fatos se revelam igualmente inesperados. O oráculo ordena a Orestes que ele mate os assassinos de seu pai e ele o faz. Não há, portanto, um equívoco na interpretação do oráculo, já que Orestes sabe que Clitemnestra assassinou seu pai e que ela é sua mãe. Mas há um sentido inesperado no oráculo, visto que Apolo

\footnotetext{
${ }^{24} \mathrm{O}$ oráculo diz extamente o seguinte: "Quando o mulo for rei dos medos, então, lídio dos pés moles, ao longo do Hermo pedregoso põe-te em fuga. Não te detenhas nem te envergonhes de ser covarde". ('A $\lambda \lambda$ '

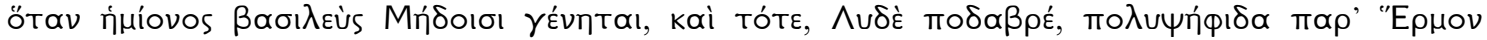

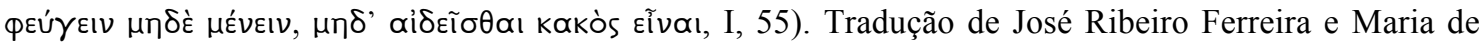
Fátima Silva (2002).

${ }^{25}$ Heródoto narra o seguinte: "Quando lhe transmitiram estes versos, Creso alegrou-se muita mais do que com todas as outras respostas, pensando que nunca um mulo chegaria a ser rei dos medos, em vez de um homem, e que, portanto, nem ele nem seus descendentes perderiam alguma vez o poder. (Toútoı

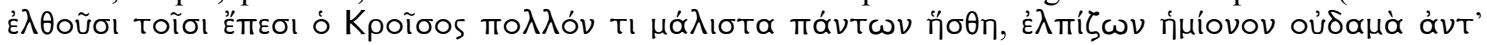

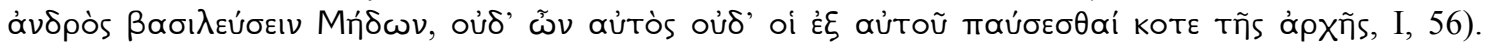
Tradução de José Ribeiro Ferreira e Maria de Fátima Silva (2002).

${ }^{26}$ Tradução de José Ribeiro Ferreira e Maria de Fátima Silva (2002).
} 
argumenta que, embora Clitemnestra seja mãe de Orestes, eles não são realmente consanguíneos. É como se Apolo, em reposta à questão das Erínies - um oráculo proveniente de Zeus pode ordenar que se cometa matricídio? -, respondesse "Yes [...], I did tell Orestes to kill his mother, but his mother is not really his parent" (ROBERTS, 1984, p. 54). É isso que se pode compreender a partir do argumento utilizado por Apolo

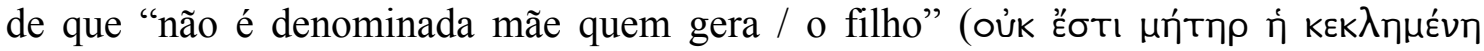
TÉKvou / Tokeús, Eu. 658-9). Esse entendimento revela um sentido inesperado ao oráculo: Zeus não ordenou algo sacrílego, como pareceria à primeira vista, pois não houve de fato derramamento de sangue comum.

Assim dadas por concluídas as falas de ambas as partes em contenda, Atena solicita aos juízes darem seus votos enquanto faz um discurso de instituição do tribunal do Areópago, no qual se dirige tanto aos cidadãos presentes a esse momento mítico de sua fundação quanto aos que dele usufruirão no porvir. A deusa, com palavras muito semelhantes, respalda o que o Coro havia dito no segundo estásimo a respeito da prudência, da moderação e da necessidade do temor na cidade para assegurar a reta observância da justiça por parte de seus cidadãos.

Os juízes depositam seus votos em meio a um áspero diálogo entre as Erínies e Apolo. As antigas deusas aconselham os juízes a não desprezá-las, pois sua presença pode ser danosa à região. Apolo, por sua vez, aconselha-os a temer os oráculos: "Eu vos

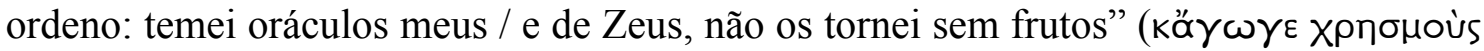

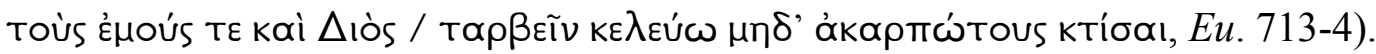

Essa sua admoestação assemelha-se à admoestação de Pílades a Orestes quando este hesita por um momento em matar a mãe. Naquele momento decisivo, Pílades lembra Orestes de sua responsabilidade na realização do oráculo apolíneo, pois, se Orestes não o cumprisse, o que seria dos "vaticínios de Lóxias dados em Delfos"

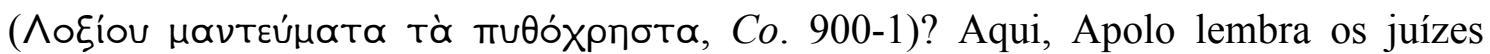
dessa mesma responsabilidade: se estes não isentarem Orestes da culpa, seu oráculo não será realizado. Essa relação de reciprocidade entre deuses e mortais no diálogo divinatório torna-se, nesta tragédia, ainda mais necessária, porque, como se enfatiza uma e outra vez, os oráculos de Apolo são uma expressão dos desígnios Zeus. Dessa

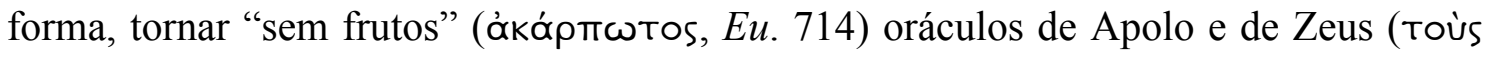

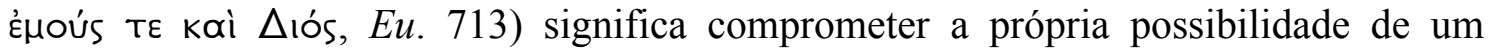
diálogo divinatório. Para as Erínies, o fato de Apolo compactuar com o crime de 
Orestes é suficiente para comprometer os oráculos apolíneos. Elas dizem: "não darás

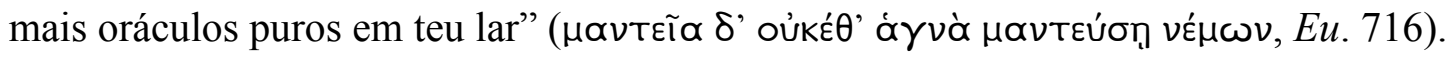

Atena então anuncia seu voto: como nenhuma mãe a gerou e é "muito do Pai"

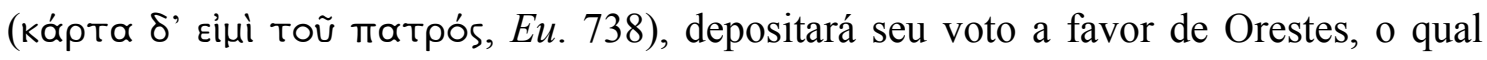
será decisivo em caso de empate ${ }^{27}$.

Antes do anúncio do resultado da contagem dos votos, há um breve momento de expectativa, em que Orestes se descreve ante duas possibilidades, a morte pela forca ou a vida, invocando, em sua ansiedade, Apolo, e as Erínies se descrevem igualmente entre duas possibilidades, perecer ou usufruir de suas honras, invocando, por sua parte, a Noite, sua negra mãe.

Empatados os votos, vence Orestes, como estabelecera e como anuncia agora

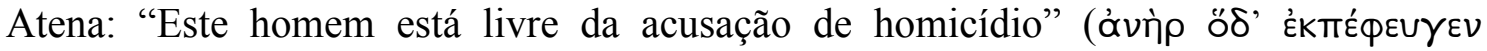

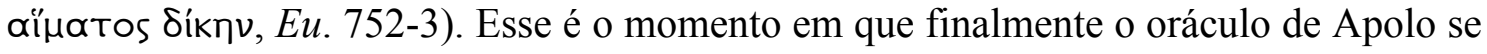
cumpre - Orestes encontra-se agora "isento de maligna culpa" (દ̇kтòs aítías kakñs, Co. 1031) - e em que a justiça de Zeus se realiza. Assim como o oráculo pítio, também a justiça de Zeus é difícil de compreender, mas, da mesma forma que é imperativo que o oráculo se cumpra, também é imperativo que a justiça divina se realize. Com sua absolvição, Orestes é assim aceito e confirmado como um sinal da vontade de Zeus e essa vontade é soberana.

Em júbilo, Orestes agradece Palas, Lóxias e Zeus, a quem atribui sua salvação. Antes de regressar à casa paterna, Orestes promete a aliança predita por Apolo entre Atenas e Argos, aliança pela qual velará mesmo depois de morto, na condição de herói, tornando ominosa qualquer tentativa de se mover exército argivo contra os atenienses e sendo benevolente para os que honrarem os aliados. É o fim, portanto, do ciclo de morte e retribuição no palácio dos Atridas.

Após demover as Erínies de sua cólera, há, no êxodo, um cortejo final, que é uma celebração da integração das Erínies à cidade, por meio do estabelecimento de sua sede e de seu culto. Tal integração é sublinhada pela mudança na cor de suas vestes antes negras e agora vermelhas, como a dos metecos ${ }^{28}$ - e pela sua renomeação, pois são ditas "Veneráveis" ( $\sum \varepsilon \mu v \alpha i ̀\langle\theta \varepsilon \alpha i ́\rangle, E u$. 1041), que, mais do que um eufemismo, como o presente ao serem designadas de Eumênides, representa o pacto entre as deusas

\footnotetext{
${ }^{27}$ A esse respeito, conferir Gagarin (1975), "The Vote of Athena".

${ }^{28}$ A respeito da mudança de cor das vestes das deusas, conferir Headlam (1906), "The Last Scene of the Eumenides".
} 
e os cidadãos atenienses, consentido por "Zeus e Porção" (Zeùs ... Moĩ ớ тє, Eu. 1045$6)$.

O texto das Eumênides deixa dúvidas relativas aos componentes desse cortejo final e não há outra alternativa a não ser imaginar quantas e quais pessoas exatamente constituíam-no. Todavia, é bastante claro no que diz respeito às tochas portadas por seus componentes. Atena, dizendo que irá à frente da procissão para indicar às Erínies o

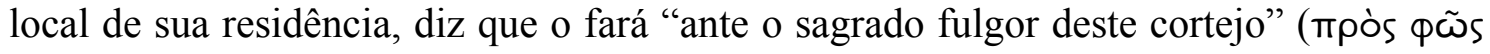

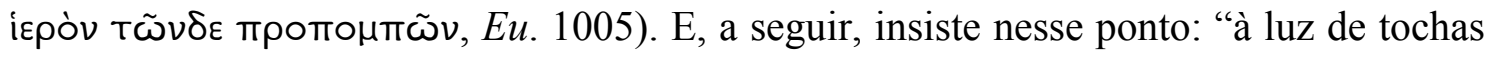

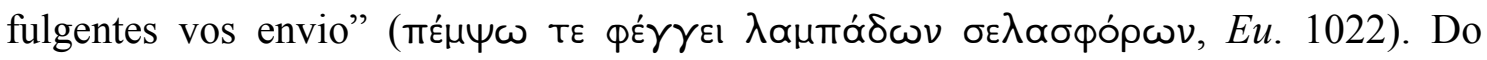
mesmo modo, os membros do cortejo dizem às Erínies que se comprazam, durante o

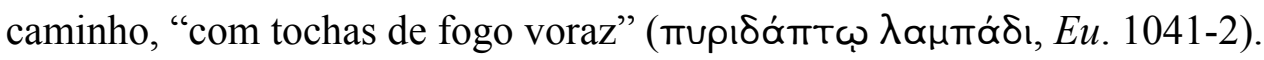

Nessa menção três vezes feita, num intervalo de poucos versos, às tochas que acompanham a procissão, poder-se-ia perceber uma alusão ao sinal de fogo avistado pelo Vigia no início da Oresteia, no prólogo do Agamêmnon. O sinal de fogo naquela ocasião era carregado de ambiguidade, parecendo ser um sinal a prenunciar mais males do que bens. Com o decorrer da trilogia e com a resolução final dos conflitos entre, de um lado, homens e deuses e, do outro, entre os deuses entre si, o sinal de fogo ressurge, agora sob a forma de uma tocha processional, que, envolta pelas preces auspiciosas das

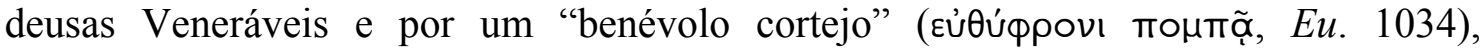
prenuncia tão-somente inequívocos bens. 
5. Prometeu Cadeeiro 


\section{Prometeu CadeEiro}

Prometeu Cadeeiro é a única tragédia supérstite de uma trilogia que Ésquilo teria dedicado ao mito de Prometeu e que se supõe ter sido composta ainda de Prometeu Libertado e Prometeu Portador do Fogo ${ }^{l}$. O nome do drama satírico que compunha a tetralogia é desconhecido e a data de sua representação é incerta. A própria autoria do Prometeu Cadeeiro tem sido vividamente debatida pelos helenistas desde o século XIX e há importantes trabalhos dedicados exclusivamente ao tema, tais como The Authenticity of Prometheus Bound, de Mark Griffith (1977), em que o autor apresenta contundentes argumentos contrários à atribuição a Ésquilo da autoria dessa tragédia, ou Sophiste et tyran ou le problème de Prométhée enchaîné, de Suzanne Saïd (1985), em que ela defende a autoria de Ésquilo, para citar somente dois exemplos entre tantos outros $^{2}$. A data de composição e de encenação deste drama é igualmente incerta, mas pode-se conjecturar que coincidam com os últimos vinte e quatro anos da vida do poeta.

A ação dramática de Prometeu Cadeeiro transcorre num precipício pedregoso, localizado em uma desolada região cita. No prólogo (Pr. 1-127), Hefesto acorrenta Prometeu, sob a vigilância de Poder e Violência, como punição por ter roubado o fogo e tê-lo dado aos mortais, contrariando os desígnios de Zeus. Tendo permanecido em silêncio até então, após a saída das outras divindades, Prometeu exprime seu sofrimento. No párodo (Pr. 128-92), entra em cena o Coro das Oceaninas, em seu carro alado, e se espanta ao contemplar a situação de Prometeu, compadecendo-se do sofrimento do deus. No primeiro episódio (Pr. 193-396), o Titã relata ao Coro por que se encontra aprisionado. Oceano, pai das Oceaninas, chega e tenta convencê-lo a reconciliar-se com Zeus, mas sem sucesso. O Coro, no primeiro estásimo (Pr. 397-435), lamenta a triste sorte de Prometeu. No segundo episódio (Pr. 436-525), o Titã narra ao Coro as dádivas com que beneficiou os mortais. No segundo estásimo (Pr. 526-60), o Coro canta seu temor diante do poder de Zeus. Io entra em cena no terceiro episódio (Pr. 561-886). Ela

\footnotetext{
${ }^{1}$ Para West, Prometeu Portador de Fogo seria a primeira peça da trilogia e diria respeito ao furto do fogo por Prometeu e sua transmissão para a humanidade, enquanto Prometeu Libertado encerraria a trilogia e diria respeito à libertação do Titã por Héracles. Em seu artigo "The Prometheus Trilogy", de 1979, o autor procura reconstruir a trilogia explorando as suas possibilidades de encenação. A respeito dessas tragédias perdidas, conferir De Dios (2008, pp. 531-83).

${ }^{2} \mathrm{O}$ debate em torno da autoria desta tragédia esquiliana é extenso. Trata-se, no entanto, de uma questão que não será aqui analisada. Prometeu Cadeeiro é uma tragédia atribuída a Ésquilo e assim será considerada, privilegiando-se, seguindo as tendências contemporâneas, o conceito de atribuição e não o de autoria.
} 
conta a Prometeu e ao Coro os acontecimentos que a levaram a errar pela terra atormentada por um aguilhão e Prometeu lhe prenuncia o fim dos seus males, revelando também que sua própria libertação depende do conhecimento que ele tem do futuro de Zeus. No terceiro estásimo (Pr. 887-906), o Coro lamenta a sorte da mortal Io. No êxodo (Pr. 907-1093), Hermes entra em cena para transmitir novas ameaças de Zeus, mas Prometeu se recusa a revelar seu segredo, sendo lançado ao Tártaro.

Durante toda a tragédia, Prometeu encontra-se acorrentado. Tudo o que the resta, portanto, são suas palavras e, através delas, o Titã prenuncia seu próprio destino, o de Zeus e o da mortal Io, que foi condenada a uma vida de errâncias, revelada por meio de frequentes sonhos e do oráculo de Apolo.

Em Prometeu Cadeeiro, como se verá, a adivinhação é caracterizada sobretudo sob três importantes aspectos: (1) como um conhecimento privilegiado que garante certo poder àquele que o possui: Prometeu alega saber de quais núpcias nascerá um filho mais poderoso que Zeus e que o deus, portanto, dependerá dele se quiser manter sua soberania; (2) como um dos elementos integrantes do processo civilizatório da humanidade: a arte divinatória figura de forma privilegiada entre os dons que Prometeu diz ter transmitido aos homens; (3) como um conhecimento que, embora de não fácil compreensão para os homens, pode ser um alento na difícil e sofrida vida dos mortais.

\section{1) Adivinhação e poder}

A tragédia inicia-se com um prólogo a que comparecem quatros seres divinos: Prometeu, Hefesto, Poder e Violência. Do diálogo entre Poder e Hefesto, depreendemse as circunstâncias da ação dramática: por ter furtado o fogo para os mortais, Zeus ordenou que Prometeu fosse encadeado pelas mãos de Hefesto, tarefa que o deus metalúrgico executa sob a atenta vigilância de Poder e Violência, num precipício pedregoso, localizado em uma desolada região cita.

A caracterização desse local descreve o que há de longínguo, inóspito, limítrofe e solitário nessa paisagem em que é executado o encadeamento de Prometeu,

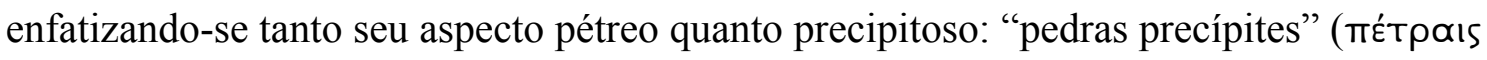
ن́

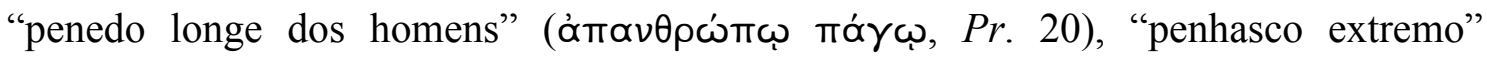

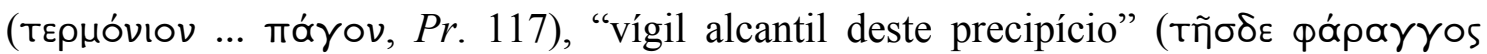




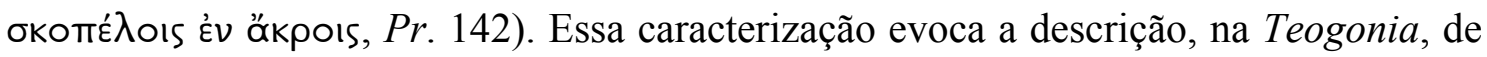
Hesíodo, da morada de Estige: longíngua, inóspita, limítrofe e solitária. Seu palácio é

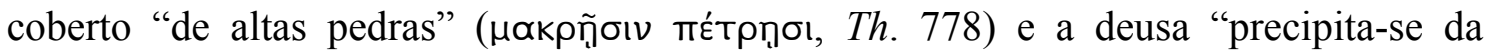

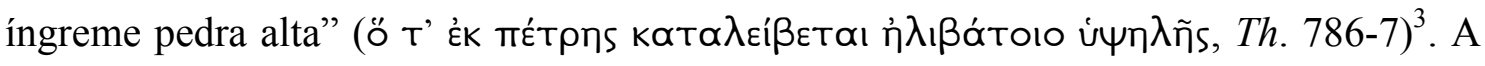
aproximação do local do encadeamento de Prometeu com a morada de Estige deixa-se perceber ainda na presença de Poder e Violência, filhos de Estige em Hesíodo (Th. 385), e na presença de Oceano e do Coro das Oceaninas, pois, na Teogonia, Oceano é pai de Estige (Th. 383). O lugar do drama e seus personagens situam-no, assim, no contexto do Grande Juramento dos Deuses, a que Prometeu é submetido (TORRANO, 2009, p. 3301).

Os versos finais da fala inicial de Poder explicitam o porquê de tal submissão:

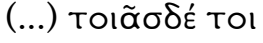

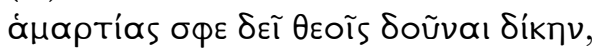

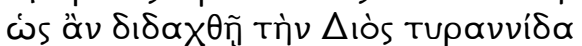

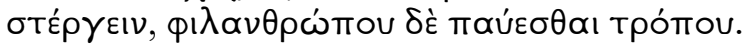

(...) Por

um erro tal, ele deve pagar aos Deuses, para aprender a anuir à tirania de Zeus e a abster-se de ser amigo de humanos.

(Pr. 8-11)

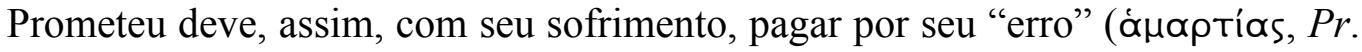
9) para aprender $(\delta เ \delta \propto \chi \theta \underline{n}, \operatorname{Pr} .10)$ a anuir à tirania de Zeus e deixar de ser "amigo dos humanos" ( benfazeja amizade que Prometeu dedica aos homens quanto a sua rebeldia, por se recusar a submeter-se à soberania de Zeus, ao desafiá-lo e entregar o fogo aos mortais contra a vontade do rei dos deuses.

A tarefa de encadear Prometeu é executada por Hefesto a contragosto. Embora não possa desobedecer as ordens de seu pai, a compaixão por "congênere Deus"

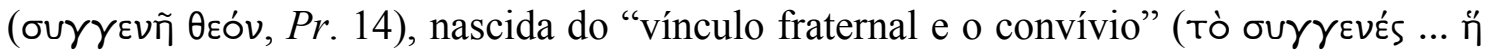

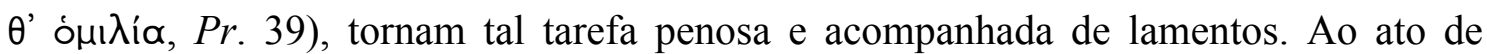

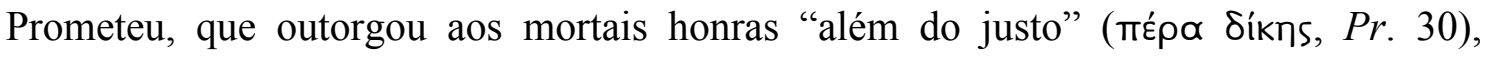
corresponde uma punição que pareceria igualmente "além do justo": sozinho, privado da companhia de seus amigos mortais, encadeado ao rochedo deserto e exposto a

\footnotetext{
${ }^{3}$ Bollack (1958, p. 21), observa que, na descrição da morada de Estige, na Teogonia, "l'évocation des rochers revient à quatre reprises, comme si le poète insistait sur cet aspect, au début, à la fin et deux fois au milieu de la description, ce qui est, dans une composition archaïque, le signe manifeste d'une mise en évidence. D'immenses rochers surplombent la deumeure, l'eau se précipite du haut d'un roc abrupt et le pays tout entier est rocheux. L'eau du Styx est moin présente à l'esprit que la roche d'où elle coule. Il se pourrait bien que la déesse d'Hésiode fùt à l'origine la demeure mème qu'elle habite".
} 
queimaduras solares, muito padecerá. Assim será consumido por este mal, pois, como

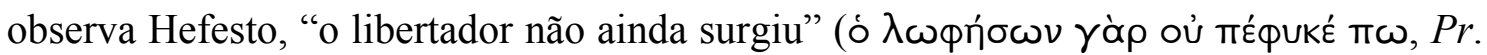
27).

Essa ligeira menção ao libertador ainda não nascido de Prometeu é um prenúncio da libertação do Titã por Héracles. Como observa Conacher (1980, p. 33),

Here, albeit unwittingly, Hephaistos gives us the first of several hints of Prometheus' ultimate liberation, for the speech is true in the literal sense in which the speaker does not mean it. All that Hephaistos means, of course, is 'the man able to free you has not been (and never will be) born'.

As palavras de Hefesto são, portanto, um kledón prenunciando o fim dos males de Prometeu, o que somente aconteceria na tragédia perdida Prometeu Libertado.

$\mathrm{Na}$ detalhada descrição do acorrentamento de Prometeu, cujos membros são presos por peias, cadeias de aço, freios, cunhas, cilhas e grilhões e fixados com "potente

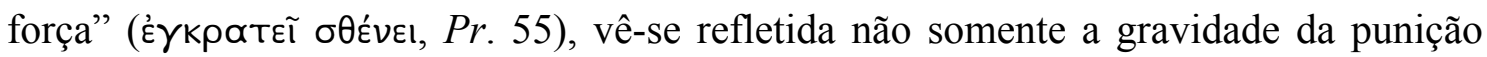
que lhe cabe, mas também a inexorabilidade do ânimo de Zeus (Pr. 34), sua aspereza ( $P r .35)$ e severidade ( $P r .77)$, cujo exercício do poder recém-conquistado é descrito nesta tragédia como uma tirania $(\operatorname{Pr} .10,49-50,310,324,942,996)^{4}$. Para Poder, é necessário assegurar que Prometeu esteja bem preso, porque sabe "achar saída até do

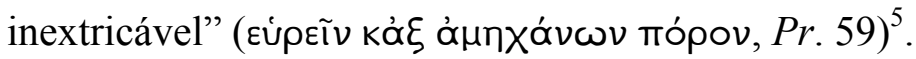

Poder, mesmo reconhecendo que Prometeu sabe "achar saída até do inextricável", e por isso é necessário assegurar que esteja bem preso, zomba do deus, dizendo ser falso o nome que os numes lhe deram - Prometeu significaria "previdente" - e que ele necessita de alguém realmente previdente para libertá-lo das cadeias forjadas pela arte de Hefesto. Ironicamente, o nome de Prometeu, ao contrário do que julga

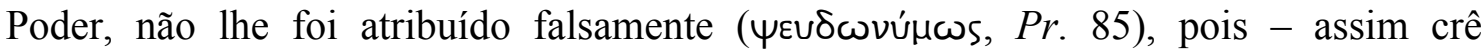
Prometeu - é seu conhecimento divinatório, o qual nenhuma cadeia pode subjugar, que lhe garantirá os meios de encontrar a libertação, mesmo que após muito sofrimento.

\footnotetext{
4 Os termos "tirano" (тúpavvos) e "tirania" (тupavvís) aparacem, respectivamente nos versos 310, 942 e $10,996$.

${ }^{5}$ Sobre o encadeamento de Prometeu, Marston (2007, pp. 121-4) observa o seguinte: "This binding is usually understood as a physical shackling to the rock, but the language [...] is evocative of the language of the magical curses". Assim sendo, conclui o autor, "though the binding is first and foremost a physical restraint and torture, $[\ldots]$ the audience would have understood the scene as simultaneously possessing a secondary meaning, that of a magical binding spell".
} 
Encontrando-se a sós, Prometeu, na segunda cena do prólogo, rompe o silêncio em que permanecera até então, invocando como testemunhas de sua deplorável condição o Éter divino, os ventos, os rios, as ondas marinhas, a Terra e o Sol ${ }^{6}$ :

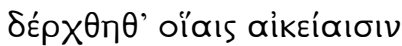

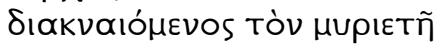

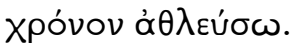

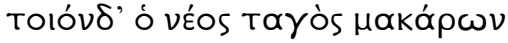

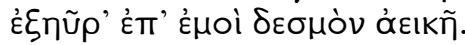

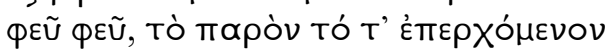

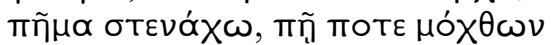

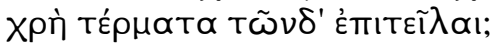

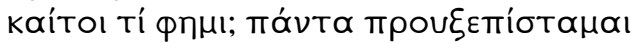

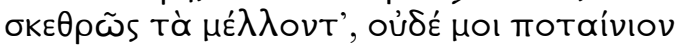

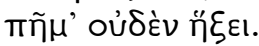

\begin{abstract}
Contemplai que afrontas
dilacerado sofrerei

durante miríades de anos.

O novo chefe dos Venturosos inventou

tal cadeia pra mim aviltosa.

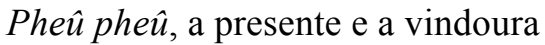
dor lamento! Como se deve, afinal, dar-se o termo destes tormentos?

Mas que digo? Bem sei de antemão todo o futuro, nenhuma dor para mim imprevista virá.
\end{abstract}

(Pr. 93-103)

Prometeu menciona, assim, logo após sua inicial invocação aos deuses, seu

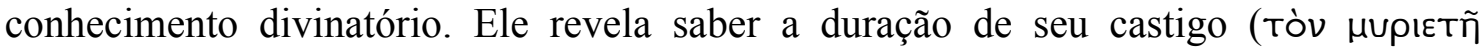

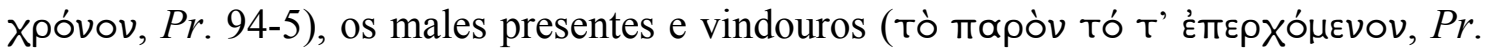

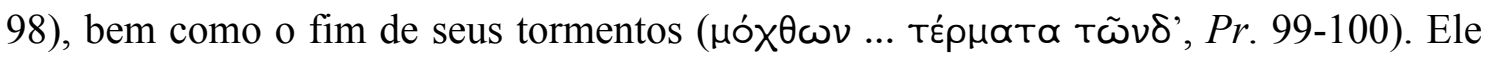

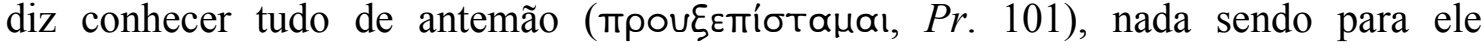
imprevisto (потаíviov, Pr. 102).

Como se respondesse às invocações e aos lamentos do deus, o Coro de Oceaninas, filhas de Tétis e de Oceano, entra em cena no párodo. As Oceaninas ouviram o eco das batidas do aço e, assim, persuadindo seu pai e afastando de si o tímido pudor, vieram em seu carro alado. Prometeu pede-lhes que contemplem a deplorável circunstância em que se encontra, pela qual as deusas, compadecidas, derramam lágrimas solidárias, percebendo na situação de Prometeu o rancor do deus que agora detém o poder e que não cessará antes que tenha saciado seu coração ou tenha seu poder arrebatado por outrem: "nem cessará / antes que sacie o coração, ou por golpe

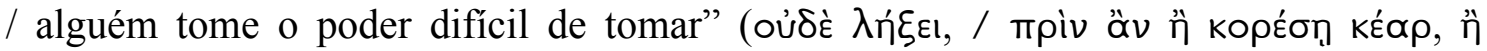

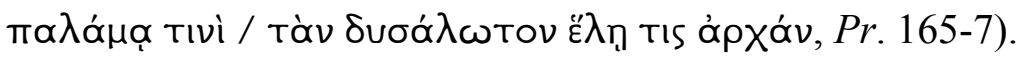

\footnotetext{
${ }^{6}$ Herington, em seu artigo "A Study in the Prometheia, Part I: The Elements in the Trilogy", de 1963, observa a importância dos quatro elementos aqui evocados por Prometeu: o ar (éter), a terra, a água (os rios, as ondas marinhas) e o fogo (o sol). Bollack (1958), em seu artigo "Styx et serments", oberva que, nos juramentos, Céu e Terra são evocados, exprimindo-se, mediante a nomeação desse par primordial, a totalidade do ser. As águas de Estige, também evocadas, são o limite entre o ser e o não-ser. Assim, não há abrigo possível para o perjuro; ele é excluído de todo ser. Note-se que Prometeu evoca o Céu (Éter divino, os ventos), a Terra e as águas de Estige (as ondas marinhas, isto é, as Oceaninas). Conferir Torrano (1996).
} 
O que para o Coro constitui apenas uma remota possibilidade - Zeus ser destronado - impõe-se, mediante a asserção de Prometeu de que conhece o futuro de Zeus, como uma realidade possível, e assim o deus prediz, como uma ameaça, que Zeus ainda há de precisar dele:

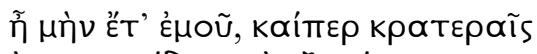

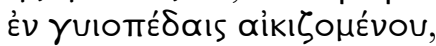

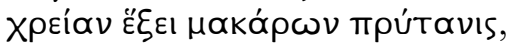

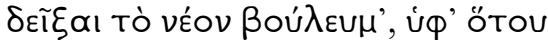

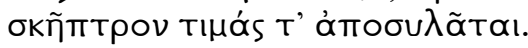

Sim, de mim, ainda que peias cruéis nos membros me aflijam o prítane dos venturosos precisará para indicar qual nova decisão lhe arrebatará cetro e honra.

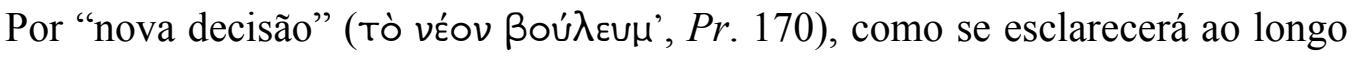
do drama, entende-se a decisão de contrair novo matrimônio, do qual seria gerado um filho mais poderoso que o pai. "Indicar" ( $\delta \varepsilon \tilde{\imath} \xi \propto l, \operatorname{Pr} .170)$, porém, qual nova decisão seria esta, Prometeu diz que o fará quando Zeus libertá-lo de suas cadeias e pagar por tal afronta, sendo vã, portanto, qualquer tentativa de dissuadi-lo, seja por meio de palavras persuasivas ou de ameaças, ameaças estas que de fato serão feitas, por intermédio de Hermes, no êxodo.

O Coro, no entanto, alheio ao caráter pressago das palavras de Prometeu, em que mais se ocultam do que se revelam os fatos, vê nelas apenas a consequência de uma língua demasiadamente solta da parte de quem, ante tais males, deveria, temeroso, recuar, e por isso as Oceaninas temem por sua sorte. Mas Prometeu insiste que, a despeito de toda aspereza e cólera de Zeus, chegará o momento em que ele virá, para ser

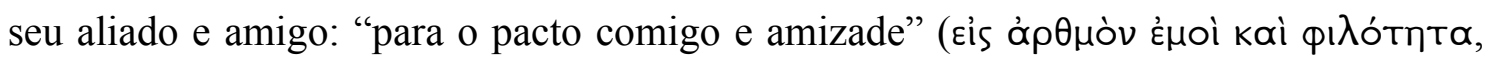
Pr. 191). Prenuncia-se, assim, um momento de harmonia e reconciliação, que só se tornará possível quando Prometeu revelar a Zeus seu conhecimento sobre o porvir. Assim, do ponto de vista do Titã, depende dele e de seu conhecimento divinatório uma futura harmonia. Essa harmonia significaria, de acordo com Prometeu, não apenas a reconciliação entre os dois deuses que agora se encontram cindidos, mas também a manutenção do poder nas mãos de Zeus.

No primeiro episódio, o Coro pede a Prometeu que lhe esclareça por qual motivo Zeus tão afrontosamente o acorrentou. Prometeu relata que, na batalha pelo poder que se deu entre Zeus, de um lado, e Crono e Titãs de outro, ele, ouvindo as profecias de sua mãe de que o poder não havia de ser conquistado pela violência (mpòs ßíav, Pr. 208),

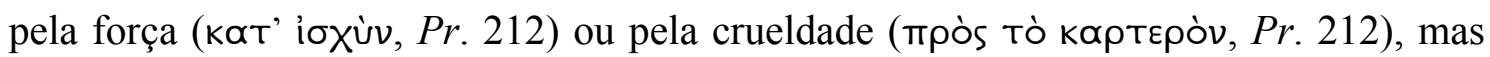




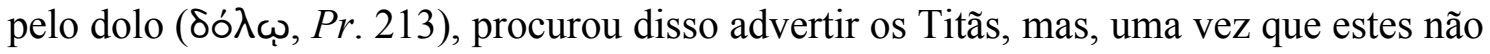
lhe deram ouvido, aliou-se a Zeus. Seguindo seus conselhos, Zeus então adquiriu o poder; porém, ao distribuir as honras entre os deuses, descuidou dos mortais, a quem desejava destruir. Prometeu foi o único que se opôs a essa decisão e, por livrar a raça dos mortais do extermínio, encontra-se agora encadeado.

Diferentemente da Teogonia de Hesíodo, em que Prometeu figura como filho de Jápeto e Clímene (Th. 507-10) ${ }^{7}$ - sendo Jápeto filho de Terra e Céu, e Clímene, filha de Oceano e Tétis -; nesta tragédia, Prometeu se apresenta como filho de Terra ou Têmis,

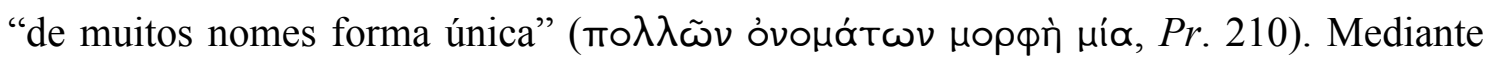
essa filiação, explicita-se e justifica-se seu saber divinatório, pois a deusa Terra, a quem

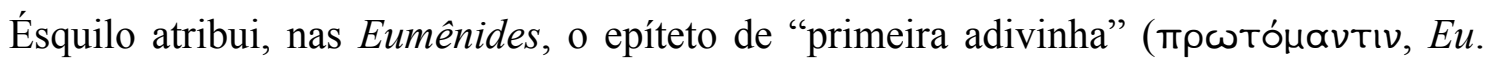
2), é a divindade profética por excelência, pois todo o ser e o acontecer são uma manifestação de sua própria natureza primordial.

Para o pensamento teogônico, a natureza e as atribuições dos deuses se definem pela linhagem divina à qual pertencem ${ }^{8}$. Como filha da Terra, a deusa Têmis partilha, portanto, de sua natureza e atribuições, de modo a se confundir com ela, tal como sugere Prometeu ao dizer que Terra e Têmis são nomes diferentes para uma forma única. Igualmente, ao filiar-se diretamente a Terra/Têmis, Prometeu compartilha de sua natureza e atribuições, de modo a poder arrogar para si não somente o conhecimento divinatório, mas também a própria autoria da vitória e da realeza de Zeus.

Como observa Saïd (1985, pp. 188),

[...] le Prométhée du culte attique n'est qu'un dieu qui préside aux arts du feu. Et le Prométhée d'Hésiode qui donne de sages conseils à son frère Epiméthée est simplement prudent, il n'est à aucun dregré devin. Pour faire de Prométhée un devin, Eschyle a même dû modifier la généalogie de son héros. Il fallait en effet expliquer l'origine du talent próphetique de Prométhée.

O fato de Prometeu se declarar filho de Terra/Têmis, não só explicaria, mas também legitimaria o seu saber divinatório, peça-chave no desenvolvimento desta tragédia, e ao mesmo tempo lhe permite responsabilizar-se pela vitória de Zeus, o que,

\footnotetext{
${ }^{7}$ Diz Hesíodo: "Jápeto desposou Clímene de belos tornozelos / virgem Oceanina e entraram no mesmo leito. / Ela gerou o filho Atlas de violento ânimo, / pariu o sobreglorioso Menécio e Prometeu / astuto de

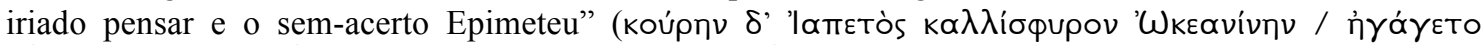

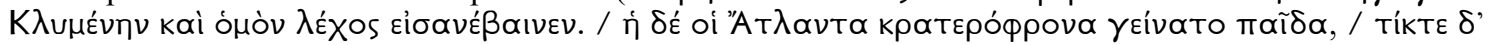

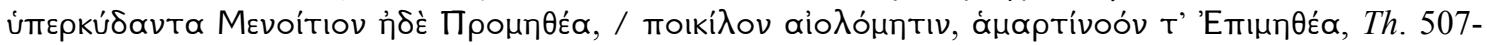
$11)$.

${ }^{8}$ Conferir Philippson (1949).
} 
do ponto de vista do Titã, torna seu atual padecimento mais injusto e impiedoso, e seu algoz, mais cruel e ingrato. Alegando ser possuidor de um conhecimento que escapa até mesmo a Zeus e de ser autor de sua ascensão ao poder, a figura de Prometeu engrandece consideravelmente, principalmente se comparada com a retratada por Hesíodo, em que ele não possui nenhuma atribuição divinatória nem participa da guerra entre os Titãs e os deuses olímpios, sendo descritas apenas suas tentativas de "trapacear o espírito de

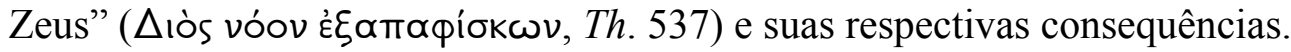

Note-se que, em Hesíodo, Prometeu é descrito como "astuto de iriado pensar"

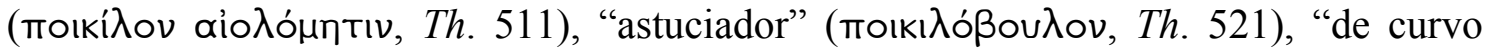

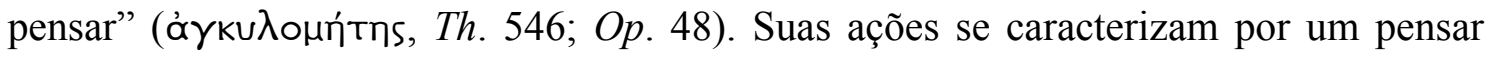

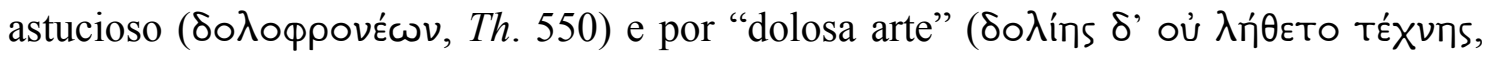
Th. 547). Sendo assim, o que caracteriza Prometeu nas narrativas hesiódicas é sobretudo a sua métis. Em contrapartida, o que caracteriza Prometeu nesta tragédia de Ésquilo é o conhecimento divinatório que ele diz possuir e do qual ele continuamente oferece provas ao longo do drama. Essa diferença é significativa, pois o fato de o Titã dizer que

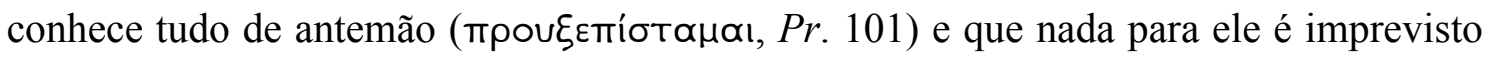
(потаíviov, Pr. 102), concede-lhe um poder em sua relação antagônica com Zeus inexistente nos textos hesiódicos, como bem o demonstram as assertivas que concluem as histórias de Prometeu na Teogonia e em Os Trabalhos e os Dias: "Não se pode furtar

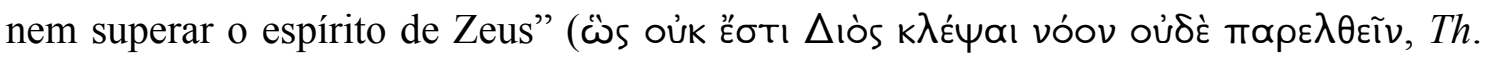

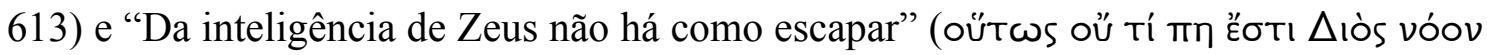

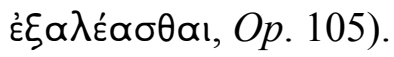

O Coro de Oceaninas pede que Prometeu lhe diga o que mais teria feito em favor dos mortais, ao que o deus responde tê-los impedido de prever a morte (Pr. 248), ao instalar-lhes cegas esperanças ( $P r .250)$, e ter-lhes outorgado o fogo ( $P r .252)$. O Coro, ainda que tenha compaixão por Prometeu, não deixa de reconhecer que ele errou.

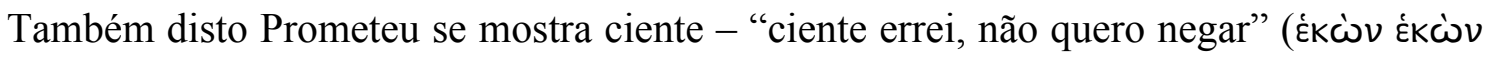

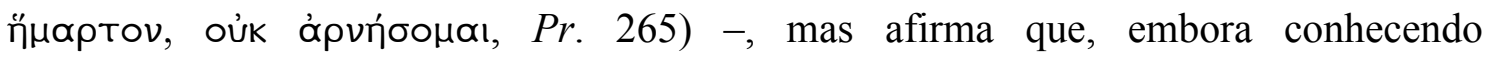
antecipadamente os sofrimentos advindos de seu ato, cometeu-o ainda assim em favor da humanidade. E convida as Oceaninas a, descendo de seu carro alado, ouvir "as

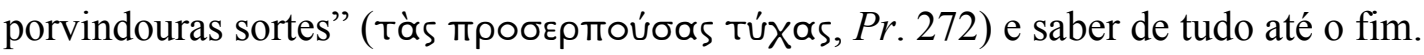


As Oceaninas aceitam de bom grado descer do carro e pisar com seus pés descalços o chão áspero. Nesse momento, entretanto, seu pai, Oceano, entra em cena ${ }^{9}$, declarando-se compadecido com a situação de Prometeu e indagando-lhe de que maneira poderia ajudá-lo, uma vez que a estima e o parentesco o impelem a isso. Prometeu pede que Oceano contemple sua dolorosa situação. Contemplando-a, Oceano aconselha Prometeu a moderar suas palavras e apaziguar sua cólera, de modo a não atrair sobre si maiores males. De sua parte, declara tentar persuadir Zeus a livrá-lo de suas fadigas. Prometeu reconhece e louva a boa vontade de Oceano, mas adverte-o da inutilidade de seus esforços, pois Zeus não há de ser persuadido. Além disso, não deseja causar males a ninguém, pois já o aflige a sorte de seu irmão Atlas, a suster a coluna do Céu e da Terra nos ombros, e a de Tífon, cujo corpo inerme repousa sob o Etna.

Nesse momento, Prometeu prenuncia que, mesmo abrasado pelo raio de Zeus, a cólera de Tífon um dia se deixará perceber sob a forma de rios de fogo que devorarão as planícies da frutífera Sicília:

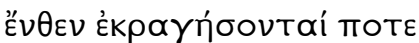

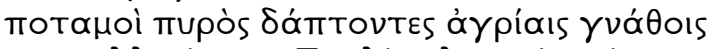

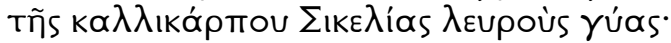

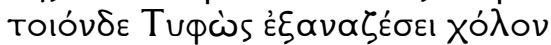

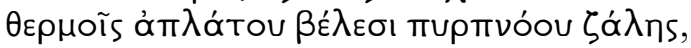

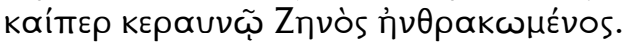

\section{(...) Daí romperão um dia} rios de fogo a devorar com ferozes queixos os lisos alqueires da frutífera Sicília, tão colérico Tífon ferverá com dardos ardentes de inabordáveis ígneos ventos, ainda que abrasado pelo raio de Zeus.

(Pr. 367-72)

Essa passagem é frequentemente entendida pelos comentadores como uma alusão à erupção do Etna ocorrida em 479/478 a.C. Qual seria, no entanto, o seu sentido? Trata-se de mais um indício que Prometeu oferece tanto do seu saber quanto de sua veracidade. Se, por um lado, para Oceano e o Coro de Oceaninas, é um prenúncio cuja veracidade eles não podem atestar, visto que ainda irá acontecer "um dia" (потє, Pr. 367), para os espectadores, por outro lado, trata-se de um prenúncio já realizado ${ }^{10}$. A audiência é, portanto, de certo modo convocada a testemunhar a legitimidade do conhecimento divinatório de Prometeu.

\footnotetext{
${ }^{9}$ Konstan, em seu artigo "The Ocean Episode in the Prometheus Bound", de 1977, analisa a importância da cena entre Prometeu e Oceano, chegando a esta, dentre outras, conclusões: "the Ocean episode reveals clearly that the archetypal level is fully present in the drama. Its effect is to inspire a sense of necessity in the rift between Prometheus and Zeus, so that their conflict seems both meaningful and right".

${ }^{10}$ Essa menção à erupção do Etna constitui um dado relevante para a difícil questão da datação desta tragédia de Ésquilo.
} 
O conhecimento do Titã a respeito do futuro da soberania de Zeus só é mencionado novamente ao final do segundo episódio, em que Prometeu fala ao Coro de todos os benefícios concedidos por ele aos mortais. As Oceaninas expressam a esperança de que, livre das cadeias, Prometeu não terá menos força que Zeus. A isso, o Titã responde:

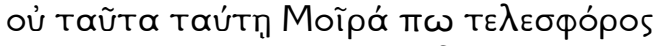

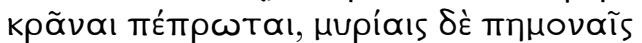

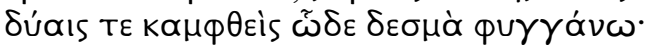

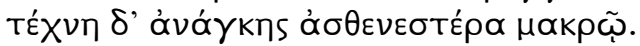

Não ainda isso assim Parte cumpridora dá a cumprir-se, mas curvado por miríades de dores e males, assim escapo das cadeias. A arte pode bem menos que a necessidade.

(Pr. 511-4)

Embora seja certo que a sua libertação se dará, o seu momento ainda não chegou, pois ainda lhe cabe padecer muitas dores e sofrimentos; assim determina "Parte cumpridora" (Moĩpa ... тє入єбфópos, Pr. 511). No entanto, como esclarece Prometeu,

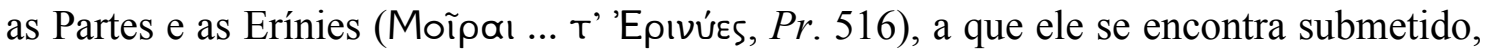
também submetem Zeus: o deus "não escaparia da parte que lhe cabe" (oưkouv àv

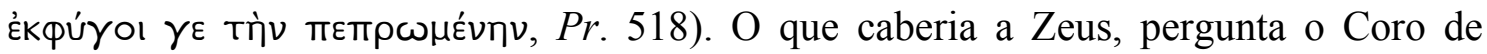

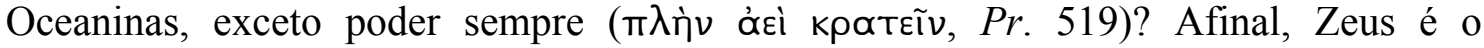
fundamento de todo exercício do poder; como seria, portanto, possível ele ser destituído do poder, de sua atribuição mais fundamental?

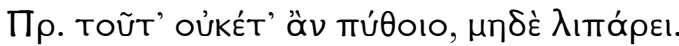

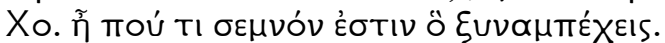

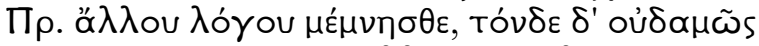

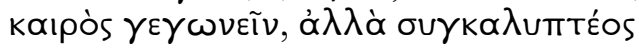

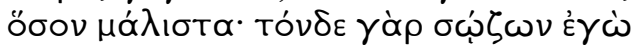

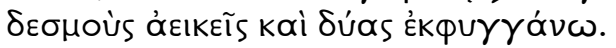

P. Isso não ainda saberias, nem insistas.

C. Talvez seja algo solene o que ocultas?

P. Lembrai outra palavra. Essa nunca é hora de dizer, mas deve-se ocultar o mais possível. Conservando-a, eu escapo de cadeias indignas e de males. (Pr. 519-25)

O conhecimento de Prometeu sobre o porvir de Zeus revela-se, uma vez mais, estritamente ligado a uma ameaça à sua soberania. Esse é o grande segredo que

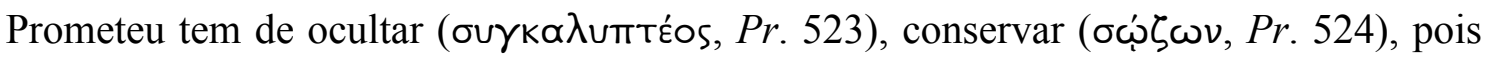
desse segredo depende a sua própria libertação e o fim dos seus males. 
No terceiro episódio, Prometeu menciona novamente o seu conhecimento do futuro da realeza de Zeus. Io, confrontada com a predição de seus males, questiona de que lhe vale estar viva, pois lhe parece preferível a morte a uma vida fadada ao sofrimento diário. Prometeu, no entanto, cujo ser divino é imortal, afirma que os tormentos de que padece só poderão encontrar um termo quando Zeus for destituído de sua realeza. Essa menção de Prometeu à possibilidade de Zeus perder a realeza dá ensejo a uma esticomitia entre Io e o Titã, em que este enfim revela o que antes apenas insinuara ao dizer ao Coro, no párodo, que uma "nova decisão" (Tò véov ßoú $\lambda \varepsilon \cup \mu$ ', Pr. 170) seria responsável por Zeus ter arrebatados cetro e honra:

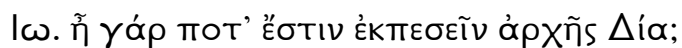

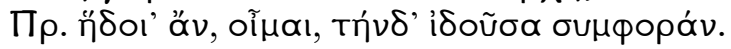

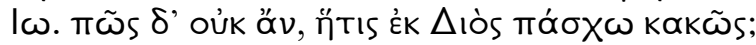

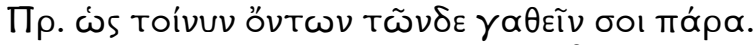

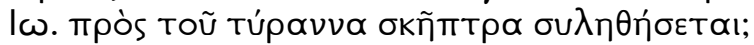

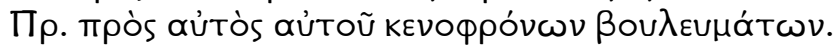

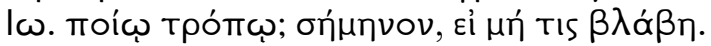

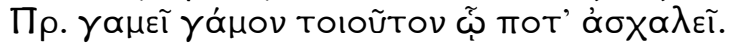

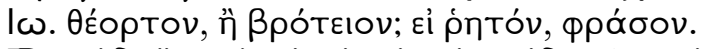

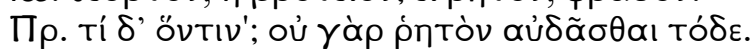

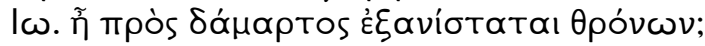

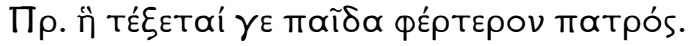

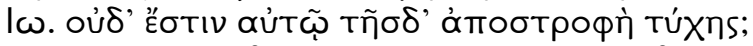

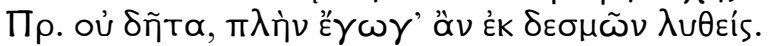

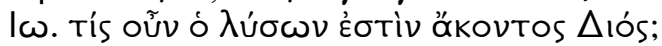

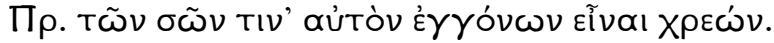

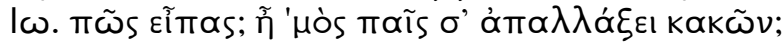

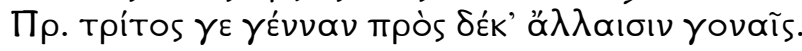

I. Mas há a vez de Zeus cair do poder?

P. Com prazer, creio, verias isto se dar.

I. Como não, eu que por Zeus padeço?

P. Podes regozijar-te de que assim é.

I. Por quem o régio cetro será roubado?

P. Por ele mesmo, por vãs decisões.

I. De que modo? Diz, se não há mal.

P. Contrai núpcias tais que se aflija.

I. Divinas ou mortais? Se dizível, diz.

P. Por que com quem? Isto não se diz.

I. Ele é pela esposa expulso do trono?

P. Parirá um filho mais forte que o pai.

I. Ele não tem um refúgio dessa sorte?

P. Não, além de mim, livre de cadeias.

I. Quem o livrará, contrariando Zeus?

P. Será alguém dos teus descendentes.

I. Que dizes? Meu filho te livrará dos males?

P. Na terceira geração, além de mais dez. (Pr. 757-74) 


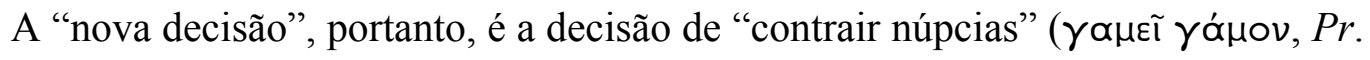

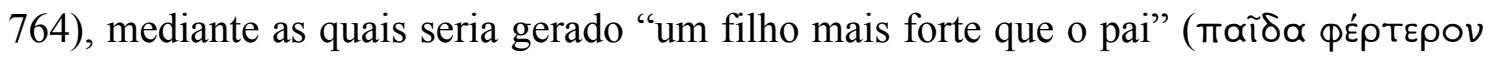
татрós, Pr. 768), que tomaria o seu lugar como rei.

Observe-se que, na Teogonia, de Hesíodo, figura a mesma ameaça à soberania de Zeus:

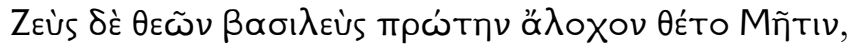

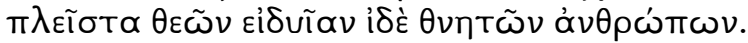

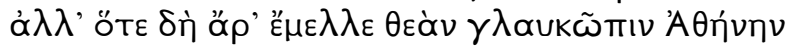

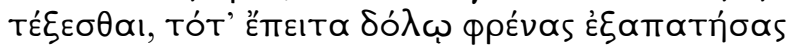

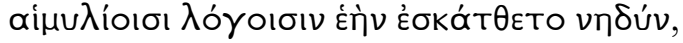

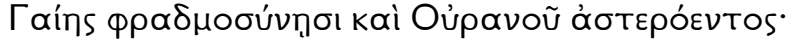

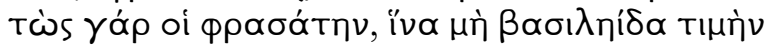

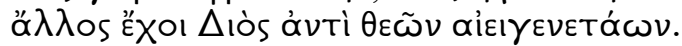

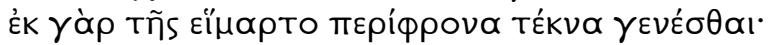

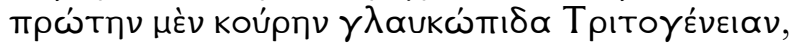

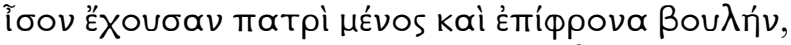

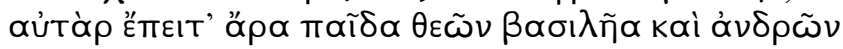

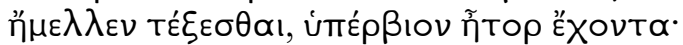

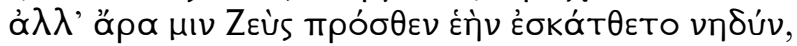

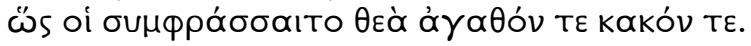

Zeus rei dos deuses primeiro desposou Astúcia Mais sábia que os deuses e homens e os homens mortais. Mas quando ia parir a Deusa de olhos glaucos Atena, ele enganou suas entranhas com ardil, com palavras sedutoras, e engoliu-a ventre abaixo, por conselhos da Terra e Céu constelado.

Estes lho indicaram para que a honra de rei não tivesse em vez de Zeus outro dos Deuses perenes: era destino que ela gerasse filhos prudentes, primeiro a virgem de olhos glaucos Tritogênia igual ao pai no furor e na prudente vontade, e depois um filho rei dos Deuses e homens ela devia parir dotado de soberbo coração. Mas Zeus engoliu-a antes ventre abaixo para que a Deusa the indicasse o bem e o mal. (Th. 886-900)

Também há aqui o vaticínio de que Zeus irá ser despojado do trono por um filho

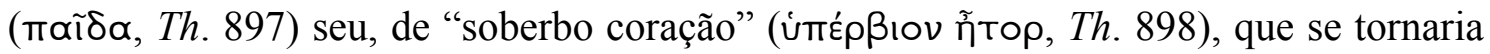

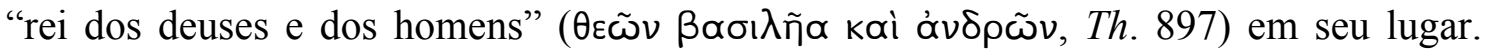
Quem prenuncia, no entanto, essa ameaça a Zeus e lhe indica como manter "a honra de

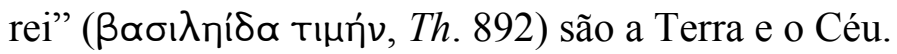

Na Ístmica VIII, Píndaro também menciona uma ameaça à soberania de Zeus por meio do nascimento de um filho mais poderoso que o pai. Narra o poeta que Zeus e 
Posídon disputavam a mão de Tétis, mas que nenhum dos dois a obteve como esposa,

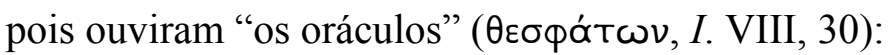

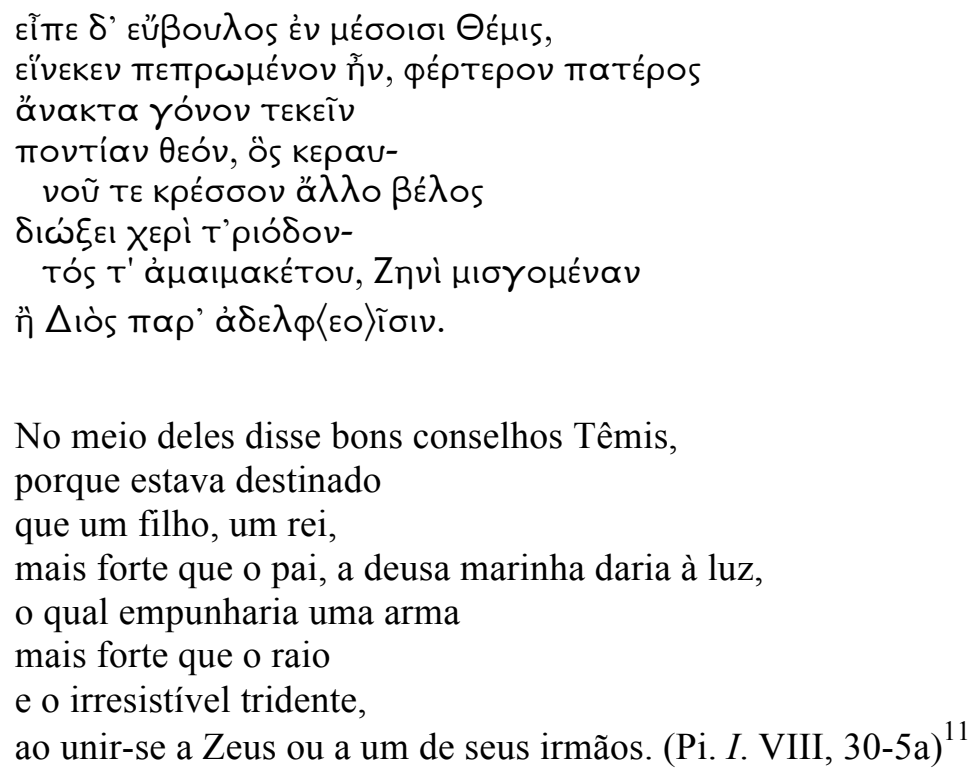

No meio deles disse bons conselhos Têmis, porque estava destinado que um filho, um rei, mais forte que o pai, a deusa marinha daria à luz, o qual empunharia uma arma mais forte que o raio e o irresistível tridente, ao unir-se a Zeus ou a um de seus irmãos. (Pi. I. VIII, 30-5a) ${ }^{11}$

Em Prometeu Cadeeiro, como se viu, o Titã reivindica para si os conhecimentos divinatórios de sua mãe Terra, que, como ele mesmo afirma, foram fundamentais para o desfecho da Titanomaquia. Naquela ocasião, a Terra "profetizava como se cumpriria o

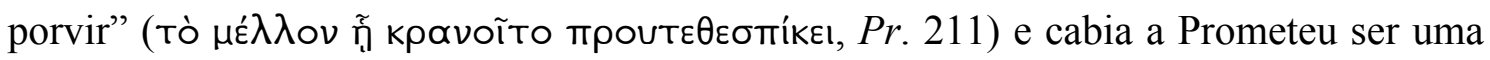
espécie de porta-voz de sua mãe, pois ele diz que "tais oráculos eu com palavras

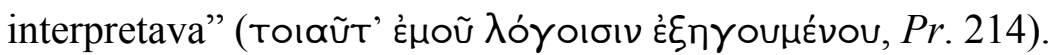

Nessa nova ameaça à soberania de Zeus - ser destronado por um filho seu -, Prometeu também reivindica para si o conhecimento divinatório de sua mãe Terra a respeito do futuro da realeza de Zeus. Na Teogonia, Terra e Céu "indicam" ( Th. 892) tanto o porvir a Zeus - a esposa da qual nasceria o temido filho seria Astúcia quanto a forma de contornar esse destino adverso - seduzindo-a e engolindo-a ventre abaixo -; na Ístmica VIII, é Têmis que fornece oráculos - da união com Tétis nasceria um filho mais poderoso que o pai - e aconselha a entregar a mão da deusa marinha a um mortal, Peleu. Porém, em Prometeu Cadeeiro, o Titã mantém o porvir ameaçador de Zeus velado, não revelando nem ao menos se a esposa que geraria o filho funesto seria mortal ou divina. Para Prometeu, revelar "com quem” (ővtıv', Pr. 766) Zeus teria esse filho seria abrir mão da única vantagem que ele possui em sua relação antagônica com Zeus e, portanto, tal conhecimento do futuro torna-se, nas mãos do Titã, uma moeda de

\footnotetext{
${ }^{11}$ A edição do poema é de Maehler (1971) e a tradução é nossa.
} 
troca a ser utilizada em benefício próprio: Zeus só poderá escapar à sorte funesta se libertá-lo das cadeias.

Prometeu, no êxodo, volta a prenunciar a queda de Zeus:

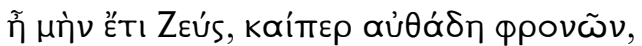

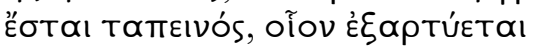

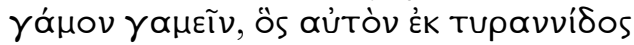

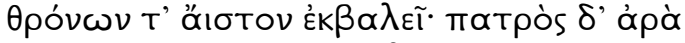

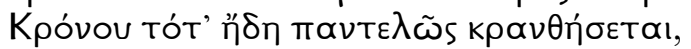

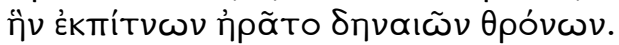

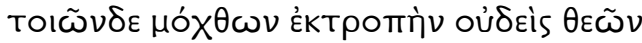

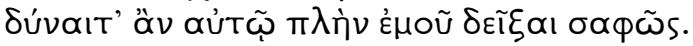

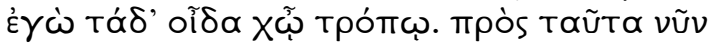

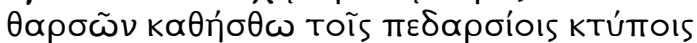

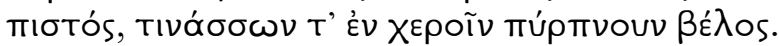

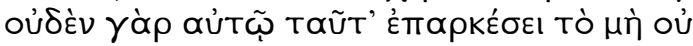

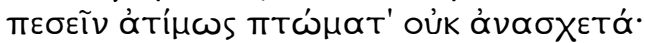

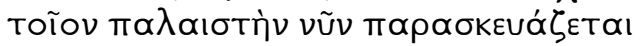

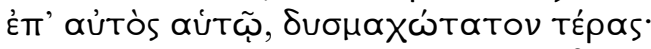

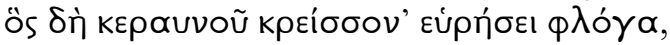

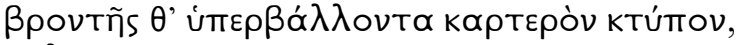

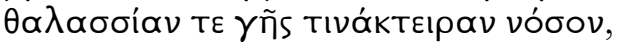

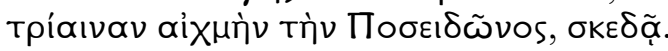

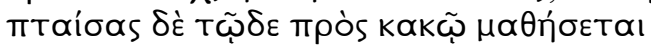

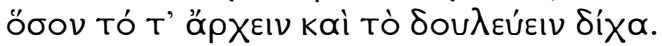

Sim, Zeus ainda, apesar de obstinado, será humilde, tais núpcias se preparam que o lançarão destruído fora da tirania e do trono. A imprecação do pai Crono nesse dia já inteiramente se cumprirá, imprecada ao cair do longevo trono. Nenhum deus, senão eu, lhe indicaria com clareza como escapar a tais penas; eu bem sei de que modo. Quanto a isso, trone resoluto, confiante nos trovões do alto, a vibrar nas mãos ígneo dardo; isso não lhe bastará para que não caia desonrosamente a insuportável queda. Tal adversário ele agora mesmo prepara contra si mesmo, incombatível prodígio, que descobrirá um fogo superior ao raio, e um potente troar triunfante do trovão, e dissipará a terremoteira moléstia marinha, tridente lança de Posídon. Ao colidir contra esse mal, aprenderá quanto diferem ser rei e ser escravo.

(Pr. 908-27)

Prometeu detém-se mais longamente a discorrer sobre o terrível poder do filho que será gerado por Zeus em tão funestas e indeclaráveis núpcias. Ele é descrito pelo

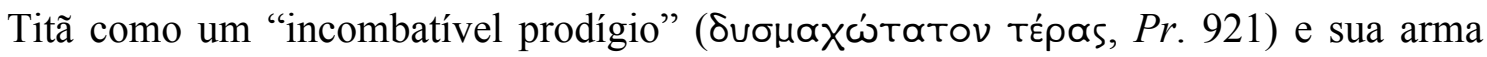
superará raios e trovões de Zeus, bem como o tridente de Posídon ${ }^{12}$. Ao enfatizar o poder do futuro adversário de Zeus, Prometeu engrandece a ameaça que espreita o porvir do rei dos deuses.

Um elemento importante é acrescido por Prometeu às suas predições a respeito da queda de Zeus: a maldição lançada sobre o deus por seu pai Crono. À queda de Zeus do poder corresponderia o cumprimento da maldição (ápó, Pr. 910) de Crono,

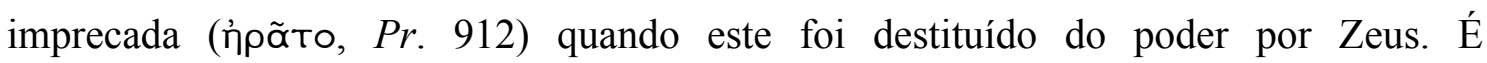
interessante observar que, na Teogonia, é Céu que, tendo sido castrado por Crono, amaldiçoa seus filhos:

\footnotetext{
${ }^{12}$ Essa referência a Posídon e seu tridente poderia sinalizar que, assim como na Ístmica VIII de Píndaro, a funesta esposa, cujo nome Prometeu obstina-se em não revelar, é Tétis.
} 


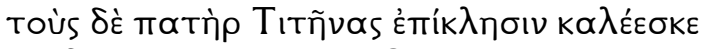

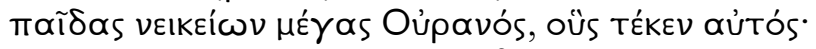

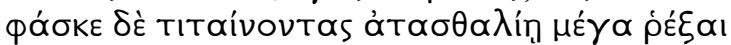

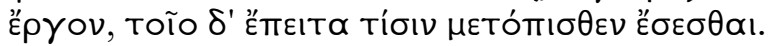

O pai com o apelido de Titãs apelidou-os:

o grande Céu vituperando filhos que gerou

dizia terem feito, na altiva estultícia,

grã obra de que castigo teriam no porvir. (Th. 207-10)

Embora, nessa passagem, Hesíodo não utilize o termo "maldição", o poeta conta que, quando Reia estava para parir Zeus, ela pediu a seus pais, Terra e Céu, que tramassem um ardil, de modo que ela pudesse parir oculta e, assim, Crono "fosse

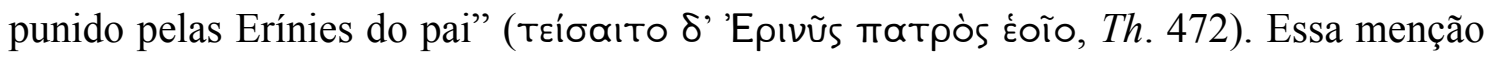

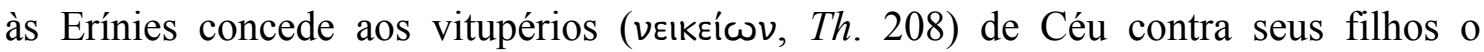
estatuto de uma maldição.

A referência que Prometeu faz à existência de uma maldição paterna que impende sobre Zeus possui uma dupla finalidade: ao mesmo tempo que reforça a inevitabilidade da ameaça à soberania que Zeus há de sofrer, torna o conhecimento divinatório do Titã ainda mais importante e necessário, pois, como ele afirma, "nenhum

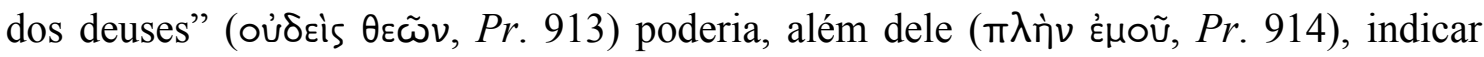
claramente a Zeus como evitar que um filho o destronasse e fosse, assim, cumprida a maldição de seu pai Crono.

O Coro vê nessas palavras de Prometeu uma manifestação, em forma imprecatória, daquilo que o Titã deseja que aconteça, mas ele logo esclarece que, ainda que seja o que deseja, será também o que acontecerá: "Além do que desejo, digo o que

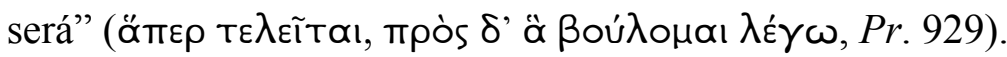

Apesar de todas as evidências de seu saber divinatório oferecidas por Prometeu ao longo do drama, o Coro reluta em acreditar que seja possível Zeus ser destronado: "E

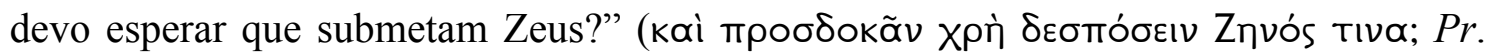
930). Afinal, para o Coro de Oceaninas, o que poderia caber a Zeus "além de poder

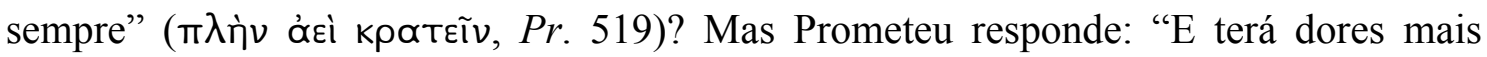

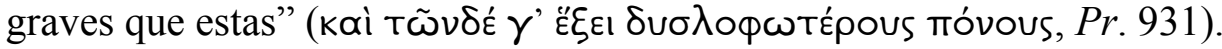

O Coro aconselha Prometeu a moderar suas palavras, pois males ainda maiores poderiam lhe afligir, e a ter prudência, mas Prometeu afirma não temer Zeus e conhecer

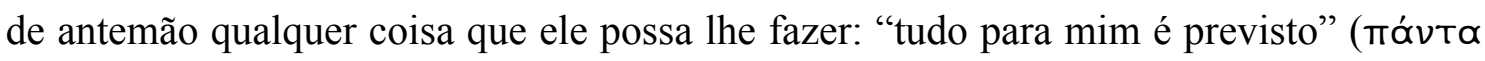




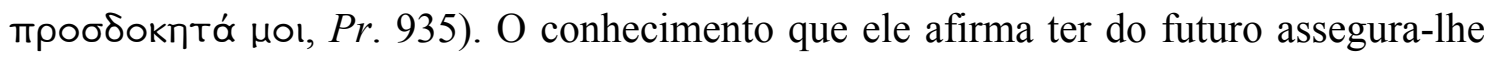
um poder capaz de dissipar quaisquer temores.

Hermes entra em cena, no êxodo, na qualidade de "fiel mensageiro de Zeus pai"

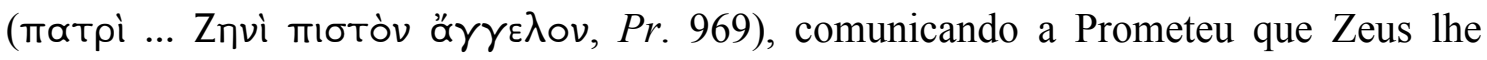
ordena a revelar, sem enigmas, quais seriam essas núpcias de que fala e por quem seria destronado:

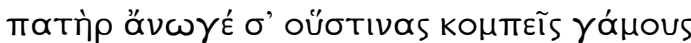

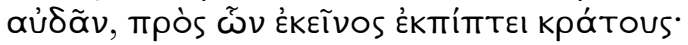

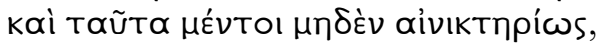

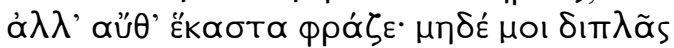

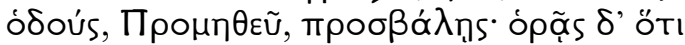
Zeùs Toĩs toloútols oúxi $\mu \alpha \lambda \theta \alpha k i \zeta \varepsilon T \alpha$ เ. o Pai te exorta a dizer que núpcias anuncias, por que ele cai do poder; e nada disso, todavia, por enigmas, mas diz cada item, e não dupliques meus percursos, Prometeu; vês que Zeus assim não se deixa abrandar.

Prometeu, contudo, mostra-se resoluto a não revelar absolutamente nada, fiando-se na convicção de que a tirania de Zeus será breve, pois, assim como ele já viu caírem do poder dois outros tiranos - isto é, Céu e Crono -, também verá Zeus ser destituído de sua realeza. Ele, assim, não teme a cólera de Zeus:

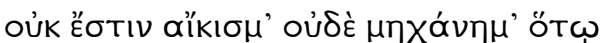

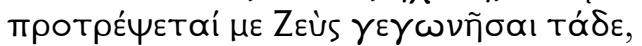

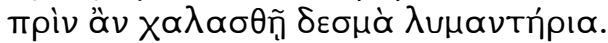

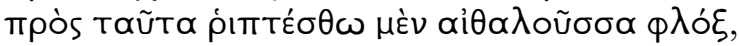

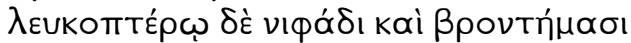

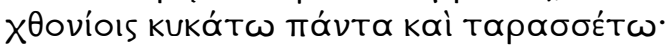

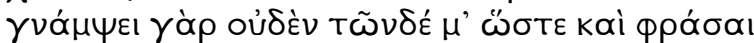

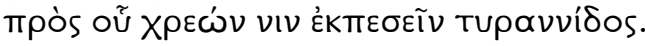

\begin{abstract}
Não há tortura nem ardil, pelo qual Zeus me persuadirá a anunciar isso, antes que relaxe as ultrajantes cadeias. Quanto a isso, lance flamejante fogo, e com neve alva e alada e com trovões subterrâneos, revolva tudo e perturbe; pois nada disso me curvará tanto que diga por que ele deve cair da tirania.
\end{abstract}

(Pr. 989-96)

Prometeu antevê o novo castigo que em breve irá sofrer, mas, ainda assim, obstina-se em manter oculto o saber de que Zeus, de seu ponto de vista, necessita para prosseguir no poder. Essa obstinação de quem não sucumbe à persuasão, à sábia prudência e às ameaças é vista por Hermes como delírio "de não leve doença" (oủ

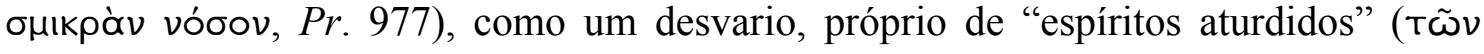

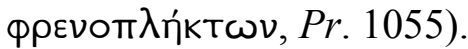

Hermes esclarece as consequências da obstinação de Prometeu: 


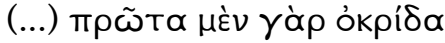

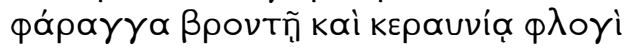

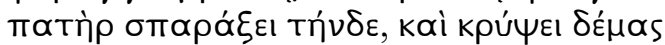

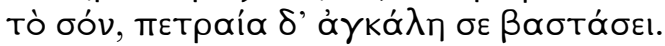

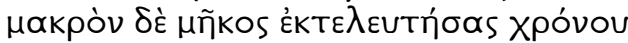

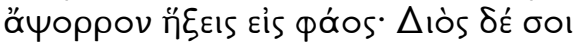

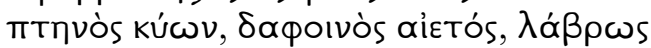

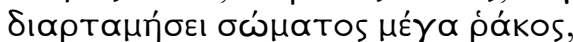

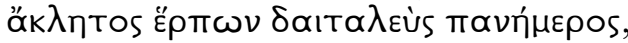

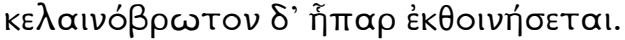

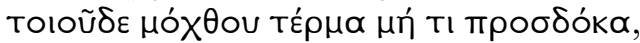

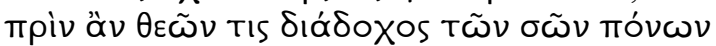

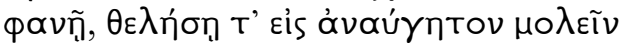

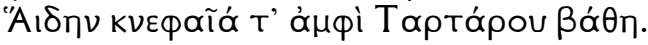

(...) Primeiro o pai

partirá este áspero precipício, com trovão e fulminante raio, e cobrirá teu corpo, e pétreo abraço te pesará. Cumprida longa longura de tempo, voltarás à luz, e o cão alado de Zeus, sangrenta águia, retalhará, voraz, grande lasca do teu corpo, ao vir não convidado conviva do dia todo, e fará banquete do negro roído fígado. Não esperes o termo de tal provação antes que surja um Deus herdeiro de tuas dores e queira ir ao infúlgido Hades, nos trevosos fundos do Tártaro.

(Pr. 1016-29)

Finaliza a descrição da punição de Prometeu por não revelar a Zeus seu segredo um irônico comentário de Hermes sobre o fim dos tormentos do Titã. Seus males só teriam fim se um deus desejasse tomar o seu lugar. Apesar da ironia, o comentário de

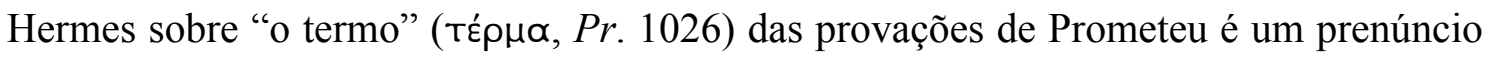
da futura vinda de Héracles e de sua futura libertação.

O castigo e a libertação de Prometeu, às mãos de Héracles, são descritos na Teogonia. Também nesse poema hesíodico Prometeu é acorrentado e uma águia vem lhe comer o fígado todos os dias, até que Héracles mata-a, defendendo o Titã e libertando-o dos tormentos (Th. 521-8), "não discordando Zeus Olímpio o sublime

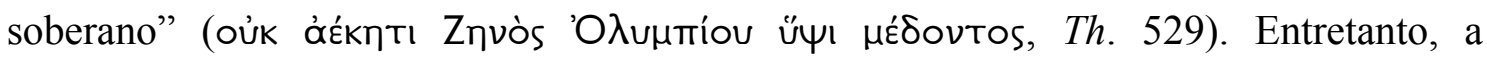
libertação e o fim dos males de Prometeu por Héracles não têm como causa, em Hesíodo, a revelação por parte do Titã de seu conhecimento sobre o futuro da soberania de Zeus e sim o desejo do deus de que "de Héracles Tebano fosse a glória / maior que

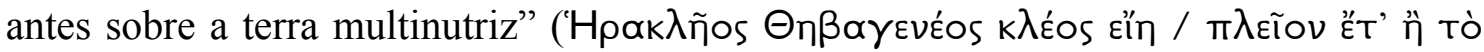

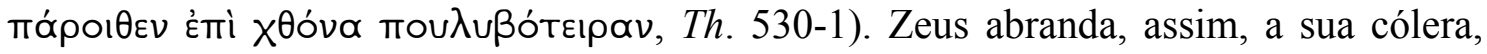
com o intuito de glorificar seu filho e não por querer saber de Prometeu quem seria a esposa com quem geraria um filho funesto à sua realeza: "Reverente ele honrou ao insigne filho / apesar da cólera pôs fim ao rancor que retinha / de quem desafiou os

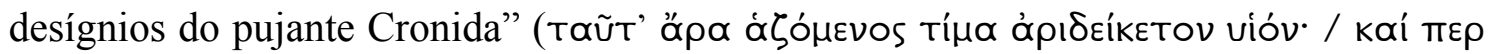

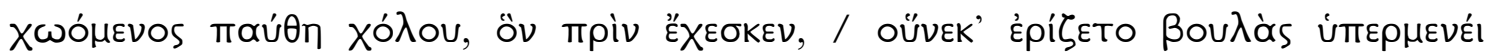
Kpovíwvi, Th. 532-4).

$\mathrm{Na}$ fala final de Prometeu, em que descreve o tremor da terra, os raios e trovões, a fúria dos ventos e do mar, mostra-se, assim, iniciada a realização das ameaças de 
Zeus, pois, como Hermes observou: "A boca de Zeus não sabe mentir, / mas cumpre

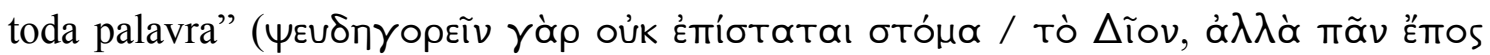
тє $\lambda \varepsilon \tilde{\imath}, \operatorname{Pr} .1032-3)$.

O Coro, embora considere apropriadas as palavras de Hermes e aconselhe Prometeu a procurar ter prudência e ainda que se mostre incrédulo quanto ao prenúncio de Prometeu de que Zeus irá ser destronado, não abandona o Titã, precipitando-se, juntamente com ele, no Tártaro, pois isso é o que cabe às Oceaninas, ententidas como uma manifestação da deusa Estige: precipitar-se de íngreme pedra alta (Th. 786-7).

\section{2) Os sonhos e o destino de Io}

Io, a única personagem mortal desta tragédia, entra em cena no terceiro episódio. Ela chega atordoada, sem saber onde se encontra, e pede: "Indica-me / em que terra

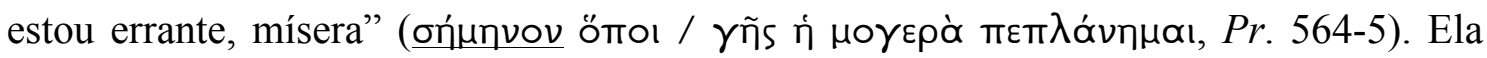
chega, como em breve se esclarecerá, cumprindo o oráculo apolíneo: errando solta "até

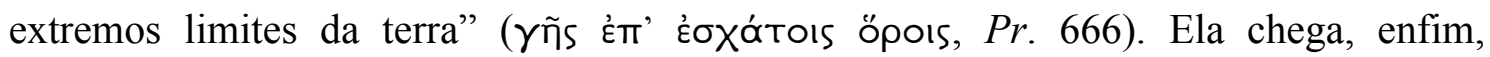
assombrada pela visão do espectro de Argo: "o boiadeiro de mil olhos / andarilho com

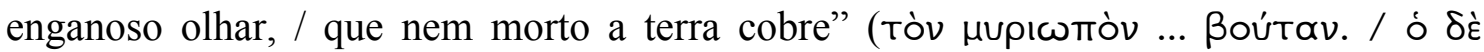

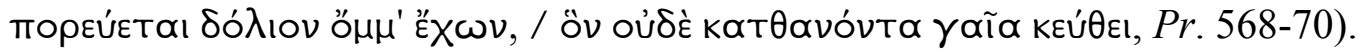

Mesmo tendo sido morto por Hermes, após tê-lo feito adormecer com o som de sua flauta, o espectro do apavorante boiadeiro de mil olhos, vindo dos ínferos, persegue-

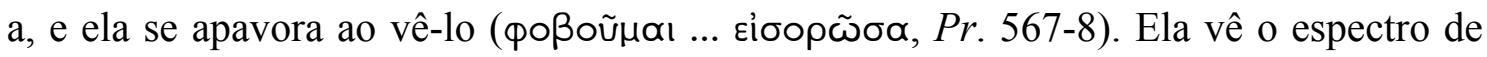
Argo a lhe perseguir, assim como Orestes, ao final das Coéforas, vê as Erínies a lhe perseguir, e sua visão é igualmente apavorante e atordoadora.

Invocando Zeus, Io indaga-lhe que erro cometeu para por tais dores ser subjugada e suplica-lhe para que lhe dê a morte, pois suas errâncias fatigaram-na demais e não vê como escapar de seus sofrimentos.

Prometeu reconhece nessa atormentada criatura a filha de Ínaco que, inflamando de amor o coração de Zeus e incorrendo, assim, na cólera de Hera, em longas correrias à força se fadiga. Admirada com o fato de Prometeu demonstrar conhecer a ela e ao mal que a aflige, pergunta-lhe quem ele é e, lamentando sua sorte, pede-lhe que diga o que resta ainda a ela padecer e se há algum remédio para seus males. 
Prometeu, então, apresenta-se como o doador do fogo aos mortais, razão pela qual diz encontrar-se assim punido por Zeus e agrilhoado pelas mãos de Hefesto. Quanto ao pedido de Io de que lhe revele quando acabarão suas errâncias, Prometeu mostra-se relutante, mas, persuadido pela jovem, decide enfim predizer-lhe o futuro. Nesse momento, contudo, as Oceaninas intervêm, solicitando a Io que narre suas provações, no que são secundadas por Prometeu, que demanda à jovem conceder esse favor às irmãs de seu pai - Ínaco, pai de Io, é filho de Oceano e Tétis e, portanto, irmão das Oceaninas.

O discurso de Io inicia-se com o relato das visões noturnas que visitavam incessantemente seus aposentos virginais e, com palavras doces, exortavam-na a unir-se a Zeus:

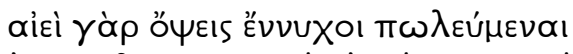

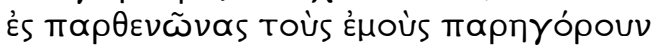

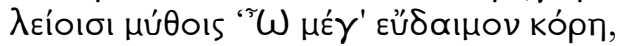

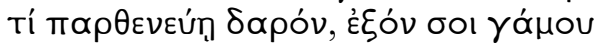

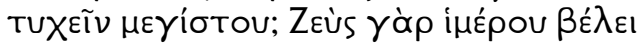

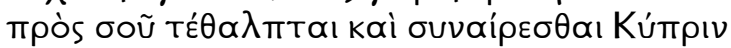

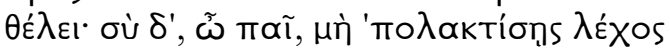

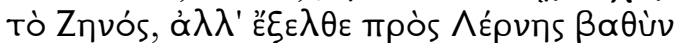

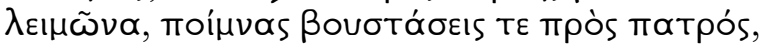

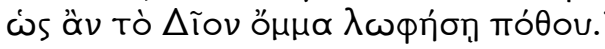

Sempre visões noturnas, a visitarem minha virgindade, aconselhavam-me com lisas palavras: "Ó moça de bom Nume, por que alongas a virgindade, se podes ter núpcias máximas? No dardo do desejo Zeus arde por ti, e quer partilhar Cípris contigo. Ó filha, não rejeites o leito de Zeus, mas vá ao profundo prado de Lerna, às tropas e estábulos do pai, para a visão de Zeus aliviar o desejo."

(Pr. 645-54)

Essas visões noturnas (őభยıs ĚvvบXol, Pr. 645) descritas por Io possuem características próprias dos sonhos epifânicos, ou homéricos, e ao mesmo tempo

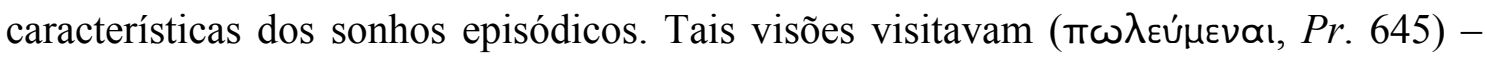

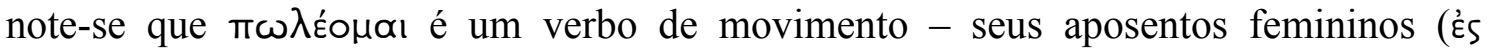

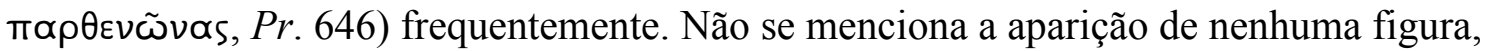

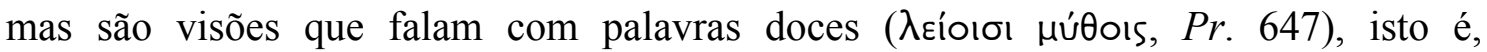
persuasivas, incitando-a a abandonar a prolongada virgindade numa união com Zeus.

Tais palavras, porém, contêm indícios que prenunciam a transformação de Io em novilha. Como observa Moreau (1985, p. 66), em "não rejeites o leito de Zeus" ( $\mu$ ทे

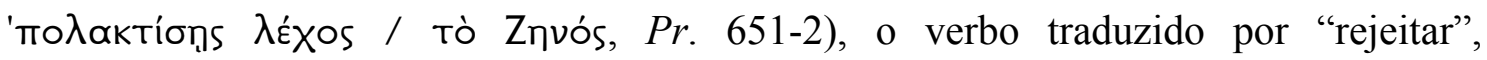

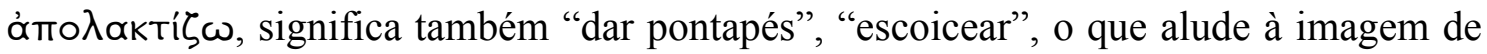
um animal rebelde. Do mesmo modo, a fala onírica lhe impele a ir "ao profundo prado

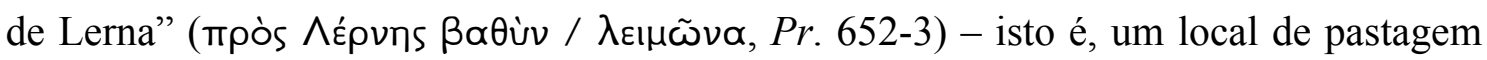




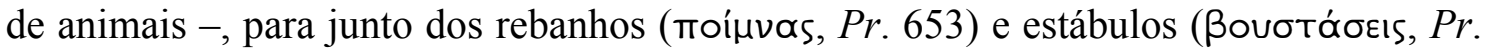
653) de seu pai. Trata-se assim de um sonho que se manifesta sob a forma de uma fala onírica que exorta e ao mesmo tempo profetiza através de imagens.

Note-se que não se trata de um sonho isolado; são sonhos recorrentes. Eles a

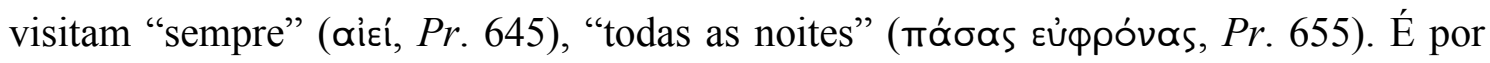
causa da recorrência de tais sonhos que Io decide revelá-los a seu pai:

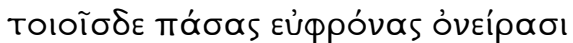

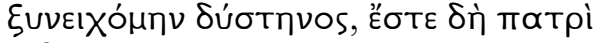

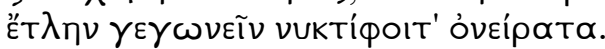

De sonhos assim, todas as noites, eu era presa infeliz, até que ao pai ousei revelar os noctívagos sonhos.

O ato de revelar seus sonhos ao pai é descrito por Io como uma ousadia (ह́т $\lambda \eta \nu$,

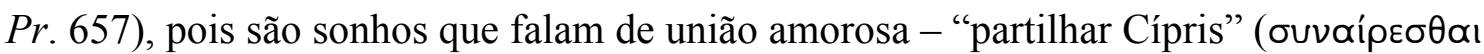

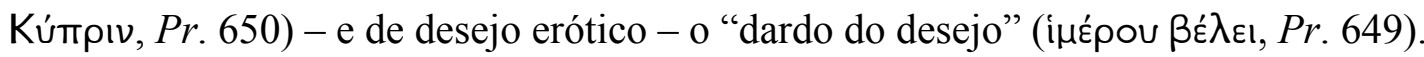

Como lidar com esses sonhos de sua filha? Qual o seu significado? Como apreender o sentido desses sinais divinos? Para descobrir isso, Ínaco recorre a oráculos:

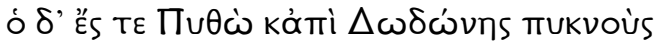

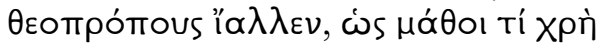

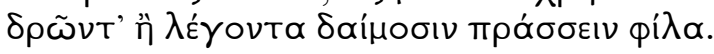

Ele fazia frequentes consultas a Deus em Delfos e Dodona, para saber o que devia fazer ou dizer grato aos Numes.

(Pr. 658-60)

Ínaco envia mensageiros ( $\theta \varepsilon$ єтро́тоочs, $\operatorname{Pr}$. 659) com a missão de consultar os oráculos de Apolo em Delfos e o de Zeus em Dodona e trazerem uma resposta. Compreender, porém, os oráculos dos deuses não é uma tarefa simples, como as palavras de Io evidenciam: "Voltavam mensageiros de variegados / oráculos obscuros e

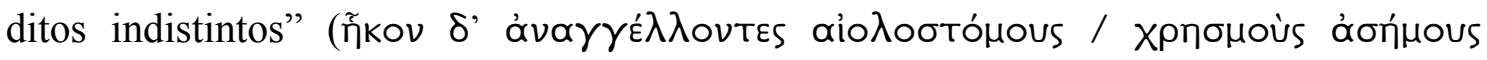

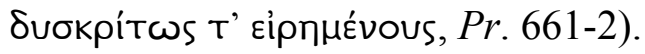

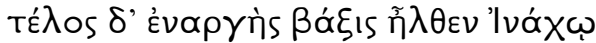

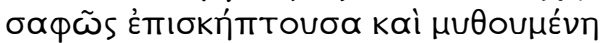

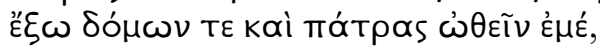

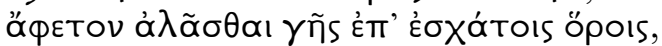

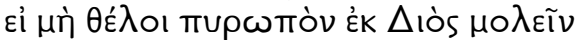

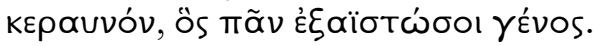

Por fim, nítida voz veio a Ínaco a incumbir e a dizer claramente que me expulsasse de casa e da pátria, solta a errar até extremos limites da terra, e se não anuísse, de Zeus viria o raio ígneo, que destruiria toda a família.

(Pr. 663-8) 
Em meio às respostas oraculares ininteligíveis (ơońnous, Pr. 662) e difíceis de

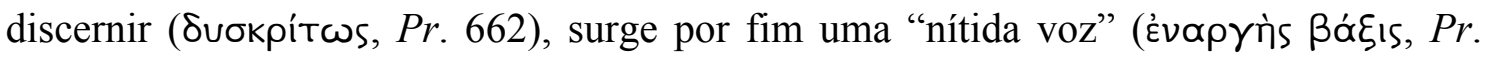

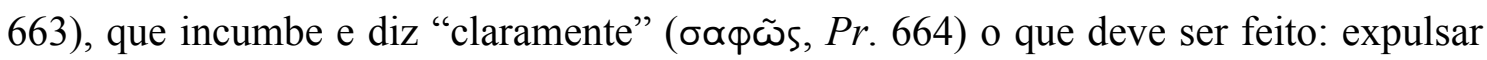

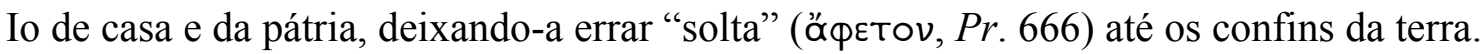
Note-se que o adjetivo traduzido por "solta", äфєtos, é o adjetivo empregado para designar o animal consagrado que se deixa pastar solto, o que constitui mais um prenúncio de sua transformação em forma bovina. Da mesma forma, a menção aos

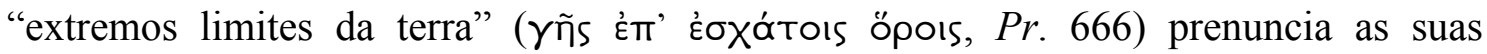
errâncias e provavelmente sua chegada ao Egito.

Da mesma forma que o oráculo de Apolo a Orestes nas Coéforas constitui-se de um comando cuja desobediência traz graves consequências, também este oráculo prevê graves consequências caso Ínaco não o obedeça: se não anuísse, o raio de Zeus destruiria toda a sua família ${ }^{13}$. Assim, Ínaco:

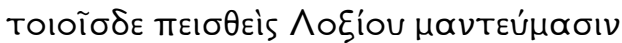

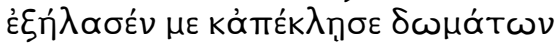

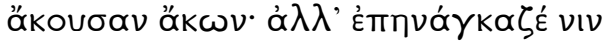

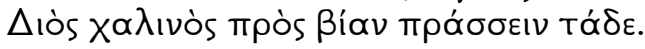

Persuadido de tais oráculos de Lóxias, expulsou-me e interditou o palácio, contra si e contra mim, mas obrigava-o o freio de Zeus por força a fazer isso.

Entre o amor pela filha e a obediência ao deus, Ínaco decide cumprir o que lhe fora ordenado por Apolo. Seu dilema, de certa forma semelhante ao de Agamêmnon, resume-se, na fala de Io, à menção de que tanto o pai expulsou-a a contragosto quanto

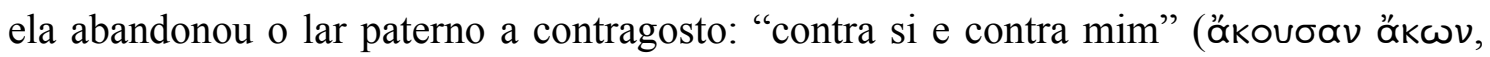
Pr. 671). Ínaco assim o faz, porque o compele o "freio de Zeus" ( $\Delta$ iòs $\chi \propto \alpha$ ıvòs, $P r$. 672), assim como a Agamêmnon compelia o "jugo da coerção" (áváł Ag. 218).

Ínaco, portanto, mesmo a contragosto, obedece as palavras oraculares e expulsa a filha de casa. Uma vez expulsa do lar paterno, a forma e o espírito de Io transmutaram: com cornos e picada por aguilhão, em louca dança dirigiu-se para a fonte de Lerna em Cercneia. A espreitar-lhe os passos e a segui-los, perseguia-a o boieiro Argo, de inúmeros olhos, cuja morte súbita não eximiu Io de, "sob açoite divino"

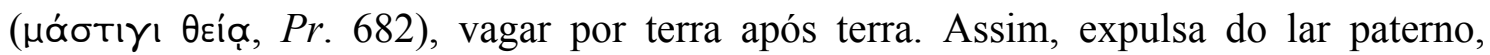
inicia-se a realização de seus sonhos e do oráculo de Apolo.

\footnotetext{
13 Saïd (1985, pp. 195-201) chama a atenção para uma certa semelhança no destino de Orestes e de Io: ambos são exilados e ambos erram pela terra perseguidos por divindades.
} 
O relato dos tormentos até então padecidos por Io faz gelar a alma das Oceaninas, que estremecem de pavor ante a situação da jovem mortal, mas são advertidas por Prometeu de que choram cedo demais, pois muitos outros males aguardam Io no porvir: "Choras cedo e estás cheia de pavor. / Espera até que saibas o

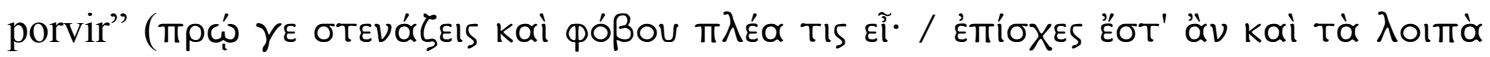

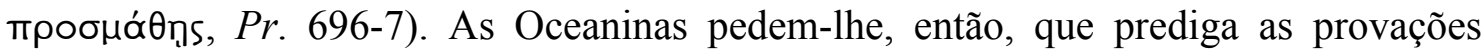
pelas quais a jovem ainda há de passar. Prometeu aquiesce e passa a prenunciar as errâncias e os sofrimentos que, por causa de Hera, Io padecerá: "Ouvi agora o porvir"

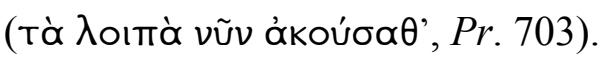

Prometeu descreve os locais pelos quais Io passará e os povos que encontrará em suas errâncias pela Europa: os citas nômades e os cálibes ferreiros, ambos hostis aos hóspedes; o rio Soberbo, de difícil travessia; as Amazonas, que no futuro fundarão a cidade de Temíscera, o istmo Cimério e o estreito Meótico, cuja travessia será lembrada pelos mortais, que, em sua memória, passarão a chamá-lo de estreito de Bósforo. Nesse momento, Prometeu interrompe suas predições, advertindo Io de que as errâncias que lhe descreveu não são mais do que um proêmio dos sofrimentos a que Zeus, desejoso da união amorosa, fez cair sobre ela.

Prometeu revela, no entanto, que um dia será libertado e que será por um dos descendentes de Io, pertencente à $13^{\mathrm{a}}$ geração. Io, no entanto, não consegue compreender as palavras pressagas do deus, dizendo: "Este oráculo ainda não é

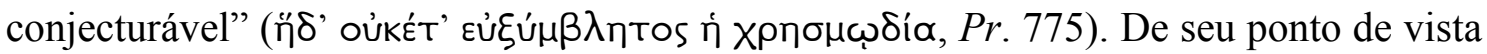
mortal e, por isso mesmo limitado, os prenúncios de Prometeu são percebidos por Io

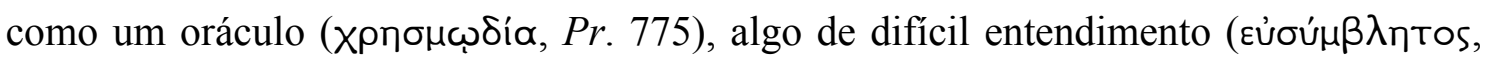
$\operatorname{Pr} .775)^{14}$.

Prometeu oferece, então, a Io que escolha entre conhecer o restante de seus males ou saber quem irá libertá-lo: "Dou, escolhe: digo claro teus males / vindouros, ou

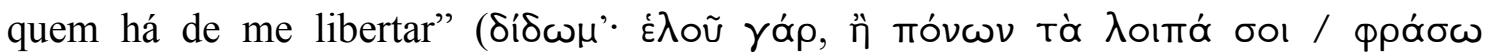

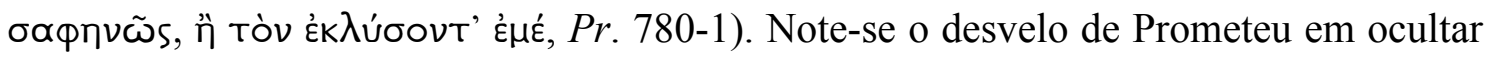
seu conhecimento divinatório: ele não irá revelar tudo, apenas uma coisa ou outra. As

\footnotetext{
${ }^{14}$ Como observa Herington (1973/4, p. 651), "Io naturally finds his 'oracle' about Heracles hard to fathom (775), as the future always is for mortals. But in calling attention to their limited comprehension, the play underscores the operation of higher powers. The destinies of lo and Heracles do not intersect accidentally. Both begin their march to glory at Lerna; both labour long and far from home in the service of Zeus; and both are guided to their final destinations by Prometheus".
} 
Oceaninas, contudo, intervêm e pedem ao deus que anuncie à jovem as futuras errâncias e a elas quem será seu libertador.

Prometeu aquiesce em revelar "tudo" ( $\pi \tilde{\alpha} \nu, \operatorname{Pr}$. 787) o que the foi demandado e inicia prenunciando as errâncias de Io na Ásia, do Bósforo ao Nilo, passando pela planície de Cistene, onde habitam as três velhas Fórcidas e, nas proximidades, as três Górgonas; pelas margens do rio Plutão, onde habitam os grifos e os cavaleiros arimaspos, que devem ser evitados; pela nação negra, que habita junto à fonte do Sol e do rio Etíope; pela catarata do rio Nilo nos montes Papiros; até o delta do Nilo, onde Io e seus filhos fundarão uma duradoura colônia.

Antes, porém, de anunciar o fím dos tormentos de Io, Prometeu dá como garantia da assertividade de suas predições o relato do que lhe sucedeu antes de que chegasse aonde agora se encontra, demonstrando, dessa forma, que seu conhecimento divinatório estende-se não apenas a seu porvir, mas também ao seu passado recente. Assim, ele narra como Io, chegando à planície molóssia, foi saudada, "claramente e sem

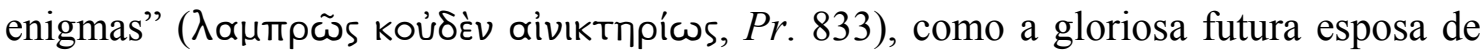

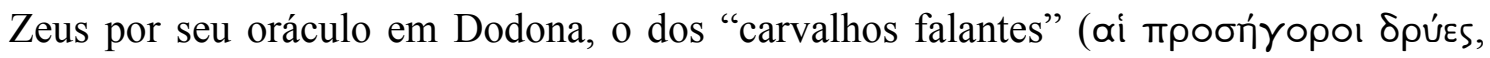
Pr. 832). De Dodona, Io seguiu para o golfo de Reia, que, futuramente será denominado Iônio, em memória à sua passagem.

Essa menção ao oráculo de Dodona é única na tragédia esquiliana, em que impera o oráculo de Apolo em Delfos ${ }^{15}$. De acordo com Bouché-Leclerq (2003, pp. 463-99), considerado o mais antigo dos oráculos, o oráculo de Zeus em Dodona ${ }^{16}$, no Épiro, situava-se aos pés do monte Tmaros, num vale úmido e fértil, constantemente sacudido pelos ventos e estremecido pelos raios de Zeus. Inserido nesse cenário, encontrava-se um ou mais carvalhos, em cujo murmúrio das folhas, balançando ao sabor do vento, ouvia-se a voz do deus. Uma fonte de água corria aos pés da árvore consagrada a Zeus e é possível que trípodes de bronze a tenham circundado.

O mais antigo testemunho da existência do oráculo de Dodona encontra-se em Homero. Na Ilíada, Aquiles, temendo por Pátroclo, roga a "Zeus, rei Dodôneo, Pelasgo,

\footnotetext{
${ }^{15}$ Castrucci, em seu artigo "Dodona versus Delphi in Greek Tragedy: The Wanderings of the Hero between Expiation and Ties of $\Gamma E N O \Sigma$ ", de 2012, faz uma interessante distinção entre os oráculos de Delfos e de Dodona na tragédia grega, assim resumida pela autora: "Dodona is the ancient oracle connected to the oĩkos and family ties, whose role is important as regards the end of the hero's journey, his final destination, while Delphi is the oracle of expiation, offering the motive and aim of the wandering, hence playing an essential role at the beginning of oracular travel” (p. 1).

${ }^{16}$ Zeus possuía, ainda, dois outros importantes oráculos: o de Olímpia e o de Zeus-Amon na Líbia. Conferir Parke (1967b), The Oracles of Zeus: Dodona, Olympia, Ammon.
} 
que longe de todos demoras, / e tens o império em Dodona gelada, onde os Selos que dormem / no áspero chão e que os pés nunca lavam, te servem de intérpretes!" (Zeũ ơv $\alpha$

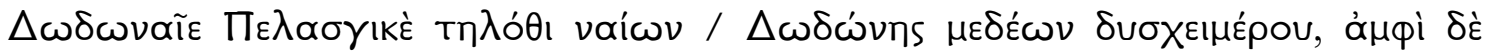

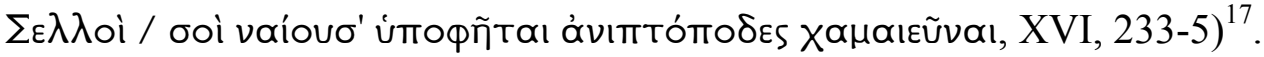

De acordo com esse relato homérico, o corpo sacerdotal ligado ao oráculo era denominado Selloí, termo que designa igualmente os antigos habitantes da região. Porém, Sófocles, nas Traquínias, diz que um oráculo foi dado a Héracles pelo

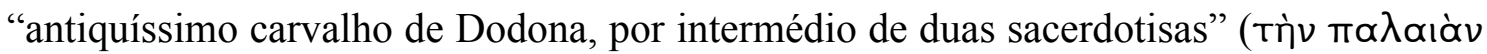

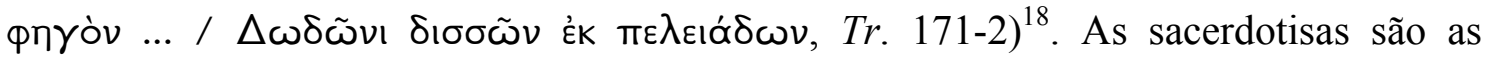
Peleiádes, ou "pombas". São essas sacerdotisas a quem Heródoto faz menção em seu relato sobre o oráculo de Dodona (Hdt. II, 52-7) ${ }^{19}$.

Aparentemente, como especula Bouché-Leclercq, o corpo sacerdotal composto pelos Selloí, mais antigo, desapareceu, sendo substituído pelas Peleiádes, as três pombas de Dodona. É possível, no entanto, que esses dois grupos tenham coexistido, embora não seja possível delimitar as funções que cada um desempenhava.

Também não é possível definir com exatidão o funcionamento o oráculo ${ }^{20}$. Pela tradição, sabe-se que a resposta de Zeus se manifestava pelo ressonar das folhas do carvalho agitadas pelo vento. Os Selloí, ou as Peleiádes, ou ambos, interpretando o murmúrio da folhagem, desvelavam os desígnios do deus aos consulentes. É provável que também o ruído das aves, como as pombas com as quais as sacerdotisas se identificavam, e o murmúrio da fonte que corria aos pés do carvalho tenham feito parte da linguagem profética de Zeus ${ }^{21}$.

As perguntas eram geralmente escritas em placas de chumbo, no reverso das quais se escrevia a resposta obtida. O maior número dessas placas encontradas pelos arqueólogos refere-se a consultas de particulares sobre questões da vida cotidiana, tais como ter prosperidade, conservar a saúde, descobrir se um objeto foi perdido ou roubado, confirmar a paternidade dos filhos, entre outras.

\footnotetext{
${ }^{17}$ Há, na Odisseia, mais duas referências ao oráculo de Dodona. Odisseu, disfarçado, narrando suas falsas aventuras ao porqueiro Eumeu, diz que ouviu falar que "a Dodona viajara Odisseu, para o oráculo / de

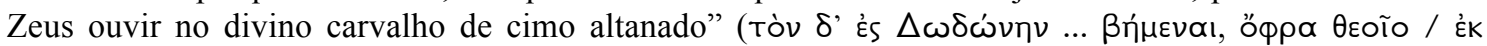

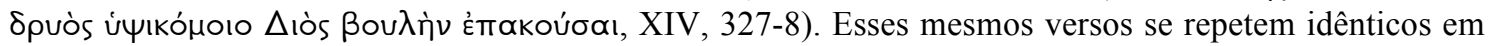
XIX, 296-7.

${ }^{18}$ Tradução de Maria do Céu Zambujo Fialho (1996).

${ }^{19}$ A respeito da identificação das sacerdotisas com "pombas" em Heródoto, conferir o artigo de Cebrián (2002), "El oráculo de Dodona y la lengua de las mujeres".

${ }^{20}$ Conferir Gartziou-Tatti (1990), "L’oracle de Dodone. Mythe et rituel".

${ }^{21}$ Conferir Rachet (1962), "Le Sanctuaire de Dodone, origine et moyens de divination".
} 
Esse conhecimento dos fatos recém-sucedidos a Io, Prometeu oferece como sinal de seu saber divinatório e, assim respaldado, prenuncia à jovem mortal como, em

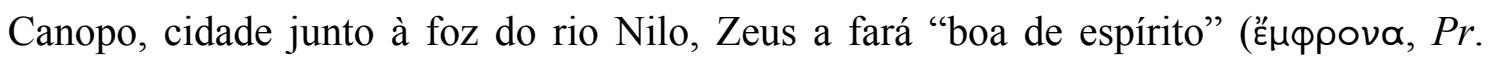
848) com o toque de sua mão, gesto que será celebrado no nome de seu filho, Épafo. Prometeu prediz ainda que, após cinco gerações, as cinquenta Danaides, fugindo de seus primos desejosos de desposá-las, dirigir-se-ão até Argos. Lá, forçadas ao indesejado matrimônio, assassinarão seus maridos na noite de núpcias. Somente uma delas, seduzida pelo desejo de ter filhos, poupará seu marido, dando à luz a prole real de Argos, da qual surgirá o glorioso arqueiro que o libertará de seus grilhões e de seus tormentos. Prometeu conclui suas predições assegurando uma vez mais a sua legitimidade ao atribuir tal oráculo à sua mãe, a prístina deusa Têmis: “A prístina mãe /

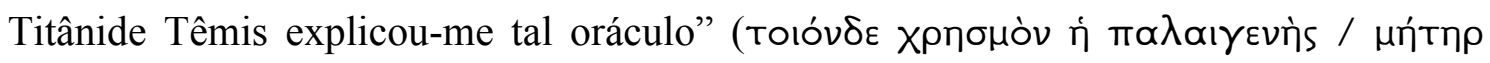

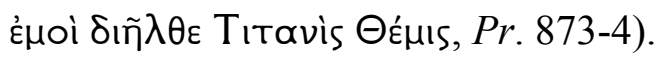

Nesse momento, Io volta a ser atormentada pela picada do aguilhão e descreve seu padecimento sob a forma de convulsão, delírios, atordoamento, pavor, desordem do pensamento e da fala. E, em desvario, parte para cumprir seu destino de errâncias. No entanto, Io agora sabe que, após muitos sofrimentos, encontrará sua libertação, assim como Prometeu sabe que também ele, após muitos sofrimentos, encontrará a sua. Vinculados pelos padecimentos a que ambos dizem estar sujeitos por obra de Zeus, encontram-se igualmente vinculados em sua libertação, pois, findas as suas errâncias, Io dará início a uma linhagem em meio a qual nascerá o libertador de Prometeu.

Portanto, na predição da libertação de Io, prenuncia-se igual e inequivocamente a libertação de Prometeu. Na predição do fim dos tormentos de Io pelo toque de Zeus, deixa-se entrever, também, a face benéfica desse deus a quem vem sendo atribuída uma crueldade tirânica. Como observa White (2001, p. 107): "Prophecy, allusion and foreshadowing thus reveal the Zeus of this play to be not the harsh and destructive despot imagined by most today, but the benevolent source and ultimate arbiter of justice for both gods and humanity". 


\section{3) Adivinhação e os dons de Prometeu}

No segundo episódio (Pr. 463-525), Prometeu enumera ao Coro as diversas dádivas com que beneficiou os mortais: a lucidez de raciocínio, a carpintaria, o conhecimento dos ascensos e ocasos dos astros, a matemática e a escrita, a domesticação de animais, a construção de naus, a descoberta de bronze, ferro, prata e ouro, bem como o conhecimento medicinal e divinatório.

Quanto à arte divinatória, Prometeu detém-se a descrevê-la mais longamente, como se pode ler nos seguintes versos:

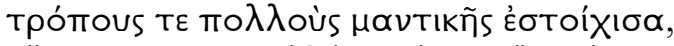

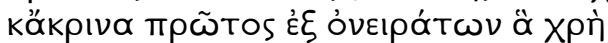

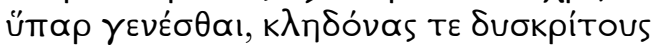

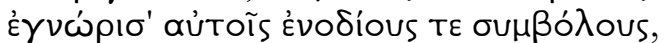

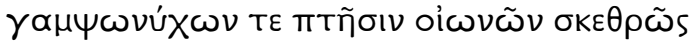

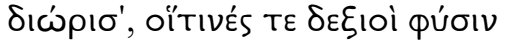

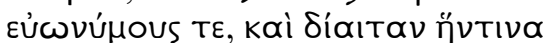

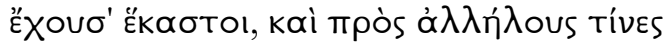
ÉX

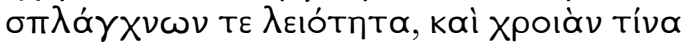

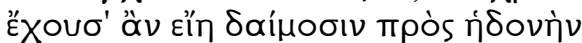

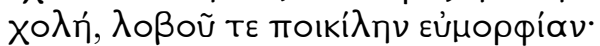

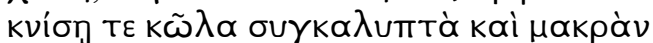

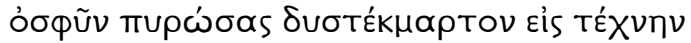

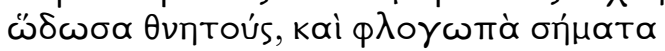

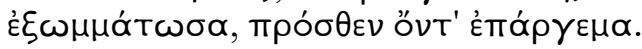

Distingui muitos modos de adivinhação, e primeiro discerni dentre os sonhos quais se verificam, e dei a conhecer presságios difíceis e sinais itinerários. $\mathrm{O}$ voo dos pássaros de curvas garras defini exato: os destros por natureza e os de bom nome, quais seus hábitos, ódios, amores e assentos comuns; a lisura das vísceras, e com que cor a vesícula seria por prazer de Numes, e a variável formosura do fígado; a queimar coxas cobertas de gordura e largo lombo por arte de difíceis signos guiei os mortais, e tornei visíveis flamejantes signos, antes obscuros.

(Pr. 484-499)

Primeiramente, é digno de nota que a descrição dos modos de adivinhação que compõem a arte divinatória é bastante mais extensa que a descrição de todas as outras artes legadas por Prometeu à humanidade. Ora, ironicamente, todos os dons concedidos pelo deus aos homens lhe são inúteis na presente situação - como observa o Coro, "não

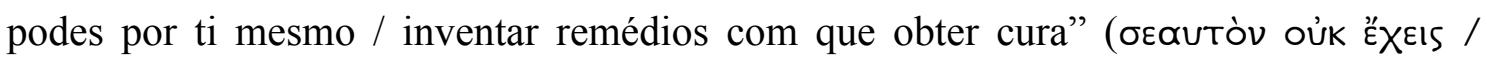

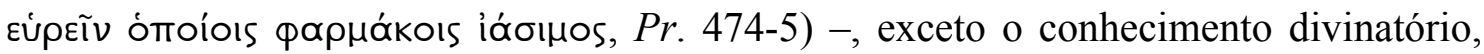
pois este lhe permite ter uma informação da qual, de seu ponto de vista, depende a continuidade de Zeus no poder e é somente pelo fato de dispor dessa informação que, como crê Prometeu, será enfim libertado depois de muito sofrimento

Distinguem-se, em sua fala, diferentes formas de adivinhação, compondo-se, assim, uma espécie de pequeno panorama das práticas divinatórias mais comuns à cultura grega clássica do século $\mathrm{V}$; a saber: 
a) a oniromancia, que aqui é descrita como a arte de discernir (kökpııa, Pr. 485), dentre os sonhos ( $̇ \xi$ óvelpót $\omega \nu, \operatorname{Pr}$. 485), aqueles que se verificam, isto é, aqueles que se realizam;

b) a cledomancia, que aqui se apresenta como dar a conhecer aos homens aquilo que na tradução de Jaa Torrano aparece como "presságios difíceis" e que literalmente significa "kledónes difíceis de discernir", "difíceis de interpretar", ou "obscuros"

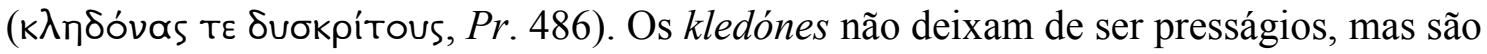
presságios que se manifestam através da linguagem.

c) a cleromancia, que denomina a forma de adivinhação regida pela sorte e que

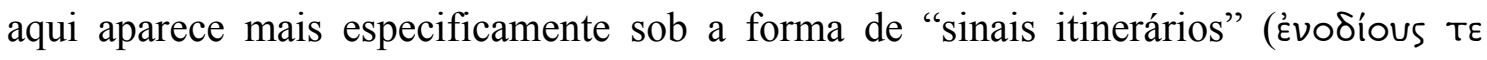

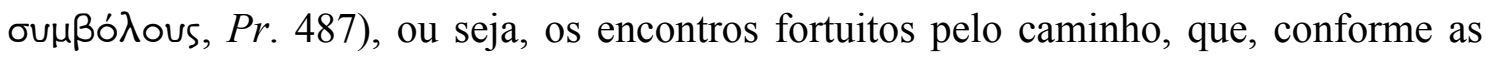
circunstâncias e com o que o indivíduo se depara - uma pessoa, um animal, um acontecimento imprevisto -, constituem um bom ou um mau presságio;

d) a ornitomancia, ou arte augural, que, como pontua Prometeu, baseia-se na observação do voo dos pássaros, em que se discernem as espécies favoráveis por natureza ou desfavoráveis, o local de sua aparição, seus hábitos e o relacionamento entre as diversas espécies;

e) a hieromancia, ou haruspicismo, isto é, a interpretação do aspecto das vísceras das vítimas sacrificiais: a sua textura, a coloração da vesícula, o formato variável do fígado;

f) e, por fim, a piromancia, que é a interpretação de sinais percebidos na contemplação do fogo que consome a vítima no altar sacrificial, a que comumente se agrega a observação da qualidade da combustão ou da direção e do movimento da fumaça que se evola ${ }^{22}$.

Como se pode perceber dessa lista de modos de adivinhação descritos por Prometeu, para os homens acederem a um conhecimento numinoso através de qualquer uma dessas formas de adivinhação é necessário, além de intermediação, um esforço interpretativo, uma hermenêutica dos sinais divinos. O homem é confrontado com sinais numinosos que ele tem de saber distinguir das aparências do mundo e, distinguindo-os, interpretá-los.

Essas diferentes modalidades da adivinhação são descritas como técnicas, como

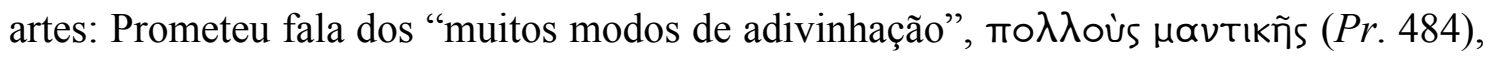

\footnotetext{
${ }^{22}$ A respeito da piromancia, conferir Bouché-Leclercq (2003, pp. 142-3).
} 


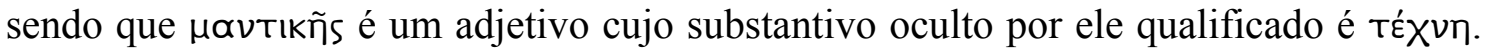
Fazem parte, portanto, das tékhnai com que Prometeu agraciou os homens, civilizandoos; constituem os dons de Prometeu; compõem o arcabouço instrumental de que os homens têm de se valer para suportar o quinhão que lhes coube: as vicissitudes de uma vida efêmera, a precária condição da vida mortal, a incerteza angustiante do futuro e todos os males que definem o que é ser mortal. Entretanto, a esses males, diz-se no mito de Prometeu narrado por Hesíodo; a esses males bens estão misturados (k@ì тoĩoı

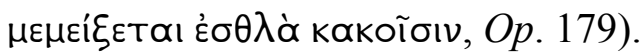

Essa condição humana precária, em que aos males se misturam os bens, ganha forma e voz na figura de Io, única personagem mortal desta tragédia, que, como se viu, entra em cena, no terceiro episódio, atordoada pela picada do aguilhão. Impelida pelo Coro, ela conta a sua história e ouve de Prometeu todos os tormentos pelos quais ainda há de passar para que enfim, após muito sofrimento, encontre sua libertação. Como se pode observar, na predição do fim dos tormentos de Io pelo toque de Zeus, deixa-se entrever, também, a face benéfica do deus: trata-se afinal de bens misturados aos males.

A história de Io, portanto, ilustra esse esforço de entendimento dos sinais numinosos - as frequentes visões noturnas, as diversas consultas aos oráculos realizadas por seu pai - e também como esse conhecimento numinoso - em um segundo momento direta e claramente transmitido por Prometeu -, embora não a isente de todos os sofrimentos contemplados pela fala do deus e embora não a impeça de ser novamente tomada pelo frenesi causado pela picada do aguilhão; ainda assim, esse conhecimento numinoso lhe permite discernir, no horizonte dos acontecimentos, o fim de seus tormentos, a sua libertação através do toque de Zeus, o destino grandioso de sua progênie.

A Io, portanto, eloquente metonímia da condição humana, são dadas as "cegas

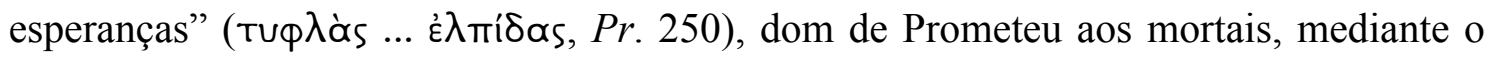
acesso a um conhecimento numinoso cuja inteligibilidade é também um dom do deus

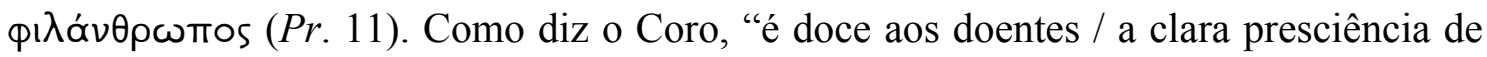

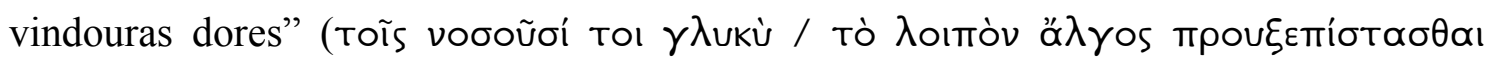

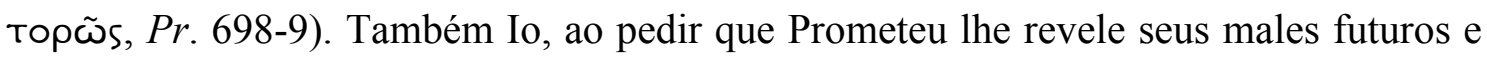
ao perceber a hesitação do deus em revelá-los, diz-lhe: "Não receies por mim, que me é

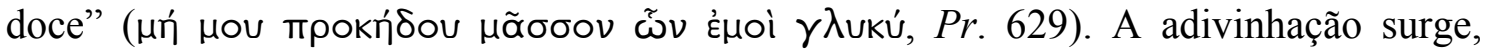
assim, como um alento na vida dos mortais, fadados como estão ao sofrimento diário. 
No que se refere às personagens divinas desta tragédia, o saber divinatório tem um valor indiscutível e, como se viu, constitui um poder, porque, de acordo com Prometeu, desse saber depende o sucesso ou a derrota de Zeus em mais esta ameaça à sua soberania. Prometeu usa esse seu conhecimento do porvir como uma ameaça velada e como uma moeda de troca no jogo de astúcias que, nos poemas hesiódicos, define a relação entre esses dois deuses.

Sendo Prometeu possuidor de conhecimento divinatório, de cuja veracidade o Titã faz questão de dar garantias ao longo da tragédia, uma questão que se impõe com relação a seu saber divino é a possibilidade que ele tem de revelá-lo ou de ocultá-lo, de falar claramente ou de falar de forma enigmática.

Essa possibilidade emerge de modo claríssimo nos primeiros momentos de seu diálogo com Io, no início do terceiro episódio. Ela demanda ao deus que lhe indique de forma clara os sofrimentos que lhe aguardam e qual seria seu término: "Eia! Diz-me

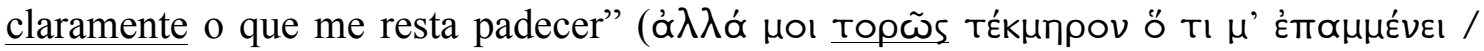

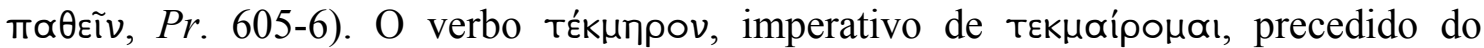

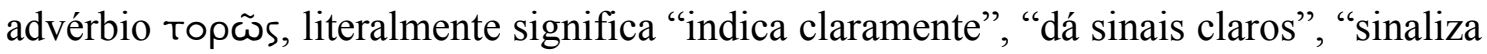
de forma clara". E Prometeu responde: "Direi claramente tudo o que queres saber, / sem urdir enigmas, e com simples palavra / tal como é justo a amigos abrir a boca" ( $\lambda \varepsilon ́ \xi \omega$

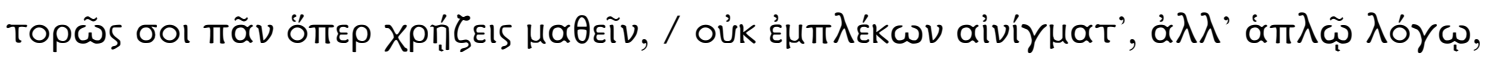

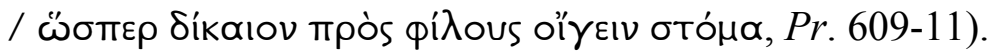

$O$ próprio Titã estabelece essa contraposição entre falar claramente $(\lambda \varepsilon ́ \xi \omega$

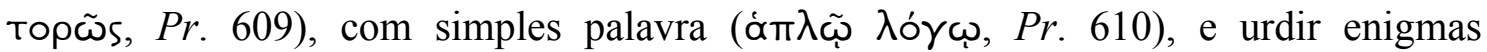

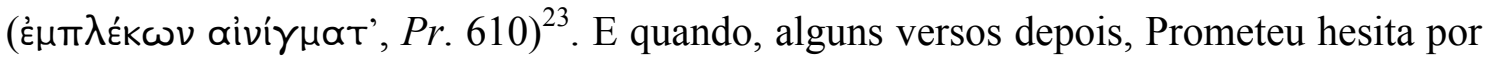
um momento em revelar-lhe o futuro, a jovem exclama: "Não me ocultes o que devo

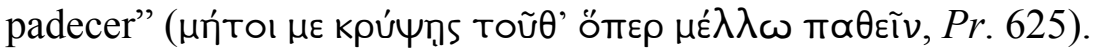

Se a Io e às Oceaninas, como é justo falar a amigos, Prometeu se dirige com palavras claras e sem enigmas, revelando-lhes o futuro; o mesmo não acontece quando se trata do futuro de Zeus, seu antagonista. Até o fim da tragédia Prometeu deixa claro que não irá revelar ao rei dos deuses de qual futuro matrimônio será gerado o usurpador de seu trono. Assim, quando o Coro lhe pergunta a esse respeito, ele responde: "Lembrai outra palavra. Essa nunca / é hora de dizer, mas deve-se ocultar / o mais

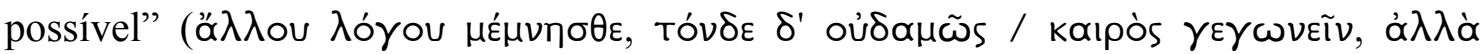

\footnotetext{
${ }^{23}$ Conferir Iriarte (1990), Las redes del enigma.
} 


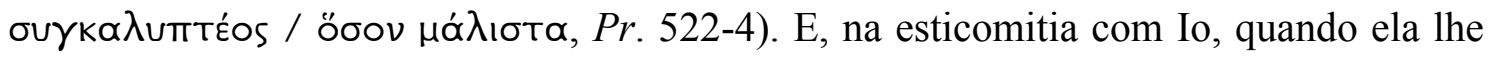
pergunta quais são as núpcias que hão de ser funestas a Zeus, ele responde: "Isto não se

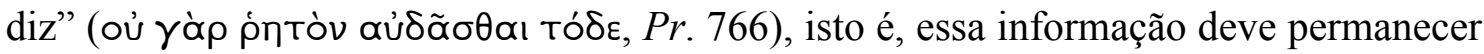
oculta. Hermes, no êxodo, chamando Prometeu de "sofista" (тòv ooфıotŕv, Pr. 944), diz que Zeus exige que ele revele seu saber divinatório sobre as núpcias de forma não

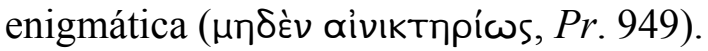

Em contrapartida, o Titã oferece a Io que escolha entre a continuação da predição clara acerca de seus males vindouros ou a revelação de quem será, dentre os descendentes de Io, aquele que o libertará: “Dou, escolhe: digo claro teus males /

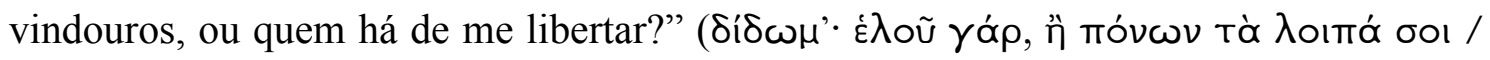

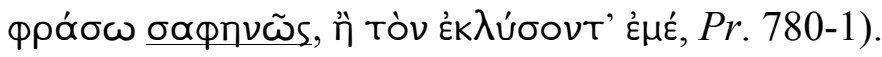

O que se observa, portanto, é que Prometeu se utiliza constantemente dessa dupla possibilidade de revelar ou de ocultar seu saber divinatório e dessas duas faces da palavra numinosa: a claridade e a obscuridade, ora despindo a palavra de toda ambiguidade, ora tornando-a opaca, revestindo-a de enigmas. A palavra, afinal, é tudo que lhe restou: ele está preso por cadeias inextrincáveis, imobilizado, afastado da assembleia dos deuses e destituído de todo poder. 


\section{EPÍlOGo}

$\mathrm{Na}$ análise dos Persas, examinaram-se as variadas formas de sinais divinatórios que figuram ao longo da tragédia - kledónes, imagens poéticas, o sonho da Rainha, o auspício/prodígio que ela avista, os vaticínios do espectro de Dario, a alusão a antigos oráculos. Verificou-se a importância desses sinais divinatórios tanto para a composição dramática da tragédia quanto para a apreensão de seu sentido trágico, isto é, como os sinais divinatórios informam a percepção e a compreensão da derrota de Xerxes e de seu grandioso exército, bem como a vitória grega, e contribuem para uma profunda reflexão sobre a justiça de Zeus e os limites do exercício do poder.

A análise da adivinhação nos Sete contra Tebas, em virtude da própria temática da tragédia, isto é, o destino de Tebas sob a querela dos amaldiçoados filhos de Édipo, concentrou-se na grande importância da palavra enquanto sinal e manifestação de desígnios divinos, seja sob a forma de kledónes, de maldição, de vaticínio ou de enunciação oracular. E, assim, observou-se a relevância da arte divinatória na estrutura deste drama - notadamente na composição do segundo episódio -, as possibilidades de efeitos dramáticos que daí emergem e como são essenciais à problematização dos grandes temas a que esta tragédia convida a refletir: a noção de justiça coletiva, a maldição familiar, os desrespeitos aos limites da condição humana impulsionados pela hýbris guerreira, entre outros.

A análise da arte divinatória nas Suplicantes impôs um desafio, em vista da existência de muitas dúvidas e especulações a respeito de que consistiriam as demais tragédias que compunham a trilogia acerca do mito das Danaides e qual a ordem das Suplicantes dentro dessa trilogia, isto é, que acontecimentos se dariam antes ou depois daqueles narrados nessa tragédia supérstite, de forma que se pudessem responder mais acertadamente a questões tais como: A que apontam os sinais divinos? Que destino prenunciam? Certamente, dúvidas e especulações existem, no que diz respeito às demais tragédias esquilianas (excetuando-se, obviamente, a Oresteia), sobre qual seria a ordem e o conteúdo da trilogia em que se encaixam, como no caso do Prometeu, dos Sete contra Tebas etc. Porém, o que parece agravar ainda mais o caso das Suplicantes é o fato de não haver alusão comprovada a qualquer manifestação divinatória mais direta como, por exemplo, um oráculo, um sonho, o vaticínio de um adivinho, um auspício, tal 
como se encontram nas demais tragédias de Ésquilo; nas Suplicantes, os sinais divinos se circunscrevem à linguagem e à expressão poética. Assim, ao mesmo tempo em se analisou e se interpretou os sinais numinosos nesta tragédia, mostrou-se como a presença (ou a ausência) desses sinais divinatórios são fundamentais para compreender esta tragédia e os temas que ela discute, tais como o poder da súplica, da persuasão e da coerção, a justiça divina.

Quanto à Oresteia, foi preciso considerar o diálogo divinatório tal como este se dá em cada uma das tragédias que compõem a trilogia, bem como a sua relevância para o conjunto da obra. Assim, no Agamêmnon, encontrou-se um abundante material para a investigação da adivinhação em Ésquilo: o auspício das aves, o vaticínio de Calcas, a maldição de Tiestes, o sentimento pressago do Coro, a ambiguidade profética do discurso de Clitemnestra, as profecias de Cassandra etc. A essa abundância de sinais divinatórios neste drama corresponde, como se viu, uma complexa configuração numinosa a presidir os destinos e os desatinos de seus protagonistas, através da qual se pensam temas tão fundamentais como a Justiça, em todos os seus aspectos, o exercício do poder, a sabedoria e a desmedida, a verdade, a linguagem, os limites da condição humana, entre tantos outros.

Especial atenção foi dada ao párodo, em que se descrevem o auspício das aves e os vaticínios de Calcas, visto que os sinais numinosos que aí se manifestam, a interpretação que deles faz o adivinho e as imagens poéticas em que são expressos são de grande relevância não só para o restante dessa tragédia, mas também para toda a trilogia. Dessa forma, o párodo, com sua riquíssima gama de sinais divinatórios e com o exemplar diálogo com o divino que aí se estabelece, emoldura todos os acontecimentos subsequentes, oferecendo os parâmetros necessários para identificar e interpretar todos os demais sinais numinosos, bem como todas as implicações das ações humanas e divinas.

Nas Coéforas, as complexas reflexões sobre os temas fundamentais à trilogia, que já foram postulados na tragédia precedente, ganham novas perspectivas através da manifestação de novos sinais numinosos, principalmente o sonho de Clitemnestra e o comando oracular de Apolo. Viu-se como o deus de Delfos está presente desde o início da tragédia e como seu oráculo é decisivo para o desenvolvimento do drama, ao impulsionar os personagens à ação, e também para a construção do sentido do trágico, seu entendimento e sua problematização. 
Todos os sinais numinosos das tragédias precedentes encontram sua plena realização e todo o seu potencial de sentido no último drama da trilogia. A ação iniciase no centro oracular por excelência da Grécia antiga, o coração pulsante da adivinhação grega: o oráculo de Apolo em Delfos. Ali se encontram as Erínies, que, enquanto uma figuração divina da Maldição ('Apó), são uma ameaça de cumprimento e de realização até os momentos finais da tragédia, quando, persuadidas por Atena, passam a prenunciar

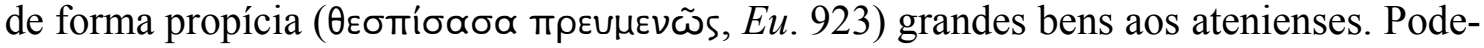
se assim se observar como, eliminando-se os intermediários, os próprios deuses, ao entrarem em cena e dialogarem com os mortais, clarificam e demarcam as fronteiras do que é justo, do que é lícito, do que é piedoso, seja no horizonte divino da ordem cósmica de Zeus, seja no horizonte político dos cidadãos da Atenas clássica.

Finalmente, em Prometeu Cadeeiro, examinaram-se o conhecimento divinatório de Prometeu, suas predições e sua conturbada relação com Zeus sobre diferentes aspectos: qual o papel que desempenha e o valor que representa, dentro do contexto da ação dramática, seu conhecimento do porvir; qual o sentido e as possibilidades que se abrem aos mortais através dos dons de Prometeu, principalmente no que diz respeito à tekhné mantiké; quais as nuances e as ambiguidades da enunciação divinatória; isto é, a fala clara e o enigma; a hermenêutica dos sinais divinos e a fragilidade do saber e da condição humana representada na história e na personagem de Io.

Viu-se, assim, como tantas das estratégias dramáticas, das características da poética esquiliana e de sua visão de mundo, tão bem estudadas ao longo dos anos, devem-se em grande parte ao uso que Ésquilo faz dos sinais divinatórios e do entendimento que deles tem o poeta. O diálogo divinatório configura-se, pois, como um elemento essencial na dramaturgia esquiliana, tornando única a relação entre a adivinhação e a obra do tragediógrafo. 


\section{EXCURSO}

\section{O vocabulário divinatório em Ésquilo}

Em Ésquilo, as palavras pertencentes ao campo semântico da adivinhação são abundantes; ainda mais abundantes, como conjectura Goward (2004, p. 56), do que as pertencentes à linguagem do sacrifício ritual. De fato, encontra-se no texto esquiliano um variegado repertório linguístico para denominar as ações, as qualidades e os fenômenos relativos à arte divinatória, como se verá a seguir, em um levantamento referente aos principais termos.

\section{1) Verbos que designam a enunciação divinatória}

Como ressalta Crahay (in VERNANT, J-P. et al., 1974, p. 216), o verbo

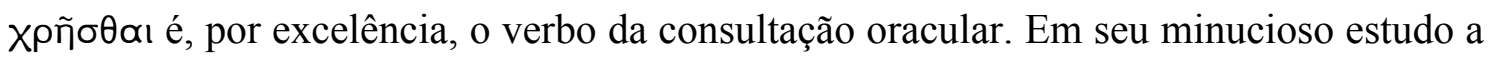
respeito desse verbo, $\operatorname{Redard}^{308}$ formula uma definição precisa de $\chi \rho \tilde{n} \sigma \theta \propto \varkappa_{1}$ significa "buscar a utilização de algo" Segundo o autor, o sentido de "responder, revelar por um oráculo, consultar um oráculo" seria uma especialização desse sentido original do verbo $\chi \rho \tilde{} \sigma \theta \propto$ เ. Enquanto verbo que indica o processo oracular, $\chi \rho \tilde{n} \sigma \theta \propto ı$ tem os seguintes sentidos, de acordo com a voz em que se encontra: 1) Voz ativa: responder, revelar por um oráculo (oraculum edo, dico vaticinans); 2) Voz passiva: ser revelado, ser anunciado por um oráculo; 3) Voz média: consultar um deus, um oráculo, um adivinho.

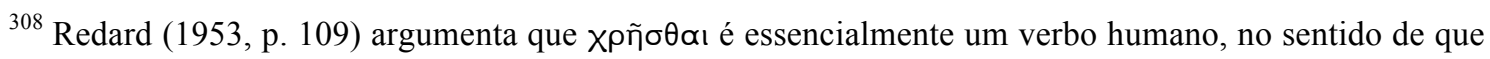
seu sujeito é sempre alguém e nunca algo. Quando se procura caracterizar o processo expresso pelo verbo, constata-se que ele se dá invariavelmente no interior da esfera do sujeito: a consulta a um oráculo não acarreta nenhuma modificação ao que é consultado, afetando somente aquele que consulta. Essa restrição do processo à esfera do sujeito tem uma ligação essencial com a voz média do verbo. Na voz média, o sujeito é interior ao processo do qual é o agente, ou seja, o verbo indica um processo cujo sujeito

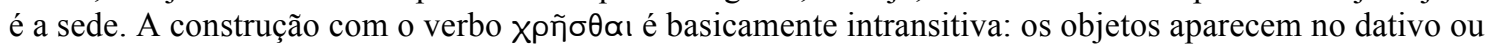
no genitivo. O objeto existe sempre fora do sujeito, que jamais o modifica; trata-se de uma exterioridade do objeto. O processo expresso pelo verbo $\chi \rho \tilde{\sigma} \sigma \theta \propto \iota$ é invariavelmente suscitado por um acontecimento, ligado a uma dada ocasião. Redard conclui o seguinte: "Il est claire qu'un Hellène du Ve s. distinguait, sans établir entre eux de lien sémantique, au moins deux verbes $\chi \rho \tilde{n} \sigma \theta \alpha \mathrm{l}$ : 'faire usage de, recourir à, emprunter' et 'consulter un oracle'. La langue en procure elle-même la preuve par certains dérivés qui ne

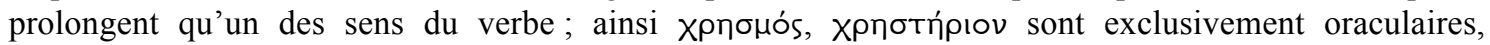

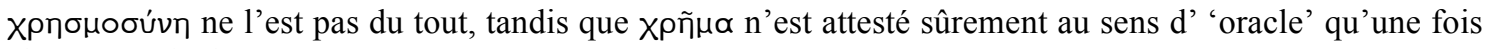
chez Empédocle" (p. 109).
} 
Em Ésquilo, há cinco ocorrências do verbo, todas na voz ativa e todas na Oresteia. Note-se que, em Agamêmnon, o verbo xpñoӨaı tem por sujeito Cassandra e as demais ocorrências, nas demais tragédias, relacionam-se a Apolo:

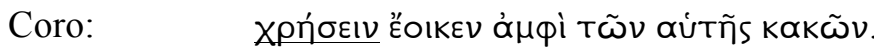
Parece vaticinar seus próprios males. (Ag. 1083)

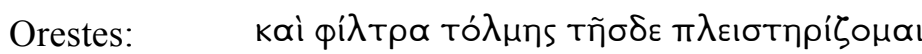

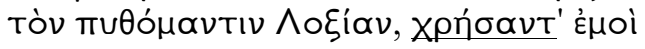
Enalteço como estímulo desta audácia o pítio Lóxias, ao dar-me oráculo (Co. 1029-30)

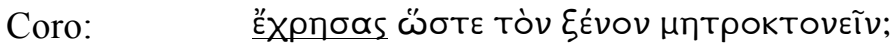
Vaticinaste o hóspede matar a mãe? (Eu. 202)

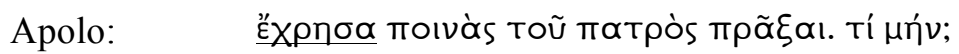
Vaticinei a vingança do pai, por quê? (Eu. 203)

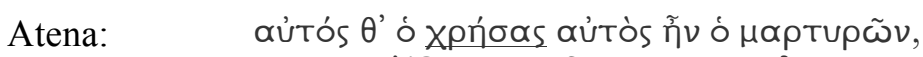

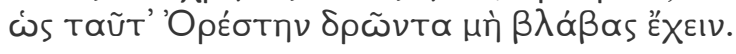
e a testemunha mesma era mesmo oráculo de que Orestes agindo assim não teria dano. (Eu. 798-9)

Outro verbo relacionado à enunciação divinatória em Ésquilo é o verbo

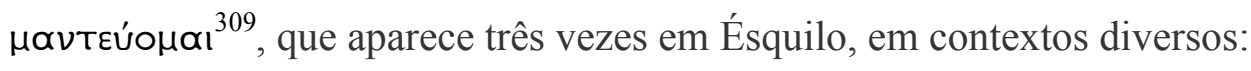

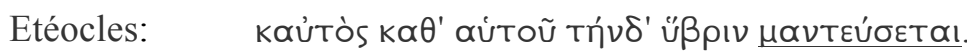
ele contra si mesmo predirá o ultraje. (Se.406)

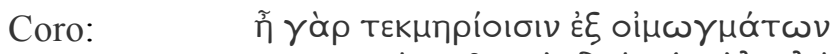

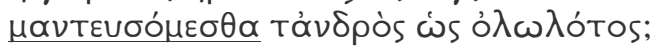
Por indícios vindo de gemidos adivinharemos que é morto o rei? (Ag. 1365-6)

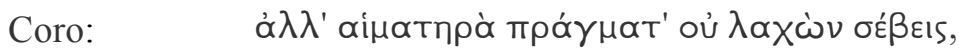

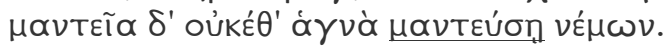
Veneras o sanguinário, não é teu lote; não darás mais oráculos puros em teu lar. $(E u .715-6)$

\footnotetext{
${ }^{309}$ Em Homero, esse verbo ocorre quatro vezes na Ilíada: I, 107 (sujeito: Calcas); II, 300 (sujeito: Calcas); XVI, 859 (sujeito: Pátroclo moribundo); XIX, 420 (sujeito: Xanto, o cavalo de Aquiles, dotado de voz por Hera). Na Odisseia, ocorre nove vezes: I, 200 (sujeito: Atena, sob a forma de Mentes); II, 170 e 178 (sujeito: Haliterses); XV, 172 (sujeito: Helena); 255 (sujeito: Polifides, adivinho melampodida); XVII, 154 (sujeito: Teoclimeno, adivinho melampodida); XX, 380 (sujeito: Teoclimeno, adivinho melampodida); XXIII, 251 (sujeito: a alma de Tirésias).
} 
Encontram-se ainda três ocorrências de $\theta \varepsilon \sigma \pi i \zeta \omega$ e uma ocorrência de seu

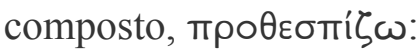

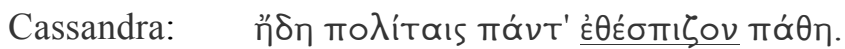

Já vaticinava toda dor aos cidadãos. (Ag. 1210)

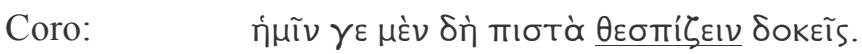

Cremos, porém, que vaticinas digna de fé. ( $\mathrm{Ag} .1213)$

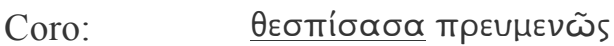

e predigo propícia $(E u .922)$

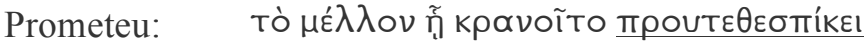

profetizava como se cumpriria o porvir (Pr. 211)

O verbo $\mu \propto v т ı \pi о \lambda \varepsilon ́ \omega$, um hápax, também tem o sentido de profetizar:

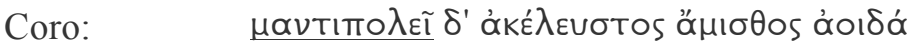

Um canto sem convite nem paga profetiza ( $\mathrm{Ag}$. 979)

Também um hápax, o verbo тєрó $\zeta \omega$ introduz a fala de Calcas em Agamêmnon:

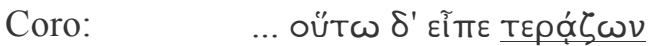

... e disse o vaticínio $(\mathrm{Ag} .125)$

O verbo ápóoưı, que significa imprecar, lançar uma maldição, aparece duas vezes: uma no Prometeu Cadeeiro, tendo como sujeito o deus Crono, e outra nos Sete contra Tebas, em que o sujeito do verbo é Polinices:

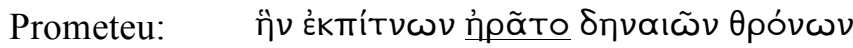

imprecada ao cair do longevo trono (Pr. 912)

Mensageiro: $\quad \ldots \pi \operatorname{mó}_{\varepsilon \varepsilon}$

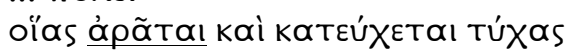

... e que sorte

para a cidade ele impreca e suplica (Se.632-3) 


\title{
2) Termos que designam resposta oracular ou profética
}

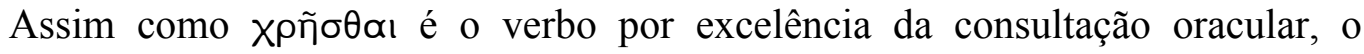

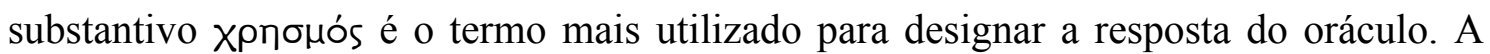
respeito desse substantivo, Redard (1953, p. 93) faz a seguinte observação:

Xpnouós n'est point la réponse en train d'être rendue, mais la réponse particulière obtenue du dieu, l'oracle dûment formulé et, de ce fait, chargé de force agissant ; c'est une formulation donnée en tant qu'elle suscite un procès, productrice des effets qu'elle énonce, le $\mu \varepsilon \gamma \alpha \sigma \theta \varepsilon v \eta ́ s ~ X p \eta \sigma \mu o ́ s ~ ‘ o r a c l e ~ t o u t-p u i s s a n t$ ' que connaît Oreste.

Nas tragédias de Ésquilo, o termo ocorre dez vezes. Na Oresteia, ele está em relação com Apolo, Zeus e Cassandra:

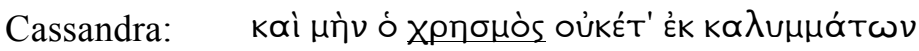

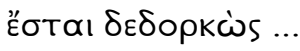 \\ O oráculo agora não mais através de véus \\ estará fitando ... (Ag. 1178-9)

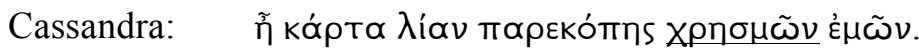 \\ Extraviaste muito de oráculos meus. (Ag. 1252)

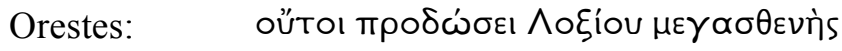

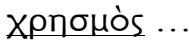 \\ Não nos trairá o oráculo plenipotente \\ de Lóxias... (Co. 269-70)

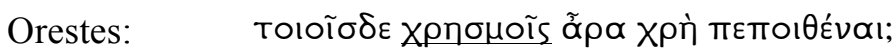 \\ Não se deve confiança a tais oráculos? (Co. 297)

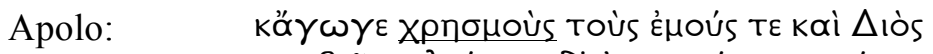

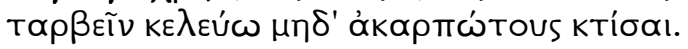 \\ E eu vos ordeno: temei oráculos meus \\ e de Zeus, não os tornei sem fruto. (Eu. 713-4)

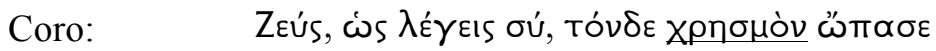 \\ Zeus, como dizes, deu este oráculo $(E u .622)$
}

No Prometeu Cadeeiro, o termo é usado uma vez com referência à deusa Têmis e outra com referência a oráculos entregues em Delfos e em Dodona: 


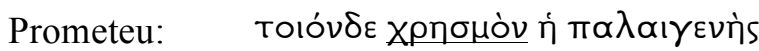

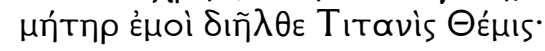
... A prístina mãe

Titânide Têmis explicou-me tal oráculo. (Pr. 873-4)

Io:

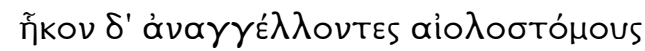

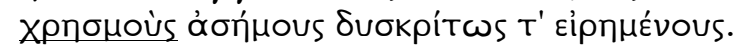

Voltavam mensageiros de variegados

oráculos obscuros e ditos indistintos (Pr. 661-2)

As duas últimas ocorrências do termo dizem respeito, nos Persas, a oráculos provenientes de alguma fonte indistinta e, em Agamêmnon, é utilizado por Clitemnestra para designar a ideia de que seu interlocutor (no caso, o Coro) compreendeu o ponto fundamental da questão em discussão ${ }^{310}$ :

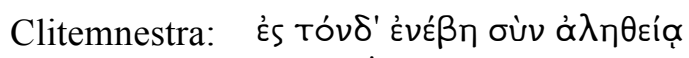

xpпouós.

Com toda verdade entraste

neste oráculo. (Ag. 1567-8)

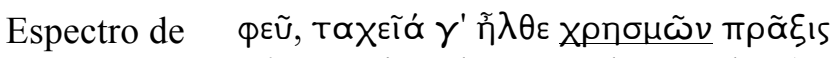

Dario: $\quad P h e \hat{u}$ ! Veio veloz o ato de oráculos (Pe. 739)

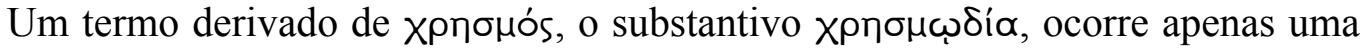
vez:

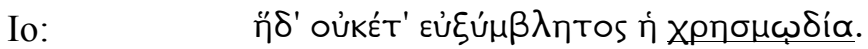

Este oráculo ainda não é conjecturável. (Pr. 775)

Da mesma raiz de Xpпouós, aparece, nas Coéforas, um substantivo composto de хрпотós: o termo muӨóxpпотоs, que designa o que foi declarado ou determinado pelo oráculo pítio $^{311}$ :

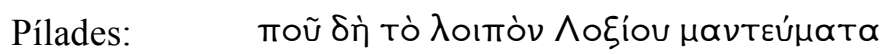

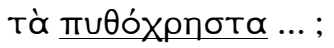

Onde no porvir os vaticínios de Lóxias

dados em Delfos ... ? (Co. 900-1)

\footnotetext{
${ }^{310}$ Esse uso, com termos diversos, é comum a todos os três tragediógrafos.

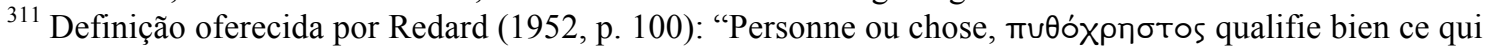

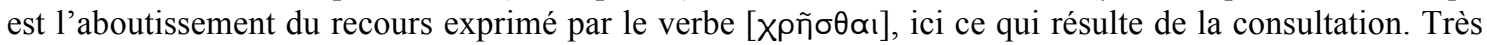
tôt le mot a servi de titre à certains exégètes investis par le dieu de Delphes d'un pouvoir de représentation et notamment chargés d'appliquer les rites de purification".
} 


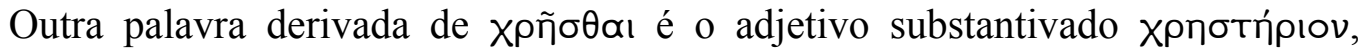
termo que pertence exclusivamente à terminologia oracular e que possui três sentidos. $\mathrm{O}$ primeiro deles é o de sede de um oráculo, ou seja, o oráculo como instituição, e ocorre três vezes na tragédia esquiliana, sempre com relação ao oráculo de Delfos. A saber:

\begin{tabular}{|c|c|}
\hline Coro: & 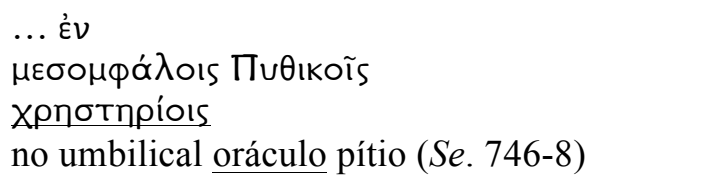 \\
\hline Apolo: & 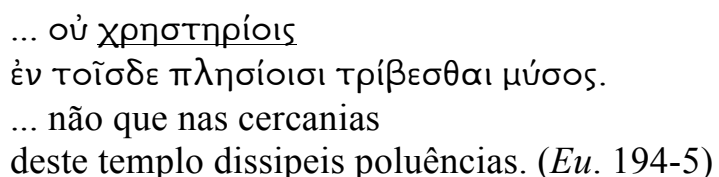 \\
\hline
\end{tabular}

O segundo sentido de Xpпotŕpıov é a resposta de um oráculo consultado. Como o lugar em que se consulta o oráculo é o mesmo em que se obtém a resposta, pode haver uma ambiguidade em seu uso ${ }^{312}$. Essa possibilidade de referência tanto à instituição, material e geograficamente localizada, quanto ao conteúdo proferido por tal instituição é o que se verifica no seguinte uso do termo em Agamêmnon:

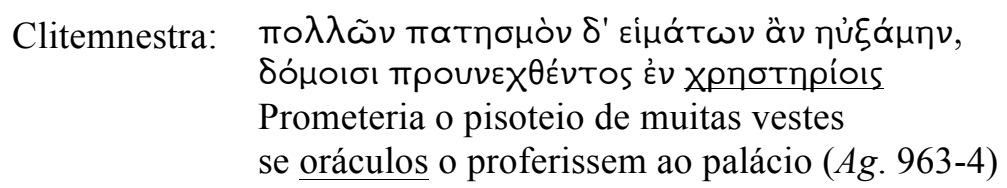

Por fim, o terceiro sentido de xpпotŕpıov é o de vítima ofertada em sacrifício antes da consulta oracular. Considerando que uma vítima preliminar é também uma vítima propiciatória, é nesse sentido que essa palavra figura em Ésquilo. O termo ocorre duas vezes: em Sete contra Tebas, faz referência aos sacrifícios preliminares ao combate e, nas Suplicantes, aos sacrifícios propiciatórios aos deuses.

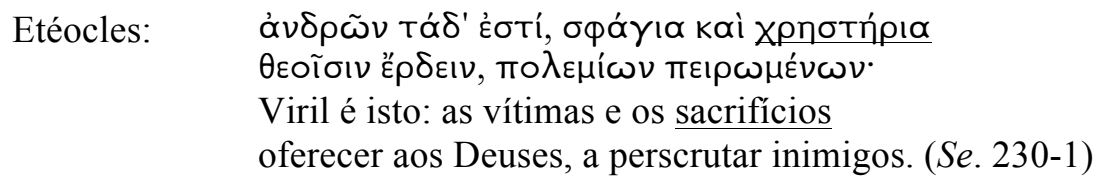

\footnotetext{
${ }^{312}$ Nas palavras de Redard (1953, p. 108), “l'endroit où l'on consulte l'oracle est aussi celui où il rend sa réponse et certains emplois du mot témoignent de cette ambiguïté, p. ex. Eurip., Ion 532 et Soph., OC. 604, Hdt, 1.73”.
} 


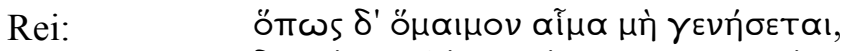

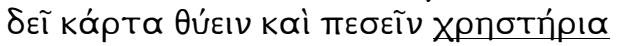

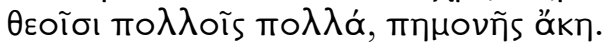
mas para não sangrar consanguíneo, deve-se sacrificar muito, e muitas vítimas caírem a muitos Deuses, curas de dores. (Su. 449-51)

Com o mesmo sentido de resposta oracular ou simplesmente de vaticínio ou

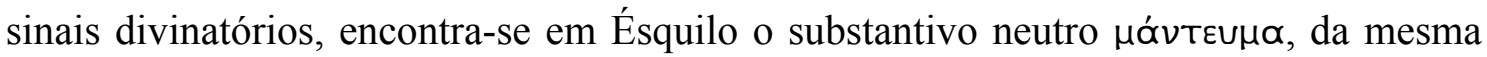

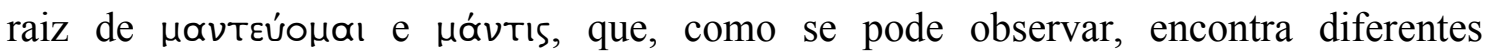
possibilidades de tradução. A saber:

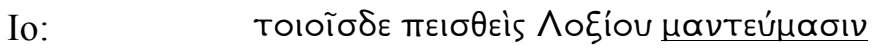
Persuadido por tais oráculos de Lóxias (Pr. 699)

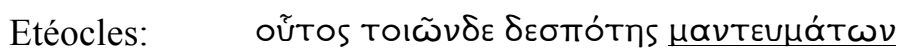
esse déspota de tais modos de adivinhar ( $\mathrm{Se} .27)$

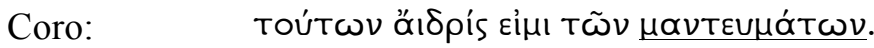
Destes vaticínios sou ignorante ( $\mathrm{Ag} .1105)$

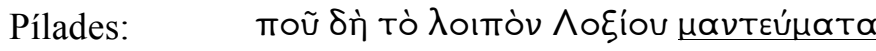
Onde no porvir os vaticínios de Lóxias? (Co. 900)

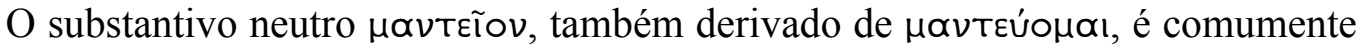
utilizado no plural e pode significar tanto a resposta oracular quanto a sede de um oráculo. Em Ésquilo, ocorre duas vezes com o significado de sede oracular, referindo-se uma vez a Delfos e outra a Dodona; uma vez no sentido de respostas oraculares, referindo-se às proferidas em Delfos; e uma vez em forma adjetiva, para caracterizar os adereços da profetisa Cassandra:

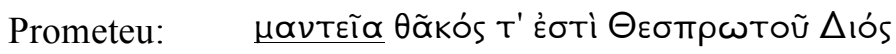
o oráculo e templo de Zeus Tesproto (Pr. 831)

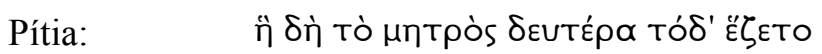
наVTEĨOV ... essa após a mãe sentava-se neste oráculo .... (Eu. 3-4)

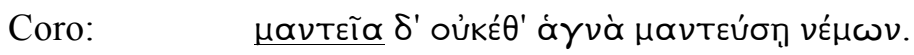
não darás mais oráculos puros em teu lar. (Eu. 716)

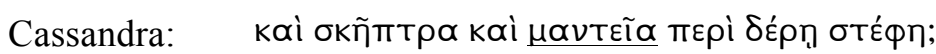
cetro e fitas divinatórias, no pescoço? $(\mathrm{Ag} .1265)$ 


\section{3) Termos que designam pessoas, coisas e sentimentos que possuem ou expressam um conhecimento divinatório}

O termo que aparece de forma mais expressiva nas tragédias supérstites de

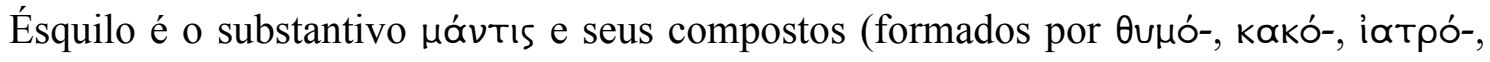

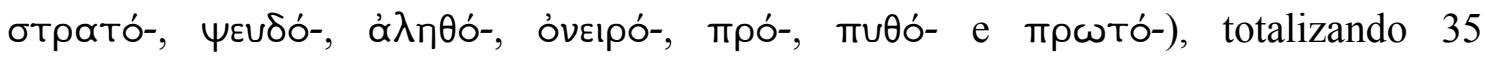
ocorrências, assim distribuídas: Persas (2), Sete contra Tebas (10), Suplicantes (1), Agamêmnon (9), Coéforas (6), Eumênides (7), Prometeu Cadeeiro (0).

Mávtıs descreve não somente a figura do adivinho - seja este Calcas, o próprio Apolo ou suas profetisas, Cassandra e a Pítia -, mas também:

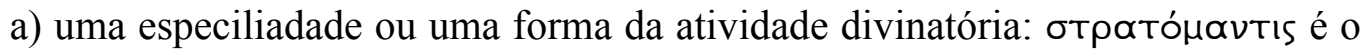

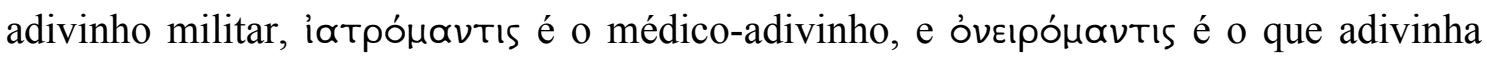
através dos sonhos;

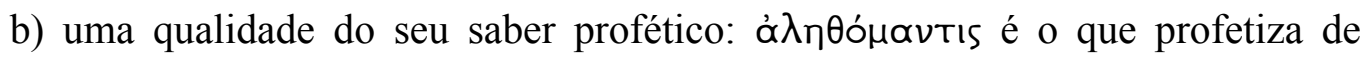

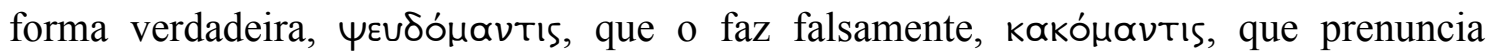
males;

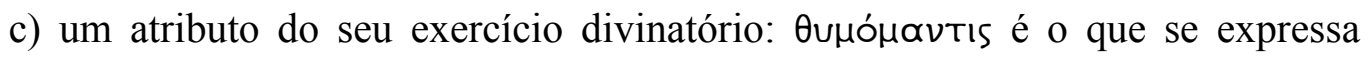

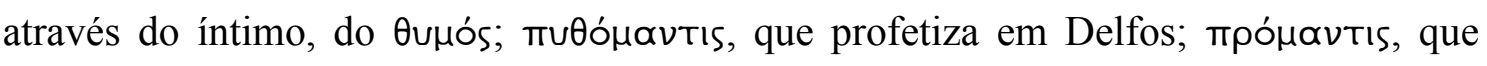

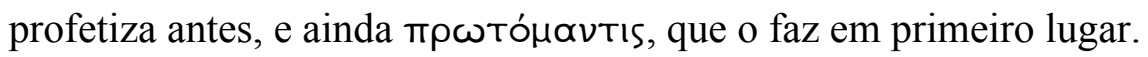

Desde Platão, a palavra $\mu$ óvtıs aparece associada à ideia de $\mu \alpha v i ́ \alpha$, isto é, de loucura, de delírio. No Fedro, o filósofo oferece a seguinte etimologia:

[...] os antigos, que deram o nome a tudo, não acharam que o delírio fosse qualquer coisa de feio ou desonroso. De outro modo, não teriam entrelaçado esse nome com a mais nobre das artes, a que permite predizer o futuro, com denominá-la manikê, mania; foi por a considerarem algo belo, sempre que se manifesta por dispensação divina, que a designaram desse modo. Porém os modernos, por carecerem do sentimento do belo, acrescentaram-lhe um ' $\mathrm{t}$ ', com o que ficou chamada mantikê, arte divinatória ou mântica $(244 b-c)^{313}$.

Como observa Casevitz (1992, p. 2), o vínculo etimológico que comumente se

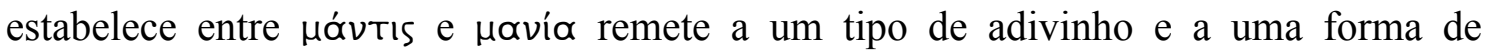
adivinhação em particular e não a todos os tipos de adivinhos nem a todas as formas de

\footnotetext{
${ }^{313}$ Tradução de Carlos Alberto Nunes (2001, 3ª . ed.)
} 
adivinhação. Como se atesta nos poemas homéricos, em que ocorre 17 vezes $^{314}$, o termo

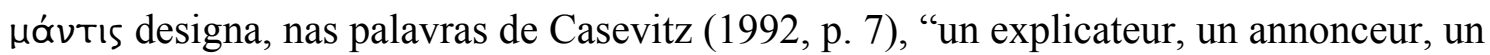

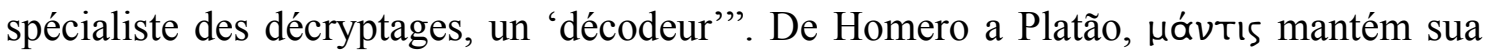
unidade semântica: designa aquele que revela e conota o saber, quer se trate do adivinho que observa os sinais (adivinhação indutiva, a única presente em Homero), quer se trate do adivinho inspirado diretamente pela divindade sem recorrer a nenhum sinal visível (como Cassandra, a Pítia etc.). Os trágicos, especialmente Ésquilo, conservaram, segundo o autor, a unidade da significação primeira de $\mu$ óvtıs.

Nos Persas, as duas ocorrências aludem ao sentimento pressago do Coro de fiéis:

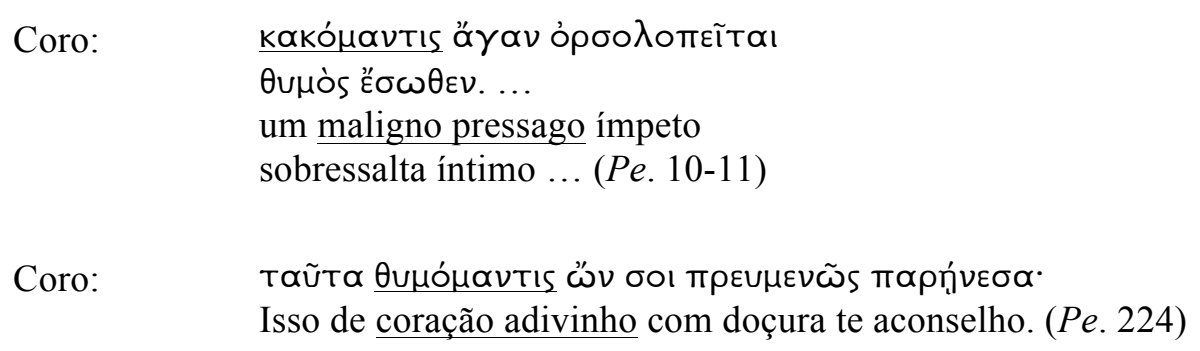

Nos Sete contra Tebas, das dez ocorrências do termo, uma diz respeito a Tirésias, seis a Anfiarau, uma à atitude hybristés de Tideu, uma à maldição de Édipo e uma ao sentimento premonitório do Coro de mulheres tebanas:

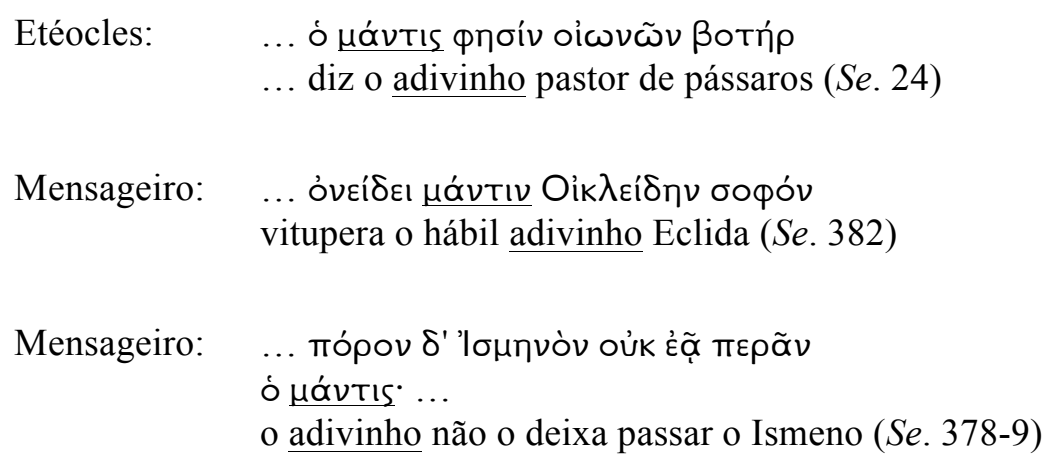

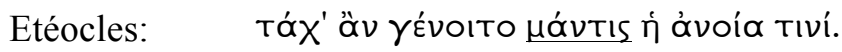
talvez a demência fosse divinatória (Se.402)

\footnotetext{
${ }^{314}$ Ilíada: I, 62 (refere-se ao ofício de adivinho), 92, 106 e 384 (Calcas); XIII, 69 (Calcas, disfarce de Posídon), 663 (Políido); XXIV, 221 (refere-se ao ofício de adivinho). Odisseia: I, 202 (diz de si mesma a deusa Atena, sob a forma de Mentes); IX, 508 (Télemo); X, 493, 538 (Tirésias); XI, 99 (Tirésias); XII, 267, 291 (Tirésias); XV, 225 (Teoclimeno, adivinho melampodida), 252 (Polifides, adivinho melampodida); XVII, 384 (refere-se ao ofício de adivinho).
} 


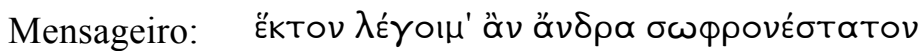

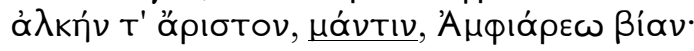

$O$ sexto homem eu diria o mais sábio,

exímio na luta, adivinho, o forte Anfiarau (Se. 568-9)

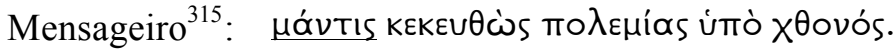

adivinho oculto sob terra inimiga ( $\mathrm{Se} .588)$

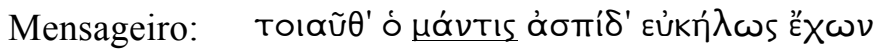

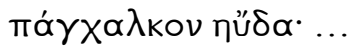

Disse tranquilo o adivinho com o escudo

brônzeo; ... (Se. 590-1)

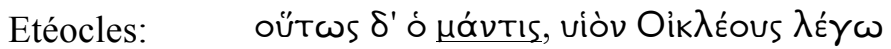

Assim o adivinho, digo o filho de Ecleu (Se. 609)

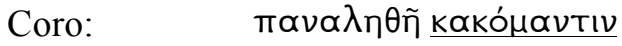

verdadeira maligna adivinha (Se. 722)

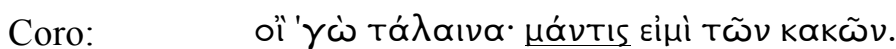

Ai, mísera, sou adivinha de males. (Se. 808)

Nas Suplicantes, a única ocorrência designa Ápis:

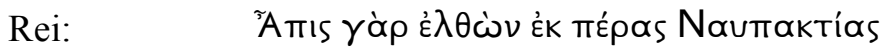

iatpómavtis maĩs 'A то́ $\lambda \lambda \omega v o s . .$.

Ápis veio do lado de lá de Naupacto,

médico-adivinho filho de Apolo (Su. 262-3)

Em Agamêmnon, uớvtıs é usado para se referir a Calcas, a Cassandra, a Apolo e em duas ocasiões ocorre sem especificação:

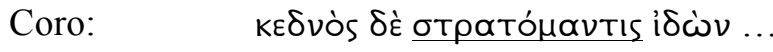

O sábio adivinho ao ver soube: ... (Ag. 122)

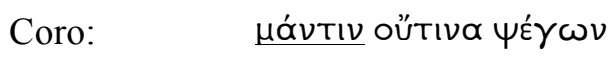

sem vitupério a nenhum adivinho ( $A g$. 186)

Coro: $\quad \mu \alpha \dot{v} v T I S$ Ék $\lambda \alpha \gamma \xi \varepsilon v \ldots$

... o adivinho proclamou ( $A g .201)$

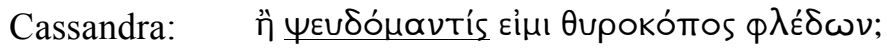

Ou sou falsa adivinha mendiga faladeira? (Ag. 1195)

${ }^{315}$ Reportando em discurso direto as palavras de Anfiarau. 


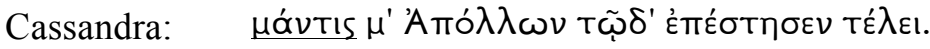
$\mathrm{O}$ adivinho Apolo me pôs neste ofício. (Ag. 1202)

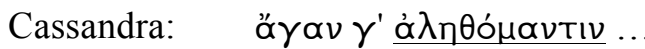

... adivinha por demais veraz. $(A g .1241)$

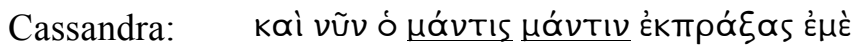

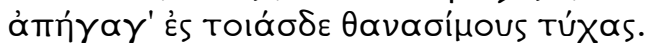

$\mathrm{O}$ Adivinho cobrou de mim a adivinha, agora me conduz a esta sorte funesta. (Ag. 1275-6)

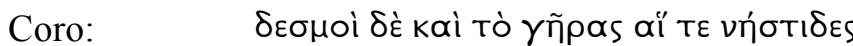

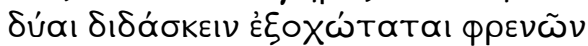

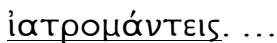

Prisão e dores de fome também para velhos são exímios mestres do espírito, médicos adivinhos. ... (Ag. 1621-3)

Nas Coéforas, a palavra $\mu$ óvtıs qualifica Apolo, o sonho de Clitemnestra e duas vezes é utilizada em sentido metafórico:

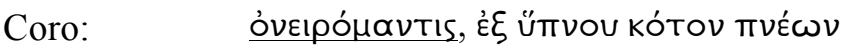
o Adivinho de sonho, tirando sono, a respirar rancor (Co. 33)

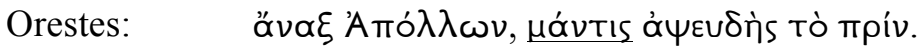
rei Apolo, adivinho sem mentira antes. (Co. 559)

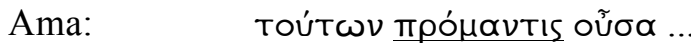

Previdente disso ... (Co. 758)

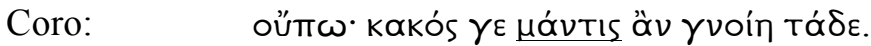
Não ainda. Mau adivinho diria isso. (Co. 777)

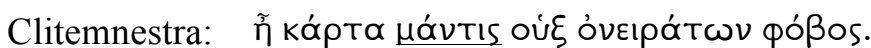
era muito adivinho o pavor dos sonhos. (Co. 929)

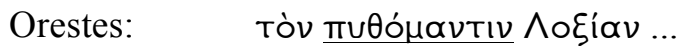
o pítio Lóxias ... (Co. 1030)

Nas Eumênides, $\mu$ óvtıs e compostos designam a deusa Terra, a Pítia e Apolo:

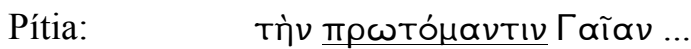

Terra, primeira adivinha .... (Eu. 2)

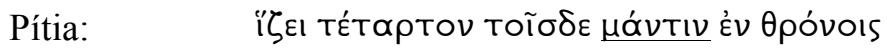
e põe quarto adivinho no trono $(E u .18)$ 


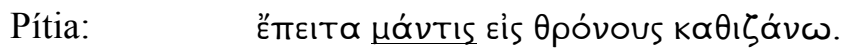

depois adivinha me sento no trono. (Eu. 29)

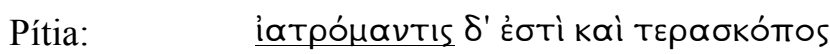

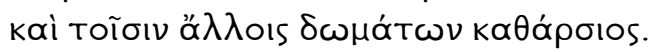
é médico-adivinho, intérprete de signos e purificador de alheios palácios. (Eu. 62-3)

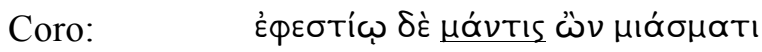
Adivinho, poluíste o íntimo lar (Eu. 169)

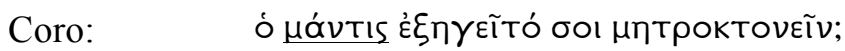
O adivinho te explicou que mate a mãe? (Eu. 595)

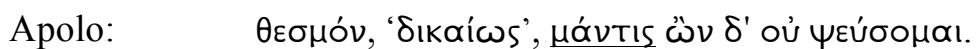
digo-o justo. Adivinho, não mentirei. (Eu. 615)

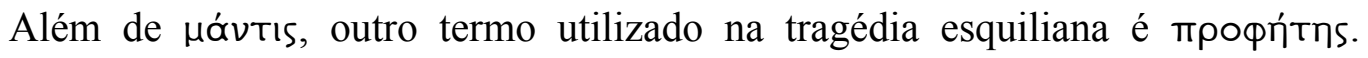

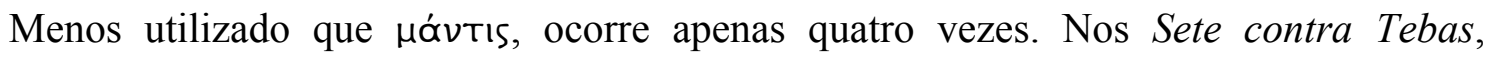
qualifica Tirésias, que nessa tragédia é frequentemente designado uóvtıs; em Agamêmnon, a primeira ocorrência designa os intérpretes do palácio de Menelau e a segunda surge do diálogo entre Cassandra e o Coro; nas Eumênides, designa Apolo.

\begin{tabular}{|c|c|}
\hline Etéocles: & 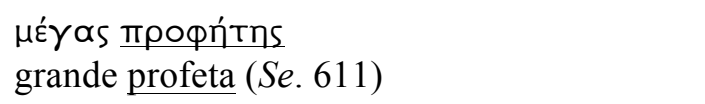 \\
\hline Coro: & $\begin{array}{l}\delta o ́ \mu \omega \nu \text { mpoфñTaı } \\
\text { os intérpretes do palácio (Ag. 409) }\end{array}$ \\
\hline Coro: & 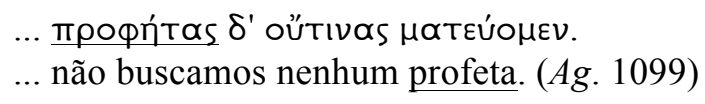 \\
\hline Coro: & 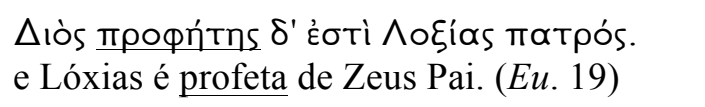 \\
\hline
\end{tabular}

Também quatro vezes ocorre o termo тєрабкóтоos. Em Agamêmnon, é usado na forma adjetiva para qualificar o coração pressago do Coro e para designar Cassandra; nas Coéforas, para qualificar Orestes após este ter interpretado o sonho de Clitemnestra; nas Eumênides, para designar Apolo.

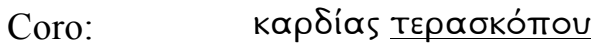
vaticinante coração $(A g .977)$ 


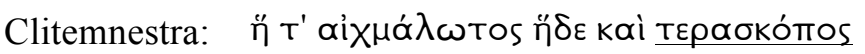

$$
\begin{aligned}
& \text { esta prisioneira e adivinha ( } A g .1440)
\end{aligned}
$$

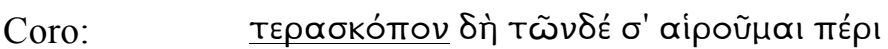

$$
\begin{aligned}
& \text { Elejo-te por isso perito em prodígio (Co. 551) }
\end{aligned}
$$

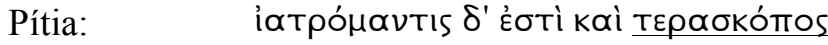

$$
\begin{aligned}
& \text { é médico-adivinho, intérprete de signos (Eu.62) }
\end{aligned}
$$

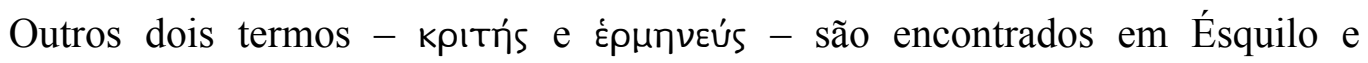
designam não algo ou alguém dotado de um dom ou de um sentimento divinatório, mas sim os que exercem a função de intérprete de algum sinal divino. Assim, as duas únicas ocorrências de kpıtńs se referem à interpretação de sonhos: o da Rainha nos Persas e o de Clitemnestra nas Coéforas:

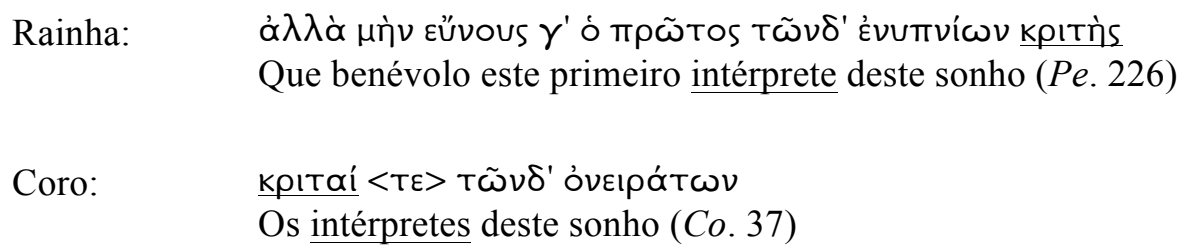

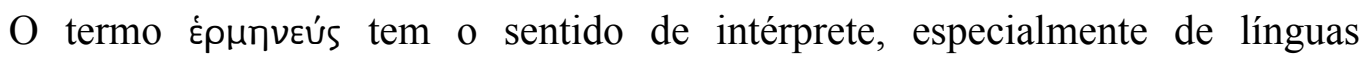
estrangeiras. Há duas ocorrências em Agamêmnon: na fala do Coro para Clitemnestra e para o Arauto no segundo episódio e na fala do Coro para Cassandra no quarto episódio. Em ambas as vezes, o termo é qualificado pelo mesmo adjetivo, topós, que significa claro, distinto, direto.

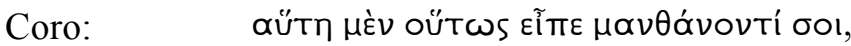

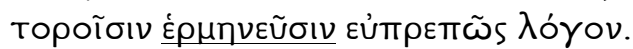

$$
\begin{aligned}
& \text { Ela assim falou transparente palavra } \\
& \text { se por claros intérpretes a entendes. (Ag. 615-6) }
\end{aligned}
$$

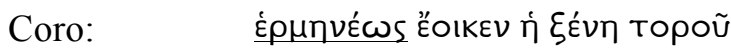

$$
\begin{aligned}
& \delta \varepsilon \tilde{\sigma} \sigma \propto \alpha_{1} . . . \\
& \text { A hóspeda parece carecer de intérprete } \\
& \text { claro. ... (Ag. 1062-3) }
\end{aligned}
$$

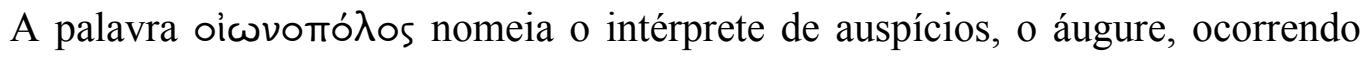
apenas uma vez em Ésquilo, no párodo das Suplicantes: 


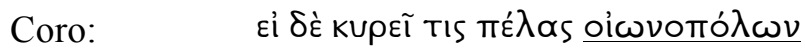

Se há por perto algum áugure $(S u .57)$

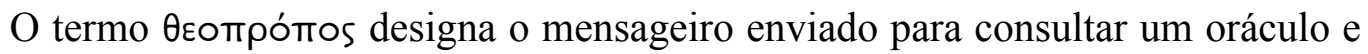
trazer a reposta. São Өєотро́то que o pai de Io envia a Delfos e a Dodona para consultar os oráculos de Apolo e de Zeus, respectivamente, como se lê na seguinte passagem:

Io:

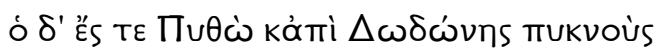

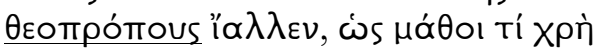

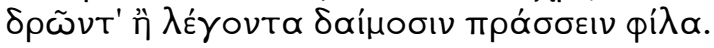

$$
\begin{aligned}
& \text { Ele fazia frequentes consultas a Deus } \\
& \text { em Delfos e Dodona, para saber o que } \\
& \text { devia fazer ou dizer grato aos Numes. (Pr. 658-60) }
\end{aligned}
$$

Dois adjetivos - Xpпotńpıos e $\mu \alpha v$ tıkós - descrevem a qualidade divinatória de algo ou de alguém. Assim, aves, vestes e ordens são qualificadas com o adjetivo xpпotńpios:

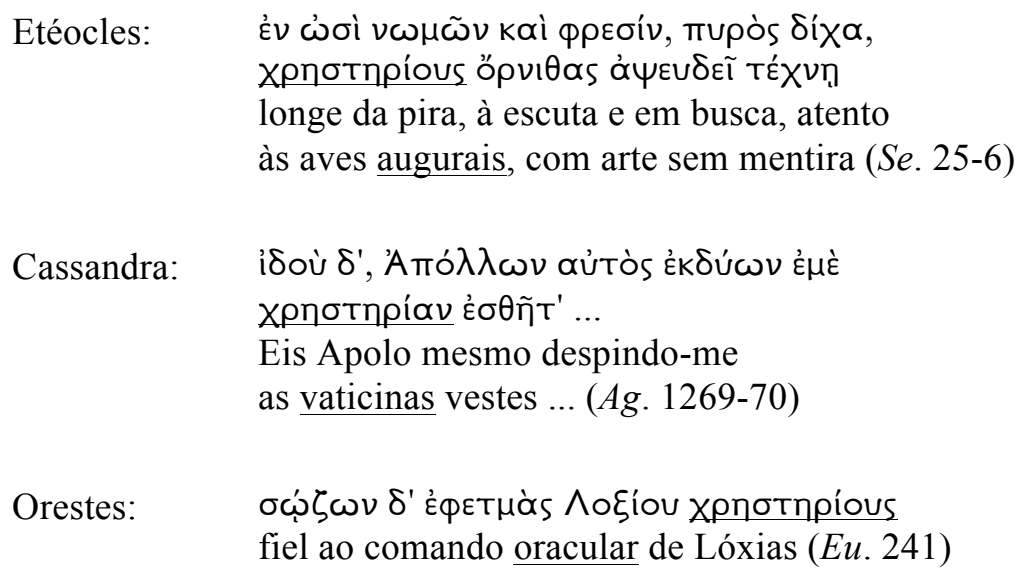

\begin{tabular}{|c|c|}
\hline Coro: & 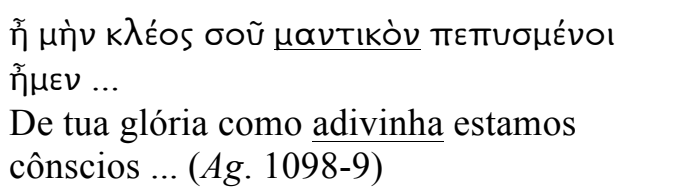 \\
\hline Apolo: & 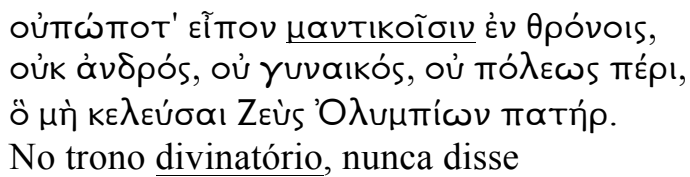 \\
\hline
\end{tabular}

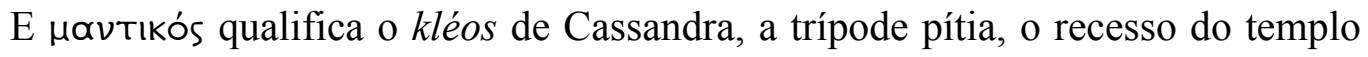
de Delfos e a própria arte divinatória: 
de homem, de mulher ou de cidade

senão ordem de Zeus Pai dos Olímpios. (Eu. 616)

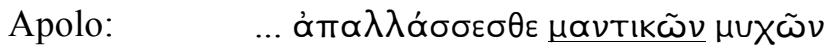
afastai-vos do recesso divinatório $(E u .180)$

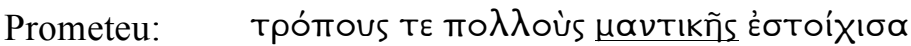

Distingui muitos modos de adivinhação $(\operatorname{Pr} .484)$

À variedade de termos que designa quem ou o que tem conhecimento ou sentimento divinatório corresponde a multiplicidade dos sinais divinos na mântica grega antiga, como se verá a seguir.

\section{4) Termos que designam sinais divinatórios distintos}

Os sonhos são designados em Ésquilo tanto pela palavra ővap quanto pela palavra öveıpos. Como regra geral, övap é um vocábulo utilizado somente no nominativo e no acusativo singular e na tragédia é frequente o seu uso no acusativo adverbial, com o sentido de "num sonho". Das cinco ocorrências do termo na tragédia de Ésquilo, somente uma diz respeito a um sonho de carácter divinatório ${ }^{316}$. Trata-se de uma referência ao sonho de Clitemnestra relatado nas Coéforas. Orestes pergunta ao Coro:

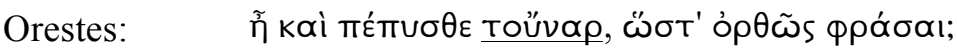

Soubeste do sonho de modo a contá-lo exato? (Co. 526)

Quanto a öveıpos e compostos, são empregados 19 vezes por Ésquilo, mas apenas 10 vezes com o sentido de sonho profético $^{317}$.

Nas Coéforas, em que o sonho profético de Clitemnestra desempenha um papel importante nessa tragédia, o termo ocorre seis vezes:

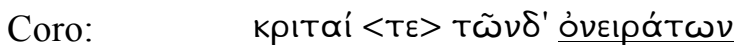

Os intérpretes deste sonho (Co. 37)

\footnotetext{
${ }^{316}$ Nas demais ocorrências do termo, duas apresentam um uso adverbial -"num sonho", em Eu. 116 e 131 - e duas, um sentido metafórico, em $S u .888$ e $A g .82$.

317 Demais ocorrências do termo: Pr. 448, 547 (íóveıрov), Ag. 13, 274, 420 (óveıрóфavтoı) 491, 891, $981,1218, E u .155$
} 
Coro:

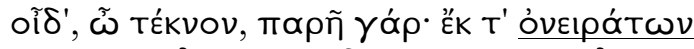

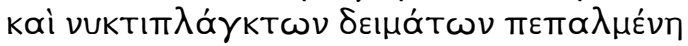

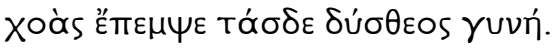

Sei, ó filho, pois presenciei: por sonhos

e por noctívagos terrores sacudida

a ímpia mulher enviou estas libações. (Co. 523-5)

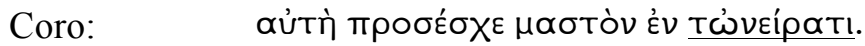

Ela mesma the deu o seio no sonho. (Co. 531)

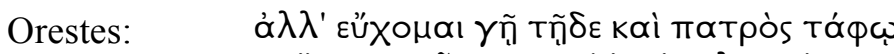

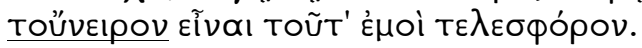

Suplico à terra e ao túmulo paterno que este sonho me seja portador de remate. (Co. 540-1)

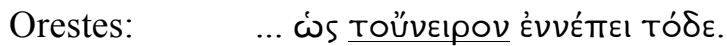

... como conta este sonho. (Co. 550)

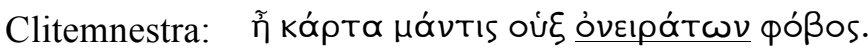

era muito adivinho o pavor dos sonhos. (Co. 929)

Em Prometeu Cadeeiro, umas das artes divinatórias ensinadas aos mortais pelo Titã, tal como ele relata ao Coro, é a oniromancia. Encontra-se aqui uma ocorrência do termo:

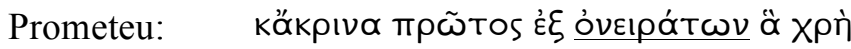

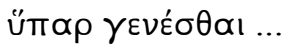

e primeiro discerni dentre os sonhos

quais se verificam ... (Pr. 485-6)

Nos Persas, a Rainha diz-se à procura de conselhos por causa de um sonho que lhe pareceu o mais claro dentre todos os demais com os quais convive desde a partida de seu filho no comando do exército persa:

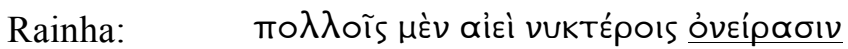

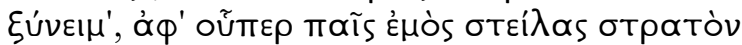

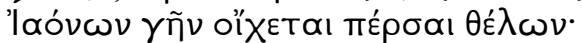

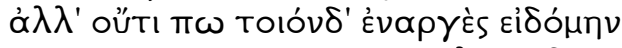

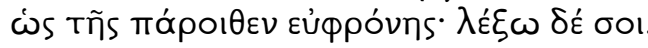
Com muitos sempre noturnos sonhos convivo, desde que meu filho com o exército foi-se à terra dos jônios para dispersá-la, mas ainda não tinha visto nada tão claro como ontem à noite, o que te contarei. (Pe. 176-80) 
De forma bastante semelhante, Io, em Prometeu Cadeeiro, relata ao Coro e ao Titã os sonhos que insistentemente a visitavam e lhe prenunciavam, através de uma fala persuasiva, a sua futura união com Zeus:

\begin{tabular}{|c|c|}
\hline Io: & 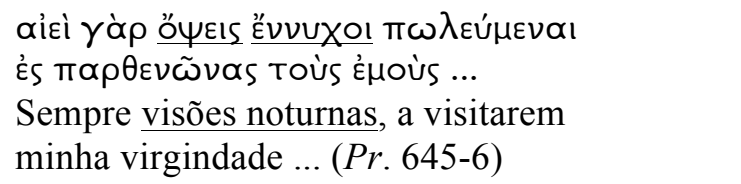 \\
\hline Io: & 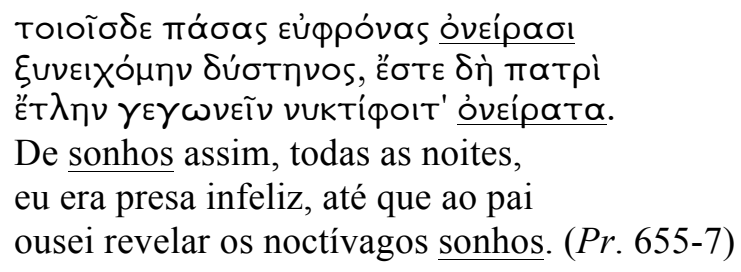 \\
\hline
\end{tabular}

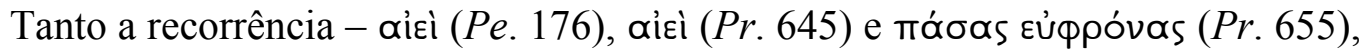
- como o caráter noturno desses sonhos - vukTépoıs (Pe. 176), ÉvvuXoı (Pr. 645) e vUKTí申OIT' (Pr. 657) - são características comuns às duas passagens. Outro ponto em comum é a descrição dos sonhos como visões noturnas. A Rainha, ao relatar o conteúdo

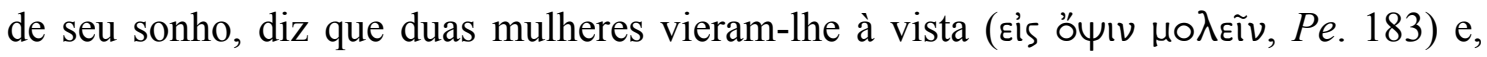
após a notícia da derrota do exército persa, ela exclama quão profético foi seu sonho,

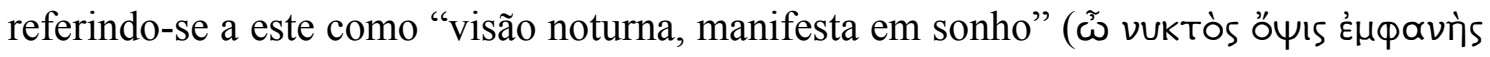

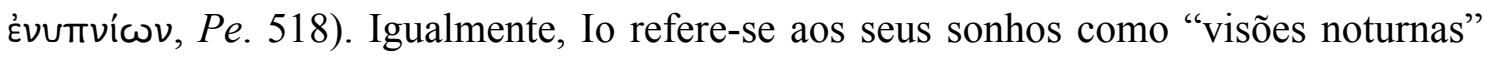

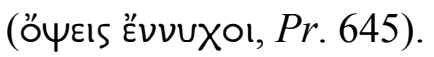

É com esse sentido de sonho profético que Etéocles, nos Sete contra Tebas, também utiliza o termo ö $\psi 15^{318}$ évuTrvíwv:

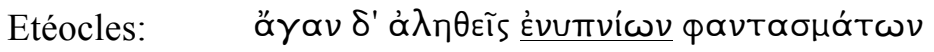
ö $\psi \varepsilon 15 . .$.
assaz verdadeiras visões de espectros de sonhos ... (Se. 710-11)

O termo Évútrviov também é usado para designar "sonho". Kessels (1978, p. 192) defende o uso de Évútrviov com valor apenas adjetivo, crendo ser este o que se

\footnotetext{
${ }^{318}$ Mesmo sem que haja uma referência à adivinhação através dos sonhos, é interessante observar como, em Agamêmnon, o sonho é descrito como visão. Assim, o Coro, ao descrever Menelau anelando por

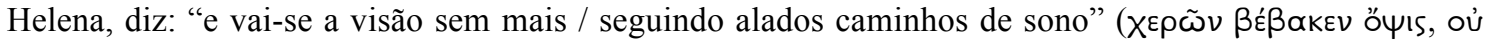

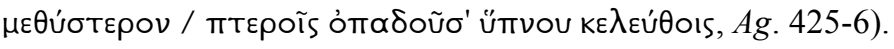


apresenta em Homero, na lírica arcaica e na tragédia. Nas três vezes em que Ésquilo utliliza esse termo, ele o faz no genitivo plural, sendo que em duas vezes dependendo de öభıs (Pe. 518, Th. 710) e em uma dependendo de kpırńs (Pe. 206). Apenas nesta última ocorrência, parece ser usado com valor substantivo, como sinônimo de őveıpos ${ }^{319}$ :

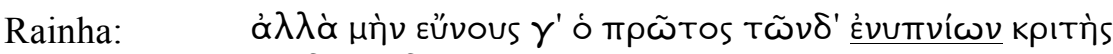

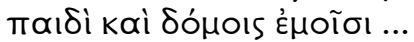 Que benévolo este primeiro intérprete deste sonho é para meu filho e palácio ... (Se.226-7)}

Da mesma família de , encontra-se o hápax, utilizado por Ésquilo nas Coéforas para se referir ao sonho de Clitemnestra:

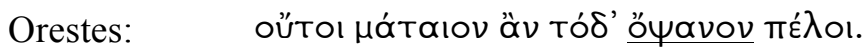

Esta visão não the poderia vir em vão. (Co.534)

Os sonhos, ao serem assim descritos com esses termos, definem-se como visões espectrais, noturnas, que assediam seus destinatários, os quais, ainda que percebendo sua importância, não são capazes de compreendê-los e buscam intérpretes quase sempre ineptos para lhes perscrutar o verdadeiro sentido.

Esse sentido de visão espectral é utilizado no párodo do Agamêmnon por Calcas

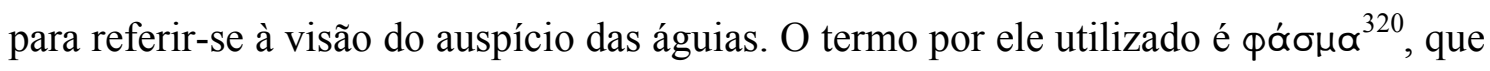
significa aparição, visão em um sonho, sinal divino, auspício, prodígio. Dada a complexidade e a magnitude de seu sentido, o auspício das aves em Áulida é denominado primeiramente, na descrição do Coro de sua aparição, como um auspício, ópvis, mas, nas palavras de Calcas, no curso de sua interpretação, ele é designado

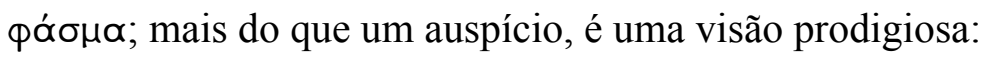

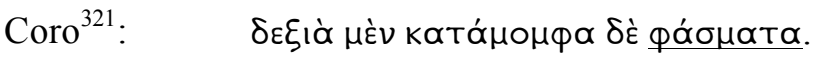

destras, mas repreensíveis visões $(A g .145)$

\footnotetext{
${ }^{319}$ Para Garrido \& Lobo (2003, p. 85), não há nenhuma diferença semântica entre Ėvútrvıov e öveıpos; ambos designam "sonho".

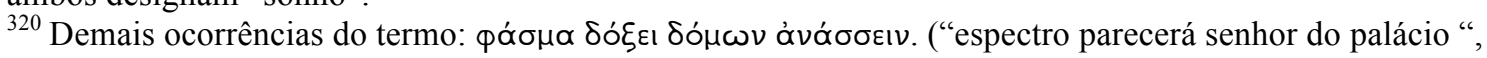
$A g$. 415), podendo referir-se tanto a um saudoso Menelau como a uma ausente Helena, e тótepa $\delta^{\prime}$

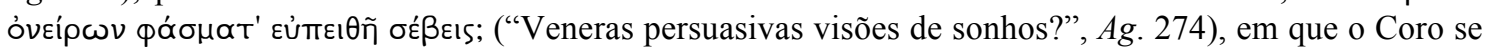
refere à crença de Clitemnestra na veracidade da notícia da conquista de Troia anunciada por sinais de fogo.

${ }^{321}$ Reproduzindo em discurso direto as palavras de Calcas.
} 
Os auspícios em Ésquilo são designados comumente pela palavra őpvıs, que, literalmente, significa pássaro ${ }^{322}$. Mais do que o auspício obtido através da observação do voo dos pássaros, a palavra ópvıs adquiriu também o sentido mais amplo de presságio, denominando assim os sinais obtidos até mesmo por outras formas de adivinhação, como parece indicar uma passagem de As Aves de Aristófanes, em que, dirigindo-se à audiência, o Corifeu diz:

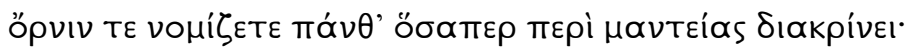

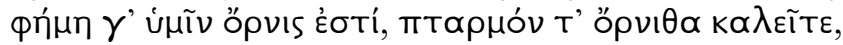

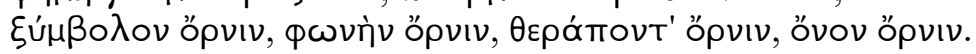

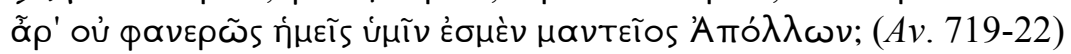

Acham que é ave tudo o que se refira aos oráculos: um boato para vocês é ave; um espirro chamam ave;

Um encontro é ave; uma voz, ave; um criado, ave; asno, ave.

Não está claro que para vocês somos o oracular Apolo? ${ }^{323}$

Em Ésquilo, öpvıs ocorre no sentido tanto de pássaro quanto de auspício. Com o significado de auspício, ocorre duas vezes nos Sete contra Tebas e duas vezes em Agamêmnon:

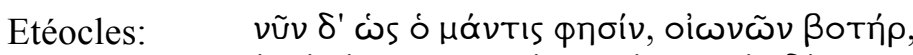

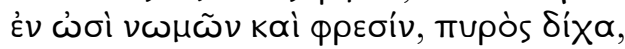

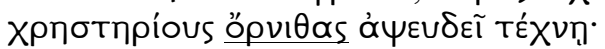
mas, agora, diz o adivinho pastor de pássaros, longe da pira, à escuta e em busca, atento às aves augurais, com arte sem mentira (Se. 24-6)

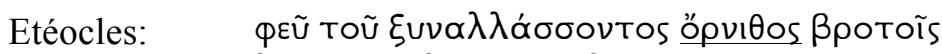

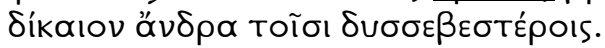

Phể! Que auspício associa o homem justo aos outros ímpios mortais! (Se. 597-8)

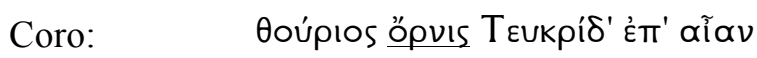
Impetuoso pássaro envia à terra têucrida $(A g .112)$

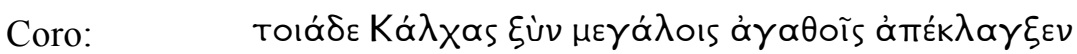

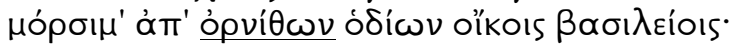

Calcas proclamou com grandes bens tais sinais de pássaros viários ao palácio real. (Ag. 156-7)

\footnotetext{
${ }^{322}$ Também a palavra oi $\omega v o ́ s$ possui ambos os sentidos de pássaro e auspício. O sentido de pássaro é o único em que oíwvós é utilizado em Ésquilo. Cf. $P r .488, S e .24$ e $A g .114$.

${ }^{323}$ Tradução de Adriane da Silva Duarte (2000).
} 


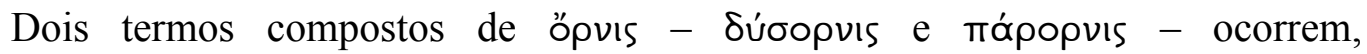
respectivamente, uma vez no Sete contra Tebas e uma vez nas Eumênides, com o sentido de "não auspicioso", "ominoso", "infausto":

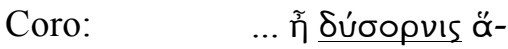

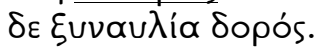 \\ infausta era esta sinfonia de lança. (Se. 838)

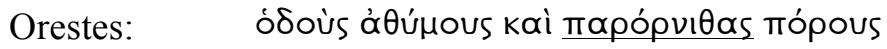 \\ desanimada marcha, infaustos passos $(E u .770)$
}

Os prodígios são descritos com o vocábulo Tépas, que descreve algo que é inusitado, grandioso, estupefaciente, monstruoso, assustador. Assim, nas Suplicantes, a visão que se tem da cornígera Io, meio novilha, meio mulher, é algo que se descreve como um prodígio: os mortais, habitantes da terra, como diz o Coro, ficam tépas $\delta^{\prime}$

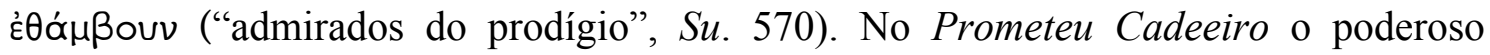
Tífon, os carvalhos falantes do oráculo de Zeus em Dodona e o futuro filho e inimigo de Zeus são todos descritos por Prometeu como Tépas, respectivamente: Sáıov Tépas

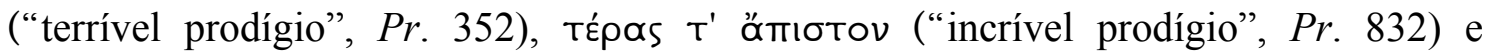

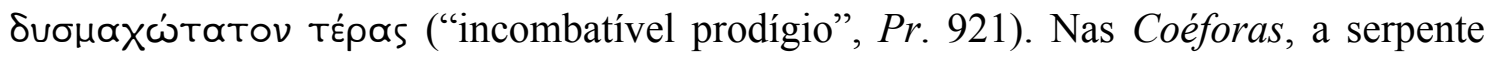

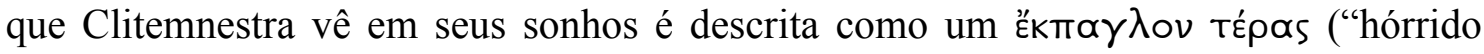
prodígio", Co. 548), ou seja, é um prodígio dentro de um sonho.

Os sacrifícios oferecem um repertório de sinais que revelam os desígnios divinos. O mesmo termo utilizado para a vítima sacrificial, oథá yıv, adquire também o sentido de sinais advindos do sacrifício. Assim, nos Sete contra Tebas, o Mensageiro relata que Anfiarau não permite que Tideu e seus homens cruzem o Ismeno porque oú

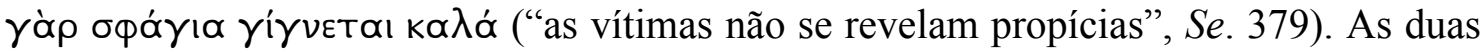
outras ocorrências do termo em Ésquilo são utilizadas no sentido de sacrifícios apenas (Se. 230 e Eu. 1006).

Também a linguagem, percebida como um dos aspectos fundamentais do mundo, é suporte para a manifestação de sinais divinatórios. Esses signos linguísticos,

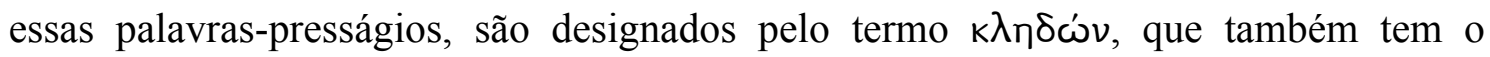
sentido de clamor, rumor, fama, palavra $\operatorname{dita}^{324}$. Com o sentido específico de uma enunciação de aspecto pressago, ocorre apenas uma vez em Ésquilo, quando, no

\footnotetext{
${ }^{324}$ E com esse sentido ocorre nove vezes nas tragédias de Ésquilo: Ag. 228, 863, 874, 927; Co. 505, 853, 1043; Eu. 397, 418.
} 
Prometeu Cadeeiro, o Titã enumera as formas de adivinhação que ele distinguiu para os mortais:

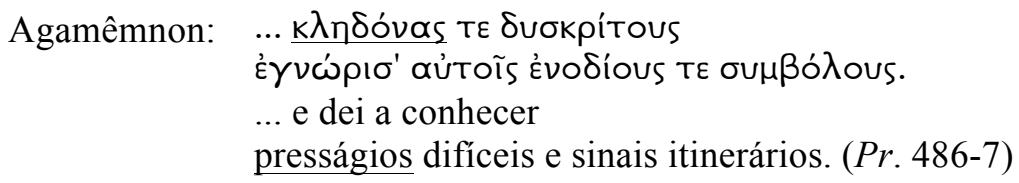

Enquanto palavra numinosa, portadora de remate, a maldição faz-se sinal divinatório, o que se evidencia no uso da palavra ópá nas tragédias de Ésquilo, que em certos contextos significa palavra imprecatória e, em outros, uma figuração do divino, sendo então traduzida com letra inicial maiúscula.

Apó ocorre 20 vezes nos dramas esquilianos. Nas Suplicantes, a única ocorrência surge no contexto de uma reflexão sobre a proteção que os altares trazem às suplicantes, protegendo-os até mesmo das palavras imprecatórias, e, no Prometeu Cadeeiro, ápá designa a imprecação de Crono contra Zeus, por este tê-lo destronado:

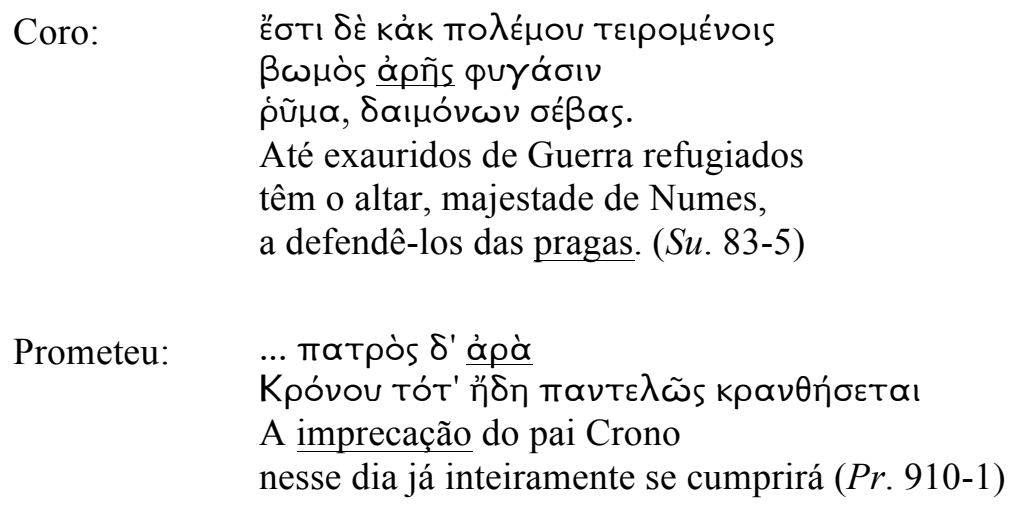

Em uma tragédia em que a maldição paterna desempenha um papel fundamental no destino do protagonista, não surpreende que o termo ápó apareça nove vezes nos Sete contra Tebas. Observe-se que, até o verso 653, quando Etéocles não sabe que irá

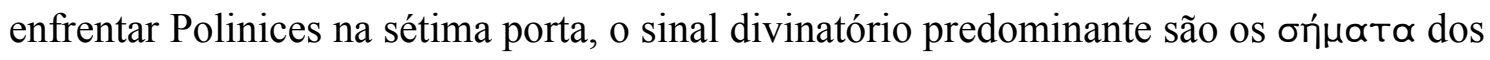
escudos que ele tem de interpretar. Após tomar ciência de que enfrentará Polinices, há várias repetições do termo ápó, que ocorrera até então uma única vez; todas as demais ocorrências se dão após o verso 653:

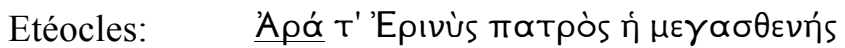
e Imprecação, Erínis do pai, a de grande força (Se.70) 


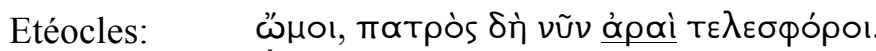

Ómoi! Cumpridoras são as pragas paternas. (Se. 655)

Etéocles: $\quad \quad \quad$ í̉ $\quad$ A

A negra Praga odiosa de meu caro pai $(\operatorname{Se} .695)$

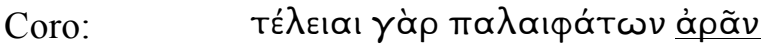

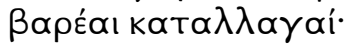

Cumprem-se os graves acordos

de outrora proclamadas pragas. $(\mathrm{Se} .766-7)$

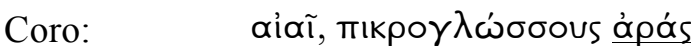

aiaû! - acerbas pragas (Se. 787)

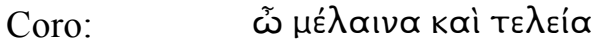

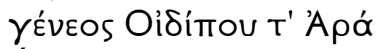

Ó negra e perfectiva

Praga da prole e de Édipo (Se. 832-3)

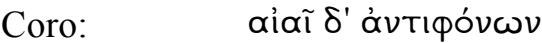

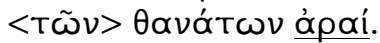

Aiầ! Pragas de

morte contra morte! (Se.893-4)

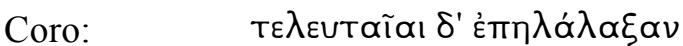

Apaì tòv ỏgùv vónov

Por fim aqui alaridearam

Pragas o canto agudo (Se. 953-4)

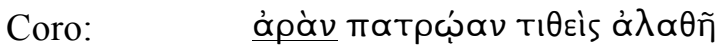

ao tornar verdade a praga paterna (Se.946)

Em Agamêmnon, a maior ocorrência de ápó (três vezes) diz respeito à imprecação pública contra os detentores do poder e apenas uma vez se refere à maldição de Tiestes lançada contra o palácio:

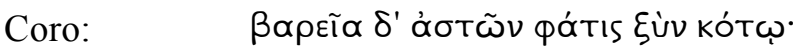

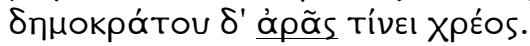

Grave é a palavra dos cidadãos irada

e cumpre o devido à imprecação pública. (Ag. 456-7)

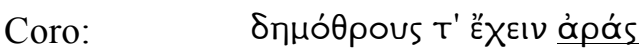

e pragas clamadas do povo ( $\mathrm{Ag}$. 1411)

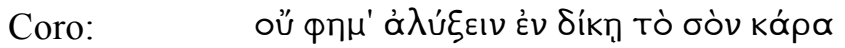

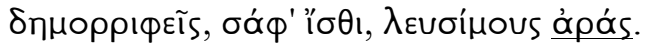

digo: com Justiça não livrarás tua cabeça

de pétreas pragas do povo, bem o sabe. (Ag. 1615-6) 


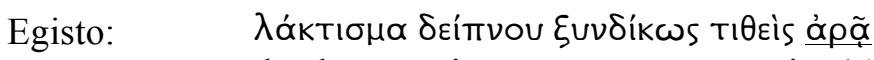
dando um coice na mesa ao praguejar $(A g .1601)$

Nas Coéforas, há quatro ocorrências do termo. Electra contrapõe a "bela prece"

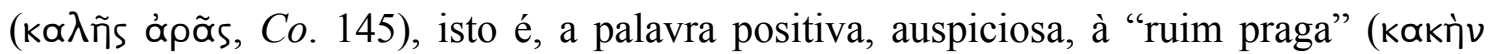
ápáv, Co. 146), a imprecação. Orestes alude ao poder das ápaí dos finados e Clitemnestra, ora à maldição do palácio, ora à sua própria:

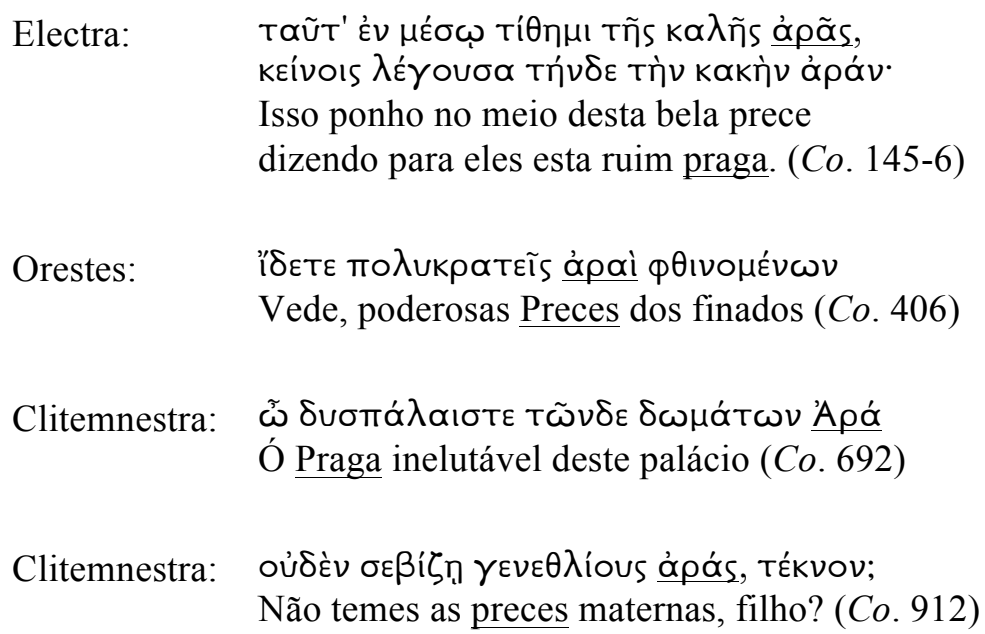

Nas Eumênides, a única ocorrência do termo é extremamente significativa, na medida em que identifica as Erínies com a própria maldição:

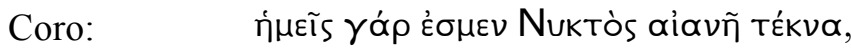

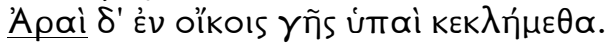
Nós somos as filhas da Noite eterna Imprecações nas moradias subterrâneas. (Eu. 416-7)

Como adjetivo, ápaĩos ocorre quatro vezes: uma nos Sete contra Tebas, com referência à maldição de Édipo, e três em contextos diversos em Agamêmnon:

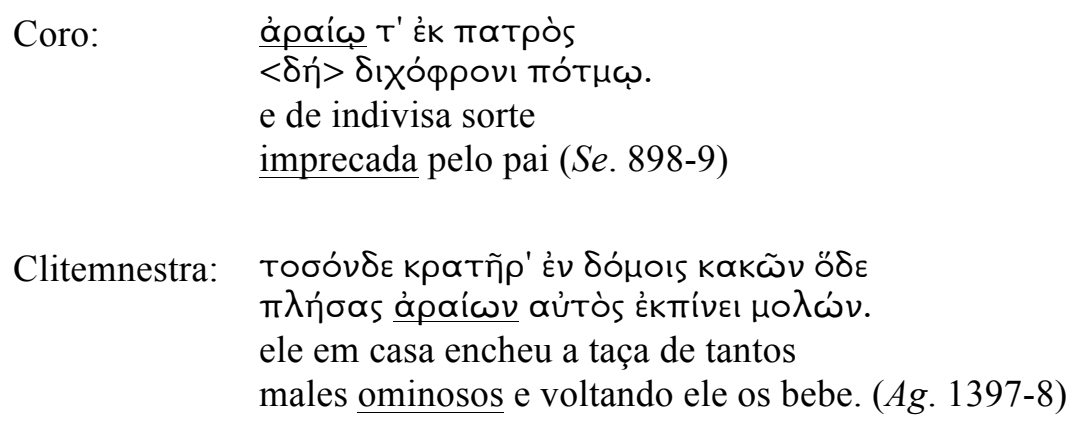




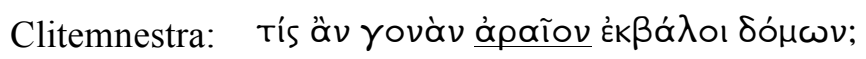

Quem baniria do palácio o nefasto grão? (Ag. 1565)

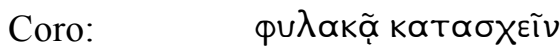

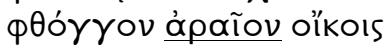
conter voz imprecatória contra o palácio (Ag. 236-7)

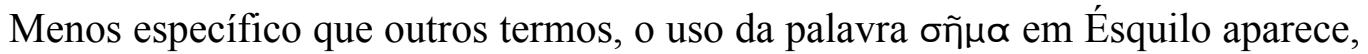
em duas ocorrências, para designar sinais divinatórios. No Prometeu Cadeeiro, esse sinais são os da piromancia e, nas Coéforas, são os sinais, não especificados, provenientes de Zeus:

\author{
Prometeu: $\quad$... kaì $\phi \lambda \circ \gamma \omega \pi \grave{\alpha}$ oń $\mu \alpha \tau \alpha$

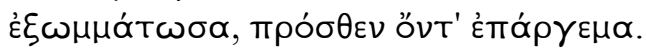 \\ ... e tornei visíveis \\ flamejantes signos, antes obscuros (Pr. 498-9)

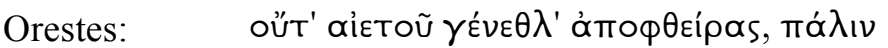

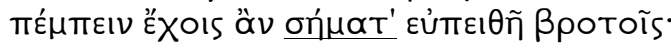 \\ Destruída a geração da águia, de novo \\ não enviarias signos fiéis aos mortais. (Co. 258-9)
}

As outras sete restantes ocorrências do termo designam as efígies dos escudos dos guerreiros nos Sete contra Tebas:

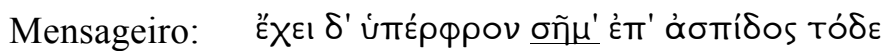

Tem sobre o escudo este soberbo signo $(\mathrm{Se} .387)$

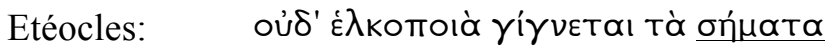
nem se tornam vulnerantes os signos $(\mathrm{Se} .398)$

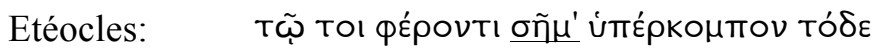
ao portador deste sobranceiro signo (Se.404)

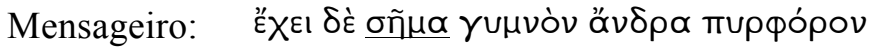

Tem por signo um homem nu ignífero (Se. 432)

Etéocles: $\quad$ Tрòs $\lambda$ óyov toũ ońmatos em razão do signo $(\mathrm{Se} .518)$

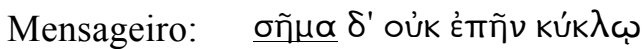
signo não havia no círculo ( $\mathrm{Se} .591)$ 


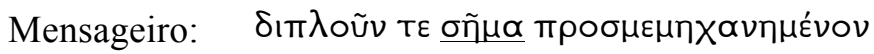

e duplo signo acrescentado com arte (Se. 643)

A rigor, portanto, tò oń arte divinatória, mas, como se pode perceber no decorrer do estudo sobre a adivinhação nos Sete contra Tebas, essas efígies são também e ao mesmo tempo sinais divinatórios a prenunciar o destino dos guerreiros que as ostentam em seus escudos.

Outro termo mais abrangente e menos específico para sinais divinatórios é o

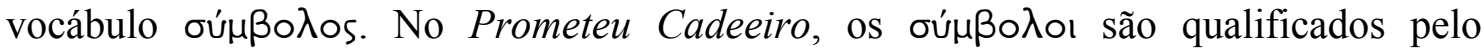

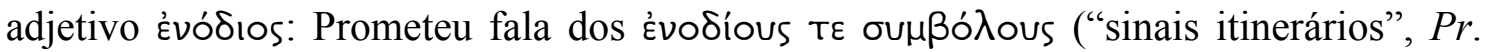
487), designando assim uma forma de cleromancia, a dos encontros fortuitos pelo caminho, que, conforme as circunstâncias e com o que o indivíduo se depara - uma pessoa, um animal, um acontecimento imprevisto -, configuram um bom ou um mau presságio.

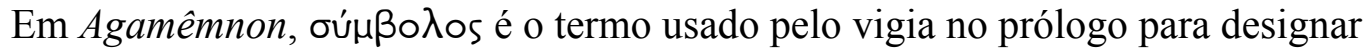
o sinal de fogo anunciador da vitória em Troia e do retorno de seu rei:

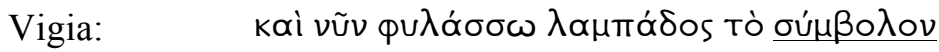
Agora aguardo o sinal do lampejo (Ag. 8)

Um exame atento do contexto em que esse termo ocorre deixa entrever que esse

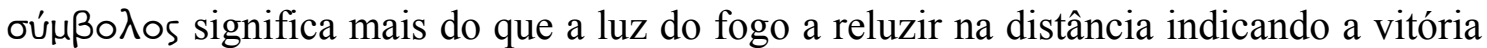
argiva; esse $\sigma u ́ \mu \beta \circ \lambda o s$ se faz numinoso e prenuncia o desencadeamento da série de crimes consanguíneos ocorridos ao longo da trilogia. Note-se que no párodo o termo é retomado dentro do contexto da interpretação de Calcas do auspício avistado em Áulida:

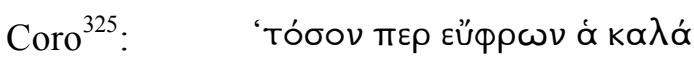

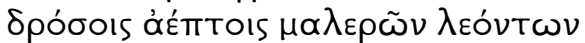

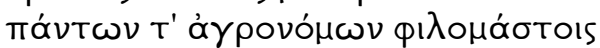

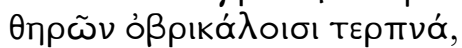

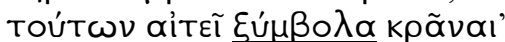

$$
\begin{aligned}
& \text { 'A Bela, porquanto benévola } \\
& \text { com filhotes inermes de árdegos leões } \\
& \text { e prazerosa com lactentes crias } \\
& \text { de todos os animais silvícolas, } \\
& \text { pede que deles se cumpram sinais' }(A g .140-4)
\end{aligned}
$$

\footnotetext{
${ }^{325}$ Reproduzindo em discurso direto as palavras de Calcas.
} 
A outra ocorrência do termo em Agamêmnon é igualmente significativa para o seu entendimento como sinal divinatório. Após o catálogo dos facheiros, em que Clitemnestra demonstra ter domínio sobre a distância espacial, ela descreve o que está acontecendo no momento em Troia e previne/prevê o que irá acontecer no retorno do exército, demonstrando assim um domínio também sobre a distância temporal. Ao fim de sua extensa fala, ela finaliza com o seguinte verso:

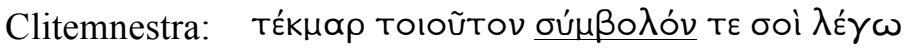

Tal é a prova e sinal que te digo $(A g .315)$

Ela oferece para o Coro seu conhecimento e seu domínio sobre a situação como

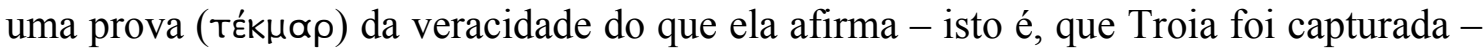
e como um sinal ( $\sigma u ́ \mu ß ం \lambda o ́ v)$. Mais do que um indício de sua certeza sobre o destino de

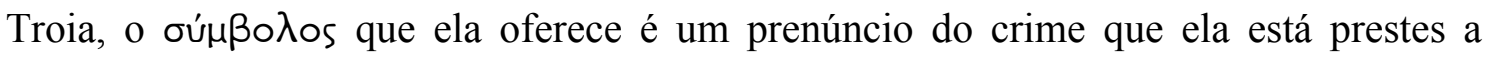
cometer.

De forma semelhante, nas Coéforas, a mecha de cabelos que Electra avista junto ao túmulo de seu pai é mais do que um indício da presença de um desconhecido; é, como ela diz ao Coro, um sinal auspicioso:

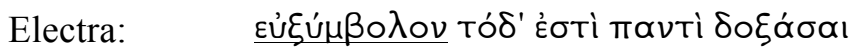

Bom sinal isto pode parecer a todos. (Co. 170)

\section{5) Verbos que designam o processo de interpretação dos sinais divinatórios}

Curiosamente, há apenas um verbo que indica o processo de interpretação dos sinais divinatórios e este verbo, kpívw, ocorre apenas três vezes nas tragédias de Ésquilo e sempre associado à onirocrítica, isto é, à atividade de interpretar sonhos:

\begin{tabular}{|c|c|}
\hline Rainha: & 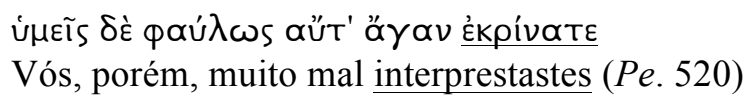 \\
\hline Orestes: & 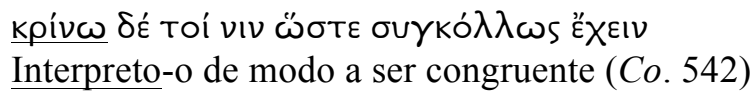 \\
\hline Prometeu: & 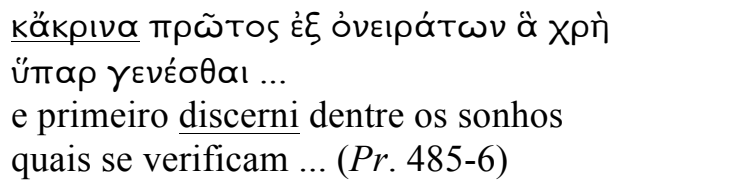 \\
\hline
\end{tabular}




\section{REFERÊNCIAS BIBLIOGRÁFICAS}

\section{Fontes primárias:}

AESCHYLI. Septem quae supersunt tragoedias. Edidit Denys Page. Oxford, Clarendon Press, 1972.

AESCHYLUS. Agamemnon. Edited by John Dewar Denniston and Denys Page.

Oxford, Clarendon Press, 1979. . Agamemnon. Edited with a commentary by Eduard Fraenkel. 3 vol. Oxford,

Clarendon Press, 1982, vol. 1: Prolegomena, text and translation, 194 pp.; vol. 2:

Commentary on 1-1055, 286 pp.; vol. 3: Commentary on 1056-1673, Appendixes, Indexes, $370 \mathrm{pp}$.

. Agamemnon. Libation-Bearers. Eumenides. Edited and translated by Alan

H. Sommerstein. Cambridge, Harvard University Press, 2008. . Agamemnon. Libation-Bearers. Eumenides. Fragments. Translated by

Herbert Weir Smyth. Cambridge, Harvard University Press, 1926.

. Choephori. Edited by A. Bowen. London, Bristol Classical Press, 1995.

. Choephori. Edited with introduction and commentary by A. F. Garvie.

Oxford, Clarendon Press, 2002.

. Eumenides. Edited with an introduction, translation and commentary by A.

J. Podlecki. Warminster, Aris \& Phillips Ltd., 1989.

. Eumenides. Edited with an introduction, translation and commentary by

Alan H. Sommerstein. Cambridge, Cambridge University Press, 1989.

. Persians. Seven against Thebes. Suppliants. Prometheus Bound. Edited and

translated by Alan H. Sommerstein. Cambridge, Harvard University Press, 2008.

. Persians and Other Plays. Translated by Christopher Collard. New York,

Oxford University Press, 2008.

. Seven against Thebes. Edited with introduction and commentary by G. O.

Hutchinson. Oxford, Clarendon Press, 1985.

. Seven against Thebes. Translated by Anthony Hecht and Helen H. Bacon.

Oxford and New York, Oxford University Press, 1991.

. Suppliant Maidens. Persians. Prometheus. Seven against Thebes.

Translated by Herbert Weir Smyth. Cambridge, Harvard University Press, 1922. 
. The Oresteia. Translated with notes by Hugh Lloyd-Jones. Berkeley, University of California Press, 1993.

. The Suppliants. Edited by H. Friis Johansen and E. W. Whittle. 3 vol. Copenhagen, Gyldendal, 1980, vol. 1: Bibliography, Introduction, Text, Apparatus, 120 pp.; vol. 2: Commentary 1-629, 517 pp.; vol. 3: Commentary 6301073, Indices, $480 \mathrm{pp}$.

APOLODORO. Biblioteca. Traducción y notas de Margarita Rodríguez de Sepúlveda. Madrid, Editorial Gredos, 1985.

APOLLODORUS. The Library. With an English translation by Sir James George Frazer. 2 vol. London, William Heinemann; New York, G. P. Putnam's Sons, 1921.

ARISTÓFANES. As Aves. Tradução, introdução, notas e glossário de Adriane da Silva Duarte. São Paulo, Hucitec, 2000.

Duas Comédias: Lisístrata e As termoforiantes. Tradução, apresentação e notas de Adriane da Silva Duarte. São Paulo, Martins Fontes, 2005. . As Rãs. Prefácio, tradução do grego, introdução e notas de Américo da Costa Ramalho. Lisboa, Edições 70, 2008. . Acarnenses, Tesmoforiantes, Rãs. Introdução, tradução e notas de Milena de Oliveira Faria. São Paulo, Martin Clairet (no prelo).

ARISTOTELES. Histoire des animaux. Text établi par P. Loius. 3 vol. Paris, Les Belles Lettres, vol. 1: 1964; vol. 2: 1968; vol. 3: 1969.

ARISTÓTELES. História dos Animais. Tradução de Maria de Fátima Silva e Sousa. 2 vol. Lisboa, Imprensa Nacional Casa da Moeda, 2008.

ARTEMIDORO. Sobre a Interpretação dos Sonhos. Tradução de Eliana Aguiar. Rio de Janeiro, Jorge Zahar Editor, 2009.

ARTEMIDORUS. Artemidori Daldiani Onirocriticon libri $V$. Edited by Roger Ambrose Pack. Leipzig, Teubner, 1963.

CÍCERO. Sobre a adivinhação. 2009. 239 ff. Dissertação de mestrado (Mestre em Linguística) - Departamento de Linguística, Universidade Estadual de Campinas, Campinas, 2009.

CICÉRON. De la divination. Du destin. Académiques. Traduction nouvelle avec notices et notes par Charles Appuhn. Paris, Librarie Garnier Frères, s/d. 
ESCHILO; SOFOCLE; EURIPIDE. I Tragici Greci. Cura e traduzione di Enzo Mandruzzato, Filippo Maria Pontani, Leone Traverso, Manara Vagimigli. Roma, Newton Compton Editori, 2010.

. Tutte le tragedie. A cura di Angelo Tonelli. Milano, Bompiani, 2013.

ESCHYLE. L'Agamemnon d'Eschyle. Le texte et ses interpretations. Jean Bollack et Pierre Judet de la Combe. 3 vol. Cahiers de Philologie, v. 6, 7 e 8. Lille, Maison des sciences de 1'homme, 1981, vol. 1: Prologue, Parodos anapestique, Parodos lyrique I, 196 pp.; vol. 2: Parodos lyrique II-III, Preséntation du premier épisode, Premier Stasimon, Index, 387 pp.; vol. 3: Deuxième Stasimon, Accueil d'Agamemnon, Troisième Stasimon, Dernier 'Stasimon', 377 pp. . Agamemnon. Les Choéphores. Les Euménides. Traduit par Paul Mazon. Paris, Les Belles Lettres, 1952. . Les Suppliantes. Les Perses. Les Sept Contre Thèbes. Traduit par Paul Mazon. Paris, Les Belles Lettres, 1953.

. Théatre d'Eschyle. Traduction nouvelle avec texte, avant-propos, notices et notes par Émile Chambry. Paris, Librairie Garnier Frères, 1946.

ESQUILO. Tragedias. Los Persas, Los Siete contra Tebas, Las Suplicantes, Agamenón,

Las Coéforas, Las Euménides, Prometeo Encadenado. Introducción general de Manuel Fernández-Galiano. Traducción y notas de Bernardo Perea Morales. Madrid, Editorial Gredos, 1986.

ÉSQUILO. As Suplicantes. Prefácio, introdução, tradução e notas de Ana Paula Quintela Ferreira Sottomayor. Coimbra, Instituto de Estudos Clássicos, 1968. . Oresteia. Estudo e tradução de Jaa Torrano. 3 vol. São Paulo, Iluminuras / FAPESP, 2004.

. Persas. Introdução, tradução do grego e notas de Manuel de Oliveira Pulquério. Lisboa, Edições 70, 1998. . Prometeu Agrilhoado. Introdução, tradução do grego e notas de Ana Paula Quintela Sottomayor. Lisboa, Edições 70, 2001. . Tragédias: Os Persas, Os Sete contra Tebas, As Suplicantes, Prometeu Cadeeiro. Estudo e tradução de J.A.A. Torrano. São Paulo, Iluminuras, 2009.

EURÍPIDES. Teatro completo. Estudo e tradução de Jaa Torrano. 4 vol. São Paulo, Editora Iluminuras, no prelo.

EUSTATHIUS. Geographi Graeci minores. vol. 2. Edited by. K. Müller. Paris, Didot, 1861. 
Eustathii archiepiscopi Thessalonicensis commentarii ad Homeri Iliadem pertinentes. 4 vol. Edited by M. van der Valk. Leiden, Brill, 1971.

HERÓDOTO. História. Tradução do grego, introdução e notas de Mário da Gama Kury. 2. ed. Brasília, Editora Universidade de Brasília, 1998.

. Histórias - Livro VIII. Introdução de Carmen Leal Soares. Versão do grego e notas de José Ribeiro Ferreira e Carmen Leal Soares. Lisboa, Edições 70, 2002.

HESÍODO. Teogonia. Estudo e Tradução de J.A.A. Torrano. São Paulo, Iluminuras, 2001 .

. Os trabalhos e os dias (primeira parte). Introdução, tradução e comentários de Mary de Camargo Neves Lafer. São Paulo, Iluminuras, 2006.

. Os trabalhos e os dias. Estudo e tradução de Christian Werner. São Paulo, Hedra, 2013.

HIGYNUS. Fabulae. Edited by H. I. Rose. Leiden, A. W. Sythoff, 1933.

HINOS HOMÉRICOS. Hinos homéricos: tradução, notas e estudo. Edição e organização de Wilson Alves Ribeiro Jr. São Paulo, Editora UNESP, 2010.

HOMERO. Odisseia. Tradução de Carlos Alberto Nunes. Rio de Janeiro, Ediouro, 2001

- Ilíada. 2. ed. Tradução de Carlos Alberto Nunes. Rio de Janeiro, Ediouro, 2002.

PINDAR. Pythian Eleven. Edited with Introduction, Translation, and Commentary by J. P. Finglass. New York, Cambridge University Press, 2008.

PINDARE. Olympiques. Tome I. Texte établi et traduit par Aimé Puech. Paris, Les Belles Letrres, 1922.

. Pythiques. Tome II. Texte établi et traduit par Aimé Puech. Paris, Les Belles Letrres, 1955.

. Néméennes. Tome III. Texte établi et traduit par Aimé Puech. Paris, Les Belles Letrres, 1955.

PLATÃO. A República. Introdução, tradução e notas de Maria Helena da Rocha Pereira. 8a. ed. Lisboa, Fundação Calouste Gulbenkian, 1996.

. Crátilo. Introdução de José Trindade dos Santos e tradução de Maria José Figueiredo. Lisboa, Instituto Piaget, 2001.

. Fedro. Tradução de Carlos Alberto Nunes. Belém, Editora da Universidade Federal do Pará, 2011. 
PLUTARQUE. Ouvres Morales. Tome VI: Dialogues Pythiques. Texte établi et traduit par Robert Flacelière. Paris, Les Belles Lettres, 1974.

PROCLUS. Recherches sur la Chrestomathie de Proclos. IV: La Vita Homeri et les Sommaires $d u$ Cycle. Texte et traduction par A. Severyns. Paris, Les Belles Lettres, 1963.

SOPHOCLE. Ajax, Oedipe Roi, Électre. Texte établi par Alphonse Dain et traduit par Paul Mazon. Paris, Les Belles Lettres, 1994.

SÓFOCLES. As Traquínias. Introdução, versão do grego e notas de Maria do Céu Zambujo Fialho. Brasília, Editora da Universidade de Brasília, 1996. . Édipo em Colono. Tradução de Donaldo Schüler. Porto Alegre, L\&PM, 2002

Tragicorum Graecorum fragmenta. vol. 1. Ed. Bruno Snell. Göttingen, Vandenhoeck \& Ruprecht, 1971.

VIRGÍLIO. Eneida. Tradução de José Victorino Barreto Feio e José Maria da Costa e Silva. São Paulo, Martins Fontes, 2004.

\section{Bibliografia de apoio:}

ABELLÁN, F. P. D. de V. Los caminos de la muerte: religión, rito e iconografía del paso del más allá en la Grecia antigua. Madrid, Editorial Trotta, 1995.

ADRADOS, F. R. "El tema del león en el Agamemnón de Esquilo (717-49)”. Emerita, 33, 1965, pp. 1-5. . El mundo de la lírica griega antigua. Madrid, Alianza Editorial, 1981. . "La divination dans les choeurs de l'Agamemnon d'Eschyle". Revue des études grecques, 102 (2), 1989, pp. 295-307.

AÉLION, Rachel. "Songes et propheties d'Eschyle: une forme de mise en abyme". In: LALLOT, Jean (Ed.) Lalies - Actes des sessions de linguistique et de littérature III, Paris, Presses de l’École Normale Supérieure, 1981, pp. 133-46. . Euripide: héritier d'Eschyle. 2 tomes. Paris, Les Belles Lettres, 1983.

ALAUX, J. "Mimêsis et katharsis dans les Perses". L'Information littéraire, 53 (1), 2001, pp. 3-13. . "La caresse divine et le rapt masculin: représentations du féminin dans les Suppliantes d'Eschyle". L'Information littéraire, 53 (2), 2001, pp. 10-20. 
ALEXANDERSON, B. "Forebodings in the Agamemnon". Eranos, 67, 1969, pp. 1-23.

ALLEAU, R. (Ed.) Encyclopédie de la Divination. Madrid, Henri Veyrier, 1973.

AMANDRY, P. La mantique apollinienne à Delphes - Essai sur le fonctionnement de l'oracle. Paris, E. de Boccard, 1950.

AMENDOLA, S. "Due scudi neri come la notte. Il giuramento degli Argivi e lo scudo di Tideo nei Sette contro Tebe di Eschilo”. In: ESPOSITO, P. \& CACCIATORE, P. V. (Eds.) Strategie del commento a testi greci e latini - Atti del Convegno [Fisciano 16-18 novembre 2006]. Saveria Manelli: Rubbettino Editore, 2008, pp. 281-294.

. Donne e Preghiera: Le preghiere dei personaggi femminili nelle tragedie superstiti di Eschilo. Amsterdam, Hakkert, 2006.

ANDERSON, Michael. "The Imagery of The Persians". Greece and Rome, 19 (2), 1972, pp. 166-174.

ANNUS, A. (Ed.) Divination and Interpretation of Signs in the Ancient World. Chicago, The Oriental Institute of the University of Chicago, 2010.

ARMSTRONG, D. \& RATCHFORD, E. A. "Iphigenia's Veil - Aeschylus, Agamemnon 228-48. Bulletin of the Institute of Classical Studies, 32 (1), 1985, pp. $1-14$

ARNOTT, W. G. "The Eagle Portent in the Agamemnon: An Ornithological Footnote". Classical Quarterly, 29 (1), 1979, pp. 7-8.

. Birds in the Ancient World - From A to Z. London and New York, Routledge, 2007.

ASSAËL, Jacqueline. "La répétition comme procédé stylistique dans les Perses d'Eschyle". Cahiers du Gita, 7, 1992/1993, pp. 15-27.

ATHANASSAKI, Lucia. Mantic Vision and Diction in Pindar's Victory Odes. 1990. 206 ff. Thesis (Doctor of Philosophy) - Department of Classics, Brown University, Providence, 1990.

. "Choral and Prophetic Discourse in the First Stasimon of the Agamemnon". The Classical Journal, 89 (2), 1994, pp. 149-162.

; MARTin, R. P. \& Miller, J. F. (Eds.) Apolline Politics and Poetics: International Symposium, Delphi 4-11 July 2003. Athens, European Cultural Centre of Delphi, 2009.

AUSTIN, J. L. How to Do Things with Words - The William James Lectures Delivered at Harvard University in 1955. Oxford, Clarendon Press, 1962. 
AUSTIN, Norman. "Name Magic in the Odyssey". California Studies in Classical Antiquity, 5, 1972, pp. 1-19.

AVERY, Harry C. "Dramatic Devices in Aeschylus' Persians". American journal of philology, 85 (2), 1964, pp. 173-184.

BACELAR, A. P. "Um ato de culto à Arte Poética: O Hino ao Banho de Palas, de Calímaco - Tradução e Comentário”. Calíope, 17, 2007, pp. 119-137.

BACHVAROVA, M. R. "Suppliant Danaids and Argive Nymphs in Aeschylus". The Classical Journal, 104 (4), 2009, pp. 289-310.

BACON, H. H. “The Shield of Eteocles”. Arion, 3 (3), 1964, pp. 27-38. . “The Furies' Homecoming”. Classical Philology, 96 (1), 2001, pp. 48-59.

BAKEWELL, G. W. "Metoikía in the Supplices of Aeschylus". Classical Antiquity, 16 (2), 1997, pp. 209-228.

BALDRY, H. C. "The Dramatization of the Theban Legend". Greece and Rome, 3 (1), 1956, pp. 24-37.

BARKER, E. "Paging the Oracle: Interpretation, Identity and Performance in Herodotus' History. Greece and Rome, 53 (1), 2006, pp. 1-28.

BARRETT, James. "Narrative and the Messenger in Aeschylus' Persians". American journal of philology, 116 (4), 1995, pp. 539-557. . Staged Narrative - Poetics and the Messenger in Greek Tragedy. Berkeley, Los Angeles and London, University of California Press, 2002. . “Aeschylus”. In: JONG, I. J. F. DE; NÜNLIST, R. \& BOWIE, A. (Eds.) Narrators, Narratees, and Narratives in Ancient Greek Literature. Leiden, Brill, 2004.

BARRETT, W. S. Greek Lyric, Tragedy, and Textual Criticism - Collected Papers. Assembled and edited by M. L. West. Oxford, Oxford University Press, 2007.

BASTIDE, R. "La connaissance de l'événement”. In: BALANDIER, G.; BASTIDE, R.; BERQUE, J. \& GEORGE, P. (Eds.) Perspectives de la sociologie contemporaine - Hommage à George Gurvitch. Paris, Presses Universitaires de France, 1968, pp. 159-168.

BATAILLE, M.-J. “Le 'fou' et le devin dans la tragédie grecque”. Cahiers du Gita, 8, 1988, pp. 147-156.

BAYARD, L. "Pytho-Delphes et la légende du serpent". Revue des études grecques, 56, 1943, pp. 25-28. 
BEDNAROWSKI, K. P. Negotiating Dramatic Character in Aeschylean Drama. 2009. 382ff. Thesis (Doctor of Philosophy) - Department of Classics, University of Texas, Austin, 2009.

. "The Danaids' Threat: Obscurity, Suspense and the Shedding of Tradition in Aeschylus' Suppliants". The Classical Journal, 105 (3), 2010, pp. 193-212.

"When the Exodos is not the End: The Closing Song of Aeschylus' Suppliants". Greek, Roman and Byzantine Studies, 51 (4), 2011, pp. 552-578.

BELFIORE, E. S. Murder Among Friends - Violation of Philia in Greek Tragedy. New York and Oxford, Oxford University Press, 2000.

BENARDETE, S. "The Crimes and Arts of Prometheus". Rheinisches Museum für Philologie, 107 (2), 1964, pp. 126-139.

BENEDETTO, V. Di. "La casa, il démone e la struttura dell'Orestea". Rivista di filologia e di istruzione classica, 112, 1984, pp. 385-406.

BENVENISTE, É. Le vocabulaire des institutions indo-européennes 1 - Économie, parenté, société. Paris, Les Éditions de Minuit, 1969.

. Le vocabulaire des institutions indo-européennes 2 - Pouvoir, droit, religion. Paris, Les Éditions de Minuit, 1969.

. "La légende des Danaïdes". Revue de l'histoire de religions, 136 (2/3), 1949, pp. 129-138.

. "L'expression du serment dans la Grèce ancienne". Revue de l'histoire de religions, 134 (1-3), 1945, 81-94.

BERMAN, David W. Myth and culture in Aeschylus' Seven against Thebes. Roma, Edizioni dell' Ateneo, 2007.

BERNAND, A. “Les animaux dans la trágedie grecque”. Dialogues d'histoire ancienne, 12, 1986, pp. 241-269.

BLOCH, Raymond. La Divination - Essai sur l'avenir et son imaginaire. Paris, Fayard, 1991.

. La adivinación en la antigüedad. México, Fondo de Cultura Económica, 2002.

BLUNDELL, S. \& WILLIAMSON, M. (Eds.) The Sacred and the Feminine in Ancient Greece. London, Routledge, 1998.

BOLLACK, J. “Styx et serments”. Revue des études grecques, 71, 1958, pp. 1-35. . "Le thrène de Cassandre". Revue des études grecques, 94, 1981, pp. 1-13. 
. "Prometheus Bound: Drama and Enactment". In: CAIRNS, D. L. \&

LIAPIS, V. (Eds.) Dionysalexandros: Essays in Honor of Alexander F. Garvie.

Swansea, Classical Press of Wales, 2006, pp. 79-89.

BONANNO, M. G. “Assenza, più acuta presenza. Ifigenia nell'Agamennone di Eschilo”. Lexis, 24, 2006, pp. 199-210.

BONNAFÉ, A. "Texte, carte et territoire: autour de l'itinéraire d'Io dans le Prométhée (1ère partie)". Journal des savants, 3/4, 1991, pp. 133-193.

. "Texte, carte et territoire: autour de l'itinéraire d'Io dans le Prométhée (2e partie)". Journal des savants, 1, 1992, pp. 3-34.

BONNARD, J-B. “'Au nom du père': la malédiction paternelle en Grèce ancienne”.

Mondes Anciens, 5, 2014, 2-13.

BONNER, Campbell. "A Study of the Danaid Myth". Harvard Studies in Classical Philology, 13, 1902, pp. 129-173.

BOOTH, N. B. "The Run of the Sense in Aeschylus' Choephori 22-83". Classical Philology, 54 (2), 1959, pp. 111-113.

BORDAUX, Lucien. "Lecture du premier stasimon des Perses, v. 532-597". Cahiers $d u$ Gita, 7, 1992/1993, pp. 71-80.

BORDES, J. "Le tirage au sort, principe de la démocratie athénienne". Ethnologie française, 17 (2/3), 1987, pp. 145-150.

BOUCHÉ-LECLERCQ, Auguste. Histoire de la Divination dans l'Antiquité. Grenoble, Éditions Jérôme Millon, 2003.

BOWDEN, Hugh. Classical Athens and the Delphic Oracle. Cambridge, Cambridge University Press, 2005.

BOWIE, Angus M. "Religion and Politics in Aeschylus' Oresteia". Classical Quarterly, 43 (1), 1993, pp. 10-31.

. “Atenas y Delfos: adivinación, ley y lenguaje en la Orestíada". In: TOBIA, Ana María González de. (Org.). Lenguaje, discurso y civilización. De Grecia a la modernidad. La Plata, UNLP, 2007, pp. 353-371.

BOWMAN, L. “Klytaimnestra's Dream: Prophecy in Sophokles' Elektra”. Phoenix, 51 (2), 1997, pp. 131-151.

BRASETE, M. F. “Agamémnon na Lírica Arcaica Grega”. Ágora, 16, 2014, pp. 11-28, 2014.

BRAUND, S. \& MOST, G. W. (Eds.) Ancient Anger - Perspectives from Homer to Galen. New York, Cambridge University Press, 2004. 
BREMMER, J. The Early Greek Concept of the Soul. Princeton, Princeton University Press, 1983.

. "Agamemnon's Death in the Bath: Some Parallels". Mnemosyne, 39 (3/4), 1986, p. 418. . Interpretations of Greek Mythology. London, Routledge, 1988. . The Rise and Fall of the Afterlife - The 1995 Read-Tuckwell Lectures at the University of Bristol. New York, Routledge, 2002.

. "Sacrificing a Child in Ancient Greece: The Case of Iphigeneia". In: NOORT, E. \& TIGCHELAAR, E. (Eds.). The Sacrifice of Isaac - The Aqedah (Genesis 22) and its Interpretations. Leiden, Brill, 2002, pp. 21-43.

. "Manteis, Magic, Mysteries and Mythography - Messy Margins of Polis Religion?”. Kernos, 23, 2010, pp. 13-35.

\& ERSKINE, A. (Eds.) The Gods of Ancient Greece - Identities and Transformations. Edinburgh, Edinburgh University Press, 2010.

BRILLANTE, C. Studi sulla rappresentazione del sogno nella Grecia antica. Palermo, Selerio Editore, 1991.

BROWN, A. D. F. "The recognition-scene in Choephori”. Revue des études grecques, 74, 1961, pp. 363-370.

BROWN, A. L. "The End of Seven against Thebes". Classical Quarterly, 26 (2), 1976, pp. 206-219.

. "Eteocles and the Chorus in the Seven against Thebes". Phoenix, 31 (4), 1977, pp. 300-318.

. "Some Problems in the Eumenides of Aeschylus". The Journal of Hellenic studies, 102, 1982, pp. 26-32.

. "The Erinyes in the Oresteia: Real Life, the Supernatural, and the Stage". The Journal of Hellenic studies, 103, 1983, pp. 13-34.

. "Eumenides in Greek Tragedy". Classical Quarterly, 34 (2), 1984, pp. 260 281.

. "Prometheus Pyrphoros". Bulletin of the Institute of Classical Studies, 37 (1), 1990, pp. 50-56.

BURIAN, Peter. "Zeus $\Sigma \Omega$ THP TPITO $\Sigma$ and Some Triads in Aeschylus' Oresteia". American journal of philology, 107 (3), 1986, pp. 332-342.

. "Biologia, democrazia e donne nelle Eumenidi di Eschilo". Lexis, 24, 2006, pp. 127-140. 
BURKERT, W. Homo Necans - The Anthropology of Ancient Greek Sacrificial Ritual and Myth. Berkeley, Los Angeles and London, University of California Press, 1986.

- Religião grega na época clássica e arcaica. Lisboa, Fundação Calouste Gulbenkian, 1993.

. "Causalité religieuse: la faute, les signes, les rites". Mètis, 9/10, 1994, pp. $27-40$.

. "A Seer or a Healer": Magic and Medicine". In: . The Orientalizing Revolution - Near Eastern Influence on Greek Culture in the Early Archaic Age. Cambridge, Harvard University Press, 1995, pp. 41-87.

BURNETT, A. "Curse and Dream in Aeschylus' Septem”. Greek, Roman and Byzantine Studies, 14 (4), 1973, pp. 343-368.

CAIRNS, D. L. Aidos - The Psychology and Ethics of Honour and Shame in Ancient Greek Literature. Oxford, Clarendon Press, 1993.

CALAME, C. Choruses of Young Women in Ancient Greece: Their Morphology Religious Role and Social Functions. London, Rowman \& Littlefield Publishers Inc., 1997a.

. "De la poésie chorale au stasimon tragique”. Mètis, 12, 1997b, pp. 181-203. . "Entre narrativa heróica e poesia ritual: O sujeito poético que canta o mito". Letras Clássicas, 9, 2005, pp. 47-65.

CALDWELL, R. S. "The Pattern of Aeschylean Tragedy". Transactions of the American Philological Association, 101, 1970, pp. 77-94.

CAMERON, H. D. "The Debt to Earth in the Seven against Thebes". Transactions of the American Philological Association, 95, 1964, pp. 1-8.

. "'Epigoni' and the Law of Inheritance in Aeschylus' Septem". Greek, Roman and Byzantine Studies, 9 (3), 1968, pp. 247-257.

. "The Power of the Words in the Seven against Thebes". Transactions of the American Philological Association, 101, 1970, pp. 95-118.

. Studies on the Seven against Thebes of Aeschylus. The Hague, Mouton, 1971.

CAQUOT, A. \& LEIBOVICI, M. (Eds.) La divination - Rites et pratiques religieuses. 2 vol. Paris, Presses Universitaires de France, 1968. 
CARASTRO, M. "Quand Tirésias devint un mágos. Divination et magie en Grèce ancienne (Ve-IVe siècle av. n. è.)". Revue de l'histoire de religions, 224 (2), 2007, pp. 211-230.

CARRIÈRE, J.-C. “Oracles et prodiges de Salamine. Hérodote et Athènes”. Dialogues d'histoire ancienne, 14, 1988, pp. 219-275.

- "La voix des femmes: Les femmes et la guerre dans les Sept contre Thèbes". In: FICK, N. \& (Eds.) Mélanges Étienne Bernand. Besançon, Les Belles Lettres, 1991, pp. 43-54.

CASEVITZ, Michel. "Les devins des tragiques”. Cahiers du Gita, 4, 1988, pp. 115-129. . "Mantis: Le vrai sense”. Revue des études grecques, 105, 1992, pp. 1-18.

CASTRUCCI, G. "Dodona versus Delphi in Greek Tragedy: The Wanderings of the Hero Between Expiation and Ties of Genos”. Logeion, 2, 2012, pp. 1-25.

CATENACCIO, C. "Dream as Image and Action in Aeschylus' Oresteia". Greek, Roman and Byzantine Studies, 51 (2), 2011, pp. 202-231.

CEBRIAN, R. B. "El oráculo de Dodona y la lengua de las mujeres". Arys: Antigüedad: religiones y sociedades, 5, 2002, pp. 31-38.

CHANTRAINE, P. Dictionnaire étymologique de la langue grecque: Histoire des mots. Paris, Editions Klincksieck, 2008.

CHAPPELL, Mike. "Delphi and the Homeric Hymn to Apollo". Classical Quarterly, 56 (2), 2006, pp. 331-348.

CHASE, George H. "The Shield Devices of the Greeks". Harvard Studies in Classical Philology, 13, 1902, pp. 61-127.

CHIASSON, C. C. 'Sophronountes en chronoi: The Athenians and Time in Aeschylus' Eumenides". The Classical Journal, 95 (2), 1999/2000, pp. 139-161.

CHIESI, G. M. "Reading Aeschylean Images: Matricide and the Blood in Maternal Milk in Clytemnestra's Dream”. Logeion, 1, 2011, pp. 31-40.

CLINTON, K. “Apollo, Pan, and Zeus, Avengers of Vultures: Agamemnon, 55-59." American journal of philology, 94 (3), p. 282-288, 1973.

COHEN, D. "The Theodicy of Aeschylus: Justice and Tyranny in the Oresteia". Greece and Rome, 33 (2), 1986, pp. 129-141.

COLLINS, D. "Reading the Birds: Oionomanteia in Early Epic". Colby Quarterly, 38 (1), 2002, pp. 17-41.

COLOMBO, I. C. “Le Dionysos oraculaire”. Kernos, 4, 1991, pp. 205-217. 
. "Teras ou les modalités du prodige dans le discourse divinatoire grec: une perspective comparatiste”. In: GEORGOUDI, S.; PIETTRE, R. K.; SCHMIDT, F. (Eds.) La Raison des signes - Présages, rites, destin dans les sociétés de la Méditerranée ancienne. Leiden, Brill, 2012, p. 221-251.

CONACHER, D. J. "Interaction between Chorus and Characters in the Oresteia". American journal of philology, 95 (4), 1974, pp. 323-343. . Aeschylus' Prometheus Bound: A literary commentary. Toronto, University of Toronto Press, 1980. . Aeschylus - The Earlier Plays and Related Studies. Toronto, University of Toronto Press, 1996.

CORNO, D. del. "Dreams and their Interpretation in Ancient Greece". Bulletin of the Institute of Classical Studies, 29 (1), 1982, pp. 55-62.

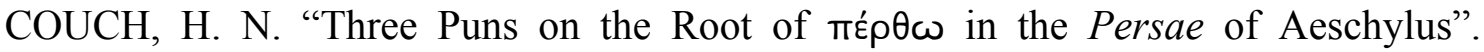
American journal of philology, 52 (3), 1931, pp. 270-273.

COULOUBARITSIS, L. “L'art divinatoire et la question de la vérité”. Kernos, 3, 1990, pp. 113-122.

CRAHAY, R. La littérature oraculaire chez Hérodote. Paris, Les Belles Lettres, 1956.

CRANE, G. "Politics of Consumption and Generosity in the Carpet Scene of the Agamemnon". Classical Philology, 88 (2), 1993, pp. 117-136.

CRIPPA, S. "Glossolalia. Il linguaggio di Cassandra". Studi italiani di linguistica teorica e applicata, 19 (3), 1990, pp. 487-508.

D'ANGOUR, A. The Greeks and the New - Novelty in Ancient Greek Imagination and Experience. Cambridge, Cambridge University Press, 2011.

D'ARMS, E. F. \& HULLEY, K. K. "The Oresteia-Story in the Odissey". Transactions of the American Philological Association, 77, 1946, pp. 207-213.

DAVIES, D. J. A Brief History of Death. Oxford, Blackwell Publishing, 2005.

DAVIES, I. "Thoughts on the Oresteia before Aischylos". Bulletin de correspondance hellénique, 93 (1), 1969, pp. 214-260.

DAVIES, J. K. "The Moral Dimension of Pythian Apolo". In: LLOYD, A. B. (Ed.). What is a God? Studies in the Nature of Greek Divinity. London, Duckworth, 1997, pp. 43-64.

DAVIES, M. “Aeschylus and the fable”. Hermes, 109, 1981, pp. 248-251. . “Aeschylus' Titans”. Hermes, 118 (1), 1990, pp. 125-127. 
DAWE, R. D. "The End of Seven against Thebes". Classical Quarterly, 17 (1), 1967, pp. 16-28.

. "Some Reflections on Ate and Hamartia". Harvard Studies in Classical Philology, 72, 1968, pp. 89-123.

DEBNAR, P. “The Sexual Status of Aeschylus' Cassandra”. Classical Philology, 105 (2), 2010, pp. 129-145.

DEFORGE, B. Eschyle, poète cosmique. Paris, Les Belles Lettres, 1986.

DEGENER, J. M. ' $\Sigma$ YMBO $\Lambda$ ON IФIГENEIA $\Sigma$ - La kledonographia de l'Agamemnon d'Eschyle". Cahiers du Gita, 9, 1996, pp. 31-51.

. "The Caesura of the Symbolon in Aeschylus' Agamemnon". Arethusa, 34

(1), 2011, pp. 61-95.

DELCOURT, M. "Tydée et Mélanippe”. Studi e materiali di storia delle religioni, 37, 1966, pp. 139-188.

DELGADO, J. A. F. Los oráculos y Hesíodo - Poesía oral mántica y gnómica griegas. Cáceres, Ediciones Universidad de Extremadura, 1986.

DEMONT. P. "Lots héroïques: remarques sur le tirage au sort de l'Iliade aux Sept contre Thèbes d'Eschyle". Revue des études grecques, 113, 2000, pp. 299-325.

DÉTIENNE, M. Les maîtres de vérité dans la Grèce archaïque. Paris, Pocket, 1994. . "Forgetting Delphi between Apollo and Dionysus". Classical Philology, 96 (2), 2001, pp. 147-158.

. The Greeks and Us - A Comparative Anthropology of Ancient Greece. Cambridge, Polity Press, 2007. . \& VERNANT, J.-P. Métis - As astúcias da inteligência. Tradução de Filomena Hirata. São Paulo, Odysseus Editora, 2008.

DEVEREUX, George. Dreams in Greek Tragedy - An Ethno-Psycho-Analytical Study. Berkeley and Los Angeles, University of California Press, 1976.

DEVITO, A. "Eteocles, Amphiaraus, and Necessity in Aeschylus' Seven against Thebes". Hermes, 127 (2), 1999, pp. 165-171.

DIAMANTOPOULOS, A. "The Danaid Tetralogy of Aeschylus". The Journal of Hellenic studies, 77 (2), 1957, pp. 220-229.

DÍAZ, M. E. “Una explicación naturalista de los sueños: el fenómeno onírico en el pensamiento aristotélico". Hypnos, 29 (2), 2012, pp. 218-236.

DIETRICH, B. C. "Reflections on the Origins of the Oracular Apollo". Bulletin of the Institute of Classical Studies, 25 (1), 1978, pp. 1-18. 
. "Oracles and Divine Inspiration”. Kernos, 3, 1990a, pp. 157-174.

. "Early Oracular Practice: Inspiration by Divination". Mediterranean Studies, 2, 1990b, pp. 7-20.

. "Divine Madness and Conflict at Delphi”. Kernos, 5, 1992, pp. 41-58.

DOBSON, M. W. D.-S. Oracular Language: Its Style and Intent in the Delphic Oracles and Aeschylus' "Oresteia". 1976. 215ff. Thesis (Doctor of Philosophy) Departament of Classics, Harvard University, Cambridge, 1976.

DODDS, E. R. The Greeks and the Irrational. Berkeley, University of California Press, 1951.

DONATO, R. di. "Ritualità e teatro nei Persiani”. Lexis, 28, 2010, pp. 59-66.

DORDA, E. C. “Adivinos y arte adivinatória en Eurípides”. Prometheus, 32, 2006, pp. 121-147.

DOUGHERTY, C. "When Rain Falls from the Clear Blue Sky: Riddles and Colonization Oracles”. Classical Antiquity, 11 (1), 1992, pp. 28-44. . Prometheus. New York, Routledge, 2006.

DOVER, K. J. "The Political Aspect of Aeschylus's Eumenides". The Journal of Hellenic studies, 77 (2), 1957, pp. 230-237.

. "Some Neglected Aspects of Agamemnon's Dilemma". The Journal of Hellenic studies, 93, 1973, pp. 58-69. . "The Red Fabric in the Agamemnon". In: (Ed.). Greek and the

Greeks: Collected Papers: Volume I: Language, Poetry, Drama. Oxford, Basil Blackwell, 1987, pp. 151-160.

DUÉ, C. The Captive Woman's Lament in Greek Tragedy. Austin, University of Texas Press, 2006.

DUMORTIER, Jean. "L'évocation des morts dans l'Odyssée". Bulletin de l'Association Guillaume Budé, n. 3, p. 27-40, 1954. . Les images dans la poésie d'Eschyle. Paris, Les Belles Lettres, 1975a. . Le vocabulaire médical d'Eschyle et les écrits hippocratiques. 2a. ed. Paris, Les Belles Lettres, 1975b.

DUPONT, F. L'insignifiance tragique: Les Choéphores d'Eschyle, Électre de Sophocle, Électre d'Euripide. Paris, Éditions Gallimard, 2001.

EAGLETON, T. Sweet Violence: The Idea of the Tragic. Oxford, Blackwell Publishing, 2003. 
EASTERLING, P. E. (Ed.) The Cambridge Companion to Greek Tragedy. Cambridge, Cambridge University Press, 1997.

EBBOTT, Mary. "The List of the War Dead in Aeschylus' Persians". Harvard Studies in Classical Philology, 100, 2000, pp. 83-96.

EDWARDS, M. W. “Agamemnon's Decision: Freedom and Folly in Aeschylus". California Studies in Classical Antiquity, 10, 1977, pp. 17-38.

EGAN, R. B. "The Prophecies of Calchas in the Aulis Narrative of Aeschylus' Agamemnon". Mouseion, 7 (3), 2008, pp. 179-212.

EIDINOW, E. Oracles, Curses and Risk among the Ancient Greeks. Oxford, Oxford University Press, 2007.

EITREM, S. "The Necromancy in the Persai of Aischylos". Symbolae Osloenses, 6 (1), 1928, pp. 1-16.

ELAYI, J. "Deux oracles de Delphes: Les réponses de la Pythie a Clisthène de Sicyone, et aux Athéniens avant Salamine”. Revue des études grecques, 92, 1979, pp. 224230.

EVANS, J. A. S. "The Oracle of the 'Wooden Wall”. The Classical Journal, 78 (1), 1982, pp. 24-29.

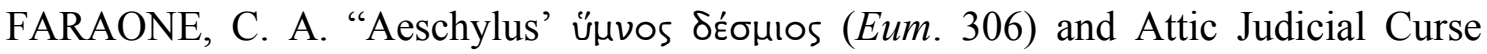
Tablets. The Journal of Hellenic studies, 105, 1985, pp. 150-154.

. \& OBBINK, D. (Eds.) Magika Hiera - Ancient Greek Magic and Religion. New York and Oxford, Oxford University Press, 1991.

FERRARI, G. "Figures in the Text: Metaphors and Riddles in the Agamemnon". Classical Philology, 92 (1), 1997, pp. 1-45.

FESTUGIÈRE, A.-J. "Tragédie et tombes sacrées". Revue de l'histoire de religions, 184 (1), 1973, pp. 3-24.

FISHER, R. S. \& LEWIS, A.-M. “Agamemnon, Troy and the Pleiades”. Revue belge de philologie et d'histoire, 62 (1), 1984, pp. 5-15.

FLACELIÈRE, R. "Plutarque et la Pythie". Revue des études grecques, 56, 1943, pp. 72-111.

. "Le délire de la Pythie est-il une légende?" Revue des études anciennes, 52, 1950, pp. 306-324.

Devins et oracles grecs. Paris, Presses Universitaires de France, 1965.

FLETCHER, Judith. "Choral Voice and Narrative in the First Stasimon of Aeschylus' Agamemnon"”. Phoenix, 53 (1/2), 1999, pp. 29-49. 
. Performing Oaths in Classical Greek Drama. New York, Cambridge University Press, 2012.

FLINTOFF, E. "The Ending of the Seven against Thebes". Mnemosyne, 33 (3/4), 1980, pp. 244-271.

FLOWER, H. I. "Herodotus and Delphic Traditions about Croesus". In: FLOWER, M.

A. \& TOHER, M. (Eds.) Georgica: Studies in Honour of George Cawkwell. London, University of London. Institute of Classical Studies, 1991, pp. 57-77.

FLOWER, M. A. The Seer in Ancient Greece. Berkeley and Los Angeles, University of California Press, 2008.

FOLEY, H. P. Female Acts in Greek Tragedy. Princeton and Oxford, Princeton University Press, 2001.

FONTENROSE, J. "The Sorrows of Ino and of Procne". Transactions of the American Philological Association, 79, 1948, pp. 125-167.

. "Gods and Men in the Oresteia". Transactions of the American Philological Association, 102, 1971, pp. 71-109.

. "The Oracular Response as a Traditional Narrative Theme". Journal of Folklore Research, 20 (2/3), 1983, pp. 113-120.

FORDYCE, C. J. "Puns on Names in Greek". The Classical Journal, 28 (1), 1932, pp. 44-46.

FOWLER, B. H. "The Imagery of the Prometheus Bound". American journal of philology, 78 (2), 1957, pp. 174-184. . “Aeschylus' Imagery". Classica et Mediaevalia, 28, 1967, pp. 1-74. . "The Creatures and the Blood". Illinois classical studies, 16, 1991, pp. 85100.

FURLEY, William D. "Motivation in the Parodos of Aeschylus' Agamemnon". Classical Philology, 81 (2), 1986, pp. 109-121. . "The Manipulation of Divine Signs". In: Andocides and the

Herms: a Study of Crisis in Fifth-Century Athenian Religion. London, Institute of Classical Studies, 1996, pp. 93-101.

GAGARIN, M. Aeschylean Drama. Berkeley, University of California Press, 1976.

GALLEGO, J. "El pensamiento trágico de la política democrática. El acontecimiento de una nueva justicia en la Orestía de Esquilo”. Gerión, 17, 1999, pp. 179-211.

. "Figuras de la tiranía, lo femenino y lo masculino en la Orestía de Esquilo". Studia historica: Historia antigua, 18, 2000, pp. 65-90. 
GANTZ, T. N. "The fires of the Oresteia”. The Journal of Hellenic studies, 97, 1977, pp. 28-38.

. "Love and Death in the Suppliants of Aischylos". Phoenix, 32 (4), 1978, pp. 279-287.

. "Divine Guilt in Aischylos". Classical Quarterly, 31 (1), 1981, pp. 18-32.

. "Inherited Guilt in Aischylos". The Classical Journal, 78 (1), 1982, pp. 1-

23.

. "The Chorus of Aischylos' Agamemnon". Harvard Studies in Classical Philology, 87, 1983, pp. 65-86.

. Early Greek Myth - A Guide to Literary and Artistic Sources. 2 vol.

Baltimore, Johns Hopkins University Press, 1996.

GARLAND, R. The Greek Way of Death. Ithaca, Cornell University Press, 1988.

GARRIDO, R. F. \& LOBO, M. A. V. “La terminología griega para ‘sueño’ y ‘soñar””.

Cuadernos de Filología Clásica, 13, 2003, pp. 69-104.

GARTZIOU-TATTI, A. "L'oracle de Dodone. Mythe et rituel”. Kernos, 3, 1990, pp. 175-184.

GARVIE, A. F. "The opening of the Choephori". Bulletin of the Institute of Classical Studies, 17 (1), 1960, pp. 79-91. - Aeschylus' Supplices - Play and Trilogy. Cambridge, Cambridge University Press, 1969. . "Text and Dramatic Interpretation in Persae". Lexis, 17, 1999a, pp. 21-40. . "Sur quelques passages de l'Agamemnon et des Choéphores d'Eschyle". Lexis, 17, 1999b, pp. 83-107. . "Alliteration in Aeschylus". Lexis, 20, 2002, pp. 3-12. . "Nuove riflessioni sulle Supplici”. Lexis, 24, 2006, pp. 32-42.

GARZYA, A. 'Le tragique du Prométhée Enchaîné d'Eschyle. Mnemosyne, 18 (2), 1965, pp. 113-125.

GASTALDI, V. "Memoria y derecho en el teatro de Esquilo: La voz del Coro en Coéforas". Letras Clássicas, 6, 2002, pp. 55-65.

GEORGE, C. H. Expressions of Agency in Ancient Greek. New York, Cambridge University Press, 2005.

GERNET, L. "Delphes et la pensée religieuse en Grèce”. Annales. Économies, Sociétés, Civilisations, 10 (4), 1955, pp. 526-542. 
GHIRON-BISTAGNE, P. "Clytemnestre, l'épouse infidèle". Cahiers du Gita, 8, 1994/1995, pp. 53-81.

GIBERT, J. “Apollo's Sacrifice: The Limits of a Metaphor in Greek Tragedy”. Harvard Studies in Classical Philology, 101, 2003, pp. 159-206.

GINZBURG, Carlo. "Sinais: Raízes de um paradigma indiciário". In:

Mitos, emblemas, sinais - Morfologia e História. São Paulo, Companhia das Letras, 1989, pp. 143-179.

GIORDANO, Manuela. La parola efficace - Maledizioni, giuramenti e benedizioni nella Grecia Arcaica. Pisa/Roma, Istituti Editoriali e Poligrafici Internazionali, 1999.

GLOTZ, G. L'Ordalie dans la Grèce primitive. New York, Arno Press, 1979.

GOFF, B. "The Shields of Phoenissae". Greek, Roman and Byzantine Studies, 29 (2), 1988, pp. 135-152.

. "The Women of Thebes". The Classical Journal, 90 (4), 1995, pp. 353-365.

. Citizen Bacchae - Women's Ritual Practice in Ancient Greece. Berkeley, Los Angeles and London, University of California Press, 2004.

GOLDEN, L. "The Character of Eteocles and the Meaning of the Septem". Classical Philology, 59 (2), 1964, pp. 79-89.

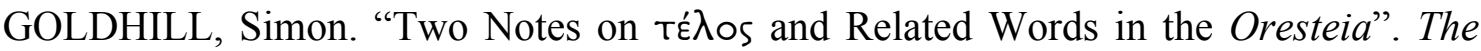
Journal of Hellenic studies, 104, 1984, pp. 169-176. . Reading Greek Tragedy. Cambridge, Cambridge University Press, 1986. . Language, Sexuality, Narrative - The Oresteia. Cambridge, Cambridge University Press, 1987.

- "Battle Narrative and Politics in Aeschylus' Persae". The Journal of Hellenic studies, 108, 1988, pp. 189-193. . Aeschylus: The Oresteia. Cambridge, Cambridge University Press, 2004.

GONZÁlEZ, M. G. "La 'metis' de Procne: acerca de Esquilo, Suplicantes 59-61". Minerva, 21, 2008, pp. 15-31.

GOSTOLI, A. "Some Aspects of the Theban Myth in the Lille Stesichorus". Greek, Roman and Byzantine Studies, 19 (1), 1978, pp. 23-27.

GOUDOT, M. (Ed.) Cassandre. Paris, Éditions Autrement, 1999.

GOUlD, T. F. \& HERINGTON, C. J. (Eds.) Greek Tragedy. Cambridge, Cambridge University Press, 2009. 
GOWARD, B. Telling Tragedy - Narrative Technique in Aeschylus, Sophocles and Euripides. London, Duckworth, 2004. . Aeschylus: Agamemnon. London, Duckworth, 2005.

GRAF, F. Apollo. New York, Routledge, 2009.

GREEN, P. "Possession and Pneuma: The Essential Nature of the Delphic Oracle". Arion, 17 (2), 2009, pp. 27-47.

GREGORY, J. (Ed.) A Companion to Greek Tragedy. Malden, Blackwell Publishing, 2005.

GRETHLEIN, J. "The Hermeneutics and Poetics of Memory in Aeschylus's Persae". Arethusa, v. 40, n. 3, 2007, pp. 363-396. . \& RENGAKOS, A. (Eds.) Narratology and Interpretation - The Content of Narrative Form in Ancient Literature. Berlin, Walter de Gruyter, 2009.

GRIFFITH, M. “The Vocabulary of Prometheus Bound”. Classical Quarterly, 34 (2), 1984, pp. 282-291.

. "Brilliant Dynasts: Power and Politics in the Oresteia". Classical Antiquity, 14 (1), 1995, pp. 62-129.

. "Slaves of Dionysos: Satyrs, Audience, and the Ends of the Oresteia". Classical Antiquity, 21 (2), 2002, pp. 195-258.

GRIFFITH, R. D. "Disrobing in the Oresteia”. Classical Quarterly, 38 (2), 1988, pp. $552-554$.

GRUBE, G. M. A. "Zeus in Aeschylus”. American journal of philology, 91 (1), 1970, pp. 43-51.

GUAL, C. G. “Tiresias o el adivino como mediador”. Emerita, 43, 1975, pp. 107-132.

HALDANE, J. A. "Musical Themes and Imagery in Aeschylus". The Journal of Hellenic studies, 85, 1965, pp. 33-41. . "Barbaric Cries" (Aesch. Pers. 633-639). Classical Quarterly, 22 (1), 1972, pp. $42-50$.

HALL, E. Greek Tragedy - Suffering under the Sun. Oxford, Oxford University Press, 2010 .

HALlidAY, W. R. Greek Divination - A Study of its Methods and Principles. Whitefish, Kessinger Publishing, 2003.

HAME, K. J.“All in the Family: Funeral Rites and the Health of the Oikos in Aischylos' Oresteia”. American journal of philology, 125 (4), 2004, pp. 513-538. 
. "Female Control of Funeral Rites in Greek Tragedy: Klytaimestra, Medea, and Antigone". Classical Philology, 103 (1), 2008, pp. 1-15.

HAMILTON, R. "Prologue, Prophecy and Plot in Four Plays of Euripides". American journal of philology, 99 (3), 1978, pp. 277-302.

HAMMOND, N. G. L. "The Battle of Salamis". The Journal of Hellenic studies, 76, 1956, pp. 32-54.

. "Personal Freedom and its Limitations in the Oresteia". The Journal of Hellenic studies, 85, 1965, pp. 42-55.

HANDS, A. R. “On Strategy and Oracles, 480/79”. The Journal of Hellenic studies, 85, 1965, pp. 56-61.

HARRIS, J. P. “Cassandra's Swan Song: Aeschylus' Use of Fable in Agamemnon”. Greek, Roman and Byzantine Studies, 52 (4), 2012, pp. 540-558.

HARRIS, W. V. Dreams and Experience in Classical Antiquity. Cambridge, Massachesetts and London, Harvard University Press, 2009.

HAVELOCK, E. A. The Greek Concept of Justice - From its Shadow in Homer to its Substance in Plato. Cambridge and London, Harvard University Press, 1978.

HEATH, John. "The Serpent and the Sparrows: Homer and the Parodos of Aeschylus' Agamemnon”. Classical Quarterly, 49 (2), 1999a, pp. 396-407.

. "Disentangling the Beast: Humans and Other Animals in Aeschylus' Oresteia". The Journal of Hellenic studies, 119, 1999b, pp. 17-47.

. "The Omen of the Eagles and Hare (Agamemnon 104-59): From Aulis to Argos and Back Again". Classical Quarterly, 51 (1), 2001, pp. 18-22.

. "Blood for the Dead: Homeric Ghosts Speak Up". Hermes, 133 (4), 2005, pp. 389-400.

HEIRMAN, L. J. “Kassandra's Glossolalia”. Mnemosyne, 28 (3), 1975, pp. 257-267.

HERINGTON, C. J. "Study in the Prometheia, Part I. The Elements in the Trilogy". Phoenix, 17 (3), 1963a, pp. 180-197.

. "Study in the Prometheia, Part II: Birds and Prometheia. Phoenix, 17 (4), 1963b, pp. 236-243.

. "Introduction to Prometheus Bound". Arion, 1 (4), 1973/1974, pp. 640-667.

HOGAN, J. C. A Commentary on the Complete Greek Tragedies: Aeschylus. Chicago, The University of Chicago Press, 1984. . A Commentary on the Plays of Sophocles. Carbondale and Edwardsville: Southern Illinois University Press, 1991. 
HOLlMANN, A. The Master of Signs: Signs and the Interpretation of Signs in Herodotus' Histories. Washington, Center for Hellenic Studies, Trustees for Harvard University, 2011.

HOLOKA, J. P. "The Point of the Simile in Aeschylus Agamemnon 241". Classical Philology, 80 (3), 1985, pp. 228-229.

HOLST-WARHAFT, G. Dangerous Voices - Women's Laments and Greek Literature. London, Routledge, 1992.

HOPMAN, M. "Layered Stories in Aeschylus' Persians". In: GRETHLEIN, J. \& RENGAKOS, A. (Eds.). Narratology and Interpretation - The Content of Narrative Form in Ancient Literature. Berlin and New York, Walter de Gruyter, 2009, pp. 357-376.

HOSE, M. "Vaticinium post eventum and the Position of the Supplices in the Danaid Trilogy”. In: CAIRNS, D. \& LIAPIS, V. (Eds.) Dionysalexandros - Essays in Honor of Alexander F. Garvie. Swansea, The Classical Press of Wales, 2006, pp. 91-98.

HUBBARD, Thomas K. "Tragic Preludes: Aeschylus' Seven against Thebes 4-8". Phoenix, 46 (4), 1992, pp. 299-308.

HUGHES, D. D. Human Sacrifice in Ancient Greece. London and New York, Routledge, 1991.

INOUE, Eva \& COHEN, David. "Verbal Patterns in the Prometheus Bound". The Classical Journal, 74 (1), 1978, pp. 26-33.

IRBY-MASSIE, G. L. "Prometheus Bound and Contemporary Trends in Greek Natural Philosophy”. Greek, Roman and Byzantine Studies, 48 (2), 2008, pp. 133-157.

IRIARTE, A. “L'ogresse contre Thèbes”. Mètis, 2 (1), 1987, pp. 91-108. . Las redes del enigma - Voces femeninas en el pensamiento griego. Madrid, Taurus Humanidades, 1990. . "Traits féminins de la mémoire primordiale". Mètis, 9/10, 1994, pp. 315326. . “Casandra trágica”. Enrahonar, 26, 1996, pp. 65-80.

IRIARTE, A. \& GONZÁLEZ, M. Entre Ares y Afrodita - Violencia del erotismo y erótica de la violencia en el pensamiento griego. Madrid, Abada Editores, 2008.

IRIGOIN, J. “La composition architecturale des Perses d'Eschyle”. Lexis, 22, 2004, pp. 29-36.

ITALIE, Gabriel. Index Aeschyleus. 2. ed. Leiden, Brill, 1964. 
JANKO, R. “Aeschylus' Oresteia and Archilochus”. Classical Quarterly, 30 (2), 1980, pp. 291-293.

JAOUËN, F. “Iphigénie: poétique et politique du sacrifice”. Littérature, 103, 1996, pp. 3-19.

JOHANSSON, K. The birds in the Iliad - Identities, interactions and functions. Gothenburg, University of Gothenburg, 2012.

JOHNSTON, Sarah Iles. Restless Dead - Encounters Between the Living and the Dead in Ancient Greece. Berkeley, Los Angeles and London, University of California Press, 1999.

\& STRUCK, P. T. (Eds.) Mantikê - Studies in Ancient Divination. Boston, Brill, 2005.

. Ancient Greek Divination. West Sussex, Wiley-Blackwell, 2008.

. "Sending Dreams, Restraining Dreams: Oneiropompeia in Theory and Practice”. In: SCIOLI, E. \& WALDE, C. (Eds.) Sub Imagine Somni: Nighttime Phenomena in Greco-Roman Culture. Pisa, Edizioni ETS, 2010, pp. 63-80.

JONG, I. J. F. DE. \& NÜNLIST, R. (Eds.) Time in Ancient Greek Literature. Leiden, Brill, 2007. ; \& BOWIE, A. (Eds.) Narrators, Narratees, and Narratives in Ancient Greek Literature. Leiden, Brill, 2004.

JOUAN, François. "Nomen-Omen chez Eschyle". In: HANI, J. (Ed.) Problèmes du Mythe et son interprétation (Actes du Colloque de Chantilly, 24-25 avril 1976). Paris, 1978, pp. 69-87.

. "L'évocation des morts dans la tragédie grecque". Revue de l'histoire de religions, 198 (4), 1981, pp. 403-21.

. "L’oracle, thérapeutique de l'angoisse". Kernos, 3, 1990, pp. 11-28.

JOUANNA, Jacques. "La main du dieu qui touche. Remarques sur l'emploi d'une maxime et sur le sens de sunáptesthai dans la tragédie grecque: Eschyle, Perses, v. 742 et 724; Euripide, Hélène, v. 1444; Sophocle, Frag. 874 (Radt)”. Cahiers du Gita, 7, 1992/1993, pp. 81-97.

. "Testo, interpretazione e spettacolo nelle Coefore di Eschilo". Lexis, 17, 1999, pp. 137-149.

. "Le chant mâle des vierges: Eschyle, Suppliantes, v. 418-437". Revue des études grecques, 115, 2002, pp. 418-437.

JUDET DE LA COMBE, P. "La langue de Thèbes”. Mètis, 3 (1/2), 1988, pp. 207-230. 
. "Lettre et niveaux de sens, Agamennon 1560-576". Lexis, 19, 2001, pp. 21-

32.

KAMERBEEK, J. C. "Prophecy and Tragedy". Mnemosyne, 18 (1), 1965, pp. 29-40.

KANTZIOS, I. "The Politics of Fear in Aeschylus' Persians". Classical World, 98 (1), 2004, pp. 3-19.

KELlEY, K. A. "Variable Repetition: Word Patterns in the Persae". The Classical Journal, 74 (3), 1979, pp. 213-219.

KENNEDY, R. F. "Justice, Geography and Empire in Aeschylus' Eumenides". Classical Antiquity, 25 (1), 2006, pp. 35-72.

KESSELS, A. H. M. “Ancient Systems of Dream-Classification”. Mnemosyne, 22 (4), 1969, pp. 389-424.

KINDT, J. "Delphic Oracle Stories and the Beginning of Historiography: Herodotus' Croesus Logos”. Classical Philology, 101 (1), 2006, pp. 34-51.

KIRKWOOD, G. M. “Eteocles Oiakostrophos”. Phoenix, 23 (1), 1969, pp. 9-25.

KITTO, H. D. F. Form and meaning in drama. London, Methuen, 1960.

. Greek Tragedy - A Literary Study. 3. ed. London and New York, Routledge, 2003.

KITTREDGE, G. L. “Arm-Pitting among the Greeks”. American journal of philology, 6 (2), 1885, pp. 151-169.

KNOX, Bernard M. W. "The Lion in the House". Classical Philology, 47 (1), 1952, pp. 17-25.

KONISHI, H. “Agamemnon's Reasons for Yielding”. American journal of philology, 110 (2), 1989, pp. 210-222.

KONSTAN, D. "The Ocean Episode in the Prometheus Bound". History of religions, 17 (1), 1977, pp. 61-72.

KUCH, H. "Eschilo, Sept. 576. Anfiarao e la 'doppia' sorte dei figli di Edipo". Lexis, 29, 2011, pp. 85-111.

KYRIAKOU, P. The Past in Aeschylus and Sophocles. Berlin and Boston, De Gruyter, 2011.

LABARBE, J. “Du bon usage de l'oracle de Delphes”. Kernos, 7, 1994, pp. 219-230.

LAMARI, A. A. “Aeschylus' Seven Against Thebes vs. Euripides' Phoenissae: Male vs. Female Power". Weiner Studien: Zeitschrift fur Klassische Philologie Patristik und lateinische Tradition, 120, 2007, pp. 5-24. 
LANZILLOTA, L. R. "Prophecy and Oracle". In: ROISMAN, Hanna M. (ed.) The Encyclopaedia of Greek Tragedy. Oxford, Blackwell Publishing, 2013.

LARDINOIS, A. P. M. H.; POEL, M. G. M. \& VAN DER HUNINK, V. J. C. Land of Dreams - Greek and Latin Studies in Honour of A. H. M. Kessels. Leinden, Brill, 2006.

. BLOK, J. H. \& VAN DER POEL, M. G. M. (Eds.) Sacred Words Orality, Literacy and Religion. Leiden and Boston, Brill, 2010.

LATEINER, D. "Signifying Names and Other Ominous Accidental Utterances in Classical Historiography”. Greek, Roman and Byzantine Studies, 45 (1), 2005, pp. $35-57$.

LATTE, K. "The Coming of the Pythia". Harvard theological review, 33 (1), 1940, pp. 9-18.

LAURENCE, M. A. "Análisis comparativo del mito de Prometeo según Esquilo y Hesíodo”. Espéculo, 44, 2010.

LAVERY, J. "Clytaimestra's Negatives and the Final Line of Agamemnon". Bulletin of the Institute of Classical Studies, 47 (1), 2004, pp. 57-77.

LAWRENCE, S. E. “Artemis in the Agamemnon”. American journal of philology, 97 (2), 1976, pp. 97-110.

. “Eteocles' Moral Awareness in Aeschylus' Seven". Classical World, 100 (4), 2007, pp. 335-353.

LAWSON, J. C. "The Evocation of Darius (Aesch. Persae 607-93)". Classical Quarterly, 28 (2), 1934, pp. 79-89.

LAZENBY, J. F. “Aischylos and Salamis”. Hermes, 116 (2), 1988, pp. 168-185.

LEAHY, D. M. "The Rôle of Cassandra in the Oresteia of Aeschylus". Bulletin of the John Rylands University Library of Manchester, 52 (1), 1969, pp. 144-177. . "The Representation of the Trojan War in Aeschylus' Agamemnon". American journal of philology, 95 (1), 1974, pp. 1-23.

LEBECK, Anne. "The Robe of Iphigenia in Agamemnon". Greek, Roman and Byzantine Studies, 5 (1), 1964, pp. 35-41.

. "The First Stasimon of Aeschylus' Choephori: Myth and Mirror Image”. Classical Philology, 62 (3), 1967, pp. 182-185.

. The Oresteia - A Study in Language and Structure. Cambridge, Harvard University Press, 1971. 
LEGRAND, P.-E. "Prophète et Pythie à Delphes". Revue des études grecques, 64, 1951, pp. 296-299.

LEHOUX, D. "Drugs and the Delphic Oracle”. Classical World, 101 (1), 2007, pp. 4156.

LEMBKE, J. “Aeschylus' Suppliants: Design in a Beholder's Eye”. Arion, 1 (4), 1973/1974, pp. 627-639.

LESKY, Albin. "Decision and Responsibility in the Tragedy of Aeschylus". The Journal of Hellenic studies, 86, 1966, pp. 78-85.

. A tragédia grega. 3. ed. São Paulo, Editora Perspectiva, 2001.

LETOUBLON, F. "Le vocabulaire de la supplication en grec: Performatif et derivation delocutive. Hikétes et hikáno, lité et líssomai”. Lingua, 52, 1980, pp. 325-336.

"Inceste, mariage et sexualité dans Les Suppliantes d'Eschyle". In: VÉRILHAC, A.-M. (Ed.) La Femme dans le monde méditerranéen I: Antiquité. Lyon, GS-Maison de l'Orient, 1985, pp. 29-45.

LÉVY, E. "Le théâtre et le rêve: Le rêve dans le théâtre d'Eschyle". In: ZEHNACKER, H. (ed.) Théâtre et Spectacles dans l'Antiquité - Actes du Colloque de Strasbourg 5-7 novembre 1981. Leiden, Brill, 1981.

LEWIS, N. The Interpretation of Dreams and Portents in Antiquity. Mundelein, Bolchazy-Carducci Publishers, 1996.

LILL, A. "Dream Symbols in Greek Tragedy: The Case of Clytemnestra". Interlitteraria, 8, 2003, pp. 178-196.

LINCOLN, Bruce. "Death by Water: Strange Events at the Strymon (Persae 492-507) and the Categorical Opposition of East and West”. Classical Philology, 95 (1), 2000, pp. 12-20.

LLOYD-JONES, Hugh. "The Robes of Iphigeneia”. Classical review, 2 (3/4), 1952, pp. 132-135. . "Zeus in Aeschylus". The Journal of Hellenic studies, 76, 1956, pp. 55-67. . "The End of the Seven against Thebes". Classical Quarterly, 9 (1), 1959, pp. 80-115.

. “The Guilt of Agamemnon”. Classical Quarterly, 12 (2), 1962, pp. 187199.

. "The Delphic Oracle". Greece and Rome, 23 (1), 1976, pp. 60-73.

. "Artemis and Iphigeneia". The Journal of Hellenic studies, 103, 1983, pp. 87-102. 
. "Les Erinyes dans la tragédie grecque". Revue des études grecques, 102, 1989, pp. 1-9.

. "Zeus, Prometheus, and Greek Ethics". Harvard Studies in Classical Philology, 101, 2003, pp. 49-72.

LLOYD, M. (Ed.) Aeschylus - Oxford Readings in Classical Studies. Oxford, Oxford University Press, 2007.

LOMIENTO, L. “L’inno della falsa gioia in Aesch. Suppl. 524-99”. Lexis, 28, 2010, pp. $67-91$.

LORAUX, N. Les expériences de Tirésias - Le féminin et l'homme grec. Paris, Éditions Gallimard, 1989.

. Maneiras trágicas de matar uma mulher - Imaginário da Grécia Antiga. Rio de Janeiro, Jorge Zahar Editor, 1988.

LYNN-GEORGE, M. "A Reflection on Homeric Dawn in the Parodos of Aeschylus, Agamemnon". Classical Quarterly, 43 (1), 1993, pp. 1-9.

LYONS, D. "Dangerous Gifts: Ideologies of Marriage and Exchange in Ancient Greece”. Classical Antiquity, 22 (1), 2003, pp. 93-134.

MACE, S. "Why the Oresteia's Sleeping Dead Won't Lie. Part I: Agamemnon". The Classical Journal, 98 (1), 2002, pp. 35-56.

. "Why the Oresteia's Sleeping Dead Won't Lie. Part II: Choephoroi and Eumenides". The Classical Journal, 100 (1), 2004, pp. 39-60.

MACKINNON, J. K. “The Reason for the Danaids' Flight”. Classical Quarterly, 28 (1), 1978, pp. 74-82.

MACLEOD, C. W. "Politics and the Oresteia". The Journal of Hellenic studies, 102, 1982, pp. 124-144.

MALKIN, I. "Delphoi and the founding of social order in archaic Greece". Mètis, 4 (1), 1989, pp. 129-153.

MANETTI, G. Theories of the Sign in Classical Antiquity. Bloomington and Indianapolis, Indiana University Press, 1993.

MANTON, G. R. "The Second Stasimon of the Seven against Thebes". Bulletin of the Institute of Classical Studies, 8 (1), 1961, pp. 77-84.

MARCH, J. R. "Klytaimestra and the Oresteia Legend". The Creative Poet: Studies on the Treatment of Myths in Greek Poetry. London, University of London. Institute of Classical Studies, 1987, pp. 81-118. 
MARGON, J. S. “The Nurse's View of Clytemnestra's Grief for Orestes: Choephori 737-740”. Classical World, 76 (5), 1983, pp. 296-297.

MARSHALL, C. W. “The Next Time Agamemnon Died”. Classical World, 95 (1), 2001, pp. 59-63.

MARSTON, J. M. "Language of Ritual Cursing in the Binding of Prometheus". Greek, Roman and Byzantine Studies, 47 (1), 2007, pp. 121-133.

MARZARI, F. "Melampo: Breve biografia di un indovino guaritore". I Quaderni del Ramo d'Oro, Numero Speciale, 2012, pp. 15-47.

MASON, P. G. “Kassandra”. The Journal of Hellenic studies, 79, 1959, pp. 80-93.

MATTEUZZI, M. "Clitemestra, il linguaggio del comando e una scena da ripensare (Aesch. Ch. 875-930)". Dionysus ex machina, 2, 2011, pp. 345-356.

MAURIZIO, L. "Anthropology and Spirit Possession: A Reconsideration of the Pythia's Role at Delphi”. The Journal of Hellenic studies, 115, 1995, pp. 69-86.

- "Delphic Oracles as Oral Performances: Authenticity and Historical Evidence". Classical Antiquity, 16 (2), 1997, pp. 308-334.

MAUXION, M. "La transmission de la parole oraculaire”. Langages, 85, 1987, pp. 914.

MAXWELL-STUART, P. G. "The Appearance of Aeschylus' Erinyes". Greece and Rome, 20 (1), 1973, pp. 81-84.

MAZZOLDI, S. “Cassandra's Prophecy between Ecstasy and Rational Mediation". Kernos, 15, 2002, pp. 145-154.

MCCALL, M. "The Chorus of Aeschylus' Choephori". In: GRIFFITH, M. \& MASTRONARDE, D. J. (Eds.) Cabinet of the Muses: essays on classical and comparative literature in honor of Thomas G. Rosenmeyer. Atlanta, Scholars Press, 1990, pp. 17-30.

MCCARTNEY, Eugene S. "Puns and Plays on Proper Names". The Classical Journal, 14 (6), 1919, pp. 343-358.

MCCLURE, L. "Clytemnestra's Binding Spell (Ag. 958-974)". The Classical Journal, 92 (2), 1997, pp. 123-140.

. Spoken like a Woman - Speech and Gender in Athenian Drama. Princeton, Princeton University Press, 1999.

. "Maternal Authority and Heroic Disgrace in Aeschylus's Persae". Transactions of the American Philological Association, 136 (1), 2006, pp. 71-97. 
MCCOSKEY, D. E. “'I whom she detested so bitterly': Slavery and the violent division of women in Aeschylus' Oresteia". In: JOSHEL, S. R. \& MURNAGHAN, S. Women and Slaves in Greco-Roman Culture. London, Routledge, 2001, pp. 35-55. MCNEIL, L. "Bridal Cloths, Cover-ups, and Kharis: The 'Carpet Scene' in Aeschylus' Agamemnon". Greece and Rome, 52 (1), 2005, pp. 1-17.

MEDDA, E. "Ifigenia all'altare. Il sacrificio di Aulide fra testo e iconografia (Aesch. Ag. 231-242)”. Eikasmos, 23, 2012, pp. 87-114.

MEIER, Christian. De la tragédie grecque comme art politique. Paris, Les Belles Lettres, 1991.

MEJER, J. "Recognizing what, when and why? The Recognition Scene in Aeschylus' Choephori". In: BOWERSOCK, G. W.; BURKERT, W. \& PUTNAM, M. C. J. (Eds.) Arktouros: Hellenic studies presented to Bernard M. W. Knox on the occasion of his 65th birthday. Berlin and New York, Walter de Gruyter, 1979, pp. 115-121.

MENESES, A. B. de. As Portas do Sonho. São Paulo, Ateliê Editorial, 2002.

MERIDOR, R. “Agamemnon 944-57: Why Does Agamemnon Give in?”. Classical Philology, 82 (1), 1987, pp. 38-43.

MESSER, W. S. The Dream in Homer and Greek Tragedy. New York, Columbia University Press, 1918.

METZGER, E. “Clytaemnestra's Watchman on the Roof”. Eranos, 103 (1), 2005, pp. $38-47$.

MICHELINI, Ann N. Tradition and Dramatic Form in the Persians of Aeschylus. Leiden, Brill, 1982.

MIKALSON, J. D. Athenian Popular Religion. 3. ed. Chapel Hill, University of North Carolina Press, 1987.

. "Unanswered Prayers in Greek Tragedy". The Journal of Hellenic studies, 109, 1989, pp. 81-98.

. Ancient Greek Religion. Oxford, Blackwell Publishing, 2005.

. Greek Popular Religion in Greek Philosophy. Oxford, Oxford University Press, 2010.

MIRALLES, C. "Dioniso nel prologo delle Eumenidi". Lexis, 19, 2001, pp. 15-20.

MITCHELL-BOYASK, R. "The Marriage of Cassandra and the "Oresteia": Text, Image, Performance. Transactions of the American Philological Association, 136 (2), 2006, pp. 269-297. 
. Aeschylus: Eumenides. London, Duckworth, 2009.

MITCHELL, L. G. "Greeks, Barbarians and Aeschylus' Suppliants". Greece and Rome, 53 (2), 2006, pp. 205-223.

MOREAU, Alain. "Fonction du personnage d'Amphiaraos dans les Sept contre Thèbes: le 'blason en abyme'”. Bulletin de l'Association Guillaume Budé, 1976a (1), pp. 158-181.

. "L'oeil malefique dans l'oeuvre d'Eschyle". Revue des études anciennes, 78/79, 1976b, pp. 50-64.

. Eschyle. La violence et le chaos. Paris, Les Belles Lettres, 1985.

. "Transes douloureuses dans le théatre d'Eschyle". Cahiers du Gita, 4, 1988, pp. 103-114.

. "Les ambivalences de Cassandre". In: LAURENS, A.-F. (Ed.) Entre hommes et dieux - Le convive, le héros, le prophète. Paris, Les Belles Lettres, 1989, pp. 145-167.

. “Déjouer l'oracle ou la précaution inutile”. Kernos, 3, 1990, pp. 261-279.

. "Le songe d'Atossa. Perses, 176-214. Éléments pour une explication de textes". Cahiers du Gita, 7, 1992/1993, pp. 29-51.

. "Les Danaïdes des Mélanippidès: La femme virile". Cahiers du Gita, 8, 1994/1995, pp. 119-151.

. "La Clytemnestre d'Eschyle". Cahiers du Gita, 8, 1994/1995, pp. 153-171.

MORGAN, K. “Agamemnon 1391-1392: Clytemnestra's Defense Foreshadowed". Quaderni urbinati di cultura classica, 42 (3), 1992, pp. 25-27.

MORGAN, K. A. “Apollo’s Favorites”. Greek, Roman and Byzantine Studies, 35 (2), 1994, pp. 121-143.

MORITZ, H. E. "Refrain in Aeschylus: Literary Adaptation of Traditional Form". Classical Philology, 74 (3), 1979, pp. 187-213.

MORRELL, K. S. "The Fabric of Persuasion: Clytaemnestra, Agamemnon, and the Sea of Garments". The Classical Journal, 92 (2), 1997, pp. 141-165.

MOSSMAN, J. M. "Chains of Imagery in Prometheus Bound”. Classical Quarterly, 46 (1), 1996, pp. 58-67.

MOUSBAHOVA, V. "The meaning of the termes sophisthés and sóphisma in the Prometheus Bound". Hyperboreus, 13 (1/2), 2007, pp. 31-50.

MUNTZ, C. E. "The Invocation of Darius in Aeschylus' Persae". The Classical Journal, 106 (3), 2011, pp. 257-271. 
MURNAGHAN, S. "Women in Groups: Aeschylus's Suppliants and the Female Choruses of Greek Tragedy”. In: PEDRICK, V. \& OBERHELMAN, S. M. (Eds.) The Soul of Tragedy - Essays on Athenian Drama. Chicago, The Chicago University Press, 2006, pp. 183-198.

MURRAY JR., Robert Duff. The Motif of Io in Aeschylus' Suppliants. Princeton, Princeton University Press, 1958.

NAGY, G. "Acient Greek Poetry, Prophecy, and Concepts of Theory”. In: KUGEL, J.

L. (Ed.) Poetry and Prophecy - The Beginnings of a Literary Tradition. Ithaca, Cornell University Press, 1990, pp. 56-64.

. "Dream of a Shade: Refractions of Epic Vision in Pindar's Pythian 8 and Aeschylus' Seven against Thebes". Harvard Studies in Classical Philology, 100, 2000, pp. 97-118.

NAIDEN, F. S. Ancient Supplication. New York, Oxford University Press, 2006.

NESCHKE, A. 'L'Orestie de Stésichore et la tradition littéraire du mythe des Atrides avant Eschyle". L'Antiquité classique, 55, 1986, pp. 283-301.

NEUBURG, M. "Clytemnestra and the Alastor (Aeschylus, Agamemnon 1497ff)". Quaderni urbinati di cultura classica, 38 (2), 1991, pp. 37-68.

NIETO IBÁÑEZ, J. M. “Fórmulas homéricas y lenguaje oracular”. Minerva, 2, 1988, pp. 33-46.

. "La prosodia del hexámetro délfico". Minerva, 4, 1990, pp. 53-73.

NILSSON, M. P. Greek Folk Religion. Philadelphia, University of Pennsylvania Press, 1998.

NOËL, M-P. "La reconnaissance d'Oreste et d'Électre chez Eschyle, Sophocle et Euripide: enjeux esthétiques et dramaturgiques". Arrêt sur scène / Scene Focus, 2, 2013, pp. 9-24.

NUSSBAUM, M. C. The Fragility of Goodness - Luck and Ethics in Greek Tragedy and Philosophy. Revised ed. Cambridge, Cambridge University Press, 2001.

NUTTALL, G. F. "Cassandra and the Language of Prophecy". The Heythrop Journal, $36(4), 1995$, pp. 512-520.

OBERHELMAN, S. "Popular Dream-Interpretation in Ancient Greece and Freudian Psychoanalysis". Journal of Popular Culture, 11 (3), 1977, pp. 683-695.

O’DALY, G. J. P. "Clytemnestra and the Elders: Dramatic Technique in Aeschylus, Agamemnon 1372-1576”. Museum Helveticum, 42 (1), 1985, pp. 1-19. 
OGDEN, Daniel. Greek and Roman Necromancy. Princeton, Princeton University Press, 2001.

. "The Ancient Greek Oracles of the Dead". Acta classica, 44, 2001, pp. 167195.

. Magic, Witchcraft, and Ghosts in the Greek and Roman Worlds: A Source Book. Oxford, Oxford University Press, 2002.

. A Companion to Greek Religion. Malden, Blackwell Publishing, 2007.

OLIVEIRA, F. R. de. "Duas ou três coisas sobre mitos e história: Os Persas de Ésquilo". Letras Clássicas, 6, 2002, pp. 37-53.

OLSON, S. D. "The Stories of Agamemnon in Homer's Odyssey". Transactions of the American Philological Association, 120, 1990, pp. 57-71.

O’NEILL, K. "Aeschylus, Homer, and the Serpent at the Breast”. Phoenix, 52 (3/4), 1998, pp. 216-229.

ORWIN, C. "Feminine Justice: The End of the Seven against Thebes". Classical Philology, 75 (3), 1980, pp. 187-196.

OTIS, B. "The Unity of the Seven against Thebes". Greek, Roman and Byzantine Studies, 3 (4), 1960, pp. 153-174.

OTTO, Walter Friedrich. Os deuses da Grécia. Tradução de Ordep Serra. São Paulo, Odysseus Editora, 2005.

PAPADOPOULOU, T. Aeschylus: Suppliants. London, Bristol Classical Press, 2011.

PARKE, W. Greek Oracles. London, Hutchinson University Library, 1967a.

. The Oracles of Zeus: Dodona, Olympia, Ammon. Cambridge, Harvard University Press, $1967 \mathrm{~b}$.

PARKER, V. 'Herodotus' Use of Aeschylus' Persae as a source for the Battle of Salamis”. SO, 82 (1), 2007, pp. 1-29.

PELliCCIA, H. "Aeschylus, Eumenides, 64-88 and the Ex Cathedra Language of Apollo". Harvard Studies in Classical Philology, 95, 1993, pp. 65-105.

PELLING, C. (Ed.) Greek Tragedy and the Historian. Oxford, Clarendon Press, 2001.

PEPE, L. "I Sette contro Tebe e la spartizione dell'eredità di Edipo". In: CANTARELla, E. \& GAGLIARDI, L. (Eds.) Diritto e Teatro in Grecia e a Roma. Milano, Edizioni Universitarie di Lettere Economia Diritto, 2007, pp. 3167.

PERADOTTO, John J. "Some Patterns of Nature Imagery in the Oresteia". American journal of philology, 85 (4), 1964, pp. 378-393. 
. "Cledonomancy in the Oresteia". American journal of philology, 90 (1), 1969a, pp. 1-21.

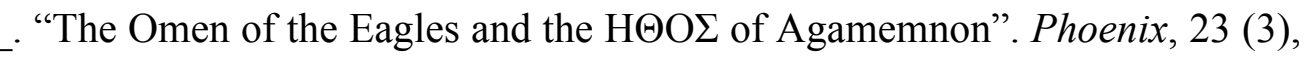

1969b, pp. 237-263.

. "Odyssey 8 .5 64-571: Verisimilitude, Narrative Analysis, and Bricolage".

Texas Studies in Literature and Language, 15 (5), 1974, pp. 803-832.

. Man in the Middle Voice - Name and Narration in the Odyssey. Princeton:

Princeton University Press, 1990.

. "Prophecy and Persons: Reading Character in the Odyssey". Arethusa, 35

(1), 2002, pp. 3-15.

PEREIRA, S. M. "Poética dos sonhos e das visões em estado de vigília I". Humanitas, 60, 2008, pp. 11-28.

. "Poética dos sonhos e das visões em estado de vigília II". Humanitas, 61, 2009, pp. 5-18.

PÉREZ, D. "Contextualizing Symbols: 'the Eagle and the Snake' in the Ancient Greek World”. Boreas, 33, 2010, pp. 1-18.

. "La serpiente como símbolo en el mundo griego: escenas del "Más Acá"”.

In: MANZANO, M. A. S. Sabiduría simbólica y enigmática en la literatura grecolatina: símbolos, enigmas y sabiduría en las literaturas clásicas. Madrid, Tecnos, 2011.

PÉRON, Jacques. "Réalité et au-dela dans les Perses d'Eschyle". Bulletin de l' Association Guillaume Budé, 1982 (1), pp. 3-40.

PETROPOULOS, J. C. B. (Ed.) Greek Magic - Ancient, Medieval and Modern. London and New York, Routledge, 2006.

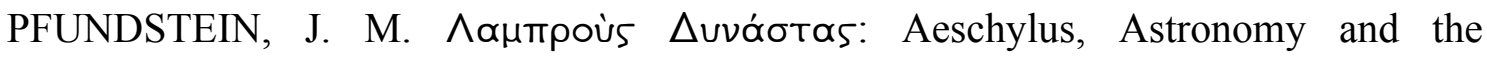
Agamemnon. The Classical Journal, v. 98 (4), 2003, pp. 397-410.

PHILIPPSON, Paula. Origini e forme del mito greco. A cura di Angelo Brelich. Torino, Giulio Einaudi, 1949.

PICKERING, P. E. "Verbal Repetition in Prometheus and Greek Tragedy Generally". Bulletin of the Institute of Classical Studies, 44 (1), 2000, pp. 81-101.

PINO, M. C. "Hablar enigmáticamente: función y forma de los oráculos en Edipo Rey". Archivum, 61/62, 2011/2012, pp. 59-78.

PODLECKI, Anthony J. "The Character of Eteocles in Aeschylus' Septem". Transactions of the American Philological Association, 95, 1964, pp. 283-299. 
. "Omens in the Odyssey". Greece and Rome, 14 (1), 1967, pp. 12-23.

. "Reciprocity in Prometheus Bound". Greek, Roman and Byzantine Studies, 10 (4), 1969, pp. 287-292.

. The Political Background of Aeschylean Tragedy. 2. ed. London: Bristol Classical Press, 1999.

POLLARD, J. R. T. "Birds in Aeschylus". Greece and Rome, 17 (51), 1948, pp. 116127.

. Birds in Greek Life and Myth. New York, Thames and Hudson, 1977.

PONTANI, F. "Shocks, Lies, and Matricide: Thoughts on Aeschylus Choephori 653-

718”. Harvard Studies in Classical Philology, 103, 2007, pp. 203-233.

PORTER, J. "Patterns of Perception in Aeschylus". In: GRIFFITH, M. \& MASTRONARDE, D. J. (Eds.) Cabinet of the Muses: essays on classical and comparative literature in honor of Thomas G. Rosenmeyer. Atlanta, Scholars Press, 1990, pp. 31-56.

PÒRTULAS, J. "Miasma in Eraclito e in Eschilo. AIMATO $\Sigma$ KAӨAP $\Sigma$ IOY $\Sigma$ ФАГАI". Lexis, 24, 2006, pp. 23-29.

POWELL, A. "Thucydides and divination". Bulletin of the Institute of Classical Studies, 26 (1), 1979, pp. 45-50.

PRATT, L. “Odyssey 19 .535-50: On the Interpretation of Dreams and Signs in Homer”. Classical Philology, 89 (2), 1994, pp. 147-152.

PUCCI, P. “L'apologie d'Apollon dans Hérodote, 1,91”. Mètis, 8 (1/2), 1993, pp. 7-20. . "Prométhée, d'Hésiode à Platon". Communications, 78, 2005, pp. 51-70.

PULQUÉRIO, M. de O. “De novo o párodo do Agamémnon”. Humanitas, 37/38, 1986, pp. 3-8.

QUANTIN, F. “Gaia oraculaire: tradition et réalités”. Mètis, 7 (1/2), 1992, pp. 177-199.

RABEL, R. J. "Apollo in the Vulture Simile of the Oresteia". Mnemosyne, 35 (3/4), 1982, pp. 324-326.

RABINOWITZ, N. S. Greek Tragedy. Malden, Blackwell Publishing, 2008.

RACHET, G. "Le Sanctuaire de Dodone, origine et moyens de divination". Bulletin de l'Association Guillaume Budé, 1, 1962, pp. 86-99.

RADEMAKER, A. Sophrosyne and the Rhetoric of Self-Restraint. Leiden, Brill, 2005.

RADER, R. “'And Whatever It Is, It Is You': The Autochthonous Self in Aeschylus's Seven Against Thebes". Arethusa, 42 (1), 2009, pp. 1-44. 
RAEBURN, D. \& THOMAS, O. The Agamemnon of Aeschylus - A commentary for students. Oxford, Oxford University Press, 2011.

RANKIN, D. "The Second Stasimon of the Choephori”. Classical review, 7 (2), 1888, pp. 222-223.

RASH, J. N. Meter and Language in the Lyrics of the Suppliants of Aeschylus. New York, Arno Press, 1981.

REDARD, G. Recherches sur XPH, XPH $\Sigma \Theta A I$ : Étude Sémantique (Bibliothèque de l'École des Hautes Études, fasc. 303). Paris, Librairie Ancienne Honoré Champion, 1953.

REEVES, C. H. "The Parodos of the Agamemnon". The Classical Journal, 55, 1959/1960, pp. 165-171.

REHM, R. Greek Tragic Theatre. London and New York, Routledge, 1994.

RIBEIRO JR., W. A. "Hesíodo fr. 23a Merkelbach-West: Tradução e Comentários". Calíope, 12, 2004, pp. 84-92.

. Iphigenia Aulidensis de Eurípides: introdução, tradução e notas. 2006.

297ff. Dissertação (Mestrado em Letras Clássicas) - Departamento de Letras Clássicas, Universidade de São Paulo, São Paulo, 2006.

RIVIER, André. "Remarques sur le 'nécessaire' et la 'nécessité' chez Eschyle”. Revue des études grecques, 81, 1968, pp. 5-39.

ROBERTS, Deborah H. Apollo and his Oracle in the Oresteia. Göttingen, Vandenhoeck \& Ruprecht, 1984.

. "Blood or Fate: A Note on Choephori 927”. Classical Quarterly, 34 (2), 1984, pp. 255-259.

. "Orestes as fulfillment, teraskopos, and teras in the Oresteia". American journal of philology, 106 (3), 1985, pp. 283-297.

ROBERTSON, D. S. "The Delphian Succession in the Opening of the Eumenides". Classical review, 55 (2), 1941, pp. 69-70.

ROBERTSON, N. "The True Meaning of the 'Wooden Wall'”. Classical Philology, 82 (1), 1987, pp. 1-20.

RODRÍGUEZ, E. "Los lechos de Casandra en Troyanas y Hécuba de Eurípides y en Alejandra de Licofrón”. Estudios Clásicos, 124, 2003, pp. 25-46.

ROISMAN, H. M. “Clytaemnestra's Ominous Words: Aeschylus, Agamemnon 345347”. Zeitschrift für Papyrologie und Epigraphik, 66 (1), 1986, pp. 297-284. 
ROMILLY, Jacqueline de. "L'évocation du passé dans l'Agamemnon d'Eschyle". Revue des études grecques, 80, 1967, pp. 93-98.

. La crainte et l'angoisse dans le théâtre d'Eschyle. 2. ed. Paris, Les Belles Lettres, 1971.

“A propos d'Iphigenie dans l'Agamemnon d'Eschyle". Illinois classical studies, 19, 1994, pp. 19-26.

Le temps dans la tragédie grecque. 2. ed. Paris, Librairie Philosophique J. Vrin, 1995.

ROOD, N. "Implied Vengeance in the Simile of Grieving Vultures (Odyssey 16.21619)”. Classical Quarterly, 56 (1), 2006, pp. 1-11.

ROSE, H. J. "Ghost Ritual in Aeschylus". Harvard theological review, 43 (4), 1950, pp. 257-280.

ROSENBLOOM, David. Aeschylus: Persians. London, Duckworth, 2006.

ROSENMEYER, T. G. The Art of Aeschylus. Berkeley, Los Angeles and London, University of California Press, 1982.

RÖSLER, W. 'Klytaimestra paidoktonos. Variazioni del mito degli Atridi nell'Orestea di Eschilo". Lexis, 24, 2006, pp. 13-21.

ROUSSEAU, G. S. "Dream and Vision in Aeschylus' Oresteia". Arion, 2 (3), 1963, pp. 101-136.

ROTH, P. "The Theme of Corrupted Xenia in Aeschylus' Oresteia". Mnemosyne, 46 (1), 1993, pp. 1-17.

ROUX, G. "Eschyle, Hérodote, Diodore, Plutarque racontent la bataille de Salamine". Bulletin de correspondance hellénique, 98 (1), 1974, pp. 51-94.

. "L'eau et la divination dans le sanctuaire de Delphes”. In: MÉTRAL, F. \& SANLAVILlE, P. (Eds.) L'Homme et l'eau en Méditerranée et au Proche-Orient. Vol. 1. Lyon, GIS-Maison de l'Orient \& P. U. de Lyon, 1981, pp. 155-159.

RUFFELL, I. Aeschylus: Prometheus Bound. London, Bristol Classical Press, 2012.

RUFFY, M. "Visualization and 'Deixis am Phantasma' in Aeschylus' Persae". Quaderni urbinati di cultura classica, 78 (3), 2004, pp. 11-28.

RUTHERFORD, R. B. Greek Tragic Style: Form, Language and Interpretation. New York, Cambridge University Press, 2012.

RUTTER, N. K. \& SPARKES, B. A. (Eds.) Word and Image in Ancient Greece. Edinburgh, Edinburgh University Press, 2001. 
RYZMAN, M. "The Curse, the Oracle and the Sisters in Aeschylus' Septem". Revue belge de philologie et d'histoire, 67 (1), 1989, pp. 18-29.

SAÏD, Suzanne. La faute tragique. Paris, François Maspero, 1978.

. Sophiste et tyran, ou le problème du Prométhée enchainé. Paris, Klincksieck, 1985.

- "Pourquoi Psyttalie ou Comment transformer un combat naval en défaite terrestre". Cahiers du Gita, 7, 1992/1993, pp. 53-69.

. “Tragédie et renversement. L'exemple des Perses". Mètis, 3 (1), 1998a, pp. $321-341$.

. "Le Prométhée enchaîné, un hymne au progrès? Les arts et les images". L'Information grammaticale, 23, 1998b, pp. 33-37.

SAILOR, D. \& STROUP, S. C. "Phthonos d' Apesto: The Translation of Transgression in Aiskhylos'Agamemnon". Classical Antiquity, 18 (1), 1999, pp. 153-182.

SANTIS, Guillermo de. "La tragedia griega, Persas y los límites del género". Letras Clássicas, 9, 2005, pp. 67-94.

SCHAMP, J. “Apollon prophète par la pierre”. Revue belge de philologie et d'histoire, 59 (1), 1981, pp. 29-49.

SCHAPS, D. M. "Aeschylus' Politics and the Theme of the Oresteia". In: ROSEN, R. M. \& FARRELL, J. J. (Eds.) Nomodeiktes: Greek Studies in Honor of Martin Ostwald. Ann Arbor, University of Michigan Press, 1993, pp. 505-515.

SCHEIN, S. L. "The Cassandra Scene in Aeschylus' Agamemnon". Greece and Rome, 29 (1), 1982, pp. 11-16.

SCHENKER, D. "The Queen and the Chorus in Aeschylus' Persae". Phoenix, 48 (4), 1994, pp. 283-293.

SCOTT, W. C. "Wind Imagery in the Oresteia". Transactions of the American Philological Association, 97, 1966, pp. 459-471. . “The Confused Chorus (Agamemnon 975-1034)". Phoenix, 23 (4), 1969, pp. 336-346.

. Musical Design in Aeschylean Theater. Hanover, University Press of New England, 1984.

. "The Development of the Chorus in Prometheus Bound". Transactions of the American Philological Association, 117, 1987, pp. 85-96.

SEAFORD, R. “The Last Bath of Agamemnon”. Classical Quarterly, 34 (2), 1984, pp. 247-254. 
. "The Tragic Wedding". The Journal of Hellenic studies, 107, 1987, pp. 106-130.

. "Homeric and Tragic Sacrifice". Transactions of the American Philological Association, 119, 1989, pp. 87-95.

. "Historicizing Tragic Ambivalence: The Vote of Athena". In: History,

Tragedy, Theory: Dialogues on Athenian Drama. GOFF, Barbara (Ed.) Austin, University of Texas Press, 1995, pp. 202-221.

. "Aeschylus and the Unity of Opposites". The Journal of Hellenic studies, 123, 2003, pp. 141-163.

SÉCHAN, L. “Le sacrifice d'Iphigénie”. Revue des études grecques, 44, 1931, pp. 368426.

SEFERIS, G. \& CLAY, D. “Delphi”. Arion, 12 (3), 2005, pp. 1-15.

SERRA, O. O Reinado de Édipo. Brasília, Editora Universidade de Brasília, 2007.

SERRANO, D. de P. "Cassandra e le donne tragiche”. Myrtia, 26, 2011, pp. 123-139.

SEWELL-RUTTER, N. J. Guilt by Descent - Moral Inheritance and Decision Making in Greek Tragedy. Oxford, Oxford University Press, 2007.

SIDER, David. “Atossa's Second Entrance: Significant Inaction in Aeschylus' Persai”. American journal of philology, 104 (2), 1983, pp. 188-191.

SIDWELL, K. "Purification and Pollution in Aeschylus' Eumenides". Classical Quarterly, 46 (1), 1996, pp. 44-57.

SIMON, B. "Quelques idées grecques sur le rêve, d'Homère à Artémidore”. Les études classiques, 47 (2), 1979, pp. 107-122.

SKUTSCH, O. "Helen, Her Name and Nature". The Journal of Hellenic studies, 107, 1987, pp. 188-193.

SMITH, N. D. "Diviners and Divination Comedy in Aristophanic". Classical Antiquity, 8 (1), 1989, pp. $140-158$.

SMITH, O. "Some Observations on the Structure of Imagery in Aeschylus". Classica et Mediaevalia, 26, 1965, pp. 10-72.

SMITH, P. M. On the Hymn to Zeus in Aeschylus' Agamemnon. Chicago, Scholars Press, 1980.

SMYTH, H. W. Aeschylean Tragedy. Berkeley, University of California Press, 1924.

SOLMSEN, F. "The Erinys in Aischylos' Septem". Transactions of the American Philological Association, 68, 1937, pp. 197-211. . Hesiod and Aeschylus. Ithaca, Cornell University Press, 1995. 
SMITHERMAN, V. H. "Hearing the Erinyes' Voices: Thoughts on the 'Binding Song' (Eu. 307-96)". Proceedings of the Annual Meeting of Postgraduates in Ancient Literature, 2013, pp. 1-15.

SOMMERSTEIN, A. H. "Notes on Aeschylus' Suppliants". Bulletin of the Institute of Classical Studies, 24 (1), 1977, pp. 67-82. . "Artemis in Agamemnon: a Postscript". American journal of philology, 101 (2), 1980, pp. 165-169.

. "Notes on Aeschylus' Seven against Thebes". Hermes, 117 (4), 1989, pp. $432-445$. . Aeschylean Tragedy. Bari, Levante Editori, 1996.

. The Tangled Ways of Zeus - And Other Studies in and around Greek Tragedy. Oxford, Oxford University Press, 2010. . \& TORRANCE, I. Oaths and Swearing in Ancient Greece. Berlin, De Gruyter, 2014.

SOURVINOU-INWOOD, C. "Reading” Greek Death - To the End of the Classical Period. Oxford, Clarendon Press, 1995.

SPIER, Hedwig. "The Motive for the Suppliant's Flight”. The Classical Journal, 57 (7), 1962, pp. 315-317.

STANFORD, W. B. Aeschylus in his Style: a Study in Language and Personality. Dublin, University Press, 1942.

STEHLE, E. "Prayer and Curse in Aeschylus' Seven against Thebes". Classical Philology, 100 (2), 2005, pp. 101-122.

STEINER, G. Después de Babel: aspectos del lenguaje y la traducción. México, Fondo de Cultura Económica, 2001.

STINTON, T. C. W. "The First Stasimon of Aeschylus' Choephori”. Classical Quarterly, 29 (2), 1979, pp. 252-262.

STONEMAN, R. The Ancient Oracles - Making the Gods Speak. New Haven and London, Yale University Press, 2011.

STOREY, I. C. Euripides: Suppliant Women. London, Duckworth, 2008.

STRATEN, F. T. VAN. Hiera Kala - Images of Animal Sacrifice in Archaic and Classical Greece. Leiden, Brill, 1995.

STROLONGA, P. "The Foundation of the Oracle at Delphi in the Homeric Hymn to Apollo". Greek, Roman and Byzantine Studies, 51 (4), 2011, pp. 529-551. 
SULLIVAN, S. “'Dark' Mind and Heart in Aeschylus". Revue belge de philologie et d'histoire, 75 (1), 1997, pp. 59-67.

SULZBERGER, M. “ONOMA EП $\Omega N Y M O N$ : Les noms propres chez Homère et dans la mythologie Grecque”. Revue des études grecques, 39 (138), 1926, pp. 381-447.

TAPLIN, O. "Aeschylean Silences and Silences in Aeschylus". Harvard Studies in Classical Philology, 76 (1), 1972, pp. 57-97.

. The Stagecraft of Aeschylus: The Dramatic Use of Exits and Entrances in Greek Tragedy. Oxford, Clarendon Press, 2001.

. Greek Tragedy in Action. London, Routledge, 2003.

TERRANOVA, C. "Gli oracoli e il mythos nella Grecia di IV e III sec. a.C. Studi sull'antico culto di Amphiaraos ad Oropos". Studi e materiali di storia delle religioni, 32 (1), 2007, pp. 159-192.

THALMANN, W. G. Dramatic Art in Aeschylus' Seven against Thebes. New Haven, Yale University Press, 1978.

. 'Xerxes' Rags: Some Problems in Aeschylus' Persians". American journal of philology, 101 (3), 1980, pp. 260-282.

. "Speech and Silence in the Oresteia 1: Agamemnon 1025-1029". Phoenix, 39 (2), 1985a, pp. 99-118.

. "Speech and Silence in the Oresteia 2". Phoenix, 39 (3), 1985b, pp. 221237.

. "Aeschylus's Physiology of the Emotions". American journal of philology, 107 (4), 1986, pp. 489-511.

TORRANCE, Isabelle. Aeschylus: Seven against Thebes. London, Duckworth Companions, 2007.

. "In the Footprints of Aeschylus: Recognition, Allusion, and Metapoetics in Euripides". American journal of philology, 132 (2), 2011, pp. 177-204.

TORRANO, J. A. A. Eurípides - Bacas. O mito de Dioniso. Estudo e tradução. São Paulo, Hucitec, 1995.

. O Sentido de Zeus: O mito do mundo e o modo mítico de ser no mundo. 2. ed. São Paulo, Iluminuras, 1996.

. O pensamento mítico no horizonte de Platão. São Paulo, Annablume, 2013.

TORRE, E. S. de La. “Adivinación y Profecía en Píndaro (I)”. Minerva, 2, 1988, pp. 65106.

. “Adivinación y Profecía en Píndaro (II)”. Minerva, 3, 1989, pp. 63-101. 
- "Parole de poète, parole de prophète: les oracles et la mantique chez Pindare”. Kernos, 3, 1990, pp. 347-358.

. "Les pouvoirs des devins et les récits mythiques: l'exemple de Mélampous". Les études classiques, 60, 1992, pp. 3-21.

. "Sibylles, mantique inspirée et collections oraculaires. Kernos, 7, 1994, pp. 179-205.

. "La 'rationalité' des mythes de Delphes: les dieux, les héros, les médiateurs". Kernos, 15, 2002, pp. 155-178.

. "The Portrait of a Seer: The Framing of divination - Paradigms through

Myth in Archaic and Classical Greece". In: DILL, U. \& WALDE, C. (Eds.) Antike

Mythen. Medien, Transformationen und Konstruktionen. Berlin and New York, Walter de Gruyter, 2009b, pp. 158-188.

TOSI, R. “Alcuni esempi di polisemia nell'Agamennone di Eschilo: esegesi antica e filologia moderna". Lexis, 3, 1989, pp. 3-24.

. "Note di lessicografia eschilea". Lexis, 24, 2006, pp. 43-51.

TOTARO, P. "Eschilo in Aristofane (Rane 1026-1029, 1431a-1432)". Lexis, 24, 2006, pp. 95-125.

TOURRAIX, Alexandre. "Les Perses, la géopolitique et l'histoire”. Cahiers du Gita, 7, 1992/1993, pp. 99-117.

TRACY, S. V. "Darkness from Light: The Beacon Fire in the Agamemnon". Classical Quarterly, 36 (1), 1986, pp. 257-260.

TSITSIBAKOU-VASALOS, E. Ancient Poetic Etymology - The Pelopids: Fathers and Sons. Stuttgart, Franz Steiner Verlag, 2007.

TURNER, Chad. "Perverted Supplication and Other Inversions in Aeschylus' Danaid Trilogy". The Classical Journal, 97 (1), 2001, pp. 27-50.

TYRRELL, WM. Blake. "Zeus and Agamemnon at Aulis". The Classical Journal, 71 (4), 1976, pp. 328-334.

USTINOVA, Y. Caves and the Ancient Greek Mind - Descending Underground in the Search for Ultimate Truth. Oxford, Oxford University Press, 2009.

VAUGHN, J. W. "The Watchman of the Agamemnon". The Classical Journal, 71 (4), 1976, pp. 335-338.

VELlACOTT, P. "Has Good Prevailed? A Further Study of the Oresteia". Harvard Studies in Classical Philology, 81, 1977, pp. 113-122. 
. “Aeschylus' Seven against Thebes”. Classical World, 73 (4), 1979/1980, pp. 211-219.

VERDENIUS, W. J. "Notes on the Parodos of Aeschylus' Suppliants". Mnemosyne, 38 (3/4), 1985, pp. 281-306.

VERMEUlE, E. Aspects of Death in Early Greek Art and Poetry. Berkeley, Los Angeles and London, University of California Press, 1981.

VERNANT, J.-P. A Morte nos Olhos - Figurações do Outro na Grécia Antiga: Ártemis, Gorgó. Rio de Janeiro, Jorge Zahar Editor, 1988a.

. "Artémis et le sacrifice préliminaire au combat". Revue des études grecques, 101, pp. 221-239, 1988 b.

. Mito e pensamento entre os gregos. 2. ed. Rio de Janeiro, Paz e Terra, 1990.

. Mortals and Immortals - Collected essays. Edited by Froma I. Zeitlin. Princeton, Princeton University Press, 1991.

. Mito e sociedade na Grécia Antiga. Rio de Janeiro, Editora José Olympio, 1992.

. As origens do pensamento grego. 20. ed. Rio de Janeiro, Difel, 2011.

. et al. Divination et Rationalité. Paris, Éditions du Seuil, 1974.

. \& VIDAL-NAQUET, P. Mito e tragédia na Grécia antiga. São Paulo, Perspectiva, 2005.

VERNIÈRE, Y. "La théorie de l'inspiration prophétique dans les dialogues pythiques de Plutarque”. Kernos, 3, 1990, pp. 359-366.

VERSNEL, H. S. (Ed.) Faith, Hope and Worship - Aspects of Religious Mentality in the Ancient World. Leiden, Brill, 1981.

VICAIRE, Paul. "Pressentiments, préssages, prophéties dans le théatre d'Eschyle". Revue des études grecques, 76, 1963, pp. 338-57.

. "Platon et la divination". Revue des études grecques, 83, 1970, pp. 333350.

. "Images d'Amphiaraos dans la Grèce archaïque et classique". Bulletin de l' Association Guillaume Budé, 1979 (1), pp. 2-45.

VIDAL-NAQUET, P. “Temps des dieux et temps des hommes. Essai sur quelques aspects de l'expérience temporelle chez les Grecs". Revue de l'histoire de religions, 157 (1), 1960, pp. 55-80. 
. The Black Hunter - Forms of Thought and Forms of Society in the Greek

World. Baltimore and London, The Johns Hopkins University Press, 1986.

WALSH, L. "The Rhetoric of Oracles". Rhetoric Society quarterly, 33 (3), 2003, pp. $55-78$.

WERNER, Christian. “As performances de Cassandra em Troianas de Eurípides". Letras Clássicas, 6, 2002, pp. 117-133.

WERNER, Cynthia. The Erinyes in Aeschylus' Oresteia. 2012. 295 ff. Thesis (Doctor of Philosophy) - School of Art History, Classics and Religious Studies, Victoria University of Wellington, Wellington, 2012.

WEST, M. L. “The Prometheus Trilogy". The Journal of Hellenic studies, 99, 1979a, pp. 130-148.

. "The Parodos of the Agamemnon". Classical Quarterly, 29 (1), 1979, pp. 1-

6.

. Studies in Aeschylus. Stuttgart, Teubner, 1990.

. Greek Epic Fragments. Edited and translated by Martin L. West. Cambridge: Harvard University Press, 2003.

WHALLON, William. "The Serpent at the Breast". Transactions of the American Philological Association, 89, 1958, pp. 271-275.

. "Why is Artemis angry?" American journal of philology, 82 (1), 1961, pp.

78-88.

. "Maenadism in the Oresteia". Harvard Studies in Classical Philology, 68, 1964, pp. 317-327.

. Problem and Spetacle - Studies in the Oresteia. Heidelberg, Carl Winter Universitätsverlag, 1980.

WHITE, Stephen. "Io's World: Intimations of Theodicy in Prometheus Bound". The Journal of Hellenic studies, 121, 2001, pp. 107-140.

WILSON, P. "Dikēn in the Oresteia of Aeschylus". In: DAVIDSON, J.; MUECKE, F. $\&$ . (Eds.) Greek Drama III: Essays in Honour of Kevin Lee. London, University of London. Institute of Classical Studies, 2006, pp. 187-201.

WINNINGTON-INGRAM, R. P. "The Rôle of Apollo in the Oresteia". Classical review, 47 (3), 1933, pp. 97-104.

. "Clytemnestra and the Vote of Athena". The Journal of Hellenic studies, 68, 1948, pp. 130-147. 
. "The Danaid Trilogy of Aeschylus". The Journal of Hellenic studies, 81, 1961, pp. 141-152.

. "Zeus in the Persae". The Journal of Hellenic studies, 93, 1973, pp. 210-

219.

. Studies in Aeschylus. Cambridge, Cambridge University Press, 1983.

WOHL, V. Intimate Commerce - Exchange, Gender, and Subjectivity in Greek Tragedy. Austin, University of Texas Press, 1998.

ZANUY, T. Q. "Voces femeninas en el mito antiguo: el maleficio de un enigma". Scriptura, 12, 1996, pp. 13-31.

ZEITLIN, Froma I. "The Motif of the Corrupted Sacrifice in Aeschylus' Oresteia".

Transactions of the American Philological Association, 96, 1965, pp. 463-508.

. "Postscript to Sacrificial Imagery in the Oresteia (Ag. 1235-37)".

Transactions of the American Philological Association, 97, 1966, pp. 645-653.

. "La politique d'Éros". Mètis, 3 (1/2), 1988, pp. 231-259.

. "Patterns of Gender in Aeschylus's Drama: Seven against Thebes and the

Danaid Trilogy. In: GRIFFITH, M. \& MASTRONARDE, D. J. (Eds.) Cabinet of

the Muses: essays on classical and comparative literature in honor of Thomas G.

Rosenmeyer. Atlanta, Scholars Press, 1990, pp. 103-115.

. "Thebes: Theater of Self and Society in Athenian Drama". In:

\& WINKLER, J. J. (Eds.) Nothing to Do with Dionysos? Athenian Drama in its

Social Context. Princeton, Princeton University Press, 1990, pp. 130-167.

. Playing the Other: Essays on Gender and Society in Classical Greek

Literature. Chicago, University of Chicago Press, 1996.

. "Redeeming Matricide? Euripides Rereads the Oresteia". In: PEDRICK, V.

\& OBERHELMAN, S. M. (Eds.) The Soul of Tragedy - Essays on Athenian

Drama. Chicago, The University of Chicago Press, 2006, pp. 199-225.

. Under the Sign of the Shield: Semiotics and Aeschylus' Seven against

Thebes. 2. ed. New York, Lexington Books, 2009.

ZIMMERMANN, B. “Aischylos und Homer”. Lexis, 22, 2004, pp. 191-199.

. "A Study in Form: Recognition Scenes in the Three Electra Plays". Lexis,

30, 2012, pp. 361-378. 